UNIVERSIDAD POLITÉCNICA DE MADRID ESCUELA TÉCNICA SUPERIOR DE ARQUITECTURA

\title{
El Objeto en el marco de la vida: de la Un-home a la muchacha nómada de Tokio
}

TESIS DOCTORAL

Autor: Manuel Carmona García. Arquitecto

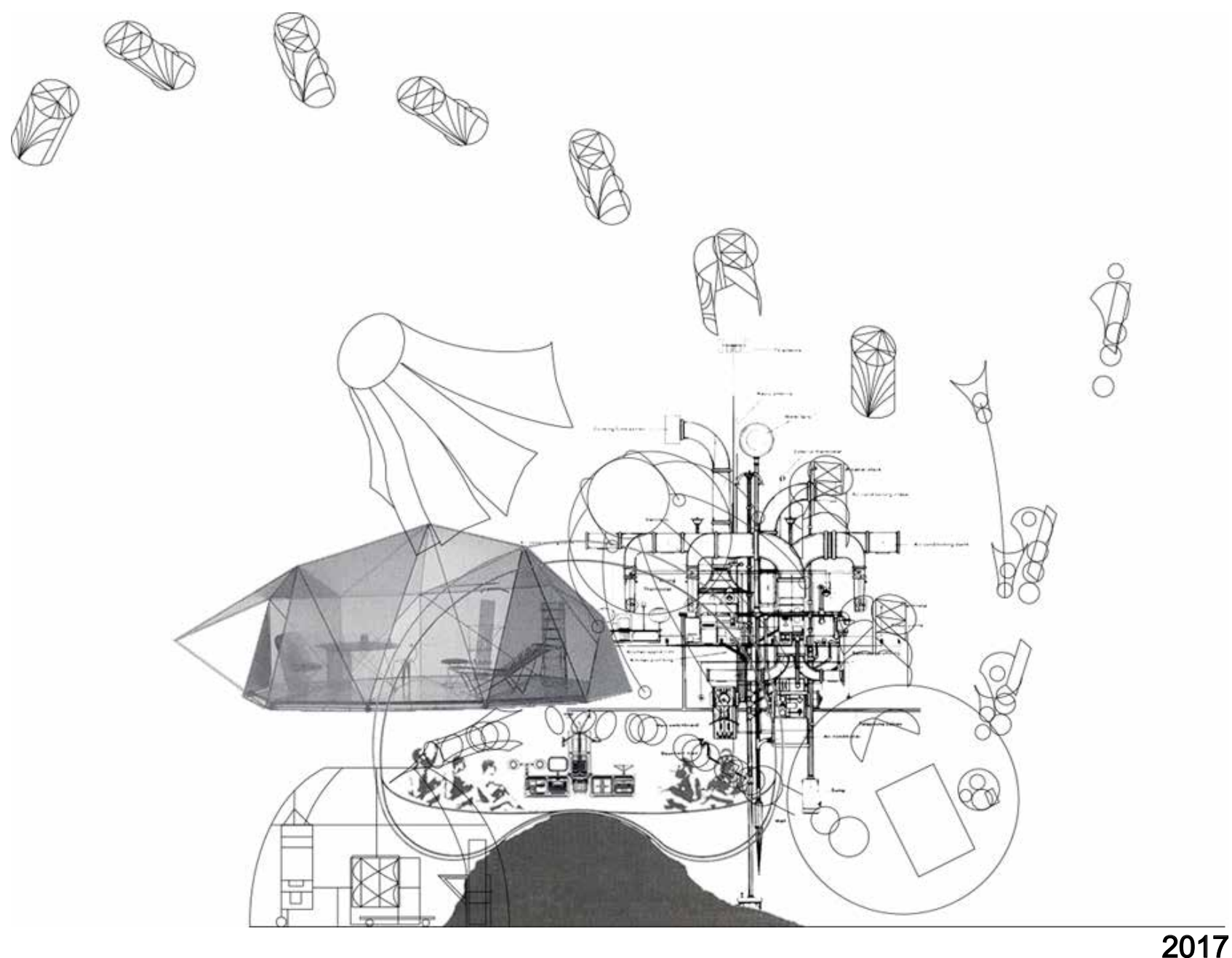



DEPARTAMENTO DE COMPOSICIÓN ARQUITECTÓNICA ESCUELA TÉCNICA SUPERIOR DE ARQUITECTURA

\section{El Objeto en el marco de la vida: de la Un-home a la muchacha nómada de Tokio}

TESIS DOCTORAL

Autor: Manuel Carmona García. Arquitecto Directora: Emilia Hernández Pezzi. Doctora en Geografía e Historia 

Tribunal nombrado por el Magnifico y Escelentisimo Sr. Rector de la Universidad Politécnica de Madrid

El día de de

Presidente D.

Vocal D.

Vocal D.

Vocal D.

Secretario D.

Realizado el acto de defensa y lectura de la Tesis: "El Objeto en el marco de la vida: de la Un-home a la muchacha nómada de Tokio".

El día de de en

Calificación

EL PRESIDENTE LOS VOCALES

EL SECRETARIO 

Mi agradecimiento a todas las personas que me han apoyado en la realización de esta tesis.

Especialmente:

a Patricia, por su apoyo, por creer en mí, por su ayuda, por su amor... por todo.

a mi familia, por su confianza. a Milla, mi directora de tesis, por su dedicación, por su generosidad, por su criterio y acierto. a Barbara y Marco, por su compañía en este viaje. 

INDICE

- RESUMEN/ABSTRACT 3

- INTRODUCCIÓN 9

I El papel del objeto en el marco doméstico contemporáneo. Presentación 18

II Configuraciones del espacio a través de los objetos. Objetivos 23

III Ámbitos y elementos: Reconocimiento-análisis-clasificación. Método 27

IV Marco teórico y práctico. Estado de la cuestión 30

1. UNANUEVA VISIÓN DEL OBJETO 41

1.1 TEORÍAS DEFINICIONES Y CLASIFICACIONES

1.2 OBJETOS: NUEVOS CONCEPTOS $\quad 62$

Función vs. significado $\quad 64$

Los dominios de los muebles $\quad 66$

Fenomenología y objetos $\quad 70$

La incidencia de los transformables $\quad 74$

Elementos transformadores $\quad 77$

Simbología y memoria $\quad 80$

La TV como objeto $\quad 86$

1.3 LACASA DENTRO DE LACASA 90

1.4 LA OBJETUALIZACIÓN DEL ELEMENTO ARQUITECTÓNICO 98

2. EL ESPACIO INTERIORA TRAVÉS DE LAS EXPOSICIONES 103

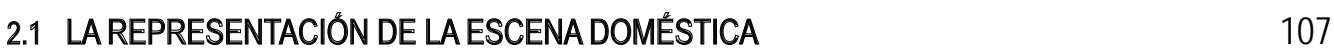

2.2 EL 'BUEN DISEÑO' Y LOS NUEVOS MODOS DE VIDA 118

2.3 DE LAERA ESPACIALAL MUNDO INTERIOR 121

2.4 EL NUEVO 'PAISAJE' DOMÉSTICO 130

2.5 LA DISOLUCIÓN DEL OBJETO Y LA DESAPARICIÓN DE LAESCENA 148

3. OBJETOS Y ESPACIO DOMÉSTICO: RELACIONES Y CONFIGURACIONES 159

3.1 ESPACIO, ORDEN Y JERARQUÍA 171

3.2 MOVILIDAD YESPACIO MUTANTE 183

3.3 LAAPROPIACIÓN COMO ACTO CREATIVO 194

3.4 MECANISMOS DE TRANSFORMACIÓN ESPACIAL 204

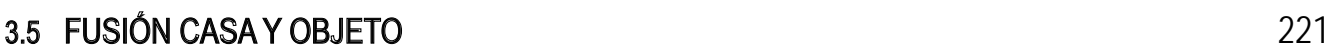

3.6 LAAGRUPACIÓN Y EL ESPACIO FONDO 232

3.7 RECORRIDOS, OBJETOS Y CARACTERIZACIÓN DEL LUGAR 237

$\begin{array}{ll}\text { - CONCLUSIONES } & 249\end{array}$

- BIBLIOGRAFIA 271 

RESUMEN / ABSTRACT 



\section{RESUMEN}

La presente tesis trata sobre el papel que cumple el objeto en el proceso de configuración del espacio doméstico contemporáneo.

El trabajo se acota en un periodo de cambios sociales y de cultura de consumo. Dicha etapa abarca tres décadas, desde los años 60 hasta finales de los 80 del siglo XX. Este lapso de tiempo viene representado a través de dos propuestas de hogares alternativos que forman parte del título de esta tesis: la Un-home -no casa- presentada por Reyner Banham en la revista Art in America en 1965, y el Pao de la muchacha nómada de Tokio, de Toyolto, exhibida en Shibuya, Tokio, en los años 1985 el Pao-1, y 1989 el Pao-2. En ambas propuestas se sintetiza el concepto de hogar a través de un sistema de objetos que se relaciona con el habitante y con el entorno.

Esta tesis realiza un acercamiento a la visión del objeto en el marco contemporáneo siguiendo los estudios sociológicos de Baudrillard, Moles 0 Barthes, entre otros. Dichas teorías constatan que el objeto cotidiano, inmerso en esta nueva sociedad, adquiere nuevas acepciones, prevaleciendo sobre las demás su condición de signo y su capacidad para comunicar, lo que se traduce en la aparición de un nuevo lenguaje. La cultura de consumo también propicia que las exposiciones y ferias de mobiliario y enseres para el hogar proliferen a partir de los 60 . Las exhibiciones se convierten en un campo de exploración para estudiar el papel del objeto en la conformación de los hogares contemporáneos en su modo más enfático e intencional.

En el marco doméstico contemporáneo, que los nuevos modos de vida reclaman más abierto y más libre, los objetos gracias a su nueva faceta semántica, participan en la organización y cualificación del espacio. En dicho proceso de configuración los elementos actúan, por un lado distribuyendo y ordenando, organizados en sistemas basados en relaciones topológicas y geométricas, y por otro añadiendo una nueva dimensión psicológica a los nuevos ámbitos, permaneciendo como elementos simbólicos o actuando como mecanismos que influyen en la vivencia y en la percepción espacial.

A través del análisis y utilizando una amplia casuística, en esta tesis se establece un sistema de clasificación que determina una correspondencia entre características y cualidades que son propias del espacio doméstico contemporáneo y los modos de actuación de los objetos en dichos entornos, constatando, de esta manera, que los objetos contribuyen a configurar ámbitos con unas determinadas propiedades gracias a sus modos de relación y conexión en el espacio. 



\section{ABSTRACT}

This thesis deals with the role of the object in the process of configuring contemporary domestic space.

The work is marked in a period of social changes and consumption culture. This stage covers three decades, from the 60s to the end of the 80 s of the twentieth century. This time period is represented by two alternative home proposals that are part of the title of this thesis: the Un-home -no home- presented by Reyner Banham in the magazine Art in America in 1965, and The Pao for the Tokyo nomad girl, by Toyo Ito, exhibited in Shibuya, Tokyo, in the years 1985 the Pao1 , and 1989 the Pao-2. Both proposals synthesize the concept of home through a system of objects that relates to the inhabitant and the environment.

This thesis makes an approach to the vision of the object in the contemporary framework following the sociological studies of Baudrillard, Moles or Barthes, among others. These theories confirm that the daily object, immersed in this new society, acquires new meanings, prevailing over others its condition of sign and its ability to communicate, which translates into the appearance of a new language. The consumer culture also encourages the proliferation of exhibitions and fairs of furniture and household items from the 60's. Exhibitions become a field of exploration to study the role of the object in the shaping of contemporary homes in its most emphatic and intentional way.

In the contemporary domestic context, which the new ways of life claim more open and freer, objects participate in the organization and qualification of the space thanks to their new semantic facet. In this configuration process the elements act, on the one hand distributing and ordering, organized in systems based on geometrics and thematic relations, and on the other hand adding a new psychological dimension to the new areas, remaining as symbolic elements or acting as mechanisms that influence the spatial experience and its perception.

Through the analysis and using a broad casuistry, this thesis establishes a classification system that determines a correspondence between characteristics and qualities that are typical of contemporary domestic space and the modes of action of the objects in such environments, noting, this way, that the objects contribute to configure areas with certain properties thanks to their modes of relationship and connection into the space. 

INTRODUCCIÓN 



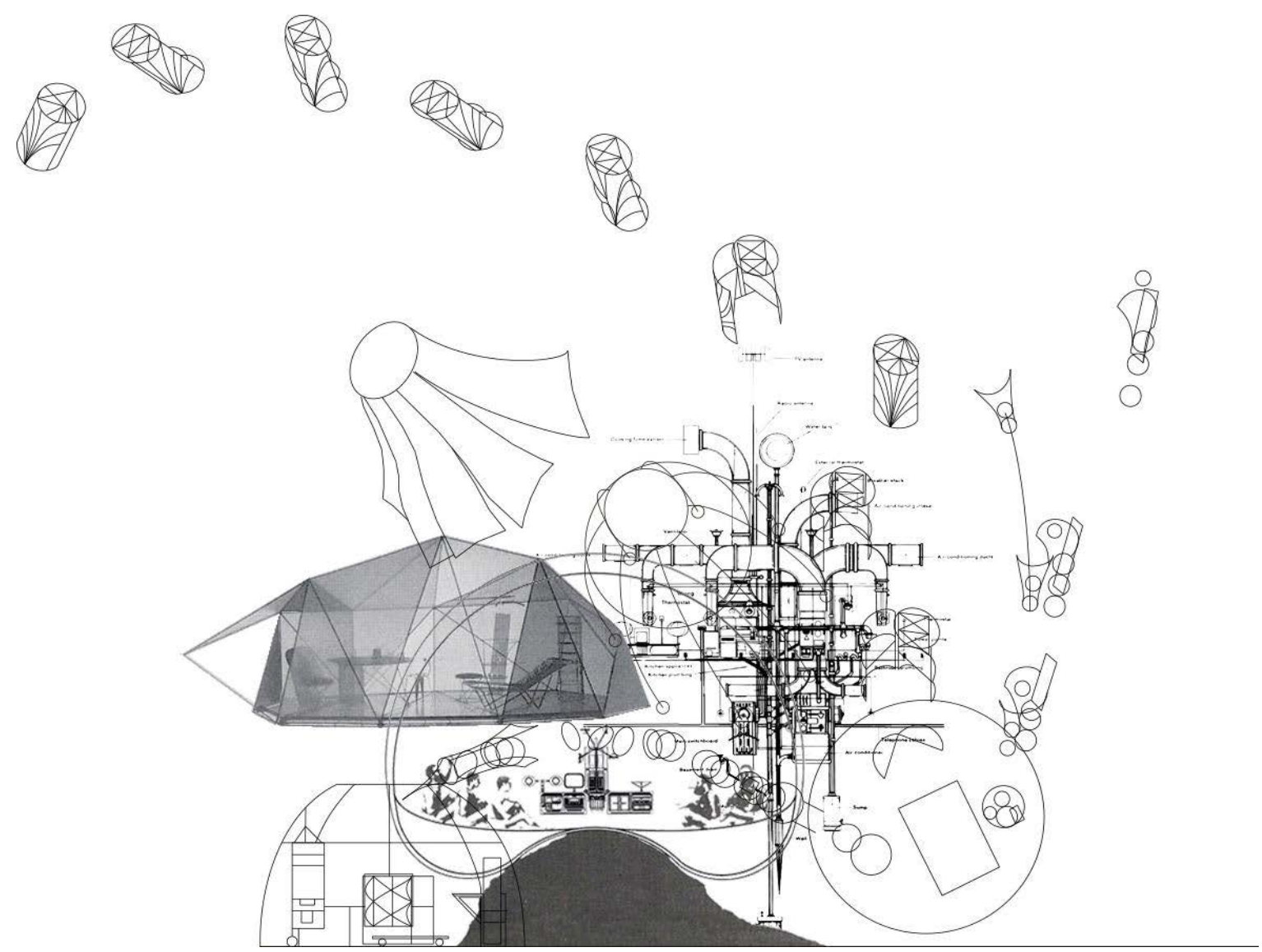

\section{INTRODUCCIÓN}

Sin relación no hay espacio, pues el espacio no existe sino abierto, suscitado, ritmado, ampliado por una correlación de los objetos y un rebasamiento de su función en esta nueva estructura. El espacio es, de alguna manera, la libertad real del objeto. Hoy en día los objetos no se responden, comunican (...) Conforme a una combinatoria ilimitada, el hombre establece con ello su discurso estructural.

Jean Baudrillard ${ }^{1}$

La presente tesis trata sobre el papel que cumple el objeto en el proceso de configuración del espacio doméstico contemporáneo. Los objetos se conforman organizados en sistemas en el interior de los hogares modernos, y en base a sus relaciones y conexiones, organizan y cualifican el espacio. Todo ello se genera de modo que pueden relacionarse las características de los entornos que albergan los objetos y sus modos de actuación. El trabajo se enmarca en un periodo de cambios en los modos de vida, en un momento emergente para la cultura de consumo y donde surgen nuevos patrones culturales y sociales. A partir de la segunda mitad del siglo XX, los entornos domésticos se establecen a partir de nuevas estructuras como respuesta a las necesidades del habitante moderno. Las ansias de libertad frente a los principios tradicionales establecidos y los nuevos hábitos en torno a la familia y al trabajo se traducen en espacios más abiertos y polivalentes. Al mismo tiempo que cambian las relaciones del individuo con su entorno y con las cosas que le rodean, cambia el estilo de los objetos cotidianos y su organización. El alcance de la publicidad y la importancia de la imagen hacen que los objetos y muebles tengan una mayor incidencia sobre la gente y se conviertan en un elemento

1 Jean Baudrillard. El Sistema de los Objetos (México: Siglo XXI, 1969) p.17. 
social, adquiriendo nuevas acepciones aparte de la funcional, sobre todo por su significado y por consiguiente por su capacidad comunicativa. Teniendo en cuenta que el nuevo marco doméstico ofrece más disponibilidad para una mayor libertad de organización, la faceta semántica del objeto permite que al ubicarlo, combinarlo y relacionarlo con otros elementos, se genere un nuevo discurso con un lenguaje que, basado en todas las posibilidades de relaciones de objetos, forme parte activa en el proceso de configuración del espacio. La semantización del objeto se produce, según el semiólogo Roland Barthes ${ }^{2}$ en el momento que éste es normalizado, producido en serie y consumido por la sociedad, por lo que el establecimiento de la cultura de consumo en estos años es decisivo en su nuevo papel. En palabras del sociólogo Abraham Moles ${ }^{3}$, es en ese momento cuando "surge el concepto de lenguaje de los objetos". Este fenómeno forma parte del proceso de desarrollo del espacio doméstico contemporáneo.

Todo el entorno moderno pasa, en bloque, al nivel de un sistema de signos.

\section{Jean Baudrillard ${ }^{4}$}

Con este trabajo nos adentramos en el mundo del espacio interior doméstico en un periodo en el que la idea de hogar varía, al tiempo que cambia la sociedad y se adquieren nuevos hábitos, lo cual afecta al uso de los objetos cotidianos. Es un proceso que, autores como Beatriz Colomina 5 , lo sitúan casi en los 50, a través del proyecto de la casa de los Eames en California ${ }^{6}$ donde Charles y Ray ponen en marcha una forma completamente nueva de operar en un momento, pasados los años de posguerra en Estados Unidos, en que la sociedad reclama nuevos ámbitos para habitar. En este contexto, los Eames utilizan la tecnología industrial para crear un recinto que contiene lo esencial para una vida confortable. La idea de contenedor abierto, sin ataduras a tiempos pasados, permite al habitante transformar la estructura creando su propio discurso personal con accesorios de su propia vida.

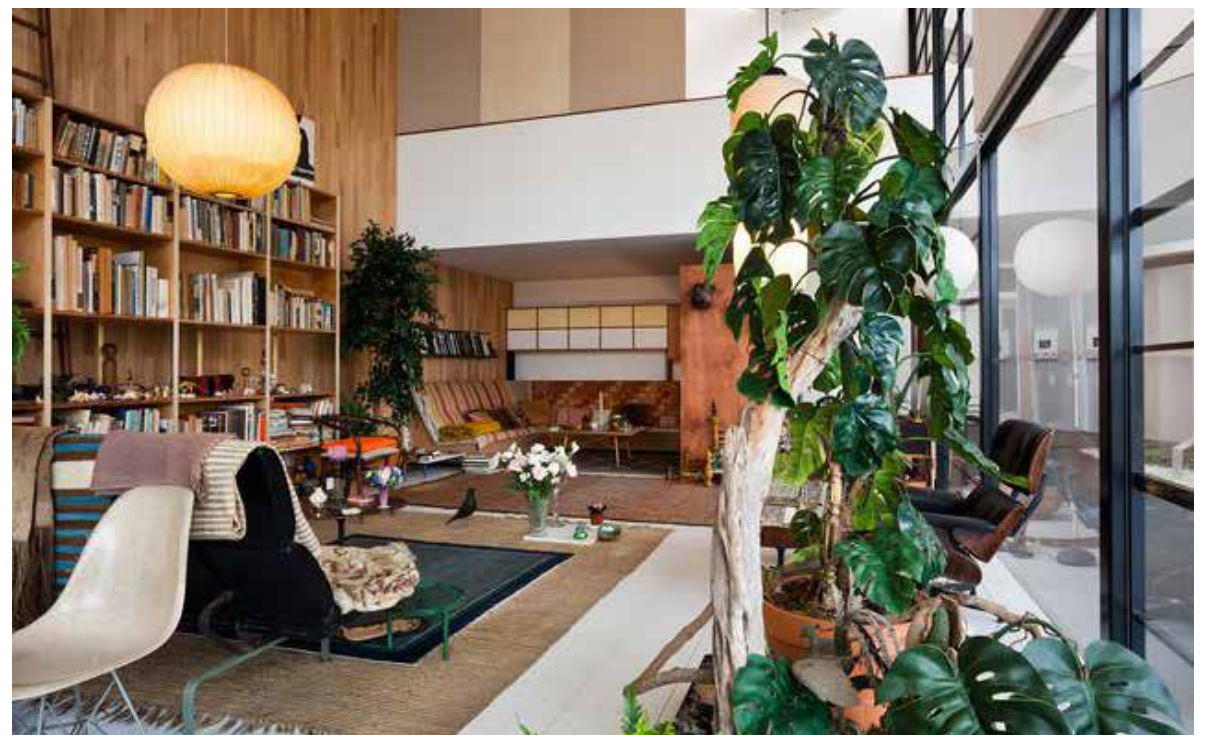

2 Roland Barthes, "Semántica del objeto" en Arte e Cultura nella civilita contemporánea, editado por Piero Nardi (Florencia: Sansoni, 1966).

3 Abraham A. Moles, Teoría de los objetos (Barcelona: Gustavo Gili, 1975), 111.

4 Jean Baudrillard. El Sistema de los Objetos (México: Siglo XXI, 1969), 41.

5 En Beatriz Colomina. "Reflexiones sobre la casa Eames". Ra. Revista de Arquitectura (nº, 2007) 3-16.

6 Casa Eames, conocida como la Case Study House $n^{\circ} 8$, en Santa Monica, California, por Charles \& Ray Eames en 1949.
Imagen: Casa Eames en Santa Monica, California, por Charles \& Ray Eames en 1949. 


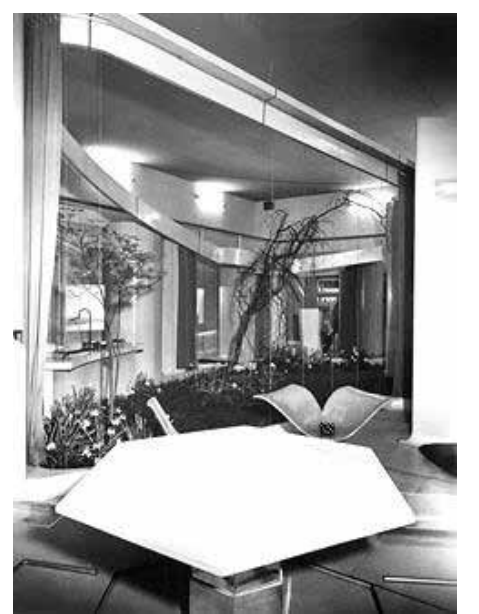

Imagen:' La Casa del Futuro', Daily Mail Ideal Home Exhibition, Londres. Por Alison y Peter Smithson en 1956. Vista interior de la instalación.
En las casas de los Eames los elementos de la vida cotidiana permiten el control y definen el espacio. De las nuevas capacidades de los objetos para generar un discurso, se hace referencia en los estudios sociológicos de los años 60.

El nuevo tipo de habitante es un informador activo del ambiente. Dispone del espacio como de una estructura de distribución; a través del control de este espacio, dispone de todas las posibilidades de relaciones recíprocas y por lo tanto, de la totalidad de los papeles que pueden desempeñar los objetos.

Jean Baudrillard ${ }^{7}$

Años después los Smithson, conscientes de los efectos que producen la proliferación de electrodomésticos en los nuevos ámbitos, proponen como respuesta a dicho problema la llamada 'Casa del Futuro's. Un modelo en la que no sólo tratan de encontrar un método para absorber las posibilidades de combinaciones de electrodomésticos sugiriendo una clase de vivienda nueva, sino que proponen un nuevo estilo de vida, teniendo en cuenta nuevos patrones como la desintegración de la cocina como consecuencia del preenvasado.

Algunos arquitectos ya comienzan a plantearse que las casas pueden y deben ser más adecuadas a la vida de los habitantes ${ }^{9}$. Los americanos Moore, Allen y Lyndon, en su libro La casa: forma y diseño, editado en $1974^{10}$, encuentran en la configuración abierta de las casas la forma más adecuada para dar respuesta a las nuevas formas de vivir:

El desarrollo de la planta abierta demostró una preocupación no sólo por una configuración novedosa de las habitaciones sino por el problema de acomodar las máquinas, la casa se convertía en un marco para el equipamiento.

\section{Charles W. Moore, Gerald Allen, Donlyn Lyndon ${ }^{11}$}

Pero para ellos la casa significa algo más. Es un gran escenario preparado para las acciones de la vida que no sólo existe para colocar muebles, objetos y equipamiento, sino que se convierte en un ámbito donde los aspectos emocionales y subjetivos de los habitantes también forman parte de los elementos fundamentales a tener en cuenta en el proyecto de la casa. La idea de hogar comienza a ser vista desde la perspectiva de una serie de lugares especiales que albergan desde las máquinas hasta los sueños de sus habitantes: "la casa debe parecer el lugar más importante del mundo para sus habitantes"12. Los nuevos ámbitos requieren preocuparse tanto de la organización de los equipamientos como de ubicar en el espacio elementos simbólicos y objetos personales.

La adaptación de la planta libre y la forma abierta, como respuesta a los

7 Jean Baudrillard. El Sistema de los Objetos (México: Siglo XXI, 1969), 26).

8 Presentada en la exposición Daily Mail Ideal Home Exhibition, Londres en 1956).

9 Charles W. Moore, Gerald Allen, Donlyn Lyndon. La Casa: Forma y Diseño. (Barcelona: Gustavo Gili, 1999).

10 Ibídem.

11 Charles W. Moore, Gerald Allen, Donlyn Lyndon. La Casa: Forma y Diseño. Edición en castellano, (Barcelona: Gustavo Gili, 1999) 77.

12 Charles W. Moore, Gerald Allen, Donlyn Lyndon. La Casa: Forma y Diseño. (Barcelona: Gustavo Gili, 1999) 51. 
nuevos hábitos sociales, también es relacionada por Norberg-Schulz ${ }^{13}$ con la contemporaneidad cuando vincula "el modo de vida moderno" con la casa entendida como un gran escenario, abierto y vacío que proporciona las oportunidades para que ocurran cosas. El espacio surge en base a las oportunidades que se presentan por la interrelación entre los elementos que allí se ubican. Norberg-Schul ${ }^{14}$ pone como ejemplo los apartamentos realizados en Sea Ranch en 1964 por MLTW, al norte de San Francisco.

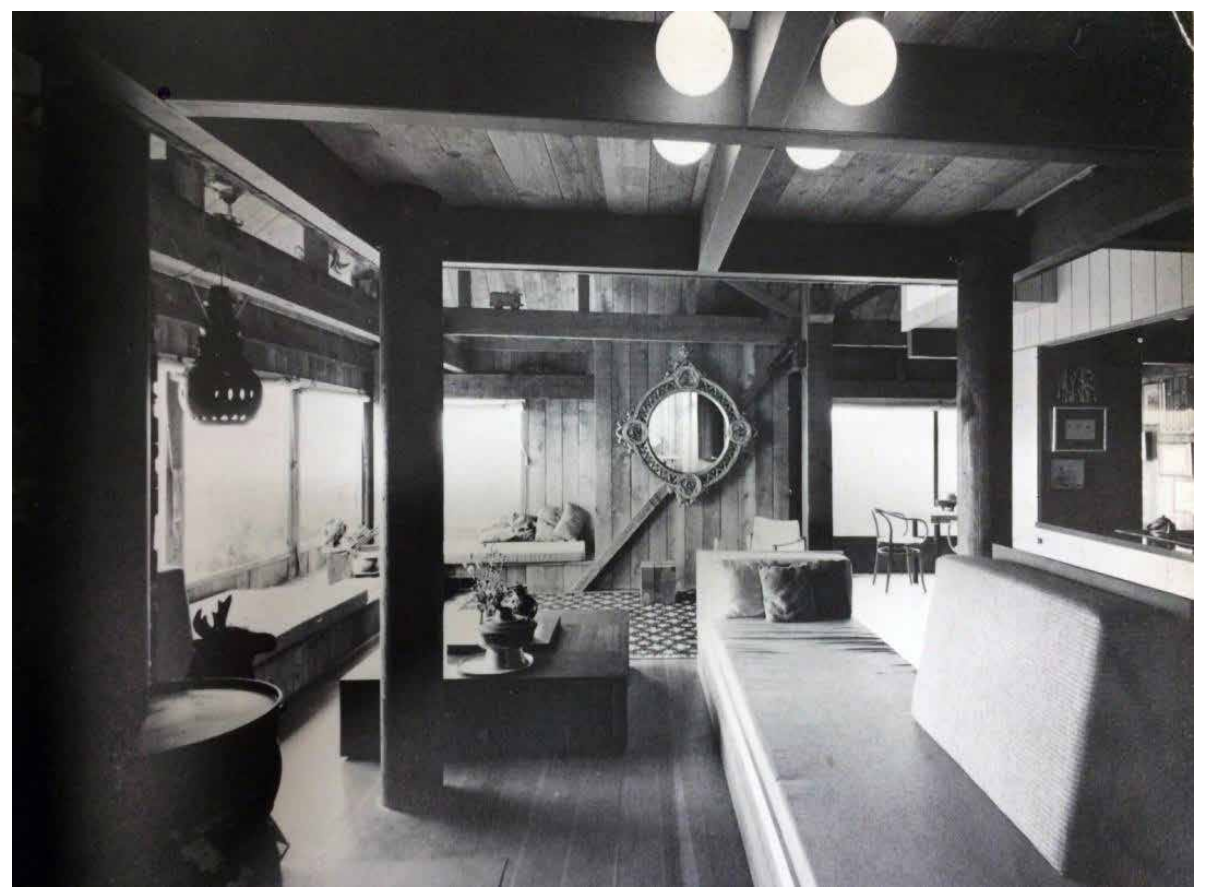

Este complejo, que se compone de 10 viviendas, concebidas siguiendo la estética de los antiguos 'graneros', representa la idea de esos espacios abiertos, en los que los elementos que discurren en su interior, son los que marcan las pautas de la organización espacial. Esto es el reflejo de una nueva forma de entender la vida. Las circunstancias que giran en torno a los nuevos modos de habitar y que reclaman nuevos ámbitos, sobre todo en Estados Unidos, vienen a ser situadas por C. Ray Smith ${ }^{15}$, principalmente en los cambios sociales de los 60. Tanto en Europa como en América los movimientos revolucionarios de los sesenta -el Mayo francés del 68-, los movimientos pacifistas, las luchas por los derechos de las minorías, el primer viaje espacial y la transgresión de los principios de la sociedad tradicional, reclaman un nuevo vocabulario, una nueva visión, que se traduce en las casas, en el diseño, en todo lo que significa la cotidianeidad del ser humano. El espacio quería dejarse ver, ser más abierto. La humanidad ya había visto las imágenes de la Tierra desde el espacio, por lo que las distancias disminuyen y la visión se expande.

Otros arquitectos como Joe Colombo, representan a esa línea de diseñadores cuyas inquietudes, en estos años, trabajan en torno a aspectos como la relación espacio-tiempo. Colombo se aferra a la idea de la cuarta dimensión, según M. Kries y A. von Vegesack ${ }^{16}$, tanto en la configuración espacial como en el diseño del mobiliario. Pensar en la transformación y adaptación del entorno a

13 Christian Norberg-Schulz en Los Principios de la Arquitectura Moderna. Edición original, 2000). 14 Ibíd. p. 68.

15 Smith, C. Ray. Supermannerism: New Attitudes in Post-Modern Architecture (Nueva York: E.P. Dutton, 1977).

16 Mateo Kries y Alexander von Vegesack en Joe Colombo. Inventing the future. (Weil am Rheim: Vitra Design Museum, 2005) 41
Imagen: Sea Ranch Condominium Sea Ranch, California. Por MLTW, en 1964. Vista interior de uno de los apartamentos.

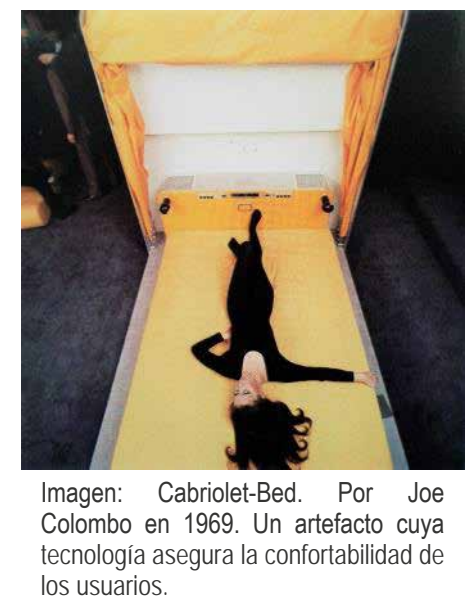

os usuarios. 

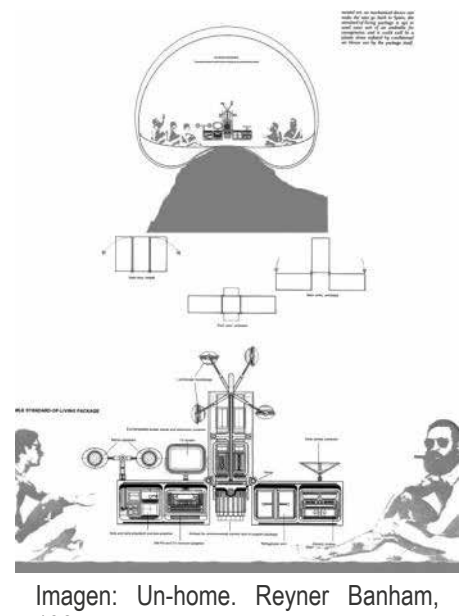
1965.

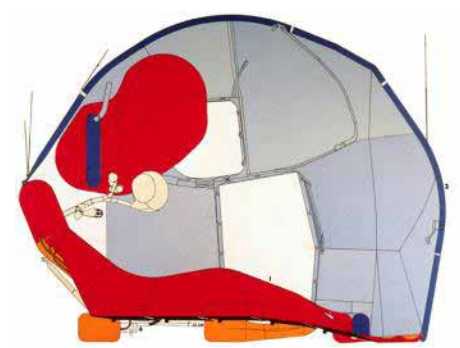

Imagen: Stanley Tigerman Keck House, Highland Park, Illinois, 1977 lo largo del tiempo según las necesidades, es un planteamiento que implica de forma directa al mobiliario en la capacidad de la casa para ser flexible. Sirvan como ejemplo la Cabriolet-Bed o el Roto-Living, dos artefactos diseñados por Colombo en 1969 cuya tecnología permite contar con todo lo necesario para que el usuario pueda realizar la vida confortablemente en un apartamento prácticamente vacío y sin divisiones.

Una propuesta más radical pero más fiel a este concepto, es la Un-home de Reyner Banham, que plantea la escisión entre casa y hogar con afirmaciones como: "cuando tu casa contiene tantas instalaciones que el equipamiento puede mantenerse por sí solo, sin necesidad de apoyarse en la casa ¿para qué tener una casa que lo contenga?"17. En los 60 Reyner Banham propone la Un-home bajo el lema "un hogar no es una casa" -a home is not a house-. En este caso, el planteamiento es importante ya que, frente a los nuevos modos de vida y el avance de la tecnología, separa la idea de domesticidad de la imagen de la casa tradicional. El hogar de Banham se sintetiza en un gran objeto que comprende todo lo necesario para proporcionar técnicamente todas las condiciones de confortabilidad necesarias, pudiéndolo ubicar en cualquier lugar, sin necesidad de delimitar un espacio con paredes y cubierta. Otras propuestas como The Cushicle -1966-, o Suitaloon ${ }^{18}$ de Archigram demuestran que en estos años hay más arquitectos y diseñadores que se mueven en la confianza de las nuevas tecnologías para adaptarse a las nuevas formas de vida con artefactos provistos del equipamiento completo necesario para una existencia nómada confortable. Según autores, como Juan Herreros ${ }^{19}$, esta perspectiva, objetual y orientada a las cosas como portadoras de una vida mejor representa un punto de partida hacia un mayor interés por el espacio interior, por los modos de interacción de las personas con los equipamientos y por sus formas de significación y de relación, más que por la casa como imagen final. En definitiva, el hogar se convierte en un marco más libre, y en él los objetos, así mismo, se liberan de la única circunstancia que tradicionalmente les daba fundamento.

Al mismo tiempo que cambian las relaciones del individuo con su entorno y con la sociedad, cambia el estilo de los objetos mobiliarios (...) la organización cambia también (...) las cosas se repliegan y se despliegan, desaparecen, entran en escena en el momento deseado.

Jean Baudrillard20

En estas circunstancias, Baudrillard habla de "el objeto moderno liberado de su función"21, pero en realidad los objetos cotidianos forman parte del entorno doméstico desde que el ser humano necesita un espacio para habitar y desde que éstos dan respuesta a sus necesidades existenciales.

Grande y mutable es el destino del hombre, y no solo del hombre, sino de todas las cosas pequeñas y grandes de las que cada uno le gusta rodearse aquí abajo y que constituyen tantos reinos minúsculos, sí, pero no menos respetables que los reinos mayores. Aparte de eso, ¿qué es la vida de un hombre, comparada con la de muchos

17 Reyner Banham. "A home is not a house". Art in America. n² (abr-1965) p.70.

18 Suitaloon, presentadop por Archigram en la Triennale de Milán en 1968.

19 Juan Herreros en "Mutaciones en la arquitectura contemporánea. El espacio doméstico". Tesis Doctoral. Universidad Politécnica de Madrid, ETSAM, 1994.

20 Jean Baudrillard. El Sistema de los Objetos (México: Siglo XXI, 1969), 15.

21 Ibídem. 
compañeros del hombre; nos referimos a los muebles, a todos aquellos objetos que fiel y silenciosamente escoltan la vida de un hombre, una familia, de varias generaciones?

Alberto Savinio ${ }^{22}$

Norberg-Schul ${ }^{23}$, también considera los objetos parte integrante del marco doméstico desde que aportan sentido y orden al mundo de acontecimientos y acciones que rodea al ser humano dentro de su propio hábitat. Ya de por sí los propios actos tienen implicaciones espaciales y suelen ir unidos a movimientos y actividades que provienen de la interacción frente a uno o varios objetos. Las cosas que nos rodean son parte de nuestras vidas y suelen estar ubicadas en el espacio más privado e inmediato. Desde los objetos más personales, con relaciones afectivas o connotaciones simbólicas, hasta el equipamiento o los gadgets de última generación. En cualquier caso, todos ellos tienen relación directa con las acciones que conllevan y las áreas que precisan a su alrededor para poder acceder cómodamente a ellos e interactuar. Así, de la misma manera que los objetos cotidianos dan respuesta a una necesidad, ubicados en el espacio también empiezan a tener otras implicaciones. Por ejemplo, organizan un espacio abierto en base a un programa de necesidades, su disposición es un sistema para ordenar las acciones previstas en una sala, consiguen despertar la atención de los usuarios funcionando como hitos, logran calificar un ámbito utilizando códigos que van unidos a una mayor 0 menor densidad de mobiliario, o simplemente marcan un punto de importancia de la casa acoplando un objeto que tenga un mayor poder de atracción que el resto.

Así mismo el habitante precisa de los objetos para orientarse en su propia casa, e incluso para estructurar espacialmente el hogar en un acto que podría equipararse al de 'ordenar las ideas'. Sirve como ejemplo la campaña publicitaria realizada por una cadena sueca de mobiliario y objetos domésticos, cuyo eslogan es: "Redecora tu vida". Este anuncio juega con la idea de que el hecho de renovar los muebles de una casa es capaz de modificarla de tal manera que puede cambiar la vida de quien la habita... lo cual nos dirige cuestiones como las que plantea Georges Perec en Especies de Espacios ${ }^{24}$, sobre si una habitación puede pasar a ser otra distinta simplemente cambiando la posición de los muebles. En los aspectos compositivos y configurativos que conllevan la disposición y ubicación de objetos cotidianos en el espacio, dentro del marco doméstico, en sus relaciones y conexiones está la respuesta y es la base de este trabajo.

La investigación se acota en un periodo de tiempo que comprende casi tres décadas, desde los años 60 hasta finales de los 80 del siglo XX, por razones que sobre todo están relacionadas con los cambios socio-culturales y con el avance de la técnica. En este lapso de tiempo afloran factores que influyen en el proceso de desarrollo del espacio doméstico contemporáneo: la imposición de la cultura de consumo en la sociedad, el auge imparable de la publicidad, la incidencia de la contracultura en los nuevos modos de vida y la puesta en cuestión de los pilares tradicionales de la sociedad occidental. En momentos de auge económico y efervescencia social afloran nuevas necesidades y, por consiguiente, nuevas respuestas. Los espacios donde habitar deben

22 En Souvenirs, "La vida a subasta", c.p. Mario Praz. La casa de la vida (Madrid: DeBolsillo, 2004), 519

23 Christian Norberg-Schulz. Existencia, espacio y arquitectura. (Barcelona: Blume, 1975), 9

24 Georges Perec. Especies de espacios. (Barcelona: Montesinos, 2007), 46.

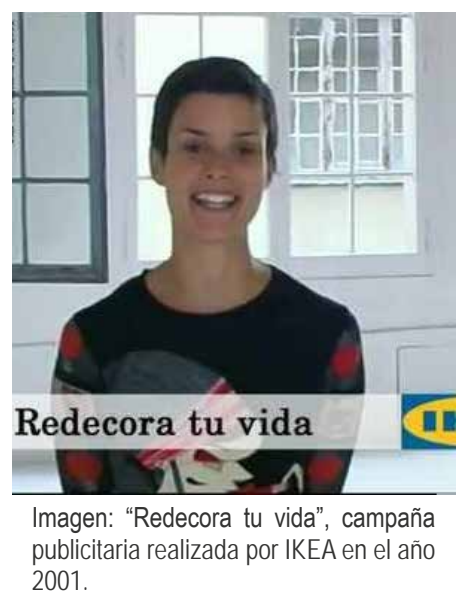

2001. 
adaptarse a lo que la sociedad reclama: ámbitos menos compartimentados, más versátiles y flexibles en el uso y que permitan fácilmente cambios a lo largo del año e incluso a lo largo del día. Así mismo, los avances técnicos proporcionan nuevas posibilidades constructivas y mejoras importantes en los sistemas de climatización e instalaciones en general, por lo que aumentan las opciones para construir edificios más amplios, con buenas condiciones de habitabilidad y con sistemas cada vez más eficaces para mantener un gran volumen de aire en condiciones óptimas. Así pues los hogares, al no necesitar tabiques por motivos constructivos y de acondicionamiento, precisan de los elementos cotidianos como los muebles y los objetos para distribuir y organizar el espacio según las necesidades. Además, en una sociedad que ya puede denominarse como objetual y de consumo, también empieza a tomar valor por lo que significa, ya que es parte de ese mensaje publicitario que gira en torno a la sociedad. El objeto ahora también sirve para comunicar. Y gracias a ello, a través de un nuevo lenguaje, los objetos son capaces de crear un discurso por el cual ordenan, estructuran y aportan sentido al entorno y, en muchos casos, incluso añaden aspectos simbólicos y subjetivos al ámbito en el que se ubican, recuperando esa lírica del espacio que ya reclamaban Sert, Giedion y Léger en 1943 en "Nueve puntos sobre monumentalidad"25.

Llegados a este punto, los planteamientos son posibles si logramos reconocer, a través de este trabajo, ese lenguaje en los códigos y modos de actuación basados en una recombinatoria de sistemas de objetos en el espacio, y conseguimos vincularlos a características y cualidades que son propias de los ámbitos domésticos contemporáneos.

25 Sigfried Giedion, Fernand Léger, Josep Lluis Sert. en "Nueve puntos sobre monumentalidad", 1943, en el punto 9 del manifiesto, reclamaban "recuperar el valor lírico de la arquitectura", argumentando que través del uso del color, aprovechando los efectos creados por los nuevos materiales y los elementos móviles, y con la incorporación de árboles y plantas en los edificios, la arquitectura lograría una nueva libertad y desarrollaría nuevas posibilidades creativas. 


\section{El papel del objeto en el marco doméstico contemporáneo Presentación}

Este es un tema que surge por varias razones, la primera de ellas es mi interés por la arquitectura doméstica y por todo lo que es capaz de sugerir su interior, tanto desde sus posibilidades configurativas como por todo lo que gira en torno a su consideración desde el punto de vista de la vivencia y la percepción. La segunda razón deriva de una investigación realizada sobre el espacio doméstico del arquitecto norteamericano Charles W. Moore - 19251993 - por el que descubrí el papel que pueden jugar los objetos en el proceso de configuración de la arquitectura doméstica. Moore es un buen ejemplo para presentar el tema de esta tesis. Como arquitecto, nómada y prolíico, que traslada su lugar de residencia en función de sus quehaceres académicos ${ }^{26}$, realiza nada menos que ocho casas para sí mismo a lo largo de su vida, en los diferentes lugares donde precisa establecerse. Aunque cada uno de sus hogares es diferente, la conformación de todos ellos surge tras un juego en el espacio de multitud objetos personales, colocados de múltiples maneras, y recombinados a su vez con otros elementos. Habitualmente en un mismo ámbito. Con los objetos crea su discurso, son un retrato de sí mismo, para Moore la impronta es "no tener miedo a decir demasiado". Esas casas son la esencia de un trabajo de provecho ${ }^{27}$, no escaso de experimentación, donde los objetos juegan un importante papel en la conformación de los interiores. Y quizá ahí radica su fertilidad, en una época de cambios, que también afecta al marco doméstico.

Este acercamiento supone una oportunidad para explorar sobre el camino recorrido hacia el acomodo de nuevos modos de vida en casas que expresan libertad, en espacios abiertos donde el mobiliario y objetos cotidianos dialogan entre 'edículos', bajo canopias, frente a supergráficos que unifican paredes y techos, o mezclándose entre planos que se superponen provocando efectos ópticos. Lugares donde nichos y estanterías se modelan con la presencia de innumerables objetos, de colecciones personales, representando una nueva manera de concebir el entorno doméstico, como si el espacio surgiera de la relación entre elementos tradicionales que conviven con piezas de arte pop, objetos folclóricos o retratos decimonónicos junto a luces de neón, y donde especialmente los elementos y objetos adquieren un especial protagonismo: las camas se conciben como espacios, los descansillos de las escaleras se convierten en una oportunidad, gracias a los elementos que en ellos se ubican, "deberíamos aprender a vivir mucho más en las escaleras, pero ¿cómo?" clamaba Georges Perec ${ }^{28}$, y donde los muebles son colocados cuan hitos para sugerir recorridos interiores e invitar a adentrarse en un mundo de sorpresas y acontecimientos.

La condición itinerante del habitante moderno, antes asociada casualmente a la figura de Moore, es en cierto modo lo que puede dar respuesta a ese incremento del valor de las pertenencias del habitante urbano que se produce en esos años, de aquello con lo que ocupa su entorno próximo y con lo que elabora su propio discurso -el del habitante moderno-, y que, esté donde esté,

26 Charles Moore, de 1950 a 1993, impartió clases y ocupó cargos académicos en las Universidades americanas de Salt Lake City, Princeton, Berkeley, Yale, Los Angeles y Texas.

27 Eugene J. Johson, en una monografía que editó en 1986 sobre la obra de Charles W. Moore, Charles Moore. Buildings and Projects 1949-1986 (Nueva York: Rizzoli, 1986) clasificó sus proyectos en cuatro categorías según deseos del propio Moore. La primera categoría, a la que llamó "Houses for the Architect" contiene exclusivamente sus ocho casas.

28 Georges Perec. Especies de espacios (Barcelona: Montesinos, 2007) 67. 
Imagen: Casa Moore. New Haven Connecticut. Por MLTW/Moore-Turnbull en 1967. Vista del interior

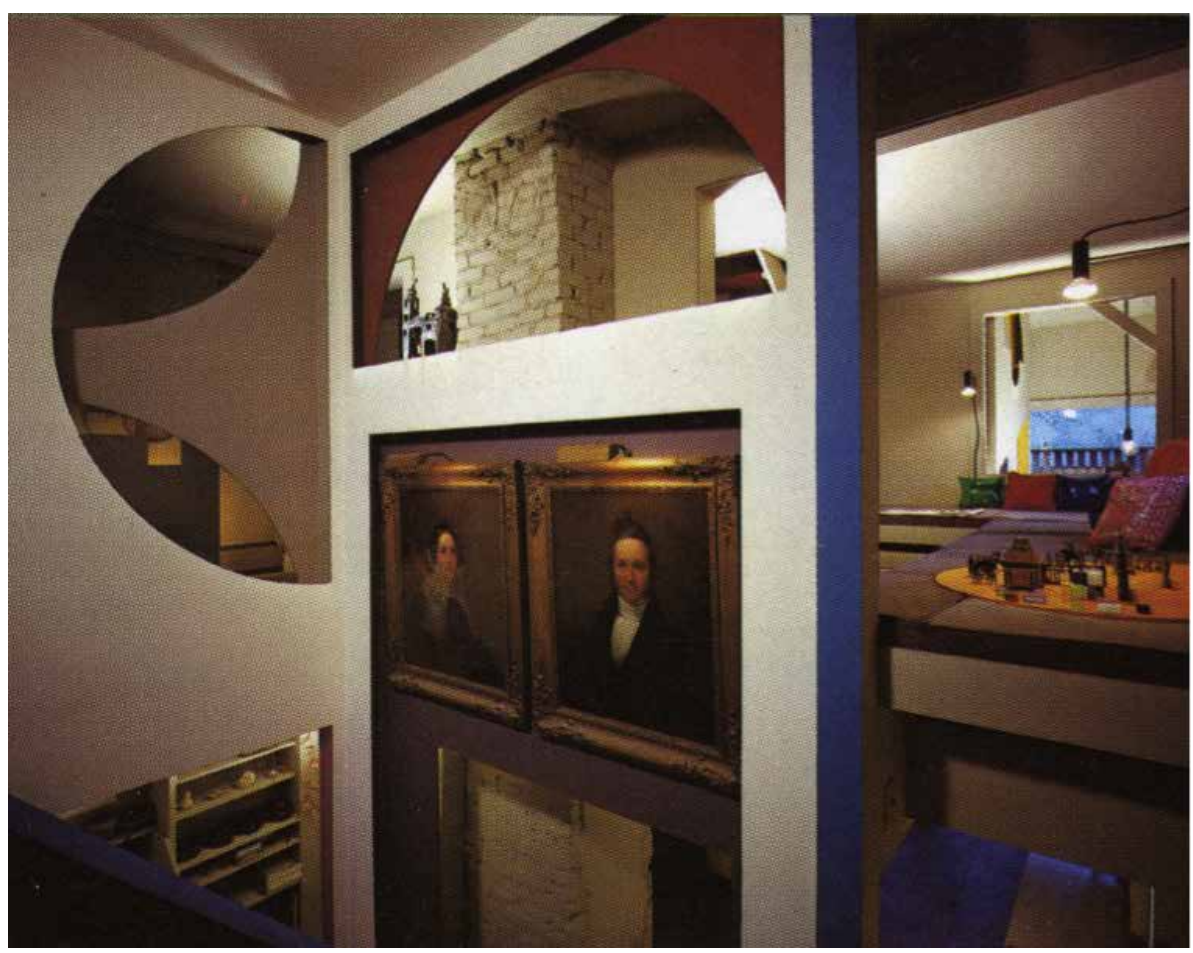

se convierte en ese 'espejo donde mirarse'. Esta idea parte en cierto modo de la condición nómada como metáfora, tal y como indica Juan Herreros ${ }^{29}$ en "Espacio Doméstico. Sistemas de Objetos" para interpretar las prácticas y los modos de vida del sujeto contemporáneo desde los años de posguerra hasta finales de los 80 , años entre los que se ha vivido un proceso de transformación de los valores y que el autor define así:

(...) si en los sesenta éste ${ }^{30}$ es todavía un cruce entre el autómata de ciencia ficción de Archigram y el hombre 'natural' de Reyner Banham ${ }^{31}$, el hippy, hoy este sujeto, ya descrito en su itinerancia e imprecisión, ha abandonado por completo aquella militancia técnica y vital volcando sus intereses a un mayor reconocimiento de la propia subjetividad que comenzaría, probablemente, por una reconstrucción de su propio cuerpo, por una subjetivación de la experiencia que viene asociada al medio productivo y sus prácticas derivadas como el consumismo o la particular relación, aleatoria y banal que establece con las cosas. En gran medida se trataría de una nueva, manipulada y sofisticada ejercitación de la reconstrucción del individuo, un modelo de conducta sintetizado con especial precisión en los proyectos desarrollados en torno a la "Chica nómada de Tokio"32 (PAO 1,1985 y PAO 2, 1989) sin duda una de las propuestas recientes más sólidamente argumentadas en torno a la pregunta qué puede ser una casa nómada treinta años después de la Un-home.

Este argumento de Herreros sirve como referencia para la acotación en el tiempo de la presente Tesis. Entre dos propuestas que, como veremos, sintetizan el espacio doméstico en un sistema de elementos con cuya relación,

29 Juan Herreros, "Espacio Domestico. Sistemas de Objetos". AULA 261, Universidad San Pablo CEU, 2012. http://aula261.blogspot.com.es/.

$30 \mathrm{El}$ autor se refiere al sujeto contemporáneo.

31 El autor se refiere a la propuesta Un-home, que Banham publicó en 1965 y de la que se ha hecho referencia en el apartado anterior.

32 En el n 351 de julio de 1986, la revista Japan Architect, publicaba la primera instalación con el nombre de "The Pao for Tokyo's nomad woman", sin embargo en otras publicaciones aparece como "Pao for the Tokyo nomad girl". En realidad el personaje pretende ser bastante joven, por lo que en esta Tesis se ha decidido traducir como "El Pao de la muchacha nómada de Tokio". 
entre ellos y con el personaje que lo habita, se explica la evolución del sujeto contemporáneo y el desarrollo de la idea de hogar a través de los objetos. El lapso de tiempo abarca pues tres décadas, de los 60 a los 80, que representan años de cambios y de proceso en el espacio doméstico contemporáneo. Un periodo cuya evolución, desde la sociedad hasta la arquitectura, Mary McLeod sintetiza perfectamente en su artículo "La era de Reagan, del posmoderno a la deconstrucción" ${ }^{\prime 3}$ desde los 60 , en los que la autora encuadra en el movimiento posmoderno, el periodo en el que los arquitectos buscan la justificación ideológica no en el programa, ni en la función, sino en el significado, y abanderan la defensa de la complejidad como algo perdido durante el movimiento moderno. Entre ellos estan Robert Venturi, Denise Scott Brown o Colin Rowe. Posteriormente pasa por los 70 en los que la incorporación de la cultura popular en el discurso arquitectónico podía verse reflejada en arquitectos como Charles Moore, y llega hasta finales de los 80, como un periodo de auge económico que da paso al abandono de las dimensiones críticas y transgresoras de las décadas anteriores y ratifica un estado de cultura ecléctica atada a las fuerzas del consumo y la acomodación. La idea que tenían muchos marxistas de los 60, que consideraban que la tecnología era esencial para mejorar la vida social, en los 80 pasa a considerar la tecnología como una fuente de placer y de juego, cuya tendencia es a lograr que el contenido del entorno doméstico sea cada vez más efímero, fácilmente transformable y consumible. Este espíritu, inmerso en las prácticas de consumo y la cultura de seducción, define los modelos de conducta de finales de los 80 , y que se ven fielmente reflejados en torno a 'la muchacha nómada de Tokio', en el Pao-1 de 1985 y el Pao-2 de 1989, presentados por el arquitecto Toyo Ito en un centro comercial de Shibuya, Tokio.

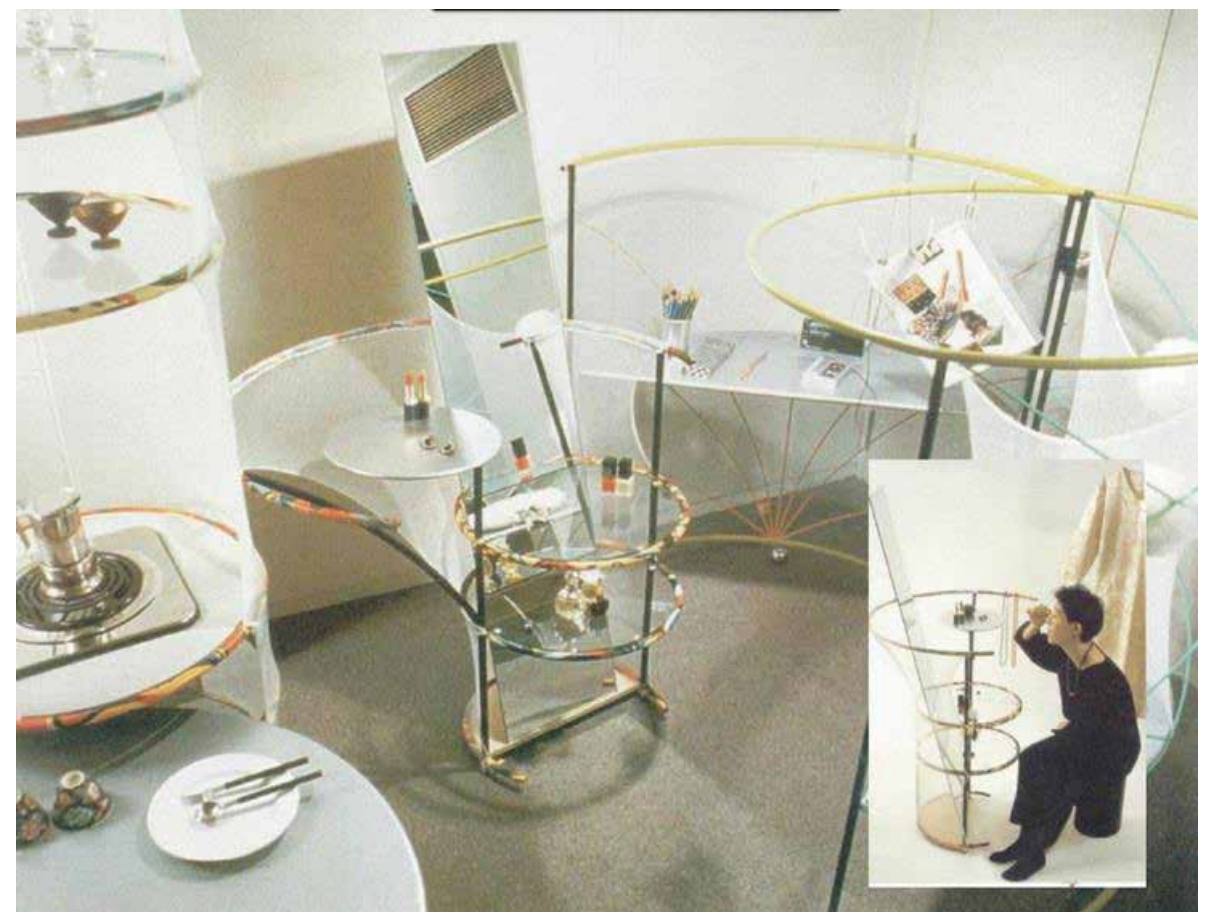

Los modos de vida de los nuevos habitantes urbanos, que ya se relacionan a través de las redes, representados por las muchachas nómadas, aparecen encarnados en sus casas y sus objetos. El Pao o tienda de campaña, es la casa, de piel translúcida y transportable, y se coloca suspendida en los parques o lugares públicos. Dentro de la tienda solamente se sitúa una cama y otros tres muebles a su alrededor. Los objetos son livianos, casi transparentes

33 Mary McLeod. "Arquitectura y política en la era de Reagan. Del posmoderno a la deconstrucción". Arquitectura Viva, (n8, oct-1989), 7-19.
Imagen: El Pao de la muchacha nómada de Tokio, Pao-1. Japan Creative Exhibition, Sheibu Department Store en Shibuya, Tokio. Por Toyo Ito en 1985. Vista de los muebles que ocupan el interior del Pao. 
y representan tres facetas de la vida de la muchacha: el mueble para la acción de estar informada y conocer las actividades de la ciudad, el mueble para el coqueteo y actividades relacionadas con la imagen personal y por otro lado el mueble para el consumo de comida ligera. "La muchacha deambulaba por los espacios muy de moda y pasa la vida cotidiana como en un ensueño"34.

El Pao de Toyo Ito se conforma en torno a un sistema de objetos etéreos entre los que el sujeto se desenvuelve de modo afectivo más que funcional. Prevalece el hedonismo, en un escenario en cuya transparencia se disuelve la privacidad. Este es el momento en el que se produce ese cambio de escenario, pero también un cambio de intereses y de sistemas de relaciones, y en el que se cierra el paréntesis que acota cronológicamente la presente Tesis. Ambas propuestas, que representan distintas fases de un proceso, tratan de características e ideas que rondan en torno al hábitat del momento a través de objetos, en ámbitos difusos con vocación de escenarios abiertos previstos para la acción humana. Los objetos toman especial protagonismo repesentando entornos domésticos que son reflejo de las ideas que giran en torno al desarrollo del hábitat contemporáneo. Así pues, en el estudio de los objetos, de las ideas y de los ámbitos, se basa el presente trabajo, para deducir tras un proceso de análisis los sistemas de relaciones de objetos que configuran el espacio contemporáneo.

(...) cómo son vividos los objetos, a qué otras necesidades aparte de las funcionales dan satisfacción, cuales son las estructuras mentales que se solapan con las estructuras funcionales y las contradicen, en qué sistema cultural, infra o transcultural se funda su cotidianidad vivida.

Jean Baudrillard 35

Surge una nueva visión de los objetos en el marco contemporáneo, en un mundo cuyo rasgo más peculiar precisamente reside en la proliferación y consumo de productos manufacturados. En una cultura básicamente 'objetual', arquitectos, psicólogos, sociólogos, ponen especial atención en encontrar los conceptos que giran en torno a la consideración moderna del objeto, sobre todo en el contexto del espacio doméstico como el último eslabón de la cadena comercial. En este aspecto, por su influencia como elemento de consumo, autores como Roman Gubern ${ }^{36}$ hacen hincapié en el interés sociológico y la urgencia de nuevas definiciones, teorías, sistemas de clasificación y de otros medios de acercamiento a las ideas ligadas al objeto cotidiano. La mayoría de las teorías estudiadas, de sociólogos y semiólogos como Baudrillard, Moles 0 Barthes, coinciden en la faceta semántica del objeto moderno, y de su influencia en la configuración del espacio contemporáneo, estableciendo incluso normas sintácticas que regulan la colocación de los elementos en el espacio ${ }^{37}$. En este trabajo se abarcan los nuevos conceptos, ligados a diferentes aspectos como la prevalencia del significado, la incidencia de la nueva transformabilidad de los muebles, la consideración de la influencia psicológica de los objetos en el espacio, su implicación por la fenomenología aplicada a la arquitectura, etc. Son conceptos que en muchos casos van ligados a modos de actuación,

34 Toyo Ito en "El pao de las muchachas nómadas de Tokio" (1988) Edit. por José Ma Torres Nadal en: Toyo Ito. ESCRITOS. (Murcia: Colegio de Aparejadores de Murcia, 2000), 61-65.

35 Jean Baudrillard. El Sistema de los Objetos (México: Siglo XXI, 1969), 2.

36 Roman Gubern en Prólogo, en Abraham A. Moles, Teoría de los objetos (Barcelona: Gustavo Gili, 1975.

37 Abraham A. Moles, Teoría de los objetos (Barcelona: Gustavo Gili, 1975) p.111. Moles enuncia las 'Leyes de sintácticas de acoplamiento'. 
para cuyo análisis algunos estudiosos, como Roland Barthes ${ }^{38}$, recurren al distanciamiento, para analizar el comportamiento del objeto en su modo más enfático e intencional, cuyo orden viene dado, por ejemplo, por el teatro, el cine 0 la publicidad.

Recurriendo a este método de Barthes, se analiza el comportamiento del objeto implicado en una forma de publicidad: las ferias, muestras y exposiciones de mobiliario, equipamiento y accesorios domésticos. Así, en este estudio, se incide sobre las ideas que giran en torno a la vivienda contemporánea como respuesta a los nuevos modos de vida. Y por ello son de gran relevancia los conceptos que surgen de las exposiciones y muestras de mobiliario y objetos del hogar, dada la importancia en sus modos de actuación para llegar a la redefinición de una forma ideal de vida. El alcance cada vez mayor de los medios de comunicación y la llegada así de la información a sectores más amplios de la sociedad, hace que las muestras tomen especial relevancia como modo de expresión y divulgación. Emilio Ambasz, comisario de la mítica exposición Italy: The New Domestic Landscape, celebrada en el MoMA de Nueva York en 1972, planteaba la muestra como los resultados de "una investigación del paisaje doméstico con el sentido de sus lugares y la postulación de espacios y objetos que dan forma, las ceremonias y formas de conducta que les dan un significado"39. Lo que da testimonio de que en estas ferias se están gestando importantes ideas que relacionan nuevos modos de vida con objetos y ámbitos. Desde las exposiciones Good Design organizadas por el MoMA en los 50 que dan muestra de cómo debe vivir cómodamente el ciudadano medio americano a través de montajes realizados por los Eames, Paul Rudolph y otros tantos arquitectos de la época, hasta las Triennale de Milán ${ }^{40}$, que se convierten en una plataforma de reflexión sobre los nuevos modelos de vivienda surgidos de los modos de vida del momento, sin perder el carácter poético y experimental, y donde el objeto cotidiano se convierte en pieza fundamental en la recreación de los ambientes domésticos, entornos que en realidad reflejan las características que se aproximan a lo que serían los ámbitos reales. Por lo que el análisis de los casos reales, que se vinculan a través de un sistema de clasificación, las características de los ámbitos y los modos de relación de objetos en el espacio, es lo que ocupa la última parte de este trabajo y ratifica la tesis de partida.

38 Roland Barthes, "Semántica del objeto" en Arte e Cultura nella civilita contemporánea, editado por Piero Nardi (Florencia: Sansoni, 1966).

39 Emilio Ambasz, "El diseño como postulación". Temas de Diseño (n³, jul/ago-1972), 15.

40 Una de las más significativas es la XVII Trienal de 1983, llamada "Le case de la Triennale". 


\section{Configuraciones del espacio a través de los objetos Objetivos}

Como se ha expuesto en los apartados anteriores, el proceso progresivo de liberación socio-cultural y de cambios en los hábitos de consumo, a partir de los años de posguerra, han ido involucrando al espacio doméstico en el panorama contemporáneo. Los nuevos modos de habitar producen importantes alteraciones en los aspectos que caracterizan el hogar tradicional. La apertura social se traduce en espacios también más abiertos y diáfanos. Los avances de la técnica permiten que los artefactos, máquinas y muebles adquieran mayor autonomía respecto a lo construido. Las nuevas prácticas de consumo y la implicación del diseño en los equipamientos llevan hacia una nueva consideración del bienestar y el confort, dirigiendo su mirada hacia los objetos más que al contenedor en sí mismo. La vivienda tradicional es puesta en cuestión, y el hogar puede plantearse en cualquier lugar. Lo característico se va convirtiendo en habitual, y difiere de lo establecido hasta el momento. Los espacios, más libres y también más ambiguos, responden a nuevas necesidades de flexibilidad y polivalencia.

En ese contexto, el equipamiento empieza a marcar las pautas, no sólo en cuestiones de bienestar, sino en los procesos distributivos y organizativos, pasando de los tabiques y muros -que van siendo cada vez más escasos 0 móviles- a los muebles y objetos como elementos ordenadores del espacio. Ahora es el mobiliario el que participa en la organización de la planta, en base al programa. La polivalencia de los espacios hace posible que los habitantes puedan ocupar y transformar las habitaciones según sus necesidades, y un sistema de organización de mobiliario fácilmente cambiante puede conseguir variar la función de la pieza según la hora del día, la estación del año...

En este proceso de transformación del hábitat, la sociedad reclama un nuevo espacio cuyo rasgo más característico reside en la proliferación en su interior de objetos manufacturados para su consumo, en el incremento del valor de las pertenencias y también en la consideración de los aspectos ligados a la percepción sensorial en el marco en que se ubican. En la casa contemporánea la funcionalidad ya no es la única justificación, el cuerpo se convierte en una referencia ergonómica y en el depositario de las sensaciones de confort asociadas a los sentidos. La orientación en el espacio y el sistema háptico o sentido del tacto, empiezan a ser parte fundamental para el entendimiento de la tridimensionalidad, encontrando en los objetos propiedades hápticas excepcionales ${ }^{41}$, "son el sine qua non de la experiencia arquitectónica"42. La casa surge como una auténtica metáfora corporal donde existe una relación directa entre los sentimientos asociados a las interacciones del cuerpo con las cosas o con otras personas y su reflejo en las actividades domésticas. Este punto de vista hace entender el interior como un lugar en el que las personas se mueven llevadas por acciones, inducidas por la disposición de ciertos hitos o señales.

El argumento espacial según la relación de los elementos entre sí y por su interacción con las personas, según sus formas de significación y de relación, es el aspecto que mueve a esta investigación. Estudiar los efectos configurativos de sistemas, generados por las conexiones entre elementos dentro del

41 Pensadores como Henry Lefebvre en La producción del espacio (edición original 1974), y arquitectos como Charles Moore y Kent Bloomer, en Cuerpo, memoria y arquitectura (edición original 1977) tratan del movimiento del cuerpo como una forma de conformar espacio.

42 Charles Moore y Kent Bloomer, en Cuerpo, memoria y arquitectura Introducción al diseño arquitectónico. (Madrid: H. Blume, 1982) p.46. 
espacio doméstico, como un factor contemporáneo y como consecuencia de las nuevas maneras de entender el ámbito doméstico, es uno de los objetivos de esta tesis.

Con estas premisas es importante recalcar que cambia la manera de entender los objetos y de relacionarse con ellos. Al mismo tiempo que varían las relaciones del individuo con la familia y con la sociedad, cambian también los objetos, el mobiliario y su organización. Arquitectos como Colombo comienzan a trabajar con sistemas de mobiliario teniendo en cuenta no sólo el sentido espacial sino también el temporal. Introduciendo el parámetro espacio-tiempo a través de muebles transformables y movibles, se aumentan las posibilidades del espacio doméstico dirigiendo los intereses hacia la simultaneidad. Es objeto de esta tesis indagar en estas cuestiones: desde el punto de vista de la conformación de los espacios, establecer relaciones entre las características de las casas que reclaman los nuevos modos de habitar y la manera en que los elementos, también asociados a las necesidades del habitante contemporáneo, se organizan con una finalidad. Por ejemplo analizar cómo determinados elementos, movibles, transformables, variables, dentro de un espacio, y constituidos como un conjunto cambiante, son agentes activos en la configuración de un espacio que responde a unas determinadas características, en este caso, la de ser flexible, polivalente, multifuncional.

Ante la vivencia de los objetos frente a sus nuevas acepciones, aparte de las funcionales, para entender el sistema cotidiano de los objetos en el marco contemporáneo el análisis funcional se hace insuficiente, por ello los estudios se dirigen hacia el sistema 'hablado' de los objetos, hacia el análisis del discurso que establecen gracias a su significado. El objeto se 'libera' de su función y libera también al hombre moderno de su relación con el objeto según los parámetros tradicionales. Los elementos cotidianos dejan de ser exclusivamente funcionales. Es objetivo de esta investigación averiguar, a través del estudio de teorías, definiciones y clasificaciones, los planteamientos más importantes en torno al objeto con el fin de entender su nuevo papel en el espacio doméstico contemporáneo, donde el espacio discurre entre los objetos, donde se convierte en el fenómeno de sus relaciones: "Una cama es una cama y una silla es una silla, no hay relación entre ellas mientras no sirvan más que para lo que sirven. Sin relación no hay espacio", decía Baudrillard ${ }^{43}$. El espacio surge en una correlación de objetos, liberados de su función dentro de una nueva estructura. Frente a un sistema constituido en sus relaciones, según una combinatoria que podría ser ilimitada, es necesario saber si esa falta de límites les confiere todas las opciones y cuáles son las posibilidades en esa combinatoria. El espacio surge como una estructura de distribución. A través del control de ese espacio se dispone de todas las opciones de relaciones recíprocas y en este aspecto, uno de los objetivos principales es deducir, de todas las posibilidades, las más significativas de todos los papeles que podrían desempeñar los objetos, y su incidencia en las características del espacio en el que se ubican. El habitante contemporáneo utiliza pues los objetos en el proceso de manipulación, de ordenación, control y dominio; en la búsqueda del equilibrio táctico del sistema. Partiendo de que la organización de las cosas pretende ser objetiva, incluso tras un proyecto de ordenación en el que todo comunica, en el interior contemporáneo aparece otra variante unida al sistema de colocación: la creación de ambiente. Así pues otro de los objetivos es reconocer el concepto de ambiente como un sistema de tratamiento del espacio, desde el punto de vista del uso del objeto como signo, como factor

43 Jean Baudrillard. El Sistema de los Objetos (México: Siglo XXI, 1969), 17. 
cultural y social, así como desde la relación del objeto en el espacio con otros factores como son el color, la textura, el olor, etc. Sistemas que despiertan los sentidos, que enfatizan la labor semántica del objeto y donde en muchos casos los avances técnicos comienzan a estar involucrados.

La creación de ambiente realmente surge como un imperativo publicitario en la cultura de consumo. Estando inmersos en una sociedad ya establecida en un mundo de producción y promoción son también las exposiciones las que influyen en la manera de visualizar los interiores domésticos, sobre todo en cuanto a la recreación de esos ambientes. En las exhibiciones de espacios interiores, en las muestras de mobiliario y equipamiento, los objetos ejercen esa labor de juego y de cálculo, en su estado más enfático. Su colocación se convierte en factor de ambiente. En estas muestras en estos años, que generalmente están patrocinadas por productoras de muebles 0 de electrodomésticos, el recurso de la representación de escenas domésticas para la promoción de los productos es bastante utilizado, de manera que se instaura como una forma de ambientación en torno a la interacción de unos personajes con sus muebles, equipamientos, objetos domésticos en general, en una recreación de ámbitos ideales que invitan a determinados modos de vida gracias a cómo organizar o de qué manera utilizar el equipamiento. Por ello, es objeto de esta investigación estudiar estas muestras como ejemplos de sistemas organizativos y de creación de ambiente, lo cual, al ser mayormente intencional, permite estudiarlo desde un punto de vista más objetivo. Muchos montajes en algunas de las exposiciones trascendieron y aparecen en los textos de referencia de la historia de la arquitectura. Aun siendo instalaciones efímeras y temporales influyen en gran medida en la consolidación de nuevos hábitos domésticos y en la evolución de la vivienda en general.

Al discurso del ambiente se unen otros factores. En la combinación sistemática de elementos surge el 'aditamento'44 como componente subjetivo que se incorpora al espacio y que incide principalmente en la percepción y en la vivencia del mismo. Al sistema de conjunto, al mismo tiempo o en situaciones distintas, con el fin de recuperar otro factor olvidado por la arquitectura como es la memoria, se añaden también otras connotaciones ideológicas y culturales a través de objetos antiguos, elementos singulares, barrocos, folklóricos, exóticos, que representan el tiempo, respondiendo a deseos de la índole de testimonio, recuerdo, nostalgia, evasión: "al rodearnos de cosas que tienen para nosotros un significado especial, podemos añadir una nueva dimensión al lugar que habitamos y a su capacidad para nutrir nuestra imaginación", reclamaban para sus casas Moore, Allen y Lyndon ${ }^{45}$. Estudiar el papel que juegan estos elementos en la percepción de los espacios y en su configuración es parte de esta tesis. Analizar para poder explicar cómo significan y de qué manera influyen en el desarrollo de los interiores domésticos, en un mundo de consumo e imagen. Incluso ante sistemas como las colecciones, frente a antecedentes como la antigua casa museo de John Soane en Londres ${ }^{46}$, es

44 Charles Moore, Gerald Allen, Donlyn Lyndon en La casa: forma y diseño. (Barcelona: Gustavo Gili, 1999) p.214, hablan de la posibilidad de añadir algo a la casa con objetos personales, colecciones, etc. con el fin de que las connotaciones que llevan implícitas, recuerdos, vivencias, preferencias, puedan establecer un vínculo entre el espacio y el que lo habita.

45 Ibídem.

46 Casa Soane, Londres por el arquitecto John Soane en 1792-1834, de la cual Pedro Moleón en John Soane (1753-1837) y la arquitectura de la razón poética, (Madrid: Mairea, 2001) p.170, dice: "Se crea así un espacio que define su perímetro por los elementos que colonizan su interior, mediante relaciones de situación entre los miembros del sistema con ellos creado (...) Importa más que los objetos en sí, la interrelación que se establece entre ellos en función de su posición relativa". 
objetivo de este estudio analizar de qué manera actúa un grupo de elementos reunidos bajo una pasión privada, en un mundo de avances tecnológicos, dentro de los hogares contemporáneos. Su reconocimiento como sistema de configuración, incluso como elemento inherente al propio espacio, hace que encontremos sistemas de objetos conectados de forma similar en el siglo XX, a través de la casa de los Eames o en proyectos de Steven Holl, con un lenguaje lógicamente diferente.
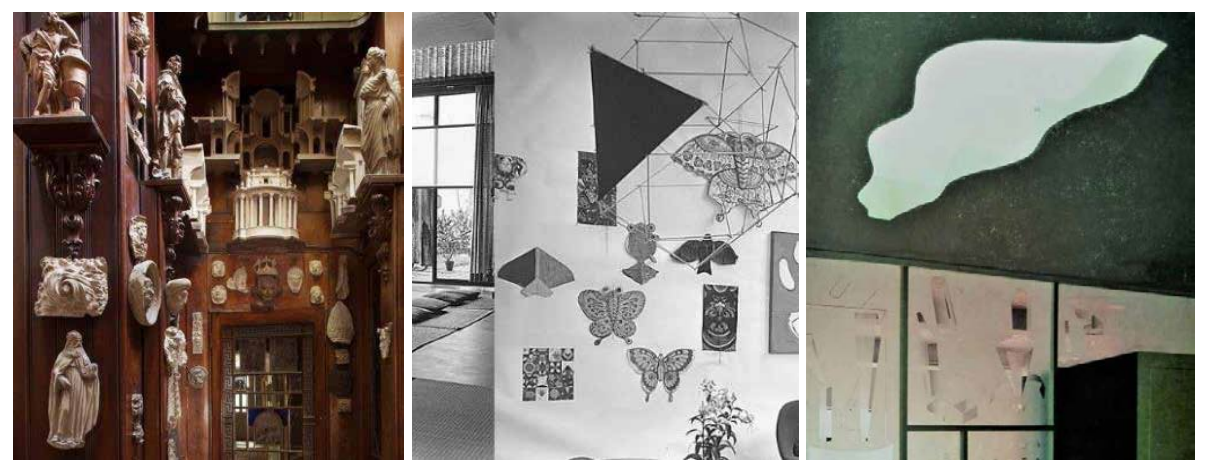

Los objetos al igual que comunican, también evocan y actúan como nexo, como unión emocional entre el sujeto y el espacio que habita. Son como su propio espejo, ya que el usuario es quien los controla. Pero también son reflejo de la sociedad y marcan el estatus. Incluso delimitan su propio territorio en torno a ellos y establecen jerarquías en el espacio. En muchas ocasiones todo gira en torno a sus relaciones topológicas, a la interacción con los habitantes, a las tensiones provocadas por su disposición que, en muchos casos no está falta de una gran intencionalidad. Distribuyen y organizan, cualifican el lugar, lo transforman. Inducen al movimiento a través de recorridos, generan rituales. A través de relaciones formales, de interpenetración o de disolución, funden con la piel que delimita el entorno. Nuestros objetivos están puestos en analizar y reconocer todos estos sistemas de configuración.

Frente a una condición distinta del objeto, en un tiempo de cambios socioculturales, de nuevos hábitos de consumo, en el que la imagen, la publicidad y las exposiciones y ferias de mobiliario hacen llegar a la sociedad el mundo del diseño, nos interesa conocer cuáles son los mecanismos empleados y qué ideas son las que se manejan para influir en los modos de vida, en los ambientes, en los interiores domésticos. Frente a nuevos espacios, que surgen por los avances de la técnica, por las nuevas necesidades, por los cambios culturales, donde proliferan los objetos cotidianos, y adquieren más acepciones, los objetivos son estudiar cómo intervienen en la configuración espacial, cuáles son los sistemas de relación, de conexiones, de organización, y cómo intervienen en las características y cualidades del espacio. Indagar sobre las asociaciones funcionales y formales de los elementos. Establecer que existen relaciones entre los nuevos modos de apropiación a través de objetos y la configuración de espacios domésticos contemporáneos.

Y también así poder responder a aquella pregunta, aparentemente ingenua, que se hacía Georges Perec ${ }^{47}$ :

Pequeño problema

Cuando en una habitación dada se cambia de sitio la cama, ¿se puede decir que se cambia la habitación, o qué? (Cf. topo-análisis).

47 Georges Perec. Especies de espacios. (Barcelona: Montesinos, 2007), 48. El autor plantea esta pregunta como reflexión y a través de la cual dirige al lector a un análisis topológico de la configuración del espacio.
Imágenes: de izda. a dcha:

Casa John Soane, Londres 1834.

Casa Charles \& Ray Eames, California 1949.

Apartamento Cohen. Steven Holl, Nueva York 1983 


\section{III. Ámbitos y elementos: Reconocimiento-análisis-clasificación. Método}

El trabajo para la elaboración de la presente tesis, se estructura en tres bloques metodológicos:

- El primer apartado comprende lo relacionado con el reconocimiento de la visión del objeto en el mundo contemporáneo. Se incluye el estudio de textos relacionados con teorías sociológicas sobre el objeto en el mundo contemporáneo, así como textos sobre el objeto desde un punto de vista compositivo, basado en relaciones topológicas y geométricas o en temas relacionados con la percepción y la experiencia. También se incluye el estudio y el análisis de propuestas concretas de arquitectos y diseñadores para deducir los conceptos fundamentales en torno al uso de objetos en sus proyectos. Así como un acercamiento a los modos de actuación con objetos, más sistematizados e intencionales, a través de las exposiciones y muestras del momento, de mobiliario, equipamiento y de diseño de otros enseres. Este bloque está orientado a obtener ideas que den apoyo al desarrollo del capítulo 1 -una nueva visión del objeto- en cuanto a los nuevos conceptos que giran en torno al objeto en el mundo contemporáneo, y parte del capítulo 2 -el espacio interior a través de las exposiciones-, respecto a su implicación en la recreación de espacios domésticos en las ferias de mobiliario y en muestras relacionadas con la vivienda y objetos para el hogar.

- El estudio de las características de los entornos en el periodo en el que se acota la investigación y una aproximación a su relación con los objetos, comprende el segundo apartado. Entre los trabajos programados es incluye la obtención de los casos concretos tras un proceso de selección con varios filtros según diferentes criterios. Las fuentes consisten básicamente en textos de historia de la arquitectura contemporánea, en monografías de arquitectos y en las publicaciones periódicas especializadas de mayor impacto de la época en la que se enmarca la investigación. Así mismo se incluye la selección y el análisis de propuestas que surgen de las ferias y exposiciones más importantes, las cuales, al tener un carácter empírico presentan mayor enjundia desde el punto de vista de la riqueza de las ideas que se obtienen en torno a los ámbitos domésticos y modos de vida del momento. El estudio de los entornos apoya, con las ideas obtenidas, lo expuesto en el capítulo 2 -el espacio interior a través de las exposiciones- y parte del capítulo 3 -objetos y espacio doméstico: relaciones y configuraciones-. Así mismo, el capítulo 2 -el espacio interior a través de las exposiciones- se convierte en la bisagra que articula el capítulo 1-una nueva visión del objeto- con el capítulo 3 -objetos y espacio doméstico: relaciones y configuraciones-, ya que involucra de forma directa los conceptos obtenidos en torno a los objetos y sus modos de actuación a través de las exposiciones, con los casos reales gracias a las ideas obtenidas en ese debate más teórico que se produce en las ferias, que en realidad se comportan como laboratorios de ideas.

- La realización de un sistema de clasificación es el último bloque. Para cumplir los objetivos propuestos es preciso elaborar una ordenación que establezca las relaciones que existen entre las características que son propias de los ámbitos y los modos de actuación de sistemas de objetos en el espacio. Esta clasificación se expone en el capítulo 3-objetos y espacio doméstico: relaciones y configuraciones-. Su elaboración surge del análisis de los casos seleccionados, de las ideas obtenidas respecto a la nueva manera de entender los objetos, de los sistemas de relación y codificación 
de los modos de acoplamiento, de las ideas respecto a los nuevos ámbitos y de los conceptos que surgen de la teoría estudiada y de lo experimentado en las exposiciones.

El método de trabajo hace que se solapen los tres bloques metodológicos con los tres capítulos del índice, lo cual permite interrelacionar cada uno de ellos durante el proceso de investigación y cuyo material empleado se detalla a continuación:

Respecto al reconocimiento del tratamiento del objeto en el mundo contemporáneo, con el fin de obtener una base teórica sobre la que apoyar esta investigación, se ha trabajado sobre aspectos conceptuales referidos directamente a los objetos. Sobre la visión del objeto cotidiano en el hábitat del usuario contemporáneo, se ha realizado una recopilación de textos a partir de los cuales se pueden elaborar argumentos para sustentar el presente trabajo. Para ello han sido fundamentales textos como teorías de objetos y sistemas de clasificación, de sociólogos y filósofos europeos de los años 60 y 70 como Jean Baudrillard -El sistema de los objetos, 1968-, Abraham A. Moles -Teoría de los objetos, 1972-, Roland Barthes -"La semántica del objeto", 1966-, y Monique Eleb -Penser l'Habité, 1988- entre otros. De los textos se extraen ideas sobre cuál es la visión de los objetos una vez reconocidos en el ámbito contemporáneo y las nuevas acepciones que se les atribuyen en un mundo en el que ya la sociedad de consumo y la cultura de la imagen han entrado en los hogares. En esta fase de trabajo, también se han estudiado textos más cercanos en el tiempo consiguiéndose así una visión más actual del tema. Escritos de Stan Allen, Steven Holl, Jorge Otero-Pailos, Imma Forino o Fernando Quesada, nos indican cuáles son las ideas que permanecen, cuáles no, y cómo han de aplicarse en el análisis. También se incluye en este apartado la visión del objeto desde la perspectiva del arquitecto, como elemento que interviene en el proceso de proyecto. Para ello, se obtiene información estudiando los modos de actuación utilizando como base determinados proyectos de la época, siendo necesario obtener datos de monografías y revistas especializadas. Sin embargo, también se hace hincapié en los textos, en general -tanto prácticos como teóricos-, escritos por arquitectos como Charles Moore, Christian Norberg-Schulz 0 Kenneth Frampton, con el fin de contar con la mayor información posible sobre sus intenciones proyectuales y la base teórica aplicada. De forma similar, se obtiene información sobre los modos de actuación con objetos a través del estudio de las propuestas presentadas en las exposiciones por arquitectos y diseñadores como Joe Colombo, Verner Panton, Ettore Sottsass, Superstudio, o Rem Koolhaas, entre otros. De la misma manera, también se hace hincapié en lo teorizado por los autores en torno a sus propuestas.

Respecto a los ámbitos domésticos, su recopilación y selección está basada en el cumplimiento de determinadas condiciones que los califiquen como representativos de las ideas sobre las que pretendemos ahondar. Para esta labor se ha recurrido a fuentes de relevancia: textos generales de teoría e historia de la arquitectura, publicaciones periódicas especializadas, revistas y monografías sobre vivienda de la época, tanto de arquitectura como de diseño de interiores, artículos sobre proyectos concretos de interés, así como monografías publicadas sobre la obra de arquitectos concretos cuyo trabajo e ideas tienen una influencia notable en este trabajo, como Charles W. Moore y estudios de arquitectura organizados en torno a él como MLTW, de otros como Frank O. Gehry, Herman Hertzberger, Robert Venturi o Carlo Scarpa y de generaciones posteriores como Steven Holl, Rem Koolhaas, Toyo Ito o Jean Nouvel. Este material es utilizado, por un lado para deducir los factores que 
caracterizan los espacios domésticos contemporáneos, así como para obtener un soporte documental para una posterior fase de análisis y clasificación. Así mismo, tal y como se ha explicado anteriormente, de los interiores domésticos representados en las ferias y exposiciones de la época, se han seleccionado los que realmente trascendieron y los que tuvieron mayor intención de dejar su impronta por las ideas que transmiten. La intención primera de estos montajes es la de promocionar los productos, para ello recreaban ambientes basados en la representación de modos de vida relacionados gracias a la disposición de los elementos estratégicamente colocados en ámbitos perfectamente ambientados en la vivencia del espacio entre y con los objetos. Muchos de aquellos montajes, a pesar de que su intención principal es, en la mayoría de los casos, la de inducir al uso y consumo de los equipamientos y objetos, sirven para reflexionar sobre el panorama doméstico del momento. Al igual que en el bloque metodológico anterior, el estudio y el análisis de estas muestras sirven como base para obtener ideas sobre las características de los interiores domésticos del momento, ya que respondían a las demandas de los usuarios y estaban a la vanguardia del diseño y de los nuevos modos de vida. De esta manera se obtienen argumentos para apoyar la proposición de que estas muestras influyen en los sistemas de configuración de los hogares contemporáneos, marcando tendencia sobre la conformación de los espacios y los modos de vida que allí se desarrollan, en base a la interacción con los productos -los objetos- presentados por los patrocinadores y productores. Nos referimos a empresas que han dejado su impronta en el mundo del hogar como Herman Miller, Poltronova, Simon, Cassina, Oluce, entre otras, e incluso a multinacionales como la empresa química Bayer que promovió los 'Visiona' de la Feria del Mueble de Colonia a finales de los 60 y en los 70. Esta exposición, como otras muchas de las que se tratará en los próximos capítulos, es la ocasión para los diseñadores de experimentar y estar a la vanguardia de los avances técnicos aplicados al hogar, pero también son una oportunidad, aunque sea de modo artificial, para visualizar la escena y utilizarla como medio de difusión y de acercamiento al público. De este bloque metodológico y documental se obtiene la información suficiente para el desarrollo de la última fase, que vincula las características de los entornos, con los sistemas de objetos.

Para la elaboración del sistema de clasificación se tienen en cuenta por un lado la ideas y conceptos obtenidos en torno a las consideraciones sobre objetos en el mundo contemporáneo: los nuevos conceptos, los diferentes sistemas de relaciones, las leyes y normas de colocación, las teorías sobre percepción y las nuevas conformaciones que se producen en los nuevos ámbitos. Y por otro lo que se deduce tras el reconocimiento de los ámbitos domésticos analizados: las ideas y las características de las viviendas, tanto desde el punto de vista espacial como desde la perspectiva de los modos de apropiación, así como de los modos de relación de sistemas de elementos que se detectan en el análisis de los casos reales. De manera similar se procede en el reconocimiento de los montajes analizados en las exposiciones, sin embargo al tratarse de casos experimentales, se incide más en las ideas que en la propia forma. De esta manera, aislados estos aspectos, se procede a la elaboración de un sistema de clasificación que consiga identificar configuraciones basadas en relaciones y conexiones entre elementos y las vincule a las características de los ámbitos generados. Siempre dentro del marco doméstico y entre las décadas de los 60 a los 80 . Para una mejor comprensión, se elabora un sistema de esquemas gráficos con el fin de sintetizar visualmente cada uno de los apartados de la clasificación.La estructura finaliza con las conclusiones, que estarán basadas en lo investigado en los apartados anteriores y en las que se incidirá en los sistemas de objetos y en las características de los ámbitos domésticos. 
IV. Marco teórico y práctico. Estado de la cuestión

El cuadro de Antonello de Messina titulado San Jerónimo en su escritorio -1475, y el análisis que hace Georges Perec en Especies de Espacios -1974- sobre la composición de una escena que representa un ámbito configurado gracias a un sistema de objetos, nos sitúa de forma muy clara sobre los mecanismos en los que se basa la presente investigación: un grupo de objetos, a través de sus relaciones, en un marco concreto, reconfiguran un espacio -existenteconfiriéndole nuevas cualidades.

Todo el espacio se organiza por entero en torno a este 'mueble' -y el mueble se organiza por entero alrededor del libro-: la arquitectura glacial de la iglesia (...) sus perspectivas y sus verticales ya no delimitan el único lugar de una fe sublime; solo están presentes para dar al mueble su escala, permitirle su inscripción: en el centro de lo inhabitable, el mueble define un espacio domesticado que los gatos, los libros y los hombres habitan con serenidad.

\section{Georges Perec ${ }^{48}$}

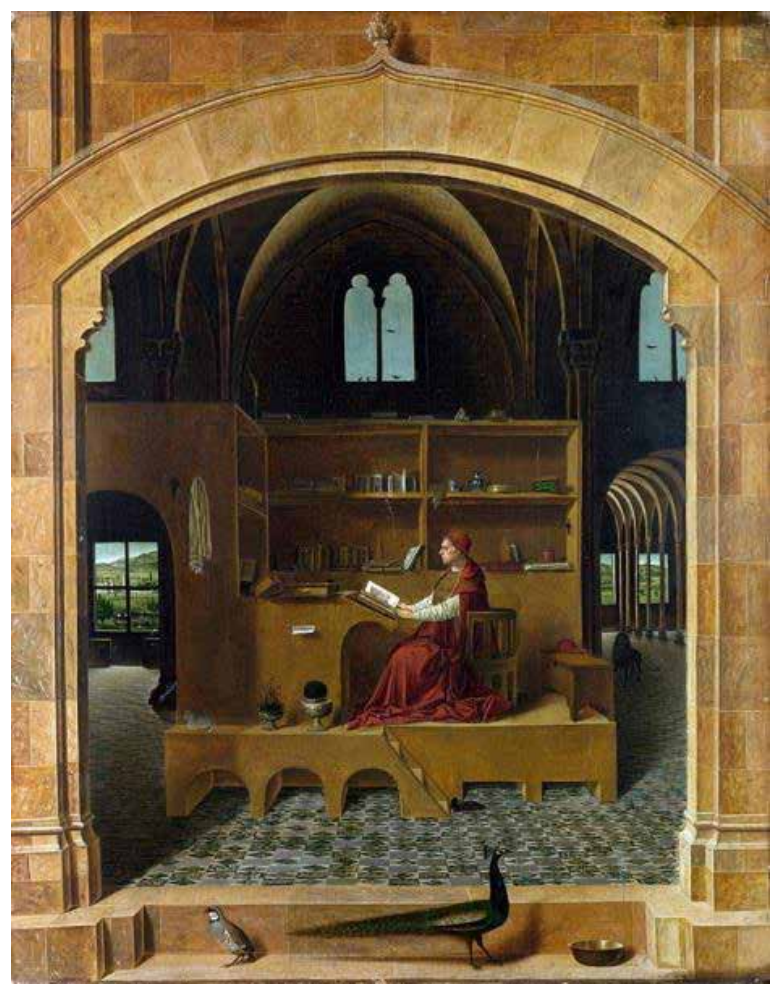

El análisis de Perec hace ver al espectador que un espacio de las dimensiones de una catedral puede llegar a adquirir una condición distinta -domésticagracias al 'lugar' que configuran un grupo de objetos, y que da cobijo al personaje de la pintura. En sus relaciones se advierten jerarquías por los diferentes tamaños, pero también existe orden y estabilidad. El mueble define un espacio de confinamiento y domestica lo 'inhabitable' con juegos de escala y con un recurso muy utilizado en los $60^{49}$ creando distintos grados de interior, 0 de privacidad. Lo que se llama 'la casa dentro de la casa'. En Especies de Espacios, se aborda un tema importante para la comprensión del tema que se trata en esta Tesis, y es el del análisis del espacio interior a través del

48 Georges Perec. Especies de Espacios. (Barcelona: Montesinos, 2007), 132.

49 Entre otros, este recurso se ve muy utilizado en proyectos de Hans Hollein, George Ranalli, 0 Charles Moore.
Imagen: San Jerónimo en su estudio. Antonello de Messina 1474-75. National Gallery. Londres. 


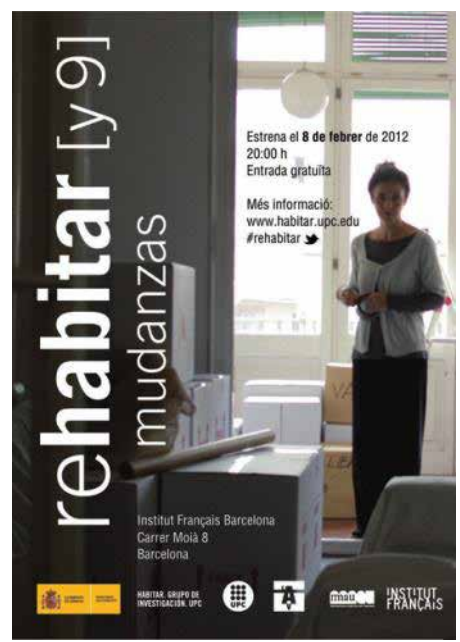

Imagen: Video 'Mudanzas', 2012. Del proyecto Rehabitar, UPC. Por Xavier Monteys y Silvia Glez. Laá.
Imagen: Dibujo que corresponde a la conferencia realizada por Xavier Monteys en la ETSAM en 2013, sobre la fase Rehabitar 9 Mudanzas perteneciente al proyecto de investigación 'habitar' de la Universidad Politécnica de Cataluña. significado de las cosas. Perec hace crítica del espacio tanto desde el punto de vista de la memoria, de lo que evocan los muebles -algo similar a lo que podemos encontrar en el libro de Mario Praz, La casa de la vida- como desde el punto de vista de las relaciones topológicas. Cuando Perec se plantea si una habitación se convierte en otra por el mero hecho de modificar la posición de la cama ${ }^{50}$, está abriendo un debate que se refleja perfectamente en el cortometraje "Mudanzas"51 ideado por Xavier Monteys, director del grupo de investigación 'habitar' de la Universidad Politécnica de Cataluña, que trabaja sobre nuevas formas de vida, tanto en el ámbito doméstico como en el urbano.

"Mudanzas" es parte del proyecto 'Rehabitar' que, a medio camino entre el ensayo arquitectónico y la ficción cinematográfica, a través de la historia de una familia al completo inmersa en una mudanza, ejemplifica y hace real la cuestión anteriormente planteada: los muebles, los objetos, tienen capacidad para transformar la configuración del espacio en virtud de su disposición y de sus relaciones topológicas y geométricas. Este acercamiento al tema que nos compete es una fase de un proyecto, editado, más amplio ${ }^{52}$ que contempla temas que son de interés para esta investigación. Por un lado, en este proyecto se trata la idea de la capacidad que tienen los muebles para convertir cualquier espacio en una casa. En 'Rehabitar' los muebles son planteados como la extensión de sus habitantes. Cambiar la disposición de los muebles, según este proyecto, es poner a prueba la capacidad de transformación de la casa. Pero además, esta publicación es un referente porque trata más aspectos que se contemplan en esta Tesis, como es el concepto de habitar basado en el reciclado y en el amueblamiento con objetos reconvertidos, aunque se aprecia una diferencia conceptual por las épocas. En la actualidad se plantea, en principio, desde el punto de vista de la sostenibilidad y en los años 60 , tenía intenciones más bien artísticas, con un sentido 'post-Duchamp', donde el uso del objet trouvé representaba un modo de habitar artístico y transgresor.

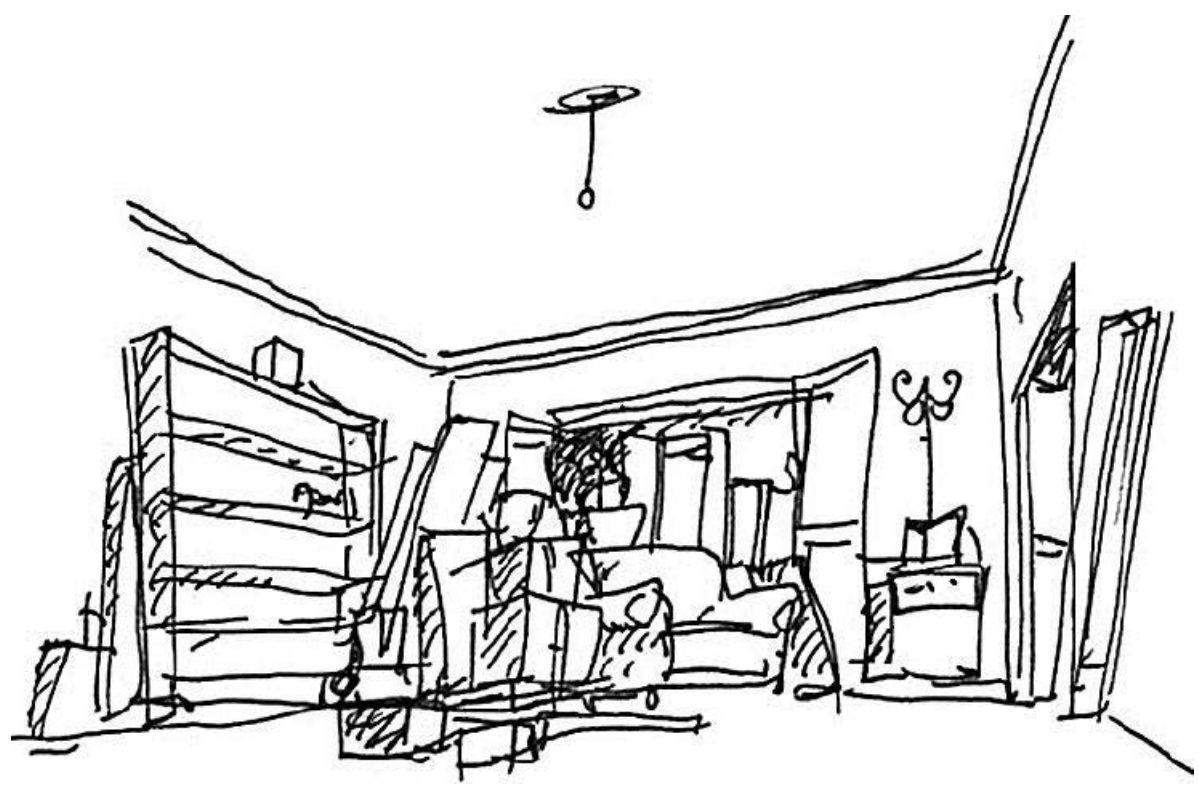

50 Citado en el apartado II "Configuraciones del espacio a través de los objetos. Objetivos" dentro de este capítulo. Georges Perec en Especies de espacios. (Barcelona: Montesinos, 2007), p.48, plantea esta pregunta: "Pequeño problema: Cuando en una habitación dada se cambia de sitio la cama, ¿se puede decir que se cambia la habitación, o qué?".

51 En http://habitar.upc.edu/2012/02/27/mudanzas/, guión y dirección: Silvia González Laá.

52 Xavier Monteys, Rehabitar. (Madrid: Lampreave, 2012). 
Desde el punto de vista del planteamiento del estudio del objeto como instrumento de proyecto, el único texto de los consultados que presenta un estudio directo desde esta perspectiva, es la publicación de 2010, Elementos y Objetos, de Graeme Brooker y Sally Stone ${ }^{53}$, aunque el enfoque es muy genérico respecto a los tipos de ámbitos y tiene un punto de vista práctico. Este libro trata el tema desde el diseño de interiores, a modo ilustrativo y casi con carácter didáctico. En él se ofrece una selección de casos, y se analizan desde el punto de vista del diseño de los espacios, de los aspectos funcionales, de los materiales empleados, de los ambientes que se generan, etc. Si bien esta publicación es aparentemente la más directa en relación con el tema propuesto, el planteamiento sin embargo difiere en esencia. A pesar de que parte del libro se centra en el análisis de los espacios y trata temas como la relación con los objetos y entre los propios elementos -su capacidad para manipular las pautas de circulación, de controlar el movimiento visual, de expresar jugando con escalas diferentes - sin embargo las conclusiones conforman un manual práctico para el ejercicio profesional. Incide poco en los conceptos, trata de los objetos como mecanismos para el diseño de interiores y los planteamientos son poco teóricos.

Planteamientos más conceptuales sí se encuentran en el texto de Imma Forino, L'interno nell'interno. Una fenomenología dell'arredamento ${ }^{54}$ que aborda el estudio del interior desde la perspectiva de la creación de nuevos espacios a través del mobiliario. Este texto es de interés porque utiliza el análisis para detectar sistemas creados por muebles que son capaces de generar espacio. El capítulo "Lo interior en el interior doméstico"55 trata de sistemas de elementos que se conciben tradicionalmente como espacios, como son los habitáculos de las camas entendidos casi como verdaderas habitaciones o los paquetes de equipamiento como resultado de los avances tecnológicos y de los nuevos modos de vida ${ }^{56}$. También aborda la idea de 'la casa dentro de la casa ${ }^{157}$ como como concepto y como mecanismo de proyecto desde el punto de vista conceptual, espacial y práctico, basándose en ejemplos concretos tanto antiguos como contemporáneos. Es de señalar que en este libro hay importantes referencias históricas desde la antigüedad hasta la segunda mitad del siglo XX. Este texto hace especial hincapié en el mobiliario y los objetos, de todas las épocas.

Más cercano en el tiempo, como se ha comentado en apartados anteriores, existe un acercamiento al objeto desde una nueva perspectiva e inmerso en una emergente cultura de consumo. Los cambios en los paradigmas de la sociedad, hacen que surja la necesidad de entender la nueva entidad del objeto. Este es un aspecto de gran importancia para entender el comportamiento del objeto en los nuevos ámbitos. De los estudios más influyentes publicados al respecto, en 1972, el ingeniero y sociólogo Abraham A. Moles, edita una Teoría de los Objetos $^{58}$, en el que aborda al objeto desde su definición, huyendo de las consideraciones más tradicionales. Ante la pregunta ¿qué es un objeto?, decide acercarse al mismo a través de diferentes sistemas de clasificación, basados en muy diversos factores, pero haciendo hincapié en todo momento en su factor semántico. Para plantearse cuales son los sistemas de configuración

53 Graeme Brooker y Sally Stone. Elementos y Objetos. (San Sebastián: Nerea, 2010).

54 Imma Forino. L'interno nellinterno. Una fenomenología dell'arredamento (Florencia: Alinea Editrice, 2001).

55 "L'interno nell'interno domestico", Ibíd. p. 19.

56 En "l'isola dei servizi", Ibíd. p. 69.

57 "Le case nella casa", Ibíd. p. 81.

58 Abraham A. Moles, Teoría de los objetos (Barcelona: Gustavo Gili, 1975) Edición original, 1972. 
o incluso para abordar otra posible clasificación, es importante establecer una definición o un grupo de definiciones de objeto en el mundo contemporáneo. En este texto se encuentran las claves para entender cómo se aborda el tema desde el campo de la sociología o la filosofía. Aparte de los distintos sistemas clasificatorios antes mencionados, Moles también enuncia algo que es de gran importancia para este trabajo: las 'leyes sintácticas de acoplamiento'. Estas normas de codificación de sistemas de posicionamiento de objetos, se basan en el concepto de orden en un espacio y en su sintaxis. Para enunciarlas, Moles pone como ejemplo los muebles que pueden existir dentro de una habitación.

Nuestro problema será ahora establecer las leyes del código, es decir, los modos de acoplamiento, la sintaxis de los objetos reunidos en el interior del discurso constituido por el despliegue cotidiano.

Abraham Moles ${ }^{59}$

Estas normas son de gran interés para este trabajo porque dese este momento se está codificando el comportamiento del objeto en el espacio, desde la perspectiva de su colocación y su significado.

Otro texto que aborda el tema del objeto en el mundo contemporáneo, desde la perspectiva de la semiología, es el editado en 1966 por el semiólogo francés Roland Barthes como trascripción de su conferencia "Semántica del Objeto"60. En este ensayo se encuentran valiosas reflexiones sobre el objeto de la cultura de consumo contemporánea, desde el punto de vista sintáctico. Sobre cómo los objetos han adquirido la capacidad de significar en el mundo moderno y en el espacio doméstico en concreto. Barthes también aborda estos temas desde la propia definición de objeto: "una cosa que sirve para alguna cosa" y aunque afirma que todo objeto tiene una finalidad, siempre hay un sentido que desborda el uso del objeto. En estas afirmaciones es de interés la consideración del objeto contemporáneo como elemento de consumo, y en el que prevalece en todo momento aquello que comunica, su significado. Aunque el texto no trata específicamente el tema del objeto desde el punto de vista de esta investigación, sí que lo enmarca en el contexto contemporáneo, y hace hincapié en un aspecto fundamental para nuestro análisis, el de la consideración del elemento cotidiano como comunicador, como vía de expresión del usuario dentro de su hábitat y como conexión con el mundo exterior a través de la imagen. Otro de los aspectos importantes de este texto para nuestra investigación radica en el método que establece Barthes para un análisis objetivo:

Para objetivar el objeto, estructurar su significación (...) hay un recurso que todo semántico del objeto puede emplear, y consiste en recurrir a un orden de representaciones donde el objeto es entregado al hombre de una manera a la vez espectacular, enfática e intencional, y ese orden está dado por la publicidad, el cine e incluso el teatro.

Roland Barthes ${ }^{61}$

Este principio ha sido de gran valor establecer la base para el análisis del capítulo 2 de esta tesis "El espacio interior a través de las exposiciones". Utilizando el razonamiento de Barthes, las exposiciones y muestras de

59 Abraham A. Moles, Teoría de los objetos. (Barcelona: Gustavo Gili, 1975) p. 111.

60 Roland Barthes. "Semántica del Objeto" en Arte e Cultura nella civilita contemporánea. Editado por Piero Nardi. (Florencia: Sansoni, 1966).

61 Ibídem. 
mobiliario que proliferaban en los 60 y 70 , y que en realidad son parte de la publicidad, se convierten en una base documental importante para elaborar este trabajo.

Dos años después, en 1968 Jean Baudrillard en El sistema de los Objetos ${ }^{62}$, también escribe sobre el mundo de los objetos cotidianos abandonando del todo el sistema de clasificación establecido tradicionalmente por la función. Los cambios de las estructuras sociales y la búsqueda de respuestas a cuestiones sobre cómo son vividos los objetos, igualmente le lleva al estudio del sistema de significados que instauran, más allá de una descripción formal. Baudrillard establece el objeto moderno básicamente como 'liberado de su función'. Esta consideración nos lleva a esa nueva relación entre el objeto y el usuario, ya no es el utilizador, es el que lo controla, el que lo maneja para elaborar un discurso. Estas afirmaciones dan pautas para entender los distintos tipos de conexiones entre el usuario y los elementos que le rodean y de las posibilidades que existen en cuanto a las relaciones que se producen entre ellos en el espacio. "Sin relación no hay espacio", dice el autor ${ }^{63}$. A través del control del espacio se dispone de todas las posibilidades de relaciones y por tanto de todos los papeles que pueden desempeñar los objetos, convirtiéndose en elementos de juego y de combinación en un sistema de signos. Estas reflexiones de Baudrillard son también de gran valor, ya que dirigen a determinar el espacio realmente como una estructura de distribución de elementos, donde se producen relaciones y conexiones.

Algunos arquitectos también reflexionan sobre este tema. Existen textos escritos por Charles W. Moore, arquitecto prolífico tanto construyendo como escribiendo, con sustanciosas referencias que apoyan los argumentos de esta tesis. En 1974 Charles W. Moore, junto a Gerald Allen y Donlyn Lyndon, publica La casa: forma y diseño64. Aunque la idea inicial para ellos es escribir una especie de libro muestrario de casas inspirado en los libros del siglo XIX en los que se describían casas para que la gente las imitase, editan algo completamente diferente. Es una referencia importante porque pone el foco sobre temas relacionados con el proceso de configuración de la vivienda y donde los objetos adquieren un papel importante. Realmente es el texto, de los estudiados, escritos por arquitectos, en el que se hace mayor hincapié en la importancia del papel del objeto en la conformación de las casas. Diferencian dos tipos de elementos: las máquinas y los sueños. Son como dos bloques conceptuales para configurar las viviendas: por un lado están las máquinas -equipamiento, muebles, objetos en general de uso cotidiano- y el espacio que generan en su entorno. Y por otro lado están los sueños, que también participan en el proceso y van directamente ligados a los objetos personales de cada habitante. Según los autores, estos elementos añaden una nueva dimensión al lugar que se habita. En este discurso los autores están determinando claramente que existen dos discursos creados por objetos dentro de la casa, uno es el que transmite un mensaje objetivo y más físico, el de las relaciones, y otro es el subjetivo y más psíquico, el de las conexiones. En la obra de Moore, estas dos ideas se aúnan en un elemento que es característico en sus casas: el edículo, un recurso que se obtiene de la arquitectura antigua y es muy utilizado en los interiores sobre todo en los 60 . Esta especie de 'casa dentro de la casa', por un lado amplifica la 'sensación' de interior en el espacio a través de un juego de escala y de figura fondo, y por otro lado simboliza el

62 Jean Baudrillard, El Sistema de los Objetos. (México: Siglo XXI, 1969) Edición original, 1968.

63 Jean Baudrillard. El Sistema de los Objetos (México: Siglo XXI, 1969) p.17.

64 Charles W. Moore, Gerald Allen y Donlyn Lyndon. La casa: forma y diseño. (Barcelona: Gustavo Gili S.A., 1999. Edición original, 1974. 
cobijo y el universo interior de los habitantes. Imma Forino $0^{65}$ también trata este elemento como algo significativo de los interiores contemporáneos, como ya se ha comentado anteriormente.

En 1977 de nuevo Moore, esta vez junto a Kent C. Bloomer en Cuerpo, Memoria y Arquitectura ${ }^{66}$ incorpora al discurso arquitectónico la idea de la consideración del espacio que rodea al cuerpo humano para el proceso de proyecto. Para los autores, el espacio corporal, por extensión, se convierte en el espacio doméstico. Partiendo de teorías psicológicas y filosóficas del siglo XX, introducen nuevas nociones aplicables al espacio doméstico: la experiencia de la arquitectura y la fenomenología, el sentido háptico y el sentido de la orientación. En este escrito Moore y Bloomer muestran el ámbito doméstico, la casa, como el escenario de relación de distintos cuerpos en movimiento por la interacción con los elementos que les rodean. Este aspecto es importante para nuestra investigación, ya que estas ideas dan muestra de la importancia se le confiere en este momento al sentido háptico en el proceso de diseño, convirtiendo al espacio en un medio totalmente topológico, importante como medio para las relaciones entre elementos y objetos. Este texto también es de gran importancia porque introduce en nociones de fenomenología en arquitectura, muy a tener en cuenta en el análisis de los espacios y en la comprensión de algunos procesos. Maurice Merleau-Ponty hacía ya esta afirmación en 1945 cuando escribía en Fenomenología de la percepción ${ }^{67}$, que el espacio no era el medio contextual dentro del cual las cosas estaban dispuestas, sino el medio gracias al cual era posible la disposición de las mismas. Es un tema común en algunos de los textos consultados, algo que acaba conjugando los objetos con las acciones y con el espacio.

La relación entre la incorporación de la fenomenología en el discurso arquitectónico y el papel del objeto en el espacio se deduce en varios de los textos analizados. En la publicación reciente con título Architecture's Historical Turn: Phenomenology and the Rise of the Postmodern ${ }^{68}$, el profesor de la Universidad de Columbia, Jorge Otero-Pailos liga la fenomenología con los cambios producidos en la arquitectura a partir de los años 60 tras un proceso de mayor intelectualización y por el que se incluyen nociones de historia, teoría y filosofía. Dando de lado a la convicción de que la tecnología cambia la historia, aquellos que promueven estas nuevas ideas, dan un giro y consideran que la historia está guiada por la búsqueda de auténticas y originales experiencias humanas. Estos arquitectos 'fenomenologistas', como los denomina el autor, pensaban que el edificio podía ser observado con más precisión si era a través de la experiencia física directa dentro de él. El autor implica la arquitectura de arquitectos como Charles W. Moore en estos planteamientos experienciales, en sus intenciones para modificar la percepción del espacio y para cambiar la experiencia de los visitantes. Según el autor, Moore usa los edículos -símbolo del interior más íntimo de la casa- para potenciar la vivencia de la arquitectura, introduciéndonos en la idea de que en este momento la casa deja de ser simplemente un lugar donde vivir y pasa a otro estado, el de un sitio especial donde vivir experiencias. Este argumento justifica el uso de objetos para crear efectos ópticos, o juegos de escala, para alentar a los visitantes a jugar con

65 Imma Forino. L'interno nell'interno. Una fenomenología dell'arredamento.

66 Charles W. Moore, Kent C. Bloomer. Cuerpo, Memoria y Arquitectura. Introducción al diseño arquitectónico (Madrid: H. Blume, 1982) Edición original, 1977.

67 Maurice Merleau-Ponty. Fenomenología de la percepción. (Barcelona: Planeta-de Agostini, 1993) Edición original, 1945.

68 Otero-Pailos, Jorge. Architecture's Historical Turn: Phenomenology and the Rise of the Postmodern. (Minneapolis: University of Minnesota Press, 2010). 
sus fantasías y con mundos cósmicos.

La relación íntima y directa entre la fenomenología y el objeto la encontramos en Intenciones en arquitectura -1966-, de Christian Norberg-Schulz. En este texto, el autor establece una relación directa entre la aparición de los fenómenos y la existencia de los objetos. Si los objetos existen significa que se constituyen relaciones entre fenómenos. Y para Norberg-Schulz los fenómenos son nuestras percepciones: "mediante la experiencia descubrimos relaciones entre fenómenos y descubrimos un mundo de objetos"69. Para el autor, los fenómenos y los objetos son aspectos de la misma cosa. Estas nociones son de gran ayuda para plantear sistemas de relaciones y de conexiones, llegando incluso a procesos en los que la mezcla hace que los espacios y los objetos se entiendan como un todo, tal y como aborda en 1994, el arquitecto Steven Holl en Cuestiones de percepción. Fenomenología de la arquitectura, el cual recurre a Merleau-Ponty y a su noción de 'realidad intermedia'70, para llegar al terreno en el que es posible reunir las cosas de modo universal. En este texto, a través de lo que él llama "experiencia enmarañada", expone que en el proceso de creación de espacio existe una fase de solapamiento y yuxtaposición de elementos, planos y perspectivas. Es un momento en el que los sistemas de conexiones y relaciones entre elementos individuales les hacen perder su claridad, y en el que los objetos se acaban fusionando con el campo. En estos planteamientos de Holl, se hace referencia a un proceso en el que las relaciones entre los elementos y el espacio pueden acabar fundiéndose, un concepto que se aplica en este trabajo:

Dentro del continuum experiencial del espacio enmarañado captamos objetos y campos definidos como un todo.

\section{Steven $\mathrm{Holl}^{71}$}

En cuanto al reconocimiento del proceso, la referencia más directa es la Tesis doctoral de Juan Herreros "Mutaciones en la arquitectura contemporánea. El espacio doméstico" por la Universidad Politécnica de Madrid, de 199472. Herreros establece que la configuración del espacio contemporáneo es un proceso que se concreta en los años de posguerra ${ }^{73}$. Esto se produce, según el autor, porque el progreso técnico trastoca los paradigmas en los que se sustentaba el espacio moderno. Toma como ejemplo la Case Study House $n^{\circ} 8$ de Charles \& Ray Eames en Los Angeles -1949-, para indicar que los nuevos usos hacen que los objetos se conviertan en materia de proyecto es decir: que partiendo de un espacio total, se procede a ocuparlo con piezas dispersas, de cuyas relaciones y tensiones surgen 'lugares' diversos que sin embargo parecen unidos por un mismo hilo. Así indica que los ámbitos se unifican y lo que identifica los usos son los implementos añadidos. La movilidad de los elementos y el nuevo estatuto adquirido por las máquinas y muebles, en espacios más abiertos y polivalentes, hace que se conviertan en lo que cualifica, diferencia y especifica. Se pasa de lo tipológico a lo topológico. Desde la perspectiva operativa, Herreros recalca el protagonismo del mueble y considera que a partir de este momento puede plantearse la vivienda desde los

69 Christian Norberg-Schulz. Intenciones en arquitectura. (Barcelona: Gustavo Gili, 1998) p. 21 Edición original, 1966.

70 En Fenomenología de la percepción.

71 Steven Holl, Cuestiones de percepción. Fenomenología de la arquitectura. (Barcelona: Gustavo Gili, 2005) Edición original, 1994.

72 Juan Herreros, "Mutaciones en la arquitectura contemporánea. El espacio doméstico". Tesis Doctoral. Universidad Politécnica de Madrid, Escuela Técnica Superior de Arquitectura, 1994.

73 Ibíd. p.103. 
elementos que la constituyen, existiendo "una desproblematización de la casa como figura final en favor de un interés por el medio interior, por la interacción de los elementos entre sí y con las personas, por sus formas de significación y de relación"74. Entender lo doméstico desde la perspectiva artefactual y entender el territorio del espacio doméstico desde el interior, sitúa como referencia la Un-home de Reyner Banham -1965-. En este escrito también se hace mención a otros aspectos que caracterizan el espacio doméstico contemporáneo, como la consideración de nuevas variantes subjetivas, la percepción multisensorial y el movimiento del cuerpo, que surgen ligadas a la vivienda y que aumentan el interés por el medio interior. La cultura objetual conlleva un espacio interior que tiende a resolverse en el proyecto desde sistemas de objetos entendidos como instrumentos topológicos. Los objetos pasan a ser materia de proyecto, no sólo con criterios funcionales sino más bien como elementos narrativos 0 de identificación del sujeto, añadiendo aspectos táctiles y sensoriales y conexiones subjetivas relacionadas con la memoria y la experiencia. A lo largo de los años, el medio consumista, según Herreros ${ }^{75}$ lleva al reconocimiento de la propia subjetividad del sujeto, así como a la particular relación, aleatoria y banal, que establece con las cosas, y que se sintetiza en torno a las propuestas de Toyo Ito de finales de los ochenta entorno a la 'muchacha nómada de Tokio' -Pao 1, 1985 y Pao 2, 1989- llevándonos a la pregunta sobre qué puede ser una cada -nómada- treinta años después de la Un-home.

La idea de disociación entre casa y hogar surge en otros textos, y sobre todo dirige a los sistemas de objetos que son los que marcan el marco doméstico. Ante la pregunta ¿hasta qué punto se reconoce una casa? En Casa collage: un ensayo sobre la arquitectura de la casa ${ }^{76}$, Xavier Monteys y Pere Fuertes reflexionan sobre la distancia que media entre los términos vivienda y hogar y sobre los factores que marcan los nuevos modos de vida de la época: el teletrabajo, las redes, los hábitos de ocio, etc. Ante esta dicotomía, es de interés la idea de los autores sobre si finalmente una casa es reconocible por sus características formales o por la presencia de una escena doméstica en su interior: "Una casa es una vivienda más la gente que la habita y los objetos que guarda"77. Los objetos cotidianos son el reflejo de los modos de vida en los ámbitos donde se desarrolla.

Otra reflexión de referencia, sobre las cuestiones de la vivienda en el mundo contemporáneo, que relaciona características propias de las casas adaptadas a los nuevos modos de vida, con el mobiliario y los sistemas de elementos que se han generado por las nuevas necesidades, es la que se presenta en Penser l'habité. Le logement en questions, -1988-, editado por Monique Eleb -socióloga especializada en analizar los modos de vida y los espacios donde se desarrollan-, Anne M. Châtelet y Thierry Mandouln ${ }^{78}$. En este texto se hace hincapié en características que son implícitas a la vivienda contemporánea y de la implicación de muebles, elementos arquitectónicos y objetos, en su configuración. Entre las propiedades principales, se incide en gran medida en la flexibilidad, como una de las principales cualidades que demanda el nuevo habitante. La respuesta a esta necesidad, se traduce a través de la disposición

74 lbíd. p. 107.

75 Herreros, Juan. "Espacio Domestico. Sistemas de Objetos". AULA 261, Universidad San Pablo CEU, 2012. http://aula261.blogspot.com.es/.

76 Xavier Monteys, Pere Fuertes. Casa collage: un ensayo sobre la arquitectura de la casa. (Barcelona: Gustavo Gili, 2001.X

77 lbíd. p. 14.

78 Monique Eleb, Anne Marie Châtelet, y Thierry Mandoul. Penser l'habité. Le logement en questions. (Paris: Mardaga, 1988. 
de tabiques móviles y otros mecanismos que se han desarrollado para manipular la geometría del espacio, y que se entiende como una especie de sistema para generar transformaciones espaciales. Para los nuevos espacios, también surgen nuevos muebles y algunos elementos arquitectónicos que, para lograr ser móviles, se han 'objetualizado'. Esta publicación también es de interés porque las reflexiones derivan de estudios sociológicos y arquitectónicos, sobre la realidad y sobre las propuestas que presentan los arquitectos a finales de los 80 . En este sentido hacen referencia a que se mantiene la tendencia a la agrupación de los equipamientos como respuesta a las necesidades de liberar espacio dentro de las casas, en una especie de lugar donde las funciones no estan fijadas de antemano, donde prevalece la aglutinación de servicios y donde han desaparecido determinados muebles ya que se diluyen en la tabiquería. También se reconocen sistemas de objetos que se mantienen con el tiempo, otros que se han perdido desde los 60 y otros que sin embargo se recuperan de la tradición después de décadas de haber desaparecido. Por ejemplo, ante la ambigüedad del espacio, los autores hacen hincapié en el objeto personal como elemento de comunicación y como vínculo del nuevo habitante con el espacio que le rodea. Ante este fenómeno surge la idea de la reconsideración de algunas áreas del espacio que se habían quedado abandonadas, como son los rincones o los recovecos, y que resucitan gracias a esta necesidad de vínculos a través de objetos personales.

Nueve años más tarde, en Urbanité, Sociabilité et Intimité. Des logements d'aujourd'hui, 1997; Monique Eleb y Anne Marie Châtelet (nota: Monique Eleb y Anne Marie Châtelet. Urbanité, Sociabilité et Intimité. Des logements d'aujourd'hui. Paris: l'Épure, 1997) tratan de nuevo temas relacionados con los modos de vida, los habitantes de la vivienda contemporánea y los objetos. En este aspecto, las autoras hacen especial hincapié en que definitivamente la idea contemporánea de hábitat queda íntimamente ligada al concepto de apropiación del espacio, ya que los planteamientos al respecto, heredados de los 70 , no han sido puestos en cuestión y continúan vigentes. Según Eleb y Châtelet existen medios arquitectónicos que son utilizados para favorecer este modo de ocupar el espacio: por ejemplo, un volumen amplio y diáfano visualmente favorece este sistema. Esta reflexión es interesante ya que las autoras reconocen la relación entre un sistema o modo de colonizar con objetos y un espacio con unas características implícitas que lo propician, implicando al objeto directamente en el proceso de proyecto.

Permaneciendo en el concepto de apropiación como modo de vida y como sistema de configuración espacial, Iñaki Ábalos, en La buena vida -2001-79, recupera esa referencia en el loft neoyorkino como arquetipo de un modo de vida de los años 60 y 70, heredado de la generación beat. Ábalos, toma como ejemplo "The Factory" de Andy Warhol en el SoHo neoyorkino ${ }^{80}$, relacionando directamente una forma de vida con una técnica para caracterizar un espacio visualmente abierto: la apropiación del espacio industrial neutro, el loft. Todo ello deriva de una situación social que C. Ray Smith en Supermannerism: New Attitudes in Post-Modern Architecture ${ }^{81}$, describe perfectamente y que relaciona aquellos fenómenos producidos en los interiores americanos de los 60 con los cambios de la sociedad de aquellos años, aportando datos históricos que

79 Iñaki Ábalos. La Buena vida. Visita guiada a las casas de la modernidad. (Barcelona: Gustavo Gili, 2001).

80 Iñaki Ábalos en "Warhol at the Factory. De las comunas freudo-marxistas al loft neoyorkino". La Buena vida. Visita guiada a las casas de la modernidad. (Barcelona: Gustavo Gili, 2001) p. 115.

81 C. Ray Smith. Supermannerism: New Attitudes in Post-Modern Architecture. (Nueva York: E.P. Dutton, 1977). 
clarifican el origen de las causas. Smith relaciona la incorporación al espacio de efectos ópticos, nuevas texturas, juegos formales, cambios de escala, juegos de luz, superposición de capas, etc. a una búsqueda expresa de inversión de los principios establecidos, propia de aquellos años, y que se traduce en un nuevo lenguaje en el diseño, lo cual influye en gran medida en la arquitectura. Esas corrientes de libertad de la época encuentran las fuentes en lo cotidiano, lo folclórico, lo kitsch, e incluso en los efectos del consumo de LSD y sus experiencias, lo cual se plasma en un nuevo vocabulario, en interiores psicodélicos y nuevos diseños gráficos. Como ejemplo, el autor se refiere a la casa Moore en New Haven, Connecticut ${ }^{82}$ y habla de un combinatoria en la disposición de objetos dentro de la casa que hubiera podido ser considerada incongruente en años anteriores, indicando que existe un cambio que se refleja incluso en la relación entre elementos dentro del espacio. Allí se amontonaban unos sobre otros: alfombras turcas, cerámicas mexicanas, una jukebox, retratos del XIX iluminados con lámparas industriales, etc. "Moore y sus socios combinaron los más disparatados elementos llegando al límite de las mayores discordancias". La idea de C. Ray Smith es relacionar esta singularidad con una época que aboga por la libertad, por la actitud subversiva de los diseñadores, propia de esos años y con una constante intención de experimentar en la arquitectura.

Para finalizar este estado de la cuestión, en el que se destacan los documentos principales relacionados con el tema y de los que surgen las ideas principales recogidas para este trabajo, hacemos referencia a otro texto de Jean Baudrillard publicado en 1983: "El éxtasis de la comunicación"83. 17 años después del Sistema de los Objetos $^{84}$, aborda el tema de los objetos y de la configuración de la escena doméstica, pero desde otra perspectiva: el anterior proceso deriva en un nuevo caso de inversión. Baudrillard proclama ya la 'no existencia de sistema alguno de objetos'. Ante la invasión de las redes en la vida de los nuevos habitantes y el establecimiento de la televisión como el objeto que domina definitivamente en los nuevos hogares, el autor nos introduce en la idea de la desaparición de la escena doméstica: el marco del hogar queda reducido a la pantalla y a la memoria del ordenador, y deja así una puerta abierta dirigiendo el discurso de la configuración del hábitat del sujeto contemporáneo hacia nuevas reflexiones.

Si bien no se han encontrado textos que aborden el tema de la presente Tesis de manera directa, sí que existe documentación, como se ha podido constatar, cuyo contenido avala las ideas sobre la que se soporta este trabajo. Tanto desde la perspectiva sociológica como desde el punto de vista de la arquitectura, los textos marcan un proceso de cambios en el lapso de tiempo en el que se enmarca la investigación. Según los documentos principales anteriormente referidos, existe la consideración general de que éste es un periodo característicamente objetual que influye decisivamente en el proceso de configuración de los interiores -y en los hogares particularmente- y que es reflejo de la cultura y de los intereses del sujeto de ese momento.

82 Por MLTW/ Moore-Turnbull, en 1966.

83 Jean Baudrillard "El éxtasis de la comunicación", en La Posmodernidad, editado por Hal Foster. (Barcelona: Kairós S.A., 1985) p.187-197.

84 Primera edición, Le système des objets (Paris: Gallimard, 1968). 

1. UNA NUEVA VISIÓN DEL OBJETO 



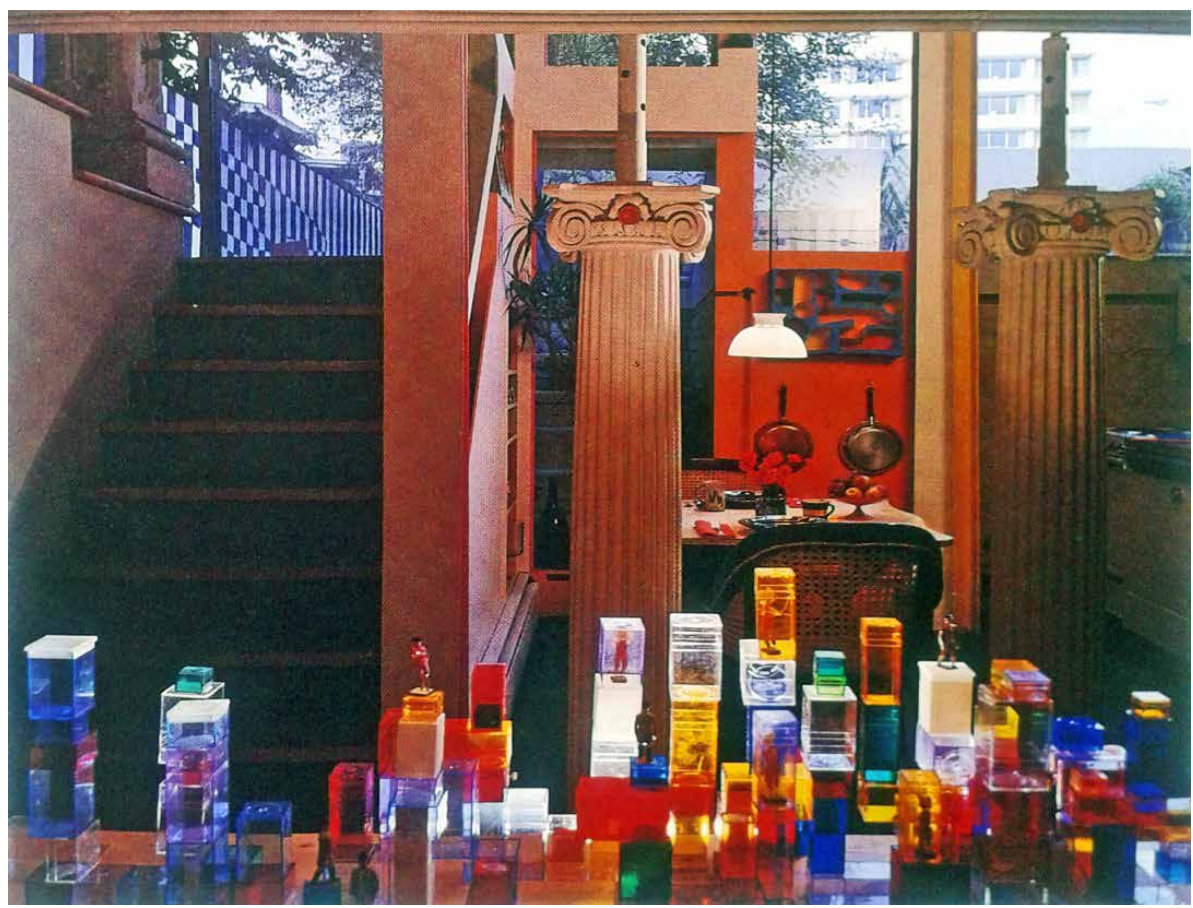

\section{1- UNA NUEVA VISIÓN DEL OBJETO}

La sociedad industrial ha transformado radicalmente el hábitat del hombre y ha creado un novísimo espacio artificial cuyo rasgo más peculiar reside en la proliferación de objetos manufacturados por el hombre.

\section{Roman Gubern ${ }^{1}$}

${ }^{1}$ Las consideraciones contemporáneas del objeto surgían precisamente en el contexto de un mundo basado en el mismo. En ese mundo, -en el de la sociedad de consumo-, arquitectos, psicólogos, sociólogos, etc. pusieron especial atención en la búsqueda de un concepto moderno de objeto. Huyendo de las definiciones clásicas, emergió la necesidad de indagar en una nueva visión que se apoyaba en la idea de objeto como elemento social y comunicativo, desviándose de las consideraciones meramente funcionales e incidiendo en el significado.

En el nuevo marco surgían preguntas ¿cómo eran vividos los objetos? ¿A qué otras necesidades aparte de las funcionales daban satisfacción? ¿Cómo eran entendidos? 0 , finalmente, ¿Cómo se percibían frente a los cambios propios del mundo contemporáneo?

Los cambios frente a las nuevas necesidades sociales, el auge de la cultura de consumo, la publicidad, etc. influían en los interiores domésticos, en los muebles que los poblaban y en el resto de los objetos domésticos. El alcance de los medios de comunicación se hizo mucho mayor a través de la televisión, la promoción de los productos para el hogar llegaba a más gente. El cine recreaba ambientes domésticos ideales en sus películas. Las revistas de decoración proliferaban, los interiores de las casas editados en ellas y la incidencia de la publicidad, cada vez mayor, de los objetos cotidianos, convertían el entorno doméstico en una parte importante del mundo comercial. El acceso y el interés cada vez mayor por la conformación de los nuevos ambientes domésticos,

1 Roman Gubern, Introducción, en Abraham A. Moles, Teoría de los objetos (Barcelona: Gustavo Gili, 1975). 
hicieron que empezaran a formar parte de los estudios sociológicos.

Desde el punto de vista del hábitat, la movilidad, el desarrollo de las comunicaciones, la tecnología y los nuevos modos de vida, llevaban a que el habitante contemporáneo precisara de espacios más diáfanos y polivalentes. Las habitaciones, y la casa misma se abrían, todo comunicaba entre sí. Si el espacio se unificaba, los que determinaban los usos eran los muebles y el resto de los objetos que existían en su vida diaria. Al mismo tiempo que cambiaban las relaciones del individuo con la sociedad, cambiaban los objetos y la manera de relacionarse con ellos. De esta forma se liberaba al objeto de su función, adquiriendo nuevas acepciones, y al hombre se le liberaba de su rol de 'utilizador de objetos'?

En la sociedad contemporánea, la categoría mundana del uso fue absorbida por el consumo, en tanto que los objetos de uso -las herramientas, por ejemplose transformaron en utensilios de "usar y tirar". Se producía un desplazamiento cuyo auténtico significado residía en la capacidad destructora del consumo como opuesto al uso ${ }^{3}$. Según Kenneth Frampton, este factor influyó decisivamente en los cambios que se produjeron en el espacio doméstico, sobre todo en la reducción cultural que consistió en la retórica de lo 'kitsch' y la 'celebración' de la técnica como un fin en sí misma. Mientras la utilidad presuponía originalmente un mundo de objetos de uso, por los que el hombre estaba significativamente rodeado, este mundo empezó a desintegrarse, de manera que cada objeto ya no era un fin en sí mismo, sino que se convertía en un medio para la consecución de otros objetos o para otros fines. Desde el punto de vista doméstico y desde la perspectiva espacial, la planta libre y la búsqueda de lugares más diáfanos y flexibles para el desarrollo de la vida moderna, reveló una nueva faceta del objeto, la de su papel en la distribución y zonificación, en un espacio más topológico que tipológico, y en el que, por la falta de elementos divisorios, lo que identificaban los usos eran los implementos añadidos: los muebles, las máquinas, los elementos decorativos, en un nuevo papel organizador, configurador e incluso cualificador, en el que según algunos autores se llegaba a la paradoja:

Simplemente una tiranía ha remplazado a la antigua (...) despojada del control de la división del espacio, la arquitectura se ve forzada a tomar el control, incluso mayor, de una nueva serie: el mobiliario

\section{A. Colquhoun ${ }^{4}$}

En el contexto del espacio doméstico y en el estudio sobre los objetos cotidianos, se produjeron diversos acercamientos al objeto en el marco contemporáneo.

2 Jean Baudrillard, El Sistema de los Objetos. (México: Siglo XXI, 1969).

3 Kenneth Frampton, "El estatus del hombre y el estatus de sus objetos: un lectura de la condición humana". RA, Revista de Arquitectura, n010 (jun-2008) 7-22.

4 Alan Colquhoun, "Le Plateau Beaubourg”, Recueil d'Essais Critiques (Bruselas: Mardaga, 1981), citado por Monique Eleb, Anne Marie Châtelet y Thierry Mandoul en Penser I'habité. Le logement en questions (París: Mardaga, 1988) p.103. 


\subsection{TEORIAS, DEFINICIONES Y CLASIFICACIONES}

En los años de cambios la invasión masiva de objetos producida por la sociedad de consumo occidental puso de manifiesto el interés sociológico y la urgencia de nuevas definiciones, teorías, sistemas de clasificación, con el fin de comprender cuál era el papel del objeto en este contexto.

Roman Gubern ${ }^{5}$

Imagen: Piero Derossi. 'La casa como lugar de trabajo". XVII Triennale de Milan, 1983. Croquis del ambiente que fue parte de la exposición.

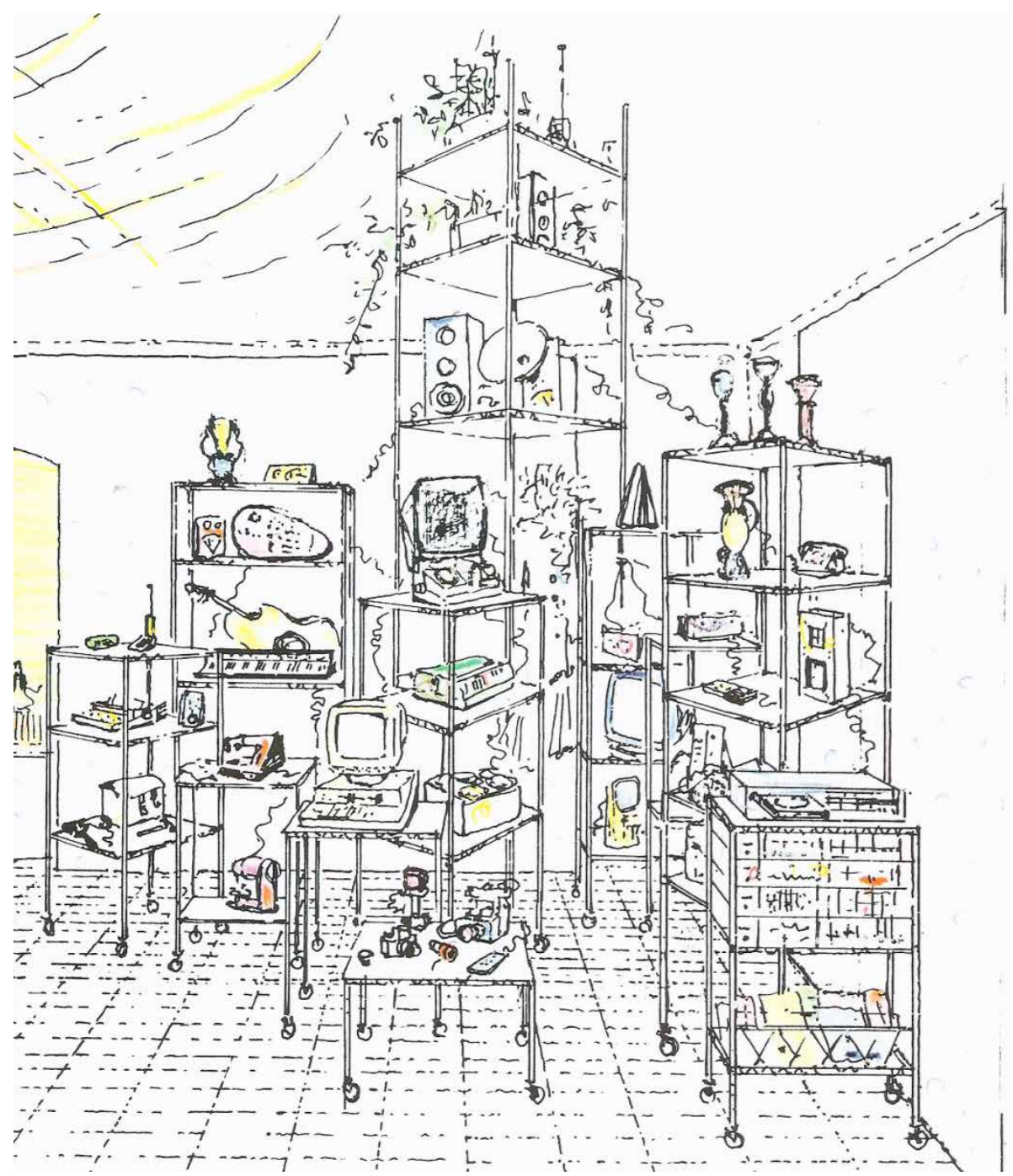

Los cambios de las estructuras sociales en los sesenta requerían respuestas sobre cómo eran vividos los objetos. Esta necesidad surgía precisamente en un mundo donde se había instaurado definitivamente la cultura de consumo y, en ese contexto, la consideración del objeto como signo emergía como fruto de la contemporaneidad.

Por su influencia en el ámbito social, los estudios lo abordaron más como elemento sociológico, que como elemento funcional. El objeto, como elemento fabricado y característico del mundo del consumo, se había vuelto social. Era significativo el fenómeno de la divulgación de los interiores modernos, de los objetos, de los muebles que conformaban espacios domésticos ideales. A través de la publicidad y las revistas, la recreación de estos ambientes llegaba

5 Roman Gubern, Introducción, en Abraham A. Moles, Teoría de los objetos (Barcelona: Gustavo Gili, 1975). 
a gran parte de la sociedad. Analizando la entidad del objeto como mediador social, los estudios partían de su función, pero todos llegaban a su significado. El objeto empezaba a ser interpretado como mensaje.

La mayor parte de los estudios realizados bajo estas premisas coincidían en que el espacio doméstico representaba el eslabón final de la cadena de consumo. Los objetos en esta etapa final, se situaban en el ámbito más íntimo y personal, y además presentaban una cierta voluntad de permanencia en ese marco.

En ese sentido, las investigaciones centraban el 'universo de los objetos' de estudio tanto en el marco de la vivienda, como el lugar donde se manifestaban los cambios del modo de vida del individuo contemporáneo, como en los objetos ordinarios, en los muebles y en su organización. Se referían pues a los objetos cotidianos, a los que se ubicaban en el espacio doméstico, los que estaban hechos a escala del hombre.

La búsqueda de una nueva definición surgía en la mayoría de los casos por la 'fenomenología de la vida cotidiana', por la experiencia provocada a través de su interacción, por su propia presencia, por la percepción de los objetos en el espacio y por su relación entre ellos. En ese contexto, huyendo de la definición etimológica y como elemento de consumo, en la mayoría de los casos, el objeto se definía como un elemento artificial, tanto en existencia como en apariencia, fabricado por el hombre, hecho a su escala y esencialmente manipulable. Accesible a la percepción y destacable de su entorno, respondía además a otros aspectos característicos, como su subsistencia al tiempo o su relación directa con la experiencia y las acciones del hombre.

En el contexto de las definiciones del objeto en el mundo contemporáneo primaba su interpretación como signo, y su capacidad de crear un lenguaje en relación con otros objetos, funcionando como un sistema o conjunto. El discurso creado a través de los objetos en conjunto se convertía en mensaje. Es por ello, que al tratar de sistemas de objetos careciera de sentido hablar de función principalmente. En este aspecto, la consideración del valor del objeto dejaba de estar en su utilidad, ni tan siquiera en su pertenencia, sino que se encontraba en la coherencia del conjunto para establecer un discurso.

El sentido nacía de un conjunto perceptible de objetos, del lenguaje de composiciones de elementos que transmitían un determinado mensaje: objetos reales ligados por una única forma de conexión, por la yuxtaposición pura y simple de un grupo de elementos. En el espacio estas relaciones eran consideradas como sistemas de agrupación, con sus códigos y sus reglas: los objetos y sus formas de conjugarse se convertían en factores determinantes en el proceso de configuración del espacio doméstico contemporáneo. Este era un dato decisivo, ya que en estudios posteriores se deducía que en los años 80 se mantenían intactos algunos sistemas de conjunto, como los sistemas flexibles o los paquetes de servicios. También surgieron nuevos sistemas, como los paquetes multimedia.

En cuanto a los criterios de clasificación, en la mayoría de los casos, iban dirigidos a la categorización de los sistemas, de los conjuntos de elementos, por lo que, como se ha comentado anteriormente, los criterios funcionales habían sido desplazados por el lenguaje. Algunos estudiosos del tema, como Abraham Moles en Teoría de los Objetos, abordaban la clasificación de los sistemas de objetos distinguiendo dos tipos de mensaje; por un lado el llamado mensaje semántico, que se basaba en el lenguaje de los objetos 


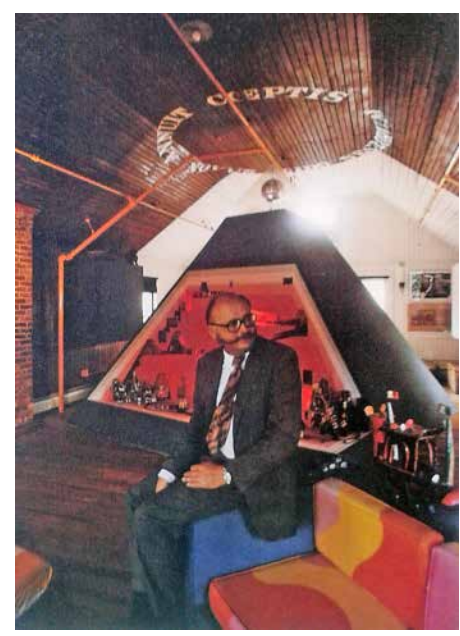

Imagen Charles Moore en su casa de Essex, Connecticut, rodeado de objetos personales Charles W. Moore Ass.,1973. reunidos en un interior, en el que la acción de apropiación del espacio se convertía en el medio para la construcción de un discurso, y por otro lado el mensaje estético, que añadía ciertas connotaciones al mensaje semántico, y dotaba al sistema de una dimensión social, estética o económica, que podría relacionarse con la idea contemporánea de ambiente. Dentro del contexto del mensaje semántico Moles estableció códigos de apropiación, que podían ser aplicables, por ejemplo, a la disposición del mobiliario en una habitación. A estos códigos, convertidos en normas de actuación las llamó 'leyes sintácticas de acoplamiento'6.

Entre estas dos vertientes, otros autores también establecieron sus bases de clasificación; es el caso de Jean Baudrillard7, que trataba el espacio como una estructura de distribución, el control de ese ámbito proporcionaba todas las posibilidades de relaciones y los factores que intervenían en el estudio de ese fenómeno, de nuevo, hacían distinguir entre la noción de colocación y la noción de ambiente. El primero era considerado como un sistema de organización, donde primaba la coherencia de conjunto; el segundo, el ambiente, se consideraba como un sistema de tratamiento del espacio, que provocaba connotaciones psicológicas que influían en el proceso perceptivo. Por tanto, por un lado estaba el sistema de la organización: de las relaciones, y por otro estaba el sistema del aditamento: de las conexiones y percepciones.

Algunos arquitectos como los americanos Moore, Lyndon y Allen ${ }^{8}$, dentro del proceso proyectual de configuración del espacio, igualmente distinguían entre la vertiente distributiva como una forma de organización espacial: a través de sistemas de agrupación, de elementos de ordenación, de objetos que inducían a la atención y al movimiento. Del mismo modo, distinguían la otra vertiente, la del aditamento como forma de transformación de la percepción para dotar al espacio de una nueva dimensión a través de elementos con características formales singulares, de elementos de rememoración, de técnicas multisensoriales, de objetos con connotaciones culturales y contraculturales, 0 de elementos con implicaciones psicológicas. En este apartado también se incluía el concepto de 'vínculo personal con el espacio' a través de la conexión entre el habitante y el lugar que habita, a través del papel que ejercían determinados sistemas completos de objetos personales cargados de connotaciones, como eran las colecciones. Charles Moore siempre incluía en sus casas diversas colecciones y múltiples objetos personales con la intención de convertir el espacio doméstico un lugar especial. Así ocurrió en el proyecto de su casa en Essex, Connecticut.

En la fase de aditamento, frente a la idea de discurso generado por un conjunto de objetos sistematizados y conectados, había una excepción que comprendía una categoría completa, la de los objetos singulares. Estos elementos podían actuar por sí solos, ya que individualmente estaban funcionando como signo. Significaban el tiempo pasado, el recuerdo, la nostalgia o la evasión. Su significado además no contradecía al sistema, ya que todo se producía en signos. Por ello habían recuperado su espacio, olvidado en los años anteriores de síntesis espacial.

Como ya se había avanzado en esta introducción, el desarrollo de la semiótica

6 Abraham A. Moles en Teoría de los objetos (Barcelona: Gustavo Gili, 1975) p.111. Moles enuncia las 'Leyes sintácticas de acoplamiento'.

7 Jean Baudrillard. El Sistema de los Objetos (México: Siglo XXI, 1969).

8 Charles Moore, Donlyn Lyndon y Gerald Allen. La casa: forma y diseño (Barcelona: Gustavo Gili, 1999). 
en los 70 sirvió para que la investigación sociológica abordase el estudio del objeto interpretándolo como mensaje. En este aspecto, Abraham A. Moles ${ }^{9}$ analizaba la entidad del objeto como mediador social dentro de la cultura contemporánea, partiendo de su función y finalmente llegando a su significado.

En aquel proceso de análisis, entró en el estudio del territorio natural de los objetos desde la tienda o gran almacén donde se adquirían, hasta la casa 0 el trabajo donde se utilizaban, terminando su ciclo en el cubo de la basura, el anticuario o el museo. En ese ciclo vital, inmerso en los procesos propios de la civilización contemporánea, Moles le atribuía al objeto la idea de producto específicamente humano, que es lo que diferencia los objetos de las cosas. En nuestra civilización, según Moles, el objeto era artificial. Por ejemplo, una piedra en sí misma no es un objeto sino una cosa, sin embargo cuando se utiliza como pisapapeles, adquiere la cualidad del objeto. Bajo estas premisas, descubrimos que el objeto ya había sido definido por haber sido fabricado por el hombre y por su vocación de permanencia.

En la labor de buscar criterios de clasificación de objetos a partir de aspectos exteriores a su naturaleza, la cuestión se centraba en torno a la consideración de que el mensaje surgía del papel realizado por los objetos principalmente en conjunto, en grupo. Este discurso, creado por las relaciones entre objetos, estaba ligado a un mensaje semántico -considerado como el mensaje básico-, más o menos vinculado a las acciones realizadas -organización, distribución, composición, interacción, función, etc.-. Pero el discurso también estaba unido a otro tipo de mensaje, el llamado mensaje estético que, sin variar las funciones, se relacionaba con las connotaciones, con un orden de variantes posibles, que se superponían al mensaje básico y que podían dotar al sistema de una dimensión social, estética, económica, etc.

En cuanto a la clasificación y con la intención de estrechar el campo de estudio, se eliminaba el objeto consumible y la pieza técnica aislada, centrándose dichos estudios en los modos aplicables y en los distintos 'universos' de los objetos: la tienda, el desván, el piso y el museo. Definidos los universos, los estudios decidieron centrarse finalmente en el piso, como el ámbito más característico del objeto, denominándolo "ámbito de apropiación"10 Además el marco de la vivienda, para el tema que nos compete, también es el más interesante.

Otro punto de vista para obtener criterios de clasificación fue el de la percepción, el objeto podía clasificarse también por sus dimensiones. De esta cualidad surgía una taxonomía por niveles de percepción basados en el sentido táctil. En base a ello se podían establecer distintos grados por tamaños, desde los llamados "maxiobjetos", en los que incluso se podía entrar, hasta los "microobjetos", cuyo tamaño hacía que se sólo se pudieran tomar entre los dedos"

9 Abraham A. Moles, Teoría de los objetos (Barcelona: Gustavo Gili, 1975).

10 Ibídem.

11 Abraham A. Moles, Teoría de los objetos (Barcelona: Gustavo Gili, 1975) p.31. Moles, en el capítulo "El objeto en el espacio tiempo" exponía sus consideraciones en cuanto al objeto caracterizado por sus dimensiones, utilizando como referencia los niveles del Modulor de le Curbusier. En base a este criterio subdividía el campo del objeto en cuatro niveles de percepción, basados en el conocimiento táctil:

Maxiobjetos. Los objetos en los que se puede entrar (coche, casa)

Objetos de nuestro tamaño y escasa movilidad (los muebles)

Objetos que pueden cogerse con la mano (un plato, un ordenador)

Microobjetos. Los que se toman entre los dedos (un alfiler, un botón). 
Hubo más sistemas de clasificación de objetos por tamaños ${ }^{12}$. Christian Norberg-Schulz también organizó los objetos por sus dimensiones de acuerdo a experiencias corporales. Puso en la clasificación primero a los que se pudieran agarrar con la mano, por ejemplo un libro estaba en esa categoría. Después fueron las casas, objetos donde pudieran hacerse en su interior movimientos pequeños y privados, de cuerpo entero. Tercero, las ciudades, objetos que contuvieran el rango de, por ejemplo, los paseos diarios. Concluía la organización con el paisaje -landscape-, que estaba en la categoría de objetos que englobaban las mayores experiencias de movilidad. Esta clasificación, sin embargo, se sale del ámbito en el que se encuadra el universo de los objetos domésticos. Volviendo a Moles y al espacio interior de dimensión humana, nos adentramos en las ideas que surgieron en torno a la calidad de permanencia del objeto y a la de sus posibilidades respecto a su posición-orientación dentro de una habitación. Todo ello le llevó a indagar en el factor de presencia/ausencia, y en la auto-correlación a través del tiempo, caracterizando a los objetos por un orden más o menos estable a lo largo del tiempo. Esto posibilitaba, poniendo como ejemplo a un escenógrafo, recrear el mundo a cada instante, como si reconstruyera periódicamente su decorado, sacando accesorios del almacén y ubicándolos en función de la escena. En este marco espacio/tiempo los personajes vivían, evolucionaban, actuaban y se desplazaban. Existían en relación con las cosas que les rodeaban.

Respecto a esas posibilidades Moles intentó racionalizar el lenguaje de los objetos reunidos en un interior a través de un método, bajo el argumento de que los elementos establecían un discurso en cuanto a su disposición y relación dentro del espacio. En realidad sobre lo que se estaba teorizando era sobre el concepto de orden y con esa idea estableció lo que llamó 'Leyes Sintácticas de Acoplamiento'. ${ }^{13}$ Estas leyes normalizaban los sistemas de relación entre elementos y sus significados, dentro del acto de apropiación del espacio por medio de objetos, como vía para la construcción de un discurso.

Estas consideraciones eran especialmente aplicables sobre todo al mobiliario, es decir, a los objetos grandes, de volumen y superficies apreciables, cuyo despliegue, en la acción de apropiación del espacio, era constante a lo largo del tiempo. La ordenación de un piso podía ser considerada como la de un gran decorado teatral en el que se movían unos actores, pero que permanecía más o menos estable.

Los sistemas de acoplamiento ${ }^{14}$ se establecían considerando aspectos como la limitación volumétrica de un espacio respecto a la envergadura de los objetos que lo ocupaban, imponían reservas de espacio para la circulación, proclamaban la necesidad de que los elementos fueran accesibles sin esfuerzo, etc. Todo aquello, entre otras cosas que se especificarán en posteriores apartados, sistematizaba las formas de organización y establecía códigos, como si fueran modos de expresión.

Jean Baudrillard llamó a este fenómeno "el sistema hablado de los objetos"15. Coincidiendo con otros autores, consideraba que para abordar este tema, el análisis funcional y tecnológico era insuficiente, y para ello liberó al objeto

12 Christian Norberg-Schulz, Existencia, Espacio y Arquitectura (Barcelona: Blume, 1975).

13 Abraham A. Moles, Teoría de los objetos (Barcelona: Gustavo Gili, 1975) p.111.

14 Abraham A. Moles, Teoría de los objetos (Barcelona: Gustavo Gili, 1975) p.111. Moles enuncia las 'Leyes de sintácticas de acoplamiento'.

15 Jean Baudrillard, "El sistema funcional o el discurso objetivo" en El Sistema de los Objetos (México: Siglo XXI, 1969) p.12. 
moderno de su función ${ }^{16}$ partiendo de los cambios del individuo contemporáneo en sus relaciones con la familia, con la sociedad, de los cambios también producidos en los objetos cotidianos, en el mobiliario, así como de los cambios de organización: "las cosas se repliegan y se despliegan, desaparecen, entran en escena en el momento deseado (...) el individuo encuentra en su movilidad, en su multifuncionalidad una mayor libertad de organización, reflejo de una mayor disponibilidad en sus relaciones sociales". Gracias a los nuevos elementos el individuo encontraba una mayor libertad de organización que además iba unida a espacios más abiertos. En el mundo contemporáneo las casas devinieron más diáfanas, las divisiones tradicionales, las paredes, habían desaparecido. Se habían liberado igual que lo habían hecho los objetos de su función. En aquel momento era el espacio el que discurría entre ellos, convirtiéndose en el marco de sus relaciones y conexiones, de sus "valores", como decía el autor ${ }^{17}$.

Otro factor a tener en cuenta fue el fenómeno de la importante divulgación que los interiores modernos, los objetos y los muebles que componían espacios domésticos ideales, tenían a través de revistas y ferias. Estos magazines, por su carácter comercial, llegaban a grandes sectores de la sociedad contemporánea. Se convertían pues en un 'dominio' con incidencia sociológica, y como factor social tenía su propia incidencia en cada uno de los individuos. Los espacios interiores que aparecían en las publicaciones ya no era creaciones de ensueño, sino que por su carácter comercial, se convertían en modelos.

Respecto a los espacios interiores, Baudrillard se acercó a su análisis centrándose en el proceso por el cual el sujeto se relacionaba con los objetos como si fuesen un anexo a su propia imagen. Su valor ya no estaba en su pertenencia, ni en su disfrute, sino en que se convertían -más por una coherencia de conjunto que por sí mismos- en un instrumento para comunicar, para elaborar un discurso, su propio discurso.

Al nuevo habitante, le llamó 'hombre de colocación'. En el acto de colocación el espacio se convertía en una estructura de distribución y, a través del control de ese espacio, el hombre disponía ante sí de todas las posibilidades de relaciones derivadas del papel que podían desempeñar los objetos. En ese proceso de configuración Baudrillard también diferenció dos aspectos, cuya combinación era la base estructural de aquella práctica: el tema de la colocación y el del ambiente. Dentro de un mismo sistema, al imperativo técnico de la colocación se añadía siempre el imperativo cultural del ambiente. Consistía en un proceso de combinación de un sistema de organización y de un procedimiento de tratamiento del espacio. Si en el proceso de colocación lo principal era la coherencia del conjunto, en las estructuras de ambiente existían otros factores, como eran: el color y sus connotaciones psicológicas en el proceso perceptivo; los materiales, sus avances y su implicación con las nuevas formas; o la revolución de las energías que, en un proceso de abstracción y miniaturización de aparatos y mandos a distancia, convertía cada gesto del usuario en múltiples funciones posibles.

16 Jean Baudrillard, "El objeto moderno liberado de su función" en El Sistema de los Objetos (México: Siglo XXI, 1969) p.15. Baudrillard dice que al mismo tiempo que cambian las relaciones del individuo con la familia y con la sociedad, cambia el estilo de los objetos mobiliarios. Sofás cama, camas de rincón, mesas bajas, estanterías, son elementos que sustituyen al antiguo repertorio de muebles, la organización cambia también: la cama se convierte en sofá cama, el aparador y los roperos en alacenas que se ocultan.

17 Jean Baudrillard, "El sistema funcional o el discurso objetivo" en El Sistema de los Objetos (México: Siglo XXI, 1969) p.20. 
Al conjunto de objetos sistematizados y conectados, de nuevo parecía escapar una categoría completa: la de los objetos singulares, barrocos, folklóricos, exóticos, antiguos. Estos elementos parecían contradecir las exigencias del cálculo combinatorio de colocación y ambiente, y respondían a aspectos de otra índole: el testimonio, el recuerdo, la nostalgia, la evasión. En este sentido podían dar a entender cierta supervivencia del orden tradicional y simbólico. Pero por diferentes que fuesen, también formaban parte de la modernidad, y en ella adquirían un doble sentido. En ese aspecto, en los objetos antiguos prevalecía la capacidad para significar sobre la capacidad para ser prácticos, sin embargo, según Baudrillard ${ }^{18}$, tampoco podían considerarse afuncionales ya que cumplían una labor muy específica en el marco del sistema: la introducción de la memoria y el tiempo. Lógicamente no se refería al tiempo real, sino al signo o a la referencia cultural del tiempo pasado. Su presencia no contradecía pues el sistema de la organización general, ya que todo se producía en signos.

Es cierto que el elemento antiguo siempre ha tenido una presencia particular, una posición psicológica especial dentro del ambiente, siempre 'se ha vivido' de otra manera. En esta dirección Baudrillard planteaba la siguiente pregunta ${ }^{19}$ : ¿de dónde emerge esa motivación tenaz hacia lo antiguo, al mueble viejo, a lo auténtico, a lo hecho a mano, a lo folklórico?, ¿por qué esa especie de atracción de los habitantes de países 'civilizados' hacia signos excéntricos en el tiempo y en el espacio, que son ajenos a su propia cultura y son casi siempre anteriores en el tiempo?, lo contrario les ha ocurrido a los habitantes de países industrialmente menos desarrollados, siempre se han interesado, sobre todo, por los productos tecnológicamente más avanzados.

En ese contexto, quizá la mayor exigencia a la que respondía el objeto antiguo era a la del valor de 'ya haber sido', el hecho de ser un objeto 'consumado y definitivo', era lo que lo hacía más auténtico. Por extensión lo mismo se podría aplicar a los objetos exóticos. Para el habitante moderno estos objetos significan viajar con la mente a tiempos pasados o a lugares lejanos; y la misma cualidad se podría aplicar a los productos hechos a mano, a los objetos indígenas, a chucherías de todos los países... y no tanto por su aspecto pintoresco, sino por las reminiscencias de los modos artesanales de fabricación, por la anterioridad de sus formas; en definitiva por las alusiones a mundos y tiempos remotos.

Todo objeto antiguo es bello simplemente porque ha sobrevivido y se convierte por ello en signo de una vida anterior (...) Por así decirlo, van precedidos de una partícula nobiliaria y su nobleza hereditaria compensa la caducidad precoz de los objetos modernos"

Jean Baudrillard ${ }^{20}$

De todo lo anteriormente expuesto se deduce que la 'semántica del objeto'21, se convertía en la estructura definitoria y clasificatoria en la visión contemporánea del objeto. Tal y como se ha explicado anteriormente, las definiciones etimológicas se presentaban vagas, por lo que Roland Barthes ${ }^{22}$ decidió

18 Jean Baudrillard, "El objeto marginal, el objeto antiguo" en El Sistema de los Objetos (México: Siglo XXI, 1969) p.83.

19 lbíd. p.84.

20 Ibíd. p.94.

21 "Semántica del objeto" es una conferencia pronunciada por Roland Barthes en septiembre de 1964 en la Fundación Cini de Venecia, dentro del marco de un coloquio acerca de 'El arte y la cultura en la civilización contemporánea. Publicada en Arte e Cultura nella civilita contemporánea, editado por Piero Nardi (Florencia: Sansoni, 1966).

22 Roland Barthes, "Semántica del objeto" en Arte e Cultura nella civilita contemporánea, editado por Piero Nardi (Florencia: Sansoni, 1966). 
intentar saber cuáles eran las connotaciones de la palabra 'objeto' para ir más allá de la típica definición de "el objeto es una cosa". Entre connotaciones existenciales y tecnológicas, surgieron consideraciones como que el objeto no era un elemento vivo sino que, tanto en apariencia como en existencia, era algo artificial. También dedujo que objeto, al tener tratamiento literario, artístico y estético, podía convertirse en un instrumento importante de expresión, lo cual no lo eximía de conducir, por tanto, hacia consideraciones subjetivas.

Desde el punto de vista tecnológico, el objeto era algo fabricado, y por tanto un elemento característico de consumo. Con estas premisas, como se dedujo en los estudios anteriormente mencionados, la conclusión era que el objeto se había convertido en algo 'infinitamente social'. "De esta última concepción del objeto quisiera partir", dijo Barthes. Así llegó a la consideración más contemporánea del mismo: el objeto como signo.

El objeto, desde que era producido y consumido por una sociedad de hombres, desde que era fabricado y normalizado, había sufrido una semantización del mismo, por eso Barthes utilizó la semiótica como base de su estudio e indagó sobre la coexistencia entre el objeto funcional desde el punto de vista de su origen más tradicional y del objeto comunicador, desde la visual más contemporánea. Aunque, como el resto, tampoco desdeñó su faceta subjetiva.

Como todo signo, según el autor, el objeto se encontraba en la encrucijada de dos definiciones, la simbólica y la taxonómica. Ninguno escapaba a la profundidad metafórica, todo elemento como significante siempre llevaba a un significado. Cualquier elemento, independientemente de lo que fuese o para lo que sirviese, siempre se lo acababa asociando con algo que no era para lo que existía en sí mismo. Y tampoco se libraba de ser incluido en algún sistema de clasificación, que normalmente era sugerido o impuesto por la sociedad. Esto implica adoptar criterios de clasificación, y para ello era fundamental que los razonamientos fueran lo más ecuánimes posibles:

Si hemos de estudiar el sentido de los objetos, tenemos que darnos a nosotros mismos una especie de sacudida, de distanciamiento, para objetivar el objeto, estructurar su significación: y para ello hay un recurso que todo semántico del objeto puede emplear, y consiste en recurrir a un orden de representaciones donde el objeto es entregado al hombre de una manera a la vez espectacular, enfática e intencional, y ese orden está dado por la publicidad, el cine e incluso el teatro.

Roland Barthes ${ }^{23}$

Como método de análisis, de estos medios de expresión contemporáneos, aunque consistieran en 'ficciones', su artificialidad no era motivo para desechar su valor como campo de estudio, sino todo lo contrario porque estos medios empleaban al máximo esa capacidad de comunicación que tenían los objetos -ese juego significante/significado- que servía para transmitir mensajes.

En este punto Barthes, avanzando hacia mayores complejidades, examinó todas las significaciones que podían ir añadidas a las pluralidades organizadas de objetos. Existían casos en los que el sentido no nacía de un objeto, sino de un conjunto perceptible de objetos. Por lo que decidió hablar principalmente de las composiciones de elementos, de grupos organizados de tal manera que podía transmitir un determinado mensaje, como en publicidad, en teatro, 
o incluso en una habitación: objetos reales ligados por una única forma de conexión, que según el autor era la yuxtaposición pura y simple de elementos. $Y$ cómo no, dentro de los significados posibles, también se adentró en las complejidades abordando la polisemia del objeto, en su capacidad de poder significar varias cosas, dependiendo de la situación o del receptor, es decir, del lector del objeto. La consideración de la lectura individual, llevaba al reconocimiento de la capacidad del objeto para suscitar lecturas incluso de nivel psicoanalítico.

Desde la perspectiva del arquitecto, los americanos Charles Moore, Gerard Allen y Donlyn Lyndon ${ }^{24}$, abordaron el estudio de los objetos desde el punto de vista de su comportamiento e influencia en el proceso de diseño. Utilizando como ejemplo sus propios proyectos de viviendas o tomando referencias históricas, para este estudio partieron de la idea de la casa como 'lugar'. Según Christian Norberg-Schulz ${ }^{25}$ la palabra 'lugar' estaba cada día más presente en el debate sobre la arquitectura, para diferenciar el espacio arquitectónico del espacio matemáticamente abstracto. Tras Wright, Mies y Le Corbusier, generaciones posteriores de jóvenes arquitectos norteamericanos se dirigían a la creación de 'lugares', utilizando como base la planta libre ${ }^{26}$. El espacio dejaba de pensarse en términos geométricos, ni siquiera como una especie de organismo topológico, y empezó a entenderse como una interrelación de elementos, 'elementos de lugar' sometidos al 'orden de las habitaciones'. Las habitaciones para Moore empezaban a concebirse como espacios no específicos, escenarios vacíos para la acción humana, que proporcionaban oportunidades para que ocurriesen cosas.

En este sentido, Moore, Allen y Lyndon ${ }^{27}$, trataron sobre el papel de los objetos en el espacio doméstico, como consecuencia de tres ideas fundamentales en su obra y en su forma de entender la vivienda. Por un lado, estaba la idea anteriormente comentada, la de la casa entendida como 'lugar', como un ámbito especial y único para sus habitantes cuya configuración precisaba de determinados elementos que, como mecanismos, hacían de la casa un 'lugar' para nuevas experiencias. Por otro lado, estaba el hecho de que mantener la idea de la planta libre en sus viviendas venía a plantear cuáles eran los sistemas de acomodación más adecuados de los objetos en dicho espacio, ya que este proceso se convertía en parte fundamental del sistema distributivo y organizativo de la planta. Y finalmente, estaba el planteamiento, por parte de los autores, de que debía existir una dimensión simbólica en la vivienda que funcionara como vínculo del habitante con el espacio, lo cual les dirigía hacia el objeto antiguo o singular en general, así como hacia las colecciones.

En nuestra práctica hemos hecho honor a nuestra fe en que las casas deben ser lugares especiales dentro de otros lugares, el centro del mundo para sus habitantes y sin embargo, cuidadosamente relacionadas con un lugar mayor al que pertenecen.

Moore, Allen y Lyndon ${ }^{28}$

Esto les llevó a crear una materialización de la idea del 'centro del universo'

24 Charles Moore, Gerald Allen y Donlyn Lyndon, La casa: forma y diseño (Barcelona: Gustavo Gili, 1999).

25 Christian Norberg-Schulz, Los Principios de la Arquitectura Moderna. (Barcelona: Reverté, 2005) p.67.

26 Ibíd. Según Norberg-Schulz los arquitectos MLTW -Moore, Lyndon, Turnbull, Whitaker- fueron de particular interés en este contexto.

27 Charles Moore, Donlyn Lyndon y Gerald Allen. La casa: forma y diseño (Barcelona: Gustavo Gili, 1999).

28 Ibíd. p.50. 
en el interior de la casa. En los proyectos de Moore y sus socios, la idea tradicional del edículo, elemento compuesto de cuatro postes y un techado dentro de un espacio mayor, donde se colocaban objetos sagrados o se coronaban a emperadores, se transpuso al mundo doméstico contemporáneo. Este elemento les permitía representar distintos grados de interior dentro de la planta libre, posibilitando la privacidad y la independencia en espacios que, por su propia naturaleza, no lo permitían. De esta manera abrían el debate de 'la casa dentro de la casa' del que se hablará más adelante.

El edículo 'moderno' además les proporcionaba un sistema de ordenación dentro del espacio. La consecución de distintos niveles de privacidad que permitía este tipo de elemento, daba un mayor sentido a la idea de la casa como 'lugar', jugando con la ambigüedad entre interior y exterior. También la imagen de 'mini-casas' dentro de la casa potenciaban el concepto por los efectos y juegos de escala. En algunos de los proyectos de Moore, sobre todo en los desarrollados por el estudio MLTW, prevaleció esa incorporación del edículo al interior como mecanismo de organización espacial, siendo el ejemplo de mayor relevancia el de la Casa Moore en Orinda, California, realizada por Charles Moore en 1961.

En una planta cuadrada libre de divisiones y de elementos distributivos, en el sentido tradicional, dos edículos conformados por cuatro postes cada uno y un techo, ordenaban y distribuían el espacio de manera más libre y natural.
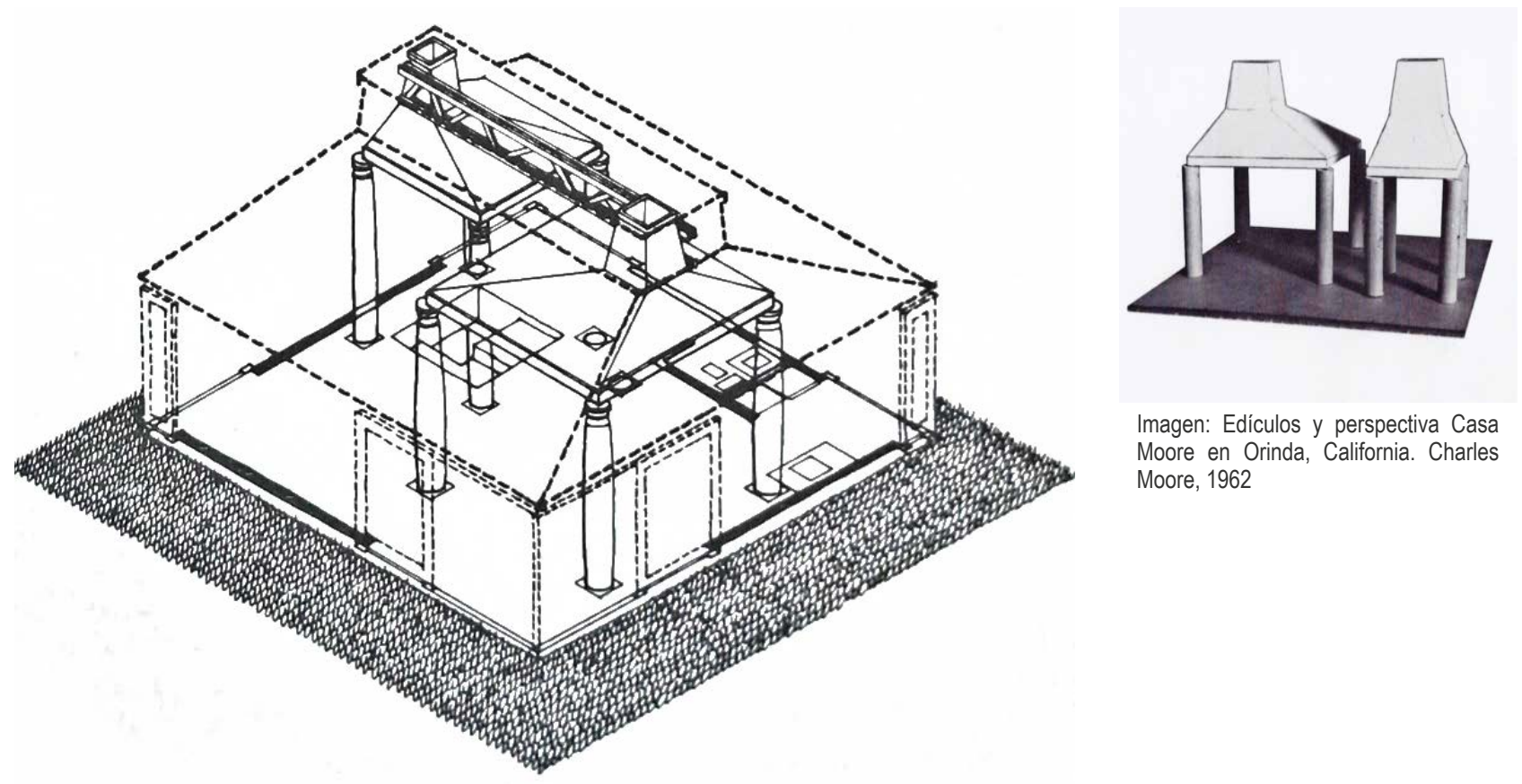

Imagen: Edículos y perspectiva Casa Moore en Orinda, California. Charles Moore, 1962

La percepción y la vivencia del lugar también eran factores importantes en el proceso proyectual. En ese aspecto, los arquitectos pensaron que podía existir la posibilidad de transformar la percepción del espacio utilizando determinados mecanismos, entre los que se incluían los objetos.

En muchos casos, dentro de este contexto cuyo proyecto más representativo es la Casa Moore en New Haven, Connecticut ${ }^{29}$, los propios elementos constructivos sufrían un proceso de objetualización y así adquirían nuevas acepciones que les permitían participar de forma más libre de aquel sistema 


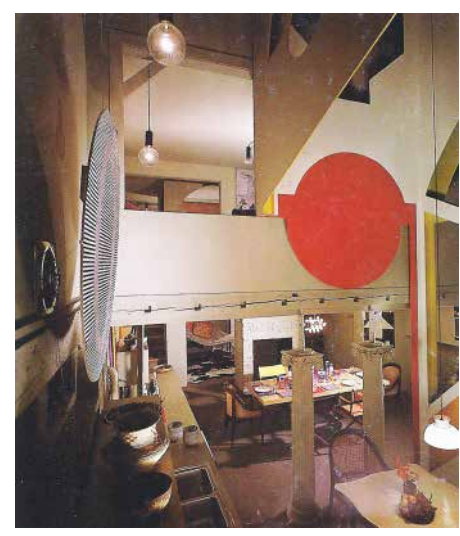

Imagen: Interior desde planta baja, Casa Moore en New Haven, Connecticut. MLTW/ Moore-Turnbull, 1967 de intenciones 'ilusionistas': columnas, canopias, muros multicapa, junto a anaformismos, supergráficos, luces de neón y retratos victorianos, potenciaban los efectos de trasformación espacial, que habían sido provocados por tres grandes cabinas incrustadas en el edificio. Estos 'fustes' comunicaban visualmente todos los niveles de la casa, tanto en planta como en sección. Con este ejemplo, los arquitectos demostraron que en el mundo moderno el objeto podía utilizarse como mecanismo para modificar la percepción espacial.

Otra de las preocupaciones de los arquitectos era cómo acomodar las máquinas ${ }^{30}$, en un espacio libre que, en realidad, se había convertido en un marco para el equipamiento.

Las habitaciones, como espacios vacíos en los que se realizaban los ritos y las improvisaciones de la vida, suministraban oportunidades que permitían hacer y ser lo que se quisiera. La idea era dotarlas de cualidades que las hicieran ser lugares especiales para habitar. Las habitaciones también eran lugares preparados para albergar las máquinas ${ }^{31}$, las cuales, tanto si necesitaban 0 no acción humana para funcionar, exigían un espacio. A estos espacios los llamaron "dominios de máquinas", pero no tenían por qué coincidir con el volumen total de las habitaciones, sino con las áreas específicas que rodeaban a las máquinas.

Si los espacios alrededor de los muebles eran más importantes que los muebles en sí, entonces ¿cómo acomodar los objetos en el espacio, teniendo en cuenta sus dominios, sin perder la pureza de la planta libre? Esta cuestión les llevó también a planteamientos sobre distintos sistemas de agrupación. Los objetos y sus formas de conjuntarse eran factores determinantes de la configuración de las casas. En cualquier caso, para Moore siempre había buenas razones para agrupar fregaderos, baños y lavabos; aunque las razones fueran más conceptuales que económicas. Por tanto, la idea radicaba en la disciplina de ordenar tanto los equipamientos como sus dominios, y liberar así el resto del espacio.

En el Condominio de Sea Ranch ${ }^{32}$, cada una de las diez viviendas que conformaban el conjunto se componía de un espacio único que contenía dos pequeñas casas: una era un simple cobertizo sobre cuatro pilares sobre el cual había un dormitorio, y la otra era una especie de casa en miniatura con una cocina y un baño abajo más un vestidor arriba. A veces estas mini-casas contaban con una buhardilla arriba. Las 'casitas' estaban hechas de madera y pintadas, en el caso de la vivienda de Moore ${ }^{33}$, estaba pintada en cinco tonos de azul para distinguirla del resto del espacio, que estaba acabado en madera vista. El efecto era el de una casa en miniatura, o el de una cabina gigante. En cualquier caso, la agrupación en base a estos volúmenes, proporcionaba la oportunidad de disponer de un espacio único que a su vez funcionaba como fondo de las cabinas policromadas. Aquello era el resultado de separar rigurosamente máquinas y dominios de máquinas, de las habitaciones.

Las máquinas estaban colocadas en una torre compacta emplazada en medio

30 Charles Moore, Donlyn Lyndon y Gerald Allen. La casa: forma y diseño (Barcelona: Gustavo Gili, 1999). Para los autores una máquina era una parte del equipamiento doméstico que ayudaba en una tarea específica. Evidentemente esto incluía frigoríficos, lavaplatos, fregaderos, hornillos, lavabos, bañeras, duchas, bidets, estufas, etc., aunque también se incluían los armarios empotrados, las escaleras, los bancos fijos, las camas, las estanterías y en realidad cualquier objeto fijo al que se recurriese para realizar un acto determinado.

31 Charles Moore, Donlyn Lyndon y Gerald Allen, "El orden de las máquinas" en La casa: forma y diseño (Barcelona: Gustavo Gili, 1999) p.15.

32 Por MLTW en Sea Ranch, California en 1964.

33 El arquitecto contaba con uno de los apartamentos, dentro del condominio. 
de un espacio-living, compuesto quizás más descuidadamente. En la planta baja de aquella torre de equipamientos había fuegos de cocina, frigorífico, lavaplatos y alacena; en el altillo un lavabo, un aseo con inodoro y bañera. Más arriba una litera. Incluso el teléfono, el termostato y los interruptores para la mayoría de las luces de la casa estaban en aquel núcleo central de las máquinas, lo cual dotaba de orden y sencillez al conjunto a pesar de su apariencia bastante compleja: "la claridad y sobre todo, la especificidad de esta disposición nos preocupó mucho pues como ya hemos señalado permite que la superficie restante del condominio sea una habitación pura y simple, un gran escenario" 34 .
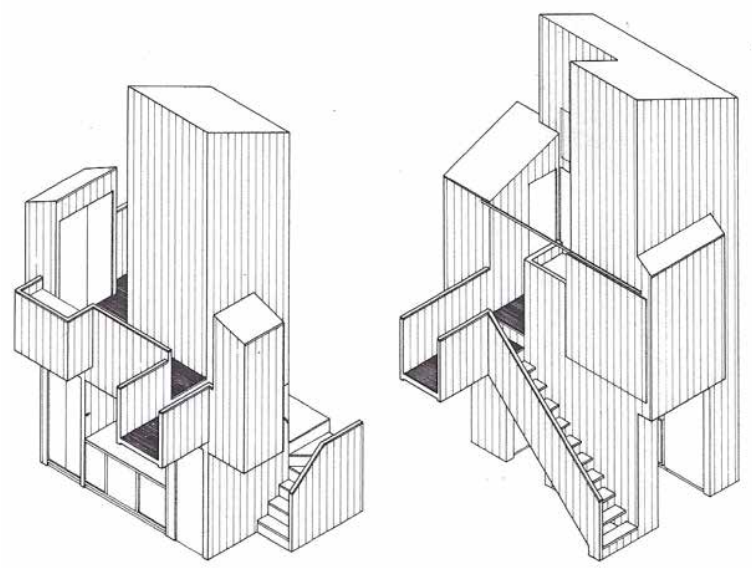

También agrupaban las máquinas fuera de las habitaciones. Una simple habitación, podía estar vacía y en espera de la acción humana, si los equipamientos específicos -cocina, baño, despensa y similares- se adosaban agrupados en pequeños cobertizos colgantes, como si fueran alforjas, a ese espacio central. Un ejemplo era la Casa Bonham ${ }^{35}$, que consistía en un espacio central a doble altura con espacios adosados tipo 'alforjas' y muchos cambios de nivel que proporcionaban 'lugares' para sentarse y colocar cosas.

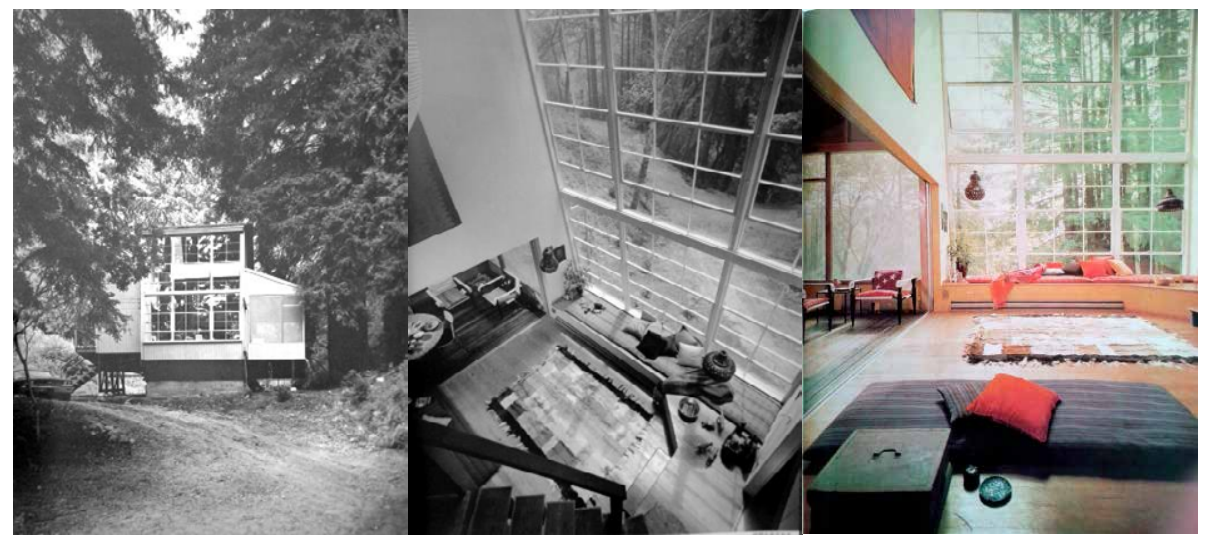

Los elementos de la cocina y el baño estaban adosados por fuera a la única habitación principal de la casa. Las ventajas de esta disposición eran la sencillez y la economía. En lugar de una serie de habitaciones de tamaño

34 Charles Moore, Donlyn Lyndon y Gerald Allen. La casa: forma y diseño (Barcelona: Gustavo Gili, 1999) p.164.

35 Proyecto realizado por MLTW en Santa Cruz, California en 1961.
Imágenes: Sea Ranch Condominium. California. MLTW 1964. Volumen de equipamientos, tipo 1 y tipo 2.

Imagen: Casa Bonham. Santa Cruz, California, por MLTW, 1961. Vista exterior e interior 
Imagen: Casa Talbert. Oakland, California, por MLTW, 1962. Plantas.

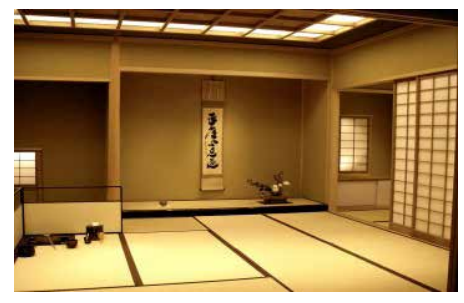

Imagen: Tokonoma tradicional japonés moderado, este sistema permitía una habitación generosa, definía claramente los dominios de máquinas y los separaba del resto. La idea era construir un espacio central de uso común y arroparlo con espacios de usos específicos, 'colgados' a él como si fueran mochilas. Cuando había poco de espacio para muebles, como era el caso, convertían todo el interior en mobiliario: una chimenea de color naranja, la barandilla del dormitorio era de color azul, y había una escalera color púrpura que resaltaba contra las paredes blancas.

Otro ejemplo es la Casa Talbertt ${ }^{36}$, una casa construida en una parcela con mucha pendiente, cuyo espacio central de muros blancos creaban un escenario a múltiples niveles, con escaleras, plataformas y miradores por la pendiente, ya que se accedía desde la parte superior de la casa.

En las habitaciones, con capacidad para el movimiento y el reposo, también se incluían objetos, como elementos inductores: un solo foco congregaba en sí la atención, estructurando la habitación en torno a un solo centro de interés, como una chimenea o un sofá. El foco único inducía al reposo.
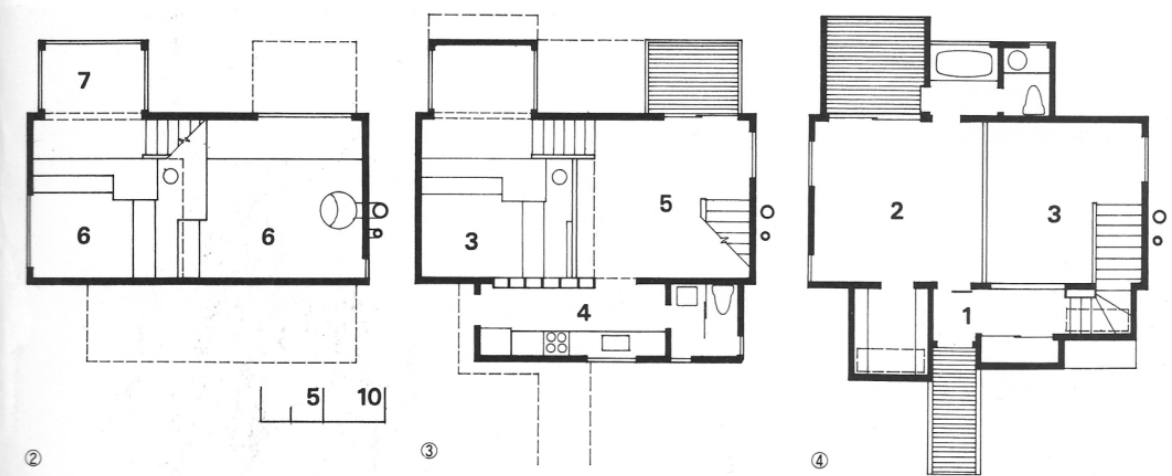

Quizá el foco histórico más representativo era el tokonoma ${ }^{37}$. Los japoneses, en sus casas tradicionales, conseguían hacer un arte de la disposición del foco. Se trataba de un nicho donde se colocaba un cuadro, o unas flores. Los objetos reforzaban el contenido emocional de los rituales que se realizaban en la habitación, como la ceremonia del té. Pero el foco en el mundo occidental era más casual, además el más característico de nuestra cultura era la televisión. Un foco desproporcionadamente influyente dentro de la habitación, y del que se hablará en otro apartado.

Al igual que el foco único inducía al reposo, los focos múltiples lo hacían al movimiento, tanto del cuerpo como de la mirada, generando recorridos y visuales, como en el caso de la Blackburn House, de Londres ${ }^{38}$.

También se contemplaron las posibilidades de "añadir algo" a la casa ${ }^{39}$, para aumentar o modificar las cualidades del espacio. A través de ese 'aditamento', en el que el ocupante utilizaba tanto los objetos, como los emplazamientos de éstos, el usuario podía establecer su propio discurso, de manera que el espacio pudiera reconocerse como suyo. El efecto se podía potenciar con los colores, las texturas y los materiales.

36 Construida por MLTW en Oakland, California en 1962.

37 Teiii Itoh, "Tokonoma", GA Houses n³ (1977) p.4-7. Definía tokonoma como un tipo de alcoba o nicho en un muro, cuyo origen se situaba en las salas de recepción o en las habitaciones de té de las casas japonesas del siglo XIV.

38 Reforma de una vivienda realizada por Peter Wilson en Heampstead, Londres en 1986.

39 Charles Moore, Donlyn Lyndon y Gerald Allen, "Recolección" en La casa: forma y diseño (Barcelona: Gustavo Gili, 1999) p.214. 


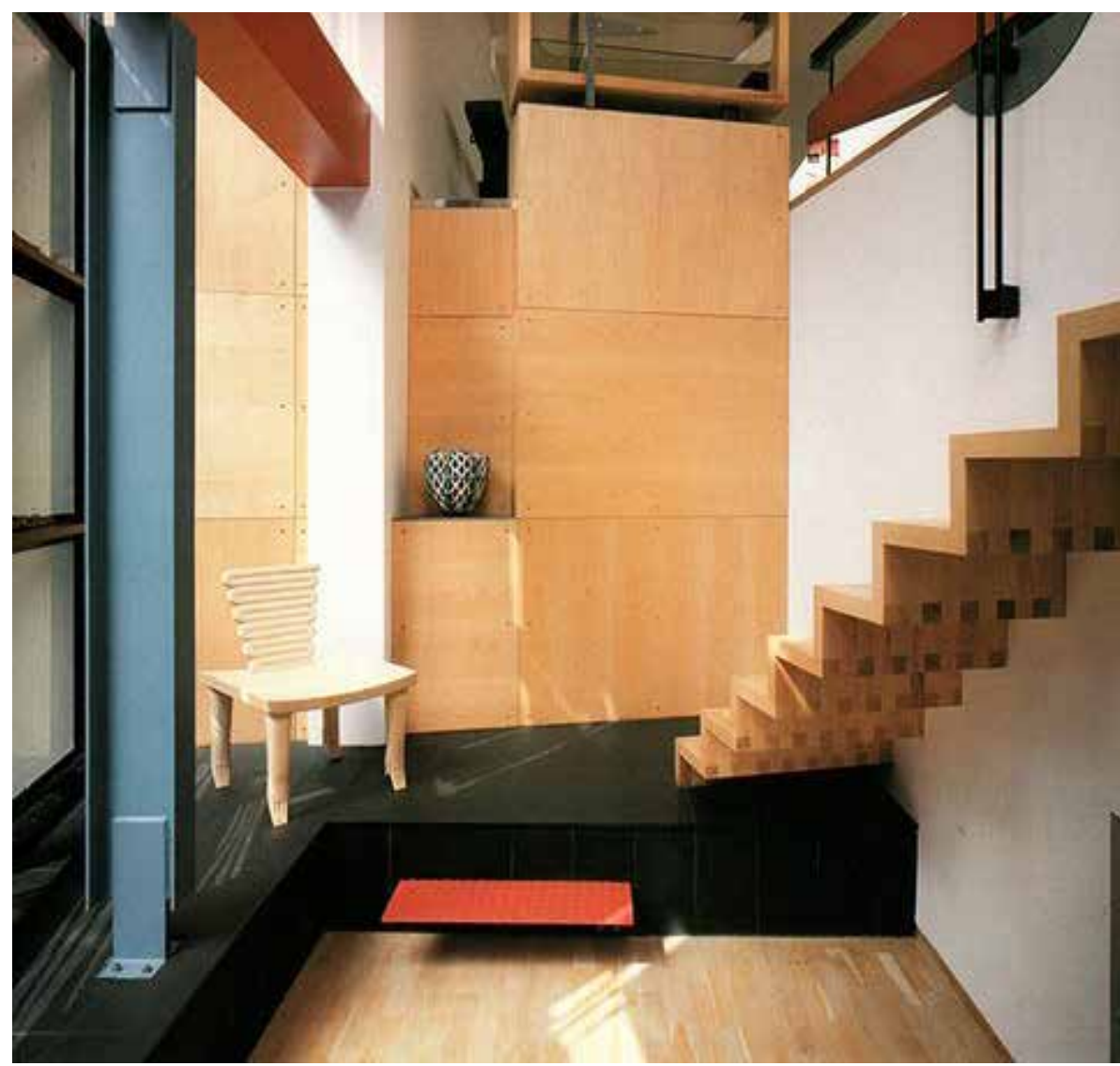

El objeto cumplía la labor de vínculo entre el habitante y el espacio, dadas las condiciones de los ámbitos modernos que morfológicamente habían devenido más asépticos e impersonales. Los colores tenían la capacidad de ampliar las cualidades del lugar, y los materiales también llevaban implícitas sus connotaciones. Igual podían ser objetos de plata antiguos, que piezas de ajedrez, soldaditos de plomo o barcos metidos en botellas. Rodeándose de cosas con un significado especial, consideraban que era posible añadir una nueva dimensión al lugar que se habitaba. Colecciones de sillas, piedras, grabados o lo que fuese, siempre adquirían su poder del acto de discriminación y compromiso que representaban. Carecían de valor si no eran personales.

"El despliegue de colecciones se convierte en parte de la casa", decía Moore ${ }^{40}$. La casa y la colección podían llegar ser inseparables en una especie de simbiosis, como ocurría en la casa de los Eames en California, la casa sin los objetos no sería aquella casa.

En muchos de los casos, estos objetos podrían englobarse entre la categoría de los llamados 'objetos físicos' y los 'objetos culturales'41. De hecho el arquitecto y teórico Norberg-Schulz, dividía el ambiente en objetos 'físicos', 'sociales' y 'culturales'. $Y$ todos ellos juntos, constituían 'el mundo'. Las categorías de objetos estaban interrelacionadas lógicamente. Entre los objetos culturales estaban las ideas, las obras de arte, etc. y se distinguían por sus manifestaciones sociales o físicas, mientras que los objetos sociales se conocían a través de los comportamientos, que eran manifestaciones físicas. Finalmente, los objetos físicos se conocían mediante la observación, y podían reducirse a datos sensoriales o fenómenos.

En ese aspecto, Norberg-Schulz relacionaba directamente los objetos con

40 Ibíd. p.218.

41 Christian Norberg-Schulz, Intenciones en arquitectura (Barcelona: Gustavo Gili, 1998) p.22.
Imagen: El pilar azul de la Blackburn House, diseñada por Peter Wilson en 1986 daba inicio a un recorrido repleto de obras de arte y de piezas maestras de mobiliario de Ron Arad, Jasper Morrison o Bruce McLean. Estos objetos actuaban como focos múltiples en el espacio incitando a realizar un recorrido de abajo a arriba, que es lo que da sentido al proyecto de la casa. 


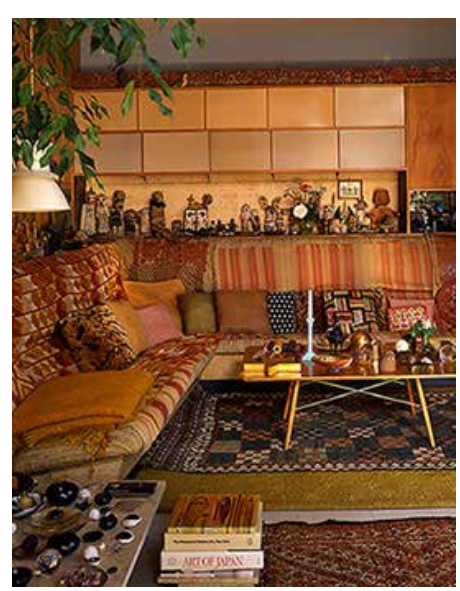

Imagen: Charles \& Ray Eames. Case Study house 8. California 1949. Vista interior de la casa repleta de objetos personales de los Eames. las acciones ${ }^{42}$. Las acciones reconocían una organización del entorno. Esa organización consistía en deducir y asociar los objetos de los fenómenos inmediatamente dados. Los objetos, es decir, la forma que asignamos al mundo, se expresaban a través del comportamiento. Para determinados propósitos era necesario fijar los objetos por medio de signos, de manera que se pudiera hablar de ellos, que pudieran ser descritos y ordenados en sistemas. Cuanto más complejo y diferenciado se volvía el ambiente, mayor era la necesidad de 'sistemas de símbolos' que permitieran su colaboración y cooperación.

Para Norberg-Schulz los 'fenómenos' y los 'objetos' eran dos aspectos de la misma cosa. El arquitecto fue uno de los precursores del desarrollo de la fenomenología en la arquitectura a partir de los años 60, un aspecto en el que, como se puede comprobar, los objetos estaban íntimamente ligados a la idea del conocimiento del espacio a través de la experiencia, y de lo que se tratará más adelante en otro apartado de este capítulo.

Hemos visto, tras lo anteriormente expuesto, que el estudio del objeto cotidiano en el marco doméstico contemporáneo, llevó a su definición y consideración desde dos perspectivas: por un lado desde el punto de vista del análisis sociológico -poco hay que añadir a su consideración como factor social por ser el principal producto de consumo- y por otro desde el punto de vista arquitectónico, es decir sobre su capacidad para participar de forma activa en el proceso de configuración espacial y en las cualidades del espacio.

Para aunar ambos puntos de vista, es de interés el trabajo que realizaron en Europa en los 80, Monique Eleb, Anne Marie Chàtelet y Thierry Mandoul ${ }^{43}$, que frente a una puesta en cuestión de la vivienda contemporánea abordaban el tema desde dos perspectivas, como estudio de la vivienda contemporánea desde el punto de vista sociológico a través del análisis de los elementos que habían influido en mayor medida en el proceso proyectual, y como un análisis más arquitectónico, sobre cómo se entendía la vivienda de finales de los ochenta. Es decir, cómo se había adaptado la vivienda a la evolución de las mentalidades y a los nuevos modos de vida.

En el estudio se deducía que seguía latente la validez de las cualidades de un espacio flexible y polivalente. En este sentido, y en muchos de los casos, el mobiliario seguía determinando el uso de la habitación según la hora del día o la estación del año. De los elementos que habían perdurado desde los 60 como parte del 'sistema flexible', el tabique móvil era el que más seguía utilizándose, posibilitando distintos grados de intimidad o permitiendo manipular la distribución transformando el espacio y convirtiéndolo en otro. También 'el paquete de servicios' se mantenía intacto como recurso proyectual para liberar el espacio.

De la misma forma que se mantenían algunos sistemas ya empleados en otras décadas, también eran detectados nuevos muebles y elementos arquitectónicos que se convertían en mobiliario, como el caso de la 'tabiquería con espesor'. Este elemento arquitectónico, a destacar por el estudio realizado, surgía como una pieza principal de la casa para absorber instalaciones y todo tipo de dispositivos: pantallas de video, teléfono, aparatos multimedia, zona de trabajo, etc. En realidad se trataba de un fenómeno de objetualización en el que un elemento tradicionalmente constructivo y divisorio, como era el

42 Christian Norberg-Schulz, "Objeto y descripción" en Intenciones en arquitectura (Barcelona: Gustavo Gili, 1998) p.36.

43 Monique Eleb, Anne Marie Châtelet y Thierry Mandoul, Penser I'habité. Le logement en questions (París: Mardaga, 1988). 
tabique, se convertía en un mueble que albergaba distintos instrumentos y aparatos de la casa. Este fenómeno surgía como un factor característico del espacio doméstico contemporáneo, por lo que es estudiado en otro apartado de este capítulo. En cualquier caso, estos nuevos muebles, surgían en relación a los avances tecnológicos en las comunicaciones y las redes, por lo que a veces también se definían como 'tabiques multimedia', que incluso se podían desplazar gracias a la existencia de un raíl para poder hacer 'mutar' al espacio dependiendo de las necesidades. Estos elementos ejercían una doble faceta, la de distribuir y la de comunicar.

También es de destacar las referencias a la noción de apropiación como sistema, que continuaba apareciendo en el espacio doméstico, para crear vínculos entre habitante y espacio: "la apropiación constituye uno de los enlaces esenciales entre el usuario y su hábitat"44. En esa fase de 'aditamento', para añadir una nueva dimensión espacio, los objetos personales de todo tipo seguían teniendo protagonismo. A este respecto, el estudio de Eleb, Chàtelet y Mandoul destacaba la recuperación en estos años de un espacio olvidado por la vivienda moderna, el rincón, el recoveco: "Estos encantos de la arquitectura, abandonados, son ahora rebuscados y reencontrados para colocar ahí el bibelot, la figurita, el fetiche, su impronta. Este tipo de lugares habían sido pasado a segundo plano, desplazados por la sencillez del plan moderno"45.

Por tanto, la visión contemporánea del objeto surgía inmersa en una sociedad de consumo que habitaba en un mundo característicamente objetual. La definición de objeto en ese contexto llevó a huir de los enunciados más etimológicos, encuadrándola en el concepto de producto de consumo y en el marco perceptivo del entorno. El objeto por tanto se definió básicamente como artificial y fabricado por el hombre. Accesible a la percepción y diferenciable del entorno. Hecho a escala del hombre y esencialmente manipulable. Con una relación tan directa con las acciones y fenómenos que cabría decir que eran parte de la misma cosa. Podía así convertirse en un instrumento importante de expresión.

Tal presencia del objeto en el ámbito social hizo que los estudios lo abordasen como elemento sociológico. El objeto empezó a ser analizado como mediador social. De esta manera, el significado desplazó a la función.

En la cadena de consumo, el espacio doméstico era considerado el eslabón final, y por tanto un entorno privilegiado para el análisis. Era el ámbito más íntimo y con voluntad de permanencia.

En este entorno, se trataba de los objetos cotidianos, de los que ocupan el hábitat del hombre, a la escala del ser humano. Los que participaban de la fenomenología del despliegue cotidiano. Los que hacían que la vivienda se entendiera como su ámbito de apropiación.

Los cambios sufridos por los modos de vida del individuo contemporáneo y los producidos en los objetos cotidianos, como el mobiliario, dieron lugar también a cambios de organización en su conjunto.

Hablar de objetos en conjunto hacía que careciera de sentido hablar de función exclusivamente. Los estudios abordaban el universo de los objetos en su capacidad de transmitir un mensaje como conjunto. En su coherencia de grupo

44 Ibíd. p.132.

45 Ibídem. 
para elaborar un discurso.

Dentro del ámbito doméstico, el mensaje se basaba en el lenguaje de los objetos reunidos en su interior. El espacio era como una estructura de distribución. Su control proporcionaba todas las posibilidades de combinaciones. Aquellos sistemas de relaciones y conexiones generaban el discurso.

En esta práctica se distinguían dos factores diferenciadores. Dos factores que coincidían en la mayoría de los estudios. Por un lado, estaba el sistema de organización, colocación o apropiación; basado en códigos de acoplamiento y sintaxis de colocación, y en el que lo más importante era la idea de conjunto. Podría llamarse, como lo denominó Moles, el "mensaje semántico" o mensaje objetivo. Por otro lado, estaba el mensaje subjetivo, el de las connotaciones psicológicas en el proceso perceptivo, el de la dimensión simbólica, lo que Baudrillard llamó "factor de ambiente", el "aditamento" según Moore, dirigido al tratamiento del espacio.

Existen algunas reflexiones que, aunque quedan algo al margen del hilo argumental, pueden ser de interés para apoyar ciertas conclusiones. Por un lado están las referencias de A. Moles sobre el factor ausencia/presencia del objeto en una habitación, como consecuencia de la técnica y de la actitud sincrónica en el pensamiento contemporáneo, sobre la de la reconstrucción del mundo en cada instante. A este argumento pueden aparecer ligadas la mutabilidad y flexibilidad del espacio, como características contemporáneas del espacio. Por otro lado, es de destacar la actitud de Baudrillard frente al objeto singular, al que engloba en una categoría completa ya que funciona como signo por sí solo. También desvela algo importante para el posterior análisis, la capacidad del objeto antiguo o folklórico para conectar con el resto de sistemas, porque todo se produce en signos. Esta realidad ayuda a no huir del objeto excéntrico en el estudio de las relaciones en el espacio. Sobre todo en el contemporáneo.

Otra idea que se ha de destacar es la de Barthes sobre la separación que debe producirse para analizar el significado del objeto, es decir, la de observarlo en su estado más enfático. Se refería a la forma en que se hace uso del objeto como mensaje en la publicidad, en el teatro, el cine. Esta reflexión de Barthes ha hecho dirigir parte del estudio a las muestras y exposiciones de mobiliario a partir de mediados del S.XX, como un campo en el que, efectivamente, el discurso realizado por los objetos es más claro y contundente para la obtención de ideas sobre el hábitat contemporáneo.

Finalmente cabría destacar el rincón descubierto por Monique Eleb en los hábitats de los años ochenta. Tras poner la casa en cuestión, descubrió que muchos de los nuevos proyectos de vivienda, aparte del bloque multimedia, incluían un espacio, que se recuperaba, y era el rincón de los objetos personales, el de los recuerdos, algo ya olvidado. Frente a la invasión de la red y la multimedia, surgía una necesidad de vínculo personal con el espacio, pero quedaba relegada al rincón. Aunque testimonial, esta actitud observada por Eleb, también es de importancia para el análisis. 


\subsection{OBJETOS: NUEVOS CONCEPTOS}

Es posible únicamente analizar el objeto si podemos definirlo como una forma de diálogo en el conjunto, si podemos demostrar cómo está colocado y las leyes que lo regulan. La existencia del objeto está definida por las relaciones establecidas entre procedimientos económicos y sociales, formas de conducta y normas técnicas. Características que aun sin ser expresadas por el objeto mismo, lo dejan nacer y permiten descubrir sus relaciones con otros objetos. Estas premisas son el consuelo y la esperanza de la realidad, la única clave de una posible interpretación del objeto, eliminando ambigüedades, contradicciones, discordias y las distorsiones de la historia.

\section{Gae Aulenti ${ }^{46}$}

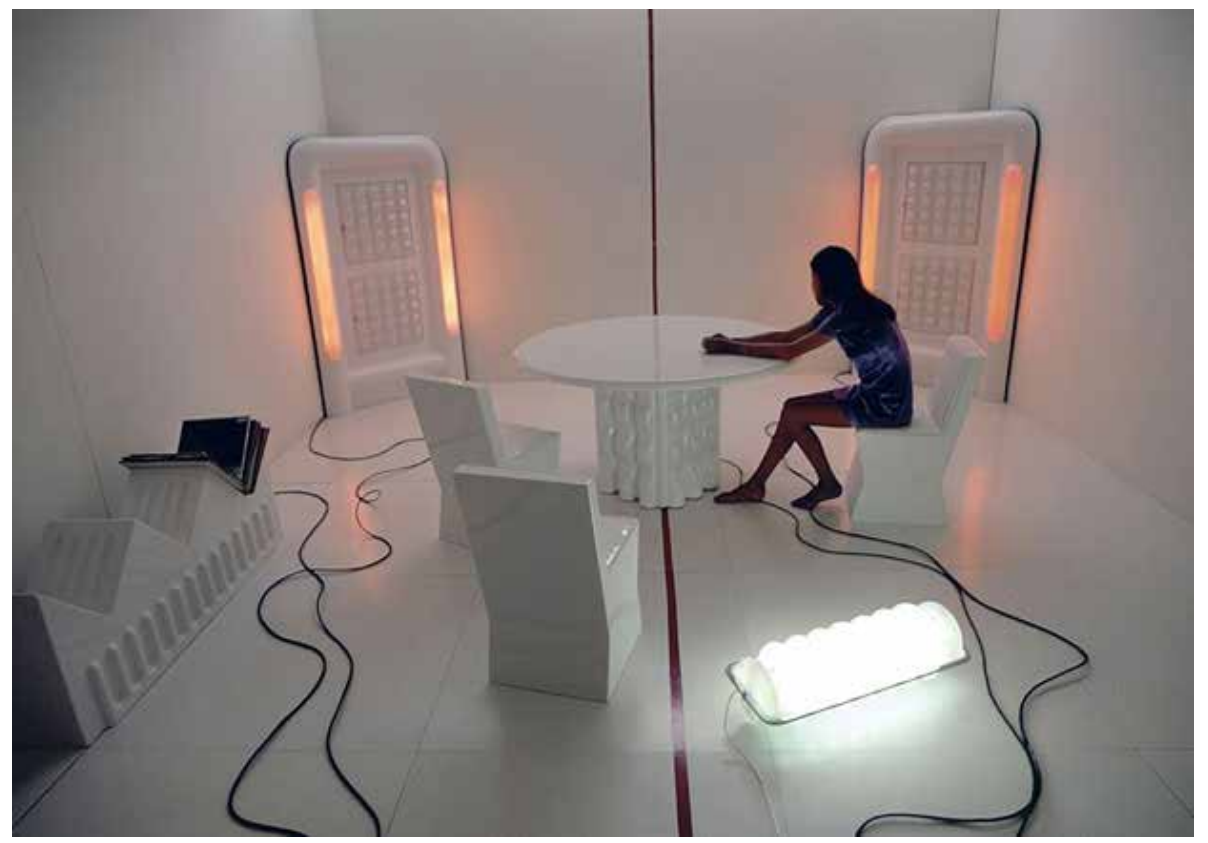

Se ha constatado, según el apartado anterior, que las nuevas estructuras sociales y la influencia del objeto en todos los ámbitos de la vida, vieron surgir una nueva mirada hacia el objeto cotidiano. Su papel como signo, como mediador social, más que como utensilio, o como elemento que servía para una determinada función, es lo que ha caracterizado, en mayor medida, a la forma de entender el objeto en el marco contemporáneo.

La clave de la visión moderna del objeto en el espacio estaba no sólo en el descubrimiento de su faceta semántica, sino en la consideración, prácticamente unánime de que, para la confección de un discurso, era casi fundamental la estructura de conjunto, la de un sistema de elementos en el espacio organizados bajo una combinatoria de relaciones y conexiones.

Esa nueva visión del objeto ha dado fruto a distintos conceptos en torno a la manera de entender el objeto en el mundo contemporáneo.

La consideración del objeto como conjunto y como mediador social, provocó que de la función, en su estudio, se pasara al significado. La función, finalmente, consistía ya en su coherencia de conjunto. En su papel en la elaboración del
Imagen: 'Mobili grigi'. Ettore Sottsass, 1970 .

El sistema de muebles grises ideado por Sottsass pretendía unificar, a través del color, todo el mobiliario de la casa con el fin de neutralizar la totalidad de las habitaciones y conseguir un entorno único. 
discurso en el marco espacial. En ese aspecto, vimos que el ámbito doméstico era considerado el marco privilegiado. El discurso, ese mensaje donde se reflejaba el propio habitante, se producía esencialmente en la casa, en el espacio más íntimo.

El discurso objetivo, el de la colocación, era el que daba sentido al espacio como estructura de distribución. Esta sistematización llevaba a establecer normas de colocación, a considerar aspectos como las áreas de influencia 0 los espacios que rodeaban a los objetos. Su lenguaje estaba en las relaciones que se producían unos frente a otros, en las jerarquías y en lo que generaban en sus propios dominios. No siempre los planteamiento iban dirigidos a 'ocupar' sino que también surgían consideraciones de índole organizativo, como las agrupaciones de equipamiento, que contrariamente iban dirigidas a 'liberar' el espacio.

Las habitaciones, según Moore, eran espacios vacíos, como escenarios preparados para la acción humana. Las acciones y la experiencia, fueron considerados factores fundamentales, en estos años, para la vivencia de la arquitectura. El conocimiento del entorno se entendía ligado, en muchos casos, a los fenómenos derivados de la interacción con los objetos y de su percepción, es decir a la fenomenología.

En el proceso perceptivo, se ha comprobado que en base a sus connotaciones psicológicas 0 a sus cualidades compositivas, algunos objetos eran capaces de transformar la percepción del espacio, introduciendo un nuevo aspecto en el proceso proyectual, el del factor de ambiente. El tratamiento del espacio como una nueva dimensión, surgía en el conjunto de los nuevos conceptos.

La simbología y la memoria, en ese aspecto, introducían la variante del tiempo. Estos dos factores se reafirmaban en la excepcionalidad, aceptada por los estudios, de los objetos singulares como elementos aislados con significado por sí mismos. Su conformación en conjunto en torno a un hilo conductor daba lugar a las colecciones.

Volviendo al aspecto organizativo, las características de los nuevos espacios precisaban muebles 'transformables' que potenciaran su polivalencia y flexibilidad. Aquellos objetos, que podían variar de forma y proporcionar muchas opciones a lo largo del tiempo, se desarrollaban en gran medida por la multifuncionalidad requerida por espacios cada vez más diáfanos y de menores dimensiones, y por el avance de la tecnología. Y precisamente, el desarrollo de las comunicaciones y de la técnica en general, llevó a la presencia de uno de los objetos más focalizadores del espacio doméstico, el televisor.

En definitiva, la clave para obtener datos sobre la visión moderna del objeto es su faceta semántica, y fundamental, la de su estructura de conjunto como forma de diálogo, sobre cómo está colocado y las leyes que lo regulan.

Los nuevos conceptos surgían de la visión del objeto como signo, como mediador social, más que como utensilio. La clave para obtener datos sobre la visión moderna del objeto es tener en cuenta su faceta semántica, y fundamental, la de su estructura de conjunto como forma de diálogo, sobre cómo está colocado y las leyes que lo regulan. 


\section{Función vs. significado}

La paradoja que quisiera señalar es que los objetos que tienen siempre, en principio, una función, una utilidad, un uso, creemos vivirlos como instrumentos puros, cuando en realidad suponen otras cosas, son también otras cosas: suponen sentido; dicho de otra manera, el objeto sirve para alguna cosa, pero sirve también para comunicar informaciones, todo esto podríamos resumirlo en una frase diciendo que siempre hay un sentido que desborda el uso del objeto.

\section{Roland Barthes ${ }^{47}$}

Jean Baudrillard ${ }^{48}$, puso en cuestión el análisis funcional y estructural de los objetos como único punto de vista para estudiar su papel en el entorno del habitante contemporáneo. Para dar respuesta a la pregunta de saber cómo eran vividos los objetos y qué otras acepciones tenían aparte de la funcional -para él era evidente que para "dar cuenta y razón del sistema cotidiano de los objetos"49 el análisis desde el punto de vista de la utilidad era insuficiente. Para el autor, en el marco contemporáneo los objetos comunicaban, y en conjunto, constituidos como sistema en base a sus relaciones, daban oportunidad al hombre para elaborar su propio discurso estructural. El valor del objeto estaba, ya no en su pertenencia, ni en su intimidad, estaba en su capacidad de transmitir información, en sus posibilidades de combinación para la invención, para el control, en su disponibilidad continua, en su significado.

El nuevo habitante, al disponer del espacio como su propia estructura de distribución, se convertía en "informador activo del ambiente"50. Este medio, según Baudrillard, le daba el control de todas sus posibilidades de relaciones y de todos los papeles que podían desempeñar los objetos, y en este contexto calificaba al hombre moderno como el artífice de un sistema de organización en el que todo comunicaba y generaba un completo sistema de signos, que era parte del ambiente.

De todo aquello se deducía un nuevo concepto de 'funcionalidad', que difería del tradiciona ${ }^{51}$. Lo funcional ya no calificaba a lo que estaba adaptado a un fin, sino a lo que estaba adaptado a un orden o sistema; en este caso 'funcionalidad' se definía como la facultad de integrarse en un conjunto para generar un discurso.

Roland Barthes ${ }^{52}$, también realizó una especie de dualidad de la idea de objeto. Primero lo presentaba como un elemento funcional y útil. Después hacía ver que en realidad la función siempre sustentaba un sentido. El significado, al ser un proceso de equivalencias y no de acción, hacía que en todo objeto existiera una especie de lucha entre la actividad de la función y la inactividad de su significación: "el sentido desactiva el objeto, lo vuelve intransitivo".

47 Roland Barthes, "Semántica del Objeto" en Arte e Cultura nella Civilita Contemporánea (Florencia: Sansoni, 1966).

48 Jean Baudrillard, "El objeto moderno liberado de su función" en El Sistema de los Objetos (México: Siglo XXI, 1969) p.15.

49 Ibíd. p.5.

50 Jean Baudrillard, "El hombre de colocación" en El Sistema de los Objetos (México: Siglo XXI, 1969) p.26.

51 lbíd. p.71

52 Roland Barthes, "Semántica del objeto" en Arte e Cultura nella civilita contemporánea, editado por Piero Nardi (Florencia: Sansoni, 1966).

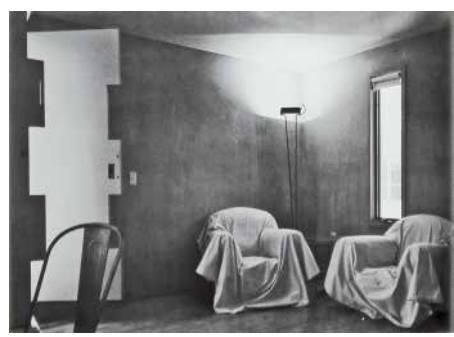

Imagen: Casa del poeta trágico. Hybrid Building, Seaside, Florida, por Steven Holl, 1985. 
Pero Barthes presentaba una tercera fase, en una especie de retorno del objeto a su faceta funcional, pero ocurría tras haber sido leído como signo. Aunque esta 'funcionalidad' no era real, ya que era un hecho ideológico en nuestra sociedad. Por ejemplo, la moda podía diseñar impermeables que no protegían en absoluto de la lluvia, sin embargo significaban como impermeables y su funcionalidad no era real. La función hacía nacer el signo, y ese signo podía finalmente ser reconvertido en "el espectáculo de una función".

Para otro sociólogo, Abraham Moles ${ }^{53}$, lo que interesaba era estudiar cómo se expresaban los seres humanos a través de los objetos, cómo se relacionaban. Hablar de las funciones que cubría un objeto era analizar cuáles eran los modos de expresión que podían tener, del lenguaje del objeto o más bien, del lenguaje del sistema de objetos ${ }^{54}$.

Ese 'lenguaje' aparecía definido por dos aspectos, a los que ya se ha hecho referencia anteriormente: el mensaje semántico -o lo que expresa en relación a su función- y el estético -que se transmite según lo que se percibe, independientemente de que su función sea una u otra-. Un servicio de té s5 $^{55}$, por ejemplo, es para tomar el té, esa sería su significación, su aspecto semántico. Sin embargo ese servicio podía ser chino o rococó, de porcelana o de vidrio, pero ese dato no modificaba sustancialmente su función explícita. Su presencia en tal lugar, qué personas lo utilizaban o qué ambiente generaba, constituían sin embargo un mensaje muy distinto, que se superponía al primero.

En el sistema de objetos, la función se convertía en la expresión del conjunto, en la razón de su significado, coincidiendo con lo dicho por Baudrillard. A este discurso se superponía un mensaje connotativo que estaba basado en otros aspectos, que aunque eran ajenos a la función, no suponían una variación sustancial de su utilidad primigenia.

Años después, también Kenneth Frampton analizaba esta dicotomía del objeto contemporáne $0^{56}$ en el sentido de que la categoría mundana del uso había sido absorbida por el consumo. Los objetos de uso -herramientas, por ejemplo- habían sido transformados por la abundancia en bienes de "usar y tirar". Ese desplazamiento, según Frampton, residía en la intrínseca capacidad destructora del consumo como opuesto al uso.

53 Abraham A. Moles, Teoría de los Objetos (Barcelona: Gustavo Gili, 1975) p.47.

54 Ibíd. p.32. Según Moles, el sistema es un conjunto de elementos reunidos en función de un carácter común y de sus criterios de subordinación. En realidad la comprensión de su complejidad era el propio mensaje, que enviaba al observador.

55 Ibíd. p.49. Ejemplo utilizado por Moles para explicar la idea de denotación y connotación en el lenguaje de los objetos.

56 Kenneth Frampton, "El estatus del hombre y el estatus de sus objetos: una lectura de la condición humana", RA Revista de Arquitectura, n010 (jun-2008) p.7-22. En este texto Frampton, basándose en las ideas de Hannah Arendt en La Condición Humana (1958), definía la situación de la arquitectura en el mundo contemporáneo analizando la situación del hombre en la sociedad en base a los objetos que producía y consumía. 


\section{Los dominios de los muebles}

(...) todo objeto irradia a su alrededor, domina psicológicamente un sector de su entorno al que denominaremos volumen propio o esfera de influencia. Para valorarlo el objeto exige un dominio autónomo, vacío de otros objetos de la misma dimensión.

\section{Abraham Moles ${ }^{57}$}

El desarrollo de la planta abierta en el siglo XX mostraba una preocupación, no por conformar lugares más diáfanos y plantas menos fragmentadas, sino también por resolver el problema de cómo acomodar las máquinas en ellos. La nueva casa, por su condición de espacio abierto y polivalente se convertía en un marco perfecto para el equipamiento ${ }^{58}$.

Para Moore, Allen y Lyndon ${ }^{59}$ una máquina era una parte del equipamiento doméstico que ayudaba en una tarea específica. Evidentemente esto incluía frigoríficos, lavaplatos, fregaderos, hornillos, lavabos, bañeras, duchas, bidets, estufas, etc. Aunque ya no era tan obvio, también se incluían los armarios empotrados, las escaleras, los bancos fijos, las camas, las estanterías y en realidad cualquier objeto fijo al que se recurre para realizar un acto determinado. Para ellos era útil concebir los espacios que rodeaban a las máquinas, no como habitaciones, sino como "dominios de las máquinas".

Las habitaciones se convertían en espacios no específicos, escenarios vacíos para la acción humana, en ellos se realizaban los ritos y las improvisaciones de la vida. Suministraban oportunidades generalizadas para que ocurrieran cosas, y permitían hacer y ser lo que se quisiera. La idea de los arquitectos era dotarlas de cualidades que las hicieran ser lugares especiales para habitar ${ }^{60}$.

Teniendo en cuenta su definición, refiriéndose a las máquinas que podían encontrarse en una casa, las dividían en dos grupos: las que operaban por sí mismas y las que necesitaban que una persona las accionase 0 usase. Al primer grupo pertenecían las calderas, los calentadores de agua, los acondicionadores de aire, así como sus conducciones y tuberías; aquellas que ejercían su labor casi automáticamente y sólo precisaban atención para mantenimiento muy de vez en cuando. Eran más fáciles de situar en una casa sencillamente porque no precisaban acercarse a ellas muy a menudo. El dominio de esas máquinas, según los autores, era suyo, no pertenecía al usuario ${ }^{61}$. Al segundo grupo pertenecían aquellas con las que había que interactuar o las que simplemente había que manejar, como estufas, frigoríicos, lavaplatos, bañeras, duchas. En este caso consideraban los autores que sus dominios, los de estas máquinas, pertenecían al usuario porque sus sensibilidades no cambiaban cuando se adentraban en sus dominios específicos. Entre estas máquinas estaban las que asistían en actividades específicas como la limpieza, el almacenamiento, la preparación de alimentos, el propio aseo, etc. Artefactos como los armarios, las escaleras, las camas y los bancos, aunque no fuesen mecánicos literalmente, también eran consideradas máquinas

57 Abraham A. Moles, Teoría de los objetos (Barcelona: Gustavo Gili, 1975) p.111.

58 Charles Moore, Gerald Allen y Donlyn Lyndon, La casa: forma y diseño (Barcelona: Gustavo Gili, 1999) p.77.

59 Ibíd. p.79.

60 Charles Moore, Gerald Allen y Donlyn Lyndon, "El orden de las máquinas" en La casa: forma y diseño (Barcelona: Gustavo Gili, 1999) p.105.

61 lbíd. p.106.

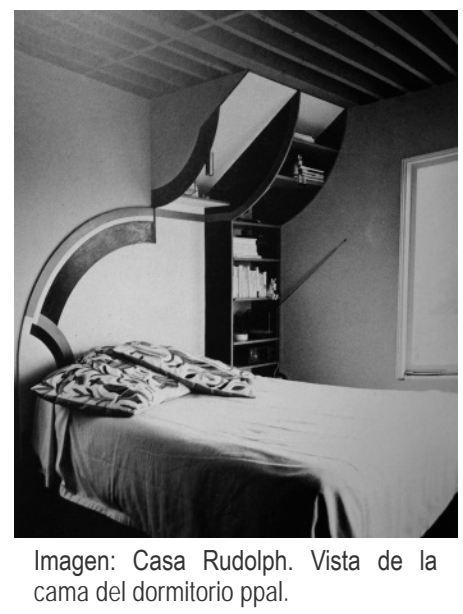



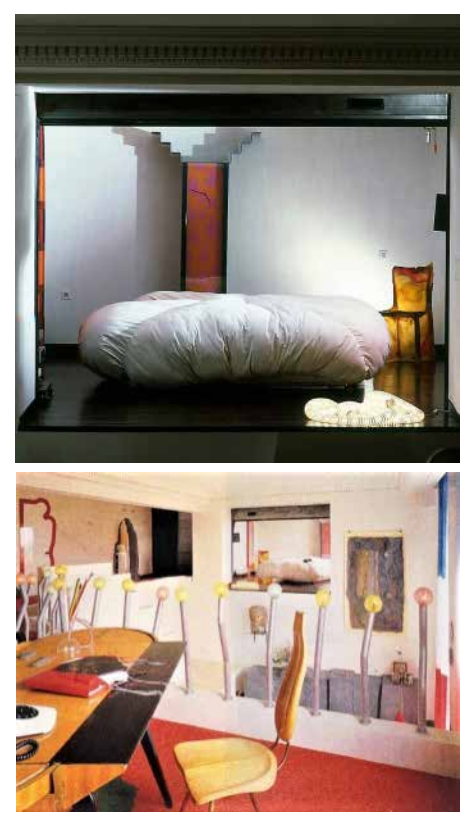

Imagen: Apartamento Marc-André Hubin. Paris, por Gaetano Pesce, 1986. Vista del dormitorio ppal. desde el espacio central, a diferentes distancias.

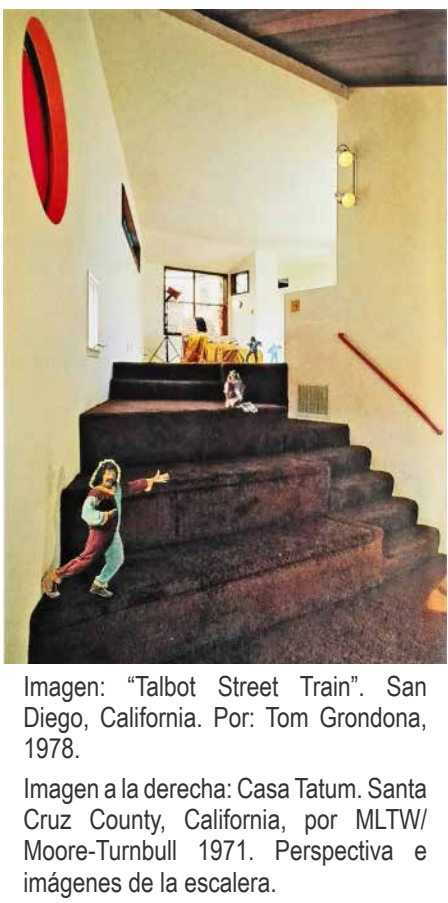

porque ayudaban a guardar cosas como la ropa y otras posesiones, también permitían desplazarse hacia arriba o hacia abajo, o mantener el cuerpo en reposos breves o prolongados. Consideraban que los dominios que rodeaban a las camas eran susceptibles de mayor variedad que las camas mismas. Su disposición y los propios dominios otorgaban a las camas una gran riqueza de connotaciones, ya fuesen máquinas simples, solemnes o informales.

En las casas de Moore, las camas tomaban gran importancia tanto en su configuración formal como en sus dominios. Como en la Casa Rudolph ${ }^{62}$, donde la propia configuración de la habitación surgía de la cama, como una prolongación de sus dominios. Discurre por los muros desde su cabecera y llega al techo materializándose en una especie de dosel-estantería. En algunos casos, como en el apartamento diseñado por Gaetano Pesce en París para Marc-André Hubin en 1986, los dominios de una cama un tanto singular (convertida en una especie de gran envoltorio) se extendían hacia el resto de la casa, a través de unas puertas de garaje mecanizadas. Aquel mueble podía divisarse desde el espacio central de la casa en doble altura, convirtiéndose en el foco visual principal de un espacio, prácticamente unificado, lleno de obras de arte y elementos simbólicos.

Las escaleras también fueron consideradas como elementos fascinantes, precisamente por sus dominios, por las connotaciones de ceremonia y coreografía de movimiento que generan, y por las posibilidades que ofrecían los descansillos entre peldaños. Podían ser como terrazas interiores, ofreciendo sitios en los que sentarse y donde exponer objetos.

No pensamos demasiado en las escaleras (...) Deberíamos aprender a vivir mucho más en las escaleras. Pero ¿cómo?

Georges Perec ${ }^{63}$
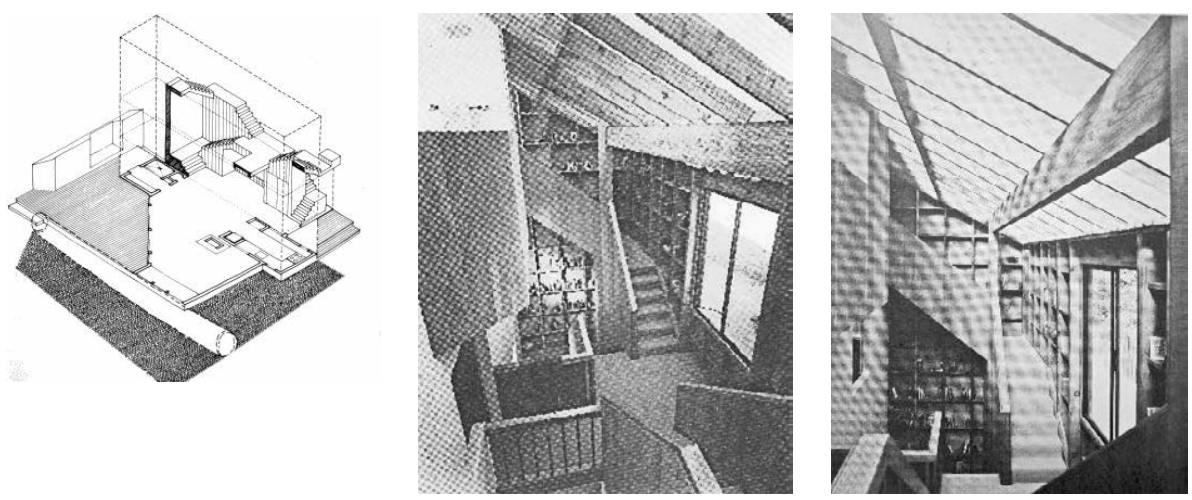

En la Casa Tatum, de MLTW en California ${ }^{64}$ la escalera se convertía en la vía principal de movimiento y en el espacio principal. Se trataba de una interpretación de una escalera barroca de dos tramos que ascendían desde los extremos opuestos, que se juntaban en un rellano y volvían a separarse. Los dominios de los numerosos rellanos, ofrecían la oportunidad de tener acceso a librerías y objetos que existían en dicho ámbito.

Las escaleras también podían proporcionar oportunidades de juegos de escala, como en la casa de Tom Grondona en San Diego, California, donde las referencias metafóricas iban unidas a una curiosa combinación de diferentes

62 Por Charles Moore Ass. en Captiva Island, Florida en 1971.

63 Georges Perec, Especies de Espacios (Barcelona: Montesinos, 2007) p.67.

64 Realizada por MLTW/ Moore-Turnbull en Santa Cruz County, California, en 1971. 
elementos, en una especie de representación escenográfica en el recorrido de la misma.

Todo consistía en lo que se quisiera expresar con los objetos disponiéndolos de una manera u otra. Y hubo quien intentó normalizar este sistema de signos. Para ello Abraham Moles ${ }^{65}$ partió del concepto del 'lenguaje de los objetos'. La presencia de un despliegue de objetos de origen social en el entorno del individuo, sirvió para establecer unas leyes basadas en los modos de acoplamiento en la esfera privada del sujeto contemporáneo. Aquellas leyes regulaban los códigos de organización de los objetos en el espacio, que eran los que finalmente le daban forma.

Estas normas 'gramaticales', de subordinación, jerarquía, concordancia, etc, surgían en gran medida en torno a esos dominios que rodeaban a los objetos. Eran las que marcaban las pautas de relación, de posición relativa, de aproximación o distanciamiento, y eran necesarias para que cada objeto pudiera coexistir en el espacio en cuanto a sus relaciones con el resto de objetos y con el usuario.

No enumeraremos en este momento dichas leyes ${ }^{66}$, pero a través de ellas Moles justificaba y racionalizaba numerosos modos de colocación y disposición de elementos en el espacio, como el hecho de reunir en un mismo ámbito objetos que correspondían tradicionalmente a habitaciones diferentes, relacionándolo con determinados códigos objetivos de acoplamiento en el espacio global que hacian precisos espacios polivalentes. Otras normas eran las que regulaban las limitaciones volumétricas, o los requerimientos de los muebles de resultar accesibles sin esfuerzo, o las relaciones basadas en jerarquías que implicaban que unos objetos quedaban contenidos dentro de otros, o que determinados elementos se colocaran debajo o encima de otros.

Los gestos y el espacio que precisaban para ser utilizados los objetos iban implícitos a la ley de la accesibilidad. La densidad óptima de elementos dentro de un espacio, la presencia mayor o menor de objetos, era una forma de significación importante. Este código de expresión también podía estar vinculado a factores connotativos, entrando en factores de 'estilo' dependiendo de la mayor o menor sensación de desnudez del espacio. También la estructura de colocación de los muebles podía catalogar los espacios en tipos de habitación ${ }^{67}$ :

"El comedor con el centro ocupado"

"El salón con el centro vacío (alfombra)"

"El cuarto de estar con ocupación lateral"

Los objetos, al igual que generaban espacio a su alrededor, lo que se viene denominando 'dominios', también se asociaban o agrupaban según determinadas reglas. Ya fuese por aspectos funcionales 0 estéticos, las sillas atraían a las sillas, los sillones a las alfombras y a las mesas bajas, las estanterías a los libros y las paredes a los cuadros.

65 Abraham A. Moles, Teoría de los objetos (Barcelona: Gustavo Gili, 1975) p.111-116. Para enunciar las 'leyes sintácticas de acoplamiento', Moles partía de un ejemplo sencillo en un entorno básico: del concepto de orden frente a la disposición del mobiliario de las habitaciones de un piso.

66 Ibídem. En el enunciado de estas leyes, Moles hacia intervenir factores gramaticales, geométricos e incluso psicológicos y establecía en ellas relaciones topológicas que implicaban aspectos organizativos como subordinación, jerarquía, o de sentido.

67 Ibíd. p.113. 
Otro de los fenómenos señalados por Moles era el efecto psicológico de la 'irradiación del objeto'. Un aspecto de importancia dentro de las consideraciones que se están exponiendo en torno al concepto del 'dominio de los muebles'. La esfera de influencia de los muebles, sobre todo la de los de mayor volumen, impedía que en su 'dominio' existieran objetos de su misma dimensión. Las áreas de influencia siempre eran mayores que su volumen neto y regulaban la disposición de otros objetos en el mismo espacio. Este código estructuraba jerárquicamente por tamaños y ordenaba el espacio en base a la no superposición de las áreas de influencia de los elementos más voluminosos.

La suma de los volúmenes de las áreas de influencia, finalmente, representaba el volumen útil de la habitación, y con este razonamiento se establecía lo que Moles llamó la 'presión psicológica del espacio', ejercida por la presencia de objetos en una habitación, o lo que es lo mismo, la impresión que provocaban en el individuo en el momento de percibir dicho espacio.

Todas estas consideraciones eran esencialmente aplicables al mobiliario, es decir, a objetos grandes, de volumen y superficie apreciables y cuyo despliegue conservaba estabilidad a lo largo del tiempo. Por ejemplo, la ocupación de un piso con muebles y demás objetos, sería comparable a ordenar un decorado teatral en el que vivirían los actores durante al menos un año.

Esta especie de 'aura' en torno a los objetos también existía en torno al cuerpo de los usuarios. A través de la teoría de la imagen corporal, basada en el psicoanálisis, Charles Moore y Kent C. Bloomer ${ }^{68}$ entendieron el sentimiento de habitar a través del movimiento del cuerpo: "toda persona sitúa su cuerpo inconscientemente dentro de una envoltura tridimensional"69.

El hombre, al trazar inconscientemente una envoltura tridimensional, hacía entender que cada cuerpo tenía un espacio interior y un espacio exterior. La frontera se iba modificando con el movimiento y por factores relacionados con el sentido háptico. Esta envoltura influía en la relación del cuerpo en el espacio, tanto con el paisaje como con los objetos más próximos. Los dominios, finalmente, se entremezclaban, tanto los de los objetos como los de los usuarios, en un campo de relaciones y conexiones que venía a considerarse espacio.

68 Charles Moore, Kent C. Bloomer. Cuerpo, Memoria y Arquitectura. Introducción al diseño arquitectónico (Madrid: H. Blume Ediciones, 1982) p.46.

69 Seymour Fisher, 1968, citado por Moore y Bloomer en Cuerpo, Memoria y Arquitectura. Introducción al diseño arquitectónico (Madrid: H. Blume Ediciones, 1982) p.48. 


\section{Fenomenología y objetos}

Los fenómenos aparecen mientras que el objeto existe. Los fenómenos no existen puesto que se caracterizan por su falta de permanencia. El que los objetos existan significa que se constituyen en las relaciones más permanentes entre fenómenos.

\section{Christian Norberg-Schulz ${ }^{70}$}

La fenomenología, como corriente filosófica, basaba su metodología en el estudio objetivo de fenómenos considerados subjetivos, como la conciencia y la experiencia -en la experiencia participarían la percepción y las emociones, por ejemplo-. Esta idea, aplicada a la arquitectura, sería como entenderla no sólo a través del conocimiento de sus dimensiones y formas, o sus funciones, sino también por medio de las sensaciones que la arquitectura transmitía al percibirla, al sentirla, a través de su experiencia.

Norberg-Schulz fue uno de aquellos arquitectos llamados 'fenomenologistas', destacado entre otros, por Jorge Otero-Pailos en Architecture's Historical Turn. Phenomenology and the Rise of the Posmodern ${ }^{71}$, que establecía el desarrollo de la fenomenología en arquitectura en los años 60 a través de algunos arquitectos de la costa Oeste de Estados Unidos. Buscando una ruptura, más bien radical, con los principios del Movimiento Moderno, intentaban dar un vuelco al mundo de la arquitectura gracias a una nueva manera de entenderla utilizando métodos experienciales.

Esta nueva formación intelectual, la fenomenología arquitectónica, tejía un discurso que unificaba la percepción sensorial, la historia de la arquitectura y la teoría en torno a la tesis de que la experiencia era la esencia para entender la arquitectura. Para apoyar sus ideas introdujeron disciplinas como la fenomenología, y así surgieron nuevos modos de escribir sobre arquitectura y también de diseñar, incorporando el factor sensorial tanto visual como experiencial. En esta corriente, las universidades americanas que más implicadas estuvieron en el desarrollo de las ideas fueron Princeton, Harvard y Yale. En Princeton enseñó el arquitecto francés Jean Labatut (1899-1986) y formó a arquitectos como Charles Moore y Robert Venturi. Sus conocimientos de las técnicas del camuflaje aprendidas durante su servicio en la Primera Guerra Mundial, le sirvieron para establecer códigos y métodos de diseño aplicados a la arquitectura, basados en ideas fenomenológicas.

Para que los edificios pudieran transmitir sensaciones que propiciaran su vivencia y experiencia, Labatut, antes de que sus estudiantes Moore y Venturi simpatizaran con el american kitsch, ya incluía imágenes de la cultura popular, dentro de composiciones espaciales abstractas. De esta manera creaba focos de atención para el visitante y estimulaba su experiencia. A este recurso también se unían los efectos de la textura de los materiales, de la iluminación y del sonido ambiente. Aplicando estos principios, en 1962 Labatut construyó en Princeton, Nueva Jersey, la Stuart Country Day School of the Sacred Heart, concebida como un sistema organizado en base a focos de atención que inducian al movimiento del cuerpo de los visitantes y generaban recorridos, "por medio de ello les daba la oportunidad de la visión de su propia

70 Christian Norberg-Schulz, Intenciones en arquitectura (Barcelona: Gustavo Gili, 1998) p. 21.

71 Jorge Otero-Pailos Architecture's Historical Turn: Phenomenology and the Rise of the Postmodern (Minneapolis: University of Minnesota Press, 2010).

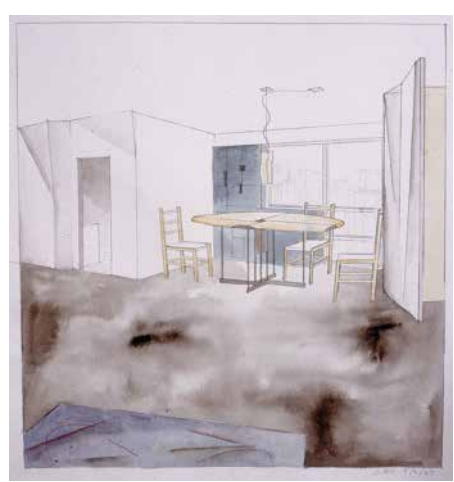

Imagen: Steven Holl. MoMA Tower Apartment, Nueva York. 1986

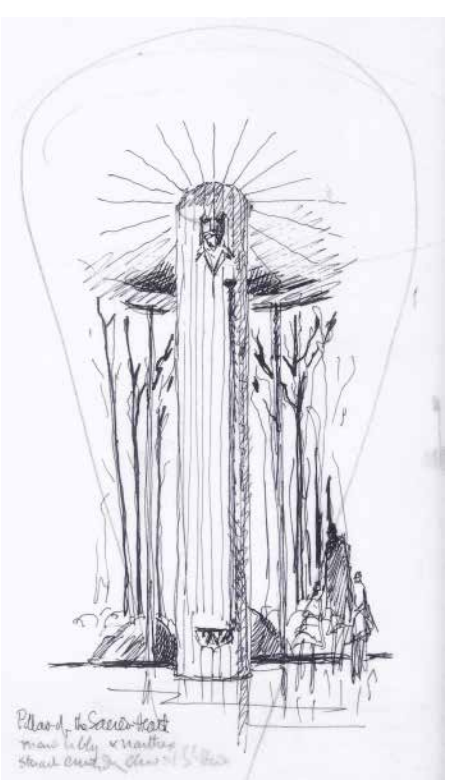

Imagen: Jean Labatut. Diseño del pilar central del Sagrado Corazón, en hormigón visto con bajorrelieve de la cara de Jesuscristo y el corazon sangrante. (Architecture's Historical Turn...p.84) 


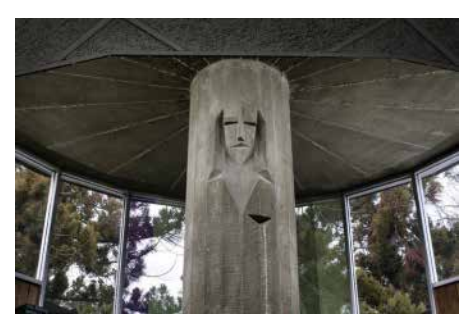

Imagen: Vista del pilar central de Sagrado Corazón, en Princeton. Por Jean Labatut, 1962.

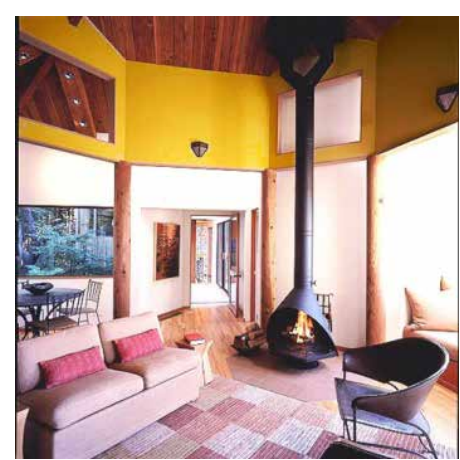

Imagen: Casa Johnson en Sea Ranch, California, por MLTW/ Moore-Turnbull, 1965. Planta y vista interior de chimenea dentro de un edículo octogonal. alma"72. Uno de los focos principales consistía en una gran columna central de hormigón que por un proceso de 'objetualización' de un elemento constructivo, se diseñó con un bajorrelieve en su superficie con la cara de Jesucristo y el corazón 'sangrante', y que se extendía hacia las alturas como una palmera de composición radial, obligando a los visitantes a dirigir su mirada hacia arriba. Labatut utilizaba numerosos recursos simbólicos potenciados con los efectos de los materiales y su conocimiento de las técnicas de atención. Como se ha comentado anteriormente, tuvo acceso a las más avanzadas técnicas de arte visual contemporáneas por medio de su colaboración con los artistas del Servicio de Camuflaje del ejército francés, y con los que puso en práctica nociones cubistas, como la disolución de la figura por medio de juegos ópticos de objeto y contorno.

En el círculo de estudiantes de doctorado que se formó en torno a Labatut en la Universidad de Princeton de 1954 a 1957, se encontraban Charles Moore, Donlyn Lyndon y William Turnbull, los cuales acabaron trabajando juntos como socios del estudio MLTW. El trabajo de Charles W. Moore estuvo muy influido por su interés por la experiencia y por legitimar la faceta intelectual del trabajo del arquitecto, lo que le llevó a la fenomenología de Gaston Bachelard. Basándose en La Poética del Espacio ${ }^{73}$, Moore se embarcó en descubrir lo que denominó la 'experiencia inmediata', un acto que se centraba en descubrir el interior del edificio, su contenido a través de su vivencia. Para provocarlo introducía en edificios, discretos exteriormente, elementos que hicieran la experiencia del visitante más amplia, más inmediata y poética, siguiendo lo descrito por Bachelard:

Baudelaire siente el aumento del valor de la felicidad cuando una casa es atacada por el invierno. En sus Paraísos Artificiales ${ }^{74}$ describe la felicidad de Thomas de Quincey encerrado en el invierno, mientras lee a Kant ayudado por el idealismo del opio (...) aceptando los ensueños de reposo que sugiere, penetraremos en cuerpo y alma en plena tranquilidad, nos sentiremos situados en el centro de protección de la casa del valle, 'envueltos' nosotros también, entre los tejidos del invierno.

\section{Gaston Bachelard ${ }^{75}$}

Moore exploraba sobre los distintos modos de conseguir 'experiencias inmediatas' tanto en el interior de edificios existentes, sobre los que actuaba, como en proyectos de nueva planta. Como ejemplo, su casa construida en Orinda, California en 1962. Pensaba que en el ojo de la mente podía haber imágenes que permitirían modificar la percepción de un espacio físico, distorsionándolo, haciéndolo mayor de lo que era, cambiando la experiencia de los visitantes. La casa en Orinda, como ya conocemos, consistía en un espacio diáfano rectangular bajo una cubierta a cuatro aguas. En el interior de la casa introdujo una combinación de dos 'edículos' o casas en miniatura. En este caso el edículo, reemplazaba el corazón tradicional de la casa americana,

72 Ibíd. p.81.

73 En 1957 el filósofo francés Gaston Bachelard (1884-1962) publicaba La poética del espacio, en el que aportaba un nuevo enfoque de la fenomenología a través del estudio del fenómeno de la imagen poética.

74 En Los paraísos artificiales (1860) el escritor francés Charles Baudelaire (1821-1867), a través de este ensayo basado en su experiencia en el mundo de la bohemia, escribía sobre los estados de evasión, éxtasis o alucinación, propiciados por el consumo de hachís, opio o por el exceso de alcohol.

75 Gaston Bachelard, La Poética del Espacio (Buenos Aires: Fondo de Cultura Económica, 2000) p.54-55. 
la chimenea, símbolo del interior más íntimo de la casa americana. En alguna ocasión, como en la Casa Johnson en Sea Ranch, California -por MLTW/ Moore-Turnbull, 1965-, Moore introducía la chimenea dentro del edículo, así el concepto de casa dentro de la casa se potenciaba, ya que la metáfora de hogar íntimo en el edículo se hacía más evidente.

En Princeton Moore también empezó a trabajar sobre el movimiento inducido por la percepción de los signos. Los cursos de Labatut enseñaron a los estudiantes que la escala y la apariencia de los signos se establecían en función de la velocidad del movimiento del observador. El movimiento del usuario se convertía en una variable clave en el proceso de percepción. Labatut también les hizo entender que por medio de técnicas se podía cambiar la apariencia y la forma de un edificio, haciendo que se percibiera más grande, más pequeño o incluso que desapareciera; recordemos sus conocimientos sobre técnicas de camuflaje, adquiridos durante la Primera Guerra Mundial.
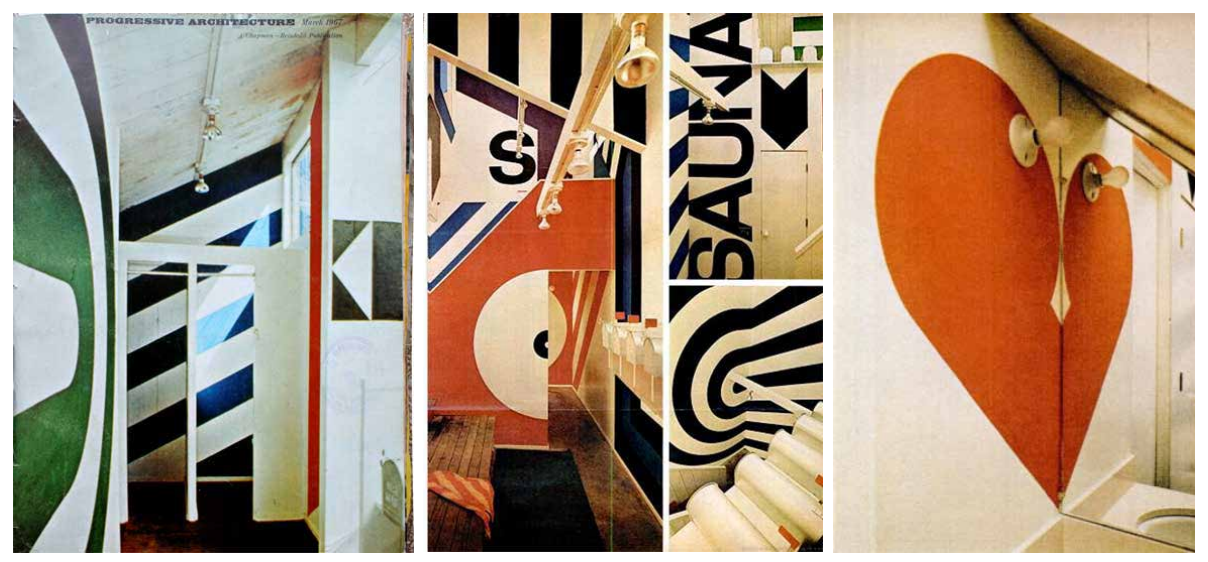

En Sea Ranch ${ }^{76}$, Moore utilizó un método novedoso de diseño con pinturas y grandes gráficos en el interior del club deportivo del complejo que se situaba frente al mar ${ }^{77}$. Dicho proyecto lo llevó a cabo junto con algunos colaboradores de Yale, de ideas afines, como Barbara Stauffacher especialista en el diseño de gráficos de gran tamaño. Dos años más tarde, el número de marzo de 1967 de la revista Progressive Architecture editaba un monográfico sobre este trabajo, en el que identificaba este método de diseño como el origen de un movimiento emergente al que denominaba Supergraphics.

Para Moore la técnica del supergraphic operaba tanto en el sujeto, trastocando sus niveles racionales de percepción, como en el objeto, modificando el orden espacial del interior del edificio.

Aparte de los supergraphics, Moore utilizaba otros muchos objetos en sus interiores para despertar experiencias, para jugar con la escala y para alentar a los visitantes a experimentar no sólo con la realidad sino con sus fantasías de mundos cósmicos o de lugares minúsculos. Para ello llenó los nichos con juguetes y casas en miniatura, o dibujó la cúpula de San Pedro de Roma en trampantojo sobre su cama, generando una especie de edículo virtual lleno de estrellas blancas, haciendo un guiño a la cultura popular ${ }^{78}$. En su afán de

76 Sea Ranch Athletic Club, en Sea Ranch, Calfornia, realizado por MLTW/ Moore-Turnbull con la colaboración de la diseñadora gráfica Barbara Stauffacher Salomon en 1965.

77 En 1950, Charles Moore se alistó y fue enviado a Seúl, Corea, donde prestó servicio como teniente en el Cuerpo de Ingenieros del Ejército. Allí desarrolló sus primeros diseños de gráficos para señalización.

78 En su casa de New Haven, Connecticut, por: MLTW/Moore-Turnbull. 1966.
Imagen: Portada de la revista Progressive Architecture, marzo de 1967. Vista del Sea Ranch Athletic Club por MLTW/ Moore-Turnbull y Barbara Stauffacher en 1965.

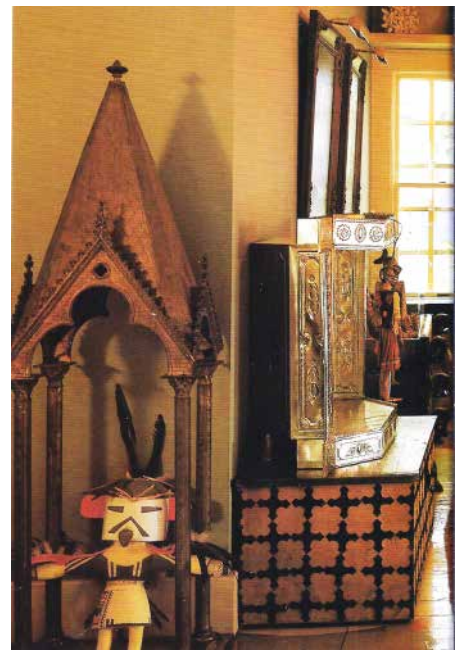

Imagen: Casa Moore en Austin, Texas. Objetos personales que crean juegos de escala. 
Imagen: Casa Moore en New Haven, Connecticut. Vista del patio trasero desde el interior donde se observa el uso del anamorfismo como mecanismo de transformación de la percepción de la arquitectura. A la izquierda de la imagen aplicado a la escalera que da acceso a la planta baja, y al fondo, a la tapia del jardín trasero.

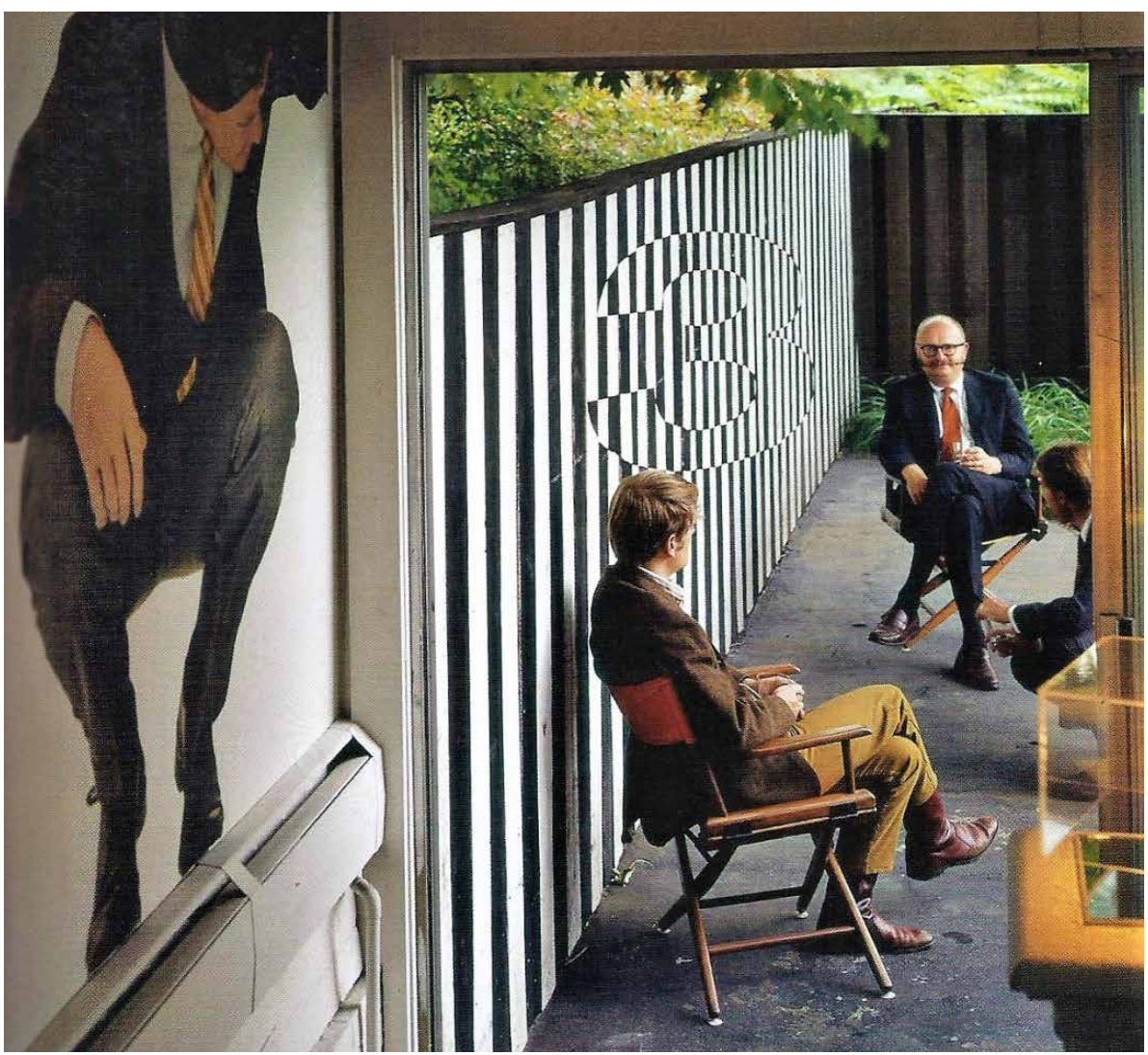

involucrar al sujeto en el proceso creativo de la vivencia del espacio también hizo acercamientos a diferentes movimientos artísticos como el cómic, el diseño psicodélico, pero sobre todo recurrió al arte óptico u Op Art ${ }^{79}$.

Utilizando esta técnica Moore introdujo una pintura en el vallado interior del patio trasero de su casa en New Haven (imagen) aunque en el interior también recurrió a otras técnicas pictóricas de 'engaño' visual, como el anamorfismo, supergraphics, así como recortes de formas incompletas que inducían al cerebro a completarlas ${ }^{80}$.

La fenomenología caló entre los estudiantes de Harvard y Yale. La presencia de Rudolph Arnheim ${ }^{81}$ en Harvard también influyó en el arquitecto y teórico Christian Norberg-Schulz, sobre todo en su interés por la percepción y la experiencia. Tanto fue, que algunos le como uno de los principales creadores del enfoque fenomenológico de la arquitectura ${ }^{82}$. Según Norberg-Schulz ${ }^{83}$ la percepción proporcionaba el conocimiento del mundo. Pero no sólo consistía en 'percibir', también había que 'comprender' o 'juzgar' las cosas que nos rodeaban para que llegaran a sernos útiles. Aquel se componía de 'fenómenos', que en realidad consistían en las propias experiencias. Con la idea de 'fenómeno'

79 En febrero de 1965 el MoMA de Nueva York celebraba la exposición 'The Responsive Eye'. En esta muestra se expusieron obras de artistas de todo el mundo entre los que destacaban Frank Stella, Victor Vasarely o Jesús Soto. La muestra se centraba en los aspectos perspectivos del arte como resultado de los efectos creados por el movimiento del cuerpo o por los efectos que generaban las relaciones entre las formas y el color. La exposición tuvo una gran acogida entre el público. El Op Art o arte óptico se hizo muy popular y no tardó en aplicarse al mundo del diseño comercial y de la moda.

80 Según la psicología de la Gestalt, 'la ley de cierre' decía que las formas abiertas o inconclusas tendían a percibirse completas en la mente del observador.

81 Rudolph Arnheim (1904-2007), psicólogo alemán influido por las teorías de la Gestalt que trabajó en el campo del arte y la percepción visual.

82 Jorge Otero-Pailos Architecture's Historical Turn: Phenomenology and the Rise of the Postmodern (Minneapolis: University of Minnesota Press, 2010) p.164.

83 Christian Norberg-Schulz, Intenciones en Arquitectura. (Barcelona: Gustavo Gili, 1998) p.21. 
se estaba dirigiendo a todo aquello que podía experimentarse, estableciendo una relación directa entre fenómenos y objetos: "un fenómeno se presenta mientras que un objeto existe"84. Los objetos aparecían si había objetos, pero la existencia del objeto también estaba ligada a los fenómenos que generaban. Según este razonamiento no tenía sentido hablar de la existencia de cada cosa por separado. La experiencia hacía descubrir los fenómenos y estos se convertían en una vía que dirigía hacia cada objeto correspondiente.

La visión del objeto era comprender las acciones que implicaba, las cuales eran reconocidas a través de la experienci ${ }^{35}$.

\section{La incidencia de los transformables}

En 1963 diseñé el mobiliario para una estancia que se dimensionó no solamente desde el punto espacial, sino también en el sentido temporal: en otras palabras, el mobiliario cambiaba... a lo largo del paso del tiempo, dependiendo de la gente que lo habitaba... un nuevo tipo de arquitectura proporcionaba un espacio elástico, expandible, móvil y flexible.

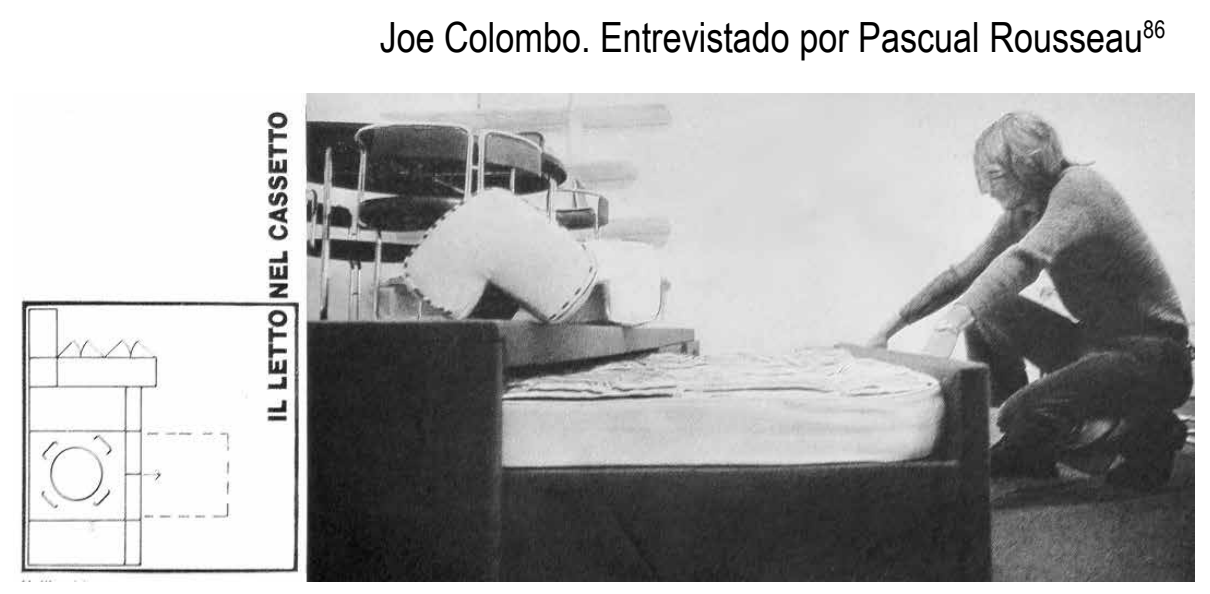

Durante los años sesenta, múltiples y variadas propuestas se desarrollaron apoyándose en una tecnología cada vez más avanzada y en las increíbles posibilidades formales que ofrecían los nuevos materiales. La libertad técnica y formal ofrecía una oportunidad única a los arquitectos y diseñadores del momento para crear espacios más acordes con los nuevos tiempos, en los que la movilidad, los nuevos roles sociales y familiares, y la presencia de hogares de dimensiones cada vez menores, iban unidos inseparablemente.

Uno de los diseñadores que más importancia otorgaba a la necesidad de transformación de los elementos dentro del espacio doméstico fue el italiano Joe Colombo. Quizá su pasión por los coches y su vida de viajes constantes le influyera para entender el hogar del habitante contemporáneo como algo básicamente dinámico. Una vez comentó: "Le Corbusier hace mucho dijo que la casa es una máquina de habitar; no creo que sea un error comparar

84 Ibídem.

85 Norberg-Schulz utilizaba el símil: "la visión de un lápiz nos indica que es algo que podemos coger para escribir". Ibíd. p.21.

86 En entrevista realizada por Pascal Rousseau a Colombo en 1968, citado por Kries y von Vegesack en Joe Colombo. Inventing the Future (Weil an Rheim: Vitra Design Museum, 2005) p.41.
Imagen: Propuesta de sistema modular de mobiliario para "ahorrar espacio", por Alfredo Simonit y Marcello Cuneo Salone delle Arti Domestiche, $8^{\mathrm{a}}$ edición Turín, 1971. 
el mobiliario con sus mecanismos internos". Colombo estaba implicando, de manera directa, al equipamiento en el sistema general que configuraba la casa.

Colombo en realidad diseñaba los espacios y su mobiliario pensando ya en su transformación y adaptación a lo largo del tiempo o en función de las necesidades de los usuarios. Para él, el tiempo era la cuarta dimensión de la configuración espacial, incluso en algún momento se planteaba -irónicamente, claro - si tendría algo que ver con la teoría de la relatividad...

Lo que sí tenía en cuenta, a la hora de diseñar los interiores de sus viviendas y los objetos que poblaban aquellos espacios -tradicionalmente casas, según Colombo- es que el hombre contemporáneo también realizaba su vida en otros espacios: el coche, el avión, el barco, y pensando en un futuro no muy lejano, la nave espacial. Todos estos espacios se movían, eran dinámicos, tanto si eran privados como colectivos. En este sentido, también se planteaba, que había otros espacios en los que también se habitaba, que sin embargo, fueran públicos o privados, eran fijos, estáticos: el apartamento, la casa, el teatro, el cine, el hospital, el hotel, etc. Para adaptar el hogar a los nuevos modos de vida, aunque el contenedor fuera físicamente un espacio estático, el contenido debía de ser dinámico. Tenía que existir, según Colombo, un 'divorcio' entre el contenedor estático convencional y el contenido, para que éste último pudiera moverse libremente en su entorno más cercano, satisfaciendo la necesidad de dinamismo y siendo capaz de someterse por entero al transcurso del tiempo y a las actividades que surgieran en su discurrir -a lo largo del día, de la noche, en el verano, en el invierno...-, de los distintos eventos -una visita, una fiesta, etc.- o los acontecimientos de la vida -un nacimiento, la pérdida de un miembro de la familia, etc.-. En este contexto, Colombo trabajaba en la búsqueda de la simultaneidad de acciones dentro del mismo espacio, a través de la movilidad y transformabilidad de los objetos que diseñaba.

Introduciendo el parámetro espacio-tiempo en el espacio doméstico observamos que tal parámetro genera dinamismo en las zonas domésticas que generalmente están estrictamente divididas. Estas dinámicas permiten la superposición de espacios en función del tiempo del uso correspondiente, permitiendo la reducción de la superficie útil. Pero también una expansión de las funciones, de manera que cada actividad pueda realizarse disponiendo de todo el espacio.
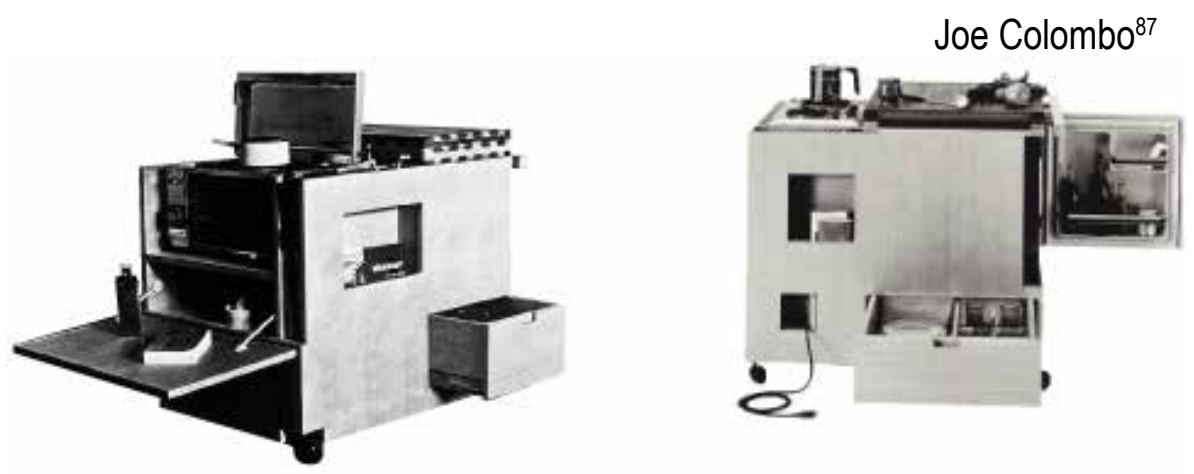

87 Joe Colombo en Orientamenti Moderni nell'Edilizia (n³-1972), citado por Kries y von Vegesack en Joe Colombo. Inventing the Future (Weil an Rheim: Vitra Design Museum, 2005) p.49. 
Durante su corta pero intensa carrera intentó ser fiel a sus principios, teniendo siempre presente la multifuncionalidad del espacio gracias a la mutabilidad de los elementos que diseñaba, como la conocida 'Mini Kitchen' presentada en 1963 en la XIII Triennale de Milán. El sistema, que era una cocina portátil, consistía en un volumen con ruedas acabado en plástico de $115 \times 65 \mathrm{~cm}$ y $90 \mathrm{~cm}$ de alto que incluía todo lo necesario para cocinar en cualquier sitio de la casa: dos placas, nevera, tabla de cortar, enchufes para electrodomésticos pequeños y apartados para almacenamiento multiusos. Incluso contaba con un compartimento para albergar libros de cocina ${ }^{88}$. La movilidad, la versatilidad y las posibilidades que se ofrecían gracias a los distintos 'despliegues' y 'repliegues' de los componentes de la mini-cocina, hicieron que este elemento ya se entendiera como parte integrante de la idea de un espacio doméstico indiferenciado donde los objetos, que rodeaban al usuario de forma constante, eran los encargados de caracterizar y de distinguir las distintas áreas del hogar. Entre los numerosos y variados sistemas transformables multifunción que Colombo creó a lo largo de su carrera, los más emblemáticos fueron los llamados 'Roto-living System' y 'Cabriolet-Bed', ambos diseñados en 1969 y presentados en 1970 en la muestra Eurodomus 3, y en la Triennale de Milán.

'Roto-living System'89, era un objeto multifuncional creado para albergar todo lo necesario para satisfacer las necesidades de la vivienda del futuro. En el frente tenía reloj, televisión, equipo de música y sistema de iluminación. De acuerdo a las necesidades, con un giro surgía una mesa de comedor o una coffee-table con bar incluido en la zona de almacenaje prevista bajo la mesa. La parte posterior servía como aparador y zona de almacenaje. 'Roto-living' era una unidad de día que se complementaba con una unidad de noche, llamada 'Cabriolet-Bed'. Este segundo bloque integraba todas las funciones de un dormitorio tradicional en un único elemento ${ }^{90}$. Con la capota cerrada ofrecía privacidad, con la capota abierta ofrecía zona de relax y para escuchar música. Por dentro estaba equipada con radio, ventilador, cenicero y otros complementos. En la parte trasera tenía un espejo, un tocador y los mandos del aire acondicionado. Aunque nunca se produjeron en serie, estos sistemas junto a 'Total Furnishing Unit' fueron los diseños con los que Colombo alcanzó mejor su objetivo de crear algo completamente nuevo, 'máquinas habitables' que respondieran a un nuevo modo de vida, más dinámico y flexible.

Tanto 'Roto-living' como 'Cabriolet-Bed'91 fueron fabricados para incluirlos en su propio apartamento en Via Argelati 30b de Milán donde, aparte de su casa, también instaló su estudio.

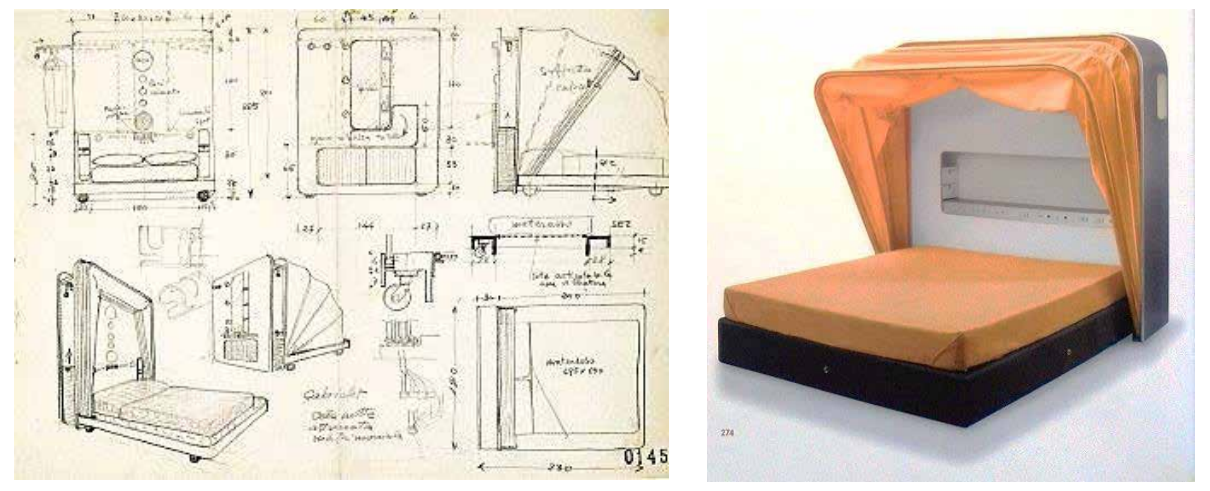

88 Publicado por primera vez en "Alla XIII triennale", Domus (n0418 sept-1964) p.31.

89 Mateo Kries, Alexander von Vegesack. Joe Colombo. Inventing the Future (Weil an Rheim: Vitra Design Museum, 2005) p.224.

90 Ibíd. p.226.

91 Ibíd. p.228.

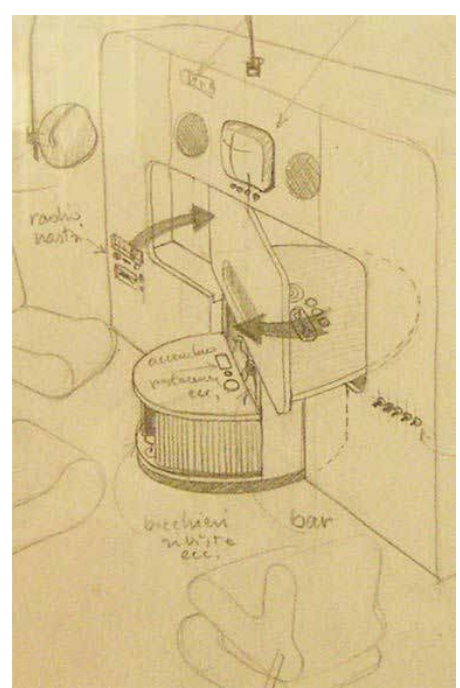

Imagen: Roto-living. Croquis de sistema de rotación.

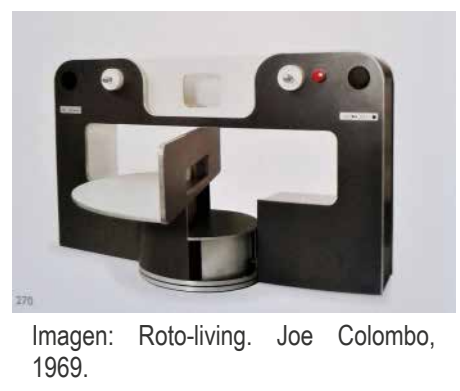

Imagen: Cabriolet-Bed. Croquis y modelo. Joe Colombo 
En los ochenta los muebles cotidianos ya habían dejado de ser fijos ${ }^{92}$, se trasladaban de un lado a otro, reencontrando el sentido de su etimología y, como sus patas no les permitían desplazarse, aparecían dotados de ruedas 0 montados sobre raíles.

Tanto los muebles grandes como los pequeños, por sus posibilidades de desplazamiento, intentaban no congelar las funciones. La movilidad del mueble permitía la fluctuación de las actividades, persiguiendo el deseo de no atribuir un rol particular a cada habitación. Ni cocina laboratorio ni cocina en el salón, la desestructuración del hábito de comer llamaba a equipamientos más difusos, menos localizados y de usos múltiples. La preparación y el consumo de las comidas se diseminaba por la casa bajo formas muy diversas. También había muebles que desaparecían, o se transformaban, como los sofás-cama, o las camas abatibles, y que participaban de estos juegos de modificaciones: ahora el sofá significa el salón, ahora la cama significa el dormitorio. Un mismo lugar se convertía sucesivamente en diferentes habitaciones, según los muebles que albergase. El tema del mueble transformable, parecía que en los ochenta estaba totalmente asimilado en un espacio doméstico cada vez más flexible y con posibilidades de mutar.

\section{Elementos transformadores}

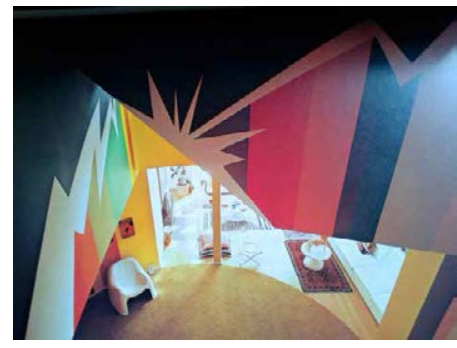

Imagen: Casa Murray Cambridge, Massachusetts.

MLTW / Moore-Turnbull, 1973
El espacio arquitectónico es una categoría especial del espacio libre, fenoménicamente creada por el arquitecto cuando da forma y escala a una parte del espacio libre (...) Curiosamente, los actos que los arquitectos pueden realizar de un modo efectivo con el espacio parecen ser contradictorios, aunque ambos parecen también ser efectivos. Se puede capturar el espacio o soltarlo, "definirlo" o "hacerlo explotar". El espacio es, probablemente una de las pocas cosas de las que se tiene mayor cantidad después de haberlas hecho explotar pero parece medrar también en la cautividad.

Charles Moore/ Gerald Allen ${ }^{93}$

Cuando Charles Moore se trasladó a New Haven ${ }^{94}$ adquirió una casa pequeña y oscura construida en la década de 1860, y necesitaba una 'ficticia' explosión interior para que su propietario, acostumbrado a los espacios amplios de California, no sufriera claustrofobia.

La solución: vaciar partes del interior e insertar tres fustes de dos plantas de altura, como gigantescas cabinas que sólo estaban llenas de espacio. Las 'torres' -con nombres propios: Howard, Ethel y Berengaria- estaban hechas con paredes dobles de contrachapado y aparecían horadadas con grandes huecos de formas regulares que se contraponían realzando la profundidad y sugiriendo muchas más cosas. Las formas de los huecos, especialmente en Howard, estaban destinadas a inducir al observador a completar las

92 Monique Eleb, Anne Marie Châtelet y Thierry Mandoul. Penser L'Habité. Le Logement En Questions. (Paris: Mardaga, 1988) p.130.

93 Charles Moore y Gerald Allen, Dimensiones de la arquitectura. Espacio Forma y Escala (Barcelona: Gustavo Gili, 1978) p.17.

94 Casa Moore en New Haven, Connecticut, por MLTW/ Moore-Turnbull, en 1967. Charles Moore, Gerald Allen y Donlyn Lyndon, La Casa: Forma y Diseño (Barcelona: Gustavo Gili, 1999) p. 62. 
configuraciones geométricas que iniciaban, permitiendo por ejemplo ampliar un arco hasta convertirlo en un círculo completo, que sería demasiado grande para caber en tan diminuta casa ${ }^{95}$.

Los fustes, que en realidad no contenían nada aparte de espacio, servían para dar más vida a la casa, para, según los autores, conducir la mente más allá de ella.

Cada fuste permite que el cuerpo siga la mirada de la mente (al menos hasta el ático) hundiéndolos directamente desde la entrada hasta la planta inferior, serpenteando alrededor de Berengaria hasta el dormitorio, el baño y la sauna de la segunda planta, o descendiendo lentamente por anchos escalones hacia el jardín de la parte de atrás, para luego doblar velozmente hacia atrás, pasando junto a Ethel y dando al fin en la protección de la cocina.

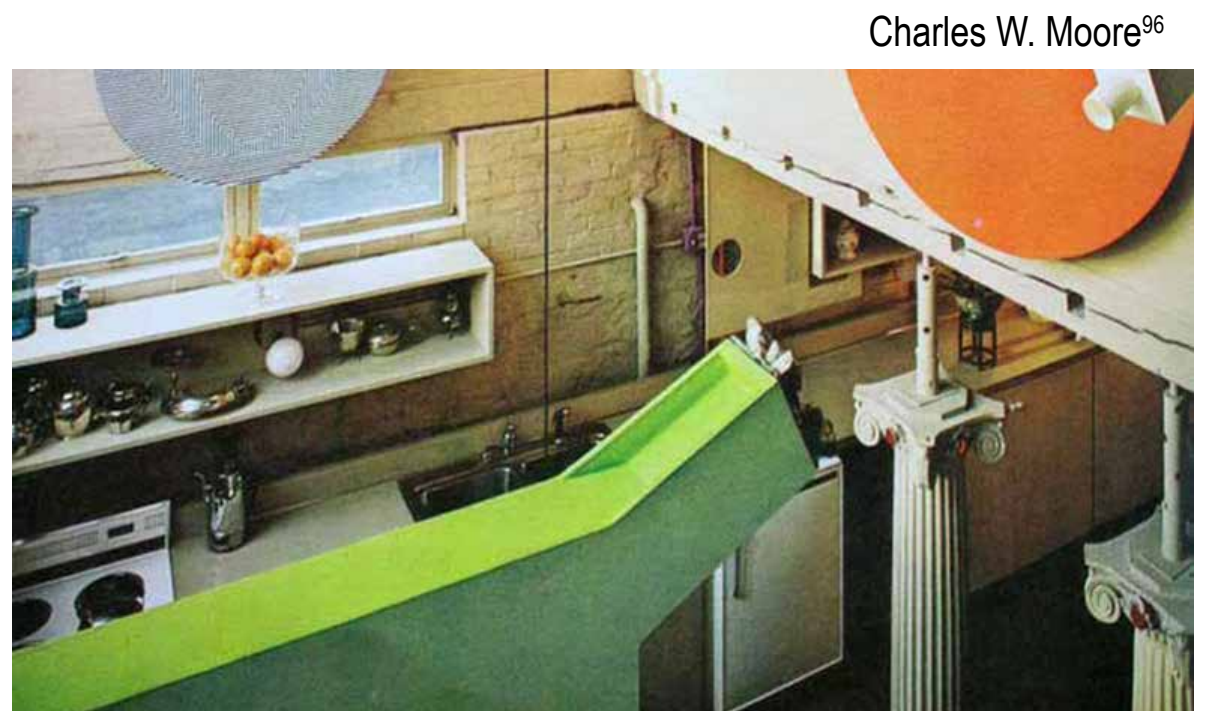

Lacasadesarrollabamúltiplesvisualesinteriores, asícomo numerososrecorridos en torno a los elementos anteriormente mencionados, que multiplicaban las posibilidades de perspectivas tanto en planta como espaciales. Este efecto se incrementaba con objetos que poblaban los huecos y rincones generados en los muros, por las diferentes capas y los entrelazamientos, abarcando todas las escalas posibles y llenando así la casa de fotografías, dibujos, estatuas, muebles, objetos pintorescos, luces de neón, etc. Recuerdos y fantasías que potenciaban la idea de la intervención, una casa fenomenológicamente transparente, de perspectivas casi infinitas y de dimensiones perceptualmente mucho mayores que las reales ${ }^{97}$.

95 Estudios sobre la psicología de la percepción, desarrollados en Alemania a principios de S.XX. La llamada 'psicología de la Gestalt', demostraba que el cerebro humano organizaba los elementos percibidos en forma de configuraciones, gestalts o totalidades. Las 'Leyes de la Gestalt' incluían la 'Ley de cierre' que determinaba que, ante una figura inconclusa, la mente añadía los elementos que faltaban para completar la figura. Perceptivamente la tendencia era a completar y llenar aquellas partes y vacíos que se presentaban incompletos, lo cual permitía una comprensión del objeto percibido en su totalidad.

96 Charles Moore, Gerald Allen y Donlyn Lyndon, La Casa: Forma y Diseño (Barcelona: Gustavo Gili, 1999) p. 62-63.

97 Colin Rowe y Robert Slutzky en "Transparencia: literal y fenomenal", (publicado por primera vez en la revista Perspecta en 1963) utilizaban términos como simultaneidad, interpenetración, superimposición, ambivalencia y espacio-tiempo, como sinónimos de transparencia, aplicada a la arquitectura contemporánea. Basándose en el texto de Gyorgy Kepes, El Lenguaje de la visión, de 1944, huían de la consideración de transparencia como cualidad óptica del material y se dirigían hacia una interpretación con implicaciones espaciales más amplias, estableciendo que la transparencia iba unida a la percepción simultánea de múltiples y distintas localizaciones espaciales.
Imagen: Casa Moore en New Haven. Connecticut. MLTW/Moore-Turnbull, 1967. Vista interior de la planta sótano. 


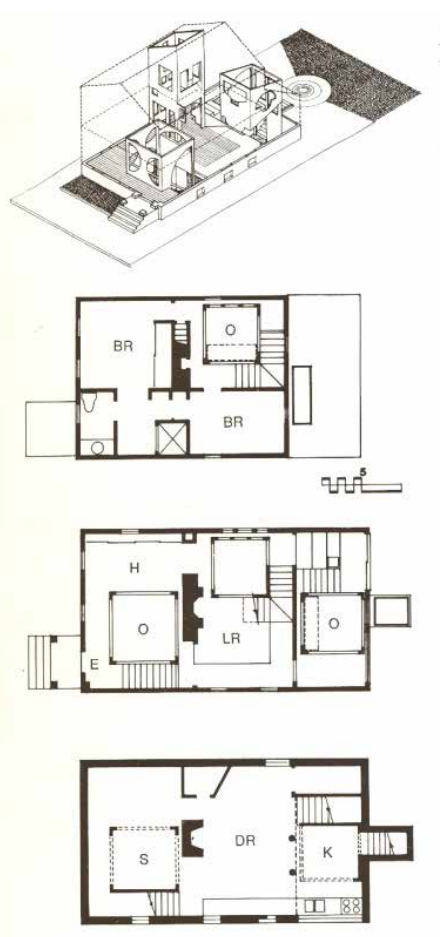

Imagen: Casa Moore en New Haven. Connecticut. MLTW/Moore-Turnbull 1967. Pespectiva y plantas.
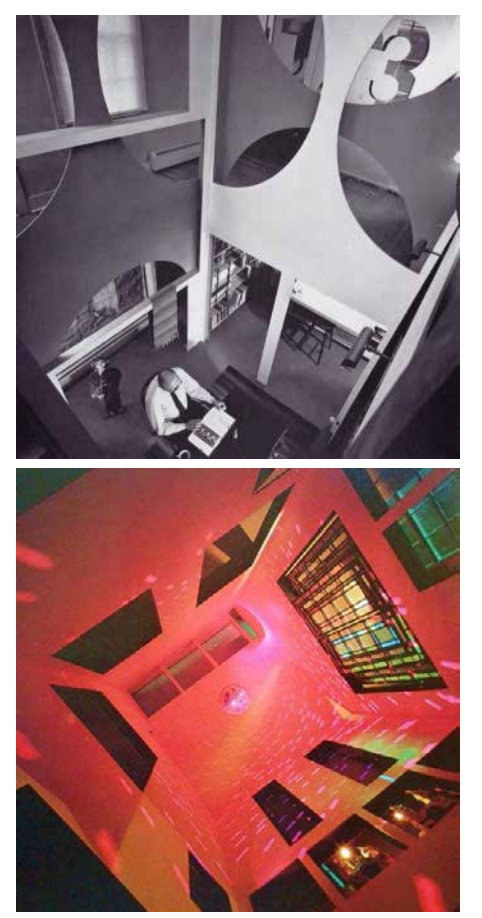

Imagen: Casa Moore en New Haven. Connecticut. Vistas interiores
Las posibilidades de transformación de la percepción del espacio a través de determinados mecanismos propiciaron en los 60, sobre todo en Estados Unidos, un tipo de lenguaje que algunos ${ }^{98}$ llamaron 'supermanierismo' porque tenía cosas en común con el manierismo de los siglos XVI y XVII, en cuanto a manipulación de los principios establecidos, alteración de la escala, reordenación en los detalles, etc. Y por sus intenciones ilusionistas, de manipulación de la imagen perceptible para conseguir nuevas y diferentes formas de ver el espacio.

El vocabulario del diseño se hizo más amplio ya que también se incluía lo vernáculo, lo popular y la cultura del cómic-ver imagen -. El lenguaje empleado en el diseño representaba el cambio en la sociedad, era como un grito contra la serena elegancia del estilo moderno. Su carácter formal era frenético, llamativo, excitante. Aceptaba un mayor rango de escalas, de materiales y también de fuentes: hubo un gran acercamiento a la contra-cultura, en contra-posición a lo académico y al mundo del arte, del gran arte. Se expresaba una revolución tanto social como política: a principios de los sesenta el primer hombre salió al espacio, surgían movimientos pacifistas y se empezaba a luchar por los derechos de las minorías. También surgía un ligero desafío musical, el rock: los Beatles, los Rolling Stones; y también el Arte Pop. La segunda mitad de los sesenta era un periodo intermedio, de gran euforia. La gente estaba desatada, en un ambiente de alegría, juventud y rareza. En estos años se llegó al punto de zenit. Eran días de la época hippie, y el diseño reflejaba los deseos de libertad e individualismo. Los arquitectos que se habían formado en ese ambiente, tan fogoso socialmente y de gran actividad en el campo del arte óptico, empezaron a experimentar con ingeniosos trucos ópticos.

El nuevo diseño era radicalmente diferente en cuanto a la visión y a la creación de espacios. El espacio quería dejarse ver, era más abierto. El hombre ya había estado en la Luna y se había visto la Tierra desde el espacio. Las distancias disminuyeron para la imaginación y la escala se expandía a dimensiones cósmicas. Había un ambiente de revolución, relevancia y compromiso. Fue muy importante la lucha de los jóvenes, de los estudiantes, inmersos en una combinación de activismo, subversión y revolución. Algunos arquitectos aprovecharon la contribución de los estudiantes, a los que incorporaban en sus estudios, como hicieron Moore y Venturi.

También influyeron las drogas, el consumo de $L S D$ y las nuevas experiencias out-of-body, que se plasmaron en interiores psicodélicos con diseños gráficos nunca vistos, y en formas y texturas ambiguas con coloristas e intermitentes proyectos de iluminación. A todo esto, los estudiantes de la Universidad de Houston lo llamaban $L S D e s i g n^{99}$. Marshall Mcluhan ya había tratado sobre la simultaneidad del uso de los sentidos, de todos los sentidos. Y los nuevos diseñadores empezaron a considerar la experiencia multisensorial como una parte de la realidad de su trabajo, así como los aspectos emocionales y subjetivos, y cualidades como la ironía, el misterio, la ambigüedad, el contraste, la yuxtaposición, el conflicto, la perversidad y la paradoja. El diseño empezó a centrarse más en los sentidos que se producen en la ocupación del espacio que por el uso. El comportamiento humano, en muchos casos, era el eje director de la expresión del diseño.

Para aumentar las fuentes del vocabulario de su diseño algunos recurrieron a

98 C. Ray Smith. Supermannerism: New Attitudes in Post-Modern Architecture. (Nueva York: E.P. Dutton, 1977).

99 C. Ray Smith, "Getting it all together aestetically". Ibíd. p.48. 
lo cotidiano, a lo anónimo, a lo kitsch, lo folklórico, lo banal, al automóvil y al centro comercial. Arquitectos como Robert Venturi reivindicaron, por ejemplo, la efervescencia de la iluminación de la Strip de Las Vegas.

El nuevo diseño aceptaba la superposición de capas, plano sobre plano, para generar ambigüedad, para jugar con los niveles de percepción ${ }^{100}$. Objetos que serían considerados incongruentes en épocas anteriores iban amontonándose unos sobre otros: paneles de vidrio tintado, alfombras turcas, cerámica mexicana, retratos del S.XIX iluminados con lámparas industriales, una Jukebox, una escultura de neón, diseños en negativo-positivo, espejos trucados, y una multitud de objetos raros y populares -pop-mod-freak-.

En la obra de Moore había innumerables ejemplos, como su casa en New Haven, con el que se ha abierto este epígrafe. En Faculty Club, de la Universidad de California, en 1968, Moore y sus asociados combinaron los más disparatados elementos llegando al límite de las mayores discordancias. En el mismo espacio combinaron objetos pop con objetos raros de otros periodos, además añadieron una original iluminación con luces de neón y banderolas combinada con un candelabro estilo Louis Philippe, del S.XIX y fotos de los Beatles. En el muro opuesto, cabezas de carnero de 'peluche' colgados como si de una logia de cazadores se tratara. La parte de arriba del comedor contenía mobilario morisco y los techos imitaban al artesonado de la Alhambra. También contaba con algunos muebles jacobinos y con una chimenea del renacimiento alemán. El conjunto era moderno, con toques aparentemente arbitrarios pero con una vitalidad que lo hacía totalmente nuevo. Este método también lo estaban empleando otros arquitectos como Robert Venturi y Denise Sccott-Brown.

El 'supermanierismo' era una expansión válida de juegos ópticos, texturas, juegos formales y cambios de escala, que se desarrolló en los años 60 , ligado a los cambios sociales y a las corrientes que relacionaban los nuevos espacios con la multisensorialidad y las experiencias perceptivas.

\section{Simbología y memoria}

Podemos sentirnos fascinados por la plata antigua, las piezas de ajedrez, los soldaditos de plomo, o los barcos metidos en botellas. Al rodearnos de cosas que tienen para nosotros un significado especial, que hemos elegido entre otras similares y de las que sabemos mucho, podemos añadir una nueva dimensión al lugar que habitamos y a su capacidad para nutrir nuestra imaginación. Sean colecciones de sillas, de piedras, de grabados, de juguetes 0 -más generalmente- de libros, siempre adquieren su poder del acto de discriminación y compromiso que representan, y de la inversión y cuidados, y de saber que las atienden. Carecen de valor si no son personales.

Charles W. Moore

"A finales de la Segunda Guerra Mundial, Giedion proclamó la arquitectura moderna en crisis por su incapacidad de satisfacer la demanda cultural del simbolismo"101. Se esperaba algo más que una mera satisfacción 'funcional' de

100 Charles Moore, Gerald Allen y Donlyn Lyndon, La Casa: Forma y Diseño (Barcelona: Gustavo Gili, 1999) p.215

101 Jorge Otero-Pailos "Intelectualidad Arquitectonica en el nacimiento del Posmoderno" en

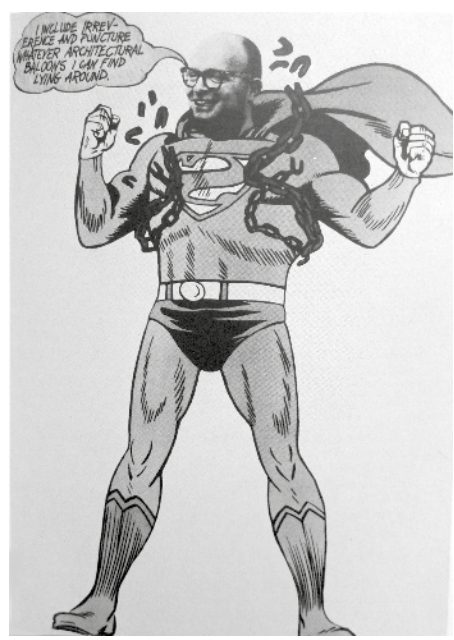

Imagen: Charles Moore irónicamente representado, con estética cómic, como 'superman-ierista'. Publicado en Supermannerism

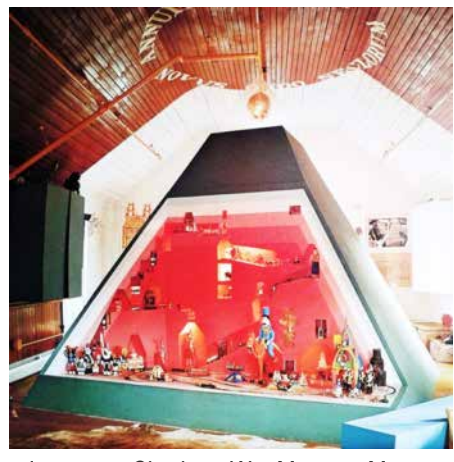

Imagen: Charles W. Moore. Moore House. Essex, Connecticut. 1973 
la arquitectura, por lo que se empezó a buscar la manera de que 'significara algo', y por extensión, se esperaba lo mismo del resto de los elementos que componían el entorno existencial del ser humano de la sociedad moderna ${ }^{102}$. En estos años se reivindica la idea de nueva monumentalidad.

Según Norberg Schulz, tal vez la palabra 'monumentalidad' podía parecer desconcertante, pero en realidad ofrecía una indicación acerca de lo que constituía el tema. En latín monumentum significaba sencillamente 'cosa que recuerda' o en otras palabras, cosa que tiene una significación duradera, es decir, dirigía a la noción de 'significado. A través del manifiesto firmado por Giedion, Sert y Lèger, "Los nueve puntos sobre la monumentalidad" -1943surgía la defensa de incorporar aspectos simbólicos y de significado al ámbito de la arquitectura, que el Movimiento Moderno había desechado. Según el manifiesto, los autores defendían satisfacer la eterna necesidad humana de los 'símbolos'.

La recuperación de la faceta lírica del espacio, según el manifiesto firmado por Sert y sus compañeros, podía surgir a través de la intención del arquitecto por medio de los efectos generados gracias al manejo de los 'conjuntos arquitectónicos', provocando efectos espaciales -sombras, color, texturas, tratamiento y movimiento de la luz, etc-, e incorporando elementos artísticos. Fruto de la colaboración con artistas -pintores, escultores-, se dotaba al espacio de la dimensión semántica necesaria para representar el sentimiento común de la sociedad, sin olvidar la inclusión de un nuevo factor de difusión en estos lugares: la publicidad.

A través de la nueva monumentalidad se reivindicaba en los edificios un medio de expresión a través de 'símbolos'. La simbolización se convierte en una preocupación fundamental. Todo ello sugiere la necesidad implícita de un lenguaje congruente de 'imágenes', 'objetos', 'comunicación'.

"Le Corbusier intuía la importancia de las imágenes espaciales cuando definía la arquitectura como "el juego sabio, correcto y magnífico de los volúmenes reunidos bajo la luz"103. En 1951, en rue Nungesser-et-Coli, Le Corbusier recibía en su casa al rector Mallet ${ }^{104}$ para hablar de arquitectura y urbanismo, al entrar no podía de dejar de mirar atentamente todos los objetos que habitan en el interior del apartamento. El diálogo que se produjo entre los dos hombres fue particularmente insistente sobre el papel de la cultura material en la transformación y la construcción de la identidad doméstica: ${ }^{105}$

¿Podría hablarnos de todos estos bibelots, de todas estas cosas que nos rodean y que crean esta intimidad tan profunda?(...) son cuadros dispuestos no como una colección de sellos sino colocados en determinados lugares e iluminados comme il faut, y también esculturas de mis amigos, de Henri Laurens, de Lipchitz, etc, y cosas antiguas, muy modestas de folklore antiguo, que son sobre todo piezas griegas

Architecture's Historical Turn. Phenomenology and the Rise of the Postmodern (Minneapolis: University of Minnesota Press, 2010) Introducción.

102 Christian Norberg-Schulz, Los Principios de la Arquitectura Moderna (Barcelona: Reverté, 2005) p.207.

103 Ibíd. p.208.

104 Robert Mallet (1915-2002) académico francés, rector de L'Academie de Paris y profesional de la radio. Trabajó para la ORTF office de radiodiffusion-télévision française donde era conocido sobre todo por sus entrevistas.

105 Caroline Maniaque. Le Corbusier et les maisons Jaoul. (Paris: Picard, 2005) p.106. 
tan sorprendentemente a escala, tan claras como inquietantes, hay cosas bizantinas encontradas en algún lugar de los Balcanes y que hablan de una época. Hay de todo (...) son utensilios extraordinarios de meditación psíquica, de resistencia de materiales, de armonía y belleza. No le voy a ocultar que a esto le llamo mi 'C.P.', mi colección particular, y que me procura un verdadero deleite ${ }^{106}$.

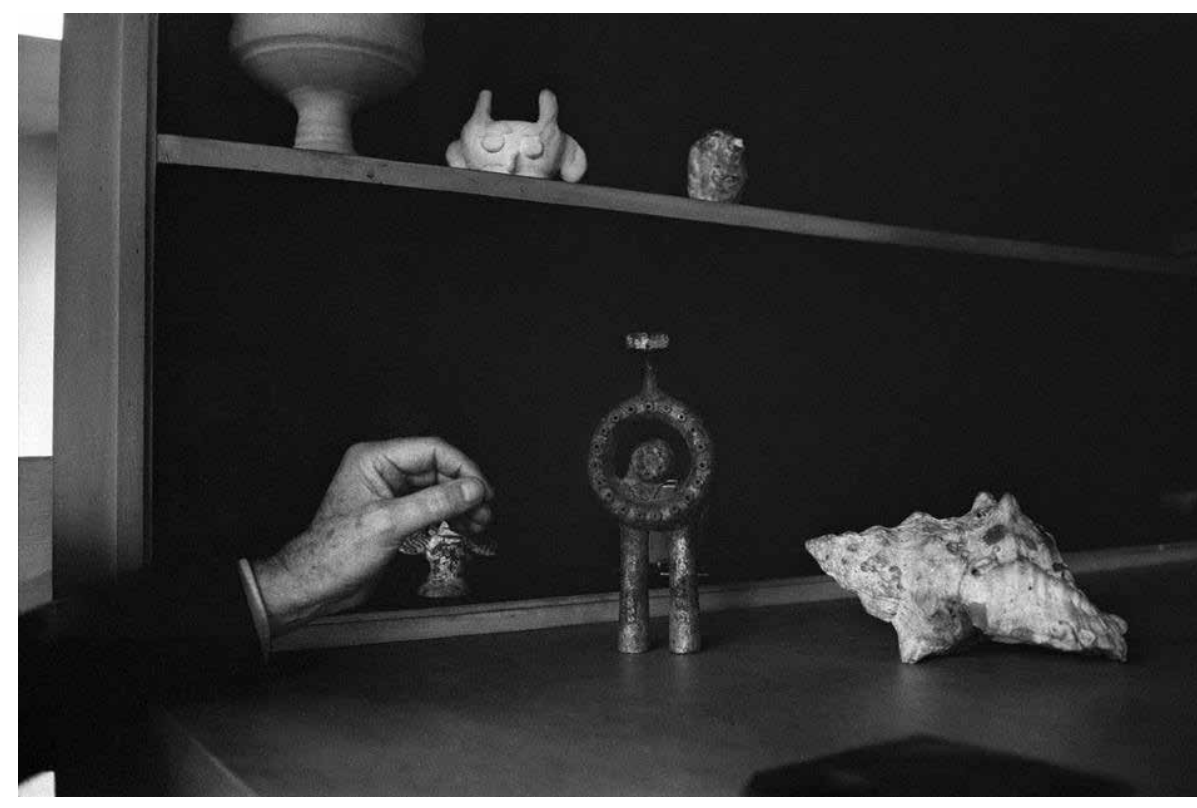

En América, y en aquellos años, con la casa de los Eames en Santa Mónica, California ${ }^{107}$, el clima general del diseño cambiaba para siempre, en parte porque la casa se publicó en todos los medios especializados y su imagen se expuso por todo el mundo. Quizás lo que se percibió como más innovador de esta casa fue la atención prestada por los diseñadores a los objetos aparentemente más 'marginales'. Los Eames trabajaron con el objeto cotidiano y personal desde una perspectiva que lo convertía casi en mágico.

La clave de esta casa es que los Eames utilizaron tecnología industrial para crear un recinto que proporcionaba lo justo para una vida confortable. Entonces, el ocupante podía transformar esa estructura llenándola con accesorios de su propia vida ${ }^{108}$. Los objetos eran lo que daba sentido al espacio, adquirían el papel del signo de las distintas disciplinas que intervenían, de la cultura popular, y del significado de lo que era la vida en el marco creado por el arquitecto. Era el símbolo, más que lo existencial, de lo vital.

Los Smithson -Alison y Peter-, amigos de los Eames, quedaron tan cautivados por su trabajo que lo tuvieron muy presente; sobre todo su contenido: "hemos seguido rumiándolo, trabajándolo, alimentándonos de él"109. El 9 de agosto de

106 Gilles Ragot y Mathilde Dion, Le Corbusier en France: réalisations et projets (Paris: Le Moniteur, 1997) p.176.

107 Casa Charles y Ray Eames, 1945-49, conocida como Case Study House nº 8, era una vivienda moderna y espacialmente agradable, que se convirtió en la casa de los propios arquitectos. Los Eames comenzaron a diseñar la casa en 1945 para el Programa Case Study House publicado en la revista de Arts \& Architecture de los Ángeles, y que se centraba en el estudio de casos que utilizaban nuevos materiales y tecnologías, desarrollados durante la Segunda Guerra Mundial. La idea era que las casas estuvieran construidas con sistemas prefabricados, que fueran fáciles de construir y que tuvieran un estilo moderno.

108 Beatriz Colomina, "Reflexiones sobre la casa Eames", RA: Revista de Arquitectura (nº j, junio 2007) p.3-16.

109 Alison y Peter Smithson en "Eames Celebration", Architectural Design (nºsept-1966) p.432, citado por Beatriz Colomina en "Reflexiones sobre la casa Eames" en RA: Revista de
Imagen: Objetos personales Le Corbusier. 
1956 se inauguró en la Whitechapel Gallery de Londres la exposición "This is Tomorrow", Alison y Peter Smithson junto con Niegel Henderson y Eduardo Paolozzi, todos miembros activos del Independent Group, realizan Patio \& Pavilion, una de las doce instalaciones que componían la exposición. Un patio abierto y un pabellón cerrado sirvieron para dar soporte a una instalación que reflejaba las necesidades del ser humano. Por medio de un sistema de símbolos, representaban las cosas que precisamos en la vida: ruedas de bicicleta, volantes, clavos, arpilleras, teselas cerámicas, pinturas, fotografías, papeles arrugados, restos arqueológicos. Por medio de un conjunto de objetos relacionados con las actividades del hombre establecían un amplio espectro de asociaciones y analogías con la existencia del ser humano.

El método de trabajo, según Peter Smithson ${ }^{110}$, hizo que los arquitectos y los artistas trabajaran en conjunto. Henderson y Paolozzi proporcionaron los objetos, que eran los signos e imágenes que dotaron de identidad al escenario, y que era la estructura facilitada por los arquitectos: el pabellón representaba el cobijo del hombre y el patio abierto que le rodeaba hacía referencia al instinto de apropiación del territorio, a la colonización del suelo como necesidad propia de cualquier civilización.

En la misma exposición, 'This is Tomorrow', Richard Hamilton, otro de los miembros del Independent Group, presentó el famoso collage titulado Just what is it that makes today's homes so different, so appealing?, la idea de Hamilton era colocar en el espacio reducido de un salón una representación de todos los objetos e ideas que abarrotaban el mundo en los años posteriores a la guerra. This is Tomorrow, en aquellos años, intentó resumir las diversas influencias que empezaban a conformar la Gran Bretaña posterior a la segunda guerra mundial. Aunque la obra representaba un interior, había elementos que hacían dudar de su categorización: el techo era una vista espacial de la Tierra, la alfombra era una panorámica de gente en la playa...según Hamilton, se trata de una alegoría más que de la representación de un espacio. En este collage los objetos, provenientes de recortes de revistas americanas de la época, formaban parte de esa alegoría a la que se refiere su autor, eran significado de un mundo en continua evolución que abrazaba un futuro halagüeño y simbolizaban las múltiples facetas de la época, con toque irónico, apoyado en la cultura popular y la tecnología más moderna.

"Todo interior es un conjunto de anacronismos, todos cuentan una historia y su narrativa puede ser fascinante"111, decía Hamilton años más tarde refiriéndose a su obra. Por esa razón para la representación de una época moderna, también incluyó otros objetos que retrotraían al observador a otros periodos de la historia -un blasón, un retrato victoriano-, porque para su autor dichos objetos eran importantes para asimilar el significado de lo actual. De esta manera presenciamos la inclusión de elementos que hacen referencia a la historia, a la memoria, como un factor para entender el espacio, algo que en cierto modo caracteriza planteamientos posteriores basados en la fenomenología aplicada a la arquitectura.

El objeto, en su permanencia, surgía como mediador entre el espacio y el tiempo, como en el cuadro de Las Meninas de Velázquez -1656- donde, como

Arquitectura (n9, junio 2007) p.15.

110 Peter Smithson, describía el método de trabajo, en 1956, en un escrito para Third Programme, de la BBC. Editado en Alison y Peter Smithson, Cambiando el arte de habitar: piezas de Mies, sueños de los Eames, los Smithson. (Barcelona: Gustavo Gili, 2001) p.109.

111 Richard Hamilton, "Una vista interior". Editado en Carta (n5, primavera-verano 2014) p. 60-63. 
decía Hamilton, cada elemento, cada detalle constituía un testimonio de la historia.

Baudrillard, en El Sistema de los Objetos, trataba de la dimensión simbólica a través de las colecciones: "El conjunto reunido y expuesto, de objetos antiguos, hechos a mano, objetos singulares, barrocos, folklóricos, exóticos, etc. suele constituir lo que llamamos colecciones, las cuales pueden llegar a ser un referente importante en la vida y en el hábitat de un ser humano". En el capítulo "El sistema marginal: la colección"112, se refería a las colecciones como un conjunto de objetos cuya reunión y exposición son fruto de una pasión, la de la propiedad privada. En ese aspecto, los objetos eran una cosa cuyo sentido era la posesión.

La posesión como tal abstraía al objeto de su función y lo volvía siempre relativo al sujeto. En la colección todos los objetos poseídos eran objeto de la misma abstracción y se remitían los unos a los otros en la medida que no remitían más que al sujeto. En ese aspecto es cuando la colección se constituye como sistema, por el cual el individuo trata de reconstruir un mundo, una totalidad privada.

A este concepto de orden, de organización del propio mundo, relacionado con el sistema de las colecciones, ya hacía referencia Walter Benjamin:

En lo que hace al coleccionista, y sin duda en cada uno de sus objetos, el mundo está presente y ordenado. Pero esto en relaciones sorprendentes, incomprensibles sin más para el profano. Pues se encuentra, en efecto, respecto al orden y esquematización que son habituales en las cosas, más o menos como el orden dominante en una enciclopedia confrontado a un orden natural. (...) Así, tanto los datos 'objetivos' como por supuesto cualquier otro dato, reúnen para el verdadero coleccionista, en cada una de sus posesiones, una completa enciclopedia mágica, un orden del mundo cuyo esbozo es el destino mismo de su objeto.

\section{Walter Benjamin ${ }^{113}$}

Abraham Moles ${ }^{114}$ también tuvo en cuenta el papel de las colecciones como elemento simbólico en su conjunto, dentro del hábitat contemporáneo.

Definía la colección como un conjunto de objetos que el individuo acumulaba y reunía impulsado a 'realizarse' en el placer que suponía la posesión del conjunto de objetos. "Una colección es una institución dentro de la población de objetos, pues tiene una estructura generalmente lineal: la de la serie, a menudo basada en la rareza de los sucesivos objetos".

Bien es cierto, tal y como exponía, que la idea misma de la colección parecía muy antigua, ya que en realidad estaba directamente vinculada a la posesión, por encima de la necesidad. La colección inscribía el tiempo en sí mediante la adquisición de sus diferentes elementos, y mientras aumentaba seguía siendo parte de un proceso. Cuando llegaba a estar completa, se eliminaba en cierto modo de la conciencia creadora e ingresaba en la categoría del macro-objeto

112 Jean Baudrillard, El Sistema de los Objetos (México: Siglo XXI, 1969) p.97.

113 Walter Benjamin. Obra de los pasajes 1. Libro V, vol.1. (Madrid: Abada 2013) Trad. Juan Barja de Quiroga Losada, H 2,7; H 2 a, 1. http://www.circulobellasartes.com/benjamin/termino. php?id=1169.

114 Abraham A. Moles, "La colección", en Teoría de los Objetos (Barcelona: Gustavo Gili, 1975) p. 137. 
u objeto múltiple.

Para Charles Moore, organizar el espacio podía proporcionar un contexto a la actuación diaria y disponer 'las máquinas' en orden podía facilitar e incluso ennoblecer actos concretos. Pero para conseguir una buena casa había que tener en cuenta además otro tipo de cosas.

Los viajes, libros, revistas, películas y programas de televisión habían revelado una variedad casi infinita de imágenes que podían encarnar en las casas lugares exóticos y muy remotos, audaces visiones del presente y del futuro, o creaciones nostálgicas del pasado que podían hacer renacer sentimientos olvidados. Para Moore la arquitectura doméstica siempre había sido un desfile de fantasías. Para ensanchar la vida imaginativa cada día, el lugar en que se habita debería permitir a diario su conversión en algo excepcional, y para ello el despliegue de recuerdos de otros tiempos y lugares era el medio más fácil y usado. Aunque consideraban que no todos los elementos que cautivaban la imaginación tenían que ser exóticos ni grandiosos, simplemente tenían que simbolizar los sueños, a través de la imaginería por ejemplo:

Tenemos que sacar a la luz nuestros sueños y fantasías. Tal vez por suerte es imposible volverlos a crear, o dotarlos de un entorno completo. La expresión de los sueños se realiza mediante su transmutación, desarrollándolos de manera que sólo permanezca su esencia, y mediante la miniaturización, es decir, reduciendo sus elementos a una escala que podamos acomodar y pagar

Moore, Lyndon, Allen 115

En el capítulo "Recolección"116, Moore, Lyndon y Allen hacían referencia a la posibilidad de "añadir algo" a la casa. Un aditamento en el que el ocupante jugaba con los objetos, los emplazamientos de éstos, así como con colores, texturas y materiales. De esta manera podía establecer un medio que pudiera reconocerse como suyo. Los colores tenían la capacidad de ampliar las cualidades del lugar, y los materiales también llevaban implícitas sus connotaciones. Sin embargo, los autores consideraban que podía haber otras características de una casa consistentes en que el habitante deseara rodearse de imágenes y materiales que nada tuvieran que ver con la construcción. Igual podían ser objetos de plata antiguos, que piezas de ajedrez, que soldaditos de plomo o barcos metidos en botellas. La cuestión era aumentar la componente simbólica dentro del espacio para mejorar sus cualidades en pos de incrementar los vínculos con el usuario.

Al rodearnos de cosas que tienen para nosotros un significado especial, que hemos elegido entre otras similares y de las que sabemos mucho, podemos añadir una nueva dimensión al lugar que habitamos y a su capacidad para nutrir nuestra imaginación

Moore, Lyndon, Allen ${ }^{117}$

Las colecciones siempre adquirían su valor del hecho de que sus objetos habían sido elegidos de entre otros, del compromiso que representaban, de la inversión que habían supuesto, de los cuidados que requerían o del lugar

115 Charles Moore, Gerald Allen y Donlyn Lyndon, La casa: forma y diseño (Barcelona: Gustavo Gili, 1999) p.138.

116 Ibíd. p.214.

117 Ibíd. p.215. 
especial que demandaban en la casa. Además carecían de valor si no eran personales.

A veces, aparecían tan arraigadas al propio espacio, que podía hablarse incluso de una especie simbiosis en el que la casa y los objetos acababan fundiéndose: "El despliegue de colecciones se convierte en parte de la casa", decía Moore ${ }^{118}$.

Poniendo como ejemplo la Casa Museo de John Soane -Londres, 1812-1834, Moore ${ }^{119}$ hacía referencia a que una extraordinaria colección de artefactos y objetos artísticos se convertía en parte integrante del lugar. La casa y la colección eran inseparables. La pasión del coleccionista se deleitaba en la yuxtaposición y agregación de significados, pero también en los misteriosos juegos de luz y sombra que generaban sus formas, en las vistas múltiples, y en los artificios ilusionistas.

Donlyn Lyndon ${ }^{120}$, hablaba del proceso de miniaturización para introducir lo simbólico dentro de la casa. El edículo, por ejemplo, espacio simbólico representado tanto en edificios como en pinturas y manuscritos como un espacio cubierto, santuario o lugar de meditación de los templos hindúes, podía reproducirse dentro de la casa, como una pequeña casa para estar y establecer un lugar especial, como una reliquia del acto de habitar. Este elemento podía servir como un foco simbólico y significar un lugar especial, al igual que la representación de un baldaquino o canopia. Un símbolo de la realeza que significaba además un lugar de atención. Su connotación de algo especial podía llevarse a sitios de la casa, por ejemplo con un falso techo separado del existente o pintando una parte para significar que se está protegido por una canopia, con colores brillantes, como las antiguas. O las columnas, que se podían utilizar también como focos, no por su función tectónica sino para marcar un lugar. Una columna podía ser un acontecimiento especial, al igual que su ornamento significaba importancia, al igual que su tamaño y altura

\section{La TV como objeto}

La televisión es el objeto definitivo y perfecto en esta nueva era, nuestro propio cuerpo y todo el universo circundante se convierten en una pantalla de control.

Jean Baudrillard ${ }^{121}$

Charles Moore ${ }^{122}$ decía que una de las características importantes de las habitaciones era su disponibilidad para el movimiento y el reposo. La quietud normalmente se estimulaba con un solo foco, congregando en sí la atención, estructurando la habitación en torno a un solo centro de interés, como una chimenea, o un sofá. El televisor, indudablemente es un foco único de atención,

\footnotetext{
118 lbíd. p.217.

119 lbíd. p.218.

120 Donlyn Lyndon "The House of the mind: Houses by MLTW" en Houses by MLTW. Moore, Lyndon, Turnbull \& Whitaker 1959-1975 (vol-1). Editado por Yukio Futagawa (Tokio: A.D.A. Edita, 1975).

121 Jean Baudrillard, "El éxtasis de la comunicación" en Posmodernidad . (Barcelona: Kairós, 1985) p.187.

122 Charles Moore, Gerald Allen y Donlyn Lyndon, La casa: forma y diseño (Barcelona: Gustavo Gili, 1999) p.96.
} 
Imagen: Fotograma de la película Farenheit 451. Dir: François Truffaut, 1966

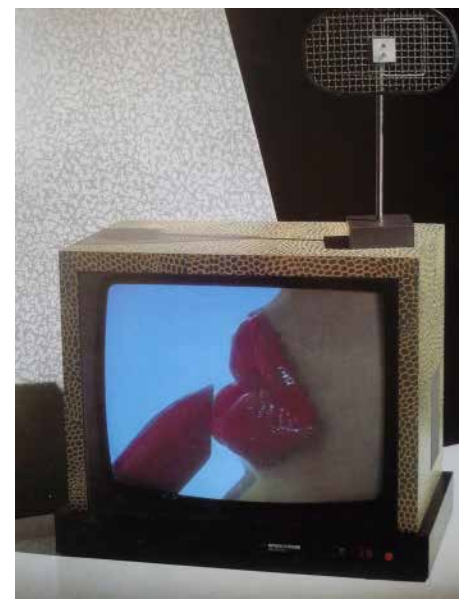

Imagen: Sottsass/Thun/Susani. Televisor para Brionvega.

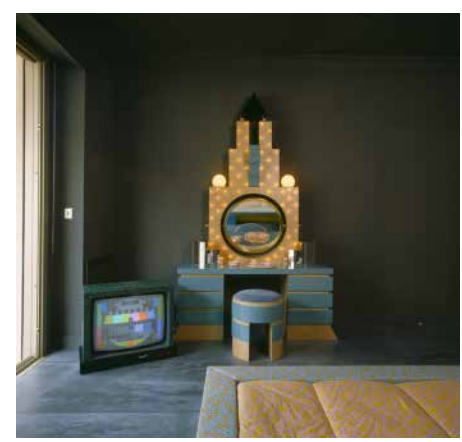

Imagen: Apart. Karl Lagerfeld, Grupo Memphis. Montecarlo, Mónaco. 1983. Vista interior del dormitorio con televisor Brionvega diseñado por Sottsass.

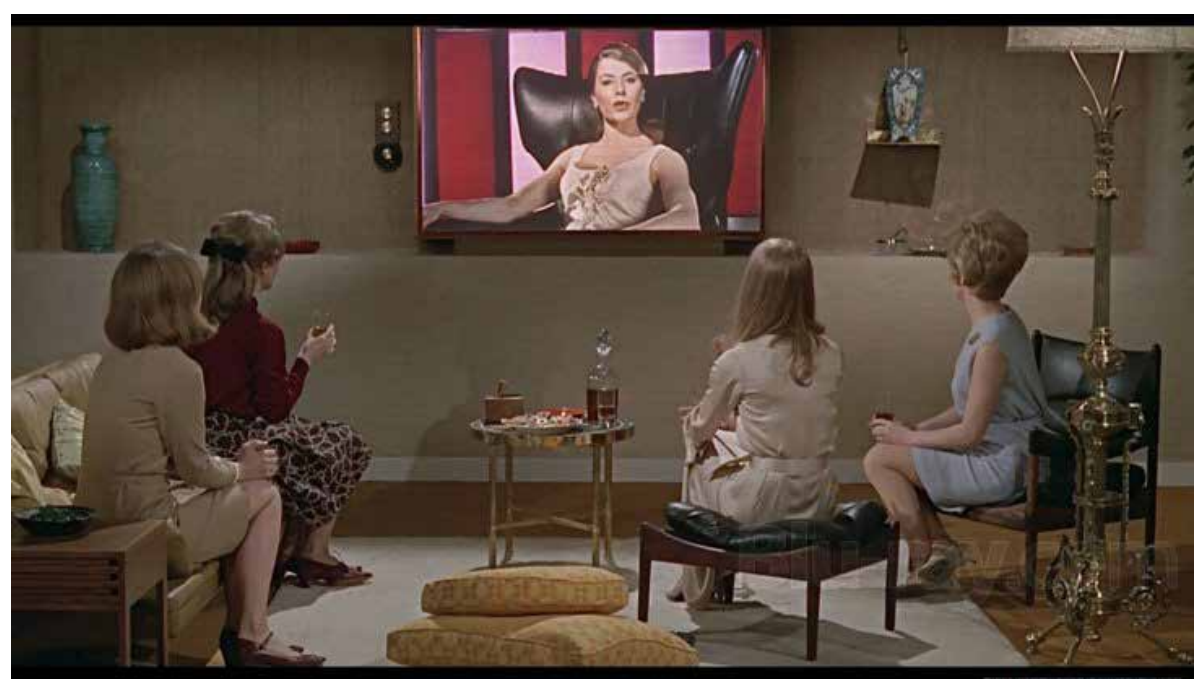

pero al estar pensado para transportarnos, adquiere una importancia focal desmesurada en relación con su tamaño. Según Moore, elementos como una mesa de café cargada de objetos, reflejaban las preocupaciones de sus dueños en ese periodo de su vida, y cumplían un papel muy útil ya que realizaban un intercambio verbal, en lugar de matarlo como hace la televisión...

Ya incluso a partir de los años 60 , cuando se hacía referencia a la figura de la televisión como parte del sistema de objetos, también se incluían las pantallas de otros terminales de comunicación e información, como decía Baudrillard"123, "la zona interfacial generalizada que acompañaba el universo de la comunicación". En muchos casos, la simple presencia de la televisión era capaz de cambiar el resto del hábitat.

El cineasta François Truffaut, en Farenheit $451^{124}$ representaba el mundo del futuro en un enclave similar al de su tiempo. Lo interesante sin embargo, en lo que respecta a este apartado, es que Truffaut en un marco doméstico tradicional, la casa de los protagonistas, introdujo un elemento 'futurista' que cambiaba la configuración del espacio, el significado de todo lo que le rodeaba, este objeto funcionaba como signo y el significado era 'una casa de ciencia ficción': una pantalla 'plana' de grandes dimensiones que más se podría parecer a las pantallas de ahora que a las de los años 60. La pantalla inundaba el resto del espacio y atraía las miradas de todos los que habitaban.

Sin embargo, la ubicación del televisor puede variar, así como su disposición con respecto al resto de los elementos, convirtiéndose en un objeto accesorio, secundario en cuanto a la jerarquía, e intentar perder ese protagonismo, del que hablaba Moore. En 1983, el Grupo Memphis diseñaba el interior y todo el mobiliario del apartamento de Karl Lagerfeld en Montecarlo. La televisión Brionvega se disponía sobre el pavimento del dormitorio, junto a otro elemento de mobiliario de singularidad formal, evitando un excesivo protagonismo.

El caso contrario, aunque huyendo de convencionalidades, se incluía en el diseño de los arquitectos Smith Miller + Hawkinson en 1989 de apartamentos tipo en un edificio de viviendas para la Policía de Nueva York. El diseño del apartamento pretendía anticiparse al futuro de la vivienda urbana, sobre todo en temas de espacio convertible y de programa doméstico, pero lo más

123 Jean Baudrillard, "El éxtasis de la comunicación" en Posmodernidad. Editado por Hal Foster (Barcelona: Kairós, 1985) p. 188.

124 Fahrenheit 451 es una película de ciencia ficción dirigida por François Truffaut, estrenada en 1966 y basada en la novela homónima de Ray Bradbury. 
significativo finalmente era la presencia de un dispositivo de televisión, móvil y articulado, que ofrecía su visión desde todos los distintos espacios: sala de estar, comedor, dormitorio y balcón. "La onmipresencia de la pantalla nos recuerda a la película de Godard, Alphaville, una inquietante referencia de los autores para este apartamento del futuro.
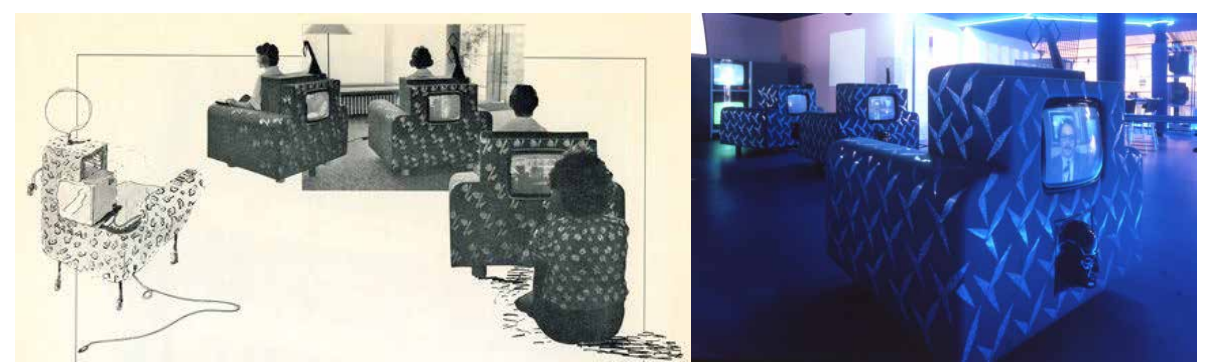

El televisor era, para Ugo la Pietra, el objeto absoluto en un sistema alienante llamado 'La Casa Telemática', y fue presentado en la Feria de Milan en 1982. La propuesta crítica de la Pietra incluía pantallas de televisión en todos los lugares de la casa, desde el dormitorio a la zona de vestidor pasando por el comedor e incluso en el cuarto de baño.

En la Slow House de Diller \& Scofidio ${ }^{125}$ no había fachada frontal, sólo una entrada. Era una casa de fin de semana que se concebía como una travesía, desde una entrada física hasta una salida óptica, o simplemente de una puerta a una ventana. Más allá de la puerta, a la izquierda había una serie de dormitorios y baños, a la derecha estaba el ascenso a la cocina y la sala de estar. Al final, la vista del mar. A ambos lados de la 'ventana de imagen' había dos pilares tipo antena. La chimenea estaba a la derecha, el aparato de video a la izquierda.

Sobre la antena izquierda se encontraba una cámara de vídeo que grababa en directo las vistas al mar, y el monitor estaba de frente a la ventana tapándola desde dentro. La vista electrónica podía modificarse, la cámara permitía el zoom o alejamiento ofreciendo una vista panorámica. Cuando se grababa la imagen podía reproducirse después. Por ejemplo, el día se reproducía por la noche. La vista compuesta formada por la pantalla delante y la imagen de la ventana detrás estaba siempre desfasada, creándose una contradicción entre lo auténtico y lo proyectado. The Desiring Eye era una instalación multimedia que contaba la historia de la casa en 24 imágenes sincrónicas, en el espacio y en el tiempo. Consistía en una realidad reconstruida a través de imágenes, no desprovista de efectos alienantes, donde quizá la ligereza en la asincronía y el hecho de que la grabación y reproducción correspondieran al mismo lugar desde donde se proyectaba, aumentaba sus efectos 'inquietantes'. Este símil de representación de realidad simulada, introducía en el debate sobre la focalización de la casa frente a uno de los objetos con mayor poder de influencia en el espacio doméstico contemporáneo, la televisión. Tal era el grado de incidencia dentro de la casa, que este elemento competía con lo real: la pantalla sustituía a la ventana tradicional y lo que se podía ver a través de ella -incluido el tiempo-.

En este apartado hemos comprobado que la nueva visión del objeto se presentaba no sólo a través de los estudios, teorías y clasificaciones, como hemos visto en la primera parte del capítulo, sino que existían múltiples facetas del objeto en el nuevo marco que hacían ver que había una nueva manera de

125 Slow House. North Haven, New York. Por Diller \& Scofidio, en 1991.
Imágenes a la izquierda: 'La Casa Telemática' . Feria del mueble de Milan. Ugo la Pietra 1982.

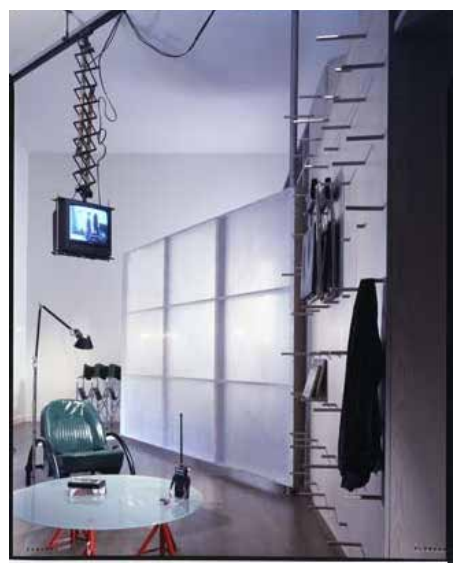

Imagen: Smith Miller + Hawkinson. Edificio de apartamentos en nueva York. 1983. Vista del interior de un apartamento.

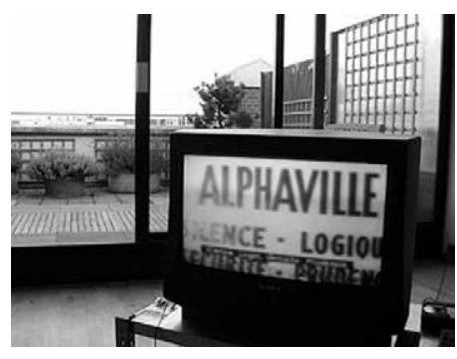

Imagen: Fotograma de la película Alphaville de Godard

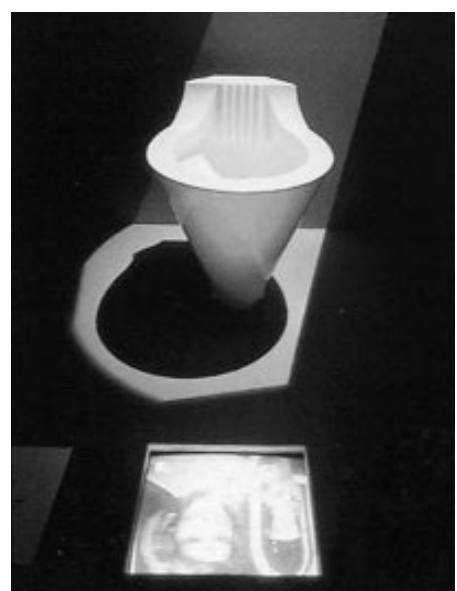

Imagen: La Casa Telematica. Feria de Milán, 1982. Ugo La Pietra. "pranzo TV", a derecha, "bagno luogo di decompressione" abajo. 


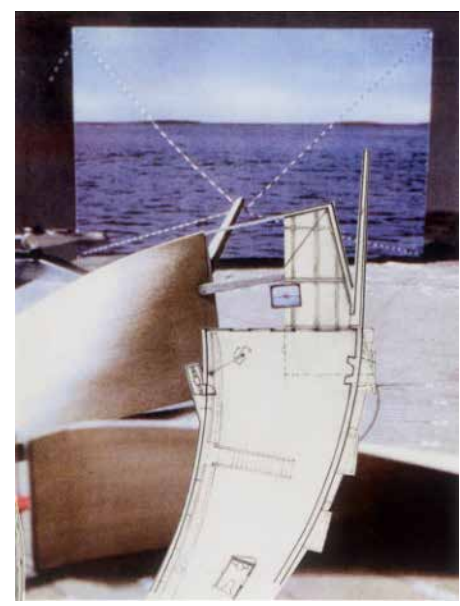

Imagen: Slow House. Diller \& Scofidio. 1991

Imagen a la derecha: Desiring Eye. Maqueta con la distribución de las 24 pantallas de cristal líquido y la instalación para la reproducción de las imágenes. Diller \& Scofidio. 1991
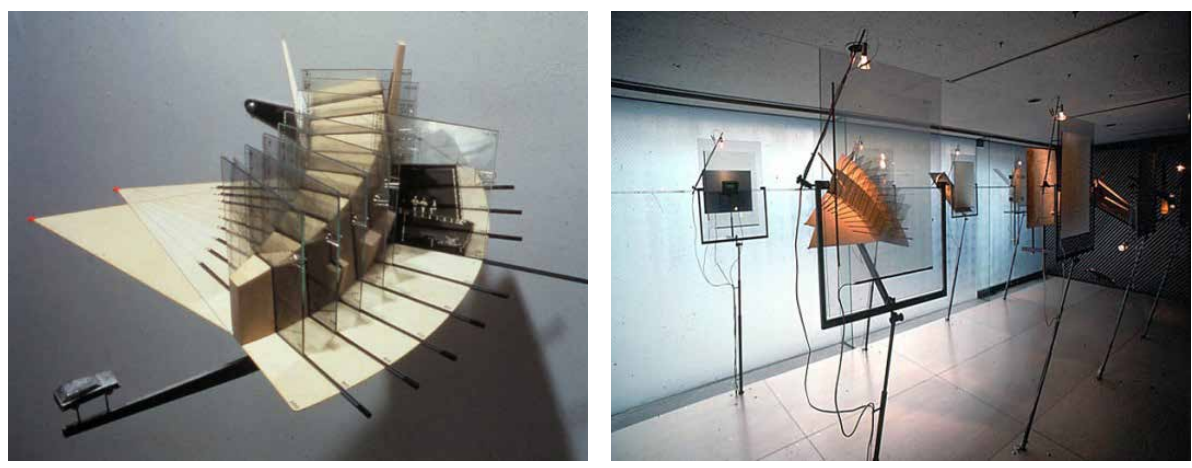

entender el elemento cotidiano. Así pues, hemos visto que el objeto adquiría nuevas acepciones que se sumaban a las tradicionales, como la predominancia de la cualidad semántica, y de su poder de participación para la elaboración de un discurso. Así mismo hemos visto su consideración topológica y también psicológica ligada a su disposición dentro de la casa. Esta condición iba unida principalmente por su poder de irradiación y a su capacidad ordenadora. Como vimos en el apartado 1.1. -teorías, definiciones y clasificaciones- deducir las normas que regulaban la sintaxis de la colocación era una de las mayores premisas en los estudios sobre objetos.

Otra de las facetas en las que podemos encuadrar la nueva visión es la de la tecnología. De ellas hemos podido constatar que los avances técnicos han influido de forma decisiva en la configuración de los hogares a partir de la segunda mitad del siglo XX. Los nuevos sistemas de fabricación, los avances tecnológicos, la miniaturización y los nuevos materiales daban respuesta a la necesidad de muebles más transportables y transformables. La nueva naturaleza de estos artefactos proporcionaban los medios para que los espacios fueran más polivalentes y abiertos.

El otro punto de vista es el subjetivo, el de la experiencia, la memoria y la simbología. Estas nuevas visiones de los objetos dentro del marco doméstico, tal y como hemos visto en los apartados anteriores, estaban ligadas a la aplicación de la fenomenología en la arquitectura y a consideraciones relacionadas con la inclusión de sensaciones y de nuevas experiencias en la vivienda, empleando el objeto en muchos casos como elementos transformadores de la percepción espacial.

Tras estas facetas, existen dos configuraciones de objetos que se han desarrollado específicamente en el proceso de configuración del espacio doméstico contemporáneo, por un lado el sistema llamado 'la casa dentro de la casa' entendido como la creación de interior en el interior y por otro lado, el proceso de 'objetualización' de ciertos elementos constructivos y su participación en la composición del espacio.. 


\subsection{LACASA DENTRO DE LACASA}

Para nosotros la imagen de la casa ejerce un gran poder sobre la mente humana, y el hecho de que una casa deba parecer el lugar más importante del mundo para sus habitantes. Desde los tiempos más remotos, este centro espiritual se ha marcado con cuatro postes que en general delimitaban un hogar (...) Posteriormente, se convirtió en la casa simbólica, el edículo en el que, por ejemplo, eran coronados los faraones, y más tarde aún en el que se colocaban las imágenes de los santos o los altares. En nuestras obras, los edículos proporcionaron un medio de acomodar esta necesidad general de un centro simbólico en pleno corazón de las demandas específicas del hogar.

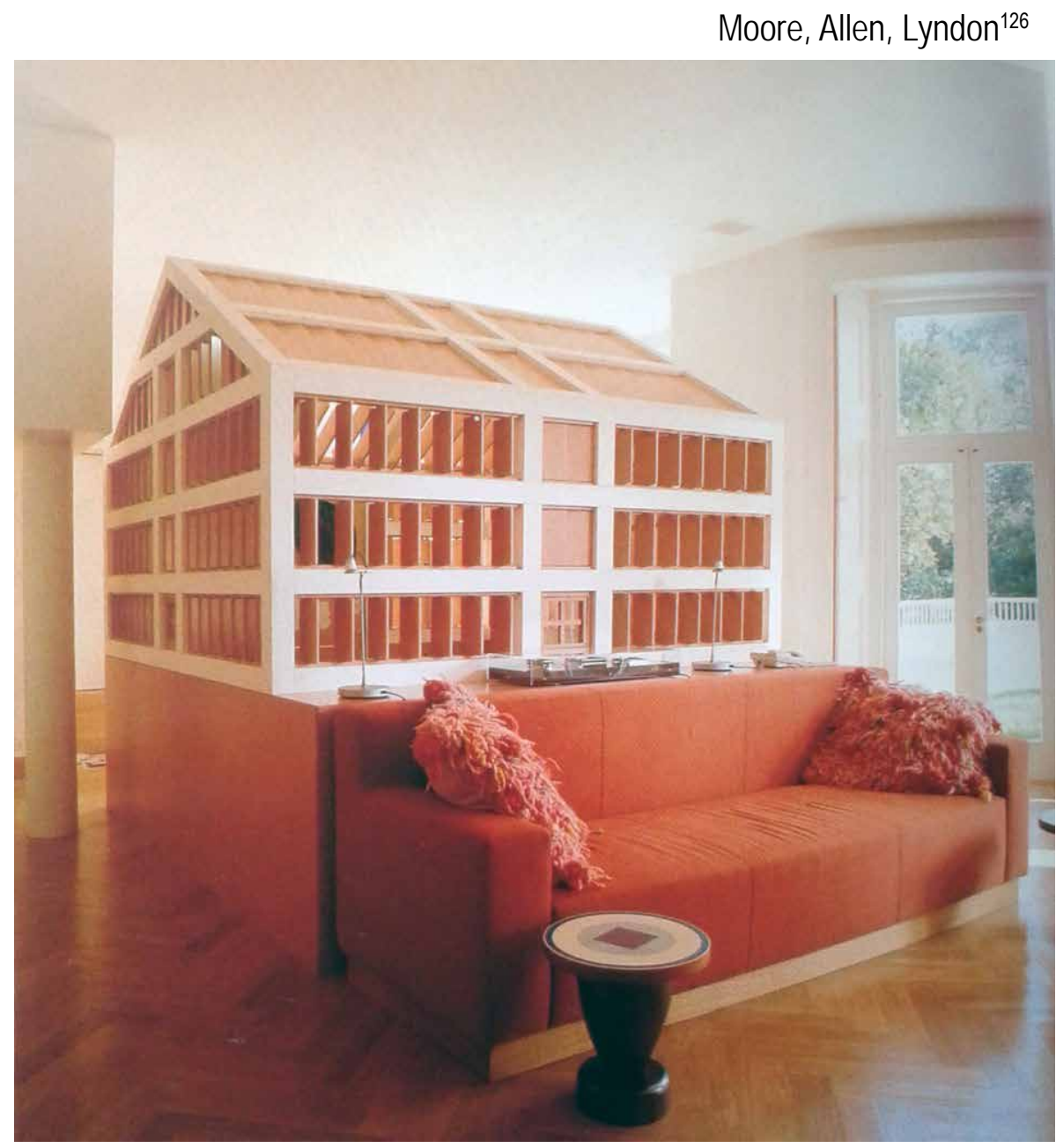

'La casa dentro de la casa' es la denominación metafórica que normalmente se aplica al fenómeno de la creación de espacio interior dentro de un ámbito interior. Este sistema tuvo especial aplicación en los interiores domésticos de los 60, aunque fue una tendencia que, según determinados autores ${ }^{127}$, era tan contemporánea como tradicional. Venturi habló de 'la cosa en la cosa', Moore de 'la habitación dentro de la habitación', Lyndon lo llamó 'estratificación', pero al final el término fue adoptado por todos. De los que utilizaron este recurso, algunos recurrieron a la imagen tradicional del edículo, como Moore y Lyndon cuya idea de crear casas dentro de la casa venía del conocimiento del libro de John Summerson, Heavenly Mansions, donde el historiador británico

126 Charles Moore, Gerald Allen y Donlyn Lyndon. La casa: forma y diseño (Barcelona: Gustavo Gili, 1999) p.51.

127 Imma Forino. L'interno nell'interno. Una fenomenologia dell'arredamento. (Florencia: Alinea Editrice, 2001).
Imagen: Greer House. Reforma de un edificio del s.XVIII para albergar un bloque de apartamentos en Londres. Por Ettore Sottsass y Johanna Grawunder, en 1993. 


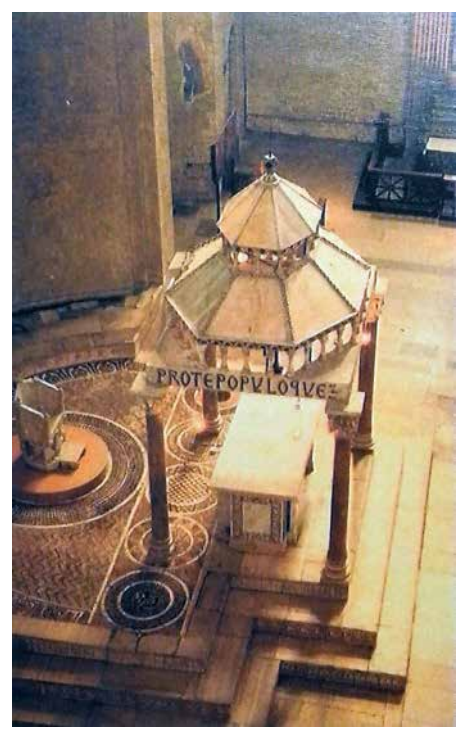

Imagen: Edículo tradicional, cimborrio de la Basílica de San Nicola di Bari. S. XII. Imagen publicada en I. Forino, L'interno nell'interno, p.128. describía en 1949 los edículos como templos en miniatura usados con fines ceremoniales a finales del barroco y en las villas neoclásicas inglesas. Moore estuvo obsesionado con los edículos durante toda su larga carrera. Utilizando la referencia histórica, su idea era conseguir que aquello se entendiera como una imagen poética dentro del hogar; que significara el centro del Universo en el interior de la propia casa: "La casa debe parecer el lugar más importante del mundo para sus habitantes". La referencia simbólica era una imagen reconocible en la memoria sobre un elemento que tradicionalmente albergaba lo sagrado, lo espiritual.

Pero existían diferentes planteamientos sobre las razones que llevaban a la representación formal de la intimidad y a la creación de distintos grados de interior en el espacio doméstico. Por un lado, estaba la intención de abstracción y de transformación del hábitat, con la finalidad de llegar a lo simbólico y a lo psicológico de lo que era el mundo interior. La creación de distintos niveles dentro del espacio íntimo, la casa, significaba huir de la realidad, ofrecer la posibilidad de poder evadirse. Esta idea podía llevarse a cabo a través del edículo, como ya se ha visto, o de manera más compleja, utilizando un sistema consecutivo de capas protectoras. El usuario podría sentirse, aunque sólo fuera por un momento, en el centro de un universo en miniatura, fuera de lo terrenal y del tiempo, rememorando lo descrito por Bachelard ${ }^{128}$ de que el confinamiento físico obligaba a la gente a experimentar "vagando concentrada"129 para sentirse como si estuviera en otra parte, a lo ya se ha hecho referencia anteriormente. En el contexto de los 60 y en la contracultura de los experimentos con drogas inductoras de experiencias extracorporales out-of-body, se asoció el edículo con la experiencia de la liberación de toda forma física, no sólo de la arquitectónica sino también de la humana. Este elemento se convirtió en un emblemático espacio poético-arquitectónico cuya función era inducir a la creatividad. Ayudaba a sus habitantes a asimilar y a olvidar a la vez la realidad externa, y a crear algo nuevo.

El ejemplo más claro era la Casa del propio Moore en Orinda, California, realizada por él mismo en 1962. Fue una oportunidad especialmente bien recibida para poder aplicar extensamente aquellos ${ }^{130}$ elementos de rememoración mítica. El diseño general de la casa adoptó la forma arquetípica de una cabaña cuadrada.

Dentro, ocho columnas formaban dos edículos de diferentes tamaños, con cubiertas piramidales asimétricas que anidaban en la parte superior de la cubierta principal y compartían un gran lucernario. Las bóvedas de los edículos eran blancas y resaltaban del resto de la cubierta principal que era de traviesas de madera vista y ennegrecida. Toda la estructura estaba unida por una cercha

128 El trabajo de Charles W. Moore estuvo muy influido por su interés por la experiencia y por legitimar la faceta intelectual del trabajo del arquitecto, lo que le llevó a la fenomenología de Gaston Bachelard. Moore aprovechó la teoría de la 'arquitectura eucarística' de su maestro en Princeton, Jean Labatut, pero la secularizó, eliminó las referencias teológicas e incorporó referencias filosóficas, que eran más apetecibles. También recurrió a Bachelard en su tesis doctoral Water and Architecture en 1957 y describió la experiencia inmediata como un acto en el que se olvidaba la forma exterior del objeto para captar su interior, su contenido. Esta invocación a Bachelard es importante, ya que fue la primera vez que se introdujo a un filósofo en un discurso arquitectónico en América, casi una década antes de que los fenomenologistas franceses, Sartre, Merleau-Ponty, etc. fuesen nombres familiares en las escuelas de arquitectura de América

129 Gaston Bachelard. La Poética del Espacio (México: Fondo de Cultura Económica, 2006) p.5455.

130 Moore decía que el compromiso del arquitecto estaba en experimentar, pero mejor si lo hacía con sus propios proyectos antes de aplicarlos a los de sus clientes, así se evitaba el problema de errar en el primer intento y no se cargaban al bolsillo de otros las consecuencias de una solución fallida. 
central múltiple pintada de naranja, que sostenía las traviesas. Los muros exteriores dejaban abiertas las esquinas y tenían una doble capa interior que albergaba estanterías, cocina y aseo. Las camas se agrupaban en torno a una gigantesca librería en el espacio entre los dos edículos. El mobiliario era libre de ocupar su lugar en configuraciones cambiantes debajo y alrededor del pabellón mayor. El edículo pequeño enmarcaba una bañera hundida en el suelo, "una especie de celebración del acto de bañarse que aquí está liberado del agobiante cuarto de baño tradicional".

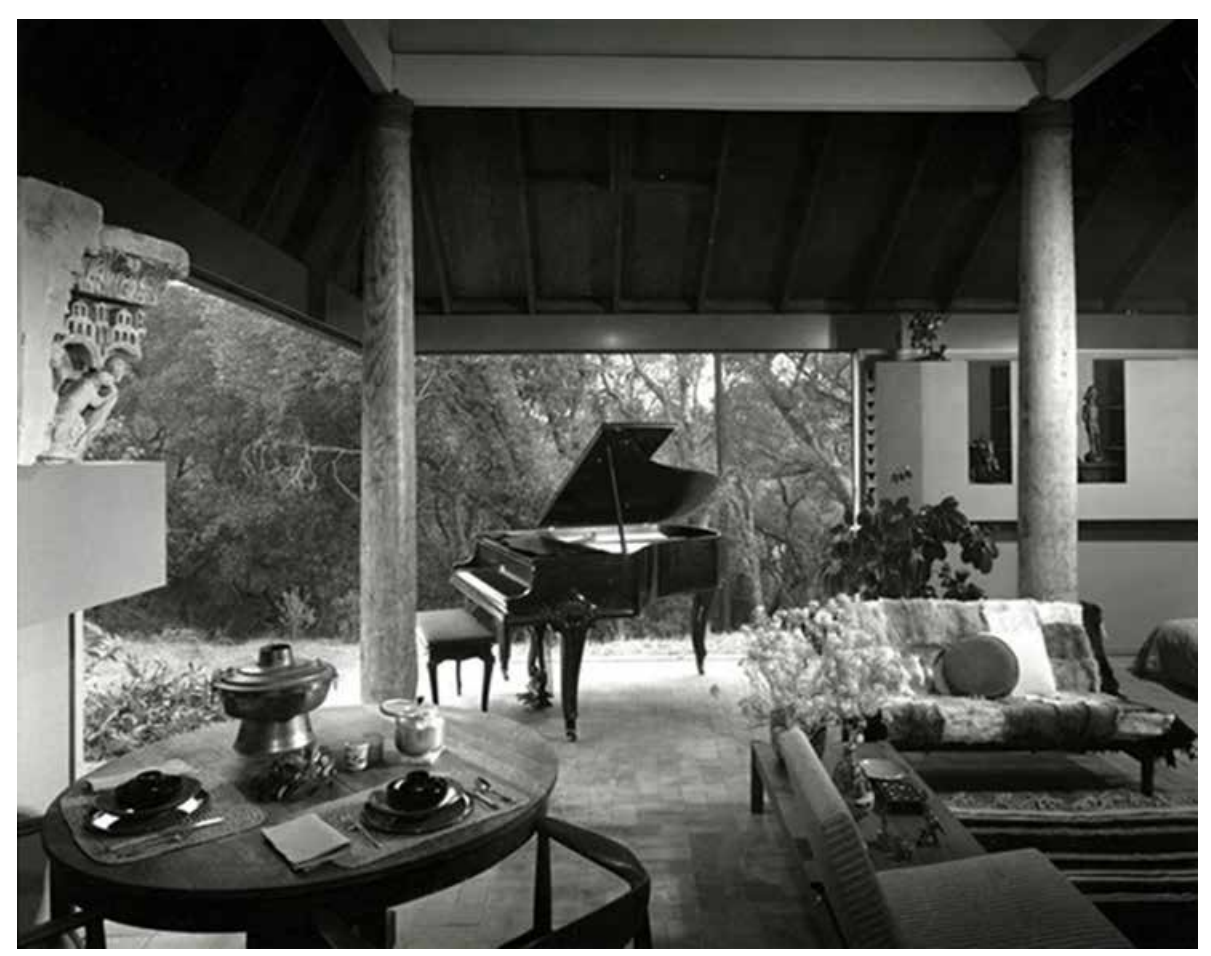

La luz natural entraba por las esquinas de la fachada que se abrían con grandes puertas correderas de granero, y también por el lucernario, a través de las bóvedas de los edículos. Esto reforzaba la sensación de que allí había muchos 'lugares' dentro de un espacio único "uno puede estar bajo una bóveda, junto a una columna 0 alejado de los pabellones para pasear libremente dentro de ese espacio mayor tipo granero". La casa albergaba colecciones, incluso las columnas, recuperadas de un derribo y cepilladas y lavadas eran al mismo tiempo unos objetos dignos de disfrutarse por sí mismos. Muchos objetos menores, estaban arropados en los estratos de los muros exteriores y servían como recuerdo del cuidado con que otros también supieron hacer las cosas en el pasado, objetos antiguos, ya consumados, cuyo valor es el de haber existido y el de rememorar cómo se hacían las cosas en tiempos pasados.

De este ejemplo, y de las relaciones generadas por la multiplicidad de elementos dentro del espacio, se podían deducir otros sistemas, por un lado, una labor organizativa dentro de un ámbito abierto y con elementos distributivos casi inexistentes. Las cuatro columnas, en cada uno de los dos edículos, ordenaban las acciones tanto en su propio ámbito como en los espacios intermedios y en los periféricos, dirigiendo la mirada hacia nuevas visuales que iban del interior al exterior. Esta relación de elementos en el espacio, no solamente cumplía una labor jerárquica y organizativa sino que también potenciaba la idea de lugar.
Imagen: Casa Moore en Orinda, California. Charles W. Moore, 1962
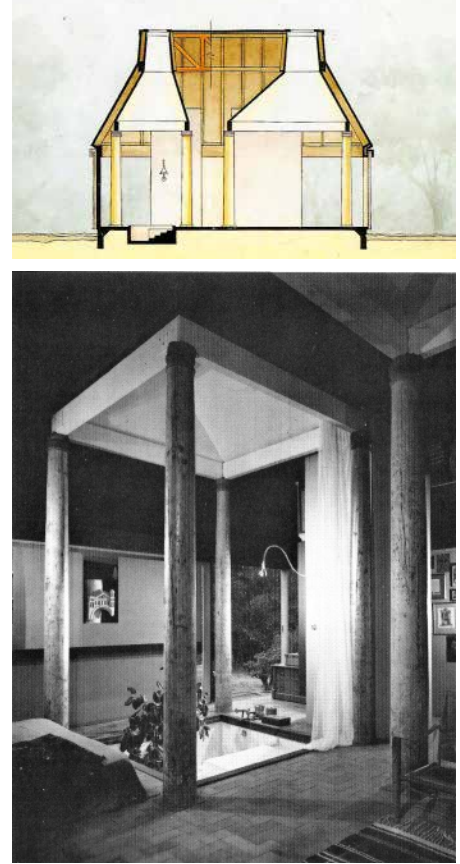

Imagen: Casa Moore en Orinda, California. Charles W. Moore, 1962. Edículos 
Imagen:. Moore House. New Haven, Connecticut. MLTW / Moore-Turnbull, 1966.

Esquemas en planta e isométrica de los elementos que estructuran el espacio y de las posibilidades de visuales y recorridos que generaban.
En la casa de Moore en New Haven ${ }^{131}$, como ya se ha comentado en apartados anteriores, la inclusión de tres fustes o tres volúmenes de 'aire' en el interior de una casa de 1860 provocaban un juego ambiguo entre los elementos nuevos y los originales.
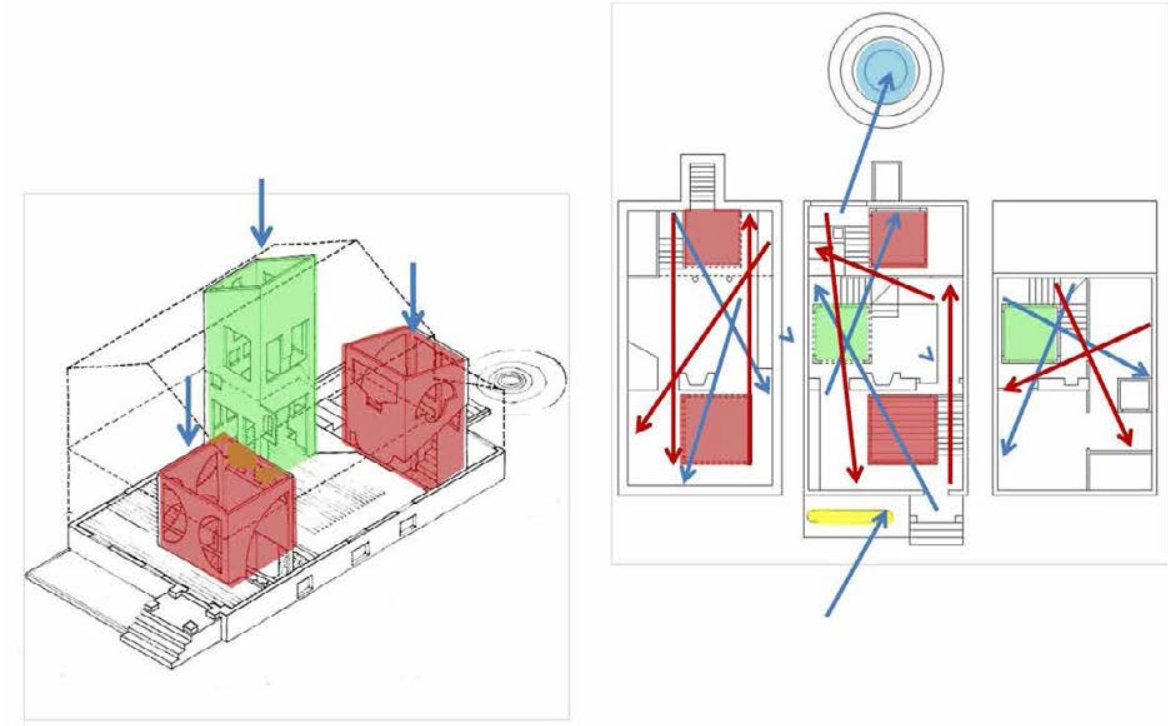

Los tres volúmenes, estaban abiertos por arriba y cerrados por los cuatro lados. Manipulando el sistema americano ballon-frame, las 'torres' se materializaban en un sistema de superposición de finas capas pintadas de colores vivos y horadadas con cortes semicirculares o con formas irregulares, lo que les daba un aspecto de mayor ligereza. La torre llamada Ethel tenía en su interior una especie de habitáculo rojo con estrellas que contenía la cama, generando un juego de niveles de interior como si de 'muñecas rusas' se tratara. Los fustes usaban la superposición para experimentar formalmente la percepción simultánea de experiencia visual, desde un extremo a otro de la casa, desde la planta más baja a la más alta, se ofrecían espacios dentro de espacios, superposiciones de usos sobre otros, decoraciones superpuestas, escenas sobre escenas. Pero, como en el caso anterior, su papel también era organizativo y distributivo, de usos y actividades, y de accesos y comunicaciones verticales. En este otro caso, la simple razón de que los volúmenes fuesen netos y definidos, no desdibujados como en la casa anteriormente analizada, y de que permanecieran aislados y perceptibles en el espacio libre, los convertía en objetos cuya propia presencia respecto al entorno propiciaba sus relaciones y articulaciones, ordenando y articulando las distintas áreas de la casa.

Se hace referencia a la casa Vandenhaute-Kieboom ${ }^{132}$, en la que Julian Lampens aprovechó este recurso hasta el extremo. La apertura absoluta dentro del edificio obligaba a la familia -una pareja con cuatro hijos- a convivir en un espacio que estaba desprovisto de privacidad tanto acústica como visual. La casa consistía en un cuadrado de 14×14 metros realizado en hormigón y vidrio, la cubierta era una losa también de hormigón visto, a una altura de 2,6m del suelo que apoyaba en pilares metálicos y en los muros de hormigón perimetrales. La caja estaba totalmente abierta al sur y al este, lo que permitía vistas al campo. Los únicos elementos fijos dentro de la casa eran tres cilindros de hormigón semi-cerrados que se elevaban desde el suelo hasta situarse a la misma altura que el cliente, Gerard Vandenhaute. En el interior de éstos estaban situados los baños y la escalera de bajada al sótano. El contrapunto a los cilindros era

131 Moore House, New Haven, Connecticut. Por MLTW/Moore-Turnbull, en 1966.

132 Casa construida en Gante, Bélgica, por el arquitecto Juliaan Lampens, en 1967. 


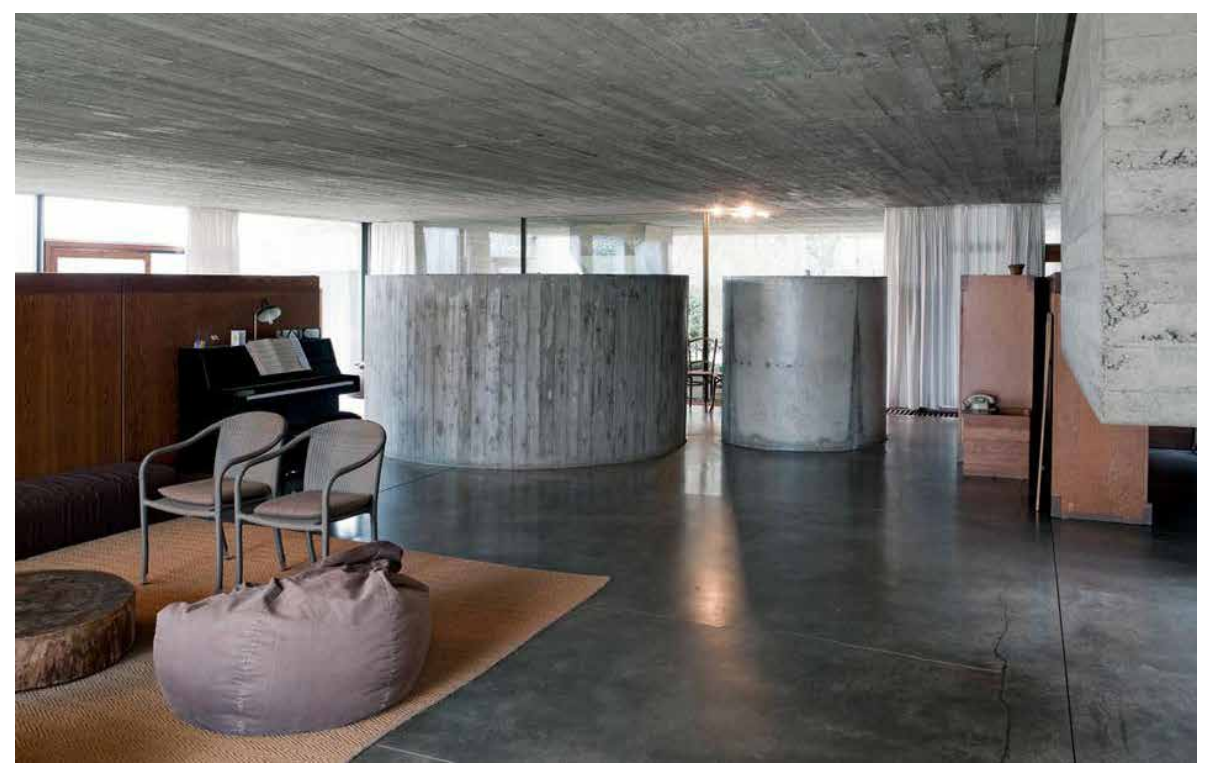

un una especie de cubo de hormigón que colgaba del techo y que descendía hasta la altura del hombro y que delimitaba la zona de la cocina. Atravesando la zona delimitada por el tubo, la superficie de trabajo de la cocina se prolongaba hacia fuera, en la zona de estar, para convertirse en la mesa de comedor. Aparte de este número mínimo de elementos fijos, la vida podía organizarse libremente entre ellos. Las unidades de dormir se componían de camas con armarios adyacentes. El resultado eran pequeños cubos de madera donde dormir, que al no ser fijos, permitían una re-organización continua del espacio, jugando con los elementos que determinaban los grados de privacidad ${ }^{133}$.

Se ha podido comprobar a través de este ejemplo que un espacio puro y neto, en ocasiones requería de ciertas parcelas de intimidad, y por esta razón, este tipo de recurso de 'la casa dentro de la casa' se ha empleado en gran medida en el espacio doméstico contemporáneo. A medida que la planta se hacía más abierta y libre, más necesidad había de recurrir a mecanismos para crear ciertas áreas de privacidad.

El loft reformado por Mark Cigolle en Nueva York ${ }^{134}$, para vivienda, representaba un tipo de intervención propia de finales de los años 70 y los 80 . En estos apartamentos, creados en antiguos edificios de talleres y almacenes

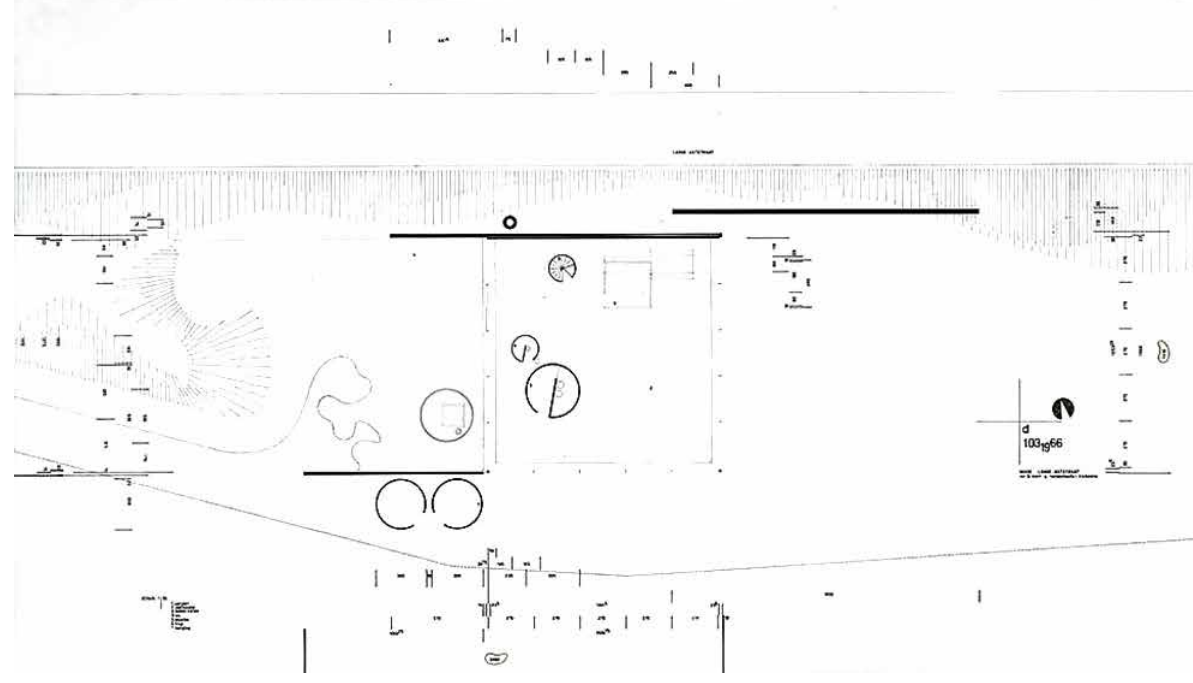

133 Angelique Campens. "Juliaan Lampens". Domus (n937 junio-2010) http://www.domusweb.it/ en/architecture/2010/06/15/juliaan-lampens.html.

134 Loft en Mercer Street, Nueva York. Por Mark Cigolle, en 1980.
Imagen: Casa Vandenhaute-Kieboom Gante, Bélgica. Juliaan Lampens ,1967. Vista del interior.

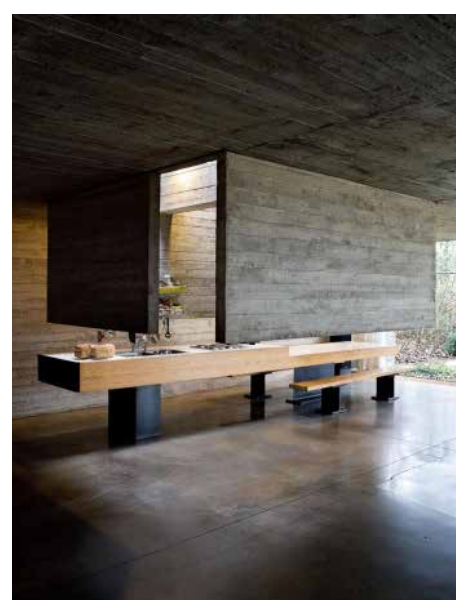

Imagen: Casa Vandenhaute-Kieboom. Gante, Bélgica. Juliaan Lampens ,1967. Vista de la cocina, abajo. A la derecha, planta. 


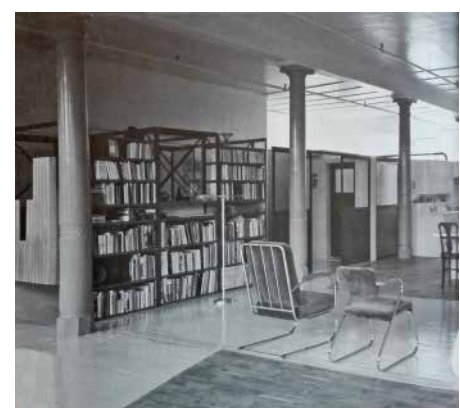

rehabilitados, para respetar las características propias de un espacio inicialmente industrial, en muchas ocasiones se recurría a pequeños subespacios que se distribuían en el interior generalmente sin llegar al techo, con el fin de resolver necesidades del programa doméstico como la privacidad de los ámbitos destinados a dormitorios. El edículo, o la casa dentro de la casa, fue un recurso muy utilizado en este tipo de actuaciones, el uso de cubículos exentos no perturbaba el espíritu original del lugar, a pesar del cambio de uso, sin embargo facilitaban cierta privacidad y articulaban las diferentes zonas de la vivienda en una planta sin divisiones.

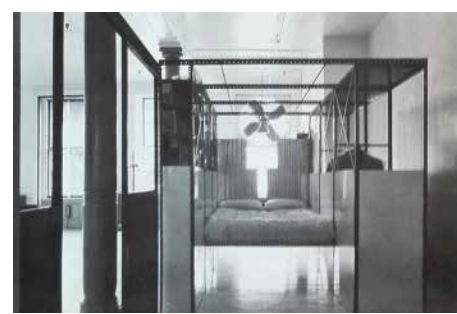

Imagenes: Mercer Street Loft, Nueva York. Mark Cigolle, 1980.
En este loft neoyorkino, el arquitecto recurrió a un sistema de estructura ligera que conformaba un volumen con altura inferior a la existente. En su interior se ubicaban los dormitorios y el baño. El cerramiento de este volumen fue resuelto intencionadamente con un sistema de almacenaje de libros. De esta manera el arquitecto conseguía desvincular a este volumen, exteriormente, de su calidad de elemento arquitectónico, convirtiéndolo en un mueble y potenciando la idea de lugar en un espacio libre y diáfano.

Como se aprecia en espacios diáfanos reformados o reconvertidos, una de las maneras de re-proyectar este tipo de ámbitos era construir la casa dentro de la casa, de manera sencilla y neta, como en la Greer House, reforma de un edificio del s.XVIII realizada por Ettore Sottsass para un bloque de apartamentos en Londres $^{135}$, o también adoptar mecanismos de inclusión, de interpenetración, de estratificación con nuevos elementos. Una de las modalidades de actuación más recurrentes era la construcción, incluso exagerada, de una especie de metáfora urbana, y por consiguiente la creación de otros espacios realizados como interiores dentro un interior que englobaba todo. En algunos casos, la casa dentro de la casa podía multiplicarse en una serie de episodios arquitectónicos que, como edificios en miniatura, ocupaban el espacio en torno a esta idea, encontrando en algunos casos auténticas ciudades en miniatura dentro de un mismo ámbito,

No tiene por qué haber una diferencia esencial entre cómo nos orientamos en el universo de una metrópolis y cómo lo hacemos en el interior de una casa. En ambos casos, lo que necesitamos es sentirnos rodeados, protegidos y centrados. Cuán agradable y alentador resulta llegar a una ciudad a través de una gran entrada, pasar por un puente 0 una muralla medieval, y después encontrar el camino hacia el centro 0 los centros con hitos reconocibles, como son las torres, plazas y otros puntos visibles en nuestro itinerario (...) Y como ocurre en la casa, las experiencias que producen el sentido de posesión se organizan alrededor de una serie de puntos muy sensibles, sobre todo a lo largo de los bordes y en las zonas centrales como son los márgenes de los ríos, los paseos y los eventuales 'miradores' de la ciudad.

\section{Kent C. Bloomer y Charles W. Moore ${ }^{136}$}

Se muestran dos ejemplos en los que, de una manera u otra, se recurrió al interior dentro del interior como metáfora de la ciudad dentro de la casa, en uno, y como metáfora de un enclave más natural, con vocación de paisaje, en otro.

135 Ver imagen portadilla. Greer House, Londres. Por Ettore Sottsass/ Johanna Grawunder, en 1993.

136 Charles W. Moore y Kent C. Bloomer. Cuerpo, Memoria y Arquitectura. Introducción al diseño arquitectónico. (Madrid: H. Blume 1982) p.66. 
En 1979 el arquitecto George Ranalli acometió la reforma del edificio de la Callender School en Newport, Rhode Island, para convertirlo en viviendas. El proyecto restauró el exterior del edificio, de 1862, dejándolo en su estado original. La transformación de esta antigua escuela en viviendas es absolutamente representativa de la metáfora urbana, pudiendo hablar incluso de 'la ciudad dentro de la casa' ya que nos encontramos con la simulación de una arquitectura dentro de otra arquitectura o con una especie de escenografía. En el condominio, la unidad de vivienda estaba constituida por volúmenes de color que simulaban fachadas urbanas. Manteniendo los límites de la arquitectura original, los volúmenes organizaban distribuciones funcionales en los distintos niveles (de dos y tres plantas). Dentro de estos 'volúmenes-edificios' se incluían las zonas de dormir, los armarios, vestidores, y los servicios; mientras que en el espacio libre (la plaza) se ubicaba el salón-comedor.

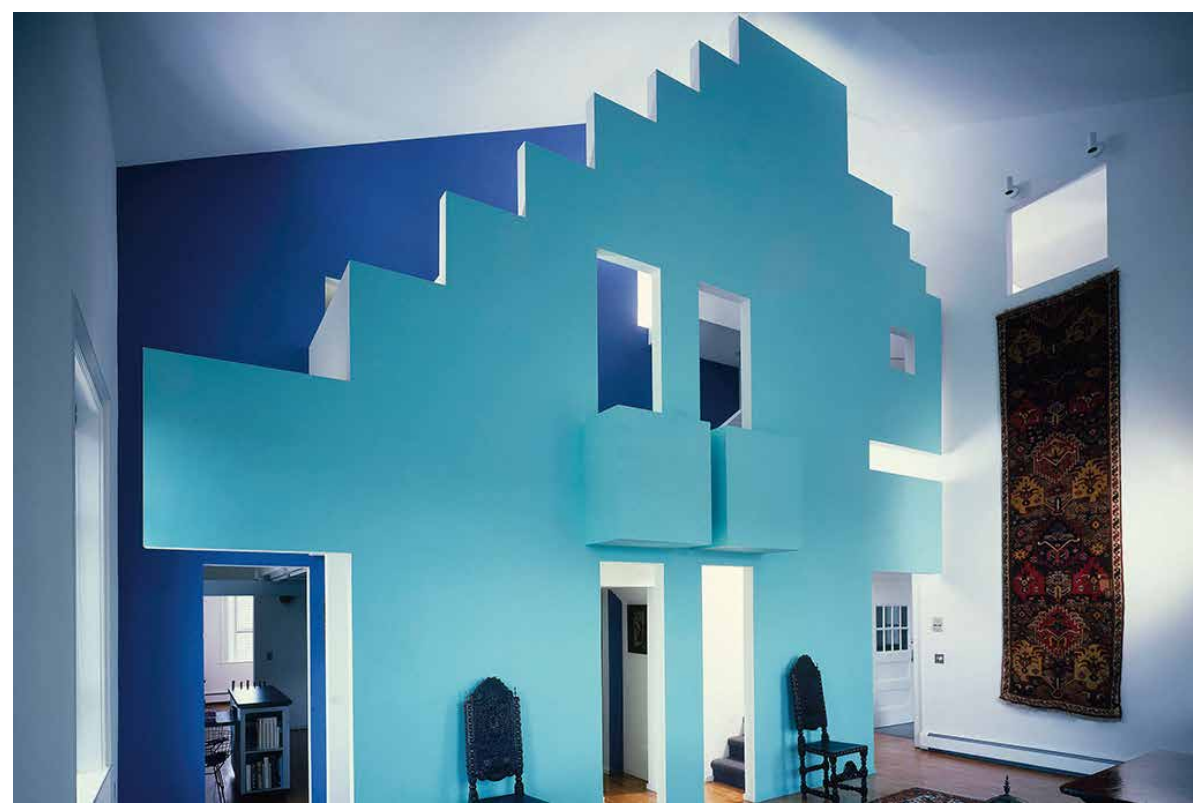

El interior de la casa Johnson, construida por Rob Quigley en 1978 en California, representaba la metáfora de la naturaleza, del paisaje natural. La vivienda se situó sobre un manantial y una gruta que existían desde 1920 . Según el arquitecto ${ }^{137}$ la casa estaba inspirada en las casas de montaña de los indios Anasazi, y además aprovechaba los recursos naturales para el acondicionamiento interior. Un ventanal orientado al sur, el manantial y los colores oscuros del ladrillo interior funcionaban como moderadores de la temperatura interior. Con implicaciones bioclimáticas, el espacio representaba la idea de la ciudad de una cultura ancestral, pero con el paisaje natural como fondo. Las conformaciones circulares generadas en torno al manantial, a modo de terrazas, potenciaban esta idea.

La metáfora de la ciudad dentro de la casa, implicaba juegos de escala que potenciaban la idea de lugar en el interior. Estos juegos también consistían en que algunos muebles, como las camas, se convertían en habitáculos y adquirían la condición de espacios. Ejemplos como los que encontramos en las propuestas como las de Moore, Munari o Sottsass, reflejan que los muebles podían adquirir un mayor protagonismo a través de una configuración más arquitectónica, colocándole una cubierta o baldaquino, por ejemplo.

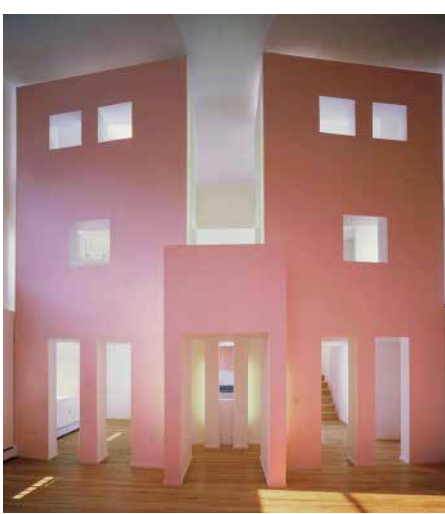

Imagen: Callender School. Newport, Rhode Island. George Ranalli, 1979. Vista interior de una de las viviendas.

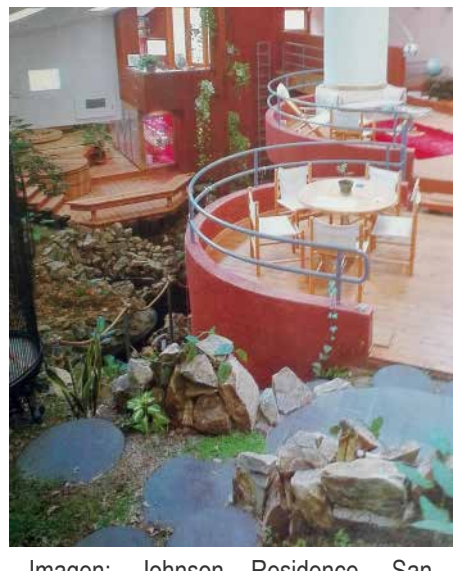
Diego, California. Rob Quigley, 1978 


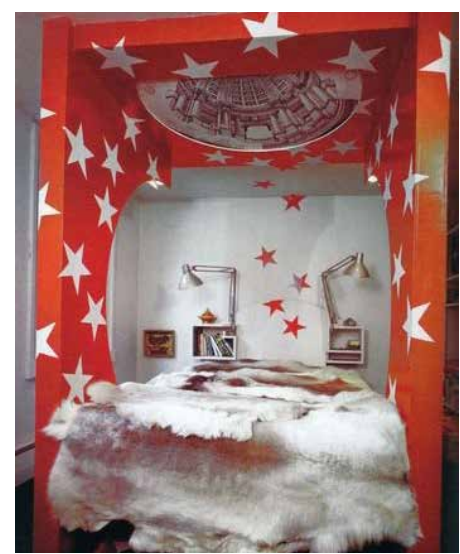

Imágenes: de izquierda a derecha en orden:

Charles Moore. Cama en Casa Moore en New Haven, 1966

Bruno Munari. Abitacolo, 1970 y Ettore Sottsass. Letto, XVII Trienale Milano, 1986.
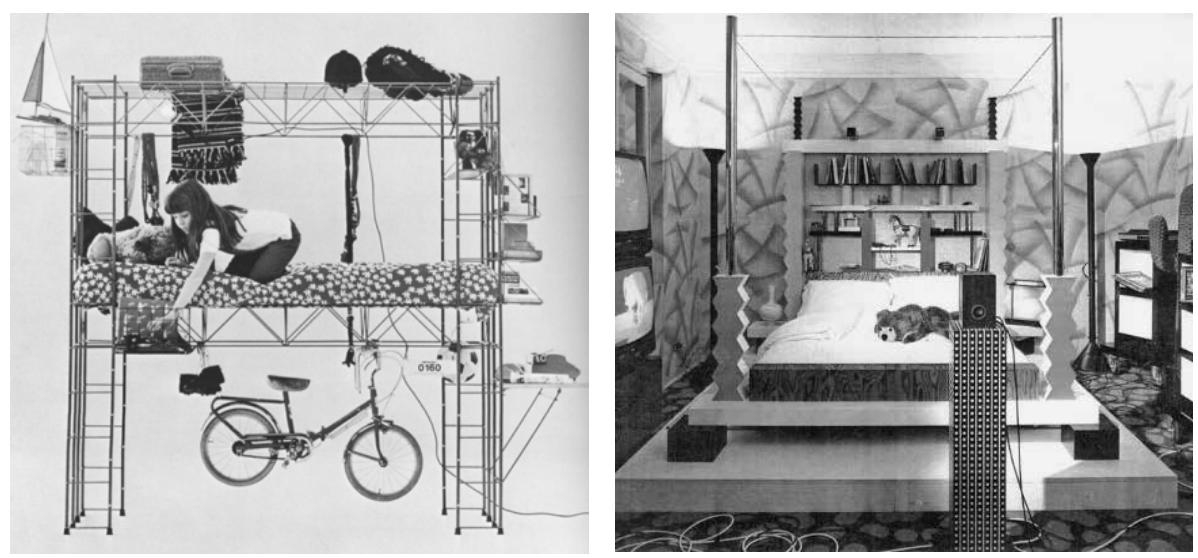

Por tanto, y desde una perspectiva más general, la idea de 'la casa dentro de la casa', como se ha visto en el desarrollo de este apartado, es una denominación metafórica que significa crear un espacio interior dentro de un ámbito interior. Esta configuración tuvo especial aplicación en los interiores domésticos a partir de los sesenta y como respuesta a la necesidad básica de generar espacios independientes -privados o simplemente diferenciados- del resto de la planta libre. Ya que no todas las razones eran prácticas, sus aportaciones eran principalmente:

Llevar al hogar lo simbólico y lo psicológico, a través de la representación de lo que era el mundo interior del habitante. Para que esta faceta del sujeto fuera entendida como lo más importante, como el centro del universo, se utilizaba el recurso de la casa dentro de la casa reflejada en algo sagrado, en una especie de templete 0 edículo. Todo ello iba en pos de crear nuevas experiencias a través de la creación de lugares especiales dentro de la casa, pero también de crear zonas de intimidad en un espacio abierto, desde un punto de vista más práctico. En los ámbitos domésticos contemporáneos, como el loft, también surgía la necesidad de diferenciar, del área general, las zonas de dormir, o los baños. A través de estos cubículos se podía organizar, ordenar y/o articular el espacio libre, así como definir zonas concretas sin perder la sensación de espacio único. Los juegos de escala, como hemos visto anteriormente, potenciaban la idea de lugar dentro del ámbito o generaban el efecto de que el propio espacio era un lugar de mayores dimensiones. Por tanto, la labor de estos pequeños elementos, que significaban un nuevo ámbito, en muchos casos era la de transformar la percepción del espacio a través de esos juegos de distintos niveles de interior que implicaban a los espacios periféricos y que aumentaban las posibilidades gracias de las visuales que se podían generar. 


\subsection{LA 'OBJETUALIZACION DEL ELEMENTO ARQUITECTÓNICO}

Lamayoría prefiere que las calderas, las unidades de acondicionamiento de aire, los calentadores de agua y las tuberías que los conectan no se vean. Con un mínimo de previsión conductos y tuberías pueden empotrarse en las paredes, los suelos y los techos de las casas. (...) pero existe otra alternativa a todo esto. No es necesario en absoluto ocultar conductos y tuberías que pueden dejarse totalmente a la vista, como las vigas y traviesas de un tejado, para sugerir los procesos cinéticos que hacen posible el funcionamiento del edificio. Y también pueden servir, menos solemnemente, como base de inflexiones y fantasías decorativas.

Moore, Allen, Lyndon. La casa: forma y diseño, p.106.

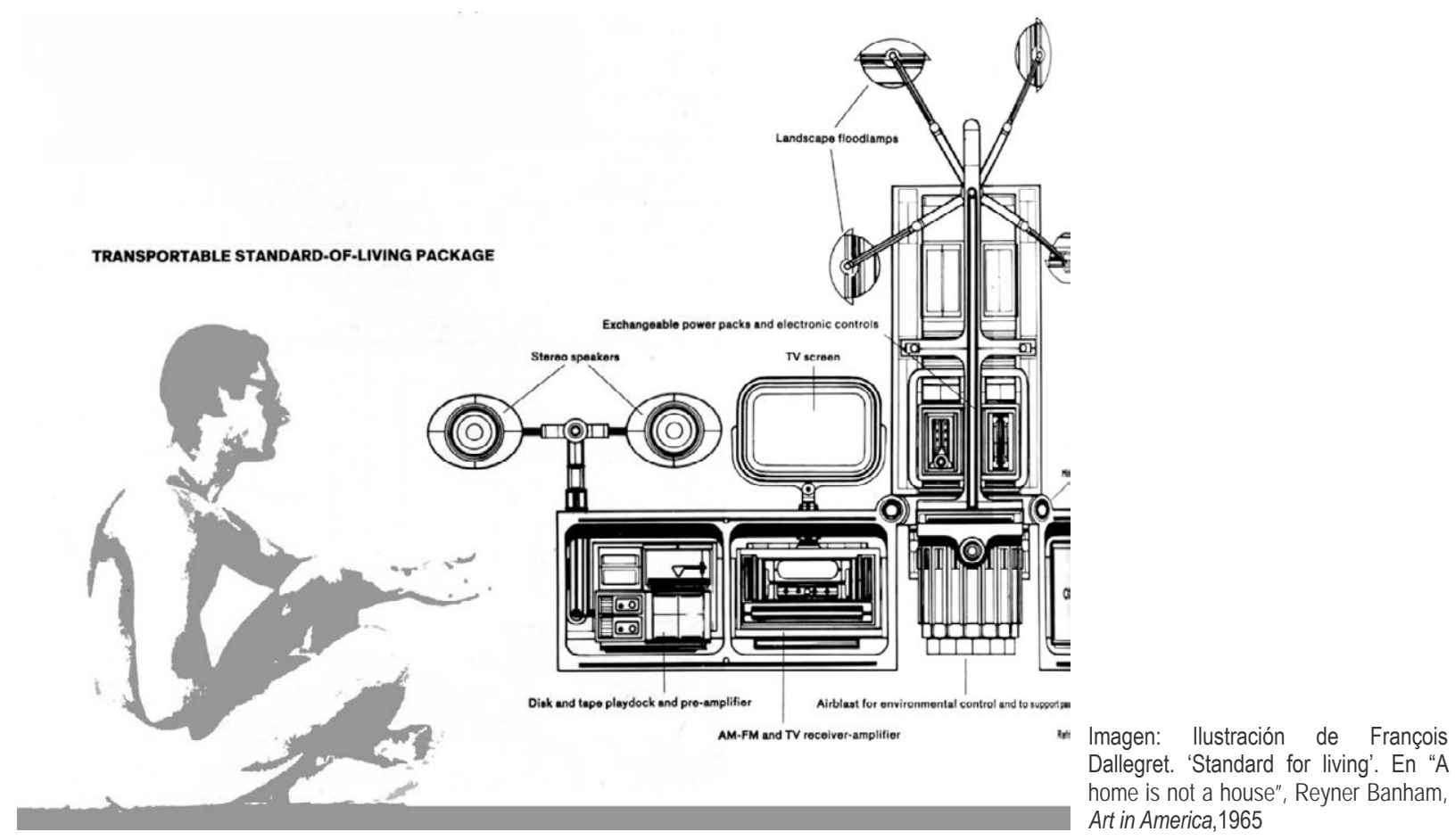

Reyner Banham en "A home is not a house" ponía en cuestión el sistema de vivienda tradicional occidental, y para ello partía de casos en los que las infraestructuras e instalaciones de acondicionamiento y demás servicios del edificio eran de tal calibre que realmente la arquitectura se reducía a ellos. Las nuevas tecnologías y los nuevos modos de vida, sobre todo en Estados Unidos, fueron la base de la crítica realizada por Banham en este artículo publicado en Art in America en 1965.

Cuando tu casa contiene semejante complejo de cañerías, conductos de humos, cables, luces, acometidas, enchufes, hornos, piletas, trituradores de residuos, parlantes de hi-fi, antenas, plenos, freezers, calentadores -cuando contiene tantos servicios que el equipo podría soportarse por sí mismo sin ayuda de la casa, ¿para qué tener una casa para sostenerlo?

Reyner Banham. "A home is not a house", 1965

A través de esta crítica a la vivienda tradicional, al mismo tiempo que se ponía en cuestión la piel de la casa se enfatizaba la figura de un elemento -el sistema de redes de instalaciones- que hasta el momento había pasado desapercibido 


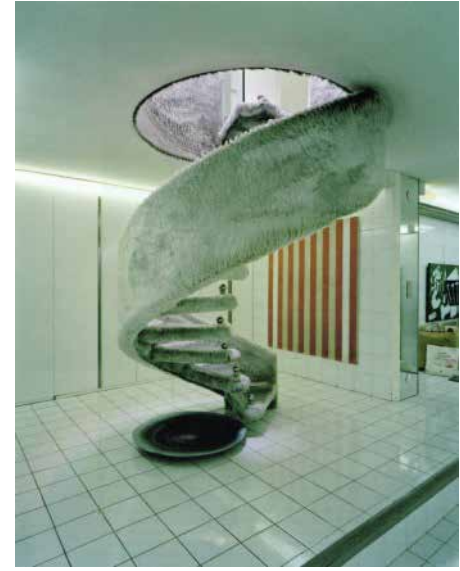

Imagen: Nanda Vigo (Gio Ponti) . Casa Sotto La Foglia. Malo, Italia. 1965. Vista del vestíbulo de la casa. o se intentaba disimular empotrándolo en muros y techos.

Al destacarlos de su entorno, algunos arquitectos descubrieron las cualidades que podían tener algunos de aquellos elementos y comenzaron a utilizarlos con fines compositivos dentro del espacio doméstico.

Norberg-Schulz ${ }^{138}$ definió el elemento arquitectónico como una unidad característica que era parte de una forma arquitectónica. El término tenía un doble significado, por un lado se podía entender como algo independiente -como figura- o como una parte que pertenecía a un contexto más amplio. Para diferenciarlos del contexto, para adquirir la condición de figura, existían determinados medios como eran la iluminación, el color y la textura. Una determinada textura - una superficie pulida y reflectante - podía difuminar la masa, mientras que otra podía acentuar su concentración. También mediante un uso apropiado del color, un elemento podía separarse visualmente de lo que le rodeaba. Finalmente la luz 'modelaba' las figuras.

El aislamiento topológico, según Norberg-Schulz era decisivo para su independencia. Un elemento aparecía como figura independiente si destacaba contra un fondo continuo y tranquilo. Además el tratamiento de las superficies límite determina el carácter del elemento.

El elemento arquitectónico, por tanto, se objetualizaba en el momento en que se independizaba como figura, es decir cuando se convertía en una pieza perceptible, distinguible del entorno, y cuando participaba del sistema de signos que componían los otros objetos en el espacio y se volvía así parte integrante del discurso.

Cuando empezaba a significar otras cosas, el elemento arquitectónico adquiría otra categoría, según un proceso de definición y de significación. Para ello era preciso un tratamiento formal específico para focalizarlo y distinguirlo del entorno. Esto podía conseguirse a través del uso de materiales que consiguieran superficies mejor tratadas estéticamente, también podía obtenerse gracias a la modificación de la forma tipo, para descontextualizar al elemento y separarlo del resto, o por medio de recursos, como el color, que los diferenciaran de los otros elementos.

En 1965, Nanda Vigo reformaba el interior de una vivienda -originalmente una casa de vacaciones diseñada por Gio Ponti- para convertirla en una casamuseo permanente para Giobatta Meneguzzo.

En su intervención, que en parte comprendía la unificación de los revestimientos de paredes y suelos con baldosa cerámica, hacía destacar un elemento arquitectónico, la escalera, forrándola completamente con moqueta gris de pelo largo. De esta manera, descontextualizándola, la convertía en una pieza escultórica y hacía de foco visual, ordenando a su alrededor la zona de vestíbulo y jerarquizando el área de articulación entre las dos plantas.

En la casa Donde, en Milán, de Angelo Cortesi, Sergio Chiappa y Carlo Ronchi. La chimenea, también adquiría la condición de foco visual por la singularidad de su forma, y esto le hacía adquirir otro significado. Emergiendo desde la planta baja hacia la doble altura, tomaba posesión del espacio con formas sinuosas que le conferían un carácter escultórico, convirtiéndose en la referencia focal de toda la casa.

138 Christian Norberg-Schulz. Intenciones en Arquitectura (Barcelona: Gustavo Gili, 1998) p.86-87. 
La objetualización de las instalaciones podía llegar a ser completa, casi obsesiva, convirtiéndose en el leitmotiv del proyecto, como en la Keck House, realizada en 1977 por Stanley Tigerman, en Highland Park, Illinois. En esta casa, el arquitecto utilizaba a la mayoría de las instalaciones y elementos estructurales como recursos compositivos, casi decorativos. Los sistemas de ventilación, las vigas, las barandillas, etc. adquirían una condición formal poco común a través de los materiales que los recubrían, los colores empleados 0 el carácter inusual de sus formas. Estos factores les conferían nuevas condiciones que les permitía participar en la composición del espacio.

La columnas también eran elementos que podían sufrir este proceso de objetualización:

Las columnas son a veces más que soportes. A veces se usan no sólo para sujetar tejados, si no para marcar un lugar un lugar para estar. Una columna es un acontecimiento especial, un lugar donde las cargas del tejado se transmiten a la tierra. Sus ornamentos significan la importancia, al igual que su tamaño y altura. Las columnatas implican un lugar público, para albergar gente junta o para permitir el paso de un lugar a otro.
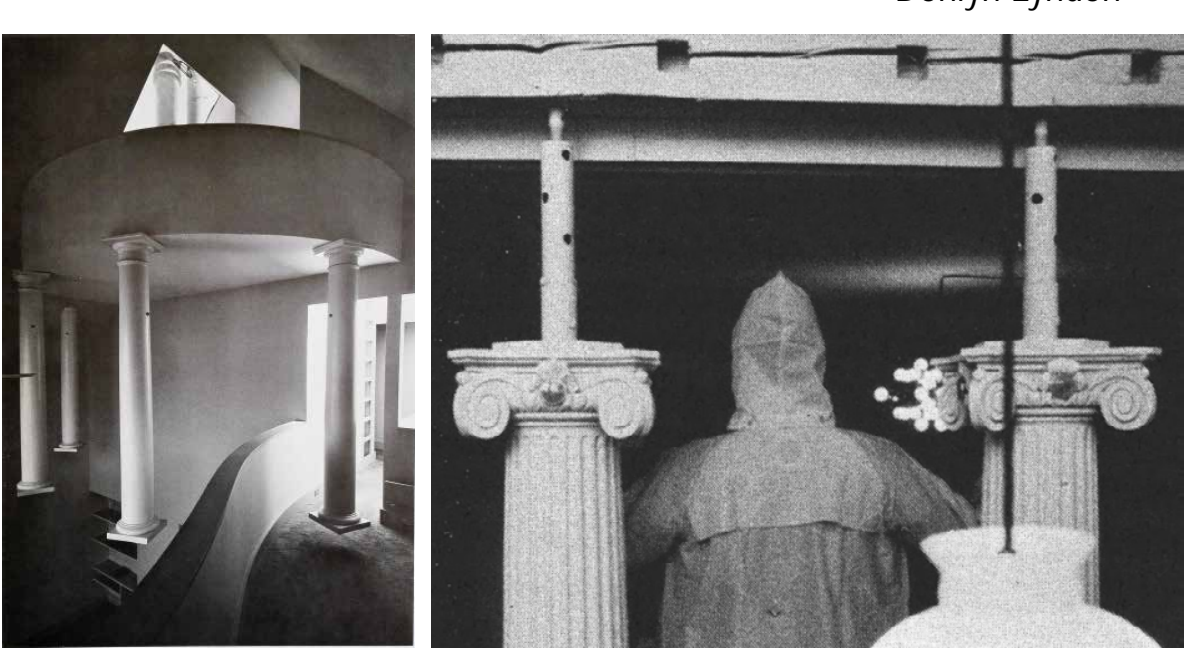

Para Moore, las columnas eran 'objetos' dignos de disfrutarse por sí mismos y de incorporarse a la estructura del lugar ${ }^{140}$.

En la casa Moore en New Haven, las columnas jónicas aparecían descontextualizadas a través de un implemento con forma de puntal. De esta manera quedaban 'exoneradas' de su carácter tectónico y se convertían en objetos cargados, en este caso, de significado.

En la casa Mittelstadt, el proceso fue el contrario. Las luminarias, se materializaron con forma de columna, en cualquier caso, su intención, independientemente de la 'forma' adoptada, era representar la importancia de un espacio de la casa, creando una especie de templete volador.

Las columnas de la casa Moore/Andersson, sufrían el mismo tipo de proceso, esta vez por medio, con intenciones más irónicas que conceptuales.

139 Donlyn Lyndon "The House of the mind: Houses by MLTW" en Houses by MLTW. Moore, Lyndon, Turnbull \& Whitaker 1959-1975 (vol-1). Editado por Yukio Futagawa (Tokio: A.D.A Edita, 1975).

140 Charles Moore, Gerald Allen y Donlyn Lyndon. La casa: forma y diseño (Barcelona: Gustavo Gili, 1999) p.60.

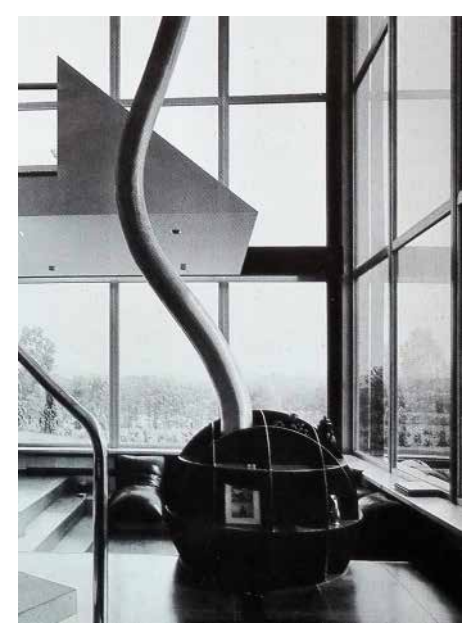

Imagen: Casa Donde. Sonico, Milán, 1970, por Angelo Cortesi, Sergio Chiappa, Carlo Ronchi. Vista de la chimenea.

Imagen: Izquierda. Casa Robert Mittelstadt. San Franciaco, California. Robert Mittelstadt, 1975. Vista del interior del espacio en doble altura sobre la sala principal.

Imagen: Derecha. Casa Moore, New Haven, Connecticut. MLTW/ MooreTurnbull, 1966. Vista del interior del espacio en planta sótano. Detalle de columnas jónicas con puntales

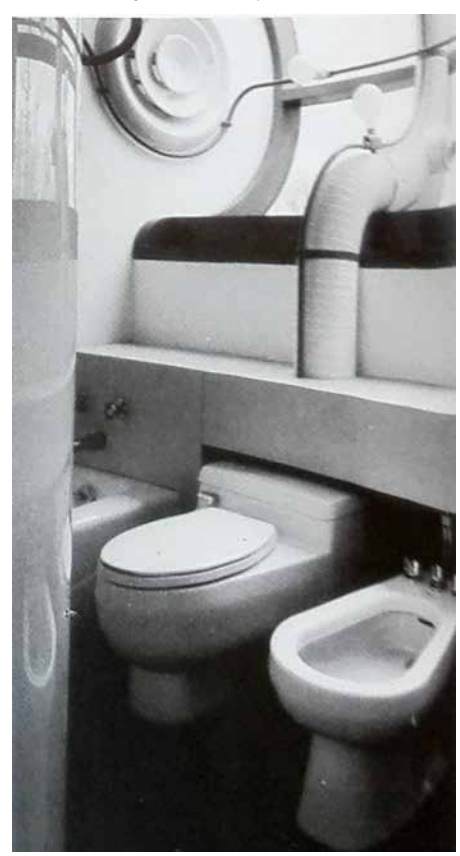

Imagen: Keck House, en Highland Park, Illinois, 1977 por Stanley Tigerman. Vista interior del cuarto de baño, en el que las instalaciones se convierten en parte del mobiliario. 


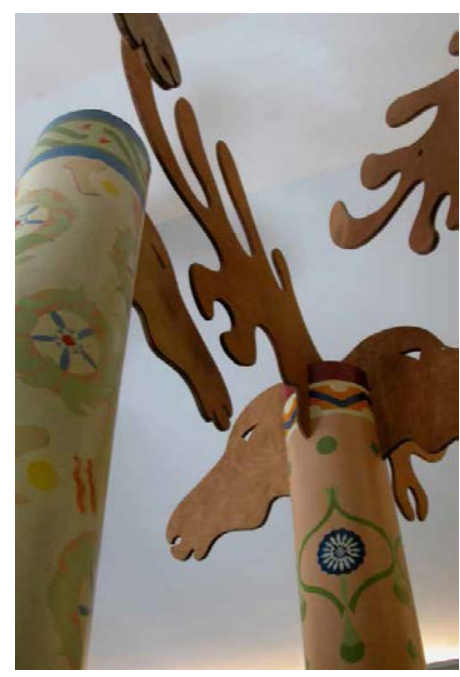

Imagen:. Moore / Andersson Compound Austin, Texas. Moore / Andersson Architects,1985. Vista de columnas del estudio, réplica de las columnas del Palau de la Música con astas de reno. Imagen: Palau de la Musica. Barcelona. Lluis Domènech i Montaner, 1908. Columnas.

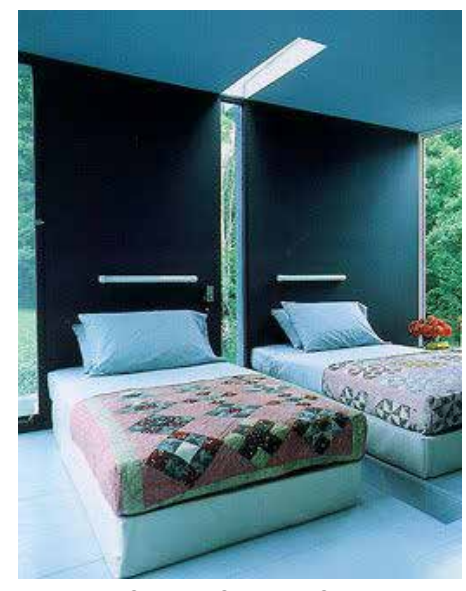

Imagen: Casa VI. Cornwall, Connecticut. Peter Eisenman, 1973.

Imagen: "Elementos de Arquitectura". Rem Koolhaas. Bienal de Venecia, 2014.

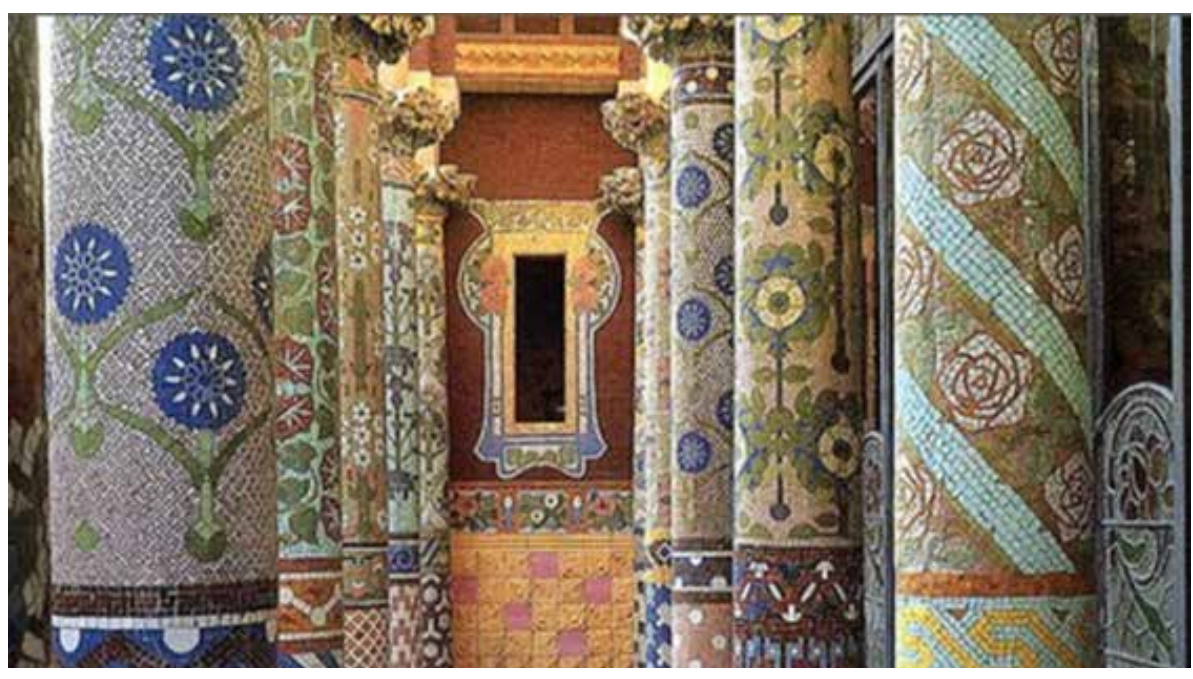

De la misma manera, ocurría con la columna ausente Peter Eisenman en casa VI, Cornwall, Connecticut, $1973^{141}$.

También la objetualización de las ventanas realizada por Rem Koolhaas, que sacadas igualmente de contexto, se convertían en una especie de muestrario de carpinterías y huecos, totalmente diferenciados y perceptibles del resto.

La puesta en cuestión de la piel del edificio a favor de las instalaciones, planteada por Reyner Banham, sirvió para enfatizar un elemento que hasta el momento había pasado desapercibido o se había intentado disimular entre muros y techos.

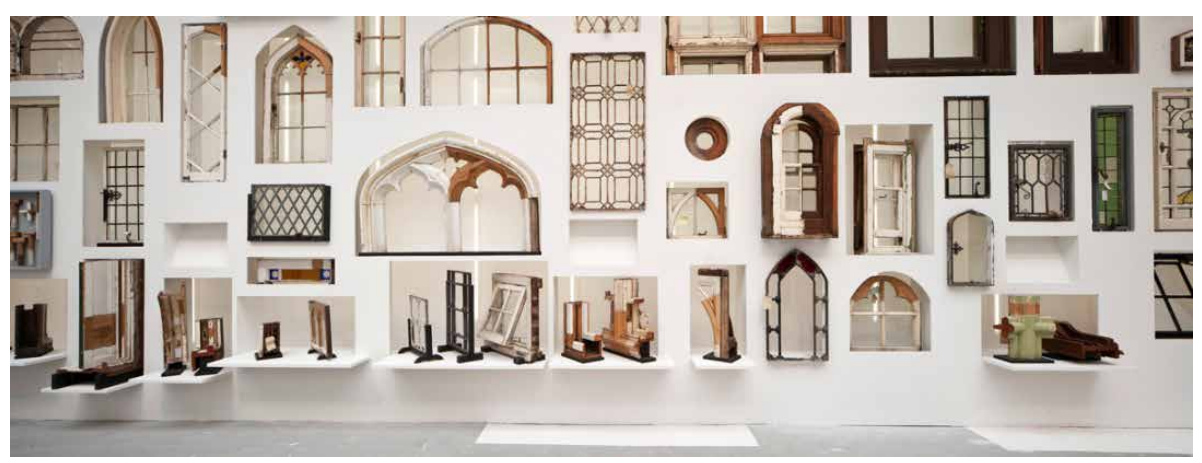

El elemento objetualizado, sacado de contexto, enfatizado, perceptible del conjunto, se empezó a utilizar con fines compositivos.

Al hacerse distinguible del entorno empezaba a participar del sistema de signos que conformaban los demás objetos en el espacio, y se convertía en parte integrante del discurso.

El sistema para objetualizar un elemento era independizándolo como figura, haciéndolo perceptible. Utilizando mejores acabados, modificando su forma tipo o utilizando colores diferentes o llamativos para distinguirlo del resto Como objeto, adquiría significado dentro del sistema, por lo que en su labor compositiva podía comportarse como: una pieza escultórica -una escalera, una chimenea-, como recurso ornamental o como objeto organizador. 

2. EL ESPACIO INTERIORA TRAVÉS DE LAS EXPOSICIONES 

Imagen: Paolo Deganello y Alberto Magnaghi, 'La casa comunal' en "Le case de la Triennale", XVII Trienal de Milán, 1983.

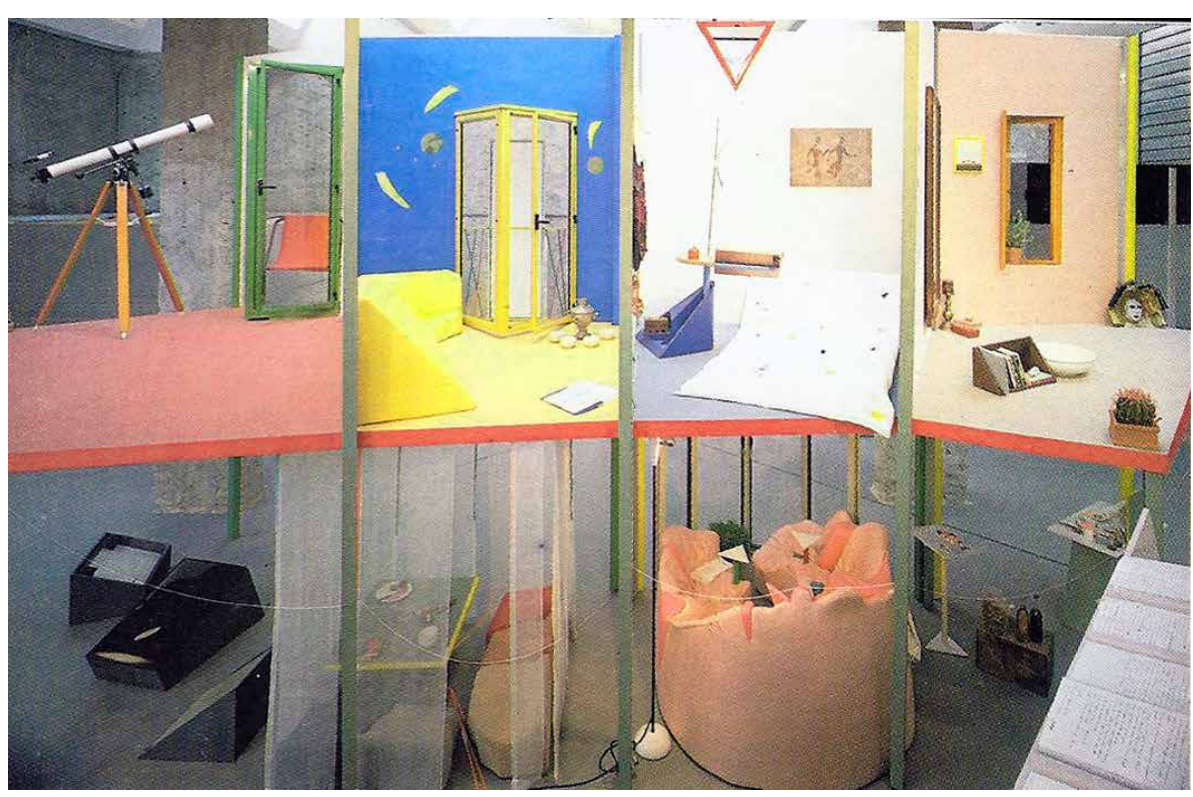

\section{2- EL ESPACIO INTERIOR A TRAVÉS DE LAS EXPOSICIONES}

Las proposiciones más radicales e influyentes de la arquitectura tuvieron lugar en el contexto de las exposiciones temporales.

\section{Beatriz Colomina ${ }^{1}$}

Las exposiciones de mobiliario y las muestras en general de elementos para el hogar, a medida que se acrecentaba la tendencia al consumo, se iban convirtiendo en un canal fundamental de promoción. No sólo los productores de mobiliario, electrodomésticos, objetos decorativos, etc. aprovecharon las capacidades de estos certámenes para llegar a la sociedad, sino que tanto arquitectos como diseñadores, o incluso museos, hacían uso de estas exposiciones para entrar en debates sobre el nuevo espacio doméstico y sobre la incidencia de los objetos en los cambios que se producían. Realmente uno de los objetivos principales de estas muestras era influir de manera directa en la imagen de los hogares, exhibiendo para el visitante las múltiples posibilidades que ofrecía el mobiliario expuesto. Para dar muestra de ello las propuestas presentadas jugaban con el espacio en su relación con los objetos, ofreciendo así todas las posibilidades posibles de su uso y disfrute.

Roland Barthes decía que una de las mejores maneras de estudiar al objeto era analizándolo en su estado más enfático e intencional. En este aspecto, se estaba refiriendo a las escenografías de teatro, a los montajes de cine 0 incluso a la publicidad. Las muestras eran una parte importante de la cadena publicitaria, y teniendo en cuenta además la creciente cultura de consumo y el florecimiento de grandes productoras de mobiliario y productos para la casa, muchas de ellas se consolidaron a nivel internacional, como la Feria del Mueble de Colonia o la de Milán.

La propia promoción de los objetos, en muchos casos, llevaba a una demostración pública de cómo había que utilizarlos y cuál era el contexto ideal para ubicarlos. Para ello se recreaban ambientes que aparecían como si surgieran de la interacción entre el usuario y los objetos, y además

1 Beatriz Colomina, "Un aire aun no respirado" en Alison y Peter Smithson. De la casa del futuro a la casa de hoy. Editado por Max Risselada y Dirk van der Heuvel (Barcelona: Polígrafa, 2007) p.47. 
representaban los hogares perfectos para albergar a aquellos nuevos modos de vida que en ellos se interpretaban. Estas recreaciones de ambientes se convirtieron a auténticos laboratorios de ideas aplicadas al marco doméstico contemporáneo. Además, el interés mostrado por los propios museos para participar en estas exposiciones, avalaban lo que en ellas se producía, como ocurrió con el MoMA de Nueva York.

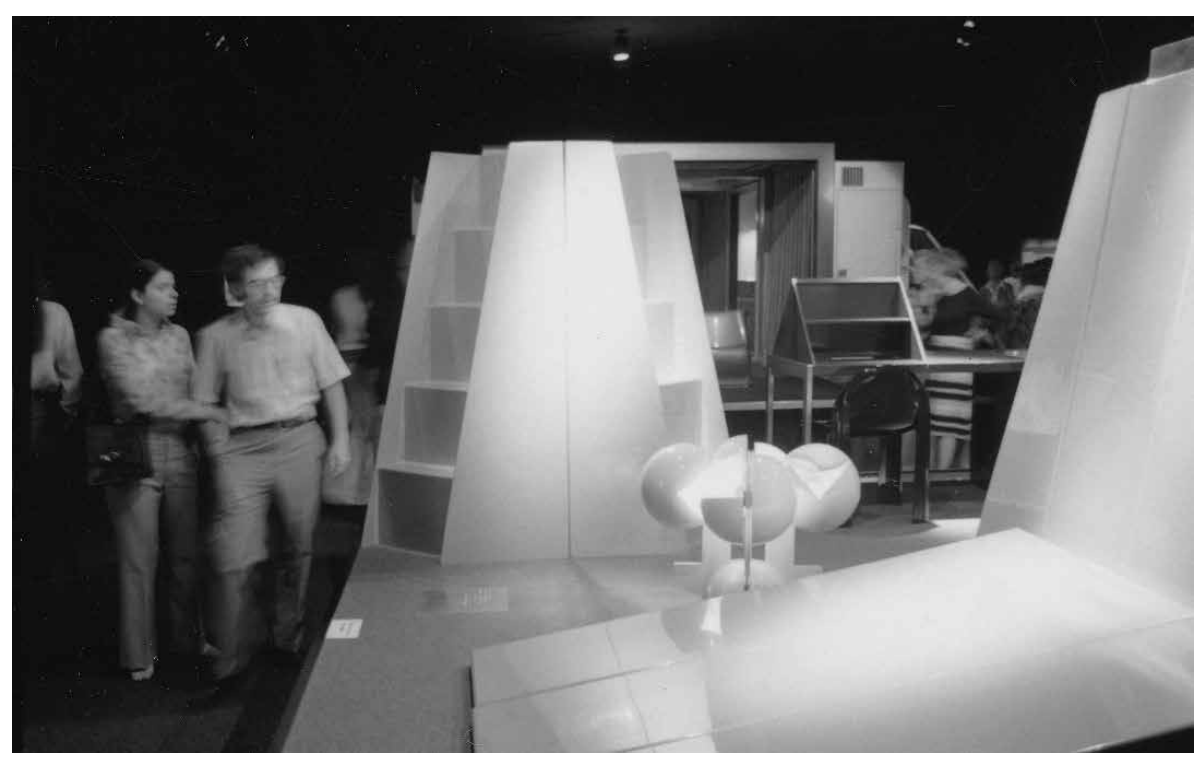

Muchas de estas exhibiciones, que surgieron principalmente a partir de los años de posguerra, tuvieron gran relevancia y muchas de ellas ya se consideran parte integrante de la historia de la arquitectura. Lo más importante es que la labor de estas ferias no sólo fue promocional, desde el punto de vista de la comercialización de los productos, sino que fueron la mejor plataforma para que muchos arquitectos y diseñadores desarrollaran nuevas y revolucionarias ideas en torno al mundo de la vivienda.

Como ya se ha comentado en el apartado correspondiente al método para la elaboración de este trabajo, el presente capítulo recoge las ideas que surgen de las ferias y exposiciones celebradas en estos años, en torno a los nuevos modos de vida y a los nuevos ámbitos domésticos. De los montajes y representaciones realizados por arquitectos y diseñadores, también pueden reconocerse los sistemas de objetos utilizados. Relacionando los conceptos que caracterizan la visión de los nuevos espacios con los modos de actuación empleados, obtenemos herramientas poder realizar el análisis y la clasificación de los casos reales que se expone en el capítulo 3 -objetos y espacio doméstico: relaciones y configuraciones.
Imagen: Visitantes de la exposición 'Italy: the new domestic landscape celebrada en el MoMA de Nueva York en 1972 


\subsection{LAREPRESENTACIÓN DE LAESCENA DOMÉSTICA}

¿Hasta qué punto reconocemos una casa, gracias a sus características formales o gracias a la presencia de una escena doméstica?

Recordando a Bruno Taut cuando afirmaba que "es irrelevante el aspecto de la arquitectura sin gente, lo que importa es el aspecto de la gente en ella" es cuando apreciamos aquellas fotografías en las que la gente parece encontrarse encajada en ese sitio, bien sea por su presencia en la imagen, bien por lo que sugiere el mobiliario y los enseres que en ella aparecen. Esto ocurre así en las imágenes que no tienen como objetivo mostrar la arquitectura, sino que esta aparece como el escenario, como el fondo del retrato o la escena del que se ocupa la imagen.

Imagen: Olivier Mourgue, 'Visiona-3'. Feria Internacional del Mueble de Colonia, 1971

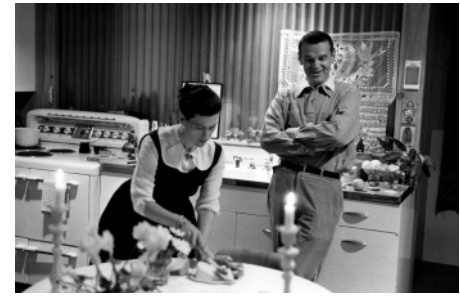

Imagen: Charles y Ray Eames en su casa de Santa Monica, California. 1949
Xavier Monteys y Pere Fuertes ${ }^{2}$

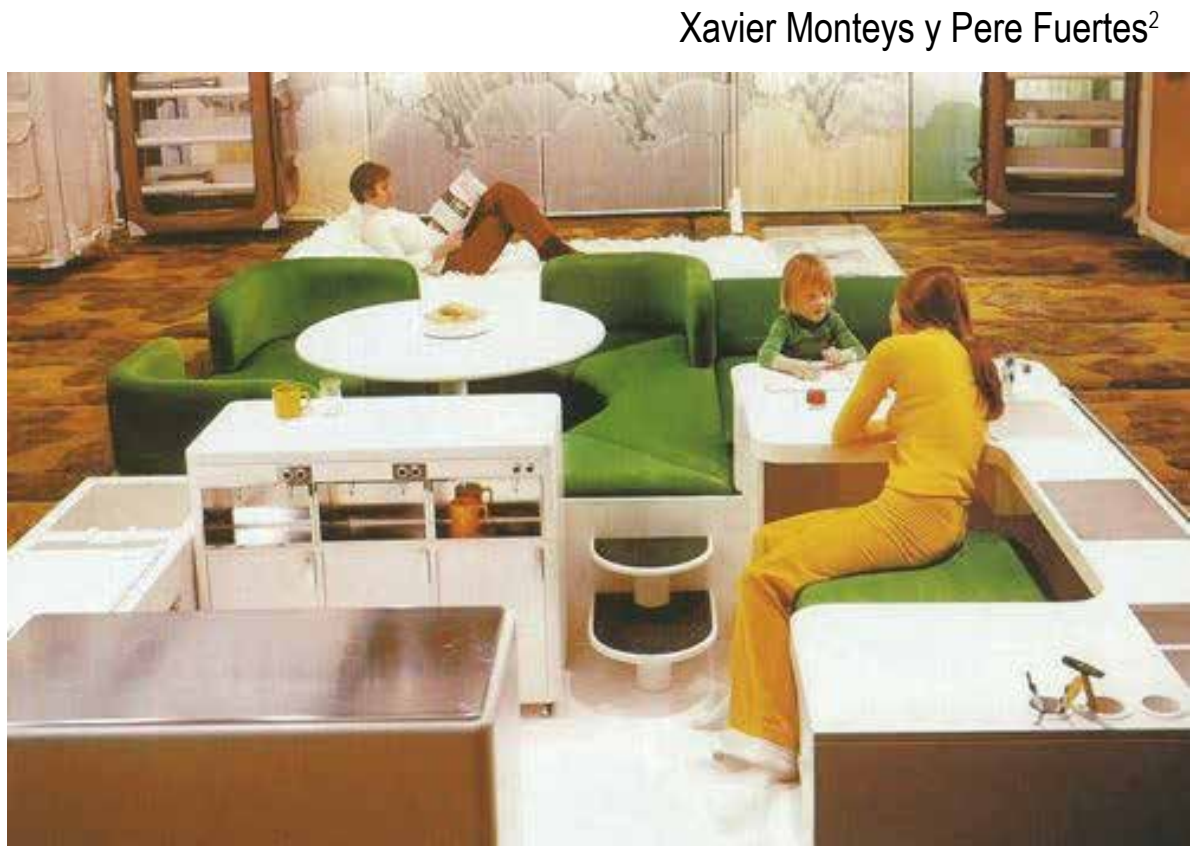

La Ceremonia del Signo, la jornada inaugural de la Colonia del Darmstadt -1899- continuó con la visita a las casas de los artistas, que se encontraban abiertas para su exhibición a los selectos visitantes. Así se brindaba al espectador la experiencia diaria de los protagonistas, ese "cambiar al artista por el hombre". Por primera vez el interior doméstico se transforma de modo codificado en un escenario en el que el espectador se incluye como personaje.

\section{Fernando Quesada ${ }^{3}$}

Refiriéndose a la casa de los Eames ${ }^{4}$, decía Beatriz Colomina ${ }^{5}$, que "la historia de la arquitectura moderna es la historia del showroom, la historia de la hibridación de la arquitectura y la exposición". La Case Study House 8, gracias a las publicaciones especializadas, y no especializadas, se había convertido

2 Xavier Monteys y Pere Fuertes. Casa collage. Un ensayo sobre la arquitectura de la casa (Barcelona: Gustavo Gili, 2001) p. 16.

3 Fernando Quesada. "La exposición de interiores como espectáculo" en La caja mágica. Cuerpo y escena (Barcelona: Fundación Caja de Arquitectos, 2005) p.131.

4 Charles y Ray Eames, Casa Eames en Santa Mónica, California, 1949. Conocida como Case Study House no8.

5 Beatriz Colomina. "Reflexiones sobre la casa Eames", RA, Revista de Arquitectura ( $\left.n^{\circ} 9,2007\right)$ p.3-16. 
en una casa internacionalmente conocida. Fue escenario para fotografías de muchas revistas, incluso magazines de moda como Vogue, donde a veces las modelos llegaban a mimetizarse con los interiores.

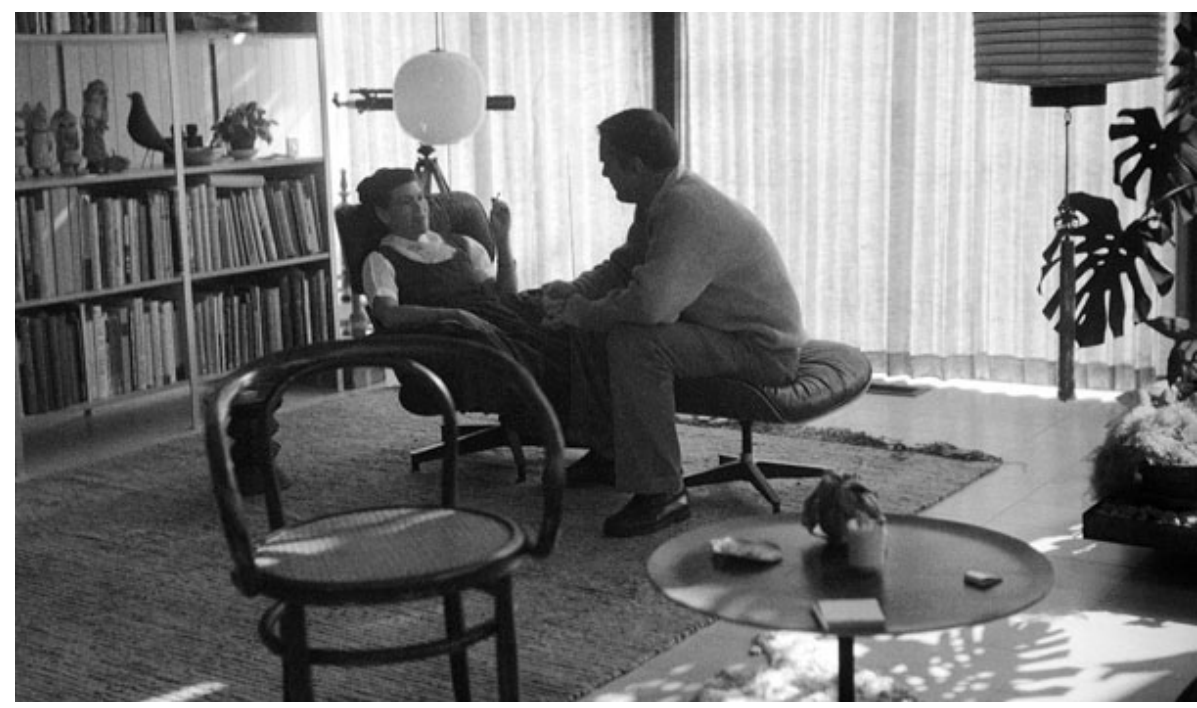

No sólo las modelos de Vogue, también era habitual ver a los Eames fotografiados en su casa realizando labores domésticas, descansando 0 posando deliberadamente sentados en el suelo rodeados de sus objetos. Parecía como si quisieran expresar que la verdadera arquitectura de la casa se encontraba en aquella reorganización de objetos dentro de ella, como si el espacio en realidad se generara a través de aquella acción constante de la vida cotidiana cuyos dueños representaban. En aquellas composiciones fotográficas, la vestimenta de los Eames también era precisa y calculada.

Charles Eames en 1941, había trabajado montando escenarios en los estudios de la Metro Goldwyn Mayer, por lo que el vestuario se lo encargaban a una famosa diseñadora que había ganado varios premios Oscar. A través de su vestimenta querían dar una imagen de pareja profesional conjuntada como cualquier otro objeto de diseño más dentro del marco, como una pieza que formaba parte de aquella composición. La casa era un escaparate a través del cual se divisaba un espacio doméstico donde se desarrollaba diariamente un nuevo modo de vida, acorde con aquel atrevido estilo californiano que ellos pretendían representar, como parte de su arquitectura.

De los Eames, los Smithson habían aprendido cómo transformar las imágenes expuestas en arquitectura: "el material mismo de la exposición convirtiéndose en el medio de organización espacial". La Casa del Futuro era un escaparate que, como los objetos que mostraba, era pura imagen ${ }^{6}$.

En 1956, Alison y Peter Smithson proyectaron y construyeron un modelo a escala real de The House of the Future para la exposición 'Daily Mail Ideal Home' en el Kensington Olympia Hall en West London, patrocinada por una empresa fabricante de electrodomésticos. La propuesta se presentó con un modelo a escala real, visitable desde el interior y desde el exterior, y mostraba cómo sería la casa suburbana convencional dentro de 25 años. Se exhibió como la representación del modo de vida doméstico del futuro gracias al escenario que mostraba una casa prefabricada de plástico, a los actores y

6 Beatriz Colomina, "Un aire aun no respirado" en Alison y Peter Smithson. De la casa del futuro a la casa de hoy. Editado por Max Risselada y Dirk van der Heuvel (Barcelona: Polígrafa, 2007) p.47.
Imagen: Charles y Ray Eames en su casa de Santa Monica, California. 1949

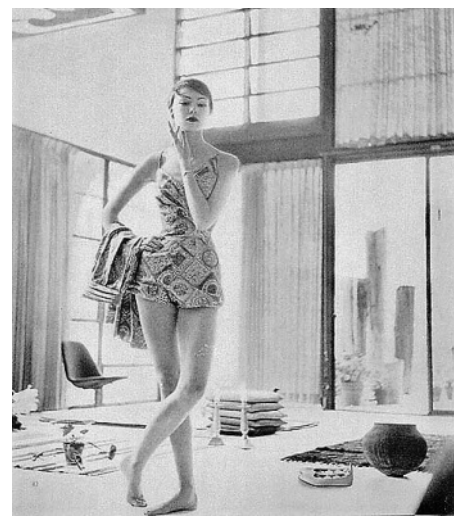

Imagen: Modelo fotografiada en la casa de los Eames.para la revista Vogue, abril de 1954
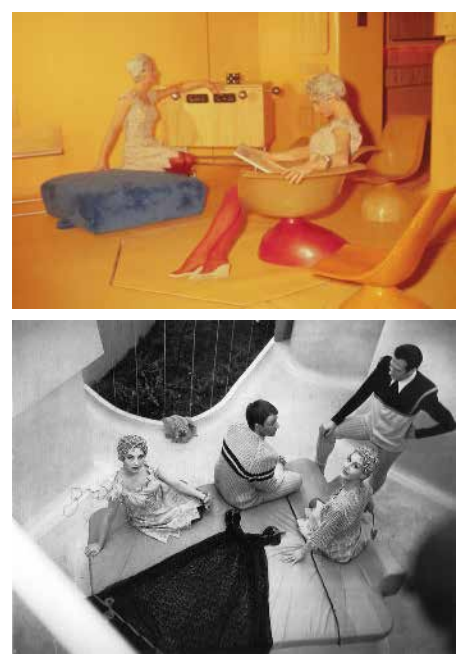

Imagen: 'La Casa del Futuro' Daily Mail Ideal Home Exhibition. Londres, 1956. Por Alison \& Peter Smithson. Actores representando la vida cotidiana, y abajo, Actores que participaban en la instalación. 


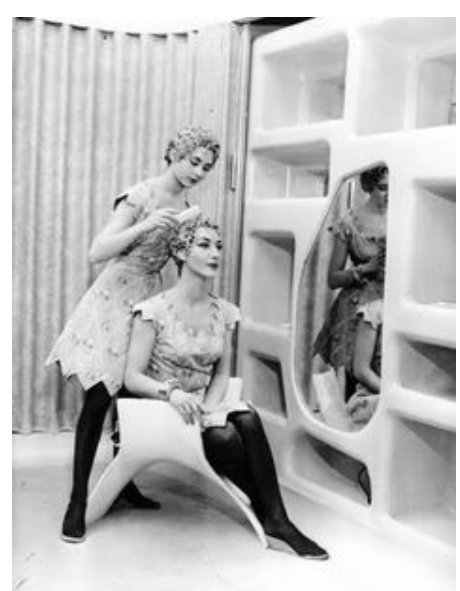

Imagen a la derecha: Diseños de Teddy Tinling para el vestuario de los actores de 'La Casa del Futuro' a los objetos que allí se convertían en el medio de organización espacial. A lo largo de la exposición unos modelos contratados mostraban a intervalos regulares cómo funcionaba la casa durante la "actuaciones". Los modelos iban vestidos por el diseñador de ropa deportiva Teddy Tinling.
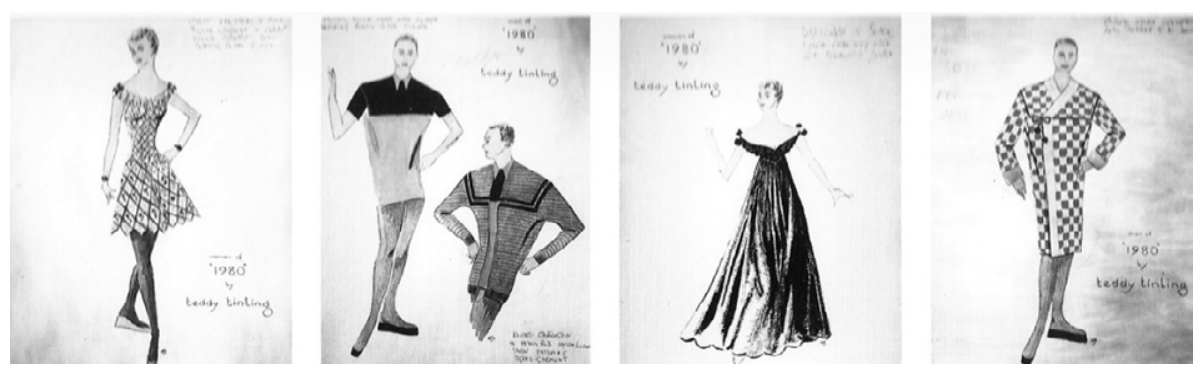

La ropa también era parte de la escena. Respecto a la vestimenta que debían llevar los actores, los arquitectos especificaron no sólo lo que esperaban del diseñador sino también cómo debería ser expuesta, reclamando el derecho de controlar el diseño del vestuario hasta el final. Solicitaron al Daily Mail, que la indumentaria debería reconocer la 'atmósfera' de la casa, lo que se entendía no sólo como la temperatura regulada de la misma, sino el sentido intencionado de percibir un lugar atractivo. Al describir los encuadres, Alison Smithson escribió:

"la impresión general que debe llevarse el público es de glamour".

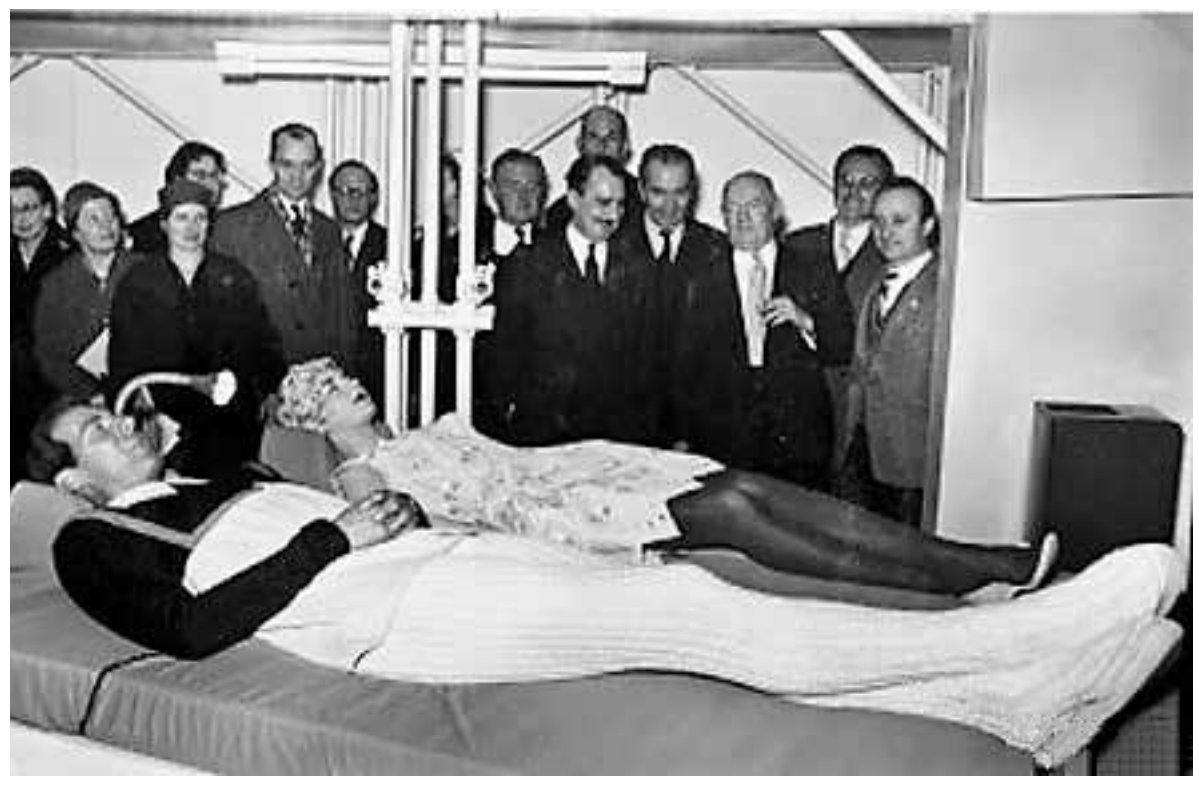

Se dice que la Casa del Futuro era al mismo tiempo una casa en exhibición y una casa exhibicionista, casi como una especie de peep show. El público al no poder acceder al interior de la casa, se veía obligado a mirar al interior asomándose a través de las aberturas que habían sido hechas con esa intención. La escena mostraba una pareja, a veces dos parejas, representando la vida doméstica del futuro. Los visitantes miraban su interior completamente absortos, como si estuvieran viendo una película o un programa de televisión? La casa se convertía así en un aparato de televisión tridimensional, incluso antes de que apareciera en la BBC y formara parte de los telediarios. Como las casas de' Gran Hermano' de hoy, la Casa del Futuro estaba cerrada al exterior por medio de paredes pero conectada al mundo externo a través de los medios de comunicación.

7 Ibíd. p.63. 
En aquel mismo año, Richard Hamilton presentaba su célebre collage titulado Just what is it that makes today's homes so different, so appealing? ¿Qué es lo que hace que las casas de hoy sean tan diferentes, tan atractivas? en la exposición This is Tomorrow, celebrada en 1956 en la Whitechapel Art Gallery de Londres. El objetivo era colocar en el espacio reducido de un salón una representación de todos los objetos e ideas que abarrotaban su mundo, posterior a la guerra.

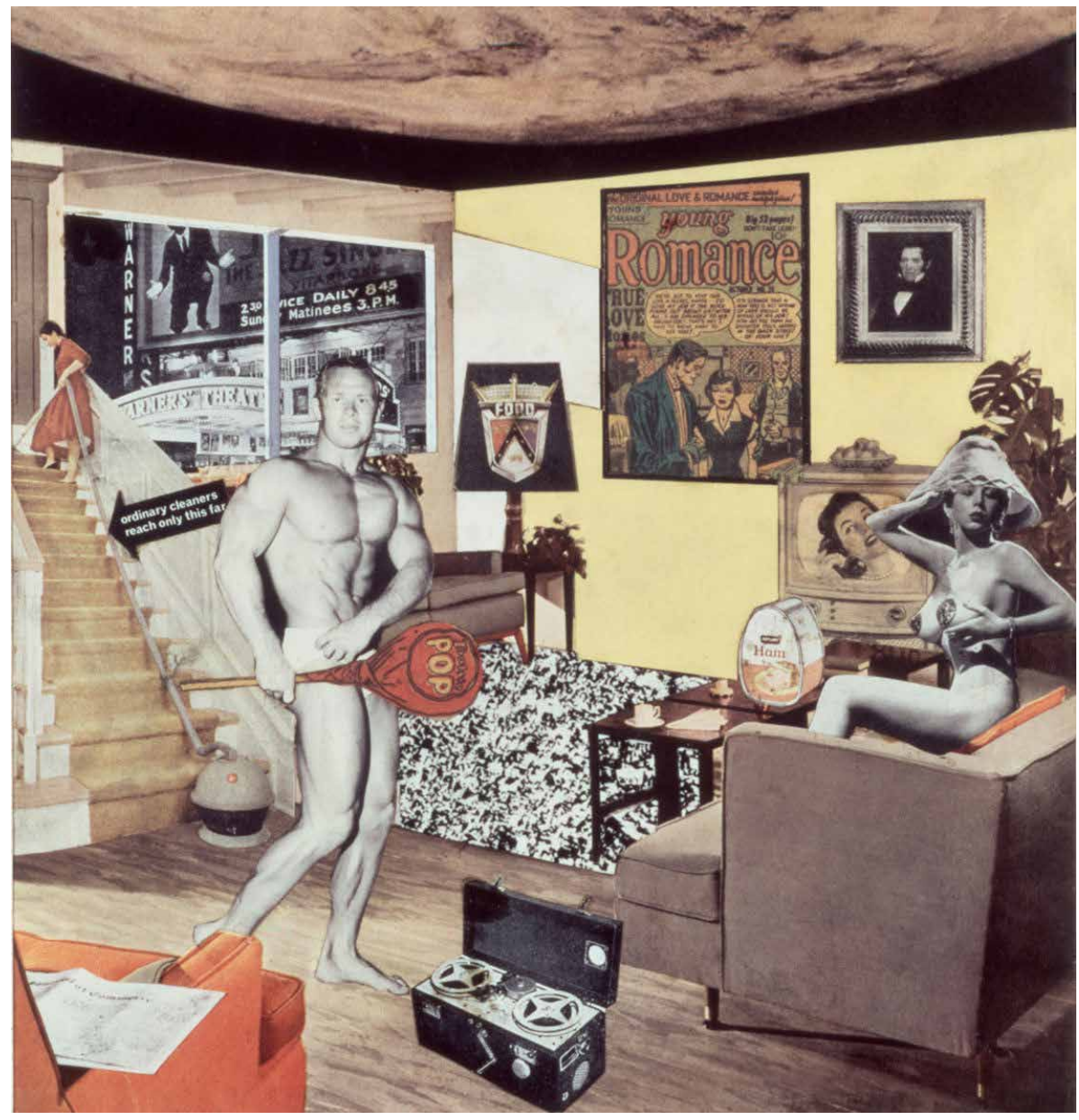

Para llevarlo a cabo, Hamilton escribió una lista de los aspectos que quería incorporar en su obra: hombre- mujer- espacio- comic- televisión- teléfonoinformación- historia- comida- periódicos- cine- coches- electrodomésticos. Para obtener imágenes sobre esos temas, recurrió a las revistas que el artista John McHale había traído de Estados Unidos. De la misma manera, el título lo extrajo de una página publicitaria de una de ellas: Ladies Home Journal, de 1955.

El collage representaba las múltiples facetas de la época, con toque irónico y apoyado en la cultura popular y en la tecnología moderna. Era un interior doméstico, con mobiliario doméstico: sillones, mesa de café, plantas, lámpara; con aparatos domésticos: aspiradora, televisión con imagen de una mujer hablando por teléfono, una grabadora que representa la alta tecnología de los años 50 . En la pared aparecía una viñeta de comic, junto a un retrato victoriano. En primer plano un periódico sobre el sillón. Al fondo, a través de la ventana se veía una sala de cine. En el centro del lienzo, colocado a modo de blasón, estaba el logotipo de Ford, en alusión a los coches, colocado a la misma altura de la cabeza del hombre. Éste estaba representado por un culturista, que posaba con una piruleta gigante en la que aparecía escrito "Tootsie Pop". El chupa-chups estaba dispuesto en dirección a la imagen de una mujer que
Imagen: Richard Hamilton, Just what is it that makes today's homes so different, so appealing? Collage, 1956. Tate Modern, Londres. 


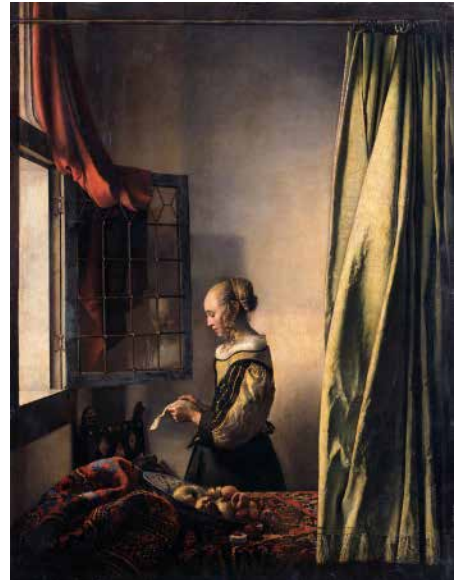

Imagen: Johannes Vermeer, Muchacha leyendo una carta 1659. Gemäldegalerie Alte Meister, Dresde. estaba situada en la parte derecha del cuadro, también semidesnuda, y que posaba sentada en el sofá en una postura un tanto artificial. Al fondo, otra mujer, con diferente actitud, limpiaba la escalera con una aspiradora que mostraba un tubo excesivamente largo. En el cuadro, sobre el tubo sobredimensionado, Hamilton colocaba una divertida indicación que decía: "las aspiradoras normales sólo llegan hasta aquí". Sobre la mesa, había una lata de jamón, HAM, que hacía referencia a la contracultura, a la comida enlatada, al diseño de los envases, y también irónicamente firmaba el cuadro con las tres primeras letras de Hamilton. Así describía el autor su obra en 1990:

El collage titulado Just what is it that makes today's homes so different, so appealing ${ }^{8}$ se resuelve a partir de la Biblia. El objetivo era colocar en el espacio reducido de un salón una representación de todos los objetos e ideas que abarrotaban nuestro mundo posterior a la guerra. Mi "hogar" habría estado incompleto sin la fuerza vital y simbólica de Adán y Eva, que posan junto al resto de aparatos. El collage tenía un papel educativo en el contexto de una exposición didáctica, This is Tomorrow, en la que intentaba resumir las diversas influencias que empezaban a conformar la Gran Bretaña posterior a la Segunda Guerra Mundial. Parecía que todo apuntaba hacia un futuro halagüeño y abrazamos el mundo en continua evolución de la alta tecnología con ingenua confianza, un arrebato de optimismo que nos condujo hasta la década de los sesenta. Aunque se trata claramente de un interior, hay elementos que nos hacen dudar de la categorización. El techo del salón es una vista espacial de la Tierra. La alfombra es una vista panorámica de gente en la playa. Se trata de una alegoría, más que de la representación de un espacio. Just what is it...? inició mi fascinación por el tema "interior".

La "forma pura" del espacio para la representación de la escena era difícil de encontrar. Para él, en la escuela holandesa, en general, y en Vermeer ${ }^{10}$, en particular, se podían hallar sus mayores exponentes. Era a ellos hacia quienes Hamilton dirigía su mirada para encontrar aquella perfecta expresión del espacio interior. En Muchacha leyendo una carta ${ }^{11}$, el tema estaba en esa relación que se establecía entre el estado de ánimo de la joven, dedicada a una ocupación privada, y los espectadores. El espacio que ella ocupaba era un decorado, un escenario creado para centrar la atención en la acción que se producía dentro. Para Hamilton, la arquitectura interior era eso, un marco en que el que uno o varios personajes llevaban a cabo una acción, o simplemente permanecían, rodeados de sus objetos y del resto de muebles que configuraban la escena. Para Hamilton el caso del mayor logro en este género era Las Meninas ${ }^{12}$ de Velázquez ${ }^{13}$, paradigma del interior clásico. Era como un gran escenario que acogía a un grupo de actores cuyas actitudes e indumentaria proporcionaban abundante información; y en segundo plano, se escondía un mensaje sutil a través de detalles como otras escenas de fondo $u$ objetos, cuyo significado iban matizando el discurso. Cada detalle de la pintura constituía un testimonio de la historia de España.

8 ¿Qué es lo que hace que las casas de hoy sean tan diferentes, tan atractivas? Traducción al castellano del título original.

9 Richard Hamilton, "Una vista interior". Carta, (n5 primavera-verano 2014) p.60-63. Edición en castellano del texto original de Hamilton escrito en 1990 para el catálogo de la exposición Exteriors, Interiors, Objects, People celebrada en 1990 en el Kunstmuseum de Winterthur.

10 Johannes Vermeer, (Delft, 1632-1675).

$11 \mathrm{~J}$. Vermeer, 1659. Gemäldegalerie Alte Meister, Dresde.

12 D. Velázquez, 1656. Museo del Prado, Madrid.

13 Diego Velázquez, nació en Sevilla en 1599 y murió en Madrid en 1660. 
En el collage de Hamilton ocurría lo mismo, pero lógicamente con planteamientos de composición contemporáneos. Aunque se trataba claramente de un interior, había elementos que provocaban dudas sobre su categorización. El techo del salón era una vista espacial de la Tierra; la alfombra, una vista panorámica de gente en la playa. Estos elementos, según el autor, desdibujaban los límites del marco, ampliaban sus fronteras y dotaban de ambigüedad al espacio a través de la indefinición de ciertos límites que acotaban la escena.

En 1990 tuvo lugar la exposición 'Exteriors, interiors, objects, people' en el Kunstmuseum de Winterthur -Suiza-, donde Richard Hamilton abordó el tema de los interiores, género que ya había tratado, como se ha visto, desde sus primeras pinturas de los 50 hasta sus últimos trabajos. En esta exposición presentaba las obras como escenarios que justificaban múltiples lecturas aceptando de forma indiscutible el género 'interior' como una clasificación fundamental del arte occidental. Entre sus representaciones, aparte de la anterior que también formó parte de la exposición, cabría destacar:

Interior-I, R. Hamilton, 1964. Esta serie también estuvo realizada con fragmentos de revistas. La base era un fotograma de la película Más fuerte que la Ley de Douglas Sirk (1948) en la que Hamilton sustituía la figura de la actriz por una imagen de una mujer de una revista, vestida a la moda de los 60 , sobre una alfombra turca. En Interior-II, de la misma serie de nuevo utiliza como base un fotograma de la película de Douglas Sirk, pero mantiene la figura de la actriz Patricia Knight. El plano azul de la derecha de la imagen hacía referencia a la obra Monocromo del artista Yves Klein. Al fondo, casi en el centro, una fotografía en la pared de una televisión con imagen del asesinato de John $F$. Kennedy ocurrido en Dallas en 1963.

Como ocurría en el collage del 56 , en Interior-I e Interior-II, las manchas de color sólido que aparecían en los márgenes de ambos lienzos, conseguían que el marco se volviera más abstracto, de forma que, de nuevo, esta confusión en los bordes modificaba la percepción del espacio en modo cuantitativo. Pero también en de modo cualitativo, pasando de un fotograma de una película de los años 40, en una impersonal habitación de hotel, a una escena doméstica en la que la semántica del objeto cumplía su papel.

Con Just what is it that makes today's homes so different? ¿Qué es lo que hace que las casas de hoy sean tan diferentes?, Richard Hamilton en 1992, aprovechaba un programa para la BBC, en el que seis artistas debian trabajar para mostrar la evolución de la tecnología en su obra, para hacer una revisión de su célebre collage de 1956, esta vez con técnica digital. El objetivo en ese momento era representar cómo había cambiado el mundo desde entonces hasta los 90 manteniendo los mismos temas de partida que la obra original de referencia: hombre-mujer-espacio-comic-televisión-teléfono-informaciónhistoria-comida-periódicos-cine-coches-electrodomésticos.

El nuevo collage, representaba una habitación de hotel, empapelada con patrón basado en circuitos de placa de ordenador haciendo alusión a la era digital. La pieza estaba llena de objetos y había dos personas, un hombre y una mujer ${ }^{14}$. Al fondo, través de las dos ventanas, se apreciaban dos escenas: un tanque, haciendo alusión a un tema de actualidad del momento como era la guerra del Golfo, y en la ventana derecha se divisaba un campo de refugiados etíopes ${ }^{15}$.

$14 \mathrm{http}: / /$ www.tate.org.uk/art/artworks/hamilton-just-what-is-it-that-makes-todays-homes-sodifferent-p11358.

15 El 28 de mayo de 1991 había dado fin la Guerra Civil de Etiopía. Dicho conflicto ya había provocado más de 500.000 desplazados.

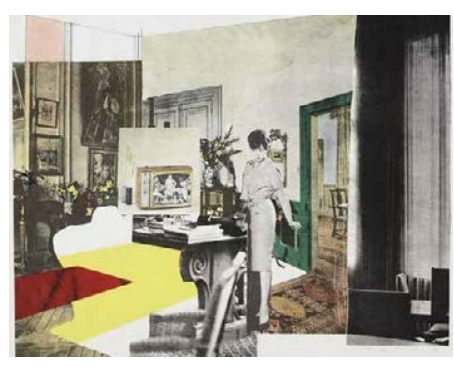

Imagen: Richard Hamilton, Interior-I Collage, 1964. Tate Modern, Londres.

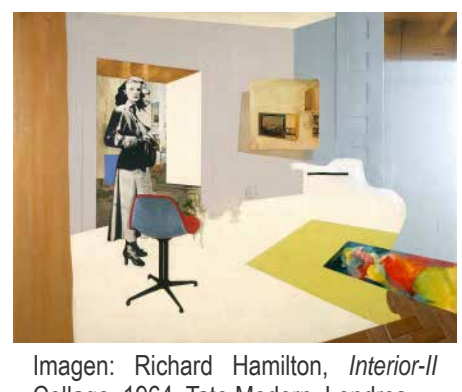

Collage, 1964. Tate Modern, Londres. 
Imagen: Richard Hamilton, Just what is it that makes today's homes so different? Collage con técnica digital, 1992. Tate Modern, Londres.

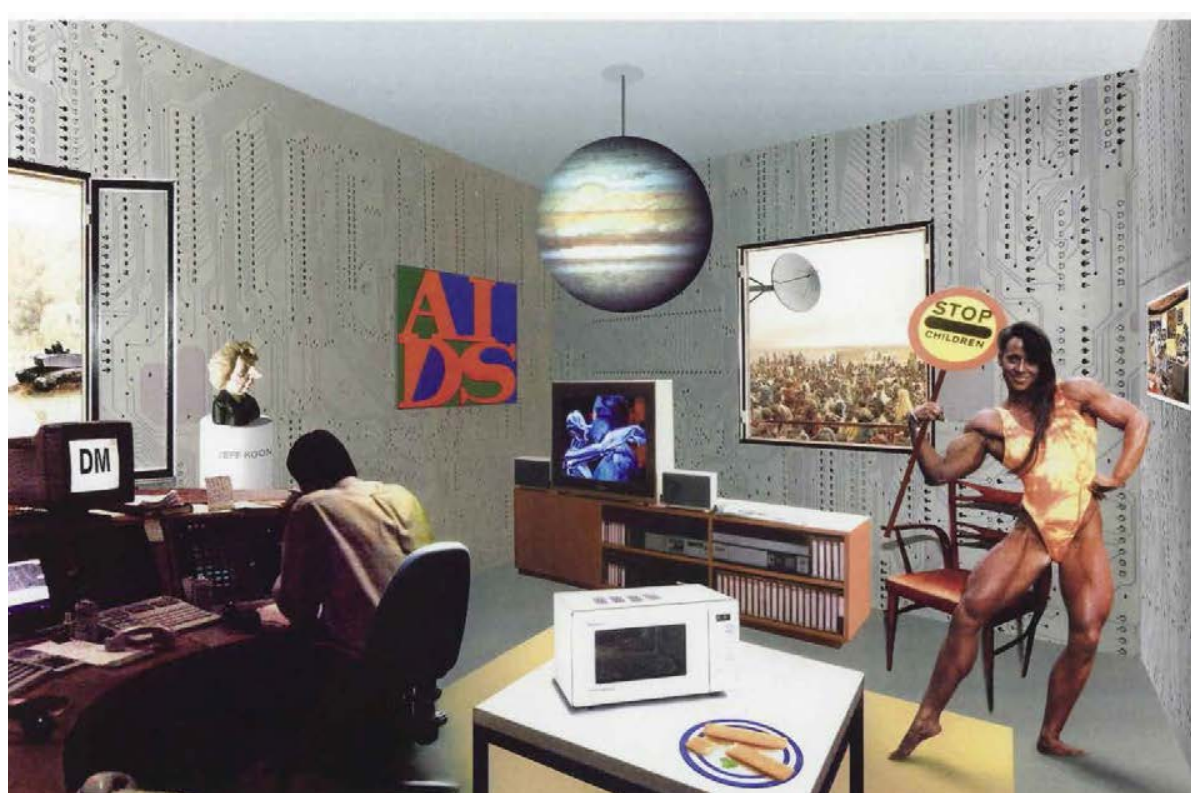

Entre las dos ventanas, en el interior, aparecía un busto de Margaret Thatcher firmado por Jeff Koons, como si fuese obra suya, como referencia irónica a la capacidad de este artista para convertir objetos kitsch en obras de gran valor en el mercado del arte. Colgado en la pared de la derecha estaba el collage original de Hamilton de 1956, y en la pared de la izquierda una imagen pop con cuatro letras que formaba la palabra 'AIDS',SIDA, que era una revisión un tanto pesimista de la icónica 'LOVE', obra del artista americano Robert Indiana de 1966.

En el centro de la habitación había un microondas colocado sobre una mesa que además contenía un plato de varitas de merluza. Detrás, una televisión con una imagen de una película de actualidad El cortador de césped (1992), del director Brett Leonard, que trataba sobre la realidad virtual. Bajo la TV, cintas de video y aparatos de grabación de imagen y sonido. En el techo aparece colgado, en este caso, Júpiter ${ }^{16}$ y detrás en la ventana, una antena parabólica.

Los personajes representan el cambio de las entidades sexuales, desde los años cincuenta hasta la sociedad del momento. La mujer era ahora la culturista y sostenía un cartel que indicaba 'STOP-CHILDREN' en respuesta a la piruleta 'Tootsie-Pop' del collage del 56, que se interpretaba como un tanto fálica al dirigirse hacia la imagen de la mujer voluptuosa. El 'macho' musculoso del cuadro del 56 había sido sustituido por un financiero encorvado sobre un escritorio, rodeado de ordenadores y teléfonos. "Sentado en su casa con un ordenador conectado a la red de los mercados financieros" decía Hamilton en referencia a una nueva tendencia, que era el resultado de la evolución del trabajo en pos de la tecnología y de las comunicaciones.

En cualquier caso y en todos ellos, el objeto sobre todo significaba. A veces Hamilton los hacía salir a escena, con ironía, como protesta, como rebelión a los cánones establecidos o a los nuevos modos de vida. Otras veces aparecían como signos culturales o contraculturales: el arte Pop en el primer collage, las referencias a Yves Klein en los collages de los 60, Jeff Koons en los 90... 0 también como reflejo de la sociedad del momento.

En otros casos el objeto aparecía como resultado de los avances de la

16 En 1992 la nave espacial 'Ulysses', tras una aproximación a Júpiter, entró en una órbita de seis años en torno al sol. 
técnica: la grabadora, los ordenadores, la televisión, el video, el microondas, la aspiradora, etc...Y en su yuxtaposición, en el marco de la escena, iban completando el discurso.

Pero qué evolución se podía entender entre el Just what it is that makes... de 1956 -a partir de ahora,1- para "This is Tomorrow" y el de 1992 -a partir de ahora, 2- para el experimento de la BBC:

\section{ESPACIO 1}

Irónico y optimista

\section{ESPACIO 2}

Contemplaba muy poco el humor, podría considerarse más bien pesimista, como si reflejara una frustración por no haberse cumplido las expectativas del espacio 1. El 'AIDS' frente al 'LOVE' del movimiento hippy; las guerras continuaban existiendo, y los avances tecnológicos, en los que tanta esperanza se había puesto para hacer un mundo más cómodo, sin embargo nos convertían en más esclavos del trabajo...

Esto se acentúa si comparamos los objetos y los materiales.

Predominio de los rojos, los blancos y los ocres.

Muebles confortables. El sofá como mueble principal

El ambiente se presentaba más cálido y confortable

\section{Respecto a la composición del marco:}

El espacio 1 se abría, delimitado verticalmente por dos planos

No existía techo, y se convertía en una vista del espacio
Predominio de los azules, los marrones y los grises

Escasos muebles y poco confortables. El mueble de trabajo como mobiliario principal

La atmósfera era mucho más fría, el espacio se tornaba aséptico y poco confortable

En el espacio 2 los planos que verticales que delimitan la escena eran 3 , el escenario se constreñía y existían menos grados de libertad

Sí existía techo

Esto era progresivo, ya que en los collages intermedios, de los 60, Interior-I, Interior-II, los marcos de la escena los delimitaban también dos planos, pero como en el cuadro de Vermeer, aparecía una cortina en primera línea que hacía que el encuadre se redujera.

En todos ellos, la pieza de arte aparecía como un elemento importante dentro de la escena. 
En el espacio 1, Hamilton hacía guiños al arte a través del retrato del S. XIX colgado en la pared junto al comic enmarcado, como si también fuese arte. Con ello Hamilton estaba visionando sobre futuras obras de artistas Pop como Lichtenstein, conocido sobre todo por sus interpretaciones a gran escala del arte del comic durante los años 60. En los espacios Interior-I e Interior-II, de 1964, sus referencias artísticas principales iban dirigidas al cine, utilizando fotogramas de una película de 1948 de Douglas Sirk, y al artista Yves Klein, donde a través de planos azules rendía homenaje a su obra.
En el espacio 2, de 1992, de nuevo convivían varias obras de arte de diferentes épocas, y en diferentes planos. Por un lado la interpretación pesimista de la obra de Robert Indiana; por otro y en el plano opuesto, la obra del propio Hamilton para la exposición This is Tomorrow, de 1956, y en un pedestal y de forma irónica, el busto de Margaret Thatcher como caricatura a la obra de Jeff Koons. Los espacios de Hamilton hablaban de la sociedad a través de las obras de arte, por su significado, pero también por su disposición en el espacio. Así el artista conseguía transmitir su interpretación de las ideas que abarrotaban el mundo.
Imagen izquierda: Feria del Mueble de Colonia: 'Visiona-1' por Joe Colombo en1969. Los actores representaban la comodidad que proporcionaban las nuevas tecnologías.

Imagen derecha: Feria del Mueble de Colonia: 'Visiona-2' por Verner Panton en 1970. Los habitantes ficticios de espacio doméstico con configuraciones psicodélicas mostraban una actitud contemplativa, casi en éxtasis.
Varios son los ejemplos que se podrían añadir a las 'representaciones' de escenas domésticas que se producían en aquel tipo de exposiciones. Cabrían destacar, por su difusión y por su similitud a lo que supuso lo acontecido en la Casa del Futuro de los Smithson, las interpretaciones de acciones 'domésticas', también con aires futuristas, que se produjeron años después durante las exposiciones 'Visiona'. Con motivo de la celebración anual de la Feria Internacional del Mueble de Colonia, la empresa farmacéutica 'Bayer' participaba en el evento con los montajes 'Visiona', creados para promocionar sus tejidos sintéticos para el hogar.
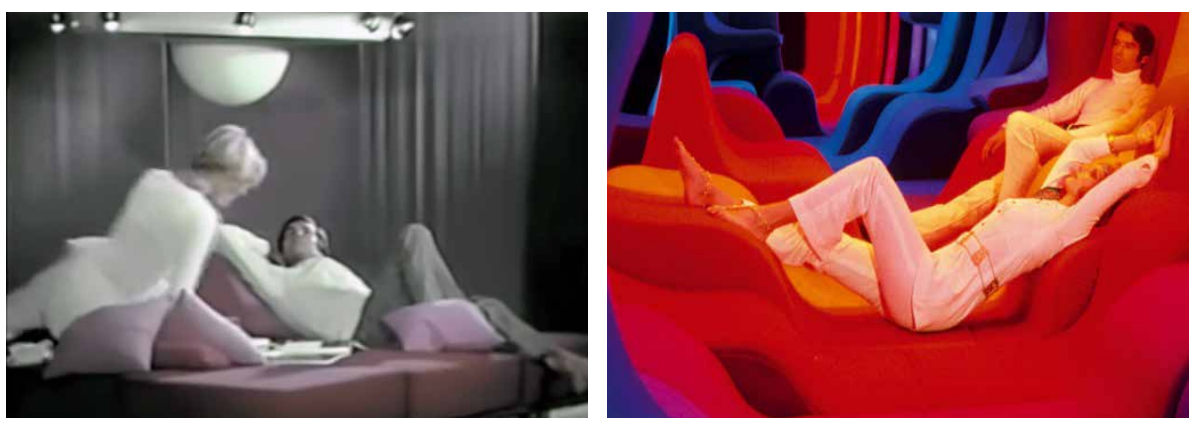

Estos espacios expositivos, de los que se hablará más adelante, se hicieron internacionalmente famosos, especialmente los comprendidos entre 1968 y 1971. Los 'Visiona'17 de aquellos años, que ya forman parte de la historia del diseño y de la arquitectura, trascendieron por por su calidad en el diseño, por su innovación tecnológica y por su sistema de promoción a través de documentales, en los que se representaba el transcurso de la vida 'cotidiana' de una familia que interactuaba con los objetos incluidos en la exposición y dentro de los ámbitos que los diseñadores habían creado para la ocasión.

Las propias características de los espacios incitaban a los movimientos pausados de los actores, significando de esta manera que las nuevas tecnologías y los nuevos materiales aplicados en dichos 'hogares' facilitaban las tareas diarias y proporcionaban un modo de vida más confortable, como

17 Los principales diseñadores encargados de diseñar el espacio para las distintas exposiciones 'Visiona' en aquellos años fueron: Verner Panton Visiona-0 en 1968 y Visiona-2 en 1970; Joe Colombo Visiona-1 en 1969 y Olivier Mourgue Visiona-3 en 1971. 
en el caso del 'Visiona-1'. También las configuraciones espaciales con formas psicodélicas, colores estimulantes, iluminación ambiental, sonidos envolventes e incluso olores agradables a los sentidos, que invadían los espacios creados por Panton en 'Visiona-2' significaban que en la vida diaria existiría el descanso, la meditación y un mayor disfrute dentro del hogar, y aquel ambiente se hacía más palpable a través de la interpretación de los actores que convivían de forma ficticia en dicho espacio en una actitud de sosiego y placer. En 'Visiona-3', la disposición de los elementos y la idea de configuración, como si fuese un 'paisaje' artificial, se evidenciaba a través del comportamiento de unos habitantes que representaban la escena doméstica cotidiana como si siempre fuera un día de 'picnic', al aire libre, acorde con el concepto de partida.

Quince años después, el habitante hedonista de los 80 representaba su día a día en 'Casa Palestra', una instalación creada por Rem Koolhaas, dentro del contexto de la exposición 'Il progetto domestico' de la XVII Triennale de Milán, de 1986.

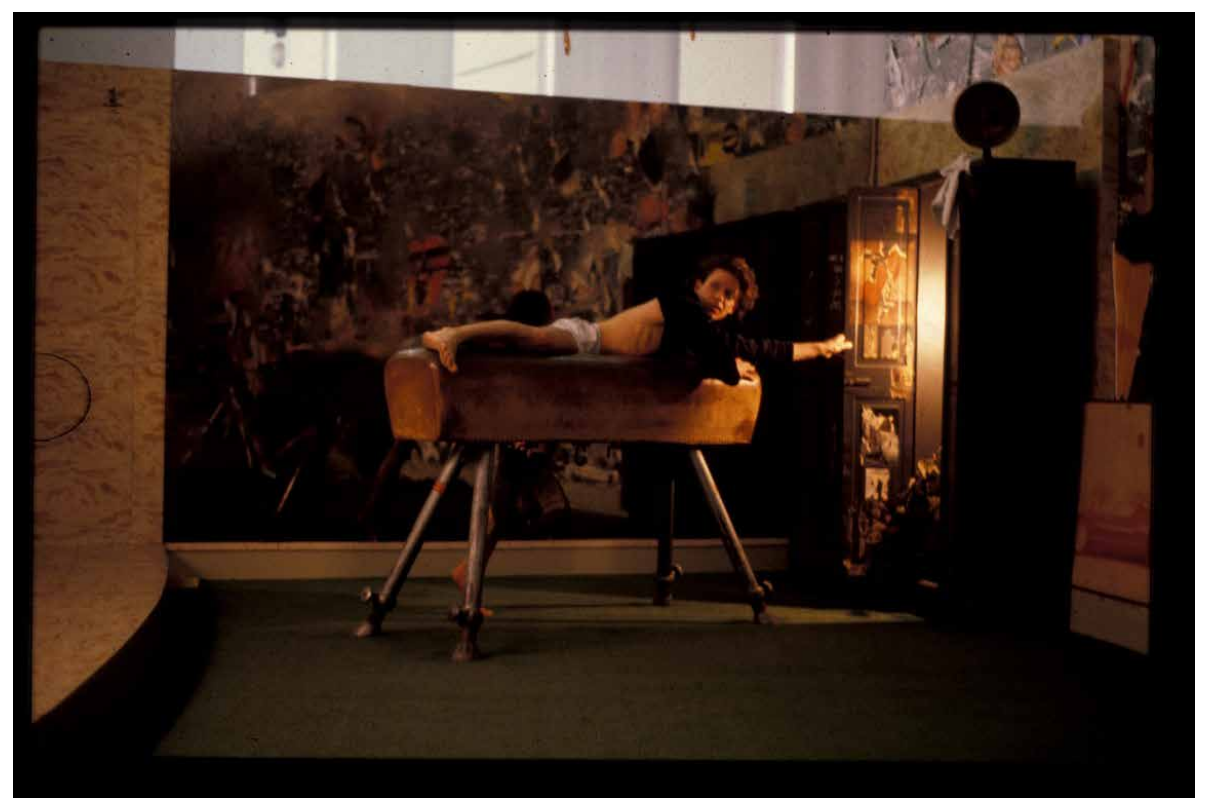

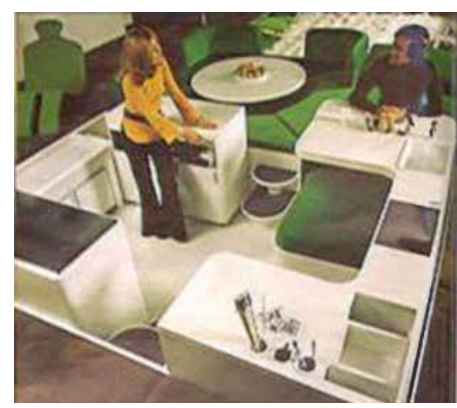

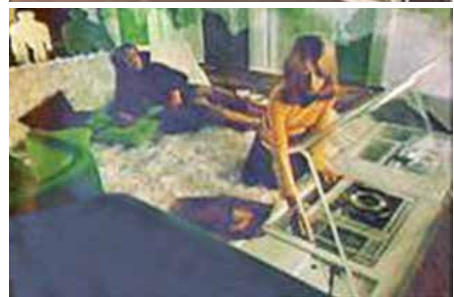

Imagen: Feria del Mueble de Colonia: 'Visiona-3' por Olivier Mourgue en1971. Un paiaje artificial donde los actores realizaban las tareas domésticas como un día 'en el campo'.

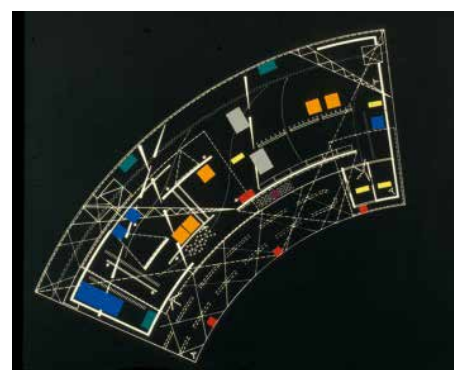

Imagen: 'Casa Palestra'. Triennale de Milan, 1986. Por Rem Koolhaas. A la izquierda: vista de la actuación representada en la instalación.

Arriba: planta del pabellón.

Para albergar la escena, un espacio icónico de la arquitectura moderna era 'deformado' y reconvertido en una casa-gimnasio para que el habitante hedonista, representante de la sociedad de consumo pudiera desarrollar su 'actuación', que era la de la vida cotidiana como si de un gimnasio se tratara:

A principios de los 80 , la arquitectura moderna se presentaba como sin vida, puritana, vacía y deshabitada. Siempre fue nuestra intuición sin embargo que la arquitectura moderna era en sí misma un movimiento hedonista, cuya severidad, abstracción y rigor podían dar pie para crear un escenario provocativo para el experimento que es la vida moderna"

\section{Rem Koolhaas ${ }^{18}$}

La primera 'provocación' de Koolhaas fue la de 'deformar' un edificio icónico del Movimiento Moderno, el pabellón de Barcelona de Mies de 1929. La versión del pabellón 'doblado' se convertía en un marco doméstico cuyo sistema de 
Imagen: 'Casa Palestra'. Triennale de Milan, 1986. Por Rem Koolhaas. Vista de la actuación representada en la instalación. Un actor realizaba ejercicio en torno al pabellón.

ocupación y toda actividad estaban relacionados con la cultura física, en el más amplio sentido de la palabra. La casa, ya habiendo sido profanada, mostraba su perfecta idoneidad para albergar los aspectos más sugerentes de la cultura contemporánea, según Koolhaas.

La acción era representada por una persona que hacía ejercicio constantemente alrededor del pabellón. La actuación iba acompañada de proyecciones, efectos de luz, olores y una banda sonora abstracta y de una voz humana que sonaba en algún lugar. La voz en off expresaba cierta ambigüedad entre lo que podía ser ejercicio físico o placer sexual.

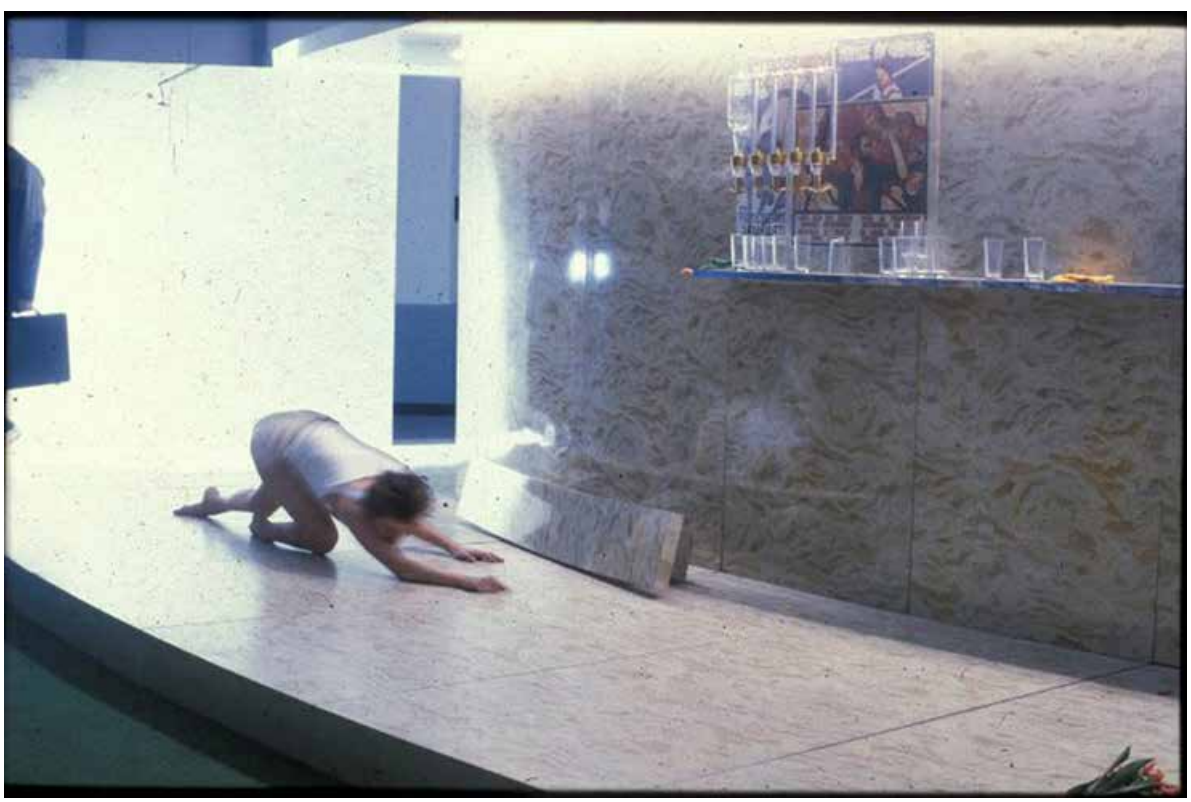

Desde lo más alegórico a lo tecnológico, las escenas domésticas en las exposiciones reflejaban las ideas en torno a los modos de vida del momento. Al tratarse, en la mayor parte de los casos, de muestras comerciales, estas simulaciones de formas de habitar 'ideales' iban ligadas a los comportamientos o fenómenos que generaba la interacción con los objetos. En su fenomenología, estas escenas representaban verdaderos entornos topológicos -cómo moverse entre los equpamientos, de qué manera tumbarse a escuchar música, cómo cocinar o descansar en artefactos polivalentes-, pero también eran importantes por su incidencia sociológica, lo cual potenciaba en gran medida la faceta semántica del objeto en la que tanto hincapié hacian los estudios realizados. 


\subsection{EL 'BUEN DISEÑO'Y LOS NUEVOS MODOS DE VIDA}

"Reconozco que algunos muebles modernos son demasiado caros, pero es debido a que son de edición limitada. Cuando aumente la demanda, pienso que los precios bajarán. Las habitaciones creadas, que forman parte del final de la exposición, deben ayudar a impulsar esa demanda"19. "Sobre una rampa ricamente enmoquetada los visitantes caminan hacia un comedor diseñado por Alvar Aalto; pasan por dos estudios -de Bruno Mathson y Jens Rison-, por un dormitorio y por un salón-comedor que representan la variedad de diseñadores; y luego, a un nivel superior, transitan por un espacio amueblado por Charles Eames llegando finalmente a un balcón desde el que se divisa una sala de estar de George Nelson. En la serena sencillez de las habitaciones y el suave sonido de la música clásica de fondo, que hace que la gente hable en susurros, una mujer suspira: "me encantaría vivir aquí" 20 .

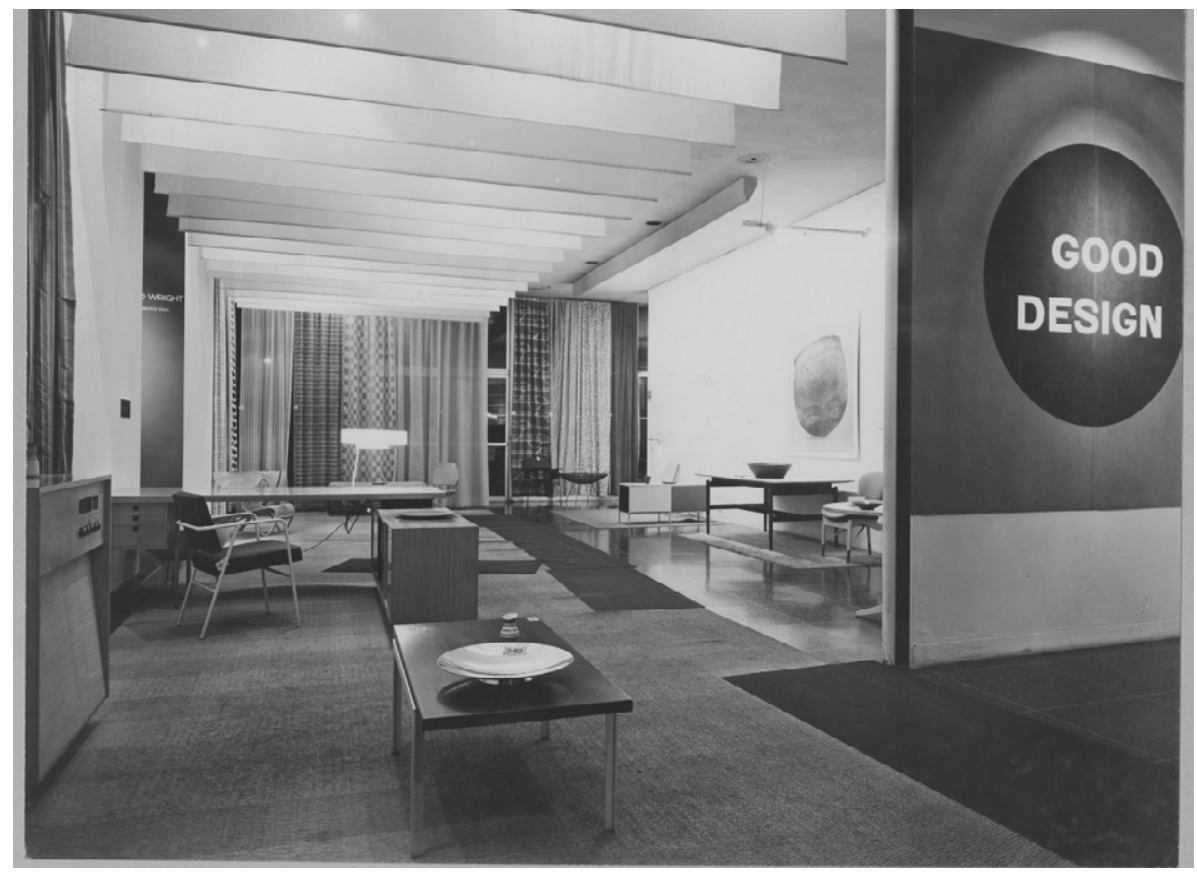

De 1950 a 1953, el Museo de Arte Moderno (MoMA) de New York junto con el centro comercial Merchandise Mart de Chicago organizaron un programa de exposiciones llamado Good Design. No era habitual que un centro comercial y un museo se unieran para presentar "Ios mejores nuevos diseños de muebles para el hogar".

Cada año se seleccionaba a un diseñador de prestigio para organizar la exposición. Por orden cronológico a las exposiciones, fueron Charles y Ray Eames, Finn Juhl, Paul Rudolph y Alexander Girard los que diseñaron aquellos espacios para el evento. En 1950, los Eames fueron los encargados del diseño y el montaje de la exposición inaugural.

En aquellos años de posguerra americana, el concepto de diseño aplicado a la mejora de la vida cotidiana de los ciudadanos, se estaba instaurando en la sociedad a través de la publicidad y demás medios de promoción. Las ferias

19 Alexander Girard en la entrevista incluida en el artículo "What is modern?"en Pathfinder News Magazine ( $n^{0} 5$ octubre 1949) p.42.

http://www.oldmagazinearticles.com/Design-for-living\#.WQ4jwIVOK01

20 El artículo "What is modern?" se publicaba en base a la exposición 'For Modern Living' que se estaba produciendo en 1949 en el Detroit Institute of the Arts.

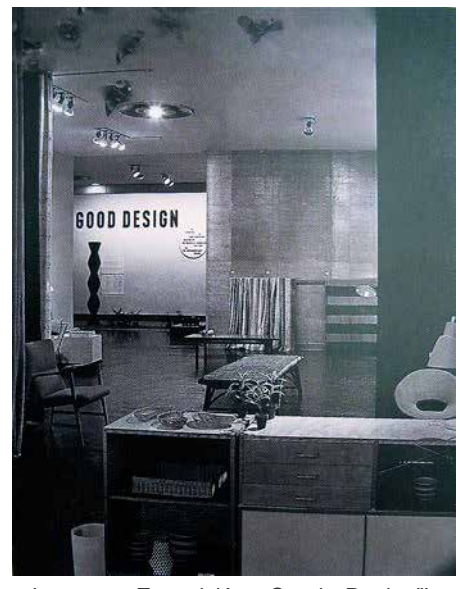

Imagen: Exposición Good Design"'. MoMA Nueva York, espacio organizado por Finn Juhl ,noviembre1951.

Izquierda: imagen del espacio organizado por los Eames en el MoMA para la exposición 'Good Design' en noviembre de 1950 


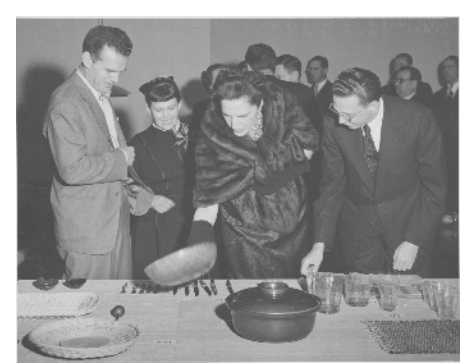

Imagen: Los Eames con visitantes de la exposición 'Good Design'. MoMA Nueva York, 1950.

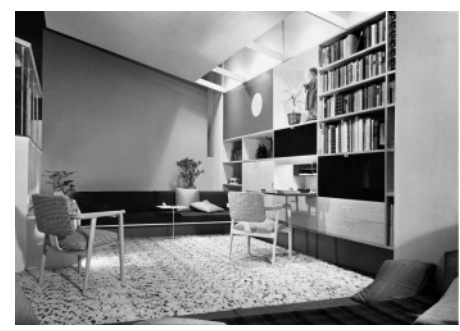

Imagen: Ambiente creado por Georges Nelson para la exposición "For Modern Living". Instituto de las Artes de Detroit, 1949

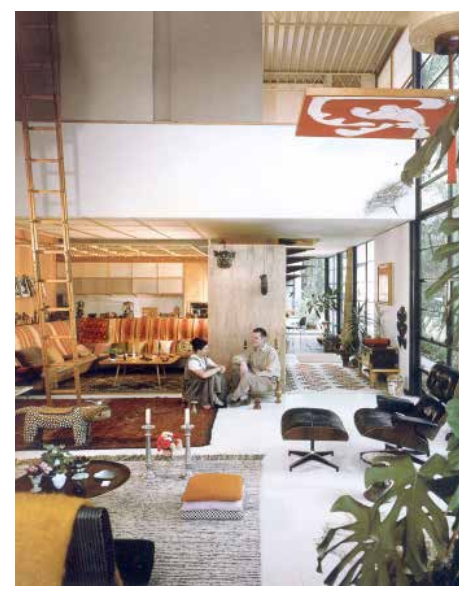

Imagen: Casa Charles y Ray Eames, Santa Mónica, California. 1949. de muebles seguían siendo dominio exclusivo de la vieja guardia, y seguían comercializando muebles de madera maciza hechos a mano. La vía para el fomento del diseño contemporáneo fue la de los museos. De las primeras muestras destacaron la llamada Good Design is your Business, celebrada en 1947 en la Albright Art Gallery de Buffalo; la exposición Well-designed Articles from Minneapolis Stores en el Walker Art Center en 1948, o la que se estaba llevando a cabo desde 1938 a 1948 en el MoMA de New York con el nombre Useful Objets.

Una de las más relevantes fue la llamada For Modern Living. Organizada en 1949 por el Instituto de las Artes de Detroit y en colaboración con los grandes almacenes J.L. Hudson Company de Detroit, la exposición fue encargada al diseñador Alexander Girard para su diseño y comisariado. La intención era hacer llegar el diseño moderno a los hogares americanos, haciendo entender a la gente que su finalidad era hacer la vida más agradable. En la muestra se presentaron más de 3.000 objetos, sin embargo lo que más trascendió de esta exposición fue la presentación de siete espacios que recreaban diferentes ambientes, y que fueron encargados a arquitectos y diseñadores de prestigio como Alvar Aalto, Charles Eames, Florence Knoll, Bruno Mathsson, George Nelson y Jens Risom. Según el diario de arte Everyday Art Quarterly ${ }^{21}$, los ambientes exhibidos demostraban que "no había un patrón fijo, ni fórmulas para la elección ni para las relaciones entre objetos", e insistía en que cada habitación representaba una propuesta individual, pero sin sacrificar en ningún caso el buen diseño.

Si bien esta exposición tenía una clara finalidad comercial, recordemos el patrocinio de J.L. Hudson, sin embargo ayudó en gran medida a revolucionar las ideas en torno a cómo presentar en un museo este tipo de colecciones, y a su vez a cómo conseguir atraer a los visitantes -en parte gracias a los carteles y viñetas encargados al dibujante Saul Steinberg-. Todo ello hace que esta exposición se considere el punto de partida del auge del diseño moderno americano y de las exhibiciones de diseño contemporáneo en general.

En los mismos años Charles y Ray Eames finalizaban su casa de Santa Mónica y, también en 1950, la productora de mobiliario Herman Miller inauguraba su espacio de exposición para venta en Los Angeles, cuyo diseño y montaje había sido realizado por los Eames.

En el showroom, también se recreaban espacios integrando mobiliario de la marca -diseñado por los Eames, Girard, Nelson, etc.-, con una amplia gama de objetos, e introducían plantas, juguetes, arte popular y fotografías para 'crear ambiente'. 


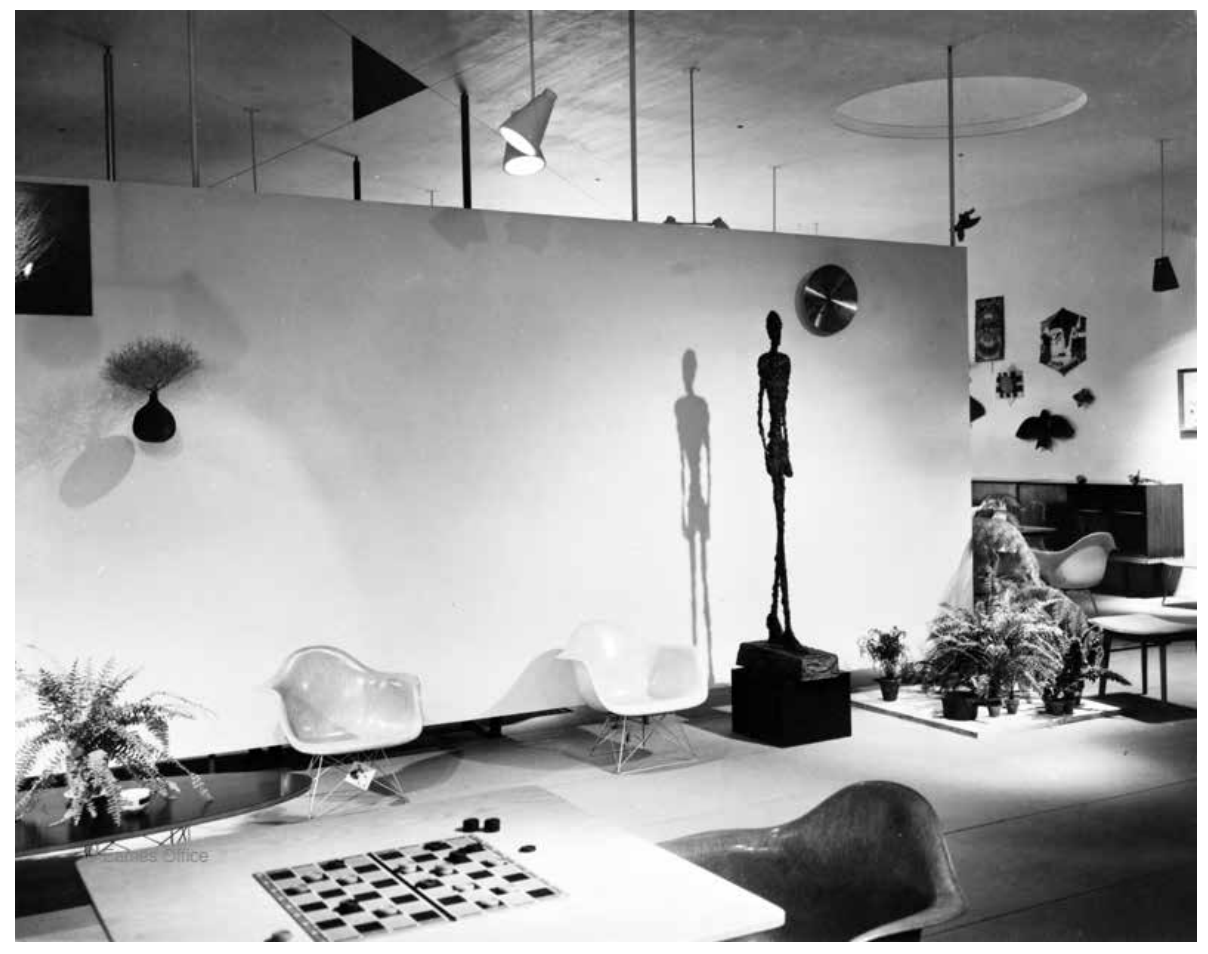

Imagen: Charles y Ray Eames, showroom Herman Miller, Los Angeles. 1950

Del mismo modo que la casa era un escaparate, el escaparate se había vuelto una casa. La casa de los Eames y el showroom de Herman Miller eran en realidad el mismo proyecto utilizando los mismos principios: un recinto ligero y no consciente de sí mismo, un mínimo de arquitectura, proporcionaba un marco flexible para una multiplicidad de disposiciones interiores ${ }^{22}$. 


\subsection{DE LAERA ESPACIALAL MUNDO INTERIOR}

Las posibilidades que se presentan por el desarrollo de los sistemas audiovisuales son enormes. Las distancias ya no serán un problema... el hábitat estará en cualquier sitio. Teniendo en cuenta la maniobrabilidad y la flexibilidad, podríamos crear un sistema habitable que pudiera adaptarse a cualquier situación en el espacio y en el tiempo

Joe Colombo

Imagen: Verner Panton, "Visiona-2". Feria Internacional del Mueble de Colonia, 1970.

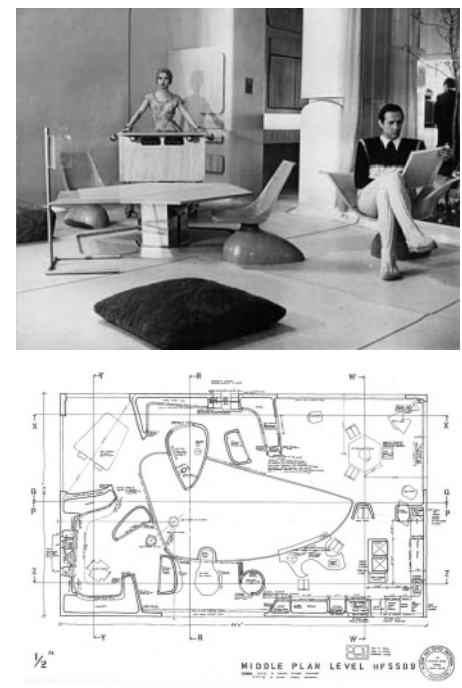

Imagen arriba: Alson \& Peter Smithson, 'La Casa del Futuro' Daily Mail Ideal Home Exhibition. Londres, 1956. Vista de la sala de estar.

Imagen abajo: Alson \& Peter Smithson 'La Casa del Futuro', 1956. Planta.

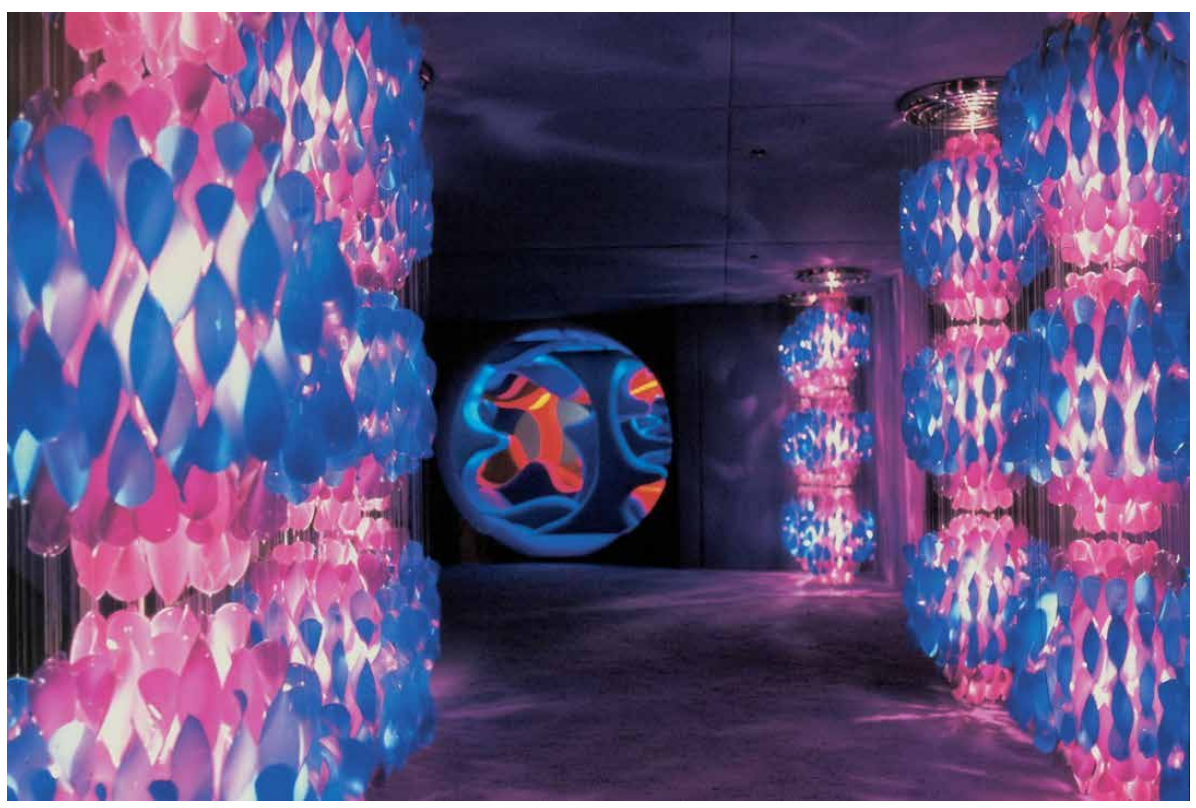

Las exposiciones, en su afán de recrear ambientes interiores que calaran en el subconsciente del visitante, ahondaban en los aspectos más paradigmáticos de la sociedad.

A la era del desarrollo de la tecnología, de los viajes espaciales, de la industria aeronáutica y de los nuevos materiales también se unía la de las libertades, la de la transgresión, el consumo de LSD y la de las protestas contra los principios establecidos. Todo ello se trasponía a los hogares, a las costumbres y a los objetos, tanto desde el punto de vista de la aplicación de las técnicas más avanzadas con propuestas casi de ciencia-ficción, como de una nueva estética aplicada al diseño, con espacios psicodélicos de formas sinuosas y ambiguas, de colores brillantes.

En los años cincuenta, Alison y Peter Smithson ya habían dedicado parte de su trabajo a establecer nuevos tipos que combinaran las nuevas tecnologías de la era de consumo con los nuevos modos de vida familiar que, de manera inseparable, se implantaban en la sociedad. Algunas de sus propuestas publicadas en artículos como la 'Casa Electrodoméstico', The Appliance House, 1956, Peter Smithson hablaba de proponer un estilo de vida. "El modo-de-vidacon-electrodomésticos" reclamaba un tipo de vivienda totalmente nuevo. Otras propuestas fueron proyectos reales, como el sistema de casas prefabricadas que diseñaron para la constructora 'Rumble' en 1954, aunque finalmente no se construyeron, y otras fueron concebidas para exposiciones, como la que presentaron en 1956 con el nombre 'La Casa del Futuro', The House of the Future, en la Daily Mail Ideal Home Exhibition, en Londres. Cada año, el Daily Mail promovía la exposición de la 'Casa Ideal', que tenía lugar en el Kensington Olympia Hall en West London. La feria, entre otras cosas, presentaba artículos de última generación para el hogar, y entre los numerosos stands que exhibían 
todo tipo de productos (por ejemplo, la recién lanzada Philishave) también había una muestra de 'el barrio de hoy y mañana' en el que se incluía la 'La Casa del Futuro' de los Smithson.

Los arquitectos recibieron el encargo de proyectar esta casa futura, en el que más o menos se les dio carta blanca para decidir cómo sería la casa suburbana convencional pasados 25 años. Como en toda feria comercial, tenía que permitir a los patrocinadores instalar en ella lo último en accesorios de cocina y electrodomésticos, tales como un 'recogedor de polvo electroestático' o un teléfono con altavoces tipo 'manos libres'.

La casa, en realidad era un escenario, realizado en contrachapado, escayola y emulsión de pintura que creaban el efecto de una superficie continua de plástico moldeado. La idea era que la casa en realidad fuera prefabricada y estaba diseñada para que se pudiera producir 'como un coche', en una sola pieza de plástico reforzado con fibra de vidrio. El prototipo estaba pensado como una casa patio con perímetro rectangular, que permitía ser fabricada de forma seriada y a la vez facilitaba el ensamblaje entre ellas, de manera que en un contexto suburbano, podría desarrollarse en grupos conformando barrios. La casa se concebía como parte de un escenario urbano de alta densidad.

No tenía habitaciones y todos los tabiques eran móviles, hechos con paneles correderos 0 armarios. Las diferentes áreas de la casa se organizaban en torno al patio, y la propia forma curva y 'moldeada' de la casa hacía que pareciera que todo fluía. Era una especie de cáscara de plástico, llena de objetos de plástico, que parecía haber sido moldeada según el movimiento natural de las personas que allí vivían -una pareja sin hijos, en la que ambos trabajaban, según los autores- y que de manera intencionada eran representados por actores.

Todos los muebles tenían formas ergonómicas, muchos se podían encastrar en el suelo, los armarios y electrodomésticos parecían haber tomado forma en función del movimiento de los brazos. La bañera, también empotrada en el suelo, adquiría incluso la propia forma del cuerpo. Los Smithson estaban proponiendo un modo de vida en un hábitat moldeado por su propia existencia, por sus actividades diarias que en muchos de los casos surgían de su interacción con los objetos que eran parte de la propia casa.

Ese mismo año, Alison y Peter Smithson junto con Nigel Henderson y Eduardo Paolizzi presentaron una visión del espacio doméstico completamente diferente a través de una instalación a la que llamaron 'Patio \& Pavilion'. Era parte de la exposición 'This is Tomorrow', que se celebró en 1956 en la Whitechapel Art Gallery de Londres. Los organizadores, entre los que se encontraban el arquitecto Theo Crosby como comisario y algunos miembros del Independent Group, asignaron un espacio de la galería para cada uno de los 12 grupos, de 3 ó 4 miembros, que habían organizado entre los participantes. En cada equipo se pretendía integrar arquitectos, artistas, músicos, diseñadores gráficos, para que realizaran una instalación sobre el tema de la vida moderna en Gran Bretaña. Algunas de las propuestas exploraron en la interrelación del arte con la tecnología y la cultura popular.

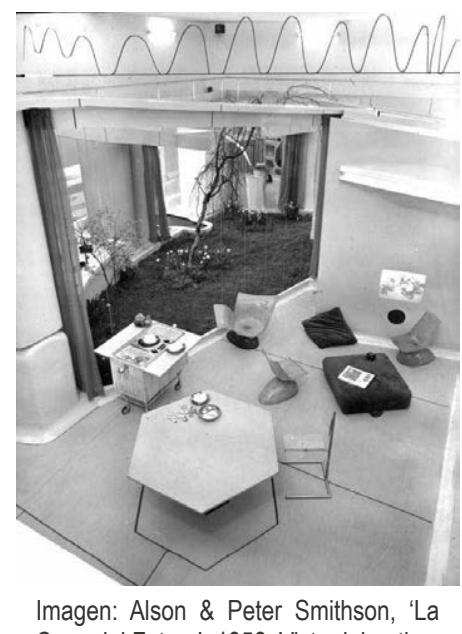

Casa del Futuro', 1956. Vista del patio.

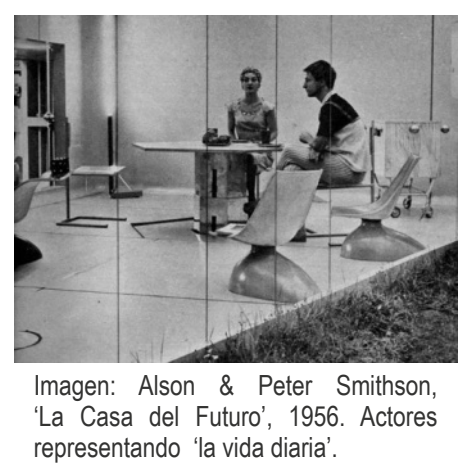




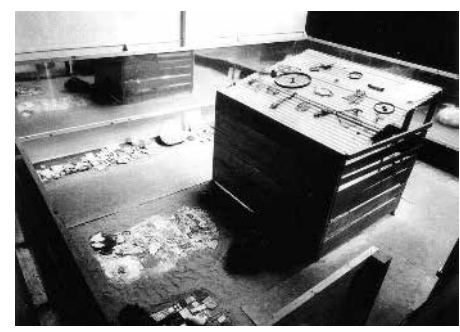

Imagen: Patio \& Pavilion, exposición 'This is Tomorrow'. 1956, Whitechape Art Gallery de Londres. Vista del pabellón.

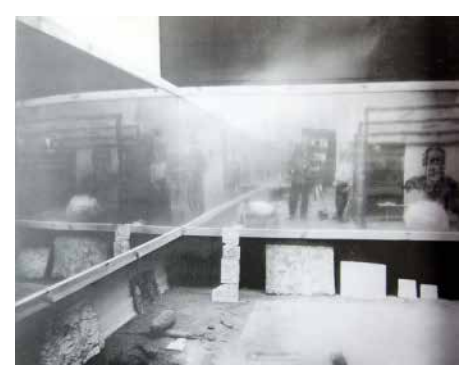

Imagen: Patio \& Pavilion, exposición "This is Tomorrow". 1956, Whitechape Art Gallery de Londres. Vista de pabellón.

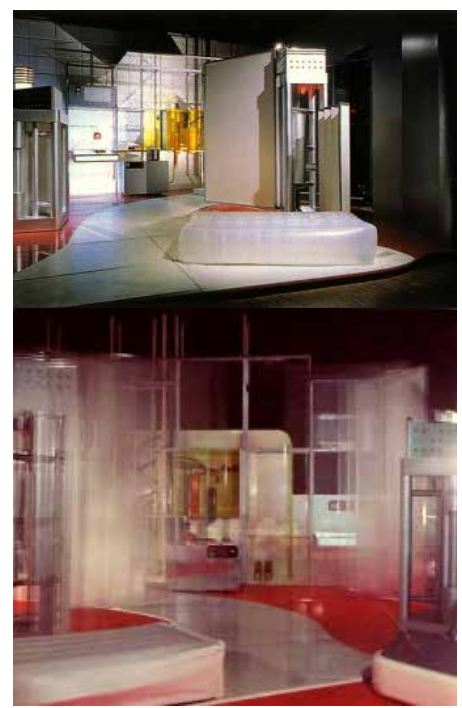

Imagen: Archigram. "Living 1990". Messrs Harrods, Londres. 1967. Vista del montaje.

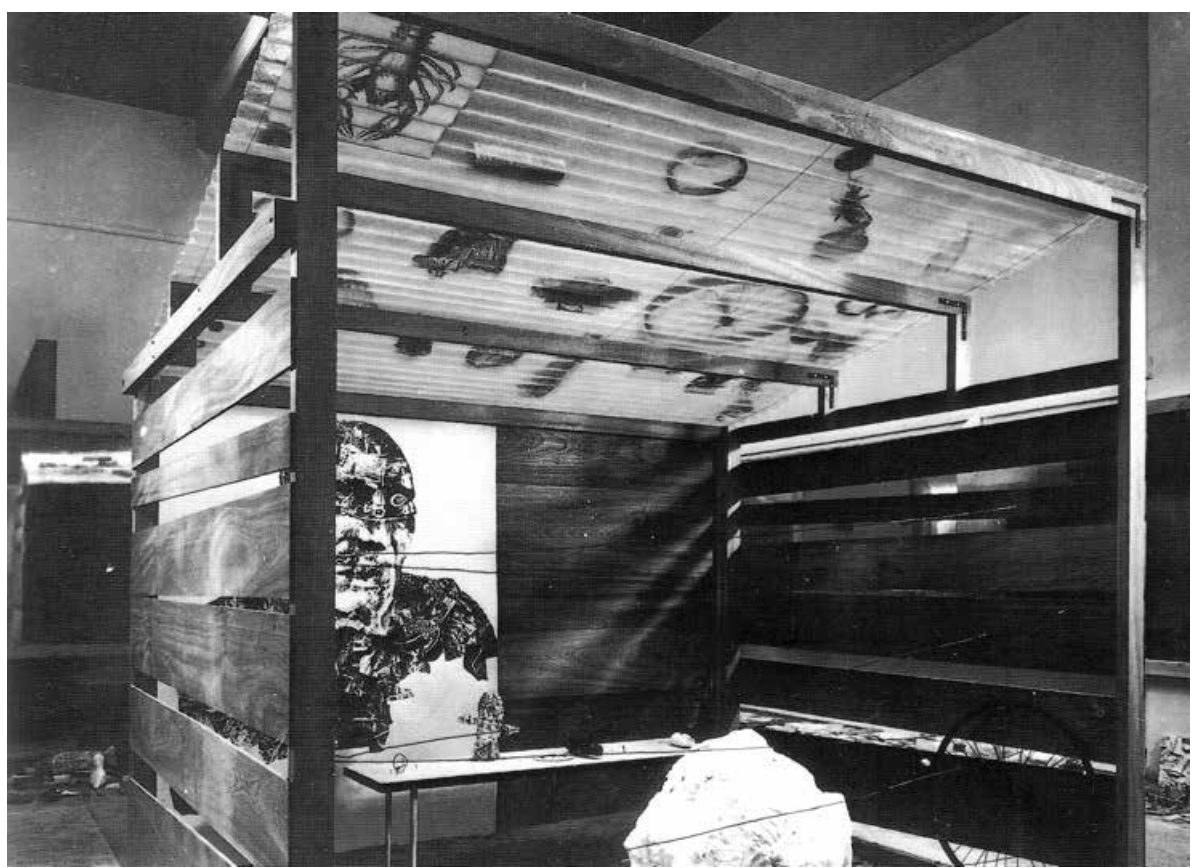

El 'Grupo 6' integrado por los Smithson junto con los artistas Henderson y Paolozzi, construyeron un pabellón con maderas de derribo, lámina ondulada de plástico y rodeado de una valla con aluminio reflectante al interior, que delimitaba un patio cubierto de arena. En términos existenciales los Smithson, que se encargaron de la parte arquitectónica, presentaban el grado cero de la arquitectura como refugio, mientras que en el interior Henderson y Paolozzi introducían elementos relacionados con las actividades humanas: una rueda, una escultura y diversos objetos rudimentarios. El efecto podía ser a la vez primitivo y moderno, con un cierto aire postapocalíptico y delimitado por alambre de espinos. El espacio estaba dominado por la obra de Henderson, Head of a Man, que era un retrato de una especie de Frankenstein moderno, semejante a los hombres-máquina rotos que Paolozzi producía en aquella época.

En palabras de Peter Smithson ${ }^{23}$, 'Patio \& Pavilion" era un tipo de hábitat simbólico en el que habían encontrado respuestas, de una u otra forma, a las necesidades básicas del ser humano.

La forma era sencilla, un patio o recinto cerrado que evocaba la necesidad del ser humano por el asentamiento y el territorio, y un pequeño pabellón que simbolizaba el cobijo. Para identificar este escenario con el ser humano, se amueblaron con objetos que simbolizaban las actividades del hombre: volantes, clavos, arpilleras, ruedas de bicicleta, teselas cerámicas, papeles arrugados, etc., un amplio espectro de signos e imágenes, de asociaciones y de analogías con el acto de habitar.

Tomando como modelo la 'Casa del Futuro' de los Smithson, y continuando con planteamientos sobre el hábitat del futuro, el Grupo Archigram fue el encargado en 1967, por el Weekend Telegraph Magazine, de diseñar una 'casa para el año 1990', para presentarla en Messrs Harrods de Knightsbridge, Londres. El montaje de los arquitectos ingleses se centró en la parte principal de la planta inferior de un módulo de vivienda.

23 Peter Smithson en 1956, en un escrito para Third Programme, de la BBC. Editado en, Alison y Peter Smithson, Cambiando el arte de habitar: piezas de Mies, sueños de los Eames, los Smithson. (Barcelona: Gustavo Gili, 2001) p.109. 
La intención de la exposición 'Living 1990' era mostrar cómo podía influir la tecnología en la forma de vida de los hogares del futuro. Warren Chalk, uno de los miembros del grupo, hablaba sobre la propuesta:

Se pretende que el espacio habitable esté en un entramado espacial o suspendido de una estructura tensegrity ${ }^{24}$. El aislamiento se consigue con membranas que se unen o separan electrónicamente. Reguladores de sonido / luz y espacio hacen que suelo y techo pasen de duros a blandos, o se inflen en algunas zonas para poder recostarse o dormir. Las mamparas ajustables de los robots -Fred y James-, definen áreas menores dentro del volumen principal, en las que uno puede aislarse totalmente y sumergirse en un ambiente generado por la proyección de films, luces, sonido u olores...

\section{Warren Chalk ${ }^{25}$}

Las paredes, techos, suelos -en este salón- se moldeaban de acuerdo a las necesidades. Los cerramientos de la zona de estar ya no eran rígidos, sino ajustables, programados para moverse hacia arriba y hacia abajo, dentro y fuera. La disposición de la planta también era variable. En determinados puntos el suelo podía ser lo suficientemente duro para bailar o lo suficientemente blando como para sentarse.

Los asientos y los lugares para dormir eran inflables, y detalles como el peso de la ropa de cama o el número de elementos acolchados eran controlados por el usuario. El antiguo concepto de silla móvil se convirtió en una silla de automóvil. El módulo del salón estaba diseñado según el principio del hovercraft, y también podía ser utilizado fuera, conduciéndolo alrededor de la mega-ciudad. La cápsula cama -no incluida en la exposición- también podía convertirse en un hovercraft y conducirse fuera. Los robots también incorporaban la radio y la televisión, incluyendo las películas favoritas y programas educativos, activándolos cuando se quisiese. La televisión era de gran formato y podía ser programada para que los espectadores pudieran estar rodeados de sonido, color y olor con efectos realistas. El bloque de servicios se conectaba con un gran servidor, compartido con la mega-ciudad y que era una de las instalaciones clave de la estructura.

Todas las zonas vivideras tenían una cocina ultrasónica provista con equipamiento de limpieza y comida rápida. Sin embargo podía haber cambios dependiendo del interés por la comida de cada usuario. Este diseño pretendía dar un paso para disipar las dudas ampliamente difundidas sobre el futuro de la estandarización y la configuración de la vivienda en base a los nuevos modos de vida.

Un año después, en 1968, y hasta 1971 la compañía química BAYER aprovechaba la Feria de Mobiliario e lluminación de Colonia -IMM-Cologne- en Alemania para promocionar diversos productos sintéticos de última generación fabricados por la compañía y aplicados al mundo del hogar. Su producto

24 La 'tensegridad' es un principio estructural basado en el empleo de componentes aislados comprimidos que se encuentran dentro de una red tensada continua, de tal modo que los elementos comprimidos (generalmente barras) no se tocan entre sí y están unidos únicamente por medio de componentes traccionados (habitualmente cables) que son los que delimitan espacialmente dicho sistema. Desarrollado en los años 50 por Buckminster Fuller y otros.

http://www.tensegridad.es/Publications/Tensegridad-Estructuras_De_Compresi\%C3\%B3n_ Flotante_by_GOMEZ-JAUREGUI.pdf

25 Warren Chalk en $A D$ Architectural digest ( $n^{\circ}$ marzo 1967). Citado por Peter Cook en ARCHIGRAM. (New York: Princeton Architectural Press, 1999) p. 62.
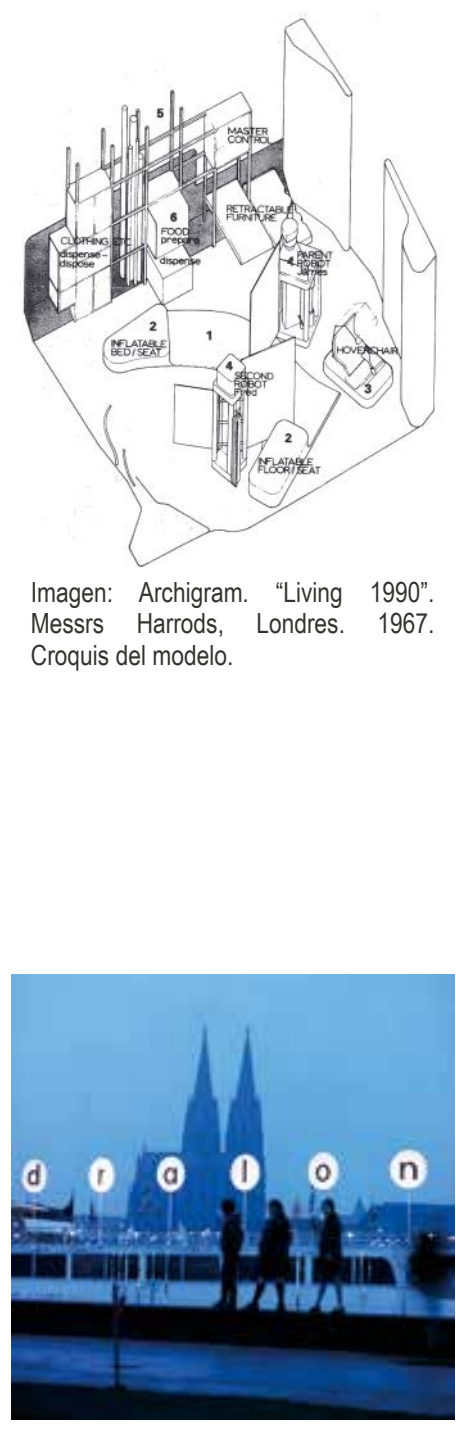

Imagen: "Visiona-0". Feria Internacional del Mueble de Colonia, 1968. Vista exterior del barco Loreley. 

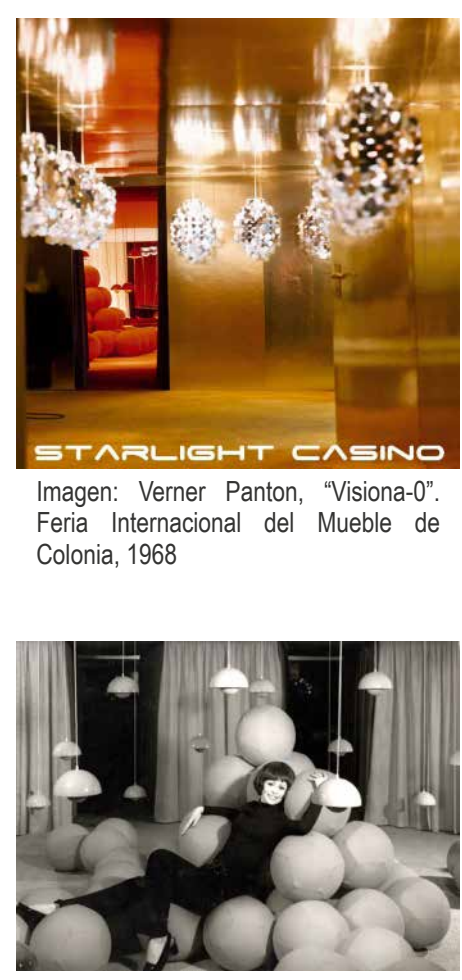

Imagen: Verner Panton, "Visiona-0". Feria Internacional del Mueble de Colonia, 1968

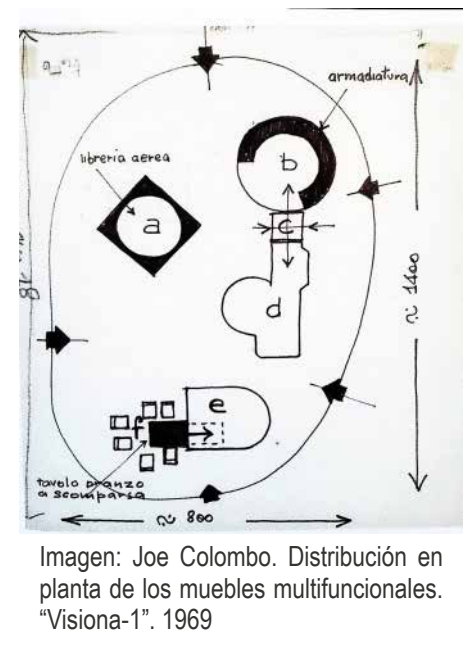

principal era la fibra sintética Dralon, y la exposición iba dirigida principalmente a mostrar sus múltiples aplicaciones en el ámbito doméstico.

Para ello, alquilaron un barco de recreo atracado en el Rhin, el Loreley, cuyo espacio interior fue transformado por distintos diseñadores de prestigio, a lo largo de aquellos años, para ofrecer muestras temporales en el contexto de la feria, y siempre en torno al tema del hábitat contemporáneo. Aunque inicialmente la sala de exposición se llamó 'Nave Dralon', finalmente fue conocida como 'Visiona' por sugerencia del diseñador danés Verner Panton, encargado de la primera exposición.

Aquella primera muestra se llamó 'Visiona 0'. Para ello, en 1968 Panton aprovechó todas las posibilidades que ofrecía el mundo textil para crear un espacio atmosféricamente denso, en el que las relaciones entre el mobiliario, la iluminación y el color jugaban un papel fundamental. En este contexto, Panton ideó un sistema de ambientes interiores experimentando con la libertad formal, que a pesar de ser calificados como utópicos, causaron gran impacto tanto en la crítica especializada como entre los visitantes.

Al no ceñirse al estereotipo de exposición de textiles, Panton consiguió que esta recreación de ambientes a través del diseño generase un vínculo entre el consumidor y el fabricante. Este concepto de exposición iniciado por el diseñador danés se mantuvo por tanto para las siguientes hasta 1971. Eran una muestra de las formas de vida de vanguardia y promovieron el debate público sobre la influencia de la nueva cultura en la vida doméstica, aunque siempre estuvieron presentes los avances de las producciones de Bayer como base de inspiración.

'Visiona 0' fue todo un éxito. Verner Panton había dado la vuelta por completo a la idea de exposición que tenía la empresa química. Consiguió que los productos fueran sólo parte de la misma, sin embargo el efecto del primer 'Visiona' superó ampliamente todas las expectativas de publicidad. Había creado un espacio, un ambiente de vanguardia que rompía con la idea tradicional de casa pero que resultaba especialmente atractivo para el visitante. La clave estaba en la introducción de otros objetos que ya habían sido diseñados por él y que a modo de atrezzo se iban integrando y recreaban un espacio doméstico, eso sí, muy novedoso. Entre estos objetos se incluían lámparas como 'Fun', 'Flowerpot', 'Topan' o 'Up-globe', así como la legendaria 'Panton chair', que ya era mundialmente conocida, lo que ayudó a que el espacio fuese percibido como algo 'familiar' para el visitante.

El enorme éxito de la primera exposición 'Visiona' allanó el camino para el año siguiente. En 1969, para el diseño de 'Visiona 1', Bayer contó con el arquitecto y diseñador de éxito Joe Colombo, cuya propuesta basada en un conjunto de módulos multifuncionales también creó gran expectación. Colombo recreó un espacio doméstico de futuro, futuro que para él ya estaba ahí, en el que los usos de cocina, baño, estar y dormir, se resolvían con respectivos muebles multifuncionales que aparecían dispuestos en el espacio continuo de la exposición, de unos $100 \mathrm{~m}^{2}$, y actuaban de manera autónoma. 
En palabras de Colombo, con motivo de la exposición:

Asistimos hoy a un caos que no deja de aumentar en el microcosmos que constituye el hábitat del hombre, cuya imagen confusa y desordenada acabará reduciéndose si evitamos convertirlo en un 'bazar' de objetos inútiles. Por otro lado, paralelamente, está la huella cada vez mayor de nuestra civilización industrial altamente tecnológica, que opera sin duda sobre la transformación global de la imagen ecológica. Alrededor de nosotros se forma un 'paisaje' que nos dirige hacia nuevos horizontes.

En este sentido debemos orientar nuestras investigaciones y experimentaciones a resolver la problemática de acorde con nuestro tiempo, más estructurado y más coordinado.

Joe Colombo ${ }^{26}$

Los bloques multifunción eran el 'central living', el 'night box' y el 'kitchen box'. El 'central living' consistía en un lugar de relajación, meditación y también de conversación. Era un módulo-salón abierto equipado por una librería suspendida del techo a modo de baldaquino, con un televisor incorporado, orientable e integrado en una esfera giratoria. El monitor recordaba al 'ojo que todo lo ve', al Gran Hermano, de la novela 1984 de Georges Orwell publicada en 1949; pero también al ordenador HAL 9000 que controlaba la nave espacial en la película de Stanley Kubrick 2001: una odisea del espacio, rodada en 1968 y de la que Colombo, entre otros muchos, era admirador. En tal caso, lógico, debido a su fascinación por la aplicación de la tecnología en el hogar (informática, robótica y domótica). A la altura del usuario el 'central living' contenía un grupo de cómodos asientos tapizados que se agrupaban en torno a una especie de coffee table central. También estaba equipado con equipo de alta fidelidad, radio, etc., y el sistema de iluminación era modificable dependiendo del ambiente que se quisiera generar. Además el zócalo del módulo contenía elementos de almacenamiento.

El 'night box' era el bloque de dormitorio con cuarto de baño. La cama o 'sleeping cell', de planta circular, también contaba con un sistema de almacenaje en la base y un monitor orientable similar al del 'cental living'. También contenía el equipamiento necesario, estaba provista de aire acondicionado y se podía independizar con un sistema de mamparas correderas. El baño, cuya carcasa estaba fabricada en plástico de una sola pieza, se diferenciaba del conjunto por una esfera que sobresalía y que albergaba la bañera-ducha.

La 'kitchen box' era una cabina que podía estar abierta o cerrada, y como el resto de los módulos, estaba totalmente equipada de forma que el usuario tuviera a mano todos los aparatos que necesitase. La mesa se plegaba horizontalmente a través de un sistema de raíles de manera que, una vez preparada la comida en la cocina, pudiera desplegarse hacia la zona de estar con un simple gesto. $Y$ en el proceso inverso, terminando de comer, la mesa de nuevo se replegaba y desaparecía.

La exposición 'Visiona 1', realizada por Joe Colombo, era el resultado de las investigaciones iniciadas por él mismo en 1961, sobre los muebles-bloque multifuncionales (recordemos su célebre 'Mini Kitchen' producida por Boffi desde 1963), y de los sistemas de organización que permitieran transformar

26 Joe Colombo "Visiona 69. Nouvelle conception de l'espace habitable". L'Architecture d'aujourd'hui, (n¹48, 1970) p.61.

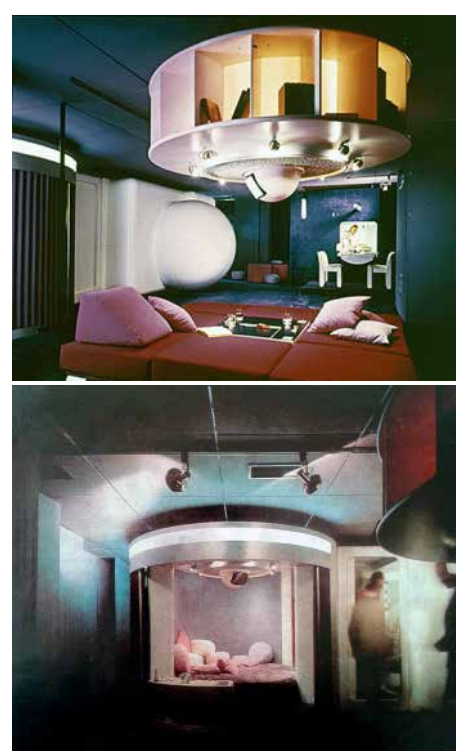

Imagen: Joe Colombo, vista del 'central living'y del 'night box'. "Visiona-1". 1969
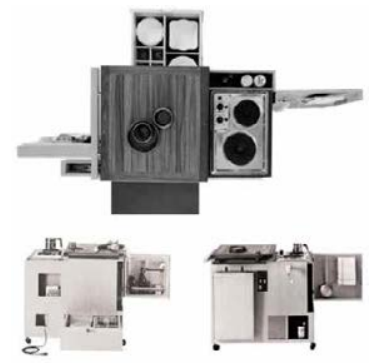

Imagen: Joe Colombo, 'Minikitchen'. 1963. Producida por Boffi.

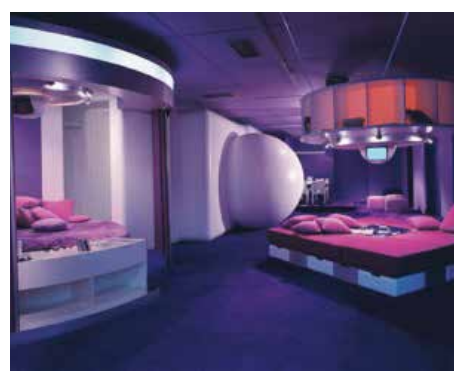

Imagen: Joe Colombo, vista general del conjunto. "Visiona-1". 1969 
Imagen: Verner Panton, "Visiona-2". 1970

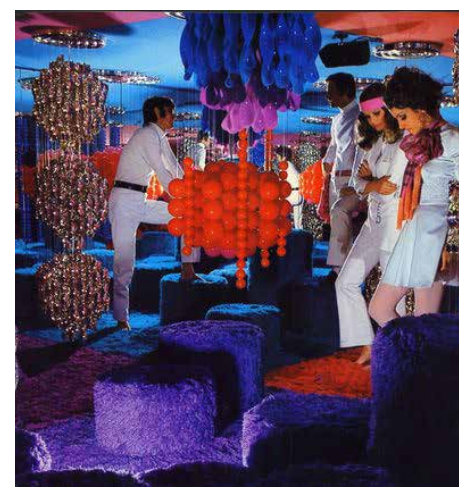

Imagen: Verner Panton, "Visiona-2". 1970 los ambientes, aplicando el concepto relación espacio-tiempo, en el hogar.

A pesar de la incidencia en la agrupación de los elementos en bloques, Colombo rechazaba estos elementos en el hábitat considerados de forma aislada; por el contrario abogaba por los conjuntos coordinados en pos de un hábitat en el que el hombre pudiera vivir en armonía con la realidad de su momento y se pudiera proyectar hacia un futuro próximo.

Las ideas de Colombo en esta exposición, que bien podían basarse en las películas de James Bond de su tiempo, o en la era espacial, con televisores en el techo y paredes móviles con minibares integrados, causaron gran expectación y dieron paso a la probablemente más famosa de las exposiciones 'Visiona', al año siguiente.

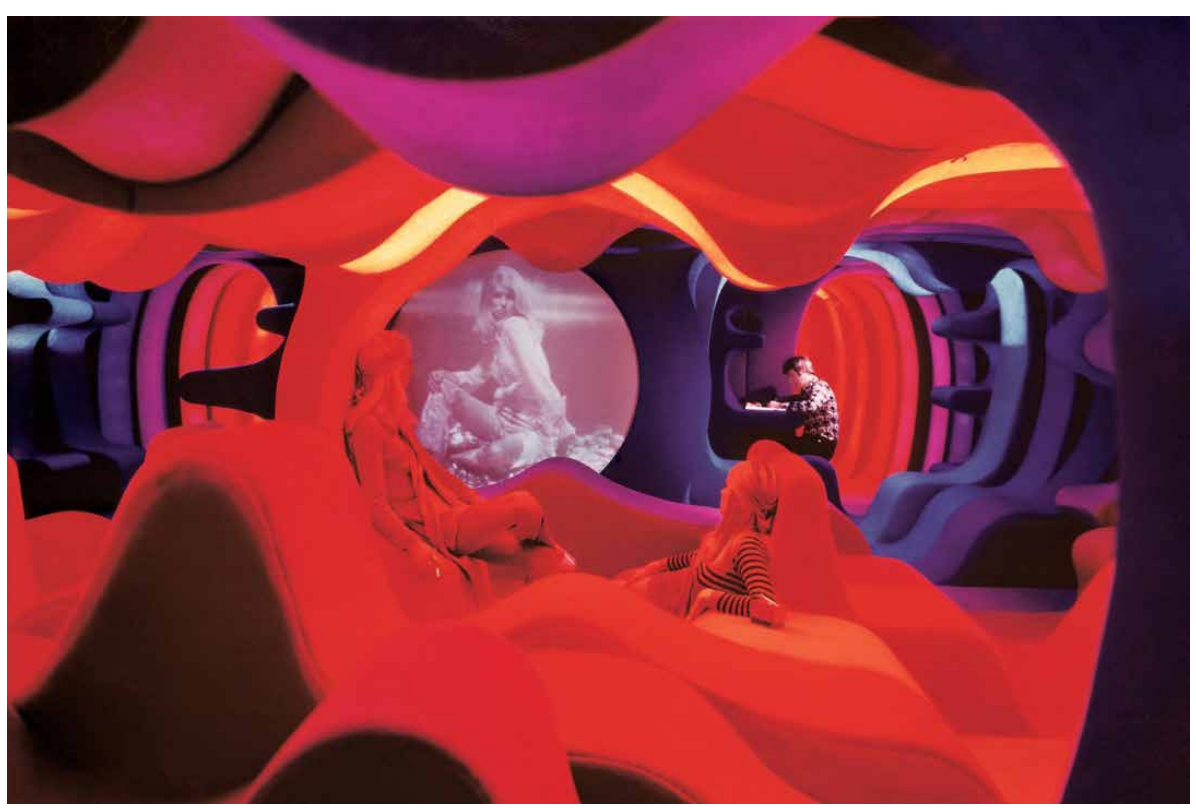

En 1972 Verner Panton fue de nuevo el encargado de diseñar el espacio expositivo de Bayer a bordo del Loreley. 'Visiona 2' consistía en una instalación que recreaba un paisaje 'de fantasía' en un viaje a través de espacios oníricos creados por un conjunto de elementos de formas orgánicas y colores brillantes que se extendían por toda la embarcación.

Comparando las exposiciones 'Visiona' que se celebraron hasta ese momento, se podría decir que 'Visiona 0 ' representaba la incursión en los nuevos modos de vida, alejándose de lo tradicional. 'Visiona 1' podía relacionarse con la era espacial en cuanto a su visión del hábitat del presente con una imagen de futuro y 'Visiona 2' más bien con el mundo interior de los seres humanos. Para este último, Panton creó una especie de 'gruta' que eludía todos los conceptos de la vivienda tradicional y rompía la idea de un espacio definido por las funciones, centrándose en aspectos como el bienestar, la relajación y la comunicación. Este 'paisaje interior' prometía una forma de vida sensual, liberada de todo convencionalismo. Con poliuretano, poliéster y polipropileno, creó una nueva perspectiva en el mundo del diseño. $Y$ todo ello fue consecuencia de los avances tecnológicos, el auge económico y los cambios sociales. El deseo superaba a la razón. Es por eso que en aquel ambiente psicodélico, que aunaba las consecuencias de acontecimientos como el Mayo del 68 en Francia, el aterrizaje en la Luna televisado o el Festival de Woodstock en 1969, cada ámbito tenía su propio sonido ambiente, su propio color y su propio olor. 
Para esta exposición Panton diseñó numerosos objetos. Recordemos que en la del 68, incorporó elementos que habían sido diseñados por él anteriormente, siendo ya algunos de ellos muy conocidos. Sin embargo para 'Visiona 2' los diseñó expresamente: muebles, estampados y revestimientos para paredes y techos. Algunos de ellos se comercializaron con posterioridad a la exposición aunque con algunas modificaciones, como la 'Amoebe chair', la 'Living tower' -producidas por Vitra- o la 'Spiral lamp'.

El éxito del mundo visionario de Panton fue imposible de superar. En 1971, un año después, Bayer encargó 'Visiona 3' al conocido interiorista y diseñador de muebles francés Olivier Mourgue, que también trabajaba como paisajista. Mourgue colaboraba habitualmente con la empresa Airborne International, con quien había producido en 1965 la serie 'Djinn chairs' que se hizo mundialmente conocida por haber sido utilizada para amueblar en 1968 la 'Estación Espacial Hilton' de la película de Stanley Kubrick 2001: una odisea del espacio. Aunque dicho espacio cinematográfico podría interpretarse como un campo blanco infinito salpicado de flores rojas, para esta exposición, Mourgue utilizó aún más su faceta de paisajista que la ciencia ficción. Fue el medio natural lo que inspiró su 'Visiona 3' de 1971, donde las referencias a la naturaleza fueron constantes a través de alfombras que representaban ríos, praderas de césped 0 incluso imitaban tierra natural.

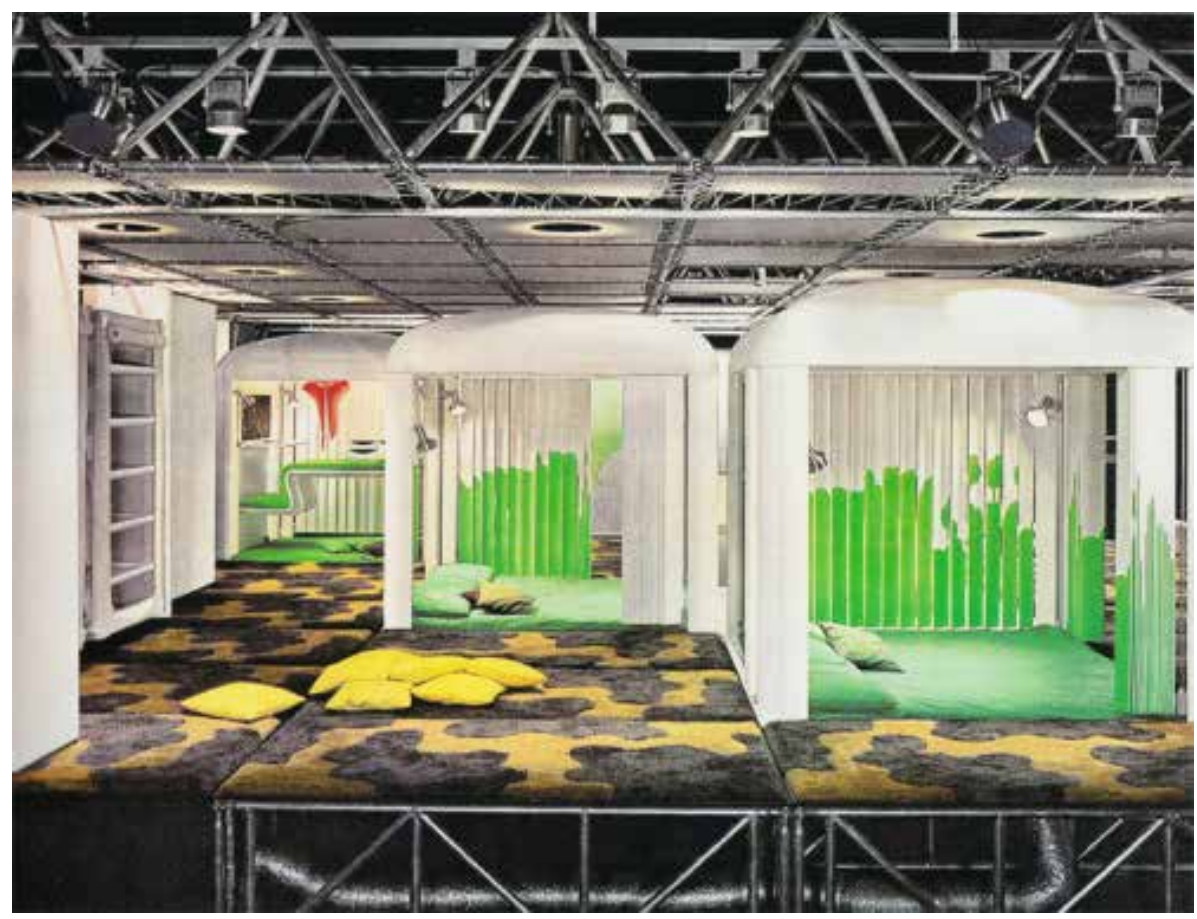

El mobiliario era modular y se integraba en el 'terreno'. Para el montaje trabajó en dos niveles elevando el nivel del suelo de manera que gracias a un sistema de dispositivos eléctricos podía esconder los elementos bajo el piso. Aquellas topografías iban generando las zonas de estar y de descanso a diferentes niveles, y se iban transformando a lo largo del día para permitir diferentes configuraciones. Los dormitorios parecían pequeñas cabañas que se distribuian en aquel paisaje ficticio. Esta instalación representaba el concepto de vivienda entendida como lugar, donde primaba la armonía entre las personas, y entre las personas y la naturaleza.

Años después, en 1974, Bayer produjo 'Visiona 4' en 'Heimtextl', Feria de Textil y Hogar de Frankfurt. En este caso ya no se actuó como en anteriores

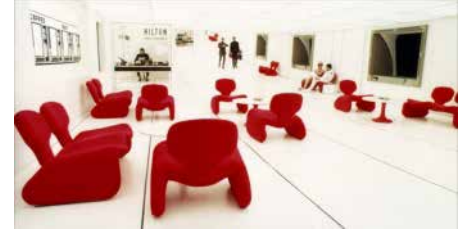

Imagen: Fotograma de 2001: una odisea del espacio, (Kubrick, 1968) Mobiliario de la serie Djinn de Mourgue en la Estación Espacial Hilton

Imagen: Olivier Mourgue, "Visiona-3". 1971. Vista del conjunto 
ocasiones, sino que se trabajó en el sentido más directo de presentación de textiles para el hogar. Fue el diseñador textil estadounidense Jack Lenor Larsen el encargado del montaje.

En 1980, también en Frankfurt, 'Visiona 5' fue de mano del arquitecto Paolo Nestler. Definitivamente se había convertido en lo que desde el principio estaba destinado a ser: un acto público para la comercialización de los últimos avances en textiles para el hogar de la empresa química Bayer.

Los 4 primeros 'Visiona' sin embargo fueron una excusa para crear un marco singular que estableciera pautas de modos de vida del futuro para el presente, con acercamientos a la era espacial, aprovechando al máximo las posibilidades que ofrecía la tecnología para crear hogares flexibles en espacios polivalentes, pero sin restar esfuerzos en la creación de atmósferas que propiciaran la sensación de bienestar, en estimular los sentidos con lugares imaginarios de formas psicodélicas, o en hacer vivir al hombre, de manera simulada, en armonía con la naturaleza a través de un espacio doméstico 'paisaje' que de manera artificial representaba un estilo de vida al aire libre. 


\subsection{EL NUEVO 'PAISAJE' DOMÉSTICO}

Lo que Ambasz ${ }^{27}$ había comprendido era que el diseño en Italia se estaba moviendo más allá de ser un arte aplicado. Se estaba convirtiendo en un lenguaje capaz de hacer comentarios sobre la realidad. El concepto de la exposición era ofrecer al público estadounidense la idea de que el diseño tiene un significado mayor, no sólo el de una colección de objetos banales, sino que puede explorar en los problemas existenciales.

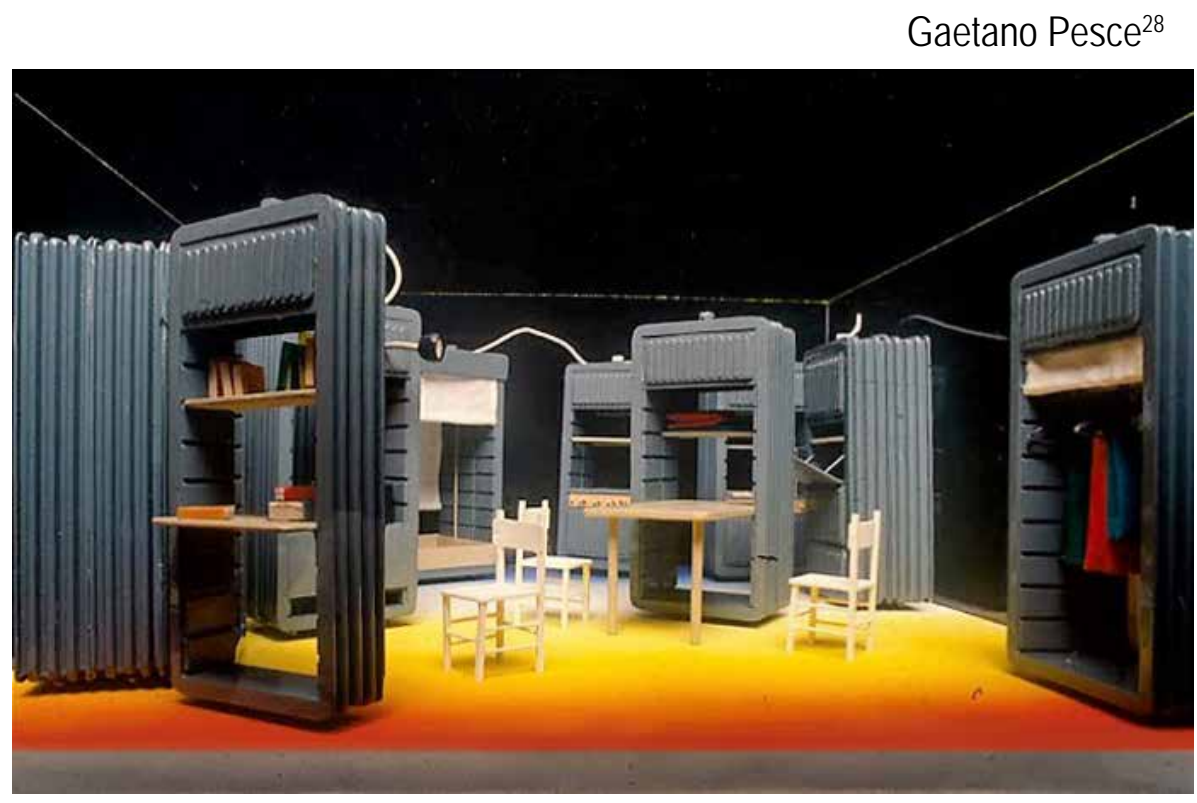

El diseño de ambientes domésticos para las exposiciones empezaba a tener también implicaciones socio-políticas, culturales, revolucionarias, etc., sin perder sus tradicionales implicaciones tecnológicas y poéticas. El diseño de los elementos domésticos empezaba a ser utilizado como vía de reivindicación en un nuevo panorama social.

En 1966 en la Galleria Jolly, Pistoia (Italia), se presentaba "Superarchitettura", una exposición y un manifiesto que hacían crítica sobre los principios establecidos en una sociedad de consumo: "la superarquitectura es la arquitectura de la superproducción, del superconsumo, de la superinducción al superconsumo, del supermarket, del superman, de la gasolina súper"..., era la primera vez que los grupos Archizoom y Superstudio organizaban una exposición juntos, y en ella mostraban también por primera vez una visión más radical de la arquitectura y del diseño sustituyendo imágenes domésticas tradicionales por un mundo alienante de objetos y visiones.

La continuación de esta exposición fue un año después. "Superarchitettura-II", se celebraba en el Instituto de Cultura de Módena en marzo de 1967. Para sus montajes utilizaron la técnica del supergráfico, traído desde América, e introdujeron mobiliario diseñado expresamente para la exposición. Algunos de estos objetos fueron producidos posteriormente por la empresa Poltronova, destacando el sofá 'Superonda' de Archizoom y la lámpara 'Passiflora' de Superstudio. En todos ellos se presentaron estampados con ondas y juegos geométricos de intensos colores como forma de adhesión Pop a la sociedad de consumo, sobre la que estaba basada la exposición.

27 Emilio Ambasz era comisario del Departamento de Arquitectura y Diseño del MoMA de Nueva York cuando se celebró la exposición 'Italiy: the New Domestic Landscape', en 1972.

28 Gaetano Pesce, c.p. Pete Collard en "Italy: The New domestic Landscape" Disegno Daily (nov2013) https://www.disegnodaily.com/article/italy-the-new-domestic-landscape
Imagen: Ettore Sottsass, ambiente creado para la exposición: "Italy: the New Domestic Landscape". MoMA Nueva York, 1972.

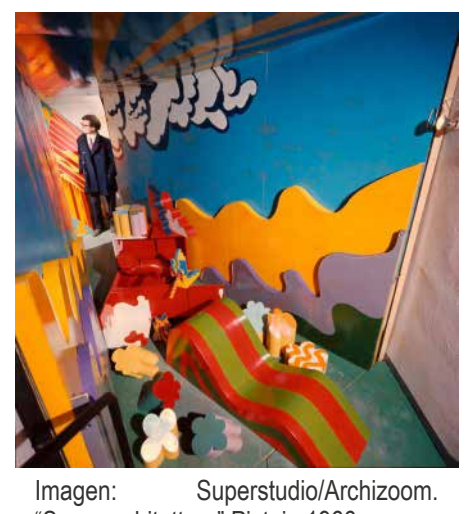

"Superarchitettura".Pistoia,1966 
Imagen: Exposición de objetos en el exterior del museo, creado por Cristiano Toraldo di Francia para la exposición: "Italy: the New Domestic Landscape". MoMA Nueva York, 1972.

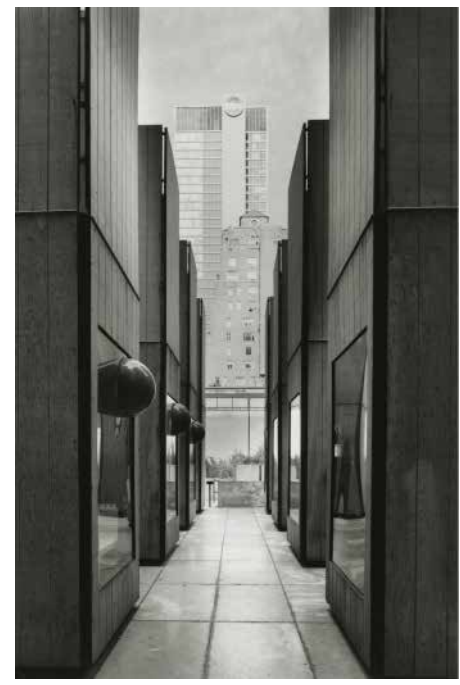

Imagen: Exposición de objetos en el exterior del museo, MoMA Nueva York, 1972.

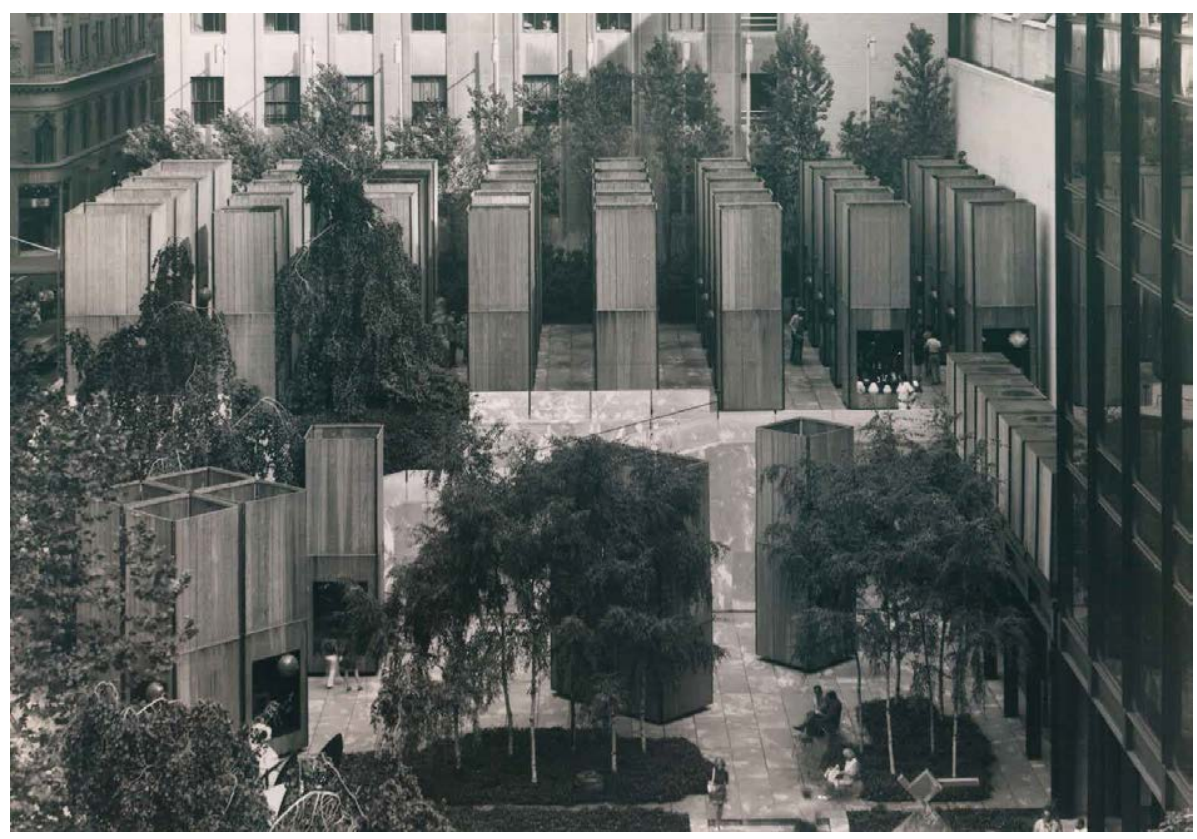

Quizá la más importante muestra que daba testimonio de la nueva manera de entender el panorama doméstico se produjo en verano de 1972 en el MoMA de Nueva York. En aquel momento, en el Museo de Arte Moderno, se celebraba una exposición, que fue revolucionaria, sobre diseño de objetos en relación con el mundo doméstico del momento. La muestra se centró en el diseño realizado en Italia, como el más representativo a nivel mundial, lo cual era constatado tanto por la organización del museo como por la crítica. La exposición, no por casualidad fue llamada Italy: The New Domestic Landscape, e iba dirigida a mostrar a sus visitantes cómo estaba evolucionado la aplicación del diseño en el ámbito doméstico, teniendo en cuenta el cambio de las necesidades físicas, biológicas, psíquicas y sociales del habitante contemporáneo, así como los avances técnicos y de nuevos materiales que permitían que el diseño avanzara con más rapidez en sus respuestas. La idea de la exposición, en parte, era ofrecer al visitante una visión del diseño del momento como un lenguaje capaz de opinar sobre la realidad, y ahí radicaba su novedosa configuración. No se planteaba como una simple exhibición de objetos, sino que se le otorgó una mayor significación ahondando en los problemas sociales y explorando en temas existenciales.

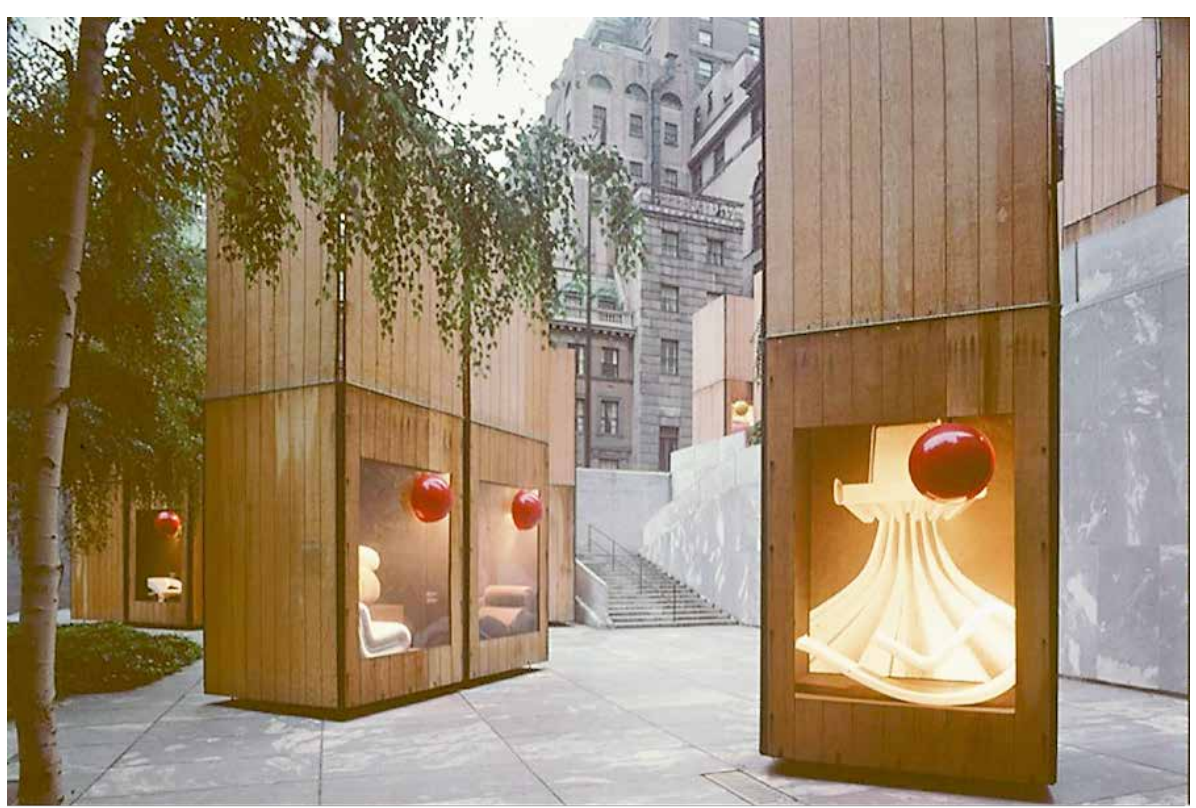


La intención era, una vez finalizada tras el verano, hacer viajar la exposición por los museos de los Estados de Norteamérica, sin embargo, por problemas económicos y de organización la muestra volvió a Italia. A pesar de su brevedad la exposición se convirtió en un hito en la historia del diseño, tanto de objetos como de espacio doméstico.

La muestra fue comisariada por el arquitecto Emilio Ambasz a través del departamento de diseño del museo. Fue organizada en dos partes diferenciadas: una la de los objetos, y otra la de los ambientes ó environments. En el jardín del museo se expusieron los objetos. La colección consistía en más de 150 piezas entre sillas, mesas, lámparas y demás artículos para el hogar diseñados en Italia y producidos por empresas como Artemide, Cassina o Kartell, entre otras.

Se presentaron dentro de cajas de madera con vitrina en el exterior del museo, con el fin de poder ser observados desde fuera, dispuestos como si estuvieran en grandes urnas en un montaje en el que una cuadrícula de cajas de considerable altura hacía alusión al skyline de Nueva York.

Los objetos expuestos se organizaron en grupos según unos criterios de selección que abordaban aspectos estrechamente relacionados con las necesidades de la vida doméstica contemporánea, como la implicación sociocultural, la innovación técnica y formal, o la flexibilidad, tanto en la colocación como en el uso. Las vitrinas se diseñaron con la intención de seducir, tal y como lo hacían los escaparates de la ciudad de Nueva York.

Se trata de la muestra más visitada del MoMA hasta el momento y supuso un éxito tanto de público como de prensa, de hecho la revista Time llegó a atribuir "el dominio del mundo del diseño de los 70" a los diseñadores italianos. La misma repercusión tuvo en las revistas especializadas, evidentemente en las italianas como Domus y Casabella, y en revistas internacionales que publicaban números especiales sobre la exposición sólo algunas semanas después de haber sido inaugurada.

Se presentaba como un evento de gran importancia por ser representativo de las formas y tendencias de vanguardia y por ofrecer una amplia panorámica de todo lo que se estaba moviendo en torno al diseño. La exhibición, a pesar del éxito del que gozó, no viajó según lo previsto. En septiembre de 1972, una vez finalizada la exposición volvió a Italia y de allí viajó a Estocolmo, Basilea y Barcelona.

A pesar de no cumplirse las expectativas de distribución iniciales, esta muestra se ha convertido en un icono de la historia del diseño por lo que mostraba y del montaje de exposiciones, por cómo lo mostraba. Parte de su éxito radicaba en el sistema de organización por el que se había optado para llevar a cabo la muestra. La exhibición contaba con dos partes diferenciadas y separadas tanto conceptual como físicamente en el espacio del propio museo: por un lado se desarrollaba la muestra de objetos en el jardín exterior, de lo que anteriormente se ha hecho mención, y por otro lado, en el interior del edificio del MoMA, se llevaba a cabo la otra parte de la muestra, que consistía en la recreación de ambientes.

Cuando Ambasz viajó a Italia para organizar la exposición descubrió que los diseñadores estaban trabajando en los objetos, pero en realidad estaban pensando en su entorno, en el ambiente en el que iban a ubicarse. El organizador

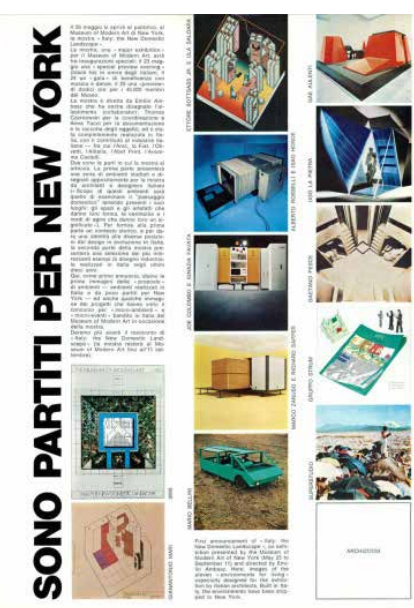

Imagen: Publicación en la revista Domus sobre los 'ambientes' creados por los 12 diseñadores para la exposicion. MoMA Nueva York, 1972

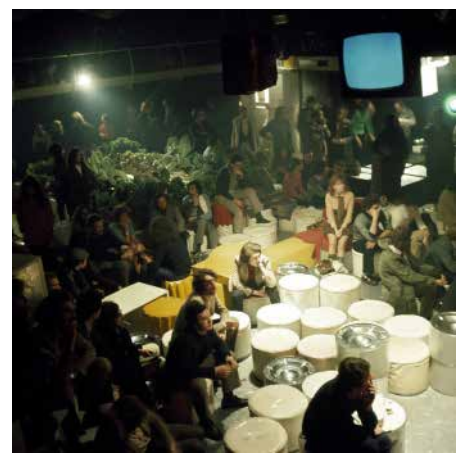

Imagen: Ambiente creado por 9999 para la exposición. MoMA Nueva York, 1972. 


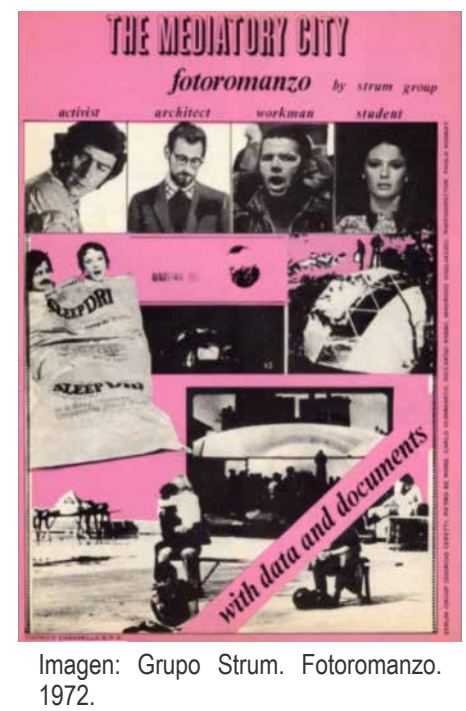

sentía que la industria (que cumplía un papel importante en aquella muestra) no ofrecía la oportunidad a los diseñadores de generar esos ambientes, por temas económicos y comerciales. Por ello decidió invitar a varios diseñadores a generar aquellos entornos para presentarlos como parte de la exposición. Contó con 12 arquitectos y diseñadores italianos, que participaron en este proyecto con propuestas muy diversas: Ettore Sottsass, Joe Colombo, Gae Aulenti, Mario Bellini, Alberto Rosselli, Richard Samper/Marco Zanusso, Gaetano Pesce, Ugo la Pietra, Grupo Strum, Archizoom, Superstudio y 9999. Los ambientes se encargaron según un programa que elaboró el director de la exposición, con consideraciones tanto generales como particulares sobre "el mundo doméstico de hoy y del mañana", con el fin de que indagasen sobre el espacio doméstico contemporáneo y que ofreciesen su visión a modo de instalación, y que pudiera exhibirse ajustándose a un recuadro de $4,80 \times 4,80 \mathrm{~m}$ con una altura máxima de $3,60 \mathrm{~m}$, además todos los diseños 'físicos' debían incluir un podio de $40 \mathrm{~cm}$ de altura en la base. El programa ofrecía la posibilidad de hacer un acercamiento a nuevas experiencias perceptuales "que concurren entre el hoy y el mañana"29, y a la búsqueda de la calidad de la existencia diaria sin ignorar los problemas de la sociedad del momento como la polución, el deterioro de las ciudades, la pobreza, etc. La intención era explorar sobre posibles soluciones a aquellos problemas y también la de propiciar a investigación sobre los significados que los ritos a lo largo de las veinticuatro horas encierran, diseñando espacios y los objetos que proporcionaban su estructura $^{30}$. Según el programa los participantes, como respuesta, propondrían microentornos (microenvironments) y microenventos, diseñando 'espacios y artefactos' que, de forma individual o colectiva, fueran soporte de la vida doméstica y mostrasen las ceremonias derivadas de su propio uso, en relación con los espacios y los objetos de su entorno.

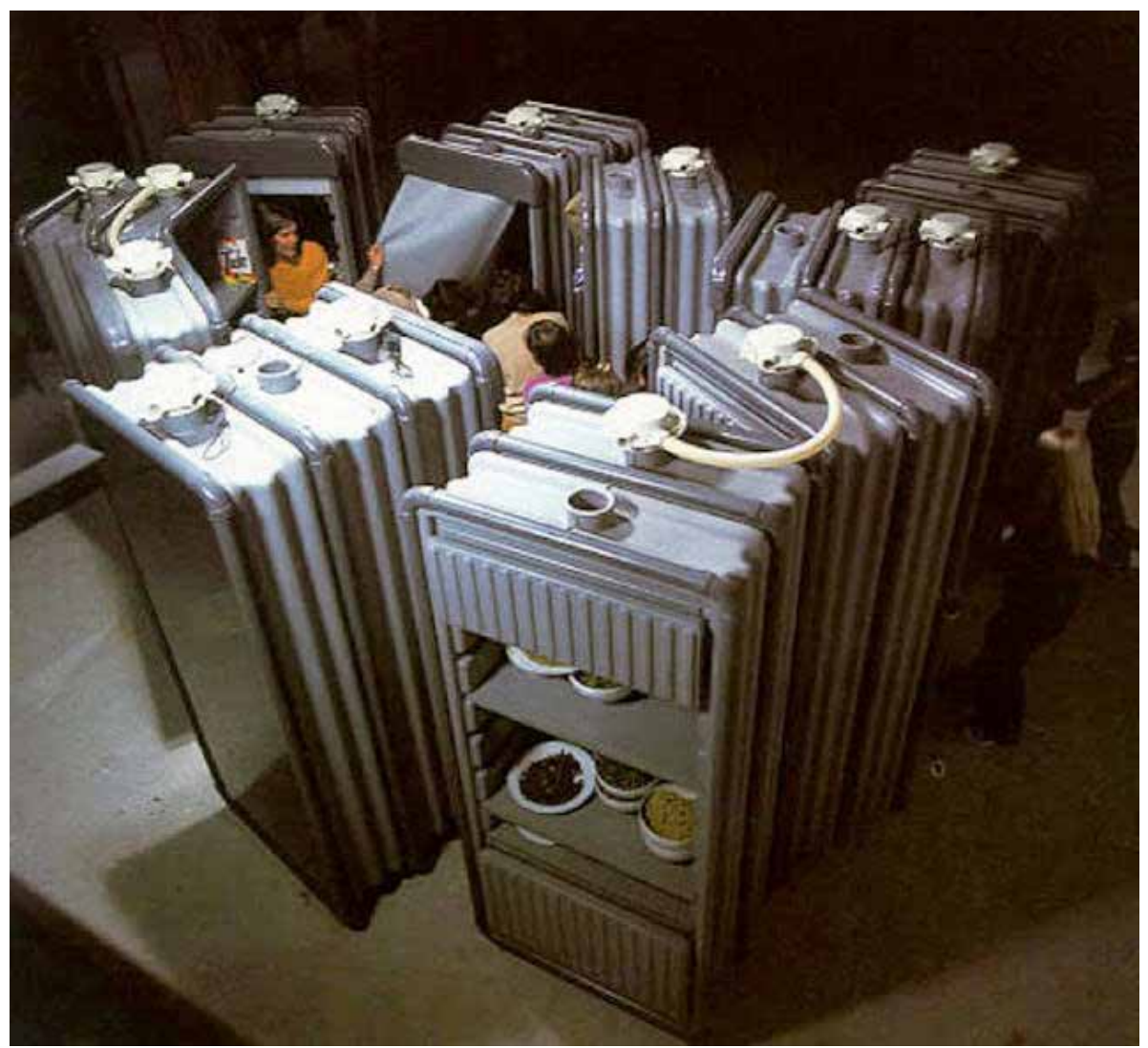

Imagen: Ambiente creado por Ettore Sottsass a base de contenedores de plástico intercambiables para la exposición: "Italy: the New Domestic Landscape". MoMA Nueva York, 1972.

29 Emilio Ambasz, "El diseño como postulación". Temas de Diseño (n 3 julio-agosto 1972) p.15.

30 Emilio Ambasz. Editado por. Italy the New Domestic Landscape. Achievements and Problems of Italian Design. (Nueva York: New York Graphic Society, 1972) p.139. 
Los diseñadores invitados, según la organización de la exposición, representaban dos actitudes en el mundo del diseño en Italia. La primera involucraba al diseño como actividad capaz de resolver, en términos físicos, los problemas que surgían del ámbito socio-cultural y del natural. A este grupo de diseñadores, que creían en el diseño como actividad positiva, se les pidió una propuesta tangible, que pudiera exhibirse dentro de los límites físicos de la convocatoria, y que fuese resultado de sus investigaciones sobre el paisaje doméstico entendido como lugar, sobre el espacio y los objetos que le daban forma y sobre los comportamientos en sus relaciones, que les otorgaban significado. Se les pidió también hacer especial hincapié en las nuevas formas y patrones de uso que eran resultado de los nuevos modos de vida, en las relaciones sociales y familiares más informales, en la evolución de las nociones de privacidad y comunidad, así como en la investigación sobre nuevos materiales y técnicas de producción.

Los ambientes no debían concebirse como unidades aisladas, contenidas en sí mismas, sino que debían exponer ideas avanzadas sobre vivienda y que fueran explícitas para conseguir nuevos conceptos sobre habitabilidad.

La otra actitud, según la organización, era la opuesta. Esta otra corriente calificada como 'contradiseño' apostaba, puesta en evidencia una necesidad, por una renovación del discurso filosófico y por el compromiso social y político, como solución a dicho problema. Con esta actitud se desligaban de los objetos y de los espacios heredados de la cultura tradicional para llegar a una forma ideal de vida. Para estos grupos se creó una plataforma desde la cual los diseñadores invitados que decidieran no producir instalaciones físicas conforme al programa, pudieran presentar sus manifiestos filosóficos y políticos.

Respecto a aquellas propuestas, Ettore Sottsass produjo una serie de armarios intercambiables y móviles, moldeados en plástico gris, todos aparentemente iguales. Su idea era eliminar las jerarquías típicas de los hogares tradicionales. En palabras del propio autor ${ }^{31}$ :

Mis muebles, a la vista en esta exposición no pueden ser más que prototipos, incluso pre-prototipos y por lo tanto si te acercas a ellos te das cuenta de que casi nada funciona, de que no fluye nada por las tuberías, de que la estufa no calienta, que la nevera no enfría, y así sucesivamente. Estos muebles representan una serie de ideas, no son productos que se pondrán en el mercado de la noche a la mañana (...) Debe dejarse muy claro que el objetivo del proyecto no es lograr un producto, sino generar ideas, no me preocupaba en absoluto la fabricación de muebles, ni un ambiente elegante, agradable, bonito o divertido y menos me preocupaba diseñar cosas silenciosas que permitieran al espectador estar tranquilo y feliz dentro de un ambiente que mantuviera psíquica y culturalmente su status quo. Realmente he hecho lo contrario. El ambiente generado no es bonito en absoluto, es una especie de orgía del uso del plástico considerado como un material que permite un proceso casi completo de 'des-condicionamiento' de la cadena interminable de auto-indulgencias sobre la posesión. Me refiero a la posesión de objetos, al placer de poseer algo que nos parece precioso porque está hecho con materiales preciosos, porque su forma es preciosa, porque es difícil de conseguir, porque es frágil, etc.

31 Ettore Sottsass. Ibíd. p.162. 
Imagen: Ettore Sottsass, distintas combinaciones de muebles-contenedor para la exposición: "Italy: the New Domestic Landscape". MoMA Nueva York, 1972. Catálogo

La forma no es bonita, es más bien brutal y desagradable, y el proceso de 'des-condicionamiento' esperado impondrá ciertamente una responsabilidad a cualquiera que se arriesgue a usar estos objetos.

Para explicar esto más fácilmente, digamos que la idea era tener éxito en hacer muebles de los que nos sintiéramos tan desarraigados que no tuvieran ninguna importancia para nosotros. De esa forma, por lo menos es la intención, pasado el tiempo se desvanezcan y desaparezcan.

Los muebles se convertían en contenedores equipados en los que, como en cajas ordinarias, se colocaban todos los demás elementos para suministrar todo lo necesario para el catálogo de necesidades que la sociedad industrial requería. Había fuegos para cocinas, nevera para guardar los alimentos, armario para la ropa, ducha, un sitio para sentarse a leer, una juke-box para música, una librería, etc. El catálogo de necesidades crece o disminuye de acuerdo a la cultura o al grupo étnico al que pertenece el usuario, pero los contenedores permanecen impasibles. No existiría ningún vínculo formal con los propietarios. Utilizarán más o menos contenedores, poseerán más o menos y resolverán en términos de cantidad en lugar de calidad. Los elementos disponían de ruedas para poderlos mover, juntarlos o separarlos.

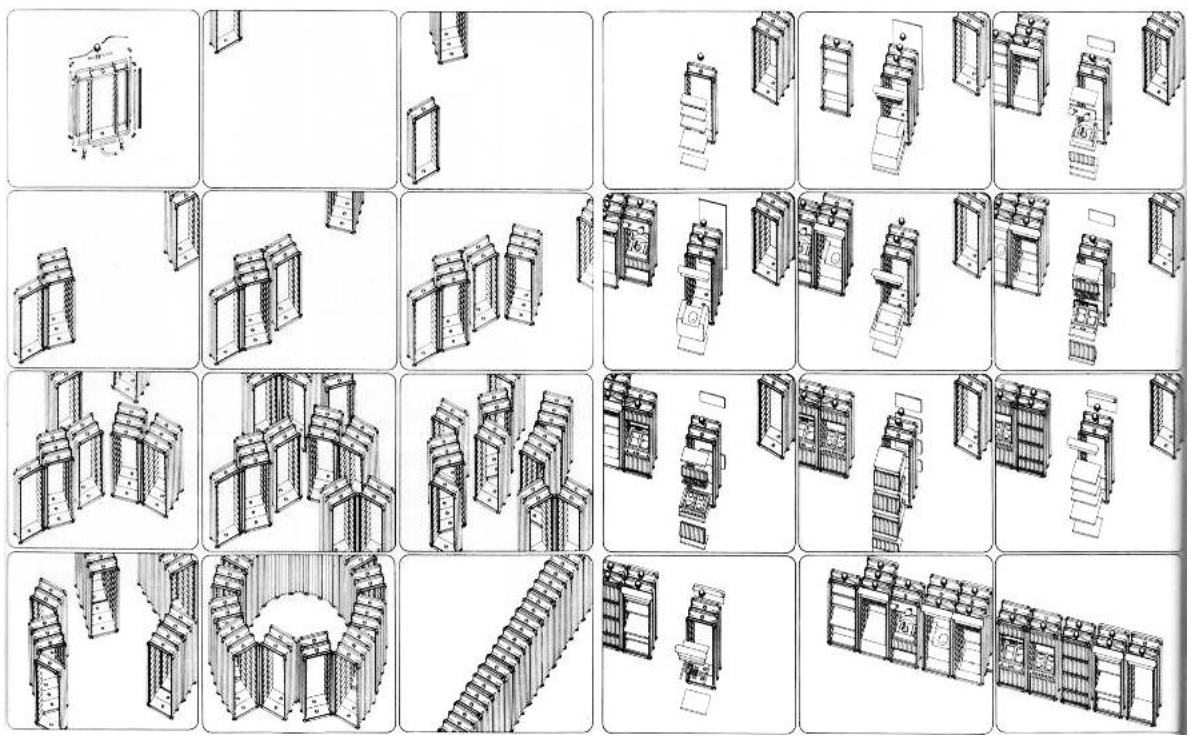

Los muebles propuestos por Sottsass podían unirse con bisagras desmontables y se conectaban con diferentes salidas de energía eléctrica, agua y aire que también eran desmontables. Los muebles no sólo podían agruparse sino que podían crear grupos que generaban formas sinuosas como una serpiente 0 como decía Sottsass "crear formas rígidas como la Gran Muralla China". El sistema también podía crear áreas cerradas o abiertas, profundas y estrechas, y también amplias; de esta forma proporcionaban la forma más adecuada para cada momento "para el drama que está a punto de tener lugar". En esta propuesta surgían cuestiones sobre la relación entre un entorno y los acontecimientos que se pudieran producir dentro de dicho ámbito.

Según el autor de la instalación, parecía que sí existía alguna relación entre el ambiente y los acaecimientos. De hecho dando por hecha dicha relación, la idea de ese entorno de muebles sobre ruedas, era que a través de su neutralidad y movilidad, de su forma informe y camaleónica, de su habilidad para arropar cualquier emoción sin llegar a involucrarse en ella, podía provocar una mayor consciencia de lo que estaba sucediendo y sobre todo de nuestra 
propia creatividad y libertad. Esto propiciaba que, en un momento dado, todos pudieran adaptar la configuración de su casa según las necesidades diarias.

El ambiente que presentó Gae Aulenti, pretendía crear nuevas experiencias a través de la relación y la combinación de diferentes elementos. Las posibilidades de su combinatoria dejaba la puerta abierta a múltiples aplicaciones. Para la creación de su propuesta, la autora se inspiró en un párrafo del texto de Jorge Luis Borges Fragmentos de un evangelio apócrifo (1969):

Nada está construido sobre piedra, todo está construido sobre arena, pero debemos construir como si la arena fuera piedra.

El entorno estaba formado por cuatro tipos de elementos. Cualquier combinación entre ellos adquiría cualidades volumétricas arquitectónicas generando espacios cóncavos y convexos. La intención era la de crear diferentes tipos de espacio en todo momento.

Los elementos en realidad eran muebles pero, inspirándose en el texto de Borges, estaban tratados como si fuesen edificios, y el escenario doméstico se convertía en la metáfora de un enclave exterior.

El primer elemento consistía en un sistema que incluía un mueble lineal y dos con forma angular, fabricados en poliéster y fibra de vidrio, en color rojo. Éstos podían combinarse de muy diferentes maneras para formar una cama,

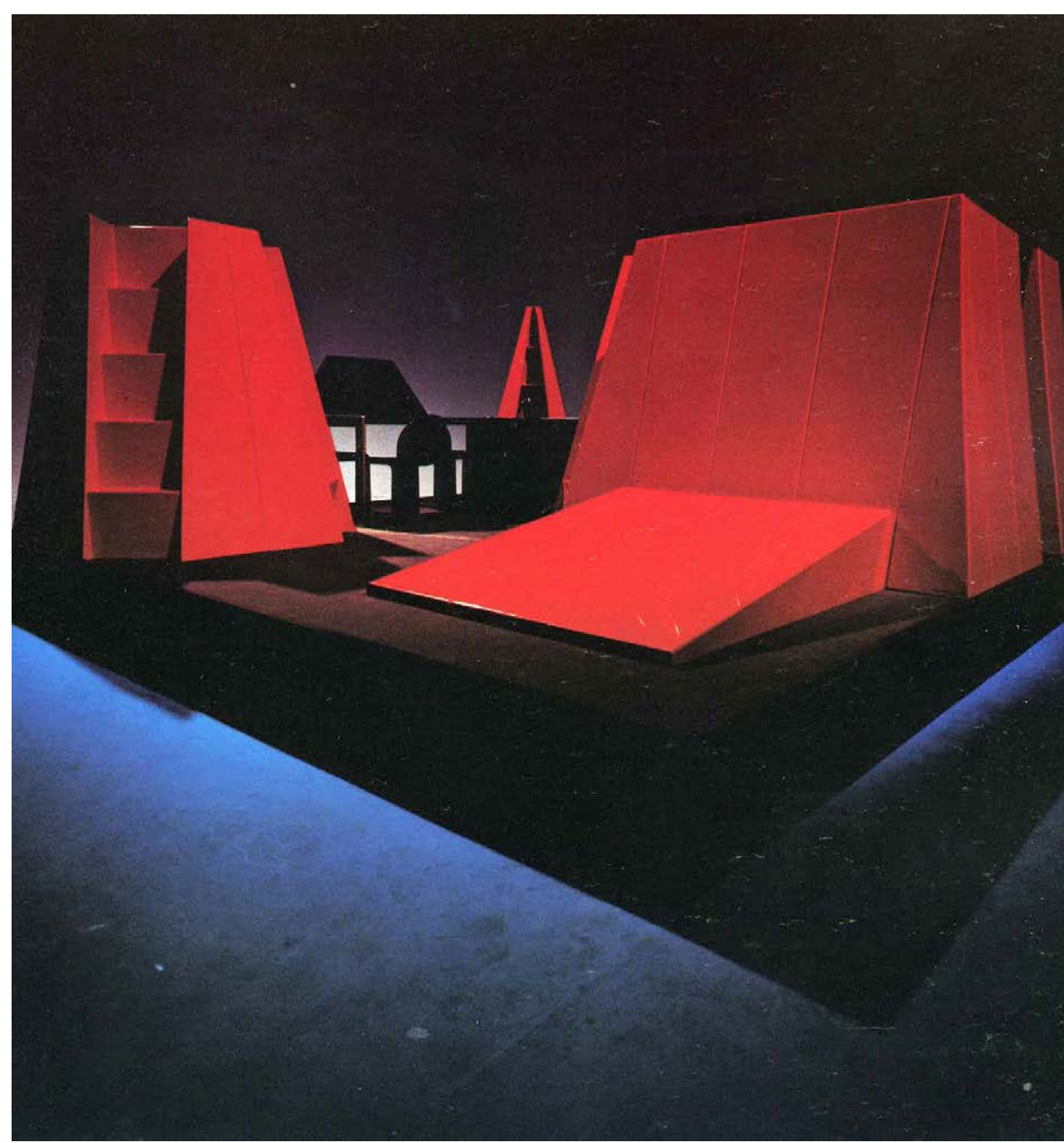

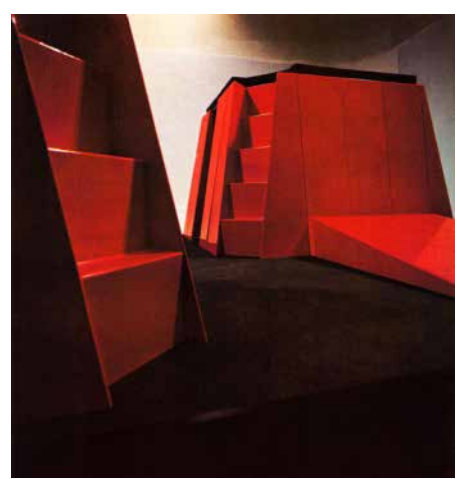

Imagen: Gae Aulenti, instalación para la exposición: "Italy: the New Domestic Landscape". MoMA Nueva York, 1972 


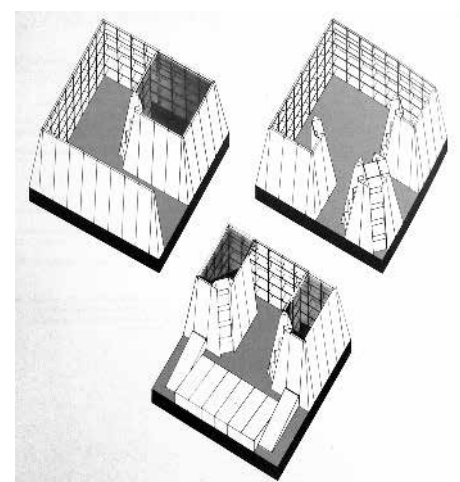

Imagen: Gae Aulenti, distintas combinaciones de elemntos para la exposición. MoMA 1972

Imagenes abajo a la derecha en orden: Unidad de Amueblamiento Total Combinaciones de modulos;

Unidad de Amueblamiento Total. Posibilidades de uso
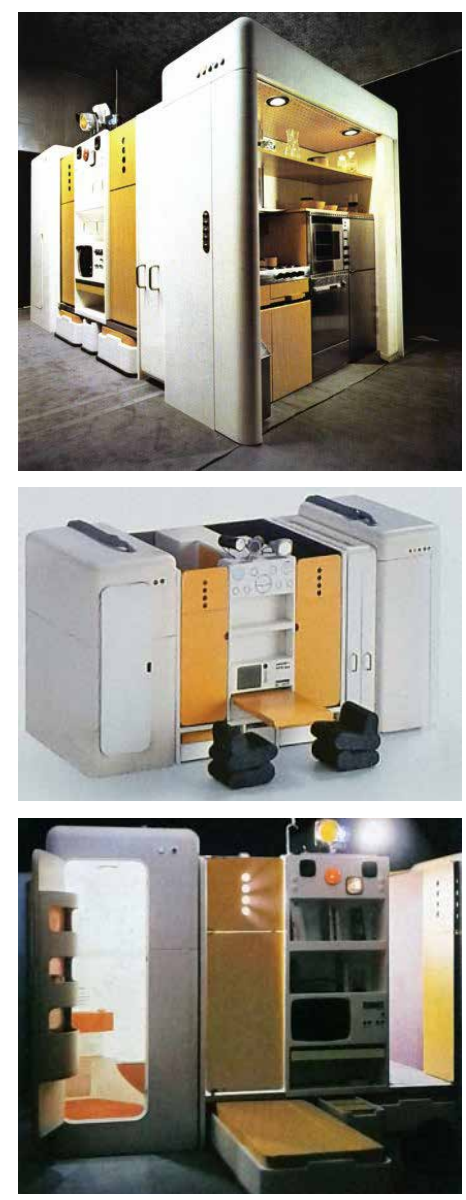

Imágenes: Joe Colombo: 'Unidad de Amueblamiento Total'. Instalación para la exposición: "Italy: the New Domestic Landscape". MoMA Nueva York, 1972. armarios, librerías o zonas donde sentarse ${ }^{32}$. Lo importante de la propuesta no eran los elementos en sí mismos, sino sus combinaciones y relaciones y la voluntad de generar experiencias a través de su vivencia.

El segundo componente consistía en una mesa extensible con dos unidades modulares de almacenaje y un tablero neutro con dos placas eléctricas de cocina, los materiales básicos empleados eran acero y plástico en color verde oscuro. El tercero era una silla de poliuretano rígido en color negro y de bordes redondeados, y el cuarto una lámpara metálica con ocho pantallas rotativas en color amarillo. Todos los objetos tenían implicaciones alegóricas en relación con sus formas: los elementos de almacenaje, por su forma piramidal hacian referencia a la arquitectura, el triángulo en la mesa era signo de mutabilidad, las formas redondeadas de la silla evocaban a las formas de una concha y por tanto a la naturaleza. La lámpara simbolizaba el fuego.

El arquitecto y diseñador milanés Joe Colombo también tuvo en consideración la combinatoria de elementos en su propuesta. A través del ambiente presentado en la exposición las intenciones iban dirigidas a formalizar sus investigaciones de los últimos años orientadas al campo de la ergonomía y la ecología, en una visión del hábitat como un microcosmos. Aquello serviría como punto de partida para la creación de un macrocosmos, que sería tangible en un futuro como un conjunto de estructuras creadas a través de sistemas programados de producción.

Según estos planteamientos, Colombo concebía el futuro de la vivienda como un sistema de unidades planeadas de acuerdo con la producción en serie y por ello las funciones debían ser casi perfectas. El espacio interior de la unidad sería dinámico, es decir, estaría planeado para poder estar en estado continuo de transformación. Físicamente sería un elemento cúbico, más pequeño de lo normal pero que sin embargo estaría aprovechado al máximo economizando sobre todo en su distribución.
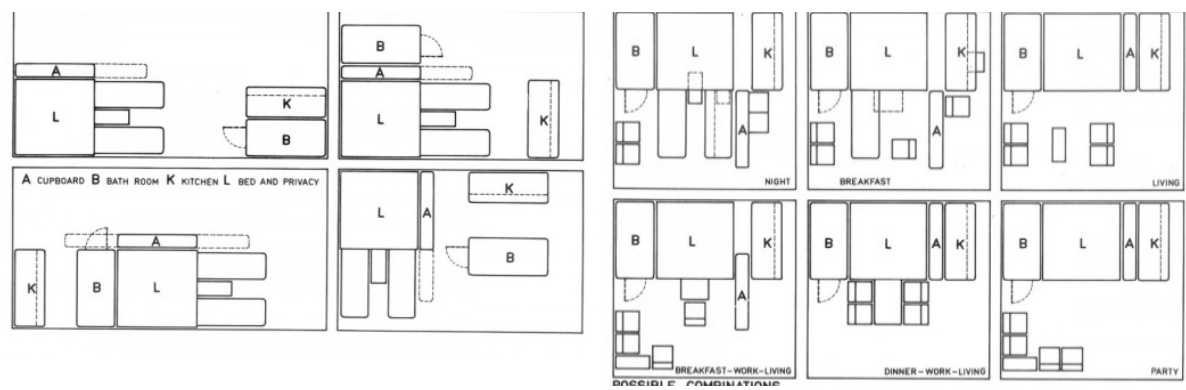

Para la exposición Colombo propuso una serie de 'Unidades de Amueblamiento Total', Total Furnishing Unit, desarrolladas para cumplir las funciones del hogar y de la vida privada con flexibilidad adaptándose a diferentes espacios y necesidades. Se proponían cuatro tipos de Unidades: cocina, armario, dormitorio y baño. Mientras que la cocina y el baño sólo servían para lo que habían sido creados, las otras unidades como el armario también servía como elemento separador entre la entrada y la zona que eventualmente se utilizara por la noche, y el dormitorio contenía todo lo necesario para las necesidades relacionadas con dormir, comer, recibir amigos o retirarse privadamente a un espacio interior diseñado específicamente para ese fin. Las unidades estaban

32 En la imagen: la combinación de elementos generaba unidades externas e internas de almacenaje, un recinto cuya cubierta se podía utilizar como cama y una plataforma inclinada para descansar. 
fabricadas en plástico laminado, tela plastificada y aluminio, en colores blanco, rojo, amarillo y violeta, y permitían diferentes combinaciones y agrupaciones. Esta exposición se había convertido en un tema de Estado para el gobierno italiano. Realmente, el nuevo panorama social y, por extensión, su traducción a los hogares de los ciudadanos era un tema que también venía interesando al Ministerio de Cultura francés a través de los ateliers experimentales de diseño para el hábitat promovidos por la institución 'Mobilier National', que dependía del ministerio.

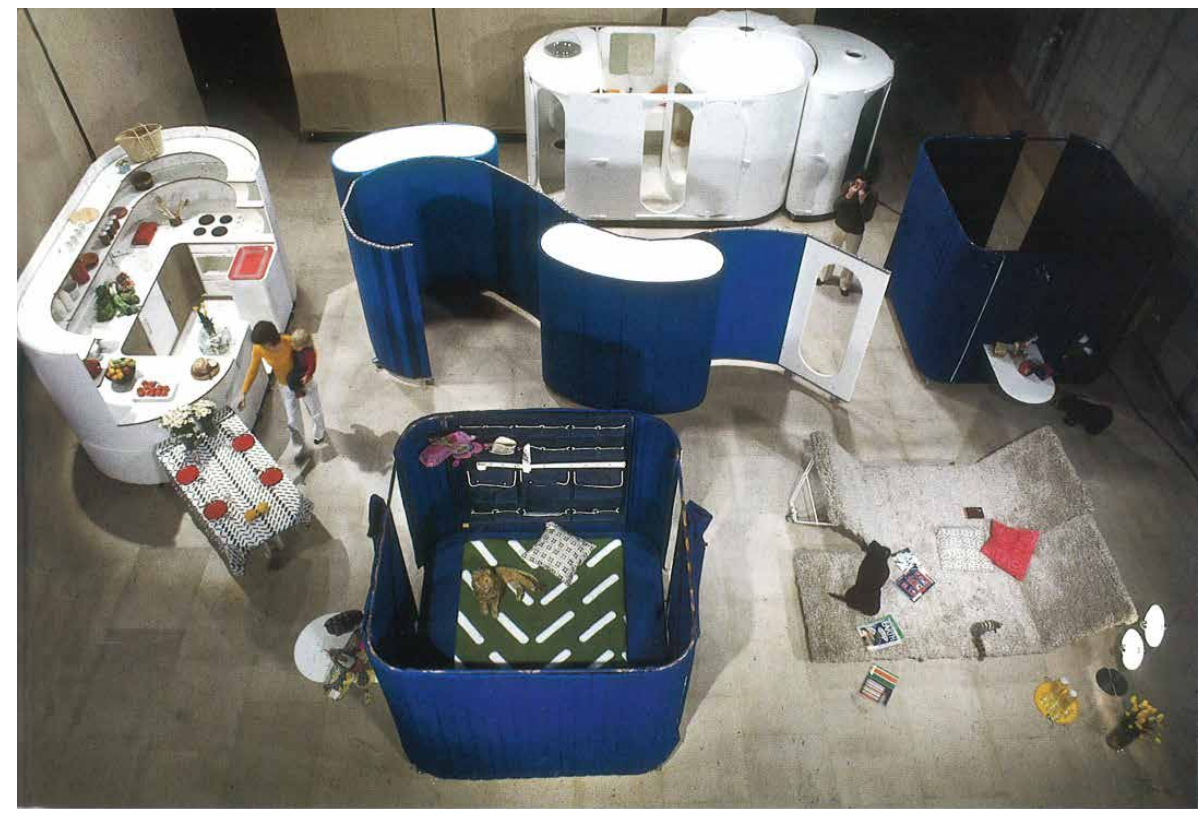

En octubre de 1971, se celebraba la muestra de diseño francés en el Centro de Creación Industrial de París, ese año concretamente sobre prototipos, como soluciones flexibles para alojamientos sociales.

El diseñador francés Olivier Mourgue aprovechó la exposición para presentar una propuesta concebida en los talleres de Mobilier National, que era el resultado de sus investigaciones realizadas sobre un sistema de configuración interior de un alojamiento tipo de dimensiones medias ${ }^{33}$ en un HLM tipo F4, de $80 \mathrm{~m}^{2}$, en uno de los nuevos complejos residenciales en la ZUP Zone à Urbaniser en Priorité, a las afueras de la ciudad de Rouen.

En esta propuesta de hábitat de dimensiones estándar, Mourgue proponía una nueva forma de vida mediante la sustitución de las áreas fijas de elementos funcionales básicos. Las particiones, los bloques de almacenamiento, los contenedores, podían deslizarse por separado, transformando el espacio mientras se adaptaban libremente de acuerdo al modo de vida que adoptara cada familia. Este espacio estaba concebido para una familia de cuatro personas, tenía, como se ha comentado anteriormente, una superficie de $80 \mathrm{~m}^{2}$ y no incluía divisiones internas fijas. La propuesta contaba con: cocina, baño, dormitorios - resueltos como bloques aislados y móviles, que se podían disponer de forma variable en el espacio libre y continuo - una mampara continua y articulada (a la que llamaba 'pantalla-mecano') que discurría adoptando formas libres, servía para separar áreas o definir recorridos, si fuera necesario. Los elementos consistían en dos bloques de noche, que eran dos cabinas móviles con ruedas, de estructura de aluminio y paramentos de tela. Estaban creados para dos personas cada uno (la superficie que ocupaban era de $\left.8,80 \mathrm{~m}^{2}\right)$. Por fuera tenían un sistema de paneles-contenedor con distintos
Imagen: "Habitat HLM type F4". Por Olivier Mourgue, 1971.

33 Olivier Mourgue. "In ottanta metri quadri”. Domus (n502, sept. 1971) 34-37. 
Imagen: Pantalla mecano, sistema de anclaje de los armarios a la mampara. Olivier Mourge, 1971.

Imagen: Pantalla mecano, detalle de la estructura segmentada con articulaciones. Olivier Mourge, 1971.

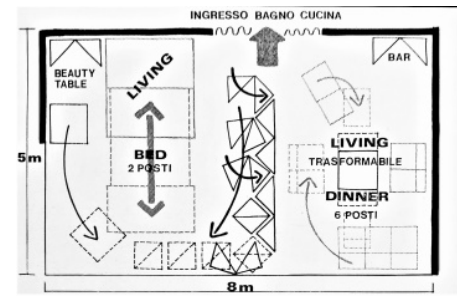

Imagen: Planta del stand de Colombo $8^{\mathrm{a}}$ edición Salone delle Arti Domestiche, Turín 1971. departamentos, también en tela, que se colgaban de los paramentos, tipo alforjas. También existían dos bloques, de cocina y baño. Ambos ocupaban el mismo volumen $3,60 \times 1,80 \mathrm{~m}$ y 1,83m de altura, y eran de plástico. El bloque del baño tenía dos entradas y estaba dividido en tres zonas.

La pantalla-mecano era el tercer elemento importante del conjunto. Consistía en un largo paramento articulado concebido básicamente para separar zonas. Los segmentos articulados eran de diferente ancho, los había de $10 \mathrm{~cm}$, de 20 y de 30 , todos con estructura base de aluminio y acabados en tela. Los diferentes anchos proporcionaban la opción de crear curvas más o menos cerradas. A este sistema se le podían incorporar unos armarios-contenedores, también móviles, los cuales tenían opción de insertarse en cualquier punto del recorrido.

El bloque cocina tenía en el interior electrodomésticos y amueblamiento fijos, así como dos contenedores cúbicos extraíbles montados sobre ruedas. En el exterior una mesa de comedor aparecía anclada a la pared curva del bloque, pudiéndose modificar el largo del tablero de la misma para cuando hubiese invitados. En ese caso los dos contenedores (que almacenaban los alimentos) se sacaban de la cocina y se ubicaban en el lugar donde hubiese que servir la comida. Para aumentar el efecto movible y transformable del sistema, las butacas y el sofá se sustituyeron por una 'alfombra-asiento', una especie de tarima acolchada y tapizada con los extremos reclinables, diseñada también por Mourgue.
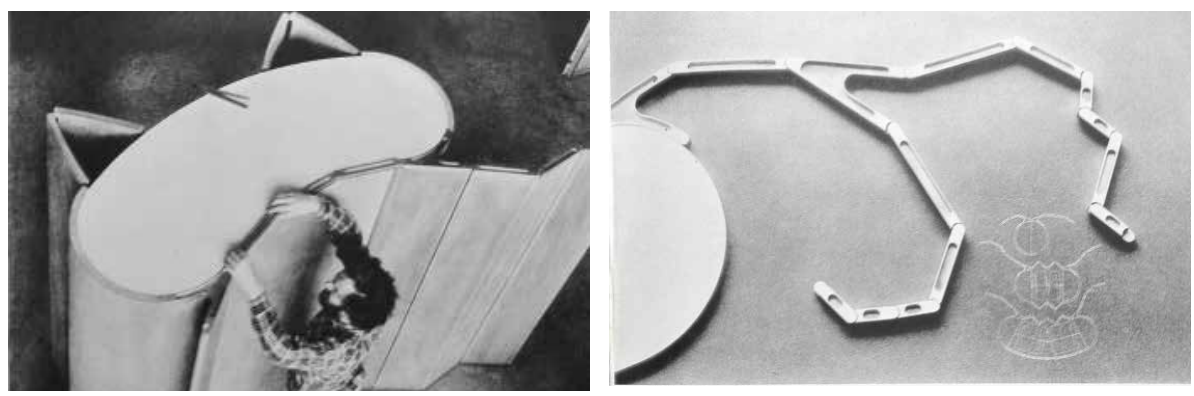

La propuesta de Mourgue, promovida por la administración francesa, era un ejemplo de que planteamientos anteriores, concebidos casi como utópicos, podían ser considerados como una solución real a las nuevas necesidades. A través de su exposición y su puesta en escena, se producía un acercamiento al nuevo panorama doméstico, ya no como crítica a los problemas sociales, como en el caso de la exposición del MoMA, sino como solución a los problemas de hábitat social, con vocación de ser factible. A través de un sistema organizado y flexible, de objetos y sistemas transportables, que se deslizaban sobre ruedas, que estaban realizados con materiales ligeros y que se articulaban como si fueran un mecano, Mourgue pretendía que el habitar pareciese más fácil y accesible a todos los estratos de la sociedad, interpretando un nuevo paisaje doméstico en el que los muebles - blandos y livianos - se disponían de forma libre como si de un escenario se tratara.

Poco tiempo después, 'Transformable' precisamente era el nombre dado a otra propuesta de Joe Colombo - esta vez un apartamento de $40 \mathrm{~m}^{2}$ de un solo ambiente, sin contar cocina y baño - para la muestra 'Nuove immagini della casa' en la octava edición del Salone delle Arti Domestiche, en Turín en 1971. El espacio recreaba una vivienda para tres personas y ofrecía la posibilidad de seis comensales. El ambiente ámbito ofrecía la posibilidad de mutar su aspecto y su uso a gracias a la diferente disposición de un sistema de elementos de 
almacenaje, todos ellos transformables y movibles. Los seis contenedores verticales, que se ubicaban inicialmente en el centro, conformaban un conjunto y podían desplegarse por todo el espacio, unirse, separarse, abrirse, cerrarse, etc. dependiendo de las necesidades de los usuarios.

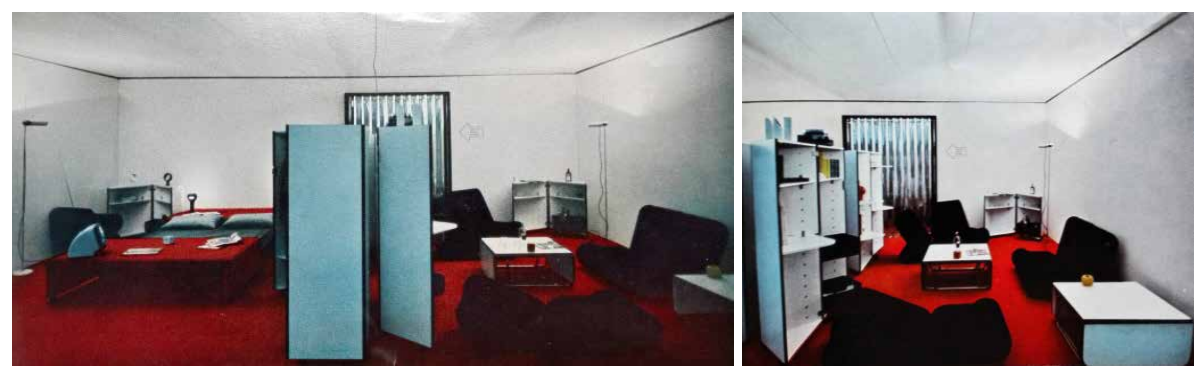

Este diseño, de Colombo, llamado 'Triangular system' comprendía un grupo de armarios de planta cuadrada y con abertura en la diagonal. Al abrirse por completo presentaban formas triangulares y gracias a un sistema de ruedas, podían desplazarse libremente, actuando en muchos casos como elementos separadores o integradores de ambientes.

El efecto 'mutante' de esta propuesta de Colombo, se potenciaba con otros elementos también con posibilidad de transformarse, como una plataforma deslizante sobre un sistema de raíles (tapizada en moqueta roja, como el pavimento) que a modo de puente cubría las camas (una cama doble y una individual) por el día, permitiendo que sobre esta plataforma se pudieran colocar cosas de uso cotidiano, como revistas, libros, televisión, etc.

Por la noche, se deslizaba para dejar descubiertas las camas. Otros elementos que contribuían a la mutabilidad del espacio, eran dos mesillas con alas plegables y las seis butacas de la serie "multi-chair" que podían configurar una zona de estar o una zona de comedor gracias a sus posibilidades de transformación.

Más de una década después, en 1983, a través de la exposición comisariada por Franco Raggi y Francesco Trabucco para la XVII Triennale di Milano, se producía desde Italia un nuevo acercamiento al 'paisaje' doméstico del momento. La muestra, llamada 'Le case de la Triennale. Otto progetti di ambienti domestici contemporanei', a pesar de su vocación experimental, reconocida por su organización ${ }^{34}$, pretendía asomar al espectador, suscitar su interés y estimularle sobre la evolución de las preferencias y de las tecnologías aplicadas al diseño de objetos de uso cotidiano.

Lejos de ser una simple exposición de productos industriales, la muestra sirvió para reflexionar sobre el espacio doméstico del momento, como vía para hacer sugerencias, o como medio para representaciones simbólicas; pero también, en muchos de los casos, permitió que se mostraran verdaderos prototipos realizados gracias a la contribución y la colaboración de empresas productoras de mobiliario u otros elementos domésticos. El conjunto ilustraba sobre cómo habían evolucionado los gustos del consumidor, sobre sus preferencias y sobre la cultura formal del hábitat. En una civilización que presentaba una brecha dramática entre lo urbano/colectivo y lo doméstico/privado, la casa se presentaba como el último espacio que se prestaba al ejercicio de la imaginación. En ese universo el individuo buscaba los espacios posibles para su representación, repartidos entre el supermercado, los medios de comunicación y los catálogos de venta por correspondencia. Para ello, de nuevo,

34 Eugenio Peggio, "Presentazioni", en Le case de la Triennale. Otto progetti di ambienti domestic contemporanei. Editado por Franco Raggi y Francesco Trabucco (Milán: Electa, 1983) p.7.

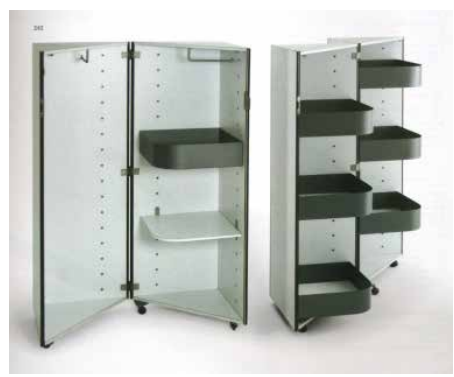

Imagen: contenedores de la serie "Triangular system". Diseño de Joe Colombo, 1968.

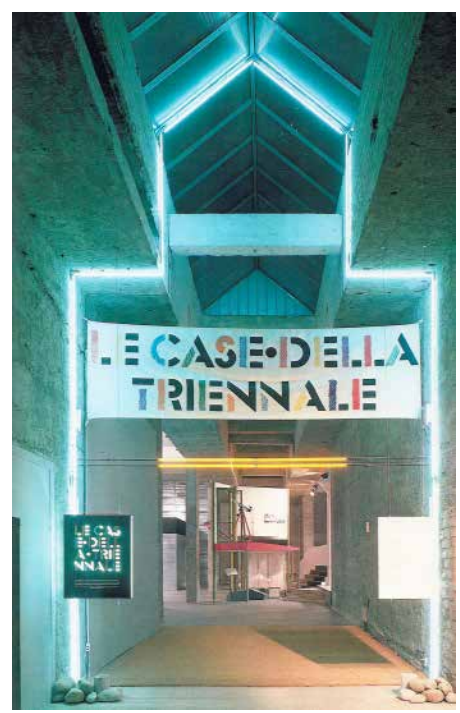

Imagen: "Le case de la Triennale", XVII Trienal de Milán, 1983. 
se recurrió al sistema de recreación de ambientes domésticos, proponiéndose así ocho temas desarrollados por ocho diseñadores, tanto desde el punto de vista psicológico como funcional, como auténticas metáforas del habitar del momento. Las propuestas contraponían a la descripción prosaica del proyecto, basado en modos de habitar según los paradigmas del momento, la poética y la simbología aplicados a la escena doméstica, donde la cualidad no estaba tan ligada a los objetos en sí como al proceso que los relacionaba ${ }^{35}$.

En algunas de las propuestas de esta muestra, la casa podía convertirse también en el enclave para los recuerdos, en el museo de uno mismo, en un enclave donde los objetos destacaban más por su significado que por su utilidad. Precisamente porque el diseño de objetos domésticos no dejaba reconocer suficientemente su sentido en la idea de utilidad, la casa seguía siendo el terreno perfecto para renovar, para expresar la poética que nacía a partir de las relaciones entre los objetos y el espacio, más la contribución de otros agentes ambientales como la luz, el color o el sonido de una casa.

Esta exposición pretendía reflexionar pues sobre los nuevos modelos de vivienda que habían surgido en base a los modos de vida del momento, sin perder el carácter poético y experimental, y con el objeto de uso doméstico como elemento fundamental para la recreación de ocho espacios diferentes, en base a sus significados, a sus relaciones, pero también a la técnica y al diseño sobre lo cual, en gran medida, se justificaba la presencia de los patrocinadores.

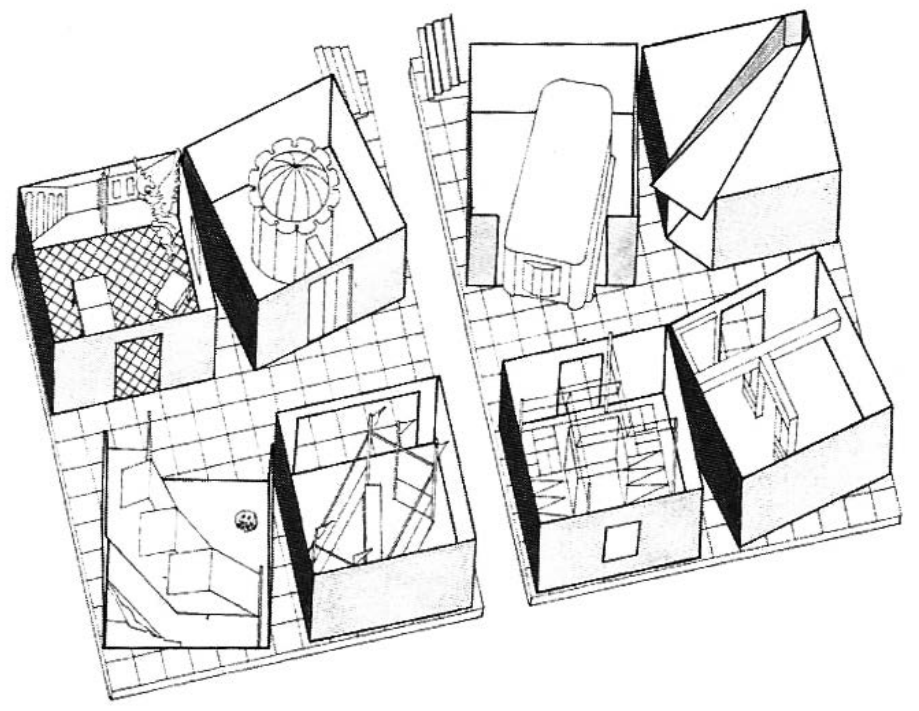

Como se ha comentado, la exposición constaba de ocho ámbitos constituidos por recintos cuadrados. Cada uno de ellos contenía la representación de un tema sobre la vivienda contemporánea. Entre los diferentes temas posibles optaron por cuatro que consideraban 'históricos' porque ya se habían tratado en el transcurso de otras ediciones pasadas de la Triennale, en particular en la de 1933. Aquellos temas eran: 'la casa de los esposos', 'la casa de vacaciones', 'la casa del artista' y 'la casa lujosa'. A estos añadieron otros cuatro que eran 'nuevos' y que les permitirían explicar algunas de las condiciones que caracterizaban el hábitat contemporáneo. Los nuevos eran: 'la casa para trabajar', 'la casa para descansar', 'la casa en común' y 'la casa onírica'. Cada uno de ellos se confió a un equipo de diseñadores que podrían utilizar piezas ya producidas por otros, piezas diseñadas por ellos y ya producidas o prototipos

35 Franco Raggi, "Metaphores d'habitation”, Ibíd. p.10. 
creados específicamente para la exposición.

Uno de los modelos nuevos de vivienda sobre los que se trabajó en esta exposición era 'La casa comunal' ${ }^{36}$, la casa compartida por varias personas sin parentesco y que no conformaban específicamente una familia, sino que compartían un lugar donde habitar, con zonas privadas e íntimas y con espacios comunes. Para la propuesta, sus diseñadores, Paolo Deganello y Alberto Magnaghi, plantearon un espacio que era compartido de manera ficticia por cuatro personajes con diferentes características que, según ellos, eran representativos de un fenómeno de ruptura/redefinición del tipo de la vivienda familiar tradicional -salón + cocina + distribuidor + dormitorio-. Pidieron a cada uno de los personajes diseñar con ellos el espacio habitado que les correspondía.

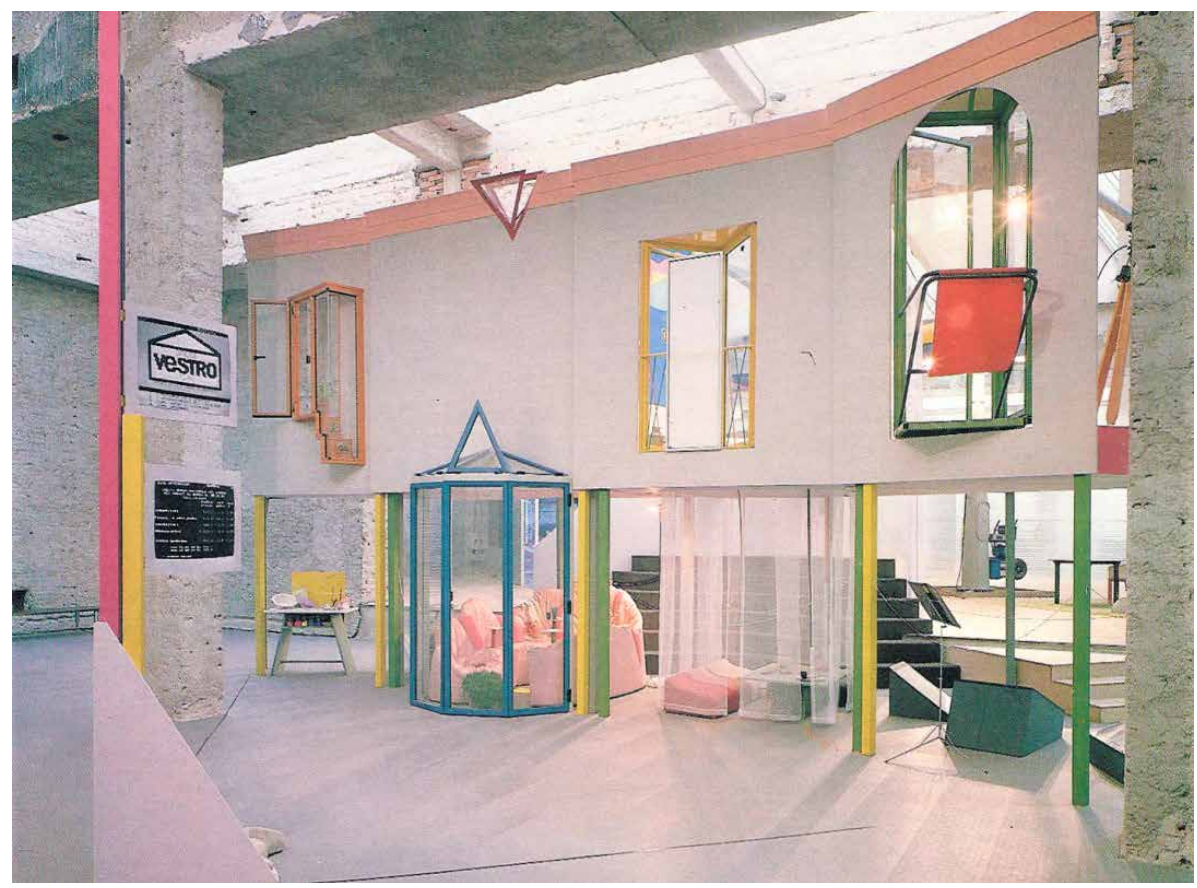

El proyecto general se organizaba en distintos niveles: los cuatro lugares de la identidad individual, de la soledad -habitaciones en el primer piso, cada una se abría a la fachada por una abertura individualizada para cada uno de los personajes-, y los lugares de la vida colectiva, espacios bajo las habitaciones, que eran completamente abiertos, diseñados para compartir experiencias, y con lo necesario para tener acceso a toda la información urbana.

Por otro lado, y continuando con los planteamientos sobre los nuevos conceptos en torno a la vivienda contemporánea, se presentó la propuesta de 'La casa como lugar de trabajo' ${ }^{\prime 37}$ de Piero Derossi. Era una reflexión sobre ciertos lugares particulares existentes en el paisaje metropolitano: las casas que, aparte de ser espacios para la vida, también se utilizaban como lugar para el trabajo. Las protagonistas eran las actividades que se producían en esos lugares. Este tipo de vivienda aparecía como consecuencia de la descentralización del sistema de producción (desde el teletrabajo a la economía sumergida) o como resultado del nomadismo metropolitano que podía surgir de la búsqueda de un refugio existencial, como decisión personal. En cualquiera de los dos casos se tuvo presente dos condiciones importantes, el orden espacial y el orden temporal.
Imagen: Paolo Deganello y Alberto Magnaghi, 'La casa comunal' en "Le case de la Triennale", XVII Trienal de Milán, 1983. 
Respecto a lo primero, ya no existiría la tradicional separación espacial del lugar de trabajo y del lugar donde vivir. La tendencia sería que el sentido del espacio surgiera del propio uso del lugar. La segunda condición sería que ya no existiera distinción entre tiempo de trabajo y tiempo de la vida, o entre el día y la noche. A este aspecto, la distribución del tiempo se planteaba como responsabilidad del individuo.

En la casa como lugar de trabajo, casi por casualidad, el poder de las estructuras fuertes de la sociedad (la fábrica, la oficina, el barrio, la familia) se alejaban dando prioridad a un espacio que se abría a un nuevo espíritu. Por ejemplo en aquel espacio, se podría crear música o arte (como aficionado o como profesional), montar bolígrafos, llevar la contabilidad de un amigo que tiene una gasolinera, hacer fotos, traducir libros, o dar clases de yoga; o hacer todas las actividades sucesivamente. Las técnicas, en pos del progreso, acababan unificándose: las tenazas podían convivir con el ordenador.

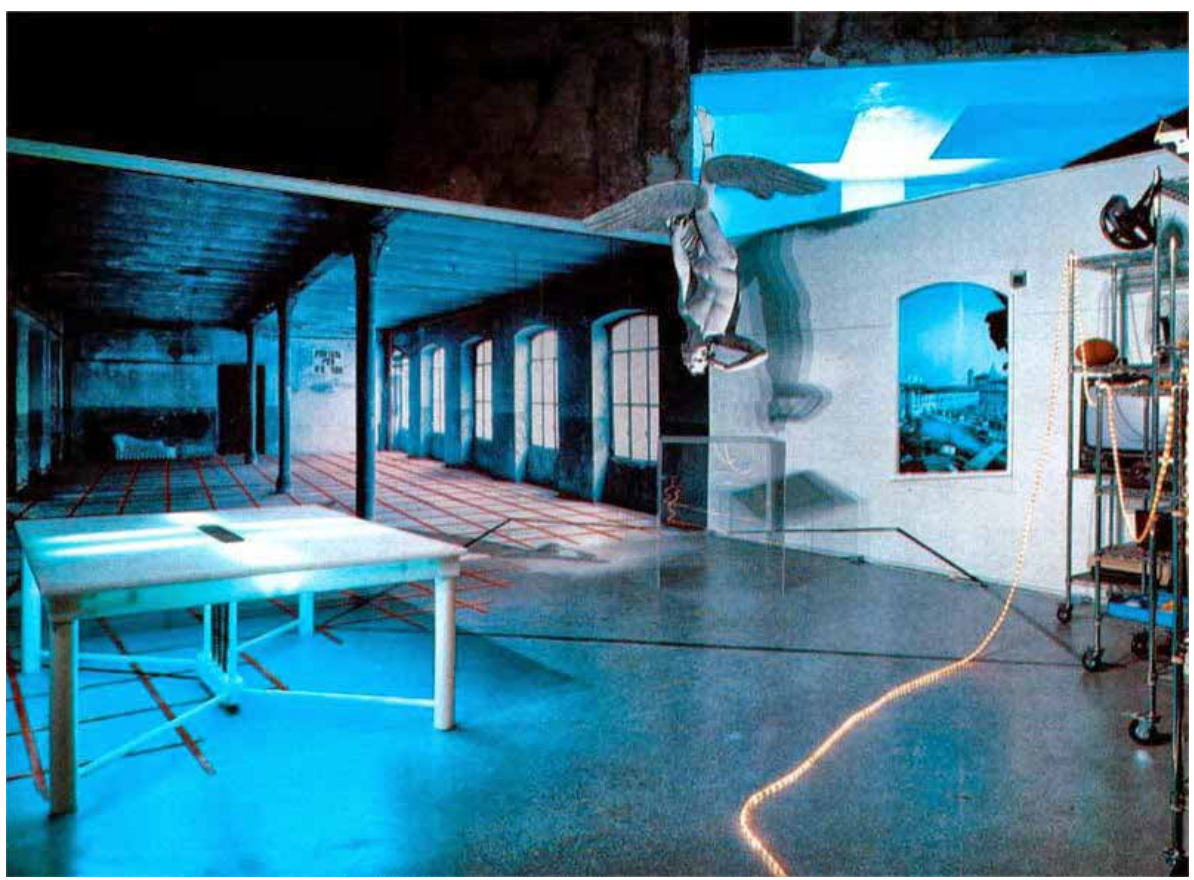

La casa era la lectura de un fenómeno metropolitano. Por paradoja o por romanticismo la acabaron asimilando al interior de una fábrica abandonada. Pero quizá no fuera por romanticismo, sino más bien se podría interpretar como la representación de otro fenómeno contemporáneo, del espacio reconvertido, del loft, muy característico de la época, y que cada vez se asociaba más al tipo de vida del profesional con éxito que proliferaba en aquellos años.

La casa estaba colonizada por múltiples objetos y muy diversos: desde máquina de escribir, ordenador, calculadora, hasta televisión, aparato de música, proyector de diapositivas, etc. Un conjunto de elementos totalmente dispares no era un impedimento para que el espacio tomara sentido a través de su diálogo.

Pasando de una novedad a un clásico de la Triennale, en esta convocatoria se presentó una revisión contemporánea de 'La casa del lujo ${ }^{38}$. En este caso la idea del lujo radicaba en la capacidad del espacio de poder contener 'todo en uno', en la complejidad con pocas cosas y en lo que pudiera sugerir emocionalmente. Este espacio fue diseñado por Gian Franco Gasparini con Studio Arcanto. 
En el centro del recinto, cuadrado, emergía un artefacto con forma de tótem, que contenía o, más bien escondía, una infinidad de pequeños objetos, fotografías, cartas y de todo lo que se pudiera encontrar en un 'baúl de los recuerdos'. Esa especie de mueble se situaba dentro de un cubo de paredes de vidrio plateado que permitían la aparición y desaparición del objeto, en función de la organización y la intensidad de la iluminación.

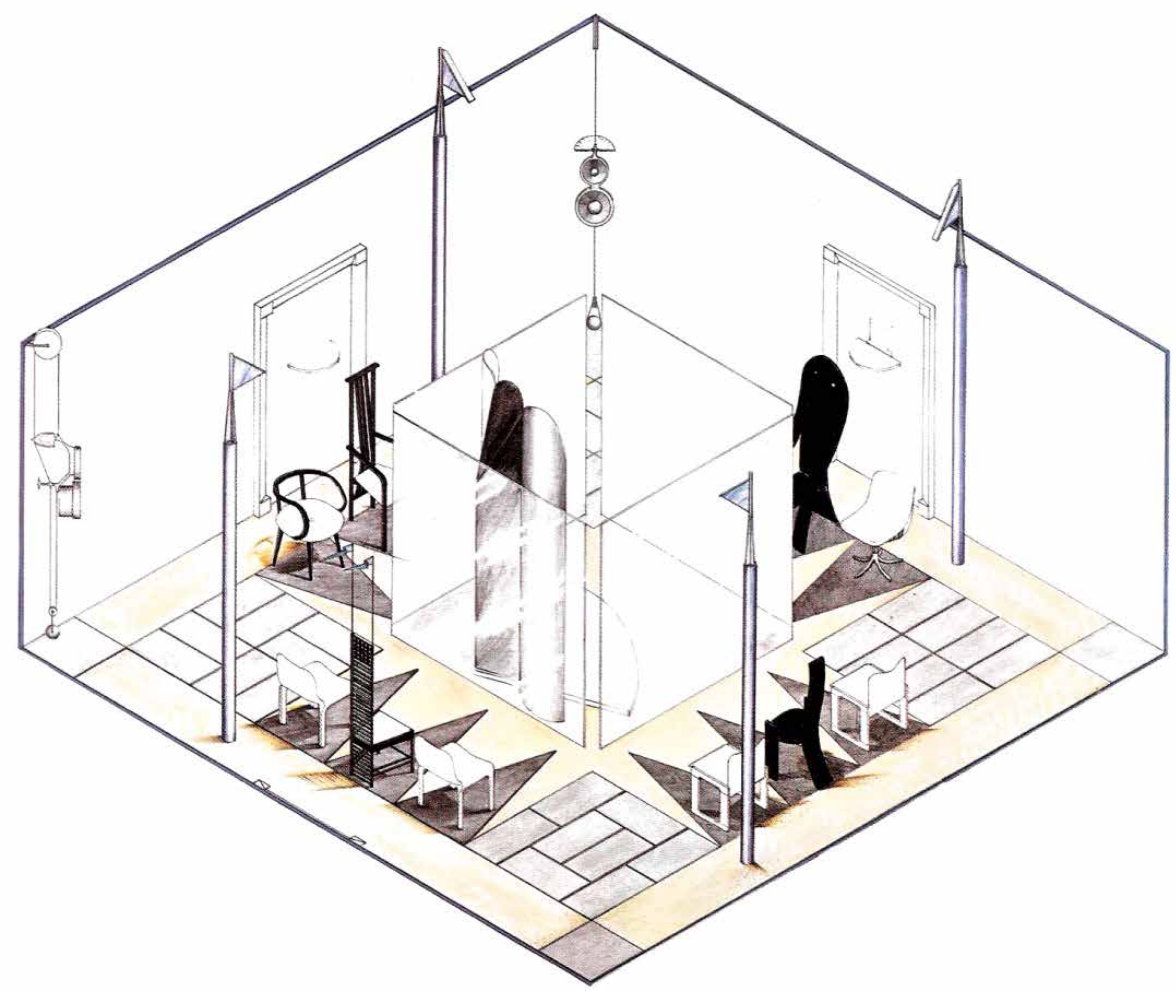

El pavimento, alrededor del cubo central, tenía dibujadas formas geométricas triangulares en blanco y negro y grandes placas rectangulares completando las cuatro esquinas del cuadrado.

Sobre los elementos triangulares se situaban varios objetos, algunos de color claro y otros oscuros, algunos altos y otros bajos que servían aparentemente de asientos. La precisión y la sistematización de su emplazamiento parecían depender de jerarquías inflexibles, cuyo orden y reglas, así como los usuarios, estaban enigmáticamente ausentes.

El ambiente estaba iluminado por un sistema de luz cambiante que variaba en función de la música que acompañaba, y que según iba orientándose significaba diferentes cosas. Por ejemplo cuando el foco era directo y concentrado indicaba un detalle concreto; cuando iluminaba a la vez a dos objetos indicaba una relación entre ellos. La luz, cuando recaía sobre los elementos diferentes, proporcionaba las claves del orden que subyacía en la obra, sobre todo en el último momento, cuando se apagaba todo y se hacía la oscuridad y el silencio. Y mientras tanto, en el contexto de la exposición, y en otro de los ámbitos para albergar un concepto novedoso de vivienda, surgía la idea de que "El artista no tenía casa". Aquello fue lo que Roberto Lucci, Paolo Orlandini y Federica Zanuso, se plantearon en su propuesta sobre 'la casa del artista'39.

Para los autores, la casa 'de artista' en el mundo contemporáneo era imaginaria, y por tanto surgía, más bien, como la imagen de una imagen.
Imagen: Gian Franco Gasparini/ Studio Arcanto. 'La casa del lujo'. XVII Trienal de Milan, 1983

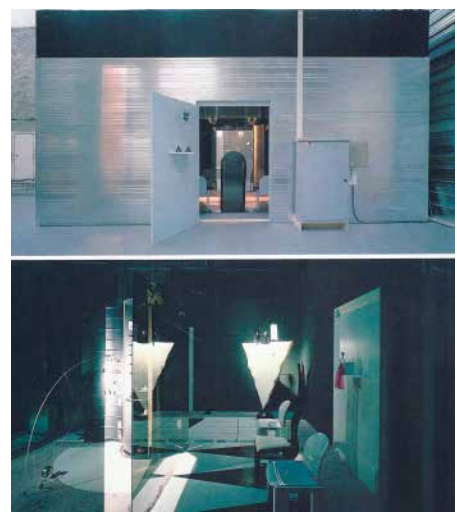

Imagen: Gasparini/ Arcanto. 'La casa del lujo'. XVII Trienal de Milan, 1983 
Imagen: Roberto Lucci, Paolo Orlandin y Federica Zanuso. 'La casa del artista'. XVII Trienal de Milan, 1983. Maqueta del espacio.

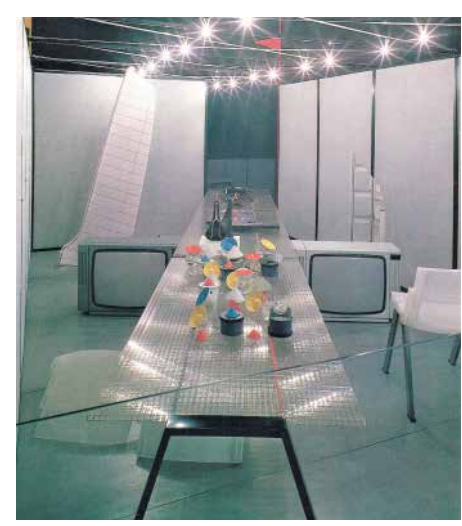

Imagen: Lucci, Orlandini y Zanuso. 'La casa del artista'. XVII Trienal de Milan, 1983. Vista del espacio creado para la exposición.
Pero también modificaron la figura de lo que se podía entender como artista, ya que además se podía asociar a la de actor, a la de funambulista, la de cantante, la de domador...Por eso la casa que planteaban también podía ser un teatro $o$ un circo. En base a estas ideas, la casa propuesta estaba coronada por banderines y era de colores. La intención era que su forma fuera rica en sugerencias y alusiones, en elementos de memoria y de espectáculo y que apareciera como atrayente y misteriosa.

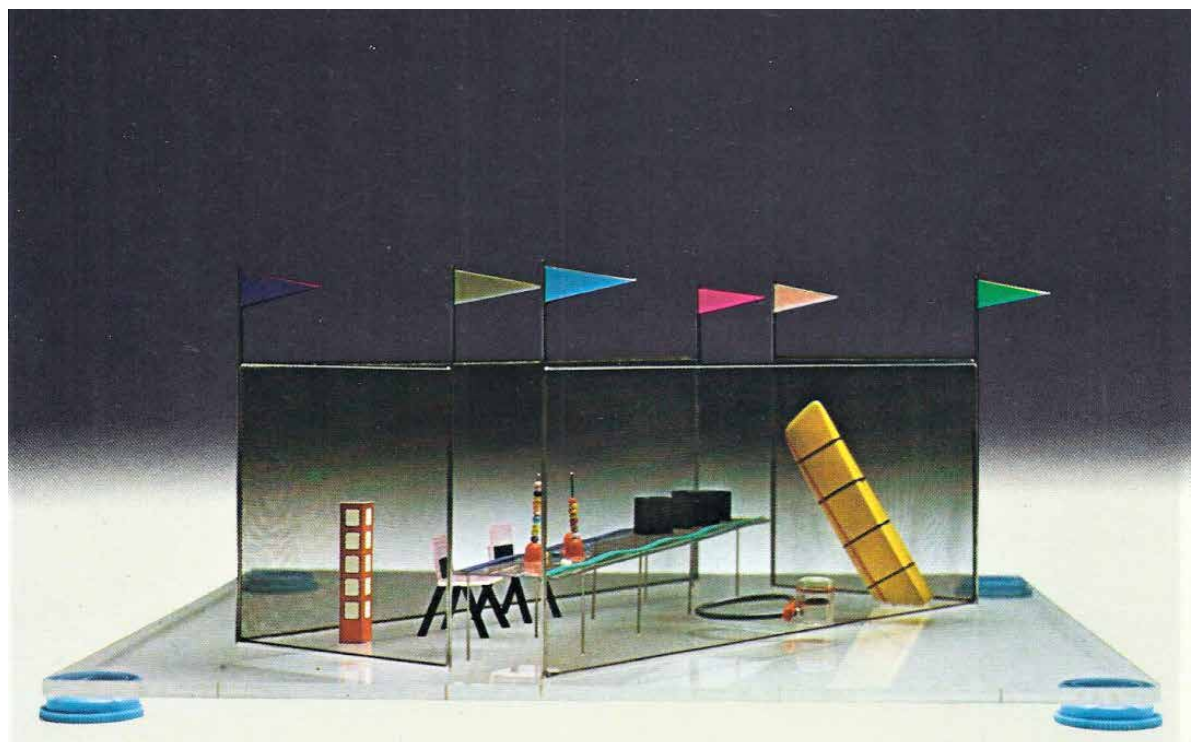

Uno de los factores que dotaba de cierto misterio al montaje era su condición de 'escena fija' llena de objetos 'inacabados' que carecían de una definición funcional precisa -muchos de ellos no servían para nada-, de riqueza formal por su carácter indefinido y su colocación extraña. Estaban a mitad de camino entre el concepto y el producto -entre los primeros modelos y el prototipo-

Tenían todavía la frescura de acabar de ser ideados, pero ya empezaban a estar contaminados por los elementos de producción; eran únicos pero se acercaban rápidamente a una forma ordenada, totalmente identificable y reproducible de manera idéntica. Eran la base de un conflicto, todavía no eran 'objetos bellos' ni 'objetos banales', pero su presencia era extremadamente vital.

La casa del diseñador, del artista, se planteaba pues como un volumen semitransparente, cuyo interior se podía ver desde el exterior. Un contenedor ligero y monumental como un circo, definía un interior que no presentaba ninguna connotación precisa sobre su uso, tan sólo toda una colección de objetos 'freak' diseñados por los propios arquitectos o por sus amigos. Aquellos objetos eran inacabados y extraños, pero también eran testimonio de un continuo feed back, como proceso de producción. La casa contenía todos los significados necesarios para desarrollar un discurso, generado por las relaciones entre los objetos y el espacio, que hablaba sobre el proceso productivo, sobre lo banal y lo bello, sobre la vida de creación artística, con sus luces y sus sombras.

Otro de los temas, de los considerados nuevos por la organización de la exposición, era 'La casa para el descanso'. El ámbito correspondiente a dicho contenido fue diseñado por Franco Mirenzi ${ }^{40}$. La propuesta representa un verdadero espacio destinado al descanso, por lo que debía cumplir todas 
las condiciones, y sobre todo, contener todos los elementos: muebles, libros, alimentos, y resto de objetos, necesarios para satisfacer la necesidad y el deseo del descanso. La flexibilidad de la propuesta reflejaba la consideración de un deseo siempre imprevisible característico del hombre contemporáneo, contradictorio y ecléctico.

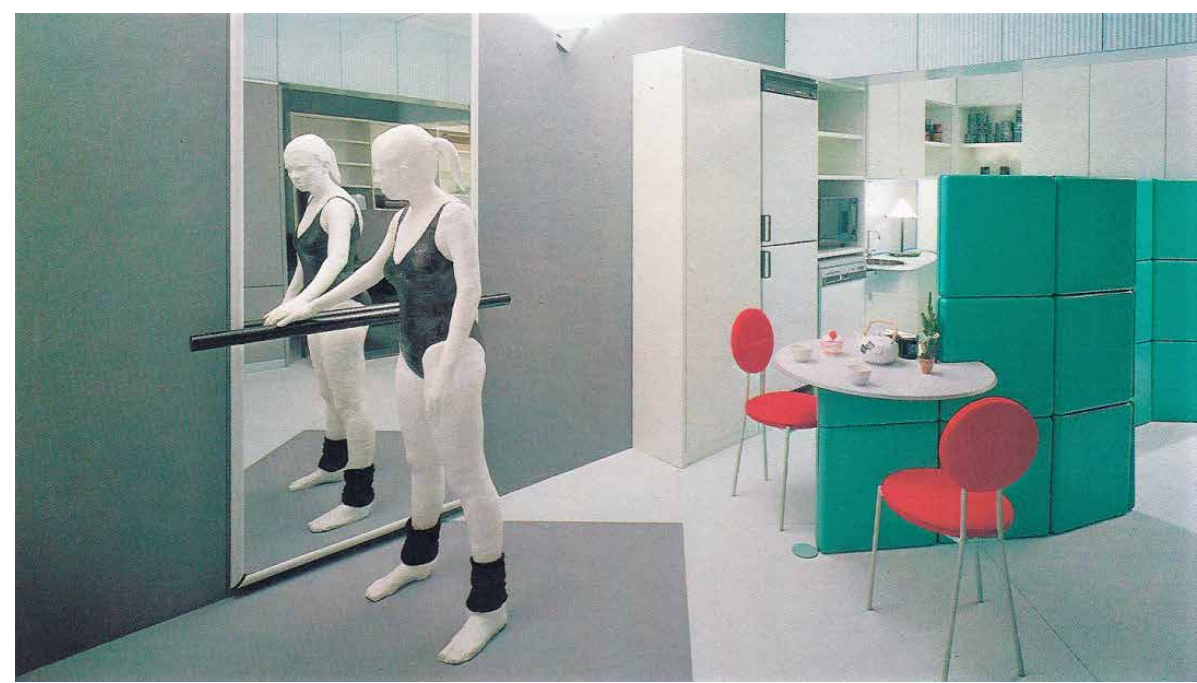

Más sofisticados fueron los recursos empleados por Denis Santachiara para la propuesta de espacio de 'La casa onírica', otro de los temas tratados en la muestra, dentro de los considerados como novedosos y característicos del mundo contemporáne $0^{41}$. La propuesta era, en realidad, la representación visual de un proyecto. No se refería a reflexiones literarias o psicoanalíticas, no se refería a las proyecciones simbólicas que lo onírico había evocado siempre a filósofos y a artistas. En la propuesta de Santachiara lo onírico aparecía como algo habitado y vivido, y no resultaba interesante por estar en su medio natural, que era de la psique del que duerme, sino más bien porque podría estar en la psique del que diseñaba, o del que utilizaba los objetos. Lo acontecido en los sueños era llevado al mundo real.

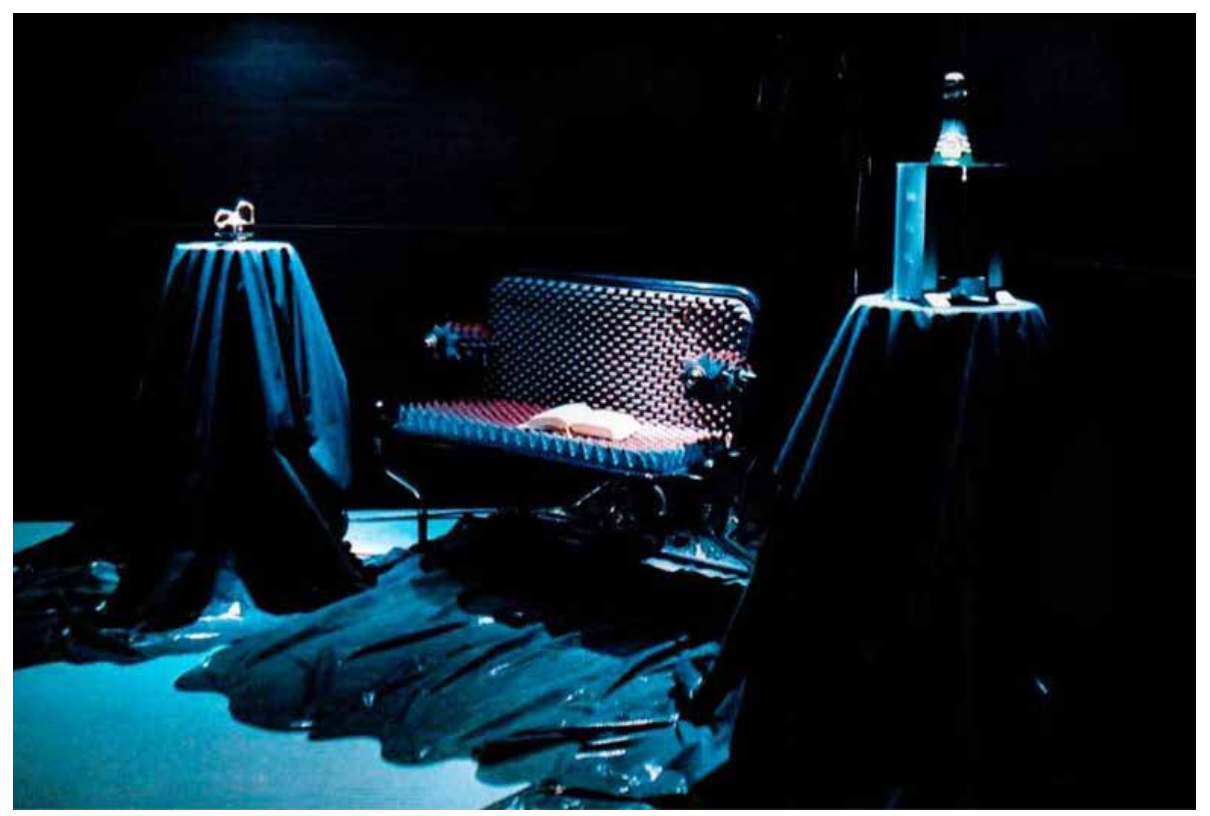

Imagen a la izquierda: Franco Mirenzi. 'La casa para el descanso. XVII Trienal de Milan, 1983. Vista del espacio creado para la exposición.
Imagen: Denis Santachiara. 'La casa onírica'. Vista de la zona de noche y de la zona de día. El ambiente interno oscuro y neutro estaba lleno de objetos diversos con una función específica y también decorativa, pero todos caracterizados por una apariencia mágica y sorprendente, en la cual el poder de las nuevas tecnologías jugaba un papel importante en crear ambiente e imagen.
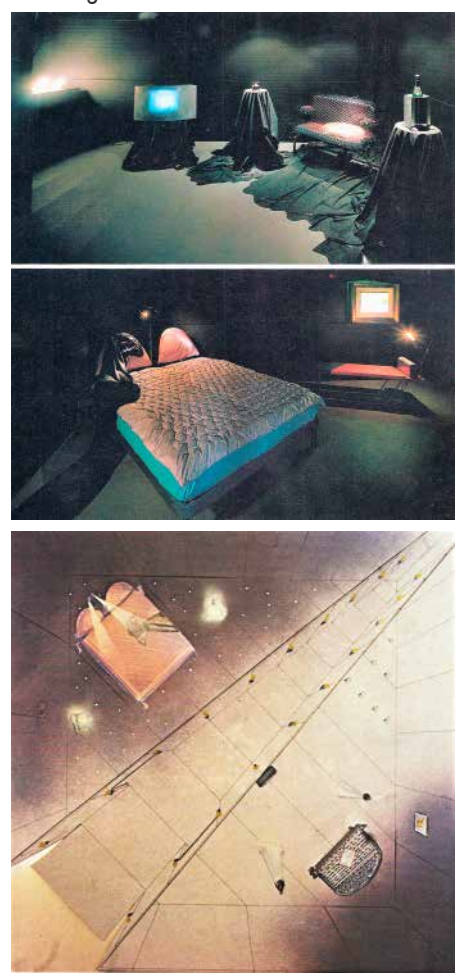

Imagen: 'La casa onírica'. Planta.

Imagen a la izquierda:

Denis Santachiara: 'La casa onirica'. XVII Triennale di Milano, 1983. Vista de la instalación, zona de día. 
Lo onírico se convertía en la práctica artificial del visionario que trabajaba con la realidad artístico-tecnológica, era como un nuevo fenómeno diurno que podía influir directamente en los objetos y en la imagen. Lo onírico era habitado y vivido, y utilizaba objetos como mecanismos de ilusión.

No se abandonaba al sueño, sino todo lo contrario, bien despierto entre las nuevas tecnologías, en la producción de atmósferas etéreas y metafísicas. Pero sobre todo entre una gama prácticamente infinita de estímulos entre los cuales el diseñador podía practicar 'la invención' como actividad de hacer 'soñar con los ojos abiertos'. La casa onírica se presentaba como un nuevo producto, fruto del truco tecnológico como mecanismo de invención y de uso. La casa sorprendía al usuario, le seducía, y como un ilusionista en un espectáculo teatral, le impedía ver sus trucos. 


\subsection{LADESAPARICIÓN DE LAESCENA Y LA DISOLUCIÓN DEL OBJETO}

Ya no existe sistema alguno de objetos (...) hoy ya no existen la escena y el espejo. A cambio hay una pantalla y una red. Algo ha cambiado, y el periodo de producción y consumo fáustico cede el paso a la era de las redes, a la era narcisista y proteica de las conexiones, contactos, contigüidad, feedback y zona interfacial generalizada que acompaña al universo de la comunicación

Jean Baudrillard ${ }^{42}$.

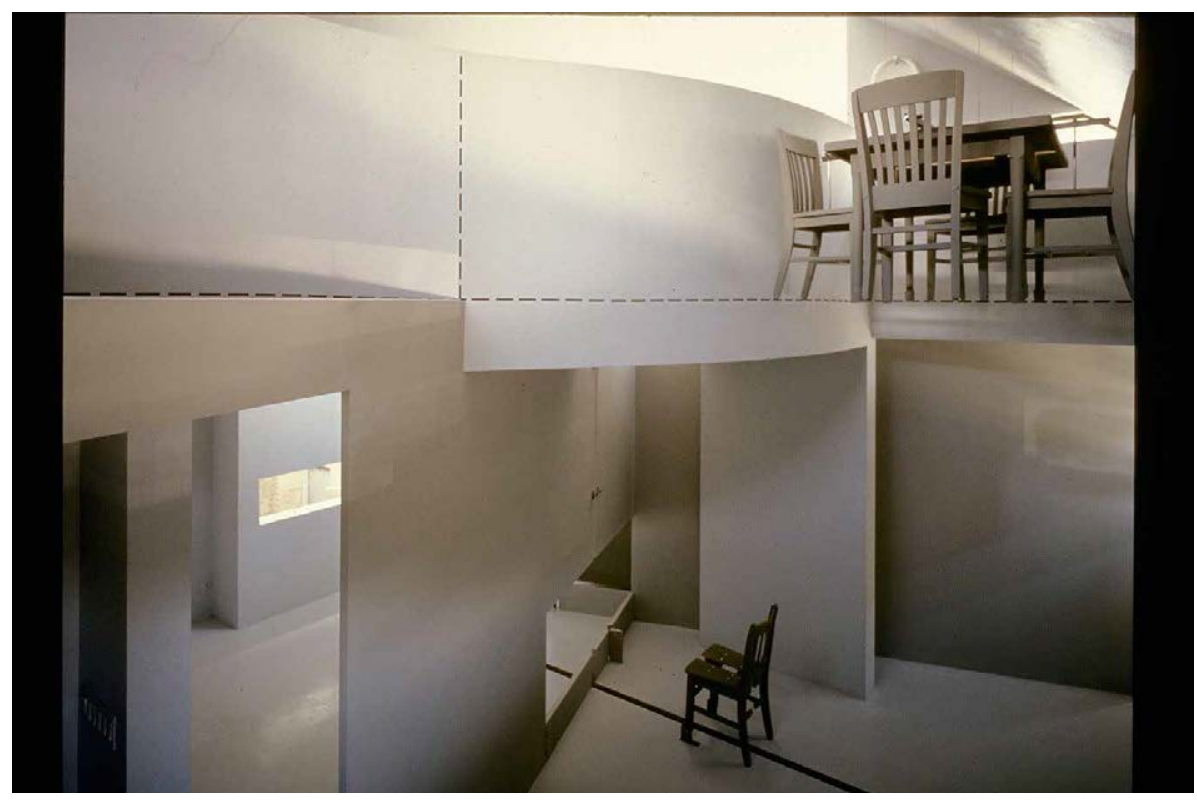

La muestra, Italy: The New Domestic Landscape ${ }^{43}$, como ya se ha podido constatar, fue fuente de muy diferentes planteamientos. Aparte de lo ya mencionado en apartados anteriores, también fue de gran interés la propuesta del grupo de Florencia, Superstudio. Para la exposición realizaron una instalación, a la que llamaron 'microentorno' microenvironment, que aparecía como una reconsideración crítica de las posibilidades de la vida sin objetos. Sus planteamientos iban dirigidos a la presentación de modelos alternativos de existencia haciendo una revisión de las relaciones entre el proceso de diseño y el entorno, utilizando para ello imágenes simbólicas.

El microentorno de Superstudio consistía en una sala cuadrada con las dimensiones dadas por la organización. El habitáculo estaba delimitado por paredes, el suelo y el techo aparecían revestidos por moqueta negra y las aristas se enmarcaban por delgadas líneas luminosas. En el centro del espacio se situaba un cubo cuyas paredes eran de espejo, salvo la que estaba frente a la entrada. El modelo, repetido hasta el infinito por el efecto de los espejos, generaba un plano reticulado sin fin donde se distribuían infinitas pequeñas máquinas de las que surgían varios terminales. Uno de ellos estaba conectado a una pantalla de televisión que retransmitía un documental de tres minutos sobre el modelo que presentaban, pero visto en distintas situaciones de reposo o de trabajo. También había una banda sonora de fondo, que daba información sobre las imágenes y los conceptos originales del modelo. En el techo se proyectaban acontecimientos meteorológicos: el amanecer, el día, el sol, nubes, tormentas, puestas de sol, la noche, etc. La iluminación del cubo

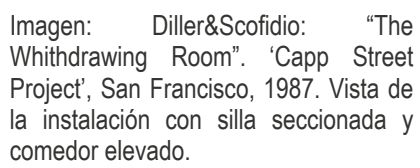

Imagen: Diller\&Scofidio: "The Whithdrawing Room". 'Capp Street Project', San Francisco, 1987. Vista de la instalación con silla seccionada y comedor elevado.

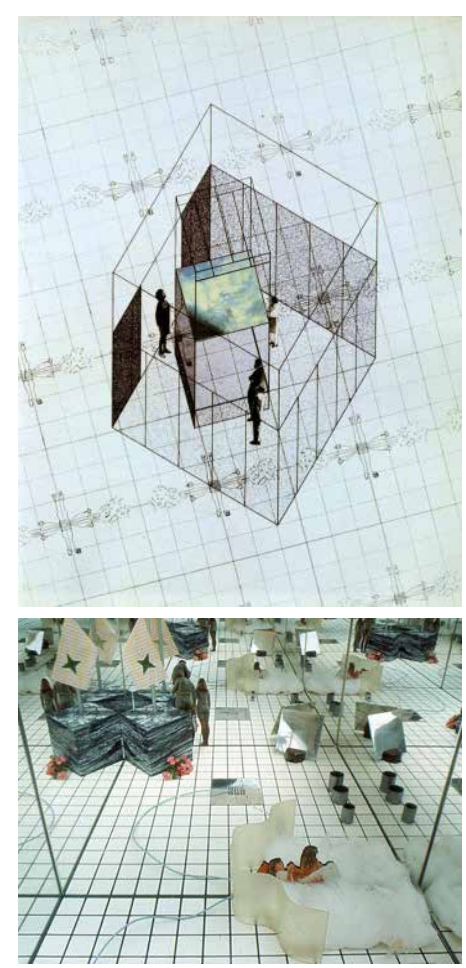

Imagen:Superstudio: "microenvironment". En Italy: The New Domestic Landscape. MoMA, Nueva York, 1972. Croquis de la instalación.

42 Jean Baudrillard, "El éxtasis de la comunicación" en La Posmodernidad. Editado por Hal Foster, (Barcelona: Kairós, 1985) p.187.

43 Celebrada en el MoMA de Nueva York en 1972. 
Imagen: Superstudio: "microenvironment". En Italy: The New Domestic Landscape. MoMA, Nueva York, 1972. Vista de la instalación.

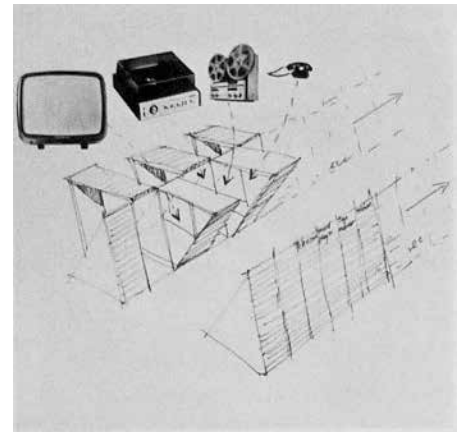

Imagen: Superstudio: "Supersurface". En Italy: The New Domestic Landscape. MoMA, Nueva York, 1972. también variaba según los fenómenos proyectados.

Según los autores la idea era presentar un concepto de diseño como proyección de una sociedad no basada en el trabajo ni en el poder, sino en las relaciones humanas desalienadas. Era la representación de un modelo alternativo de vida en la Tierra.

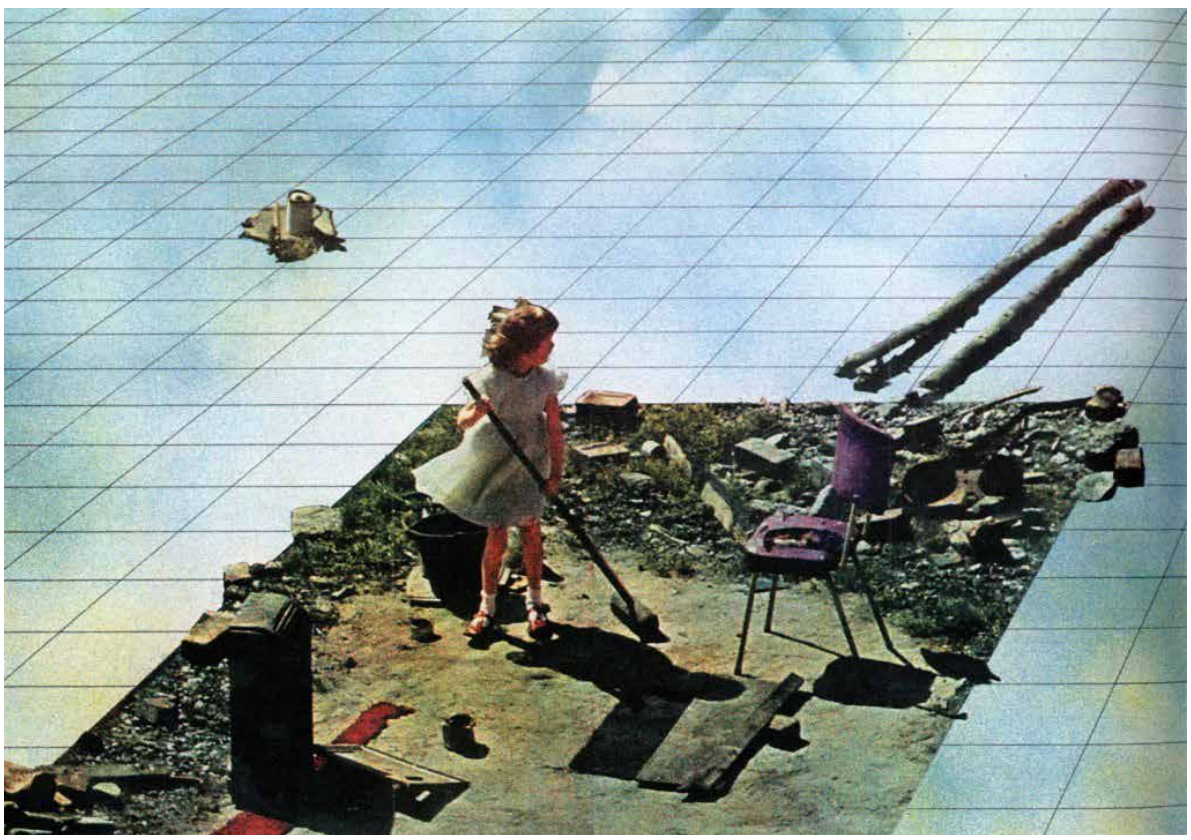

Una forma de vivir sin trabajo sostenida por una red de energía e información extendida por toda el área habitable. La red se distribuía a través de una cuadrícula cartesiana infinita que podía asumir, en algunos casos, formas diferentes. La imagen de una humanidad errante jugando o durmiendo sobre aquella plataforma cuadriculada.

El modelo constituía la eliminación de toda estructura formal transfiriendo la actividad de diseño al campo conceptual visualizando una imagen afísica como metáfora de la repulsa a la producción, al consumo y al trabajo. El mundo aparecía convertido en una red de energía y comunicaciones.

La destrucción de los objetos, la eliminación de las ciudades y la no existencia del trabajo aparecían como acontecimientos directamente relacionados. Superstudio, cuando se referían a la destrucción de los objetos, hablaban de la destrucción de sus atributos clasistas y de sus connotaciones. Reivindicaban un modo de vida con objetos reducidos a la condición de elementos neutros desechables, un no vivir para los objetos.

En la misma muestra, Ugo La Pietra, en el contexto de sus investigaciones en torno al hábitat y los sistemas de información y comunicación, también presentaba una nueva visión del hábitat, pero en su caso a través de un sistema de células domiciliarias, que simbolizadas por la forma arquetípica del triángulo, reproducían un microespacio despojado de objetos, donde la relación del individuo con el entorno y con el resto de los individuos se hacía a través de una experiencia individual de intercambio de datos. Anticipándose a internet, su propuesta utilizaba todos los medios de información y comunicación disponibles en aquel momento. Los pocos elementos que se introducían en la célula, eran incluídos sólo por sus características técnicas, mecánicas y electrónicas. Estos mecanismos además estaban ocultos dentro de los 
contenedores, aunque la ocultación no era total, ya que en la parte exterior de los módulos había inscripciones donde se indicaba el lugar donde estaban ocultos.

Las células domicilio eran puntos donde la información de fuera era recuperada y recogida a través de los medios de información y comunicación. Después de haber sido procesados, los datos podían ponerse en circulación y ser compartidos por otros. El núcleo domiciliario asumía pues el papel de un centro de acopio, procesamiento y distribución de la información. Estas microestructuras podían generar todo un sistema de información mediante la ampliación y la multiplicación de los intercambios entre personas que participaran de aquella dinámica de comunicación.

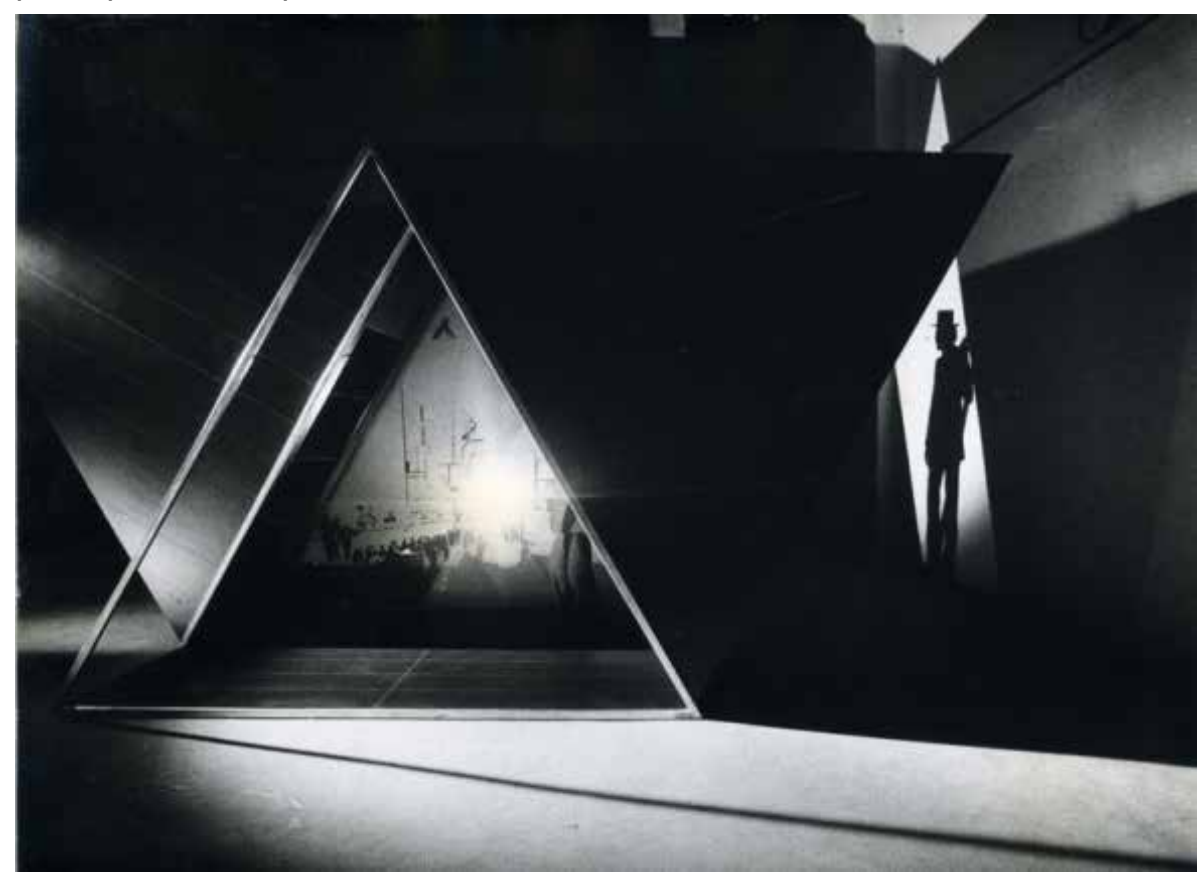

En realidad La Pietra estaba siendo un auténtico visionario de internet y de las redes sociales. En muestras posteriores, aunque algo más de una década después, las ideas en torno a una desaparición de la escena doméstica seguían ligadas a los sistemas de comunicación e información, pero también a la puesta en cuestión de los convencionalismos sociales, ligados a la vivienda como reducto de la familia y de los modos de vida tradicionales en un mundo ya de revisiones constante.

En verano de 1987, en una casa de madera de más de 100 años situada en el $n^{\circ} 65$ de Capp Street, San Francisco, reformada por el escultor David Ireland para albergar el certamen de muestras de arte experimental llamado 'Capp Street Project', los arquitectos Diller \& Scofidio presentaron una instalación llamada "The Withdrawing Room: Versions and Subversions".

La propuesta fue planteada como una crítica a la domesticidad urbana a través del desarrollo de un programa que marcaba una línea muy difusa entre lo público y lo privado. La propuesta, según sus autores, consistía en la construcción de un 'campo doméstico' en el espacio comprendido entre la cara interior de la casa y la superficie exterior de la piel del cuerpo. Se pretendía que la condición doméstica que se generaba estuviera en constante diálogo con la casa real, dando lugar a colisiones y bordes indefinidos. Había una segunda dialéctica, que se producía por la intrusión de actos privados en el dominio público y a

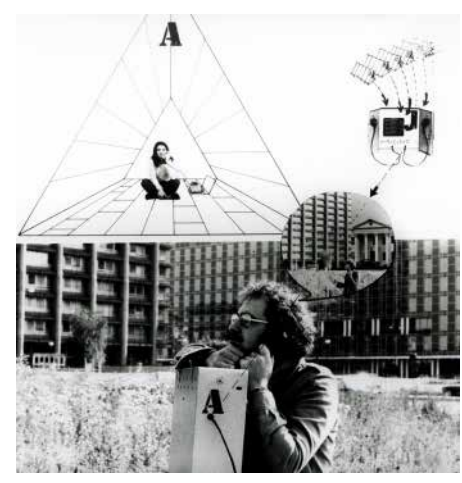

Imagen: Ugo La Pietra: "La casa telematica". En Italy: The New Domestic Landscape. MoMA, Nueva York, 1972. Propuesta de ocultación de mecanismos.

Imagen a la izquierda: Ugo La Pietra: "La casa telematica".. Sistema de recepción de datos. 
Imagen: Diller\&Scofidio: "The Whithdrawing Room". 'Capp Street Project', San Francisco, 1987. Vista desde arriba de la instalación con silla y balón elevados y silla con 'aparatus'.
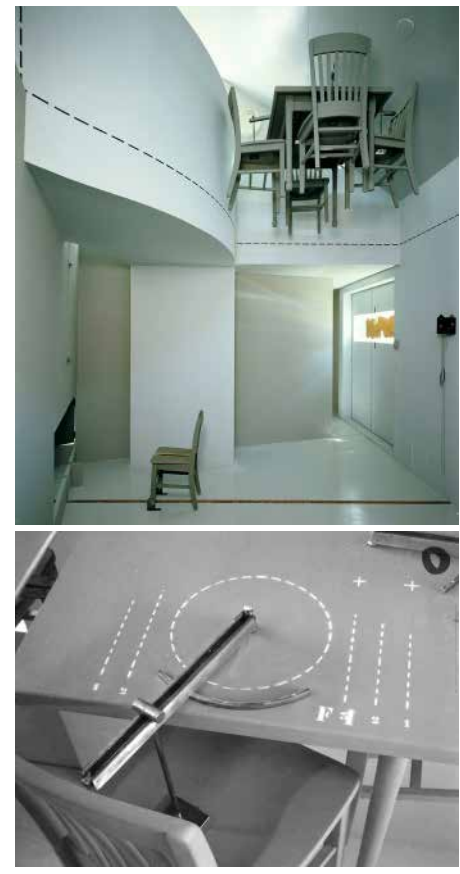

Imagen: "The Whithdrawing Room". 1987. Vista desde la planta baja con comedor elevado y silla con 'aparatus'

Imagen: "The Whithdrawing Room". 1987. Marcas circulares sobre la mesa

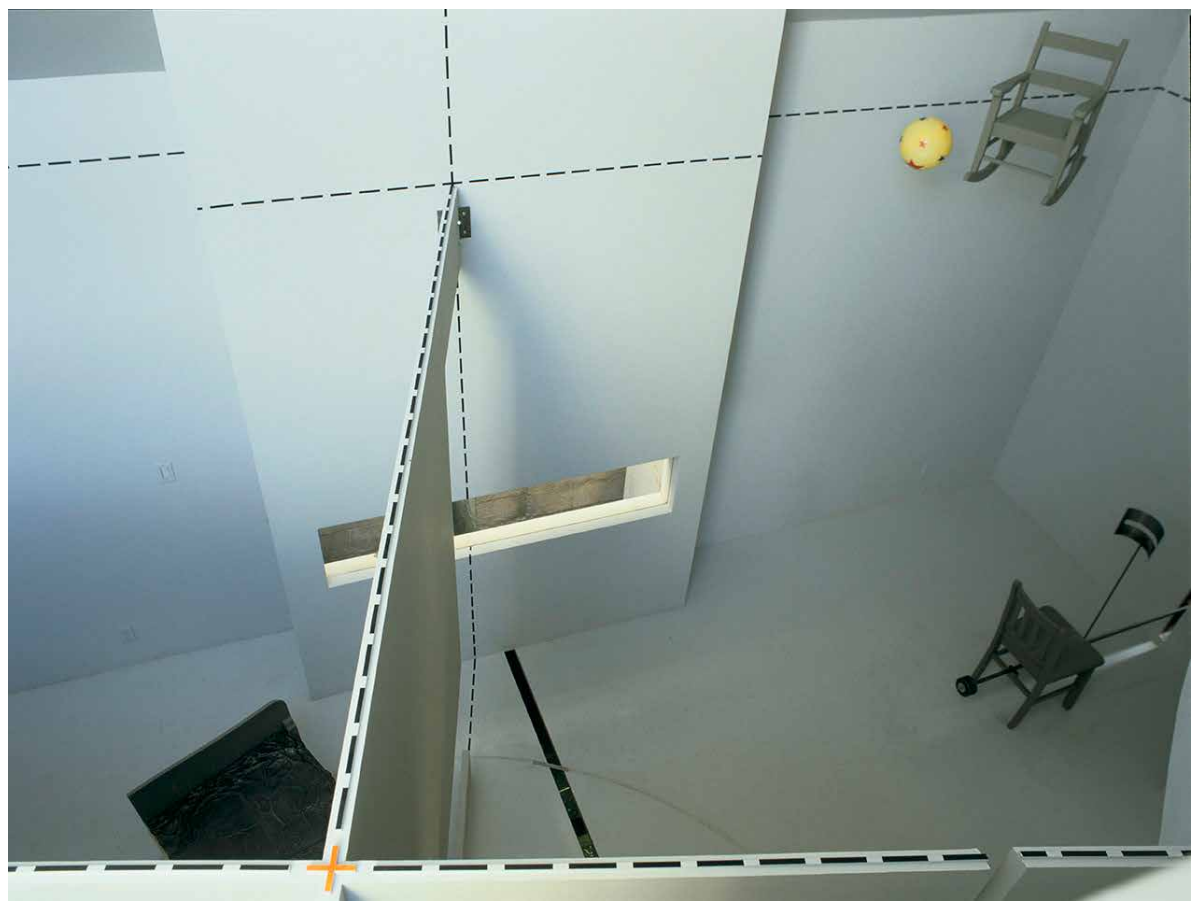

la inversa, que venía a ser como una violación pública del espacio privado. Las configuraciones eran una serie de marcos y episodios de ritual privados, que oscilaban entre intervenciones suaves y/o violentas en la topografía tanto horizontal como vertical del lugar. La altura del espacio les permitió hacer levitar elementos para que pudieran verse desde abajo y/o desde arriba. Otros elementos se montaron en superficies verticales para que pudieran verse de frente. Las visuales estaban subordinadas a los objetivos. Además la cualidad abstracta del interior permitía la convivencia de varias escalas. El objetivo final del proyecto era replantear una gramática de oposición para un programa reevaluado.

La propuesta pretendía reflejar un interior en el que se percibía la huella de muchas historias ocultas. Cada segundo borrado restauraba el lugar para la reencarnación de un orden ideal. Esta idea se representaba con el dibujo de las marcas que se dejaban inconscientemente en contextos domésticos: las marcas circulares dejadas por una taza de café sobre la mesa, el polvo acumulado bajo la cama que deja rastro cuando esta se mueve hacia otro sitio, etc.

La idea de Diller \& Scofidio era colaborar con un coreógrafo/performer para construir series de varios minutos cada uno correspondientes a episodios gestuales. Las performances tenían lugar en varias ocasiones, en torno a los siguientes elementos:

La cama: sitio de unión entre sexos, encuentros transitorios, el lugar donde el consciente y el subconsciente se separaban, el sitio donde el cuerpo se rinde a la gravedad y a la enfermedad. La mesa: un lugar con una microorganización, el lugar de etiqueta e indulgencia. 'Aparatus' (el aparato): la máquina que protegía el cuerpo contra el paso de la edad, un body-building que transformaba la energía humana en mutación plástica del espacio, el cuerpo se convertía en un autómata, en un fetiche urbano. El baño: el lugar de la obsesión de la higiene, el enclave del impulso narcisista, el espacio del autoerotismo. Ventanas y puertas: el contrato social de los límites legales y morales, el sitio del voyeurismo y el exhibicionismo, aberturas que salen fuera 
de toda referencia de tiempo y lugar.

Como crítica los autores introducían temas como el hedonismo -típico de la cultura de los ochenta- o el narcisismo, y subvertían los términos sobre los propios objetos domésticos. El mensaje tradicional importaba ya poco 0 nada: la cama ya no era el espacio para dormir o descansar, era un lugar de encuentros transitorios, el baño era el enclave propicio para el impulso narcisista, la mesa no era un lugar para comer, se convertía en el espacio de la micro-ordenación y de los formalismos.

Como decía Baudrillard ${ }^{44}$, el objeto dejaba de ser el espejo del hombre, ya no era parte de su universo porque no necesitaba un escenario para crear su propio marco.

La escena desaparecía y el objeto se desmaterializaba, levitaba o se ubicaba en lugares que desafiaban la gravedad, solo quedan sus huellas como el rastro de un mundo pasado. La idea era dar una nueva perspectiva del objeto cotidiano.

La idea de Diller y Scofidio es una nueva puesta en cuestión, más que de la casa en sí misma, del concepto de domesticidad. Transgredir el sistema de colocación de elementos, levitando o colocados en planos verticales, indicaba la disolución del objeto. Su valor ya no estaba en la pertenencia, ya no existía el vínculo, el discurso derivaba en el cuerpo, la vanidad, el hedonismo y la publicidad de lo privado, dirigiéndose hacia el exhibicionismo propiciado por las redes y las comunicaciones.

Frente a estos planteamientos, la pantalla y la red se convertían en los elementos protagonistas, en una puesta en cuestión en la que la técnica ya no era imprescindible para el desarrollo, ni para favorecer los procesos de producción industrial o de acondicionamiento, la técnica iba dirigida a la satisfacción del placer.

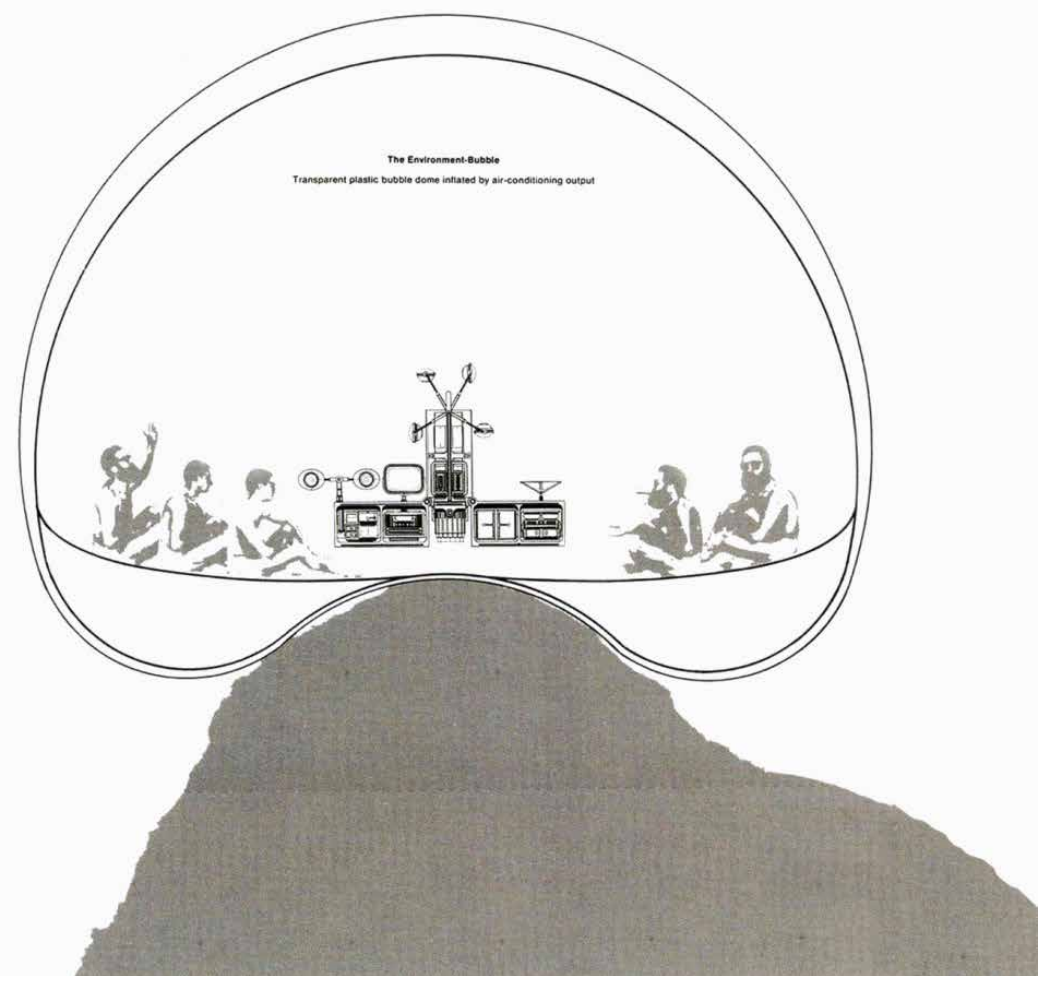

44 Jean Baudrillard, "El éxtasis de la comunicación" en La Posmodernidad. Editado por Hal Foster, (Barcelona: Kairós, 1985) p.188.
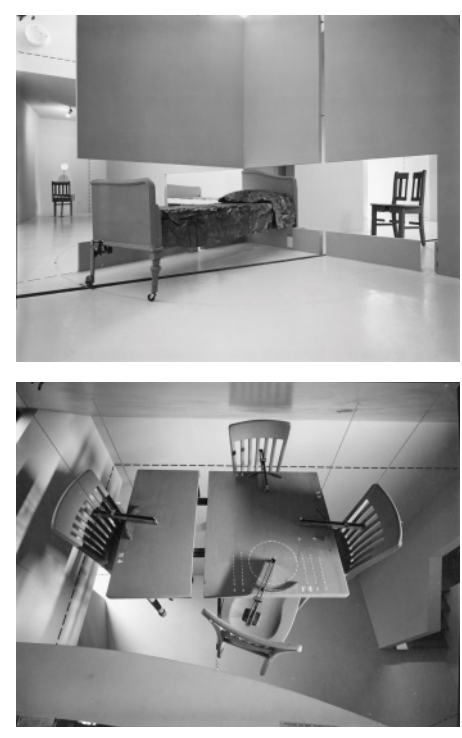

Imagen: "The Whithdrawing Room". 1987. Cama rotatoria $180^{\circ}$.

Imagen arriba: "The Whithdrawing Room". 1987. Comedor elevado.
Imagen: "The Environment-Bubble". Por Reyner Banham y François Dallegret, en "A home is not a house", publicado en 1965 en Art in America. 
En los años 60, Reyner Banham en "A home is not a house" había propuesto junto a Françoise Dallegret su casa burbuja como materialización tecnológica del espacio térmico, el campamento ancestral alrededor del fuego hipertecnificado con una envolvente estrictamente ambiental.

Posteriormente, y de manera progresiva, la miniaturización y el uso cotidiano de las comunicaciones fue cambiando las conductas urbanas, "el peep show cibernético fue convirtiendo en actores a los usuarios" 45 . Nuestra cultura fue asimilando ya por completo la telerrealidad. El sujeto contemporáneo se convertía en actor desde su nacimiento filmado, su vida era todo espectáculo y con ello lo privado se convertía en público. Todo ser humano era un artista social. Las tecnologías arrebatan lo privado a la esfera pública, tanto de forma real como virtual. En este proceso la escena doméstica iba desapareciendo como aquel escenario vacío para la acción humana, así como los ritos y las improvisaciones de la vida, y por tanto los objetos a través de los cuales el sujeto elaboraba su propio discurso.

Para Jean Baudrillard ${ }^{46}$ la gente ya había dejado de proyectarse en objetos, con sus afectos y representaciones, con sus fantasías de posesión, pérdida, duelo, celos. Lo que se proyectaba psicológica y mentalmente, como escena mental o metafórica, empezó a proyectarse directamente a la realidad, sin metáforas, pero en un espacio que, sin embargo, era simulado.

Los ochenta ya se habían convertido en los tiempos de la miniaturización, el telemando - en el que los procesos y su escena se reducian a una memoria infinitesimal y a una pantalla -el cuerpo y los placeres. La publicidad, en su nueva versión, ya no era escenario de objetos, sino el efecto de la visibilidad onmipresente de empresas, firmas, marcas y las virtudes sociales de la comunicación.

La escena doméstica de los objetos con sus reglas y sus límites, y la soberanía de un espacio simbólico, que era también el espacio del sujeto, se diluía en un proceso en una especie de obscenidad donde los procesos más íntimos de la vida se desarrollaban en el terreno virtual y alimentaban a los medios de comunicación.

Juan Herreros ${ }^{47}$, también enfocaba esta evolución, desde los años 60 hasta finales de ochenta, a través de la transformación sufrida por el sujeto contemporáneo. Este proceso de transformación iba desde el hippy de la propuesta de Reyner Banham que abanderaba una corriente crítica a la domesticidad tradicional basándose en las virtudes de la técnica para generar el acondicionamiento necesario para habitar en cualquier lugar hasta los proyectos desarrollados en torno a la "muchacha nómada de Tokio" (Pao-1, 1985 y Pao-2, 1989) "sin duda una de las propuestas recientes más sólidamente argumentadas en torno a la pregunta sobre qué puede ser una casa nómada treinta años después de la Un-home, como consecuencia del desplazamiento de intereses asociado al capitalismo tardío de las décadas posteriores" ${ }^{\prime \prime 8}$.

El arquitecto Toyo Ito, en estas exhibiciones, a las que se hacía referencia,

45 Fernando Quesada. Del cuerpo a la red. (Madrid: Ediciones Asimétricas, 2013) p.128.

46 Jean Baudrillard, "El éxtasis de la comunicación" en La Posmodernidad. Editado por Hal Foster, (Barcelona: Kairós, 1985) p.188.

47 Juan Herreros "Mutaciones en la arquitectura contemporánea. El espacio doméstico" (Tesis doctoral, Universidad Politécnica de Madrid, 1994) p.109.

48 lbíd. p.110. 
presentaba sendos modelos de viviendas denominadas "Pao de las muchachas nómadas de Tokio", para la Japan Creative Exhibition en el Sheibu Department Store de Shibuya, Tokio. Su habitante era una muchacha que vivía sola y ocupaba el 'Pao-1', y el 'Pao-2', en 1985 y 1989 respectivamente. Ella vagaba por la llamada por Ito "inmensa llanura de los media llamada Tokio", y era la que más disfrutaba de la vida de esa ciudad. Pero, ¿qué era una casa para ella? ${ }^{49}$. El concepto de casa para la muchacha nómada estaba desperdigado por toda la ciudad y su vida discurría mientras hacía uso de fragmentos del espacio urbano, en forma de collage. En realidad era un punto de información y de descanso que podía colocarse en cualquier sitio de la ciudad.
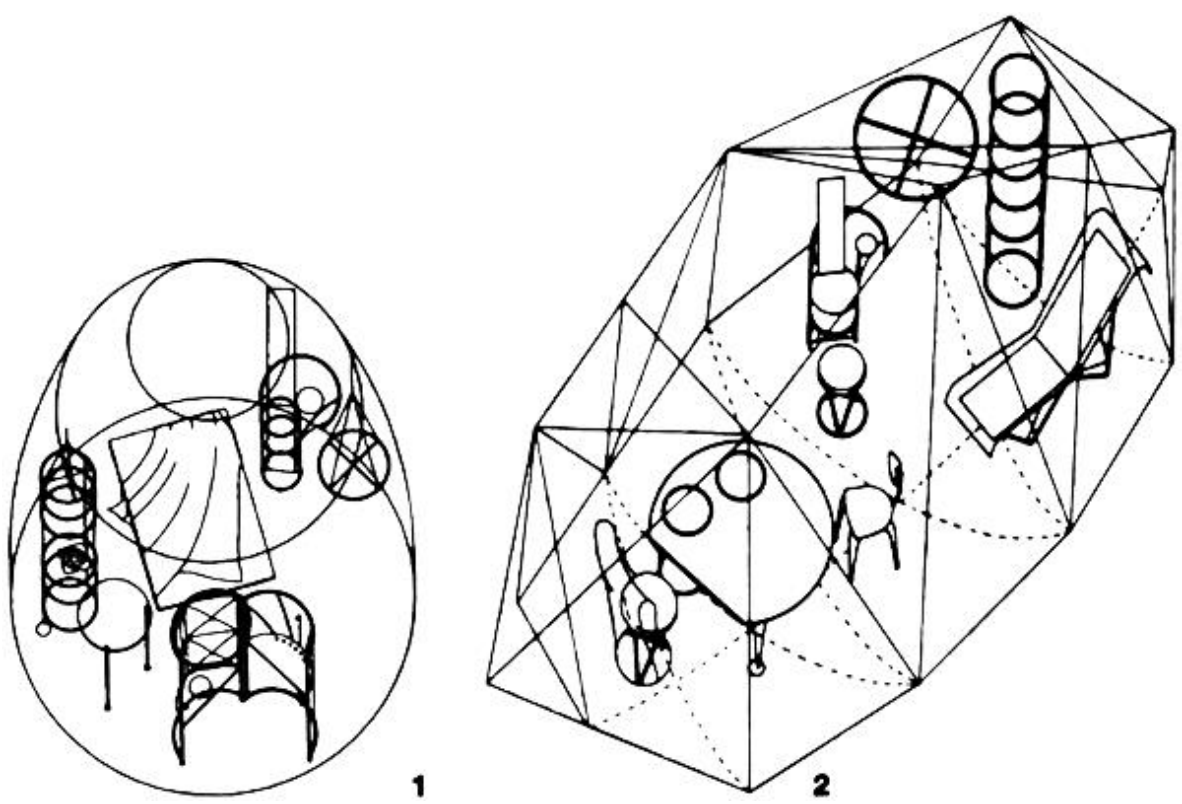

El 'Pao de la muchacha nómada' surgía como la interpretación de la cabaña primitiva de Marc Antoine Laugier en la ciudad contemporánea ${ }^{50}$. Ahora el bosque era la ciudad (un bosque de acero y aluminio), y aquella densa masa de hojas que conformaba la techumbre de la cabaña, se convertía en un velo suave e invisible.

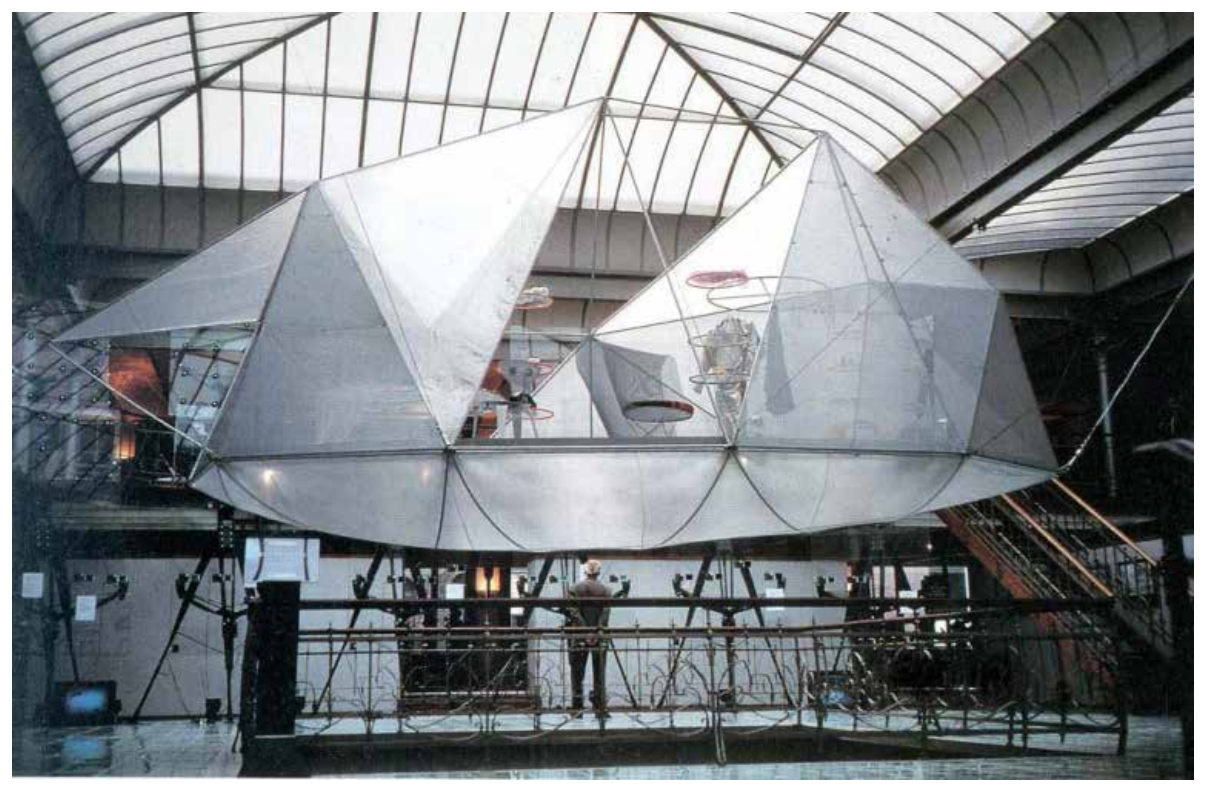

49 Toyo Ito, "El Pao de las muchachas nómadas de Tokio", en Toyo Ito. Escritos. (Murcia: Colegio de Aparejadores de Murcia, 2000) editado por José Ma Torres Nadal, p.61-65.

50 Toyo Ito, "La cabaña primitiva en la ciudad contemporánea", en Toyo Ito. Escritos. (Murcia: Colegio de Aparejadores de Murcia, 2000) editado por José M ${ }^{\mathrm{a}}$ Torres Nadal, p.45-48.

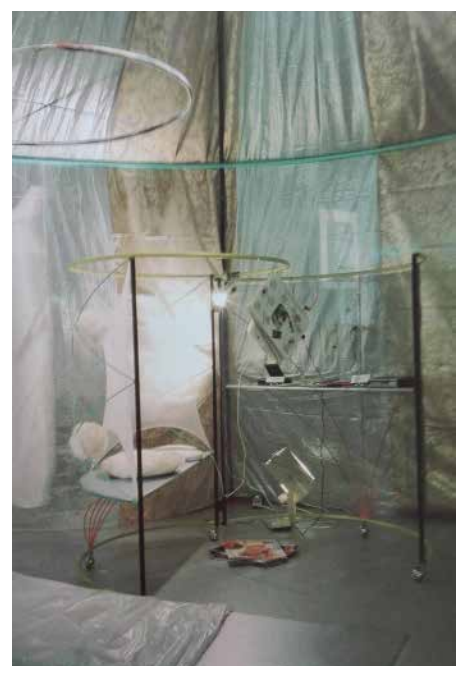

Imagen: Pao-1. Vista del interior.

Imagen a la izquierda: "El Pao de la muchacha nómada de Tokio". Izquierda Pao-1,1985. Derecha Pao-2 1989.
Imagen: "El Pao de la muchacha nómada de Tokio". 'Pao-2'. Vista de la instalación realizada en 1989. 


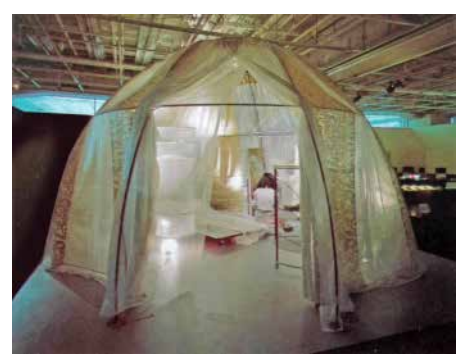

Imagen: "El Pao de la muchacha nómada de Tokio". 'Pao-1'. Vista de la instalación realizada en 1985.
Imagen: "El Pao de la muchacha nómada de Tokio". De izquierda a derecha: mueble para el coqueteo, mueble inteligente, mueble para la comida ligera.
Imagen: "El Pao de la muchacha nómada de Tokio". 'Pao-1', 1985. Croquis del concepto del hábitat urbano contemporáneo configurado como un collage de objetos que son una liviana materialización de fragmentos de la ciudad.
Las actividades propiamente domésticas, la muchacha las realizaba en la ciudad, extrapolándolas al espacio urbano.

La cabaña -el pao- del habitante urbano -la muchacha nómada-, en la propuesta de Toyo Ito, estaba conformada por un cubrimiento a modo de 'tienda de campaña', en tejido transparente, y en su interior una cama colocada en el centro y tres muebles más, que al igual que el pao, eran ligeros y estaban hechos de una película casi translúcida. El carácter efímero de los muebles parecía indicar que estos objetos estaban a punto de disolverse en el medio ambiente, que estaban perdiendo su materialidad. Lo que quería significar era que los actos que se deberían realizar dentro de la vivienda ya se habían extrapolado al espacio urbano, por lo que los objetos domésticos ya no tenían razón de ser.
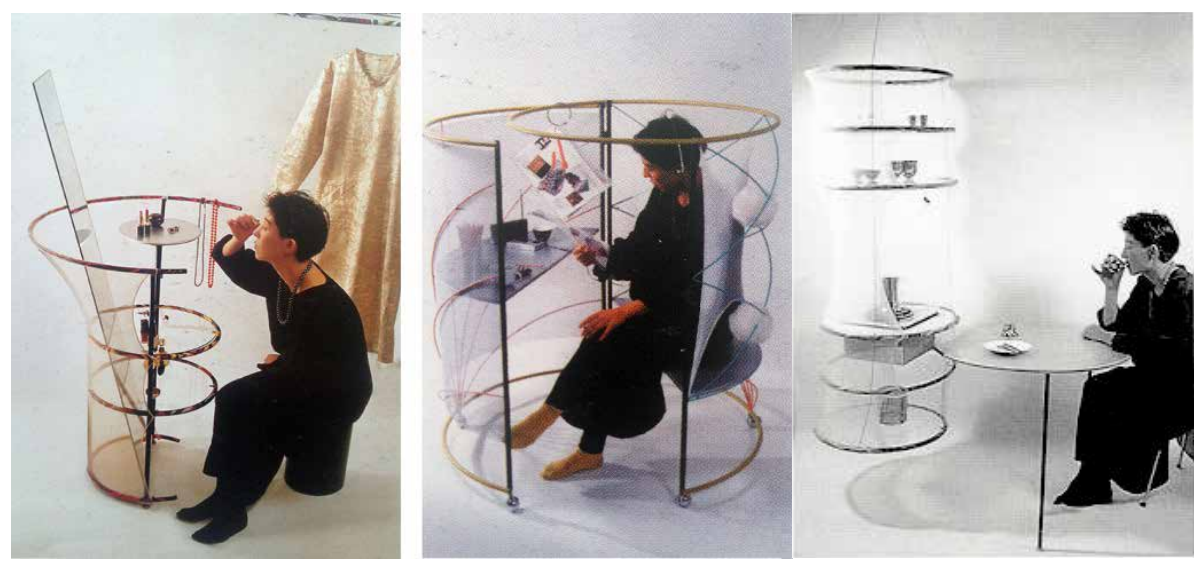

Los elementos que existían dentro del 'Pao', como se ha comentado, eran tres: el llamado 'mueble inteligente' que consistía en una especie de escritorio donde colocar el aparato destinado a obtener información de lo que ocurría en

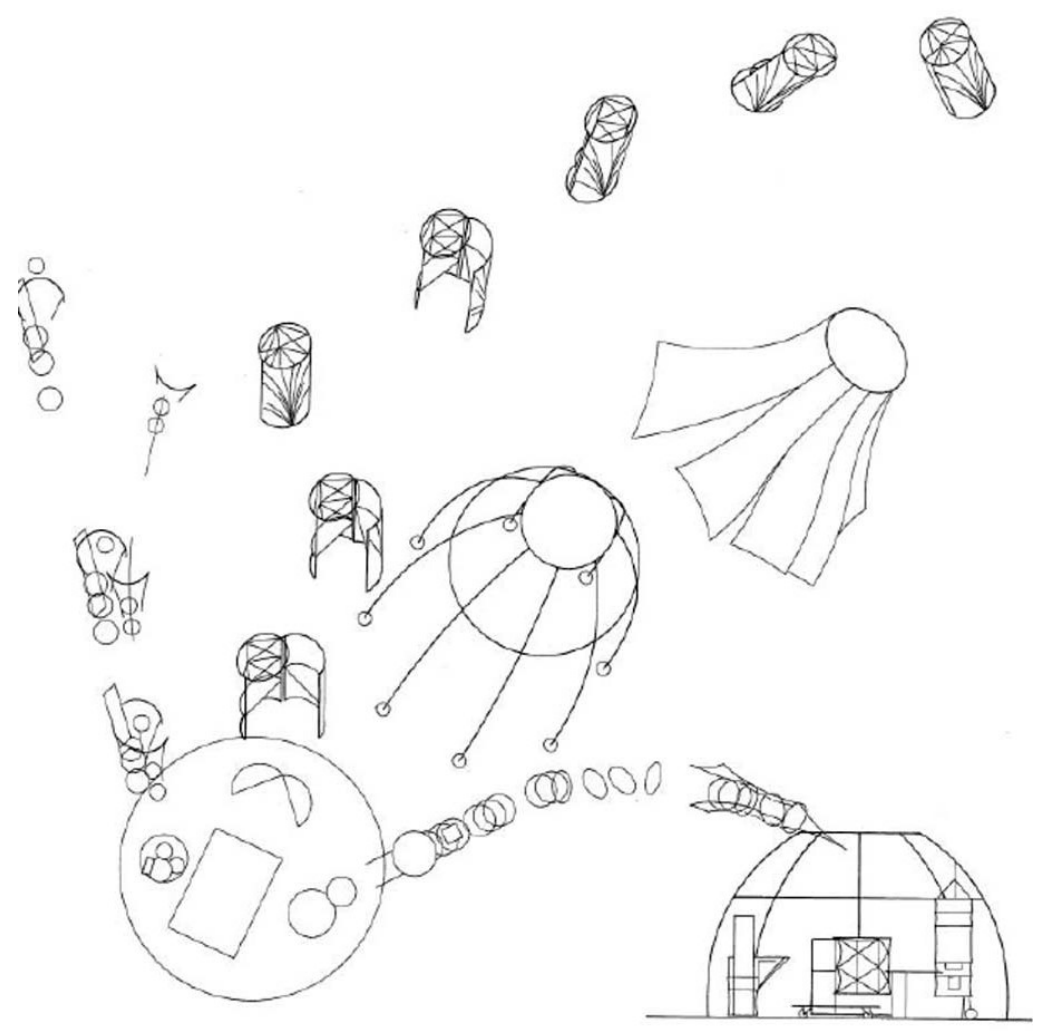


la ciudad, y donde, además, almacenarla. Como una cápsula para navegar por la ciudad. El segundo mueble fue el llamado 'para el coqueteo' que comprendía tocador y armario. El espacio urbano era el verdadero escenario, había que maquillarse y arreglarse antes de subirse a él. En este caso, como ocurría en la propuesta de Rem Koolhaas "Casa Palestra", que ya se ha comentado en apartados anteriores ${ }^{51}$, era una clara referencia a la actitud hedonista de los años 80, que se desarrolló en aquellos años gracias al auge económico. Años en los que la sociedad ya se encontraba completamente atada a la cultura de consumo y a la acomodación.

El tercer mueble era el de la comida ligera, una referencia existencial pero con matices que se distanciaban de la idea tradicional del comedor: una pequeña mesa y los utensilios justos para el consumo rápido de comida preparada. El hábitat de Toyo Ito perdía todo vínculo con su habitante, ya no pretendía ser un lugar confortable y acogedor, sino todo lo contrario, un lugar frío, efímero y transitorio.

Los muebles, la habitación, el cuerpo de la muchacha con su vestido translúcido, no presentaban grandes diferencias entre sí; ni siquiera entre las fachadas y las calles.

La casa como forma, como modelo para un desarrollo urbano, como tipo reconocible y como espacio interior zonificado dejaba de ser interesante. Era un conjunto mínimo de artefactos los que constituían el medio para realizar la existencia, como en la Un-home. Sin embargo, la idea de la casa, en la propuesta de lto, se generaba como una imagen creada por la combinación de distintos espacios ficticios de la ciudad. Era la representación de un modo de vida que se producía en las grandes ciudades donde sus habitantes estaban obligados a disfrutar de una vida 'collage'. Los actos que tradicionalmente se venían realizando dentro de la vivienda se habían descontextualizado al espacio urbano, de manera fraccionada, más diversificada, más individualizada y con menos sentido de la realidad. En la propuesta del pao, el espacio urbano absorbía al de la vivienda:

Por supuesto no solamente el salón de té y la lavandería, sino también los restaurantes de comida rápida, las tiendas de comida para llevar, los supermercados y hasta las saunas, están intentando usurpar a la vivienda espacios tales como la sala de estar, el comedor, e incluso la cocina y el cuarto de baño: y si exageramos un poco, se puede decir que como sigamos así, para una vivienda bastará con que haya un televisor y una papelera grande al lado de una cama. El espacio urbano está absorbiendo al de la vivienda de tal manera que es posible imaginarse tal cosa.

Toyo Ito $^{52}$

Para la muchacha nómada el salón era el café bar y el teatro, el comedor era el restaurante, el armario era la boutique, y el jardín era el club deportivo.

Un ejemplo claro y real que exponía Ito para entender este fenómeno es que por ejemplo, el espacio que precisaba la mesa de comedor, donde se reunía tradicionalmente la familia, se había trasladado al restaurante de la ciudad, ya que era el lugar donde ya se producían las comidas familiares. Allí se

51 En la exposición 'Il progetto domestico'. XVII Trienal de Milán, 1986.

52 Toyo Ito, "El Pao de las muchachas nómadas de Tokio", en Toyo Ito. Escritos. (Murcia: Colegio de Aparejadores de Murcia, 2000) editado por José Ma Torres Nadal, p.63. 
conportaban como si fueran la mejor familia y confirmaban su existencia ante los ojos del público.

En las reflexiones de Ito en base a su instalación ${ }^{53}$, los habitantes empezaban a comportarse como actores en un espacio ficticio e imaginario ofrecido por la ciudad, que comenzaba a percibirse incluso como más confortable que el espacio real. Si no representaban como actores, se comportaban como espectadores, o seguían interpretando también en otro escenario, ya también ficticio, que era la casa.

Como Iñaki Ábalos y Juan Herreros decían ${ }^{54}$. "La chica nómada no actúa a la presión del entorno, sino que está dispuesta a ser ella misma objeto de las acciones y ofertas del consumismo". Ito respondía a este estilo de vida, nómada metafóricamente hablando, mostrando una arquitectura que se caracterizaba por su formato efímero -aunque todavía permanente-, por su gran liviandad y transparencia.

Todo ello pronosticaba la progresiva desaparición de la escena doméstica como espacio íntimo, que había sido desacreditato como tal por la intrusión de las redes, y en el que la cultura de consumo rápido y hedonista había hecho desaparacer el objeto como reflejo de su propia existencia. 

3. OBJETOS Y ESPACIO DOMÉSTICO: RELACIONES Y CONFIGURACIONES 

Imagen: Steven Holl. Apartamento Cohen, Nueva York . 1983

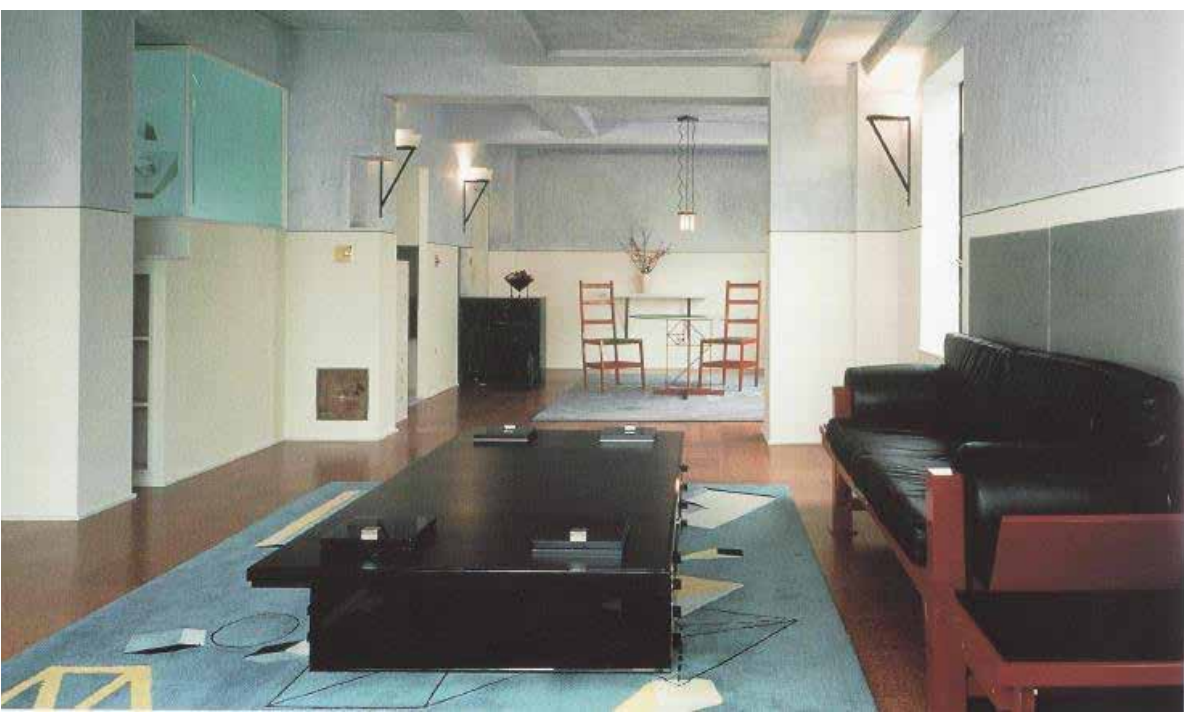

3- OBJETOS Y ESPACIO DOMESTICO: RELACIONES Y CONFIGURACIONES

Toda percepción de objetos es una percepción de objetos en el espacio. Mediante el análisis de relaciones de distancias y posición puede percibirse el espacio entre ellos. Todo ello suministra esquemas que imponen coherencia y orientación al mundo percibido.

\section{Christian Norberg-SchulzJ ${ }^{1}$}

Los objetos en el espacio, a través de sus relaciones, han jugado un papel importante como agentes configuradores. Organizados, en mayor medida, en sistemas o grupos dentro de ese marco, han contribuido a determinar las características que son propias del ámbito doméstico contemporáneo. En el mismo proceso, los objetos añadidos, también participaron en la creación de conexiones y vínculos con el entorno e incluso contribuyeron a modificar las cualidades del ámbito y la manera de percibirlo y de vivirlo, dotando al espacio de una nueva dimensión generada por sus connotaciones psicológicas.

En los diferentes acercamientos a este proceso ha habido siempre un afán por abordar el tema de forma objetiva, a través de sistemas de clasificación; tipificando, sistematizando y buscando códigos de ocupación, apropiación y relaciones entre elementos. En ese sentido, los modos de agrupación y de relación entre elementos en el espacio, así como los factores sociales y culturales añadidos y conectados al ámbito en el que se ubicaban, iban ligados a características y cualidades concretas que, en gran medida venían siendo consecuencia de los fenómenos producidos. "Por la experiencia cotidiana sabemos que los fenómenos se desencadenan de determinadas formas, hablamos de causas y efectos, significado y orden". ${ }^{2}$

La visión contemporánea del objeto se debatía inmersa en un mundo de consumo, en el que el objeto, según los analistas, se había convertido en un factor social más que en algo meramente funcional. En la cadena de mercado, considerando el objeto como producto de consumo, la mayoría de los estudios calificaban el espacio doméstico como el ámbito de ubicación del objeto que era de mayor interés, ya que se consolidaba como el eslabón final de la cadena y porque era el territorio existencialmente más íntimo del ser humano.

1 Christian Norberg-Schulz. Intenciones en arquitectura (Barcelona: Gustavo Gili, 1998).

2 Ibid. p.20. 
¿Dónde se encuentran los objetos? (...) Desde luego, el lugar más obvio para encontrar gran cantidad de objetos son las esferas inmediatas de acceso y de apropiación de cada individuo: el piso y sus habitaciones, sus rincones y armarios.

Abraham Moles ${ }^{3}$

Las definiciones cambiaban y se dirigían a conceptos como la artificialidad y la invariabilidad. En un mundo cada vez más virtual, por el efecto de las tecnologías y las comunicaciones, el objeto se definía por su capacidad de permanencia y por lo que significaba. La función había sido desplazada por el significado, desde el momento en el que el objeto se entendía como un factor social. En el proceso de configuración de ese marco más íntimo, los estudios realizados deducían que la labor semántica de los objetos era más importante cuando actuaban en sistemas organizados dentro del espacio, con unos códigos de relaciones y de conexiones. Según determinadas reglas semánticas, más o menos establecidas, se determinó que era posible la elaboración de un discurso dentro del que se podía llamar 'ámbito de apropiación', que era el espacio en el que se disponían y ocupaban. A esa ocupación organizada también se superponía un mensaje generado por las connotaciones y las conexiones de objetos personales y simbólicos que establecían vínculos entre el habitante y el espacio vivido. La percepción y la experiencia ya formaban parte de la vivencia de la arquitectura y de nuevo los objetos jugaban su papel como sistema. Había excepciones, los objetos singulares, que aunque actuasen aislados también funcionaban como signo, y dentro de aquel sistema de signos, no interferían en el discurso, sino que participaban en su elaboración.

Como dijo Baudrillard, el objeto se convertía en elemento de juego, de combinación, de cálculo, en un sistema universal de signos que, como ya se vio, en el interior moderno, se basaba en una oposición entre dos conceptos: la colocación y el ambiente. Al imperativo físico de la colocación se añadía siempre el factor cultural de ambiente. Ambos estructuraban una misma práctica, eran dos aspectos de un mismo sistema. Tanto en el uno como en el otro se ejercían los valores de juego y de cálculo, desde el significado en la combinatoria de relaciones, disposiciones, ubicación, distancias, jerarquías, agrupaciones, etc., para la colocación, hasta las connotaciones y aspectos perceptuales añadidos a través del cálculo de los colores, de los materiales, de la iluminación, de las formas, del tratamiento del espacio para el ambiente. Todo el entorno moderno pasaba, en bloque, al nivel de un sistema de signos: el ambiente.

En esa combinatoria ${ }^{4}$, para estudiar el sentido de los objetos parecía conveniente provocar una especie de distanciamiento en el análisis, para 'objetivar' el objeto y para estructurar su significación. Para ello, Barthes ya proponía un recurso que consistía en recurrir a un orden de representaciones donde el objeto fuese entregado al hombre de una manera a la vez espectacular, enfática e intencional. A ese orden correspondían la publicidad, el cine e incluso el teatro. En realidad se refería a ámbitos bastante artificiales, pero eran muy valiosos para aislar en el objeto representado, significantes y significados. En esas representaciones o simulaciones de una hipotética realidad, las exposiciones comerciales y

3 Abraham A. Moles. Teoría de los Objetos. (Barcelona: Ed. Gustavo Gili, 1975).

4 Roland Barthes, "Semántica del objeto" en Arte e Cultura nella civilita contemporánea. Editado por Piero Nardi (Florencia: Sansoni, 1966). Edición en PDF: http://mariosantiago.net/ Textos\%20em\%20PDF/semanticadelobjeto.pdf. p.4. 
Imagen: Charles \& Ray Eames. Exposición 'Good Design'. MoMA, Nueva York. 1950

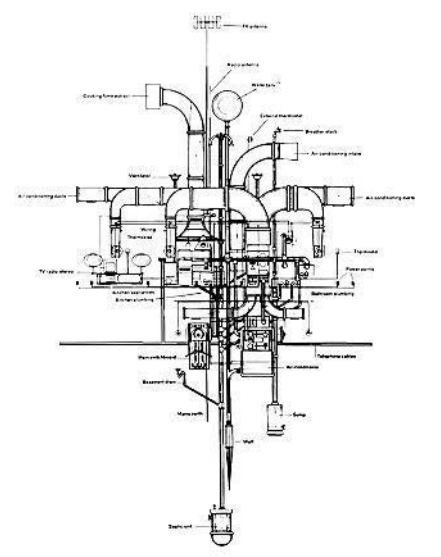

Imagen: Abajo: François Dallegret: 'Anatomía de una vivienda'. Representación del entramado de instalaciones que precisaba una vivienda, omitiendo la piel o la carcasa exterior. En "A home is not a house", $R$. Banham,1965. muestras publicitarias de mobiliario y demás elementos para el hogar, han proporcionado ejemplos suficientes para hacer un acercamiento al objeto en su estado más 'espectacular, enfático e intencional'. Aquellas muestras fueron siendo cada vez más influyentes en el consumo de los hogares, a través de la publicidad y del avance de las comunicaciones. A partir de los años 50 , sobre todo en Estados Unidos, las exposiciones comerciales y muestras se fueron celebrando durante décadas en un periodo de gran desarrollo tecnológico y de grandes cambios sociales. El acercamiento a estas plataformas promocionales, según el recurso que proponía Barthes, ha permitido asomarse a un orden de representaciones entregado al hombre contemporáneo de la manera más intencional.

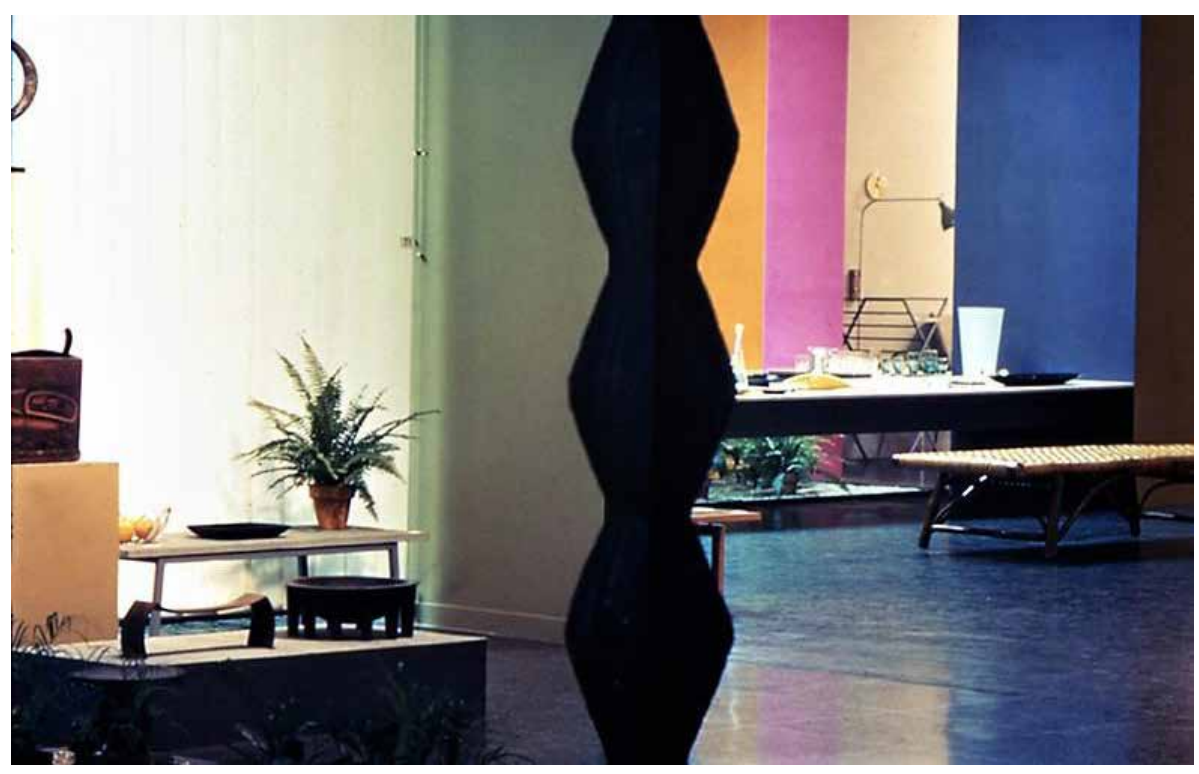

Estos 'montajes', inicialmente comerciales o patrocinados, reproducían hogares 'ideales' configurados por sistemas coordinados altamente tecnificados, representado escenas domésticas del presente y del futuro. Muchos de ellos han pasado a la historia como hitos en el mundo del diseño del espacio doméstico, pero no sólo por los avances tecnológicos y la espectacularidad de los ambientes generados, sino también por su implicación en el debate sobre las direcciones que debía tomar el futuro de la vivienda y de sus equipamientos.

En aquellos debates y en la promoción comercial por medio de las publicaciones y la afluencia en torno esas manifestaciones, radicaba en gran medida su influencia en la conformación de los interiores. Las exposiciones transmitían mensajes que, de manera muy intencional, llegaban claros y netos tanto a los consumidores como a los arquitectos y diseñadores. Los sistemas generados en los montajes también creaban pautas de relación entre el usuario y los objetos que se exhibían a través de representaciones de escenas domésticas con personajes de carne y hueso. Los muebles, los colores, la iluminación, el sonido, el vestuario, etc. configuraban hábitats ideales en los que los visitantes añoraban vivir; la sociedad reclamaba espacios adaptados a los nuevos modos de vida y estas muestras, en cierto modo, se los ofrecían.

Muchos de aquellos ámbitos que se representaban en las ferias, reproducían espacios con características que ya eran propias de la época o adelantadas a ella. Pero también hacían crítica y generaban debate, proponiendo nuevos hábitats que hipotéticamente solucionarían problemas inherentes al mundo que les tocaba vivir. 
La disociación entre la idea de la casa tradicional y el concepto de hogar, que surgía en los años 60 representado por la Un-home del artículo de Reyner Banham "A home is not a house" , era una de las principales consecuencias del debate sobre los nuevos espacios que el habitante contemporáneo reclamaba. Lo cierto es que la fractura que planteaba la forma del volumen habitable y el concepto de casa contemporánea, hacía que el equipamiento interior fuera mayormente imprescindible para poder llamar a la carcasa, hogar. Según explicaban X. Monteys y P. Fuertes ${ }^{6}$ algunos arquitectos metabolistas japoneses proponían resolver esta separación con una doble envolvente, una exterior que definía la forma de la casa y otra interior que se aproximaba al habitante. Tal era el caso del edificio de cápsulas enchufables en Ginza, Tokio, construido por Kisho Kurokawa en 1972 para albergar a gente de negocios que trabajaba durante la semana en el centro de Tokio. Un núcleo central de hormigón armado permitía el acceso, abastecía y sustentaba un conjunto de cápsulas que formaban una torre. El interior de las cápsulas estaba concebido como un estuche y el exterior como una caja. Una carcasa experimental dotada de un interior con todos los elementos necesarios 'incorporados'.

Juan Herreros en Mutaciones de la arquitectura contemporánea. El espacio doméstico ${ }^{7}$, decía que trabajar desde esa perspectiva artefactual suponía, aunque sólo fuera de forma implícita una, 'desproblematización' de la casa como figura final en favor de un interés por el medio interior, por la interacción de los elementos entre sí y con las personas, por sus formas de significación y de relación. Ello implicaba la posibilidad de separar en dos mundos la configuración tópica de la idea de alojamiento: tomar el territorio del espacio doméstico, el hogar, el interior y eliminar de momento la casa, la vivienda, el exterior.

Las características de los ámbitos domésticos surgían pues de las nuevas necesidades del habitante contemporáneo y de los paradigmas de una época caracterizada por la tecnología, la cultura de consumo y los cambios sociales. El factor más característico fue el desarrollo de la planta abierta, sobre todo a partir de la segunda mitad del siglo XX. Las causas que propiciaron la unificación del espacio doméstico en lugares más amplios y diáfanos fueron los avances técnicos, que permitían mantener acondicionada cualquier parte de la casa y un mayor volumen de espacio durante más tiempo, además los avances técnicos en la construcción permitían obtener espacios más diáfanos con estructuras cada vez más ligeras, los muros ya no eran necesarios. Por otro lado estaban los cambios sociales. El habitante, sobre todo urbano ya no ocupaba la vivienda durante generaciones, como lo habían hecho sus antepasados, ahora permanecía durante un tiempo y se marchaba a otro lugar, pasados algunos años, incluso ponía en cuestión si era necesario una habitación diferente para cada una de las actividades domésticas, teniendo en cuenta que, además, los precios eran más altos y por tanto cada vez podían permitirse una menor cantidad de metros cuadrados. A ese respecto, se fueron precisando cada vez más espacios más unificados para que fuesen más polivalentes, es decir, que admitiesen la mayor cantidad de actividades posibles. En la casa abierta la ubicación de las funciones diarias las iban marcando los propios muebles, en el tiempo y en el espacio. Los objetos adquirían nuevas acepciones en contenedores cada vez más neutros, funcionando como mecanismos de definición espacial. La casa se convertía en un marco para el equipamiento.

5 Artículo publicado en la revista Art in America ( $\mathrm{n}^{0}$ 2, abr-1965).

6 Xavier Monteys y Pere Fuertes. Casa collage. Un ensayo sobre la arquitectura de la casa (Barcelona: Gustavo Gili, 2001) p.114.

7 Juan Herreros. "Mutaciones en la arquitectura contemporánea. El espacio doméstico". Tesis Doctoral. Universidad Politécnica de Madrid, 1994.
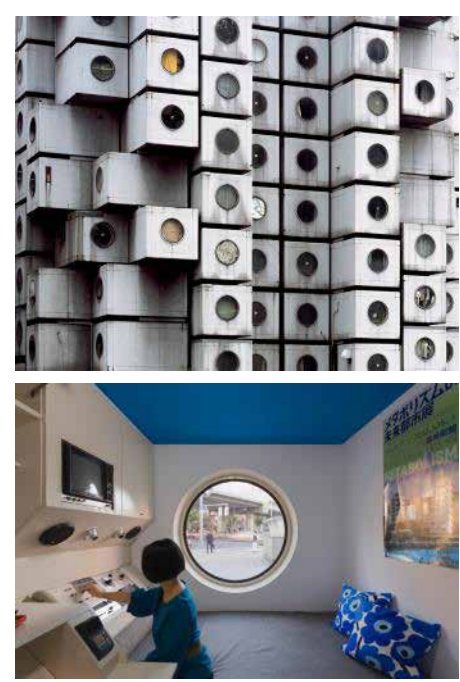

Imagen: Torre Nakagin en Ginza. Kisho Kurokawa, Tokio,1972. Arriba: vista exterior de la torre. Abajo: interior de la cápsula. 


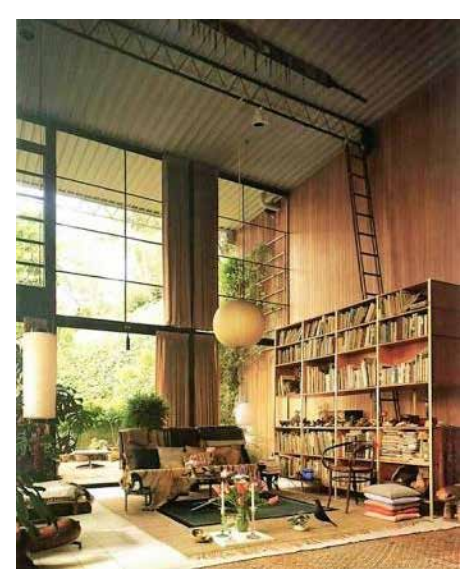

Imagen: Case Study House 8. Ch.\& R. Eames. California, 1949. Vista interior de la sala de estar donde los objetos y el mobiliario 'domestican' un contenedor tecnificado.

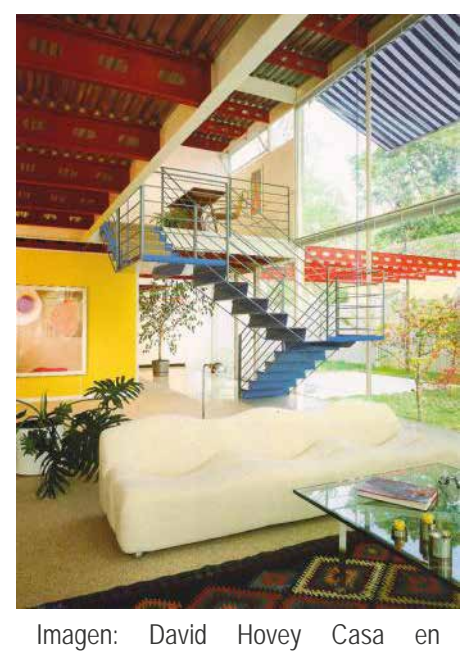

Winnetka, Illinois. 1981

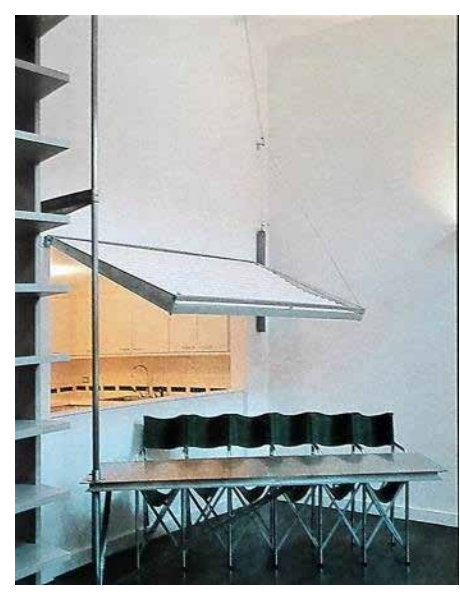

Imagen: SmithMiller+Hawkinson Apartamento en Nueva York, 1989

El mobiliario transformable flexibilizaba los usos del apartamento.
El hogar, cada vez más, evolucionaba consciente o inconscientemente en pos de los avances tecnológicos. Los sistemas constructivos, en muchos casos vinculados a los avances de la industria aeronáutica, proporcionaban espacios tecnificados que se traducían en interiores con acabados industriales y con estructuras e instalaciones vistas. Estos ámbitos, si bien ofrecían ventajas como luces mayores, amplias superficies acristaladas o una mayor libertad formal, también reclamaban implementos añadidos y sistemas de objetos personales que participaran en un proceso de 'domesticación' del espacio favoreciendo la conexión psicológica con sus habitantes, como ocurrió en la casa de los Eames. La cuestión era aumentar la componente simbólica dentro del espacio para mejorar sus cualidades en pos de incrementar los vínculos con el usuario.

Las técnicas constructivas avanzadas también evidenciaban determinados elementos arquitectónicos y como preconizaba Reyner Bahnam con la Unhome, las instalaciones de acondicionamiento y abastecimiento de las distintas áreas de la casa se convertían en auténticas protagonistas. Como decía Moore ${ }^{8}$, con un mínimo de previsión conductos y tuberías podían empotrarse en las paredes, los suelos y los techos de las casas, pero existía otra alternativa a todo eso: "no es necesario en absoluto ocultar conductos y tuberías que pueden dejarse totalmente a la vista, como las vigas y traviesas de un tejado, para sugerir los procesos cinéticos que hacen posible el funcionamiento del edificio. $Y$ también pueden servir, menos solemnemente, como base de inflexiones y fantasías decorativas". En algunos casos, la objetualización de estos elementos a través de un proceso de diferenciación (por un mayor cuidado y riqueza en los acabados, o por proceso de transformación formal de ese elemento) del resto del sistema, les hacía convertirse en focos de atención 0 hitos dentro de la casa.

La conjunción entre los avances tecnológicos, los nuevos materiales, la planta abierta y los nuevos modos de vida, caracterizaron un ámbito principalmente característico de la sociedad contemporánea: la casa flexible. La necesidad cada vez mayor de entornos multifuncionales, propiciaba la investigación en el campo de los muebles convertibles o transformables. Arquitectos y diseñadores, sobre todo en la década de los 60 y los 70, trabajaban para conseguir aunar en un solo bloque-mueble las distintas actividades domésticas. Estos elementos proporcionaban, a través de ingeniosos mecanismos, la posibilidad de realizar la vida diaria en un mismo espacio, pudiendo mutar a lo largo del día o del año dependiendo de las necesidades de los usuarios. Las propuestas de Joe Colombo, a las que ya se ha hecho mención en otros apartados, al igual que otras muchas de aquella época, eran producidas y presentadas en las ferias y muestras de mobiliario, con el fin de establecer, a través de estos muebles, un nuevo espacio doméstico que mutaba caracterizado por artefactos mecanizados y que representaba un nuevo modo de vida.

Otro de los espacios domésticos contemporáneos que surgió directamente de un nuevo modo de habitar fue el loft, o la casa abierta y desenfadada en un espacio industrial reconvertido. El loft surge cuando un grupo determinado de artistas decide trasladarse a vivir y trabajar en el sureste de Manhattan, adquiriendo grandes espacios en edificios industriales y comerciales abandonados. En los años 60 el loft representaba el ambiente vital, de creación y difusión del arte por excelencia. Así surgía una nueva manera de habitar,

8 Charles Moore, Gerald Allen y Donlyn Lyndon. La casa: forma y diseño (Barcelona: Gustavo Gili, 1999) p.106. 
no codificada por un proyecto a priori, demostrando que se podía tener un envidiable modo de vida instalándose en un espacio casi desnudo, desafiando las convicciones de los arquitectos, urbanistas y burgueses. Es interesante qué valores y qué ideas espaciales subyacían, cómo se organizaban para dar lugar a una de las formas más singulares de habitar que el siglo veinte inventó.

Interesante resulta también cómo esta larga tradición que tomó su origen en la idea de comunas de los primeros socialistas utópicos derivó finalmente en su versión más delirante: el loft neoyorkino, y éste a su vez en una forma de pensar, construir y habitar un arquetipo de casa contemporánea.

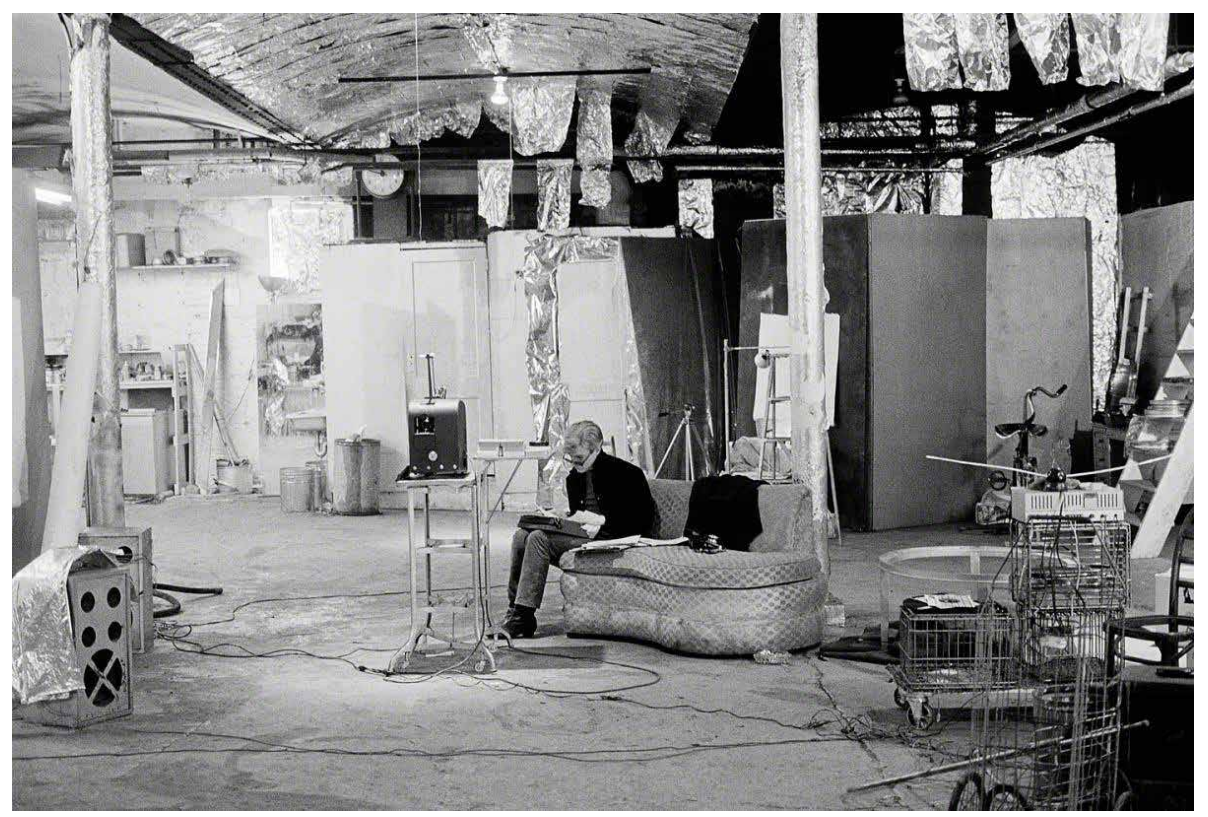

En los años 80 el loft perdió su esencia de espacio creado para la circulación de ideas y de escenario de acciones creativas, convirtiéndose más bien en la sede habitacional de profesionales hedonistas: emprendedores, personas de éxito.

Los avances tecnológicos de décadas anteriores, en los 80 , fueron orientándose a proporcionar placer y a satisfacer las apetencias de una sociedad cada vez más acomodada y materialista, algo que se hacía notar lógicamente en todo tipo de entornos domésticos. Pero lo que sí es cierto es que el espacio industrial reconvertido, arquetipo de un modo de vida de una determinada época, marcó un modo de ocupación: la apropiación. Un despliegue de objetos aparentemente desordenado, aleatorio y creativo, cambiante y muy poco convencional que de forma unívoca iba unido a un marco con unas características muy concretas.

A los espacios reconvertidos, habría que añadir la tendencia, que surgió sobre todo en Estados Unidos, de recrear antiguos graneros americanos, y como ejemplo, las viviendas de MLTW de los años 60 cerca de la Bahía de San Francisco. Recreaciones de espacios de la arquitectura vernácula llenos, sin embargo, de referencias culturales y contraculturales. La incorporación de luces de neón, la introducción de arte óptico, supergráficos y referencias cinematográficas junto a retratos decimonónicos o mobiliario barroco creaban mundos que reivindicaban la convivencia entre tiempos pasados y el presente. La casa contemporánea podía convertirse en una alegoría, en un lugar donde lo simbólico, lo histórico, lo barroco, lo exótico, junto a sistemas formados por elementos cotidianos, conformaban un discurso en un conjunto de signos y relaciones.
Imagen: The Factory. Andy Warhol. Manhattan, Nueva York, 1963.

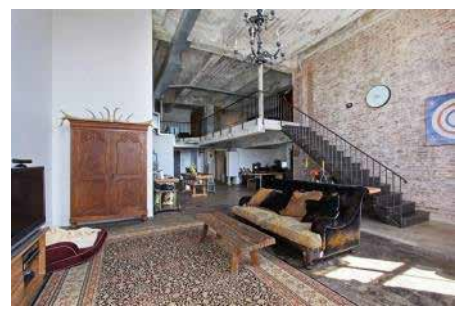

Imagen: Loft de los 80 en Brooklyn. 


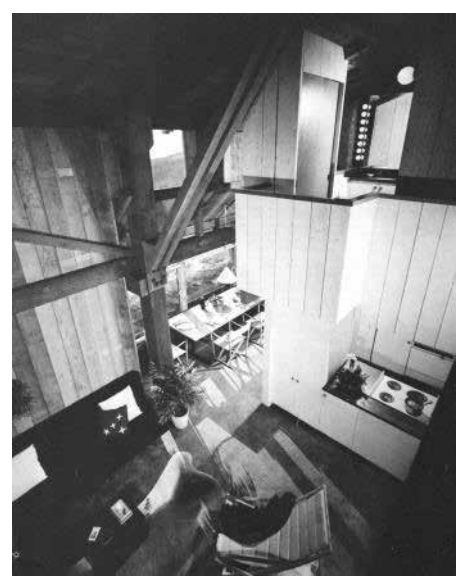

Imagen: Sea Ranch Condominium Sea Ranch, California. Por MLTW, 1964. Vista interior de uno de los apartamentos del complejo.
Imagen: Rosenak House. Hugh Newell Jacobsen. Tesuque, Nuevo México. 1987. Vista de la sala de estar. En la casa se ubicaba una colección, de los propietarios, de más de mil piezas de arte folk norteamericano.
A ese nivel, cuando todos los objetos poseídos eran objeto de la misma abstracción y se remitían los unos a los otros en la medida en que no remitían más que al sujeto, entonces se constituían como un sistema, llamado 'colección', gracias al cual el sujeto trataba de reconstruir un mundo, una totalidad privada dentro de su propia casa.

En muchos casos, estas colecciones formaban parte intrínseca del espacio, se fundían con la arquitectura de tal manera, como ocurría en la casa museo de John Soane, que la colección y la casa eran inseparables. Existen muchos casos contemporáneos en los que, de hecho, el proyecto de la casa estaba condicionado por la ubicación de una colección de gran tamaño, como la Casa Rosenak, en Nuevo México, de H.N. Jaconsen, que debía albergar una colección de los propietarios de más de mil piezas de arte folk norteamericano.

De muy diversas maneras, pero con una idea común: las características del nuevo hábitat propiciaban el papel, importante y decisivo, del objeto en el proceso de configuración espacial, por la interacción de los elementos entre sí y con las personas, y por sus formas de significación y de relación dentro del espacio.

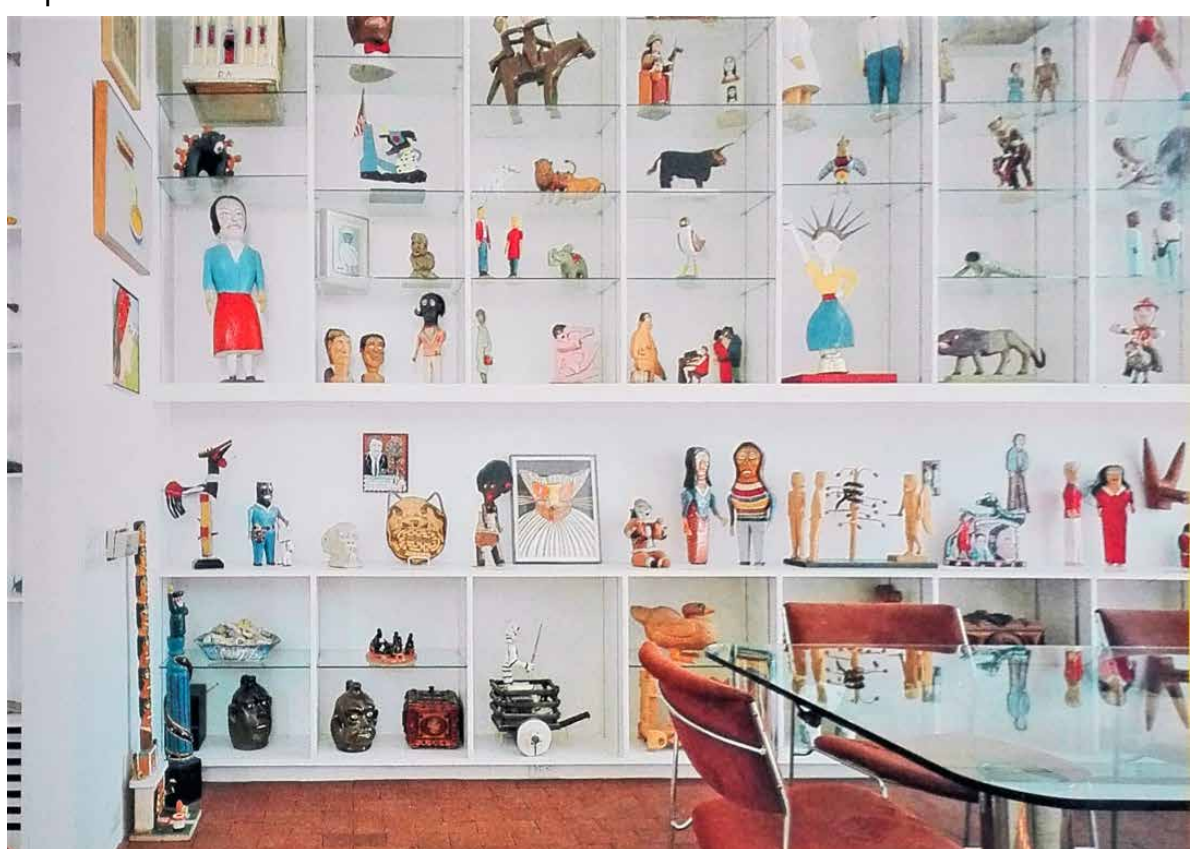

Las relaciones entre elementos suelen ser más importantes que los propios elementos, lo que no es muy sorprendente, puesto que el elemento está determinado por sus relaciones internas.

\section{Christian Norberg-Schulz ${ }^{9}$}

Para Norberg-Schulz 'relación' denotaba un modo lícito de distribuir elementos ${ }^{10}$. El análisis de relaciones de distancia y posición entre elementos ha sido decisivo a la hora de analizar y comprender el espacio entre ellos ${ }^{11}$. Se trataba de relaciones entre elementos en el espacio.

Desde un punto de vista formal, las relaciones eran tridimensionales 0 'espaciales', puesto que los elementos se consistían principalmente en masas y espacios. En este aspecto, se tendrán en cuenta las relaciones formales

9 Christian Norberg-Schulz. Intenciones en arquitectura (Barcelona: Gustavo Gili, 1998) p.94.

10 Ibíd. p.91.

11 Ibíd. p.90-91. 
establecidas por Norberg-Schulz, tanto topológicas como geométricas, de elementos en el espacio. Es decir, qué implicaba espacialmente una relación de proximidad, o si por medio de este tipo de relación, un determinado número de objetos finalmente formarían un sistema. Como se vio, los grupos o sistemas, en sus códigos de organización, establecían un discurso, por lo que en ese sentido, 'proximidad' podía implicar más cosas que estar más 0 menos cerca de una o varias cosas. Lo mismo ocurriría con otras relaciones formales, como la sucesión, la continuidad, la fusión, entre elementos, cuyos juegos de disposiciones tenían implicaciones espaciales estructurantes y de tipo organizativo. Pero además, como ya hemos visto, en las relaciones también interferían otros factores más bien de tipo subjetivo. Los objetos podían establecer relaciones sintácticas a través de conexiones. Estas podían ser culturales y sociales, simbólicas, espacio-temporales, o simplemente de tipo personal del propio usuario y que respondían a la necesidad de vínculos del habitante con el espacio vivido. Estas relaciones, a través de conexiones con factores de ambiente, también podían tener implicaciones espaciales de tipo perceptivo. Es decir, influían en la forma de entender el espacio, en base a las 'sensaciones' que se producían a través de la vivencia y la percepción.

Se han establecido características y cualidades que son propias de los ámbitos domésticos contemporáneos. También se ha constituido una muestra de aspectos en torno a los objetos en ese marco. Refiriéndonos a los que ocupan específicamente ese espacio, los objetos cotidianos, los que están fabricados por y para el hombre y los que están hechos a la escala del hombre. Los que por tamaño y características, pueden introducirse dentro de la casa.

En base a estudios contemporáneos concretos que abordaban una nueva la visión del mismo, se han establecido las bases de sus definiciones, de las teorías que se desarrollaron y de las distintas clasificaciones que, con muy diferentes criterios, iban desde su tamaño hasta su significado, organizándolos en sistemas o grupos codificados y ligados a su propio acto de ocupación y de despliegue en el espacio. Frente a estas miradas también se han reconocido nuevos conceptos en torno a ellos. El objeto como elemento de consumo, adquiría el rango de factor social y tomaba un nuevo rumbo desde el punto de vista de su estudio. En ese momento empezaba a formar parte de los estudios sociológicos, y tomaba mayor interés en el momento en el que se le observaba como sistema. Los objetos, en la sociedad de consumo, estudiados como elementos sociales ahora comunicaban y en sistemas organizados dentro del espacio, a través de sus relaciones daban la oportunidad al hombre para elaborar su propio discurso.

El objeto moderno pues, se liberaba de su función dando paso a su significado. Lo funcional ya no calificaba a lo que estaba adaptado a un fin, sino que 'funcionalidad' se definía como la facultad de integrarse en un conjunto para generar un discurso. Para ello había que entender que los muebles tenían sus propios 'dominios', es decir, que precisaban de determinado espacio en torno a ellos y que establecían códigos y reglas para entender la semántica que acompañaba a los modos de ocupación y a sus relaciones.

En ese contexto los objetos también se empezaron a utilizar para despertar experiencias, ya que algunos arquitectos, a través de la aplicación de la fenomenología a su trabajo, reivindicaban un mayor interés hacia un espacio doméstico que se convirtiera en un lugar especial para sus habitantes. Como mecanismo de 'interiorización' dentro del espacio, para despertar en el habitante una especie de 'centro del universo' se recurrió a distintos niveles de interior, a través de lo que se conoce como 'la casa dentro de la casa'. 
La importancia otorgada por los diseñadores en estos años a cómo debían percibirse sus espacios y, teniendo en cuenta que muchos de ellos consideraban que la experiencia y la vivienda eran la mejor vía para el conocimiento de la arquitectura, permitieron hacer concebir el objeto, en algunos casos, como un mecanismo de transformación de la percepción del espacio. A todo ello se unía el recurso hacia las connotaciones psicológicas asociadas a la simbología y la memoria, 0 a técnicas basadas en psicología de la percepción, en el que los objetos tomaban protagonismo.

La técnica avanzada se empleaba tanto para crear efectos, 'ambientales', como para idear sistemas de mobiliario transformables, entre otras muchas cosas. Los nuevos materiales y las nuevas tecnologías (programación, mandos a distancia) consiguieron que los muebles pudieran modificar su forma de manera sencilla a lo largo del tiempo, dentro de un espacio generalmente diáfano y con vocación de multifuncionalidad y flexibilidad. La calidad del mueble-bloque -cabe recordar el apartamento de Joe Colombo en Via Argelati en Milán, organizado en torno a dos volúmenes exentos que cubrían las actividades de noche y de día respectivamente- situado en el espacio, a través de sus relaciones y de los fenómenos que se producen en torno a él, definía definitivamente las características del lugar donde se ubicaba y además cualificaba un espacio que representaba un modo de vida contemporáneo.

Para establecer una relación entre las características y cualidades propias del espacio doméstico contemporáneo y el papel ejercido por los objetos en dicho proceso de configuración, se ha empleado la taxonomía como principio para dar forma objetiva al análisis.

¿Hay quien puede confiar en clasificar un mundo de objetos que cambia a ojos vistas y en lograr un sistema descriptivo? Existen tantos criterios de clasificación como objetos mismos (...) Ahora bien, todo objeto transforma alguna cosa.

Jean Baudrillard ${ }^{12}$

Según lo anteriormente expuesto la clasificación permite vincular los modos de relación de los objetos en el espacio y las características y cualidades del entorno. Se ha considerado, en el proceso de configuración del espacio doméstico contemporáneo, por un lado los sistemas de objetos que en él se ubican en el acto de apropiación y acoplamiento, en cuanto a sus relaciones y conexiones en el espacio: entre los propios objetos, entre los objetos y el usuario, entre los objetos y el ámbito en el que se sitúan, y en cuanto a las connotaciones asociadas a los mismos y su influencia en la percepción espacial. Y por otro lado las características y cualidades propias del ámbito doméstico contemporáneo, en el que constituyen su discurso.

En un proceso en el que los sistemas contribuyen a configurar ámbitos con unas determinadas propiedades y en el que, en otras ocasiones nos encontramos con ciertas particularidades del entorno que propician la conformación de ciertos sistemas que, de igual manera, tienden a potenciar o modificar las cualidades del espacio. 


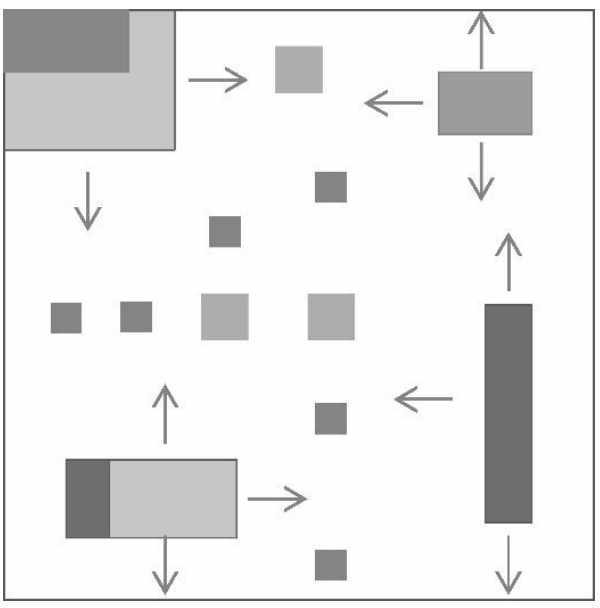

\subsection{ESPACIO, ORDENY JERARQUIA}

Todo objeto irradia a su alrededor".

Abraham Moles ${ }^{13}$

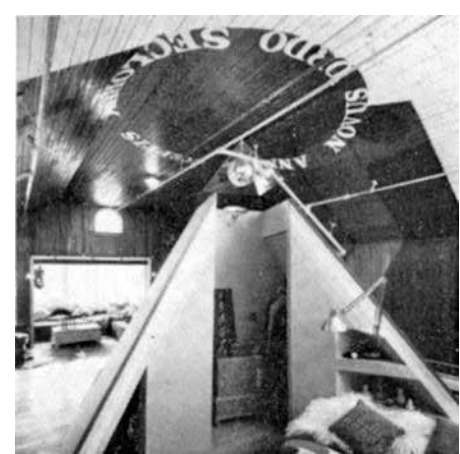

Imagen: Casa Moore. Essex Connecticut.

Charles Moore Associates,1970

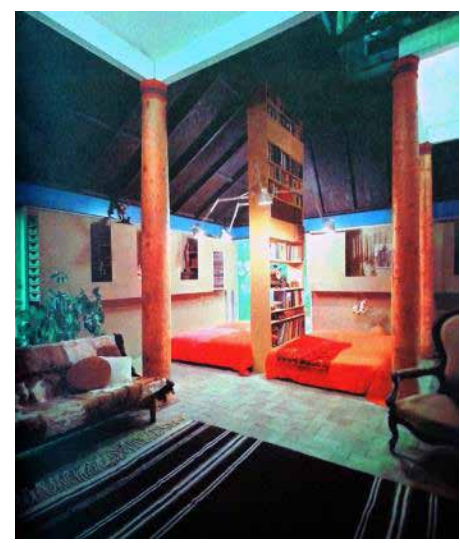

Imagen: Casa Moore. Orinda, California Charles Moore, 1962.
Según las 'leyes sintácticas de acoplamiento' todo objeto irradia a su alrededor creando un área de influencia que domina psicológicamente la parte inmediata de su entorno. La planta libre, característica de los nuevos ámbitos domésticos, potenció esta forma de significación del objeto en el espacio. Como se ha visto en anteriores capítulos, la apertura y diafanidad del nuevo marco requerido por las necesidades del habitante contemporáneo implicaba la falta de elementos arquitectónicos distributivos para delimitar áreas según los usos. En ese sentido fueron los objetos los que en gran medida tomaron el mando desde el punto de vista de la ordenación y la distribución de la planta. Un proceso marcado por relaciones topológicas de posiciones relativas en el espacio, y en algunos casos también absolutas. El nuevo espacio doméstico se configuraba pues en gran medida por el papel ejercido por las máquinas, aunque no tanto por sí mismas, sino por su capacidad de generar espacio en torno a ellas -lo que algunos arquitectos como Charles Moore- llamaron 'dominios', y básicamente por sus relaciones topológicas de orden de proximidad.

Los espacios domésticos conformados bajo la idea de lugares abiertos, como ya se ha mencionado en el apartado "la casa dentro de la casa", requerían en algunos casos, determinados ámbitos en los que se manifestara un cierto orden de interioridad y privacidad. Algunos arquitectos, como Charles Moore recurrieron a la idea tradicional del edículo y la transformaron en, cierto sentido, para que existiera un lugar en la casa, donde el habitante sintiera con un mayor grado de privacidad. Cuatro pilares y una cubierta, como en el caso de la casa para Charles Moore en Orinda, al norte de San Francisco, en California que fue diseñada y construida en 1962, eran suficientes para establecer este elemento ordenador del espacio.

La combinación de dos edículos dentro de una planta cuadrada con vocación de apertura tanto física como mental, contribuían a delimitar las zonas principales de la casa y a establecer jerarquías, ya que el tamaño de los dos era notablemente diferente.

Situada en un solar que dominaba un valle rodeado de robles, se colocó en una planicie circular que ya había sido desmontada y que ya formaba parte del

13 Abraham Moles, en Teoría de los objetos (Barcelona: Gustavo Gili, 1975) p.115, enunciaba la 'ley de irradiación' que se incluía entre las 'leyes sintácticas de acoplamiento' establecidas en 1972. 

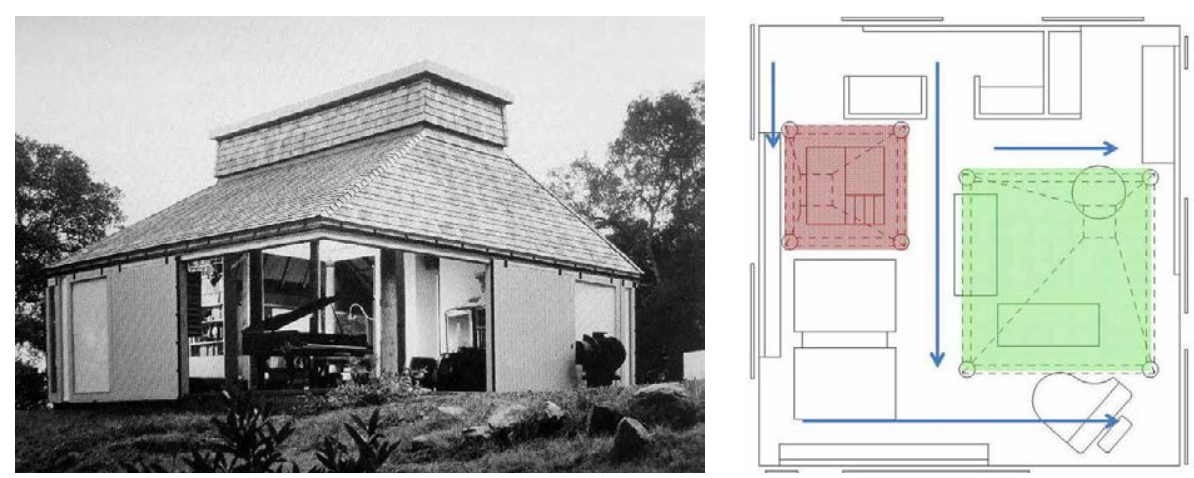

paisaje. El diseño general partió de una forma arquetípica de cabaña de planta cuadrada, y dentro se situaban dos edículos formados por ocho columnas con cubiertas piramidales asimétricas que compartían un gran lucernario. Las bóvedas de los edículos eran blancas por dentro distinguiéndose del resto de la cubierta que por dentro era de madera ennegrecida. Las columnas circulares, también de madera, provenían del derribo de una antigua fábrica. La cubierta apoyaba en los muros exteriores de fachada, que nunca remataban las esquinas, por lo que la sensación de amplitud era total desde el interior. En los muros una segunda piel, al interior, albergaba estantería, cocina y aseo, por lo que la liberación del espacio era total. La luz entraba por los lucernarios de los edículos y por las esquinas abiertas, la fachada se cerraba por medio de paneles correderos de granero que se deslizaban por los muros exteriormente. La sensación que producían los edículos era de estar en un espacio con varios lugares dentro, y donde existía un juego de límites, entre el interior y el exterior. Las camas se situaban a ambos lados de una gigantesca estantería, entre los dos edículos. El mobiliario era libre de colocarse de muchas maneras, tanto debajo como alrededor del edículo mayor. El pabellón menor albergaba una gran bañera excavada en el suelo, que era una especie de exaltación del acto de bañarse. La casa estaba "enriquecida con colecciones" que, junto con otros objetos, se situaban entre las pieles del muro exterior, que conformaban nichos y estanterías. Las columnas recuperadas, perfectamente cepilladas, lavadas y pintadas, eran 'objetos' dignos de disfrutar por sí mismos.

En esta casa el edículo principal funcionaba como elemento jerarquizador. Significaba interioridad y a la vez marcaba las zonas principales del espacio. Pero por el diálogo con el otro edículo, más pequeño, también adquiría la condición de edículo ordenador. En este caso, ambos organizaban el espacio dentro y en torno a ellos. Las relaciones de proximidad generaban espacios intermedios y distribuían la planta, creándose otros ámbitos para objetos de menor tamaño.

La casa Van Wassenhove, que diseñó el arquitecto belga Juliaan Lampens para un profesor, en 1974, es otro ejemplo, posterior, de casa organizada por dos elementos diferenciados en el espacio y que, en su diálogo, codificado por su posición, forma y material, establecen las pautas de distribución y organización del resto de la casa.

Como en el caso anterior, estos dos volúmenes -ninguno de los dos llegaba al techo, por lo que se entendían como bloques colocados en el espacio- en una planta libre y abierta al paisaje, gracias a sus diferencias, jerarquizaban y ordenaban. El volumen circular y de madera de arce cepillada, que contenía el dormitorio, se diferenciaba del otro volumen, de hormigón y cuadrado, que albergaba el estudio. Entre ambos establecían un discurso en un espacio topológico, en el que tomaban partido también la escalera y los espacios
Imagen: Casa Moore. Orinda, California. Charles Moore, 1962. Vista del exterior y planta donde se marca la posición de los dos edículos y las relaciones a través de espacios intermedios y circulaciones perimetrales.

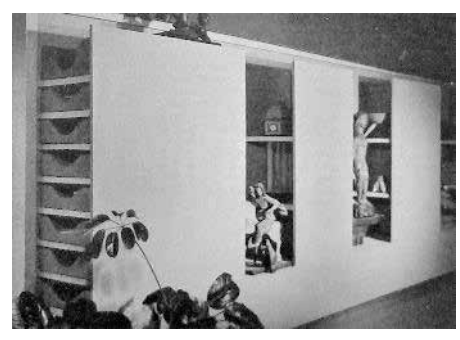

Imagen: Casa Moore. Orinda, California. Charles Moore, 1962. Vista de los nichos producidos por la doble piel del muro exterior. 
Imagen: Casa van Wassenhove en Sint-Martens-Latem. Juliaan Lampens, 1974. Vista interior y planta.
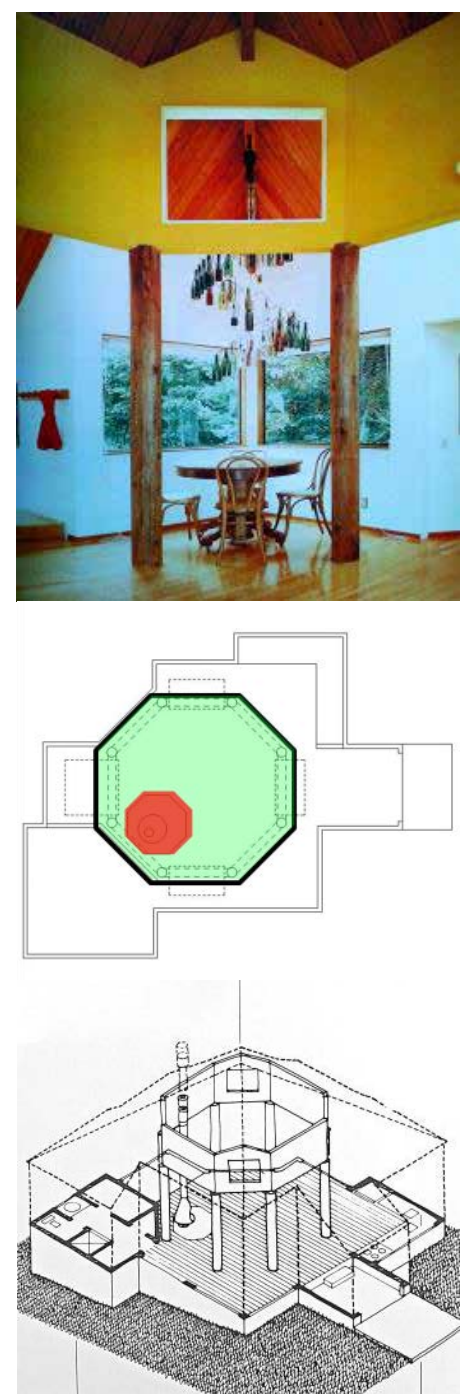

Imagen: Casa Johnson. Sea Ranch, California. MLTW, 1965. Planta donde se marca la posición del edículo y la chimeneda en su interior, y perspectiva.
Imagen: Casa Robert Mittelstadt. San Franciaco, California. Robert Mittelstadt, 1975. Vista del interior del espacio en doble altura sobre la sala principal. intermedios donde se situaban el baño y la cocina. La escalera, tangente a ambos elementos, articulaba tanto los dos niveles de la casa como las dos piezas que la definían.

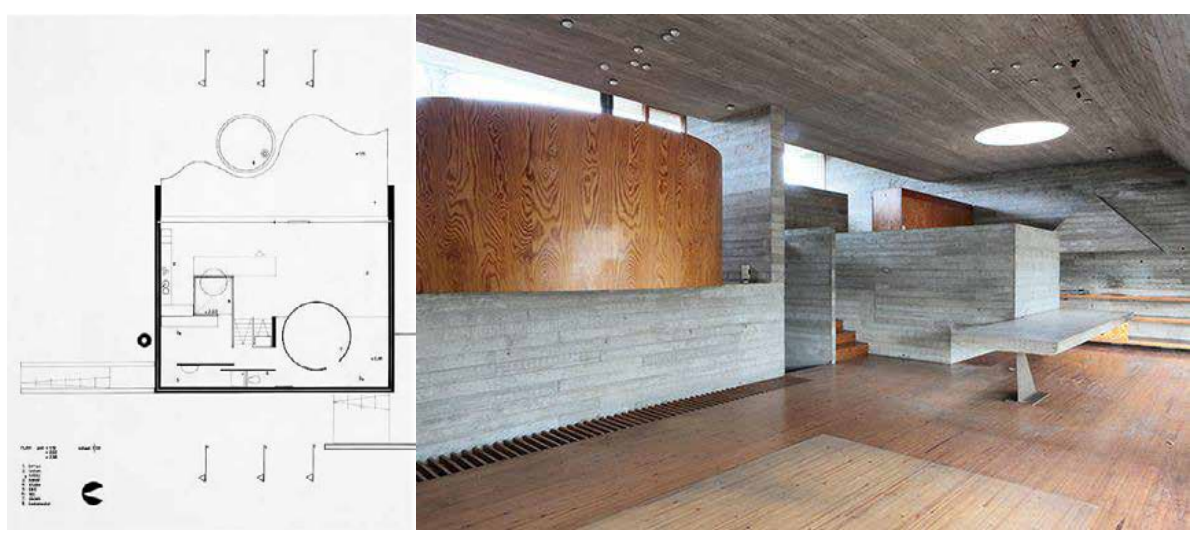

Cuando la piel del edificio era irregular, el edículo colocado en su interior podía cambiar el orden espacial en torno a él y percibirlo como ordenado y regular. La casa Johnson es un ejemplo de esta idea aplicada a una vivienda de pequeñas dimensiones y con una planta de geometría más compleja. Un edículo, en este caso octogonal, incluido en el espacio principal, relacionaba las distintas partes de la planta, unificaba el espacio y lo regularizaba perceptualmente. También posibilitaba las conexiones de las áreas funcionales, más pegadas a la piel del edificio, a través de los intercolumnios. En los espacios intermedios se producían acciones que tradicionalmente estaban reservadas a habitaciones concretas. "La conexión entre las áreas específicas y las simbólicas se asegura mediante los espacios abiertos de los intercolumnios y, más sutilmente con los cuatro huecos practicados encima del octógono"14.

Los huecos en la parte superior del edículo, a través de los cuales se podía ver la parte inferior de la cubierta, amplificaba la percepción del espacio. La cubierta y las columnas organizaban y jerarquizaban, a través de un sistema de pieles, los niveles de relación con el exterior. La ordenación del espacio se producía pues, gracias al edículo octogonal. La casa se volvía perceptualmente ordenada en torno a un espacio central, que jerarquizaba y generaba espacios intermedios, ricos en actividad, que liberaban al centro de la casa de acciones secundarias.

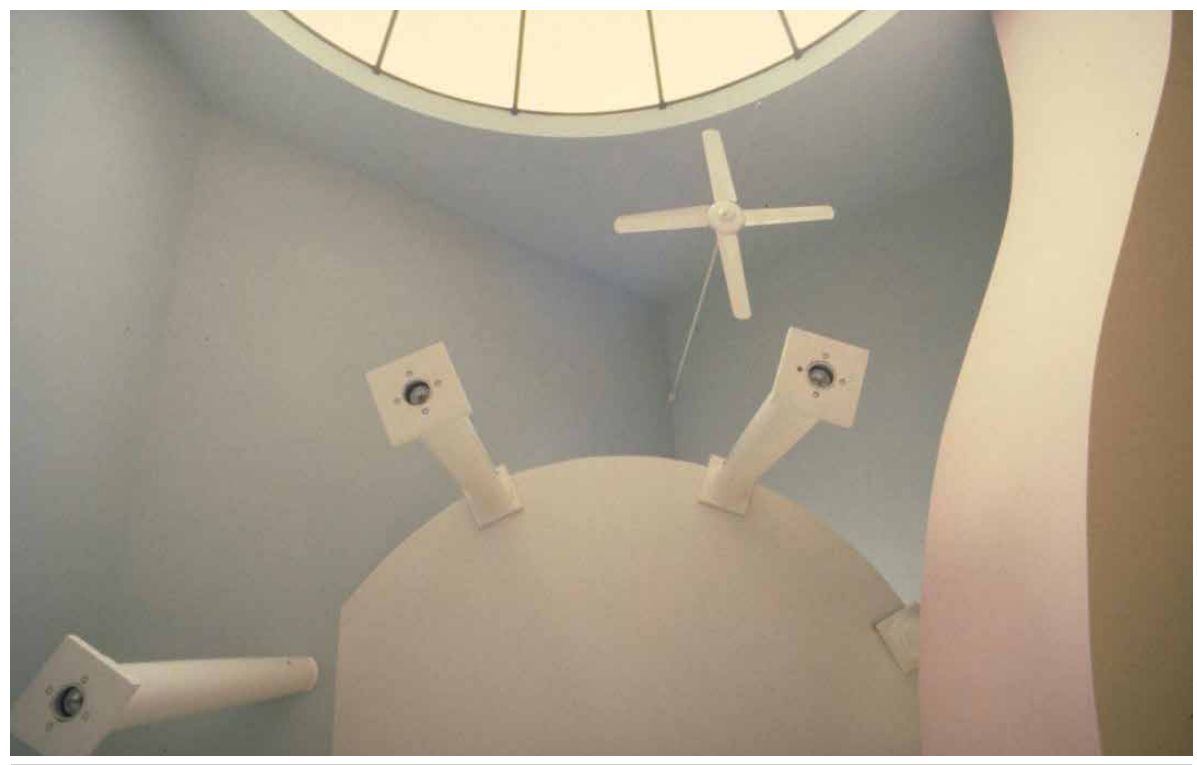

14 Charles Moore, Gerald Allen y Donlyn Lyndon. La casa: forma y diseño (Barcelona: Gustavo Gili, 1999) p.144. 
Otro ejemplo que refleja la idea de elemento jerarquizador la encontramos en una vivienda de dos plantas diseñada por Robert Mittelstadt en 1975 en San Francisco, California, para albergar su propia casa. Una especie de edículo elevado sobre la sala marcaba el espacio principal de una forma peculiar.

Fue portada en $1982^{15}$ de la revista GA Houses con el título "New Waves in American Architecture" y el motivo lo dejaban claro... era por "las columnas voladoras que aparecen en la segunda planta de este dúplex sin llegar al suelo"16.

Mittelstadt había convertido la idea de una lámpara en una especie de templete que levitaba sobre el área que rodeaba a la chimenea. Las basas de las columnas contenían luminarias. Quizá lo importante no fuese que las columnas 'volasen', si no que definiesen el área principal a través del volumen virtual que generaban.

El hecho de no 'tocar' el suelo convertía a este elemento en una pieza exclusivamente jerarquizadora, ya que no condicionaba la distribución de los muebles en torno a la chimenea. Simplemente marcaba el lugar principal.

Otra manera de generar elementos para ordenar y jerarquizar surge recordando las ideas de Reyner Banham o de Charles Moore, sobre las posibilidades compositivas que podían ofrecer las instalaciones 'vistas' en el interior de los edificios. En ejemplos, como el Mergenthaler Linotype Building -un condominio de lofts situado en una antigua zona recuperada y prevista como área de expansión residencial en el sur de Chicago- ocurría que los propios conductos, en un proceso de objetualización de las instalaciones de acondicionamiento en el interior de los apartamentos, adquirían tales formas que se convertían en una especie de 'canopias' que ordenaban y distribuían los espacios, que eran prácticamente diáfanos.

La zona donde se ubicaba, que unía el centro de la ciudad con el extrarradio, contenía varios edificios abandonados que habían sido antiguos talleres de imprenta, y que se habían quedado vacíos por el traslado de estos negocios a los suburbios.

El edificio, de 1886, aunque remodelado en 1917, se encontraba catalogado, por lo que la intervención se ajustó a las limitaciones por el grado de protección y por el presupuesto. La reconversión del edificio iba dirigida a albergar 21 viviendas en cinco plantas y locales comerciales en planta baja. La mayor premisa, según los arquitectos, era conseguir plantas ordenadas, con espacios diferenciados, pero sin perder la flexibilidad ${ }^{17}$.
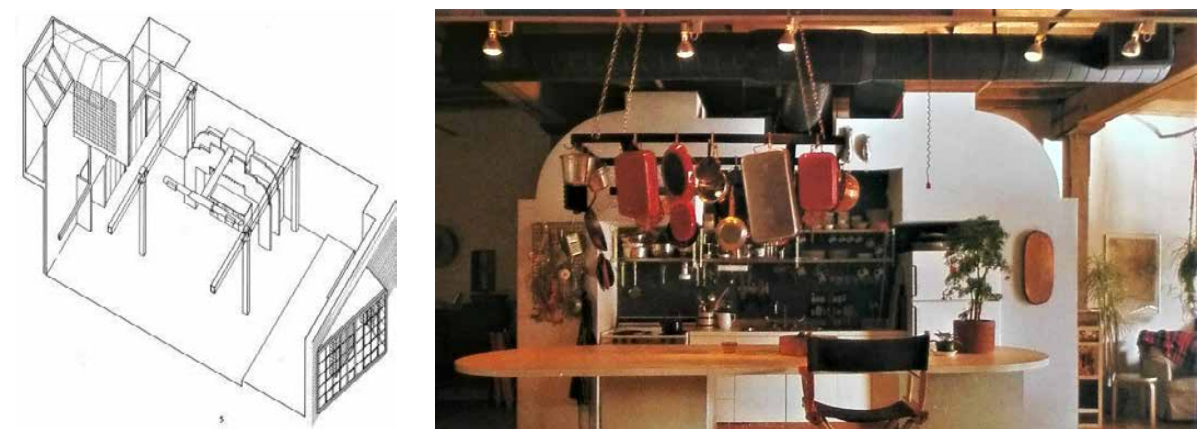

15 Robert Mittelstadt, "Mittelstadt duplex. San Franciasco, California, 1975-79", GA houses (n¹1, mayo 1982) p.52-57.

16 Ibídem.

17 Kenneth E. Schroeder. "Mergenthaler Condominiums. Chicago, Illinois, 1980", GA houses (n8 may. 1981) p.134-139.

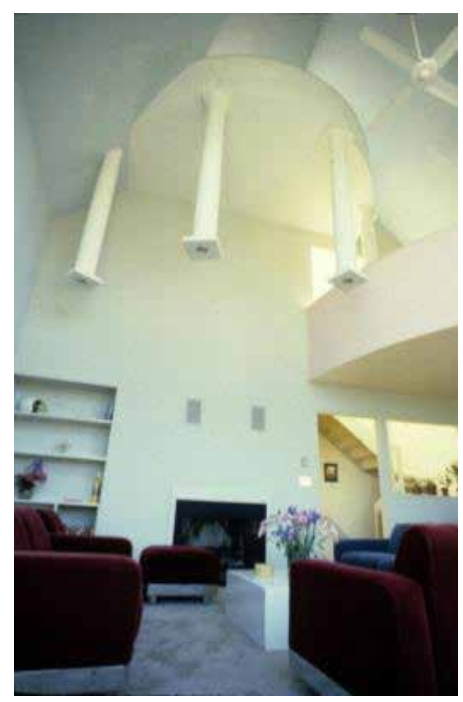

Imagen: Casa Robert Mittelstadt. San Franciaco, California. Robert Mittelstadt, 1975. Vista del interior del espacio en doble altura sobre la sala principal.
Imagen: Kenneth E. Schroeder \& Ass. Mergenthaler Condominium. Chicago, Illinois. 1979 


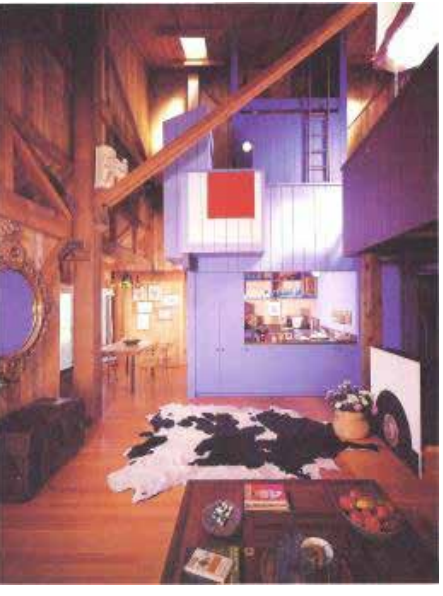

Imagen: Sea Ranch Condominium Sea Ranch, California. MLTW, 1965 Arriba, vista interior de la torre de equipamientos.
La intervención proporcionaba una gran variedad de tipos de vivienda, de una sola planta y en dúplex. Cada unidad, con grandes ventanales en todos los casos, estaba concebida como un espacio loft, diáfano y flexible, y con las cocinas, baños y vestidores como únicos elementos fijos. En el centro, unos elementos se disponían como si fueran 'grandes muebles' que flotaban en el espacio. Estos contenían los tubos de aire acondicionado y los conductos que albergaban instalaciones para la cocina. Las instalaciones formaban parte de la composición. A modo de 'canopias', estos elementos definían el espacio y además contenían las cocinas. Gracias a un sistema de pórticos, que formaba parte del diseño del mueble, se enmarcaba el espacio de la cocina y se creaban hornacinas para albergar objetos de menaje. En torno a este 'mueble' se organizaban el resto de las áreas, de forma flexible ya que los dormitorios no estaban definidos en la planta. Como norma, los ocupantes podían modificar su unidad loft añadiendo zonas de dormir, aumentando el área de cocina 0 añadiendo más armarios como elementos divisores.

Los materiales potenciaban la idea de adaptación de un edificio histórico para un nuevo uso: estructura de madera, columnas de hierro fundido, muros de ladrillo visto, tarima de madera de arce recuperada, lijada y barnizada, calefacción por aire centralizado con conductos de distribución y difusores vistos en techo...todo ello participaba en lo que Baudrillard llamaba la lógica del ambiente'. La propia solución proporcionaba la oportunidad para un modo de vida alternativo, una forma de habitar que iba implícita al loft como un tipo de vivienda contemporánea.

A través de este ejemplo vemos cómo las características del marco podían predisponer a adoptar una determinada forma de habitar. E inducían al uso de determinados mecanismos, como que las instalaciones se convirtieran en artefactos ordenadores, que organizaran, cualificaran -también gracias al imperativo cultural de los materiales- y articularan el resto del espacio.

En el condominio de Sea Ranch, California, diseñado en 1964 por MLTW -Charles Moore, Donlyn Lyndon, William Turnbull y Richard Whitaker- Ios apartamentos, a pesar de ser un proyecto de nueva planta, se concibieron expresamente con las características de los antiguos graneros de California. El interior de los apartamentos, también diáfanos y de gran altura, se organizaba a través la combinación de dos elementos similares formalmente, pero antagónicos en sus relaciones, todo ello dentro del mismo espacio. Estos elementos, situados como dos grandes muebles en el espacio, consistían en un edículo y una gran torre de equipamientos. El diálogo entre ellos daba sentido al espacio. "Cada vivienda se compone de un gran espacio único y casi todas contienen dos pequeñas casas: una es un simple cobertizo sobre cuatro postes. La otra es casi una casa en miniatura"18. En este ejemplo se combinaban dos conceptos, la idea de lugar y la de la creación de distintos grados de interior dentro de la casa.

El condominio de Sea Ranch fue construido en 1965. El apartamento n9 era propiedad de Moore $^{19}$. Comprendía cerca de 2 hectáreas a lo largo de más de 16 kilómetros de costa al norte de San Francisco, y era propiedad de la inmobiliaria Oceanic Properties. Se contrató a MLTW para que diseñara un proyecto de grupo de viviendas para que posteriormente se utilizara como

18 Charles Moore, Gerald Allen, Donlyn Lyndon. La casa: forma y diseño. (Barcelona: Gustavo Gili, 1999) p.36.

19 La imagen de la vista interior, en esta página, corresponde al apartamento de Moore. 
prototipo para un futuro desarrollo de la zona. La propuesta consistió en 10 apartamentos con torre, patios, miradores y solarios. Organizados en torno a dos patios comunes y de cara a un predominante y fresco viento del nordeste. Los patios aparecían rodeados de cubiertas que se inclinaban hacia el mar, siguiendo también la marcada topografía en descenso hacia la costa. El principio fundamental, según los arquitectos, era desarrollar una imagen de lugar a través del territorio, para ello se crearon distintos grados de interior. Desde el paisaje, progresivamente se crearon distintos espacios desde el exterior, totalmente natural, hasta el interior, totalmente abrigado, recluido y protegido. Todos los jardines y patios del conjunto se amurallaban para que formasen parte del interior. El segundo principio fue que la modulación y los elementos constructivos y acabados exteriores correspondieran con los de las construcciones de graneros y granjas locales. Las fachadas fueron de madera vista y los interiores de madera cepillada y barnizada. De fuera a dentro, siguiendo el principio de grados de interior, cada casa se sumía en un cada vez mayor estrato de cobijo, buscando la máxima domesticidad. Para ello los apartamentos se componían de un gran espacio que albergaba dos pequeñas casas, un edículo formado por cuatro postes y un dormitorio encima, y una especie de torre que contenía los elementos de equipamiento: cocina, baño, armarios, vestidor.

La torre de equipamientos jugaba con la escala y con la ley gestáltica de figurafondo, potenciado por el color azul, que enfatizaba su contraste frente al fondo de madera. El bloque se diferenciaba del resto y mostraba su silueta como si el entorno de un paisaje se tratase. El edículo, en cambio representaba el cobijo, la idea de interior y de privacidad. Organizaba los usos tanto bajo como sobre la plataforma que sustentaban los pilares, ubicando la zona de estar más privada abajo y el dormitorio arriba. A través de una pasarela que unía dormitorio con baño, ambos volúmenes dialogaban en el espacio.

En la Yano House, Arata Isozaki, el edículo y el volumen aparecían unidos, y surgían a lo largo del recorrido en el espacio que los abarcaba ${ }^{20}$. Este juego se producía en planta baja donde la altura del espacio era de planta y media, lo cual permitía dejar ver parte del volumen que contenía las habitaciones de la planta primera, como si estuviera 'flotando'. La vocación de permanencia de este elemento, en su relación con el espacio, potenciaba los recorridos periféricos y a su vez dirigía hacia una nueva manifestación de este volumen. Al llegar al espacio principal, la pieza se diluía hasta convertirse en dos
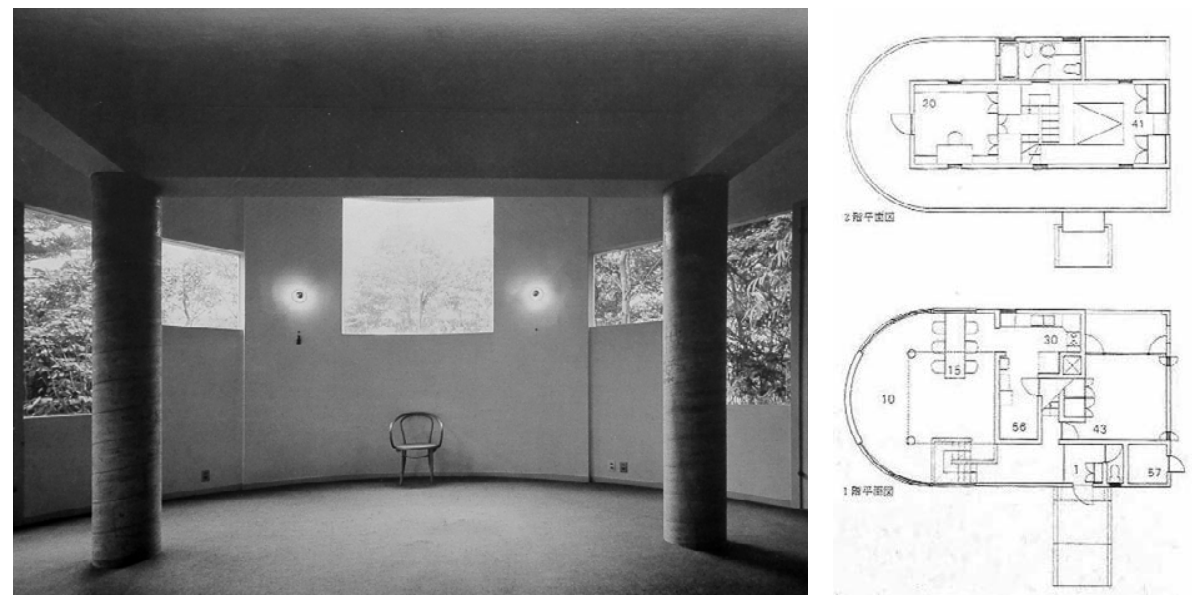

20 Arata Isozaki. "Arata Isozaki", GA houses (n01, nov. 1976) p.150-155.

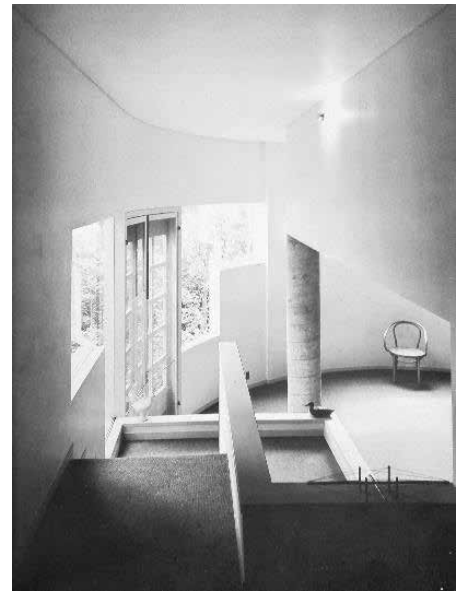

Imagen: Yano House. Kanagawa-ken, Japón. Arata Isozaki, 1975. Vistas interiores y plantas. 


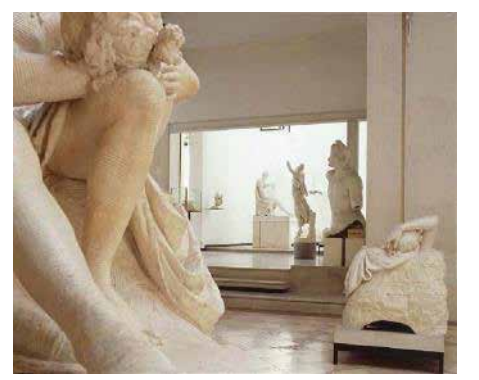

Imagen: Ampliación de la Galería Antonio Canova. Treviso. Carlo Scarpa 1957. En este proyecto museístico Scarpa decidió crear el espacio en base al diálogo que se producía entre los distintos modelos de yeso, basado en las relaciones entre las áreas de influencia de cada una de las piezas expuestas.
Imagen: Casa Balboni, Venecia. Vistas interiores de la escalera. Carlo Scarpa, 1974 columnas y un techo, como si mutase en edículo. En ese momento el espacio se volvía ordenado. Las columnas definían la zona principal de la sala y a su vez aumentaban la sensación de interior frente a una piel abierta al entorno y con grandes ventanales.

Recordando la ley de irradiación de Moles ${ }^{21}$ : "corresponde al fenómeno psicológico de que todo objeto irradia a su alrededor, domina psicológicamente un sector de su entorno al que denominaremos volumen propio o esfera de influencia. Para valorarlo el objeto exige un dominio autónomo, vacío de otros objetos de la misma dimensión", en algunos casos existían determinados objetos que establecían un volumen vacío a su alrededor y dominaban el resto del entorno. En esa área generalmente no solían existir otros objetos, o por lo menos, de tamaño similar y parece como si el espacio fluyera a su alrededor enfatizando su propia permanencia.

Refiriéndose a la obra de Carlo Scarpa, Sergio Los ${ }^{22}$ decía que una característica esencial de su trabajo era las interacciones que estableció entre la obra de arte y la arquitectura. Siempre existían contextos tridimensionales concebidos especialmente para cada objeto exhibido, parecía como si cada pieza hubiese generado el espacio en el que se ubicaba. Muchos son los ejemplos, desde la ampliación de la Gipsoteca Canoviana en Treviso hasta las exposiciones de la Biennale. Scarpa también aplicaba este principio en los espacios domésticos, como en la Casa Balboni, en Venecia.

En los años 50, Loredana Balboni heredó un apartamento de su padre en un pequeño edificio de 2 plantas en Dorsoduro. Después de una necesaria consolidación estructural, la propietaria encargó a Scarpa en 1964 la reforma de lo que sería su segunda residencia. El resultado fue un diseño unitario cuya principal característica era la continuidad espacial en los dos niveles del apartamento. Las formas redondeadas de las esquinas de los muros, las curvas de los petos de los espacios a doble altura, la ausencia de bordes nítidos entre suelos, muros y techos y la uniformidad de los acabados en estuco satinado color crema ayudaban a apreciar la fluidez y luminosidad que era la característica principal de esta casa veneciana.
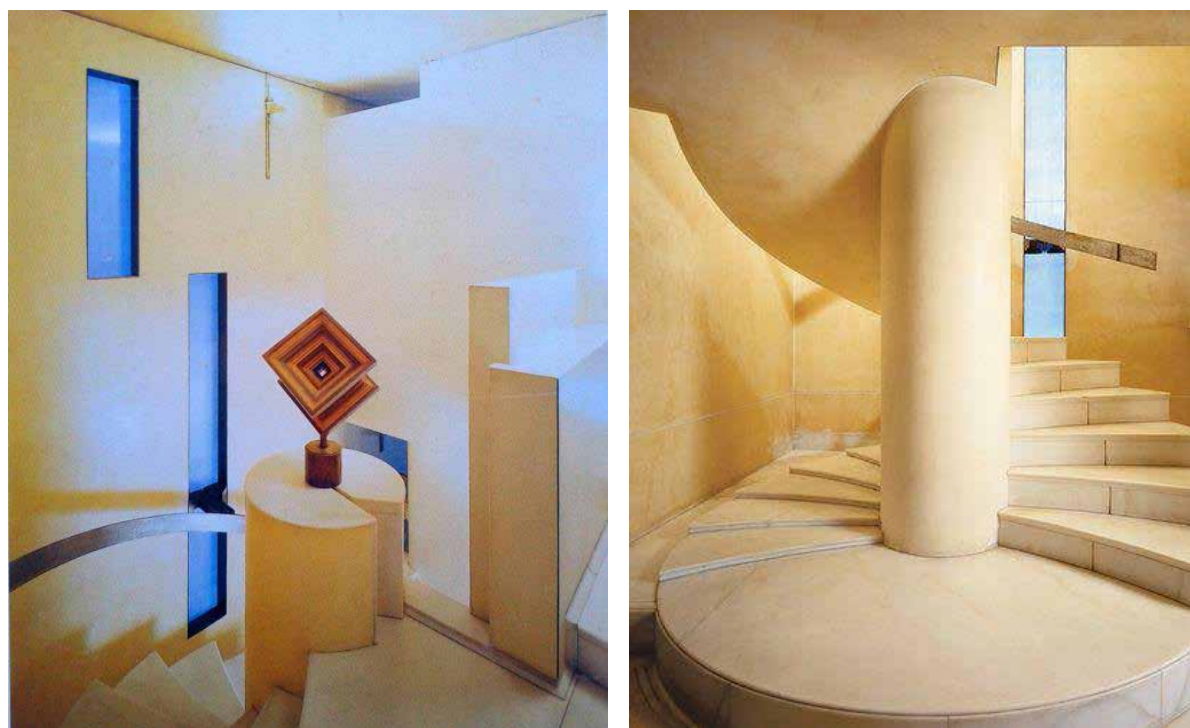

21 Abraham A. Moles en Teoría de los objetos (Barcelona: Gustavo Gili, 1975) p.115, enunciaba la 'ley de irradiación' que se incluía entre las 'leyes sintácticas de acoplamiento' establecidas en 1972.

22 Sergio Los Carlo Scarpa 1906-1978. Un poeta de la arquitectura. (Colonia: Taschen, 2009) p.16. 
El mejor testigo de esa búsqueda de la fluidez espacial y de la conexión visual entre los dos niveles de la casa, era la amplia escalera circular de mármol blanco de Lasa. Su forma era escultórica, ya que emergía sobre unos peldaños muy bajos que rodeaban a toda la base y cuyo sentido era conferir un fuerte carácter plástico a la escalera. La barandilla metálica y la escultura colocada en el remate superior reforzaban el efecto. El espacio parecía existir sólo para rodear a la pieza, una escalera que por su propia configuración, y en un proceso de objetualización por su significación, se había convertido en una obra de arte más de la casa.

Otroselementos, comounárbol, podíanconcebirse comoobjetosjerarquizadores y ordenadores. La Gertler House, de Raymond Kappe, se construyó en torno a un enorme eucalipto. Tras la construcción de la casa, el árbol, desde el terreno, emergía casi en el centro de la planta, que se elevaba del nivel del suelo para aprovechar las vistas y tener más luz natural. Todos los espacios principales se relacionaban a través del patio que rodeaba al árbol central. Por un lado, el patio que contenía el árbol, organizaba distributivamente la planta, y por otro, este elemento, que había capturado al árbol, lo había sacado de contexto y le había ofrecido un fondo. Aplicando las leyes de la Gestalt, al ser aislado del resto de los elementos similares -el bosque-, emergía como figura, generando un foco visual que articulaba los distintos espacios de la casa. Siempre en contraste con el paisaje boscoso, que rodeaba la vivienda.

En la casa de Charles Moore en Essex, un conjunto de muebles y un grupo de pequeños objetos personales conformaban un sistema con forma de pirámide cuya singularidad acaparaba psicológicamente a todo el espacio.

En 1970 Moore había dejado su puesto de decano del Departamento de Arquitectura de Yale pero continuaba dando clases en esta Universidad. Dejó su casa de Elm Street (New Haven) y se instaló no lejos de New Haven, en Essex, Connecticut. Compró una antigua fábrica, la reformó e instaló allí su estudio 'Centerbrook' y su vivienda. Gerald Allen ${ }^{23}$ decía que Moore, en esta casa, había dado rienda suelta a una de sus mayores aficiones: coleccionar, y sobre todo le había permitido exhibir sus objetos libremente. En el juego de la colección, pensaba que todo estaba perdido si no era del todo personal, y esto lo demostró con creces en su casa de Essex. Expuestos hay libros, santos mexicanos, soldados de juguete, relojes divertidos, pieles de lobo, etc. La exhibición de los objetos no era a modo de galería de arte -de hecho pocos de los objetos son obras en esos términos- ya que consistían simplemente en recuerdos y cosas personales.

En el piso superior estaba la pirámide, y todo giraba a su alrededor. Este elemento, resultado de un sistema de relaciones topológicas y de un proceso de fusión e interpenetración de muy distintos elementos, a muy diferentes escalas, albergaba la zona de dormir y un pequeño armario. También contenía una colección de soldaditos, santos mexicanos y un tren eléctrico. Su forma era de lo más enfática, de esta manera la jerarquización para mantener un orden espacial estaba asegurada. Aparte de su forma piramidal, similar a la que aparece en el reverso del billete de dólar, este mueble-espacio contenía a su alrededor otros símbolos que, de forma irónica como era habitual en Moore, potenciaban su carácter jerárquico. En el techo aparecían dibujados los lemas que acompañaban a la pirámide en el billete y colgando del mismo, como remate, pendía una bola de discoteca que representaba al 'Ojo de la providencia', seguramente una referencia masónica.

23 Gerald Allen. Charles Moore, by Gerald Allen. (Nueva York: Whitney Library of Design, 1980).

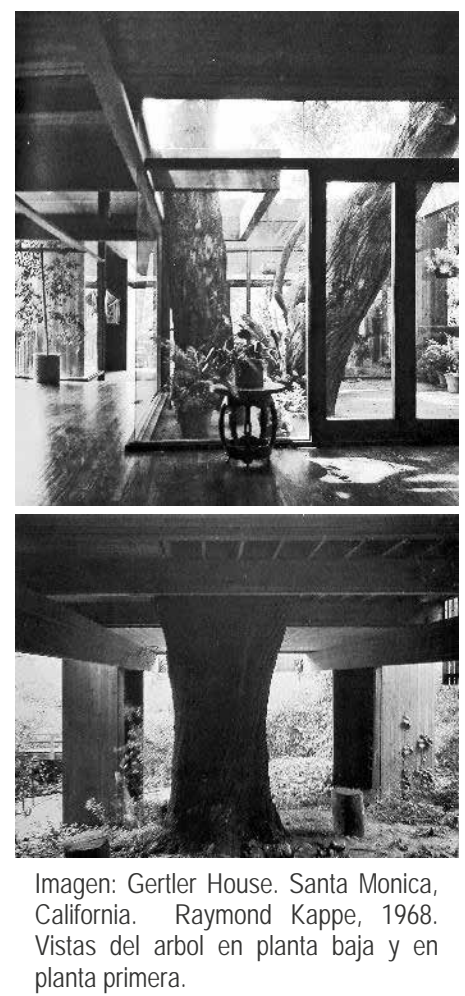

planta primera. 

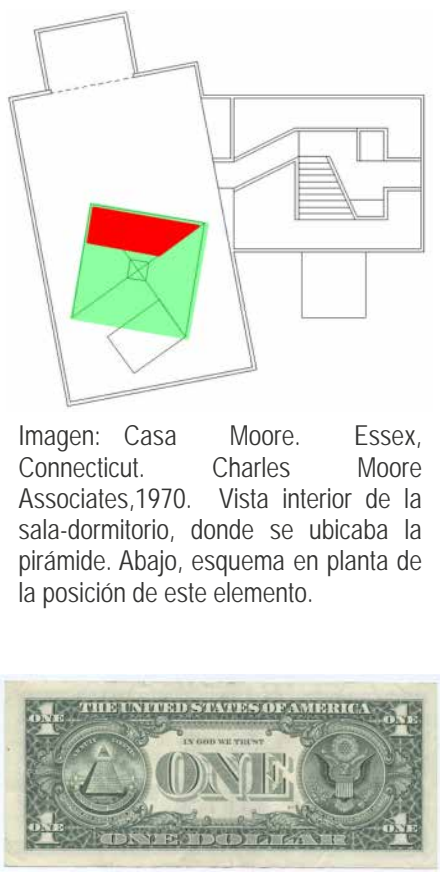

Imagen: reverso del billete de dólar americano, donde en la parte izquierda se aprecia la pirámide de las casa de Moore con los lemas que aparecían dibujados en el techo: "Annuit coeptis" y "Novus ordo seclorum". Provienen del poeta romano Virgilio y significan "favorece nuestras empresas" y "e nuevo orden de los siglos".

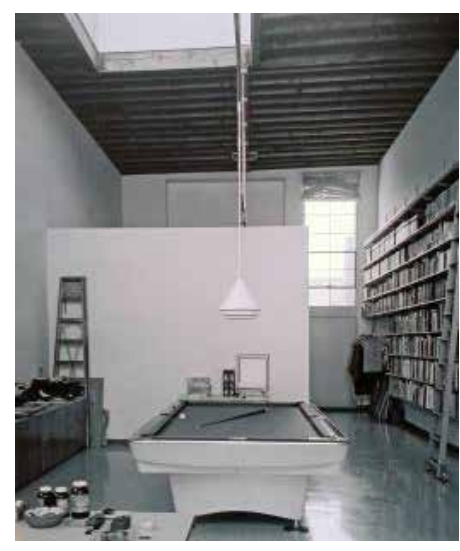

Imagen: Casa Danziger, Hollywood, California. Frank O. Gehry,1964. Vista del estudio.

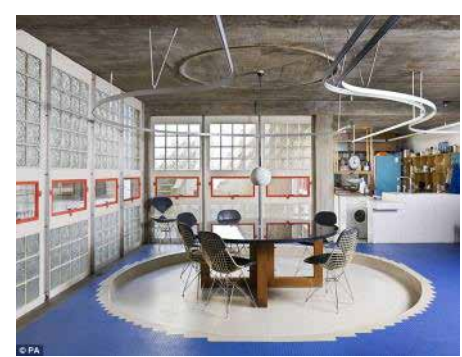

Imagen: Casa Housden. Londres. Brian Housden, 1965. Vista del comedor.

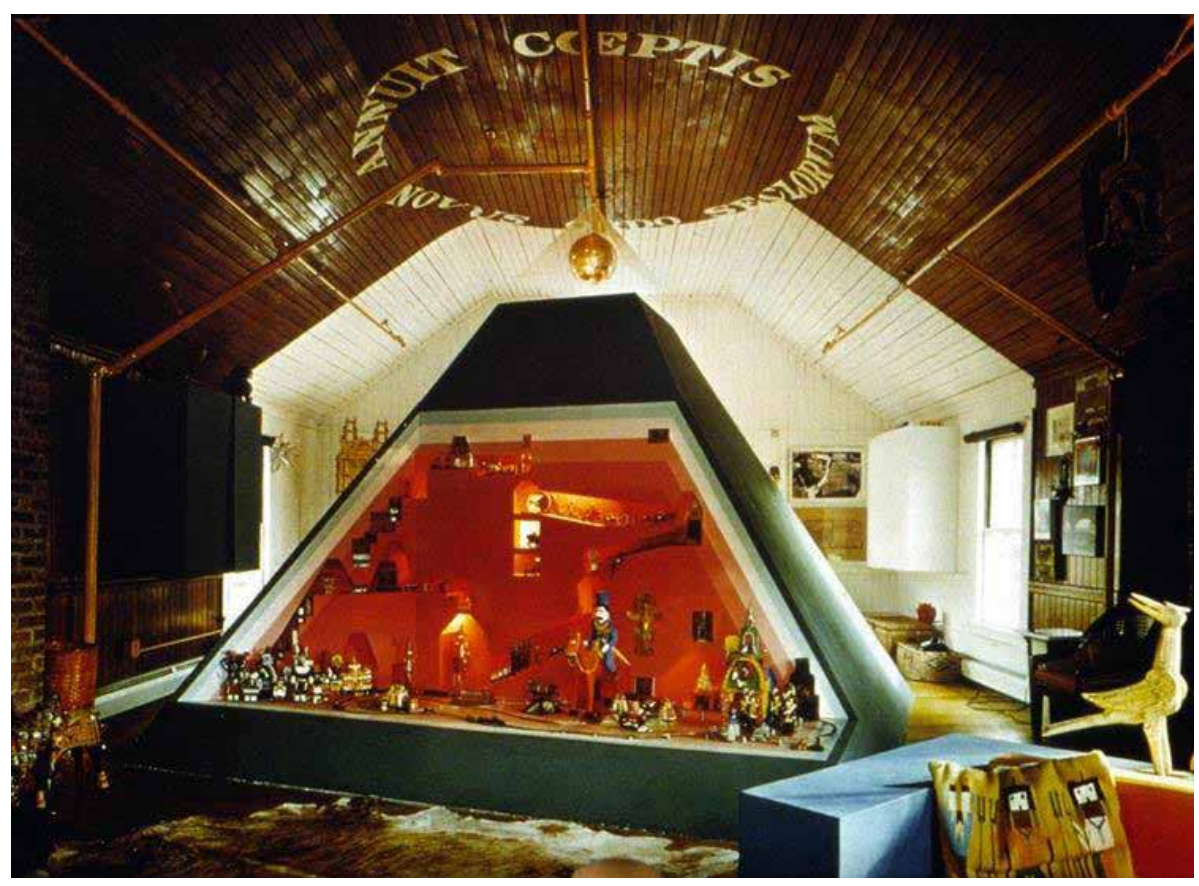

Pero no era necesario ser tan enfático para que los muebles ejercieran sus dominios en una planta libre y abierta.

Cuando Piero Derossi presentó su propuesta de 'la casa del trabajo' en la XVII Triennale de Milán ${ }^{24}$ tuvo presente dos condiciones importantes, el orden espacial y el orden temporal. Respecto a lo primero, consideraba que ya no existiría la tradicional separación espacial del lugar de trabajo y del lugar donde vivir, el sentido del espacio surgiría del propio uso del lugar. La otra condición sería la no distinción entre tiempo de trabajo y tiempo de la vida. A este aspecto, la distribución del tiempo se planteaba como responsabilidad del individuo. En 1964, Frank O. Gehry ya contemplaba estas condiciones cuando planteó la casa y estudio del conocido diseñador gráfico Lou Danziger y por eso colocó una mesa de billar en el centro del espacio de trabajo. Los dominios de este mueble desplazaban al mobiliario y a los objetos de trabajo a los bordes del estudio, manteniendo el centro despejado. Es paradójico que un elemento lúdico organizase un lugar para trabajar, sin embargo al ser tan fuerte su área de influencia, conseguía desplazar todo lo que había a su alrededor.

La densidad de mobiliario en un lugar determinado de un espacio abierto podía significar zonas concretas de la casa. La ley de densidad óptima 0 de distribución de densidades, enunciada por Moles ${ }^{25}$ dentro de las leyes sintácticas de acoplamiento, establecía que la distribución topográfica de las densidades -'mucho' o 'poco'- dentro de la casa era una expresión de significación importante. Por ejemplo, el comedor solía tener el centro ocupado, como en la casa Housden, diseñada por Brian Housden en Londres en 1965. El interior, en hormigón visto e instalaciones también vistas, ofrecía toques de color a través de un juego de cortinas interiores de colores vivos, con los pavimentos, y con 14 muebles originales de Gerrit Rietveld traídos personalmente por el matrimonio desde los Países Bajos. En la imagen, la zona de comedor estaba zonificada no sólo por la densidad de mobiliario en la zona central, sino por la huella marcada en el pavimento por el área de influencia

24 Propuesta presentada en la Triennale de Milan en el año 1983, en el contexto de la exposición 'Le case de la Triennale. Otto progetti di ambienti domestici contemporanei'.

25 Abraham A. Moles, Teoría de los objetos. (Barcelona: Gustavo Gili, 1975) p.113, enunciaba a 'ley de densidad óptima y distribución de densidades' en 1972. 
del sistema de muebles -mesa + sillas-, así como por el raíl suspendido en el techo que permitía independizarlo del resto del espacio por el juego de cortinas antes mencionado.

Es el campo privado de la morada el que reagrupa la casi totalidad de nuestros objetos cotidianos. Sin embargo, el sistema no se agota en el interior doméstico: lleva consigo un elemento exterior que constituye por sí solo una dimensión del sistema: el automóvil.

Sólo la esfera doméstica en su conjunto -muebles, aparatos, gadgets, etc.- posee, en su coherencia relativa, un valor de posición igual al del automóvil.

\section{Jean Baudrillard ${ }^{26}$}

Con estas palabras Baudrillard establecía, como sistemas, una equivalencia unívoca entre el automóvil y el resto de los objetos cotidianos del interior doméstico.

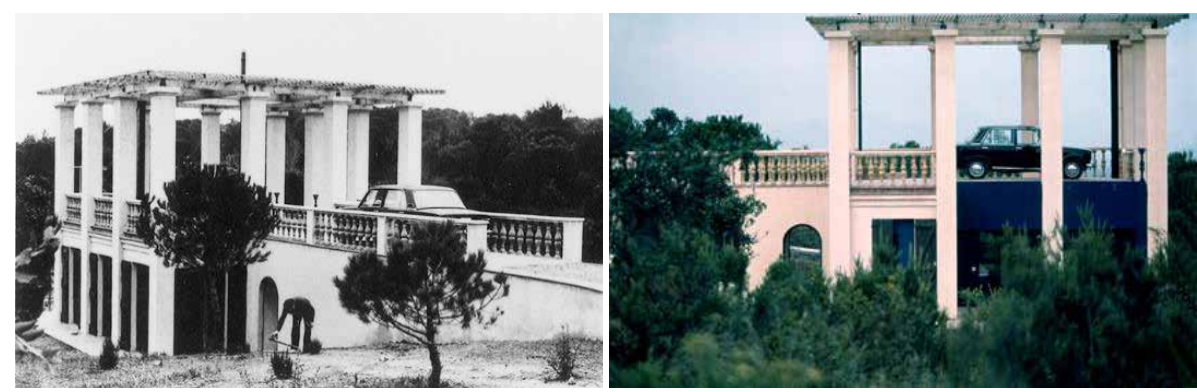

En 1972, Oscar Tusquets y Lluis Clotet con una casa en Girona, llamada 'Belvedere Georgina', planteaban una solución, un tanto insólita, para ubicar el automóvil dentro de la casa. Esta propuesta permitía una reflexión sobre la tradición, la vivienda, el automóvil y un espacio histórico. Aprovechando la topografía, los arquitectos plantearon un belvedere tradicional con acceso en vehículo desde el nivel del terreno. El espacio privilegiado de la casa, con vistas al paisaje, era el lugar destinado para albergar el coche. Bajo aquella plataforma coronada por columnas y pérgolas de madera, ocupando la proyección del cenador, se situaba una vivienda mínima.

En el interior de viviendas como la casa de Raymond Kappe en California, el sistema constructivo empleado, en este caso por las dificultades del terreno, dio lugar a un gran entramado de vigas de madera y desniveles dentro de la casa. Las características de la estructura y la amplitud interior generaron gran riqueza espacial. Los vidrios se dispusieron de manera que evidenciaran al máximo el alarde estructural de la casa, y las grandes superficies acristaladas se colocaron estratégicamente para generar vistas hacia los grandes árboles que la rodeaban ${ }^{27}$. O como la vivienda diseñada por Paul Rudolph en Westport ${ }^{28}$, los sistemas estructurales avanzados permitieron obtener amplios espacios acristalados. Con diferentes niveles en el interior, la amplitud del ámbito proporcionaba una visión total de la casa en prácticamente un solo golpe de vista. Por sus características, eran espacios diáfanos, no zonificados y sin embargo aparecian perfectamente zonificados, distribuidos y ordenados.

26 Jean Baudrillard. "El mundo doméstico y el automóvil", en El Sistema de los Objetos (Mexico: Siglo XXI, 1969) p.74.

27 Casa Kappe en Pacific Palisades, California. Por Raymond Kappe, en 1965.

28 Residencia privada en Westport, Connecticut. Por Paul Rudolph, en 1971.
Imagen: Belvedere Georgina, Llofriu,Girona. Oscar Tusquets/ Lluis Clotet.1972.

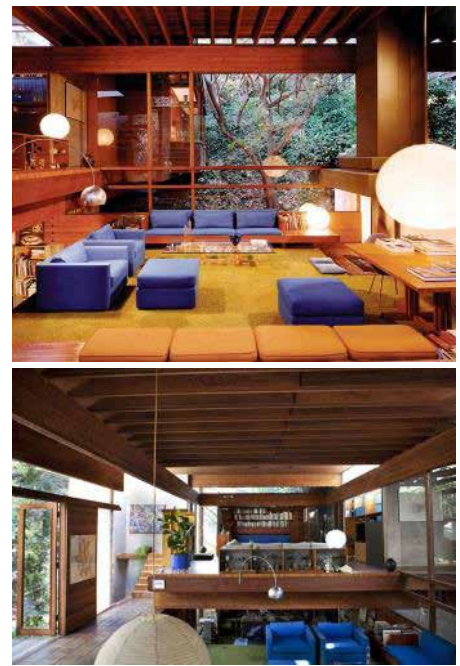

Imagen: Casa R. Kappe. Pacific palisades, California. Raymond Kappe, 1965. Vistas del espacio principal de la casa. 


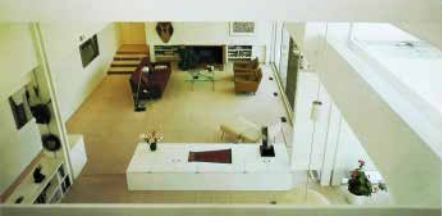

Imagen: Casa en Westport, Connecticut Paul Rudolph, 1971.

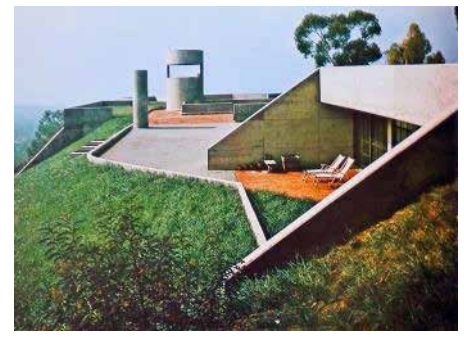

Imagen: Casa Alexander. Montecito, California. Roland Coate, 1971. Derecha: vista del espacio principal Abajo: vista exterior de la casa 'incrustada' en la colina.
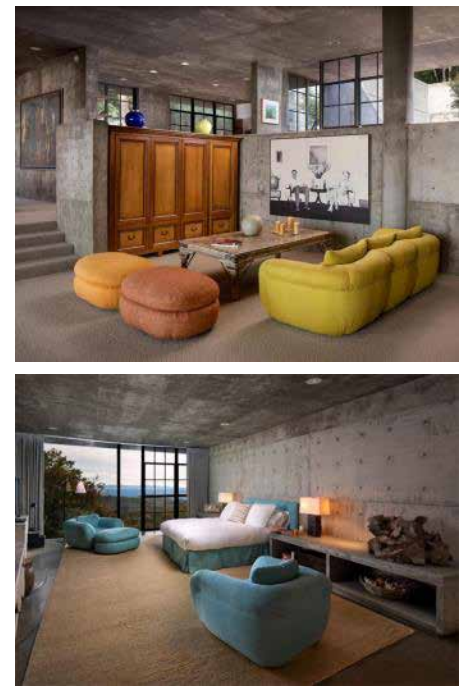

Imágenes: Casa Alexander. Vista del espacio de estar y del dormitorio principal.
Por medio de relaciones topológicas, lo muebles tomaban el espacio: zonificaban, distribuían y lo ordenaban a su antojo. Tomemos como referencia la 'ley de accesibilidad' de Moles, "para que un objeto, un mueble o una posesión cualquiera del hombre sea utilizable es preciso que resulte accesible sin esfuerzo; esto determina conscientemente la disposición topológica de una habitación". En ambos ejemplos, aunque con diferentes tratamientos del ambiente, en la apropiación del espacio radicaba la construcción del discurso.

En la casa diseñada por Roland Coate en 1971 para el fotógrafo y cineasta Jesse Alexander y su familia, se puso especial atención a la relación con el paisaje. No sólo porque el edificio, en hormigón visto, se adaptaba e integraba topográficamente a la colina donde se ubicaba, sino por las conexiones que se producían desde el interior hacia el exterior a través de los objetos y del imperativo cultural de ambiente que se imponía en el tratamiento del espacio.

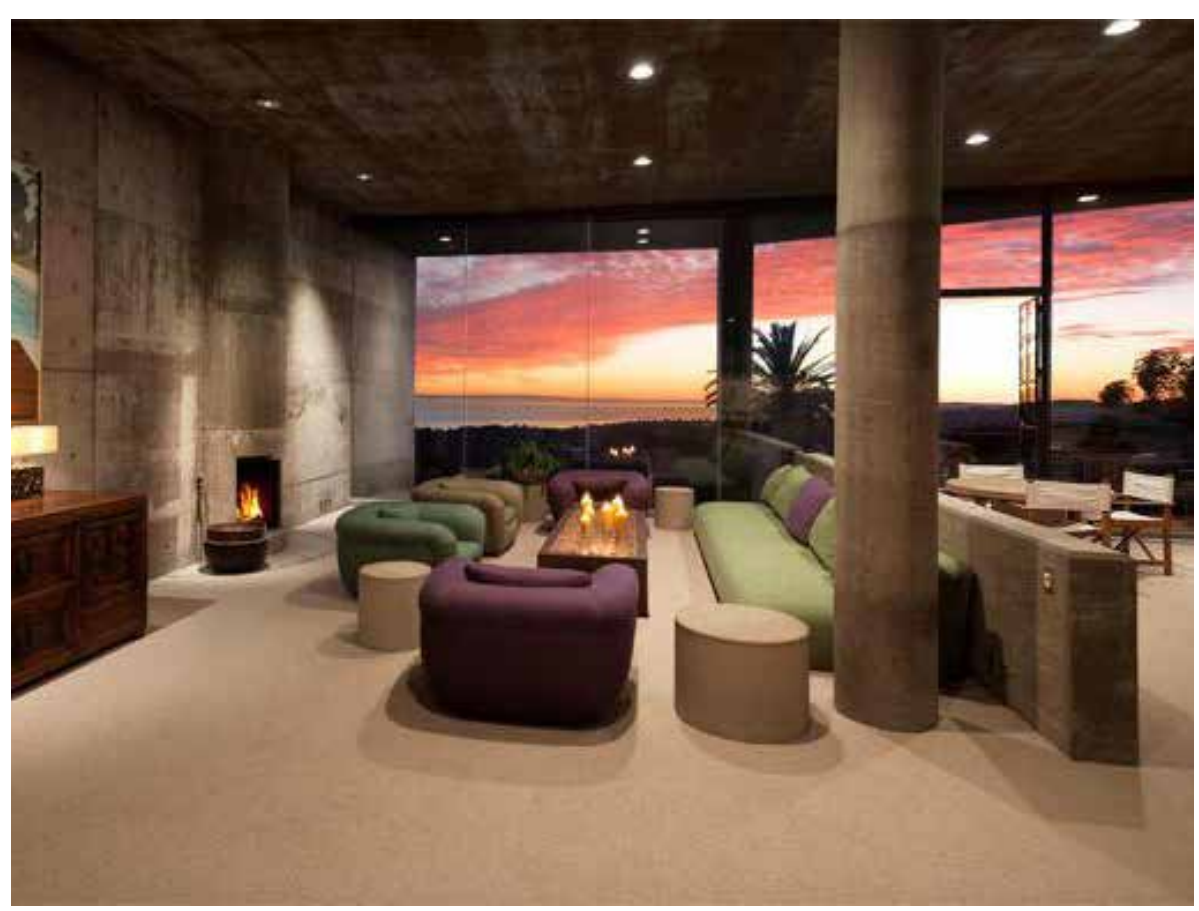

El edificio era todo de hormigón, de una planta integrada en una colina. La casa se disponía en abanico abriéndose al paisaje y captando la mayor cantidad de luz natural. Exteriormente toda era de hormigón, e interiormente también paredes, techos y suelos- salvo el acabado del pavimento en la sala principal, que era de moqueta. Como en los casos anteriormente analizados, el sistema de relaciones tipológicas que distribuía y ordenaba el espacio principal se producía a través de la apropiación por medio de los muebles, que zonificaban y codificaban el espacio gracias a relaciones de distancias y agrupación. En el contenedor todo de hormigón, el suelo del salón y los muebles armonizaban con el paisaje, por sus texturas y colores suaves. No se percibía un espacio frío, sino cómodo y confortable. El efecto general era de serenidad. Roland Coate, el arquitecto, también era pintor, lo cual se aprecia en su habilidad compositiva y en su especial sensibilidad para el juego de formas, colores, sombras y la relación entre los objetos, las formas de la casa y el paisaje. El tratamiento del espacio a través del uso del color, los materiales, la iluminación, es lo que Baudrillard consideraba parte del discurso de 'la lógica del ambiente'. 
Grandemente culpabilizado, el color llevará a cabo su liberación muy tarde (...) será la pintura la que libere al color pero se necesitará mucho tiempo para que este efecto se advierta sensiblemente en lo cotidiano: sillones de color rojo vivo, divanes azul cielo, mesas negras, cocinas policromas, salas de estar en dos o tres tonos, paredes de colores contrastados, fachadas azules o rosas (...) esta liberación está ligada a la ruptura de un orden global. Además es contemporánea de la liberación del objeto funcional.

Jean Baudrillard ${ }^{29}$ 

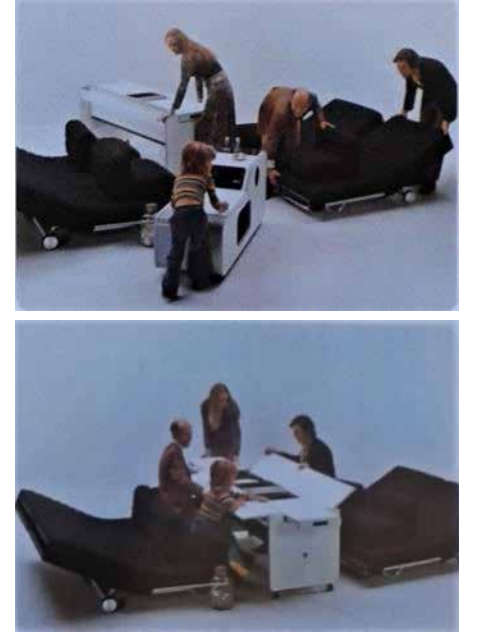

\subsection{MOVILIDAD Y ESPACIO MUTANTE}

La polivalencia del espacio era una de las premisas del marco doméstico contemporáneo, el poder ofrecer la oportunidad al usuario de ocupar y transformar las habitaciones según sus necesidades. En un espacio flexible, era el mueble el que determinaba lo que ocurriría en la estancia, según la hora del día o la época del año. La naturaleza de las habitaciones podía cambiar completamente a lo largo del tiempo gracias a la incidencia del amueblamiento.

Había elementos que desaparecían o se transformaban, participando en juegos de modificaciones: ahora es un sofá y significa el salón, ahora es una cama y significa el dormitorio. Un mismo lugar se podía convertir sucesivamente en distintas habitaciones, según el estado de los muebles que hubiese.

La movilidad de los muebles permitía la fluctuación de las actividades, persiguiendo el deseo de no atribuir un rol particular a cada habitación y no condicionar las distintas zonas en pos de la flexibilidad y las posibilidades que ofrecía para su vivencia.

Por otro lado estaban los tabiques móviles, que aseguraban los distintos grados de intimidad y permitían obtener varios lugares con vocaciones diferentes en la misma habitación. Así las habitaciones jugaban un rol indefinido en un espacio, en un lugar sin funciones ni divisiones.

Existen dos cuestiones a este respecto, que se reconocen en esta reflexión de Xavier Monteys y Pere Fuertes ${ }^{30}$.

Esta cuestión nos trae a la memoria unos comentarios de Robert Venturi sobre la flexibilidad, en los que sostenía que las habitaciones con unos usos genéricos en lugar de específicos o los muebles movibles en lugar de tabiques móviles fomentaban una flexibilidad perceptiva en lugar de una flexibilidad física, y concluía afirmando que: "la ambigüedad válida fomenta la flexibilidad útil"31.

Imágenes: Equipamiento y mobiliario Multi-system. Joe Colombo 1971.

Si Venturi lo llamó 'flexibilidad física', Monique Eleb lo denominaba 'flexibilidad permanente'32, una condición en la que la tabiquería móvil volvía a estar

30 Xavier Monteys y Pere Fuertes. Casa collage. Un ensayo sobre la arquitectura de la casa (Barcelona: Gustavo Gili, 2001) p.48.

31 Robert Venturi. Complejidad y contradicción en la arquitectura. Barcelona: Gustavo Gili, 1974, p.53, c.p. Xavier Monteys y Pere Fuertes en Casa collage. Un ensayo sobre la arquitectura de la casa (Barcelona: Gustavo Gili, 2001) p.48.

32 Monique Eleb, Anne Marie Chàtelet y Thierry Mandoul, "Flexibilidad permanente" en Penser L'habité. Le logement en questions. (Paris: Pierre Mardaga, 1988) p.108. 
directamente implicada. A través del desplazamiento rápido de tabiques móviles, el espacio de las habitaciones podía hacerse mayor o subdividirse. Estas operaciones se llevaban a cabo rápidamente varias veces al día y nunca serían irreversibles. En la práctica, según sus estudios, los elementos móviles solían utilizarse generalmente como mecanismos que graduaban una mayor o menor intimidad: entre cocina y salón, entre salón y dormitorio ${ }^{33}$. Dentro de una misma habitación también podía aprovecharse su capacidad de desplazamiento para manipular el espacio y para conseguir varios lugares diferentes dentro del mismo ámbito, diferenciando así, por ejemplo, en una alcoba, el rincón de trabajo de la zona de dormir, o la zona de juegos del área de estudios.

Frente a las características del espacio flexible, que vienen definidas por fenómenos relacionados con la movilidad y la mutabilidad, tanto en el espacio como en el tiempo, nos encontramos con dos aspectos a la hora de abordar el análisis. Por un lado, estarían los objetos móviles y muebles transformables dentro del espacio, que por su capacidad para modificar su configuración a través de mecanismos inherentes al propio artefacto, permiten una multiplicidad de fenómenos ligados a ellos. Así, dentro de un mismo ámbito, la propia capacidad para variar de forma y la diversidad de acciones y relaciones que por ello se generan, consiguen que la mutabilidad del marco en el que se ubican sea real, pero como decía Venturi, desde un punto de vista perceptivo.

Por otro lado está el otro factor, el que va ligado a espacios flexibles y cambiantes por la presencia de elementos móviles -tabiques que se desplazan o giran, suelos que se elevan o descienden, etc.- que modifican la configuración del espacio a lo largo del tiempo de una manera física, y que consiguen que el espacio mute topológicamente. En estos casos, aunque el resto de los objetos se desplacen o no, lo cierto es que, el hecho de que cambie la configuración del marco, hace que también varíen sus relaciones.

Uno de los ejemplos más claros de hogar caracterizado por su flexibilidad y mutabilidad por la incidencia de mobiliario transformable en su interior, es el apartamento que Joe Colombo diseñó en 1970 en Milán ${ }^{34}$. Era el resultado de años de investigación sobre la flexibilidad del hábitat, basándose en el diseño de muebles que ofrecieran múltiples posibilidades gracias a su capacidad para cambiar de forma y de posición a lo largo del tiempo:

En 1963-64 diseñé el mobiliario para un espacio que se dimensionó no solamente desde el punto de vista espacial, sino también en el sentido temporal, en otras palabras: el mobiliario cambiaba a lo largo del paso del tiempo dependiendo de la gente que lo habitaba (...) un nuevo tipo de arquitectura que proporciona un espacio elástico, expandible, móvil y flexible.

\section{Joe Colombo entrevistado por Pascal Rousseau en $1968^{35}$}

El arquitecto y diseñador se había convertido en el abanderado de, no sabemos si de "un nuevo tipo de arquitectura", según sus palabras, pero sí de una nueva manera de entender el interior: un espacio neutro que mutaba gracias a la

33 Ibíd. p.109

34 En Vía Argelati 30B en Milán, Colombo realizó la reforma de un apartamento para él y su familia y en el que también instaló su estudio.

35 De una entrevista realizada en 1968 por Pascal Rousseau a Joe Colombo, transcrita en Joe Colombo. Inventing the future. Editado por Mateo Kries y Alexander von Vegesack (Weil am Rheim: Vitra Design Museum, 2005) p.41. 
Imagenes: Apartamento en vía Argelati 30b, Milan. Joe Colombo, 1970. Vistas del interior del espacio principal.
Imagen: apartamento en vía Argelati 30B, Milan. Joe Colombo, 1970 Planta del espacio principal, en la que se mostraban las diferentes opciones que proporcionaba la movilidad de los muebles principales. acción de un mobiliario diseñado específicamente para transformarse según las necesidades cambiantes. En 1970, dos bloques llamados 'Roto-living' y 'Cabriolet-Bed'36 fueron fabricados para incluirlos en su propio apartamento en VíaArgelati 30b en Milán, donde también instaló su estudio. El espacio principal, acabado en blanco, fue el resultado de la transformación de un apartamento existente de $90 \mathrm{~m}^{2}$, tras la demolición de toda la tabiquería, convirtiéndose en un generoso espacio, diáfano, tipo loft. Lo más relevante era que este ámbito, creado por Colombo para él y su esposa, sólo contenía dos grandes objetos que habían sido diseñados para cubrir todas las necesidades diarias: 'Roto-living' para zona de día y 'Cabriolet-Bed' para zona de noche. Esas dos grandes máquinas, para dormir y comer -y otras muchas actividades más-, se convertían en la materialización de la satisfacción de las dos necesidades básicas dentro de la casa. Los equipos se habían colocado en el mismo ámbito. Y se podían transformar dependiendo de la hora del día, o de las necesidades que surgieran a lo largo del tiempo, recordemos que, para Colombo, el tiempo se había convertido en la cuarta dimensión, en el proceso de diseño.
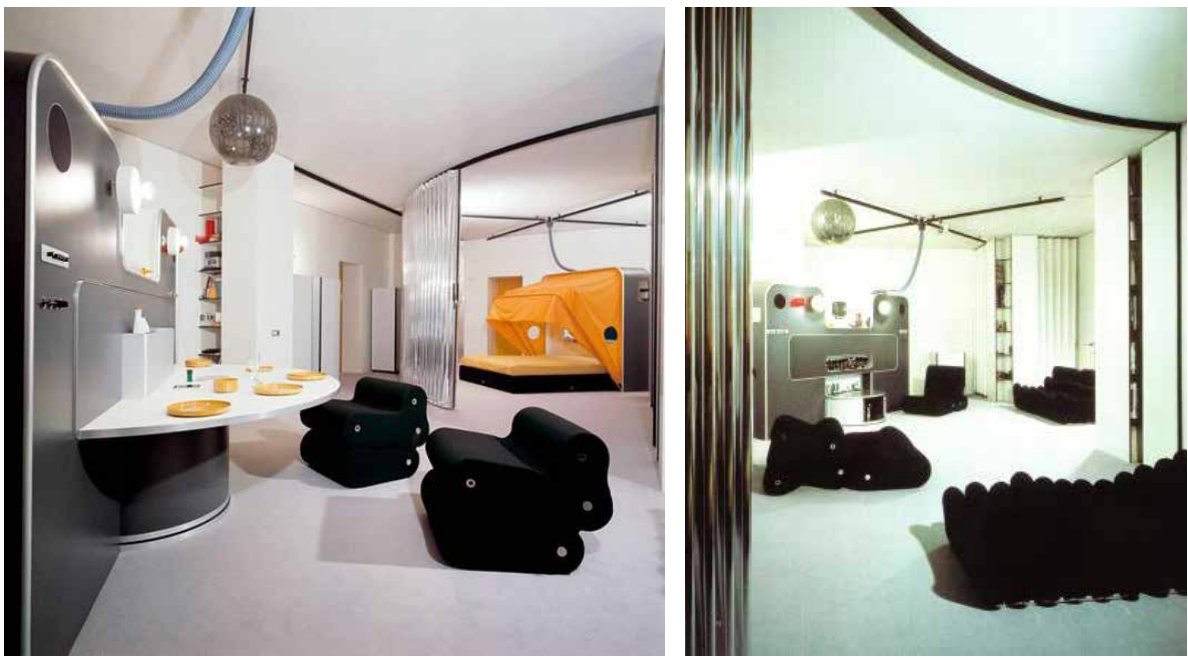

Todo estaba alimentado por cables eléctricos que colgaban del techo dentro de un tubo aspirador grande. Aparte de todos los complementos necesarios para el desarrollo de las actividades diarias, los bloques contenían también otros accesorios como un termómetro, un barómetro y un higrómetro para saber cuál era el tiempo antes de salir.

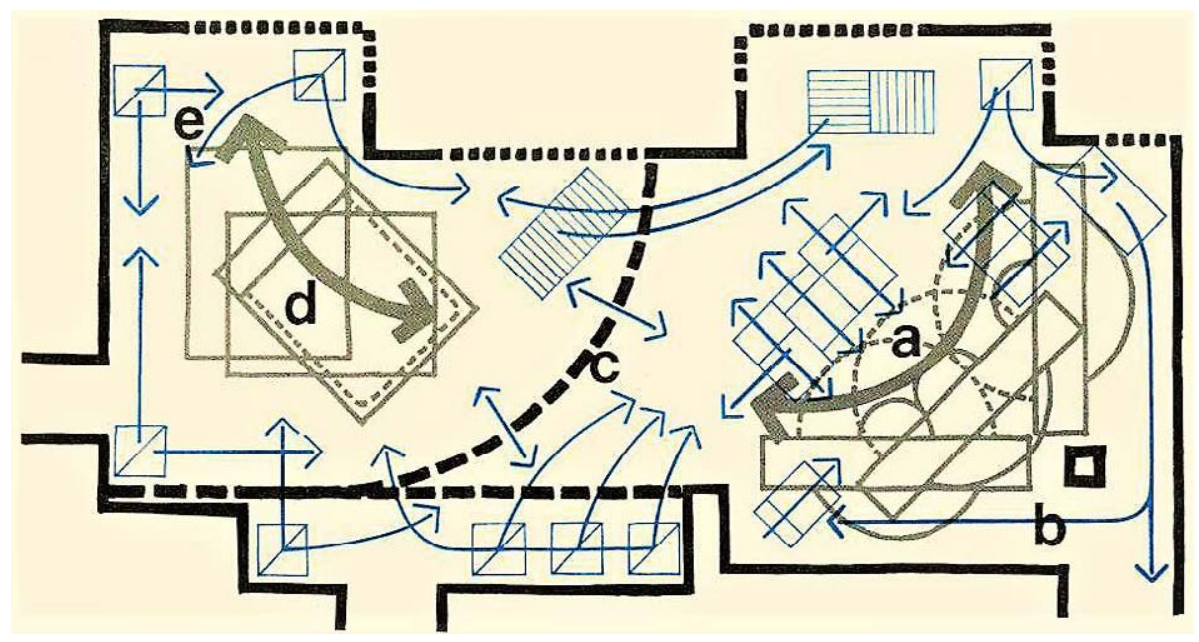

36 Ver descripción de los muebles en apartado 1.2. "la incidencia de los transformables", de esta tesis. 
Aunque los dos volúmenes principales definían claramente, en el espacio libre, las áreas de día y de noche, existía la posibilidad de independizar ambos ambientes a través de una mampara corredera translúcida. Los espacios intermedios entre ambos bloques estaban preparados, tal y como se percibía en el croquis en planta del apartamento, para albergar cualquier tipo de acción posible, en parte inducida tanto por las distintas posiciones de los muebles transformables, como por la reacción frente a los objetos secundarios que se disponían entre los dominios de los muebles principales.

Como decía Abraham Moles, todo objeto irradiaba a su alrededor ${ }^{37}$ dominando psicológicamente un sector de su entorno, que era su esfera de influencia. En el caso del apartamento de Colombo, cada uno de los dos objetos exigía un dominio autónomo, vacío de otros objetos de la misma dimensión. Entre ellos, sí había lugar para otra serie de muebles de menor dimensión y relevancia, como la 'multi-chair', un asiento de dos piezas articuladas que mostraba sus acrobacias para ofrecer distintas opciones de sentarse u otros sistemas de amueblamiento como el 'additional system' que demostraba que las relaciones topológicas por sucesión o continuidad, a las que se refería Norberg-Schulz ${ }^{38}$, podían generar hileras de longitud infinita, 'siempre que las dimensiones del espacio lo permitieran'.
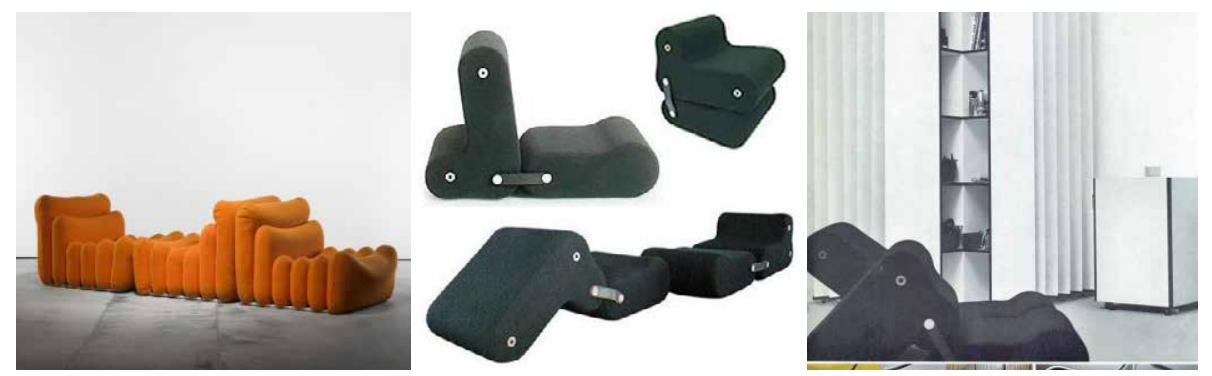

En 'Living 1990', de Archigram, todo mutaba, tanto los muebles -artefactos, robots, cápsulas- como las paredes, el suelo, incluso algunas habitaciones completas (nota: en 'Living 1990' el módulo de salón estaba diseñado según el principio del hovercraft y podía ser utilizado fuera, conduciéndolo como una cápsula alrededor de una mega-ciudad.

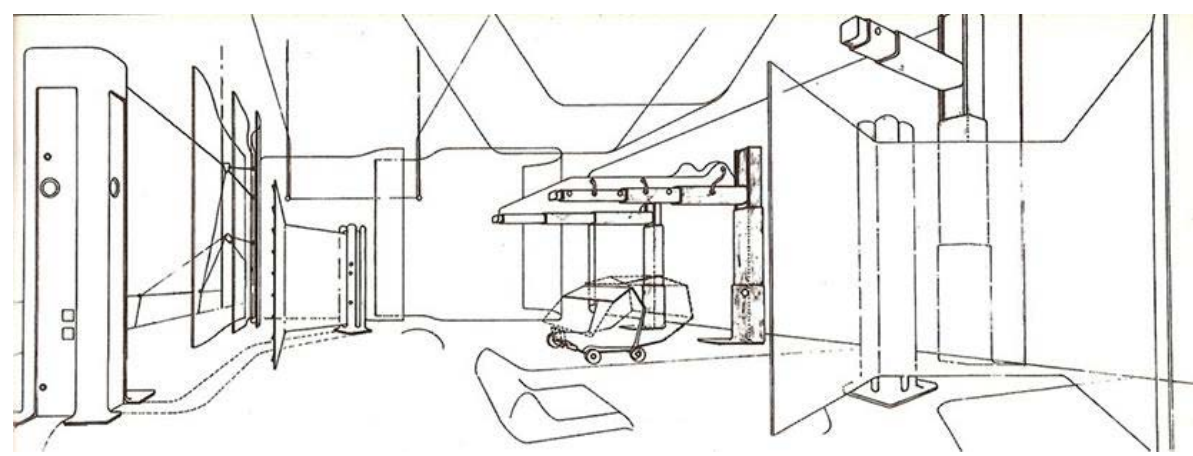

La cápsula-cama también podía conducirse fuera). Presentado para el Weekend Telegraph Magazine en 1967 con la intención de mostrar cómo podía influir la tecnología en el modo de vida de los hogares del futuro, todo era movible, enchufable y programable.

En aquella visualización de un hábitat, pasadas más de dos décadas, los de Archigram concebían un espacio doméstico donde las condiciones las

37 Abraham Moles. Teoría de los objetos (Barcelona: Gustavo Gili, 1975) p.111.

38 Christian Norberg-Schulz, "Relaciones" en Intenciones en arquitectura, (Barcelona: Gustavo Gili, 1998) p.91.
Imágenes: 'Additional system', 1967. 'Multi-chair', 1971. Interior del apartamento con sistema de almacenamiento modular y multi-chair.

Imagen: 'Living 1990'. Archigram, 1967. Croquis de la instalación. 


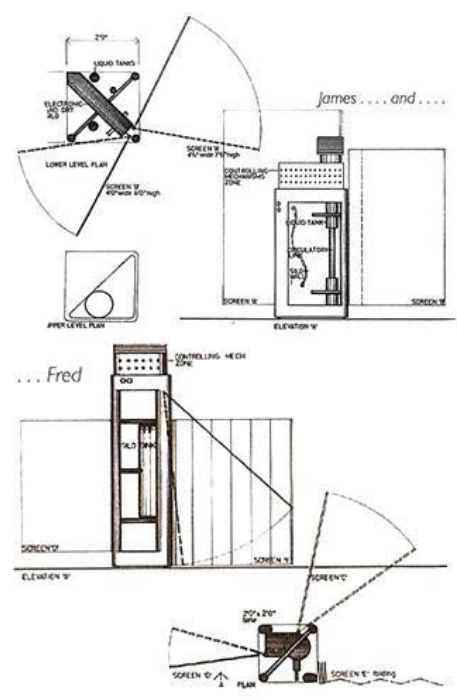

Imagen: 'Living 1990'. Archigram, 1967. Croquis de los robots domésticos James y Fred.

Imagen a la derecha: 'Living 1990', Archigram, 1967. Detalle del robot Fred incluido en la exposición. marcaban las posibles variaciones en las relaciones y conexiones entre los múltiples agentes que participaban de la vida de los usuarios, siendo todos además transformables y programables. Peter Cook tenía la idea de que aprovechando la técnica y las posibilidades que ofrecían los nuevos materiales, se podrían transformar todas las formas convencionales, desde la vivienda hasta la ciudad.

En este espacio 'visualizado' por los arquitectos de Archigram, se podría interpretar que aquella flexibilidad era creada para satisfacer los 'deseos' de sus habitantes, más que las necesidades básicas para su vida cotidiana. En el mundo doméstico que estaban representando en aquella exposición, la tecnología iba dirigida más bien a satisfacer los placeres de una sociedad de consumo que ellos ya tenían muy presente en sus propuestas.

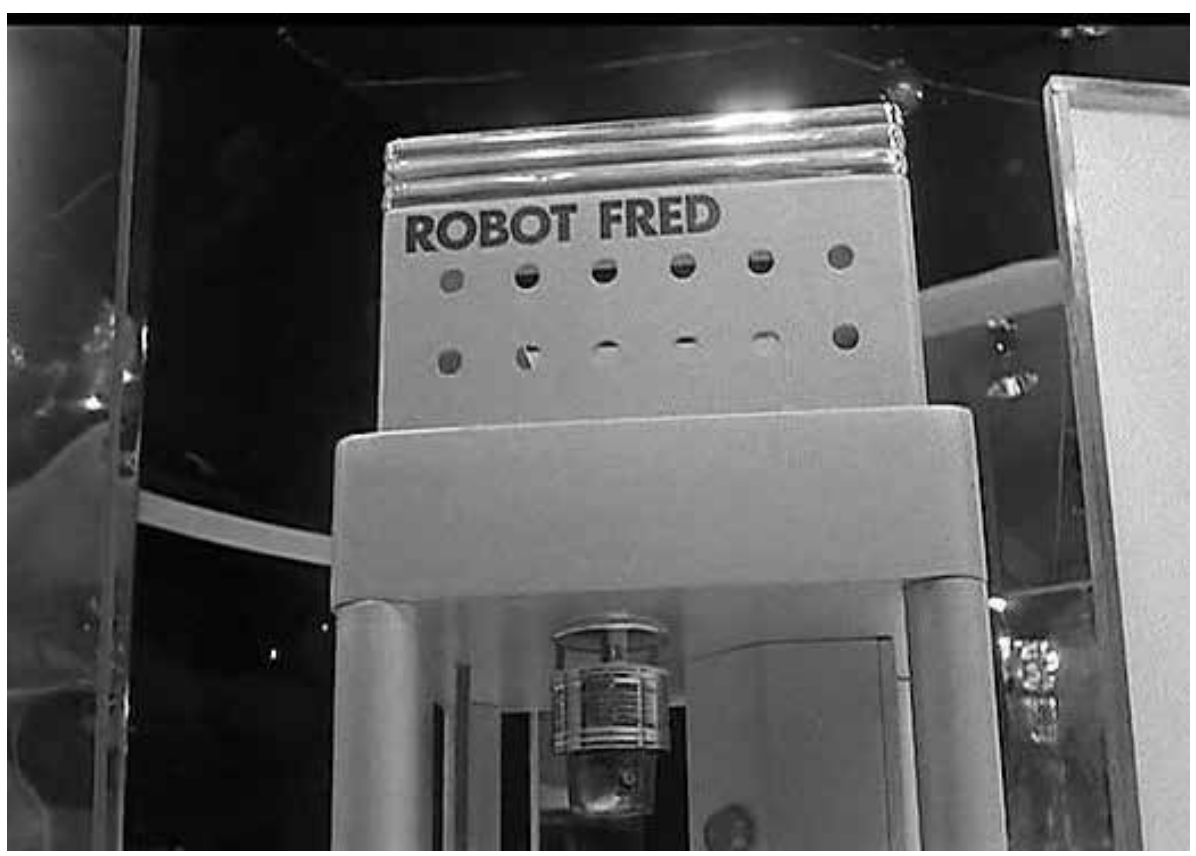

En 'Living 1990' la comida rápida, el preenvasado39, la cápsula enchufable, la mega-ciudad y los robots estaban conectados y relacionados gracias a su capacidad de cambio, movilidad y transformación. Ahí tanto los objetos como los elementos arquitectónicos, las instalaciones o las condiciones de ambiente, participaban en un proceso cuya finalidad era proveer al habitante del futuro, inmerso en el hedonismo de una sociedad de consumo.

El sistema, que configuraba aquel marco doméstico del futuro, estaba orquestado por dos robots, James y Fred, que eran una especie de híbrido entre mueble transformable y 'mayordomo'. Los artefactos podían discurrir por la casa y generaban muchos de los cambios que se producían, programando emisiones de radio y televisión en base a las preferencias de los habitantes, desplegando un sistema de mamparas articuladas para modificar la distribución o regulando factores de ambiente como luz, sonido, olor, etc.

Cercanos en la fecha, pero en este caso la real, en 1989 los arquitectos Ábalos y Herreros presentaron una propuesta de vivienda flexible para el concurso llamado 'Housing \& City', que había sido organizado por la revista Quaderns d'arquitectura i urbanisme para dar soluciones a la recuperación de una zona degradada de la ciudad a través de un plan de vivienda y urbanismo. Con

39 Peter Cook, en su afán por transgredir las normas establecidas, llegaba a decir: "la comida precocinada y congelada es más importante que Palladio". Peter Cook "Algunas cosas sobre el síndrome Archigram", Perspecta (n¹1, 1967). 
esto se pretendía realizar una apertura de la Diagonal hasta el mar a su paso por Poblenou. La propuesta -que ganó un accésit- tuvo muy en cuenta el empleo de la tecnología para que las viviendas fueran flexibles en los usos y en la distribución a lo largo del tiempo. Incluidos en un sistema de bloques verticales, los espacios de vivienda quedaban confinados entre los dos planos horizontales y el cerramiento vertical. Entre estos planos el protagonista era el usuario, entendido como agente activo que participaba del proceso de configuración de su propia vivienda.

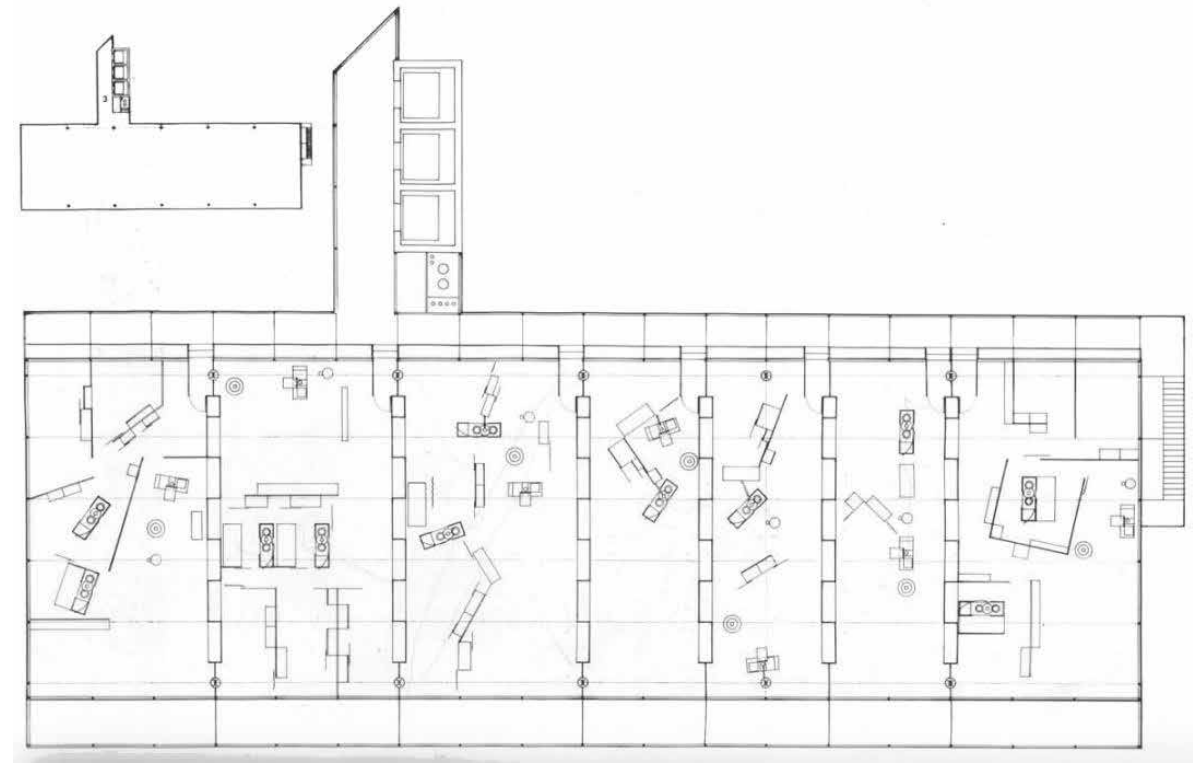

Entre las diferencias con la propuesta de Archigram 'Living 1990' estaba que, en este caso, limitaban la forma de la vivienda a los cerramientos, e introducían la tecnología en las instalaciones para permitir la movilidad de los servicios y el mobiliario. La premisa de que los movimientos y cambios fueran con la acción directa del habitante, no por sistemas programables ni robots, dotaba a la propuesta de un cierto grado de hapticidad que también se hacía notar en la escala, más humana, de los artefactos que se incluían en la casa.

El grosor de los forjados permitía la desviación horizontal de bajantes y montantes verticales, propiciando de este modo una mayor libertad para colocar los baños y las cocinas en cualquier lugar de la casa. Dependiendo de las necesidades, todo podía modificarse para y por los propios usuarios y esa flexibilidad se basaba en la escala de las pequeñas soluciones tecnológicas que propiciaban la realización de la propuesta, basada en la facilidad de utilización de un mecanismo simple y reversible, y conectable telemática y físicamente. Los pequeños artefactos, más 'manejables' se alejaban del mito de los años sesenta que asociaba flexibilidad a movilidad en planta, sin más ${ }^{40}$ Para los arquitectos la movilidad ya no significaba 'valer para todo' sino ser voluntariamente frágil, haciendo que la fragmentación, miniaturización y liviandad sean cualidades del soporte admitiendo distintos grados de obsolescencia y reciclaje. Este aspecto es el que diferencia en mayor medida la propuesta de finales de los ochenta, de las propuestas de Colombo 0 Archigram, la idea de lo tecnológico pero efímero a la vez, en un proceso de dispersión social y disolución objetual.

La liviandad de los equipamientos propiciaban la flexibilidad por su fácil manejo, desplazamiento y capacidad de transformación, pero también obligaba

40 Juan Herreros "Mutaciones en la arquitectura contemporánea. El espacio doméstico" (Tesis doctoral, Universidad Politécnica de Madrid, 1994) p.118.
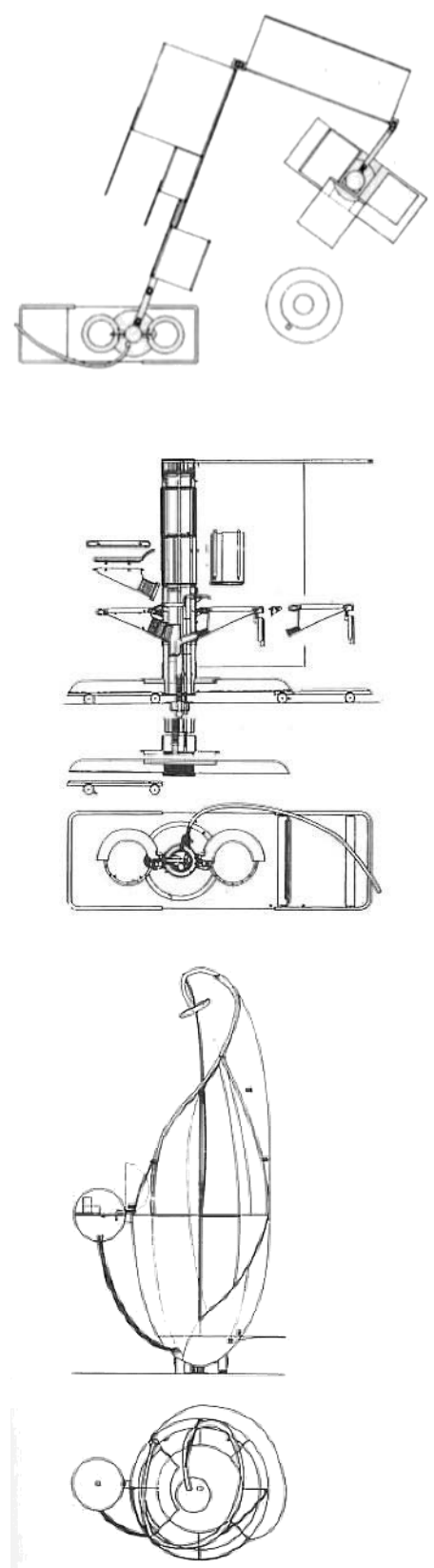

Imagen: 'Housing \& City'. Quaderns, Barcelona. Detalle de algunos de los equipamientos transformables que se incluían dentro de las viviendas.

Imagen a la izquierda: Propuesta para el concurso 'Housing \& City'. Quaderns, Barcelona. Abalos y Herreros, 1989. Planta de un bloque tipo. 


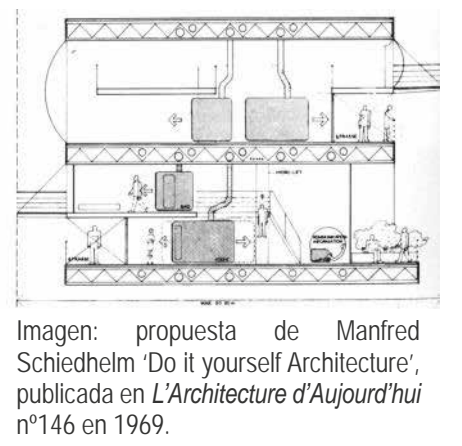
n¹46 en 1969

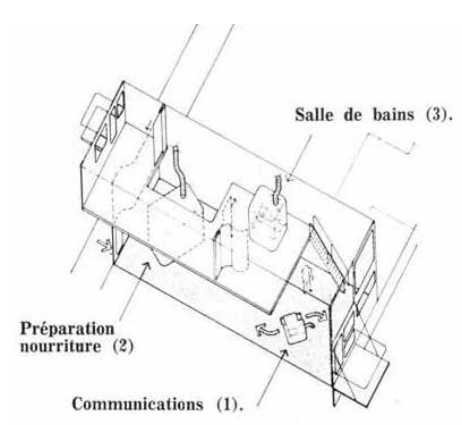

UNITES MOBILES.

Imagen arriba: seccion longitudinal de las viviendas tipo

Abajo: planta general y 'unidades móviles. Abajo, axonometría de la vivienda tipo con la disposición de las unidades móviles. a poner en servicio otros recursos, para cerrar, limitar y permitir la intimidad y la privacidad. Los elementos como tabiques, mamparas, etc., participaban en los cambios distributivos, pero siempre acompañando a las acciones, a lo largo del tiempo, orquestadas por artefactos ligeros, en un juego espacial de relaciones topológicas, de densidad y de proximidad.

Existen muchos ejemplos de propuestas que giran en torno a este concepto: un espacio neutro, cuyas características técnicas ofrecen la posibilidad de un hábitat mutante y flexible, gracias a las múltiples configuraciones que ofrecen un determinado grupo de elementos que, por sus propiedades de transformabilidad y/o movilidad, se mueven libremente en el espacio y en el tiempo en base a las necesidades o deseos de los usuarios.

A finales de los 60 Manfred Schiedhelm presentaba su propuesta 'Do it yourself Architecture':

A través de 3 elementos 'unidades móviles' los habitantes pueden configurar sus viviendas según sus propias ideas. Todos los materiales pueden ser elegidos. Sólo de esta manera se podrá llegar a una 'Freedom-architecture' que corresponde exactamente a las necesidades de sus habitantes.
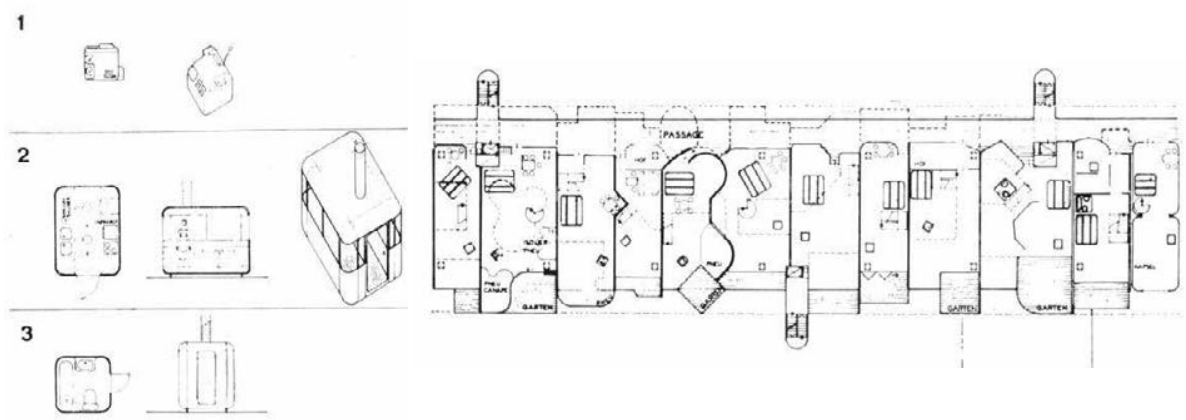

\section{Manfred Schiedhelm ${ }^{41}$}

En este sistema de viviendas industrializadas, de bloques lineales continuos y a doble altura, como en el caso que se ha analizado anteriormente, contaba con un sistema de suelos equipados que permitían que los bloques de instalaciones -cocina, baños, telecomunicaciones- principalmente, pudieran colocarse en cualquier lugar de la casa, así como que el resto de la vivienda pudiera ser configurada a modo de do it yourself por sus ocupantes.

Los bloques eran cápsulas prefabricadas con ruedas, movibles pero compactas. Su ubicación y posición con respecto a los demás bloques, en un sistema de relaciones ligado a la flexibilidad física del espacio, determinaba la combinatoria de configuraciones posibles dentro de un espacio neutro, ya que la idea era que los usuarios compraran la superficie, más que viviendas previamente configuradas, y que las pudieran conformar interiormente según sus necesidades y criterios, entrando incluso en conceptos como la apropiación, del que se tratará más adelante.

Pocos años después Olivier Mourgue exponía un prototipo de $80 \mathrm{~m}^{2}$ como solución de vivienda para los $H L M^{42}$ en uno de los complejos residenciales

41 Manfred Schiedhelm, "Anachitecture. Idées pour une ville d'aujourd'hui". L'Architecture d'Aujourd'hui (n¹46, oct-nov-1969) p.86.

42 HLM, 'Habitation à Loyer Modéré': bloques o conjuntos de viviendas sociales, en Francia. 
previstos a las afueras de Rouen. La propuesta de Mourgue, aunque aparentemente era muy similar a la de Schiedhelm -en cuanto al concepto de planta abierta con suelo técnico que permitía situar los bloques libremente según las necesidades- estaba más cerca de la propuesta de Ábalos y Herreros en el sentido de que flexibilidad ya no estaba ligada al significado de 'valer para todo', sino más bien a la liviandad del soporte, a la ligereza de los materiales -los bloques, que representaban las actividades de día y de noche, estaban compuestos por estructura de aluminio ligero y cerramientos de tela-y a la fragmentación y la articulación de los elementos, como la pantalla-mecano, una especie de biombo o mampara autoportante también de aluminio y tela, que recorría el espacio entre los bloques, relacionando y conectando cada una de las partes.

Esta propuesta representa el concepto de flexibilidad tanto basado en la mutabilidad del espacio gracias a la movilidad y capacidad de transformación tanto de los muebles -mesa, cama, armarios, etc.- como de los elementos arquitectónicos convertidos en objetos movibles y diferenciables de un fondo neutro. En 'Habitat HLM type F4', mutabilidad significaba alternancia de la configuración de lugares y polivalencia del espacio.
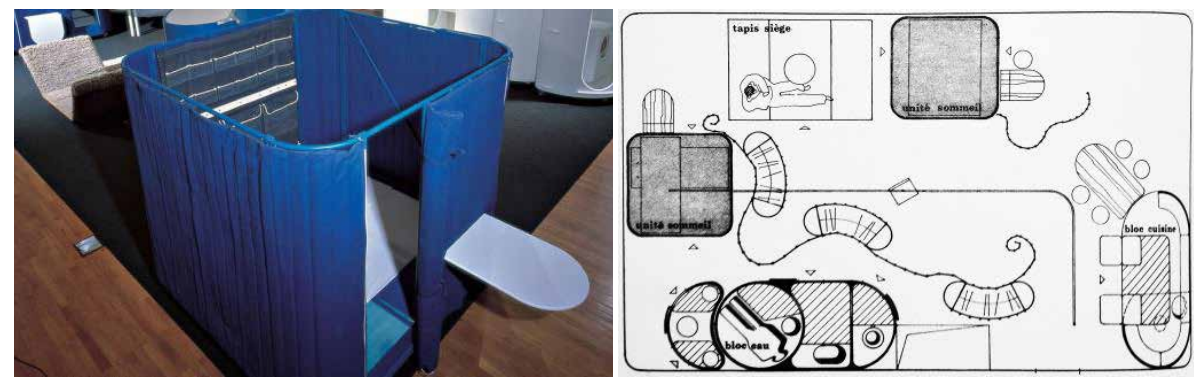

Las distintas configuraciones que podía generar un sistema de elementos móviles y objetos transformables, se reducía a 'todo en uno' en un apartamento piloto incluido en el proyecto de reforma de un edificio de viviendas para la policía de Nueva York, llevado a cabo por los arquitectos Smith Miller + Hawkinson en 1989. El diseño de este apartamento abordaba el tema sobre cuáles eran los parámetros que definían la vivienda urbana en la gran ciudad, centrándose sobre todo en aspectos como espacio convertible y comunicación.

La actuación consistía en la introducción de un mueble o aparato dentro de un espacio perteneciente al edificio existente, objeto de la reforma. La forma de la planta, entre la fachada y los núcleos de cocina y baños existentes, era irregular. La disposición del mueble perseguía deliberadamente, gracias a su linealidad y centralidad, que el espacio de la zona de estar-comedor, se percibiera como neto y rectangular. Este mueble central, que incluía una estantería entre otras cosas, estaba colocado paralelo a la fachada, regularizando el espacio, desde el punto de vista perceptivo,y creando un eje que relacionaba la entrada, el estar comedor y las zonas de servicios a través de los huecos y visuales que se generaban. Una gran puerta pivotante translúcida separaba la zona de estar del dormitorio, proporcionando privacidad sólo cuando se necesita. El mueble, en este caso se convertía en un elemento separador, gracias a la articulación que integraba la puerta dentro del mobiliario y que también albergaba la cama plegable "Murphy Bed", que convivía con los libros, la ropa, las almohadas, etc. dentro del área de almacenamiento.

La puerta en posición abierta permitía que el espacio se utilizara para otras actividades. De la pared de la cocina se desplegaba, de forma articulada, una
Imagen: "Habitat HLM type F4". Por Olivier Mourgue, en la exposición en el Centro de Creación Industrial de Paris, en 1971.
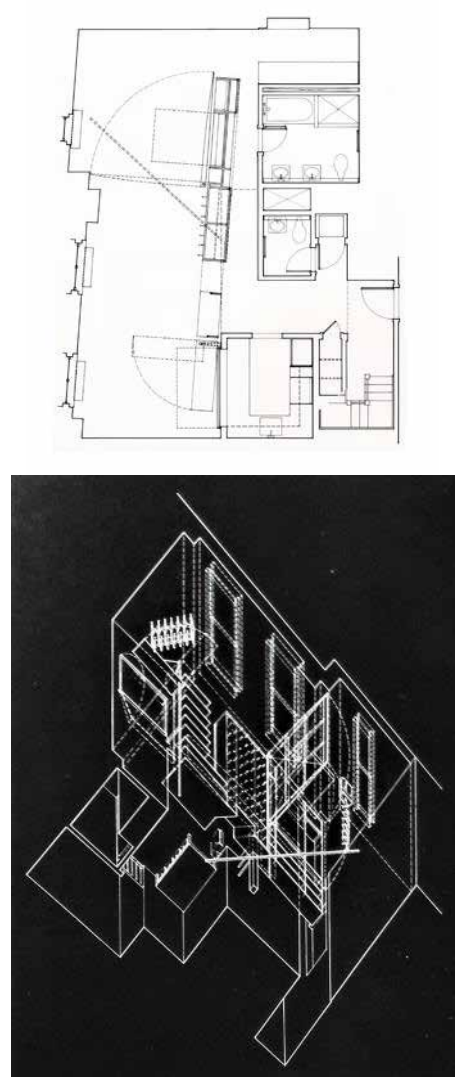

Imagen: Apartamento piloto para edificio de la Policía en Nueva York. Arquitectos: Smith Miller + Hawkinson. 1989. Planta y axonometría. 
Imagen: Apartamento piloto para edificio de la Policía en Nueva York. Arquitectos: Smith Miller + Hawkinson. 1989. A la derecha: vista interior del apartamento, donde se aprecia el mueble articulado en varias posiciones desde el espacio principal, así como la zona de cocina con el panel desplegable, la pantalla pivotante que generaba el dormitorio $y$, suspendido del techo, el monitor que recorría las distintas zonas de la casa. La relación y el diálogo entre los distintos elementos generaban un discurso que finalmente daba sentido al espacio.

Imagen: Walden 7, Barcelona. Ricardo Bofill, 1975. Vista interior de las distintas posibilidades de posición de los tatamis -divanes, según la memoria de proyecto- y mesas modulares móviles.

mesa de comedor en voladizo que creaba la zona de comedor a su alrededor, y se volvía a plegar cuando no se necesitaba. Finalmente un dispositivo de televisión móvil y articulado ofrecía su visión desde todos los distintos espacios, sala de estar, comedor, dormitorio y balcón, y creaba un nexo visual entre todos ellos.
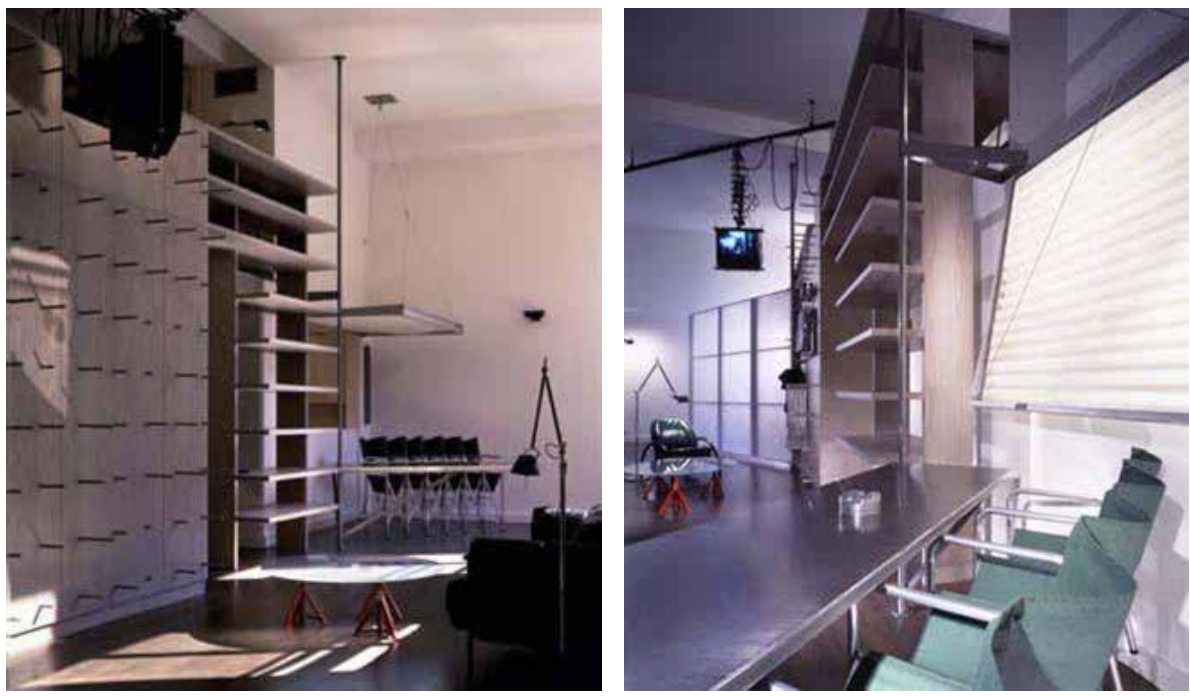

En el caso de las viviendas modulares del complejo Walden 7, realizadas por Ricardo Bofill en Barcelona en 1975, la idea de espacio cambiante, venía representada por las combinaciones posibles de un sistema de mobiliario, diseñado específicamente, con el fin de que pudieran -adaptándose a los espacios 'living-dormitorio' de todos los tipos de vivienda- proporcionar diferentes maneras de 'vivir' en cada una de las zonas de la casa. En este proyecto, se trataba de incorporar la noción de 'estar' a todas las demás actividades de la vivienda, y se planteaba de una manera sistemática y rigurosa.
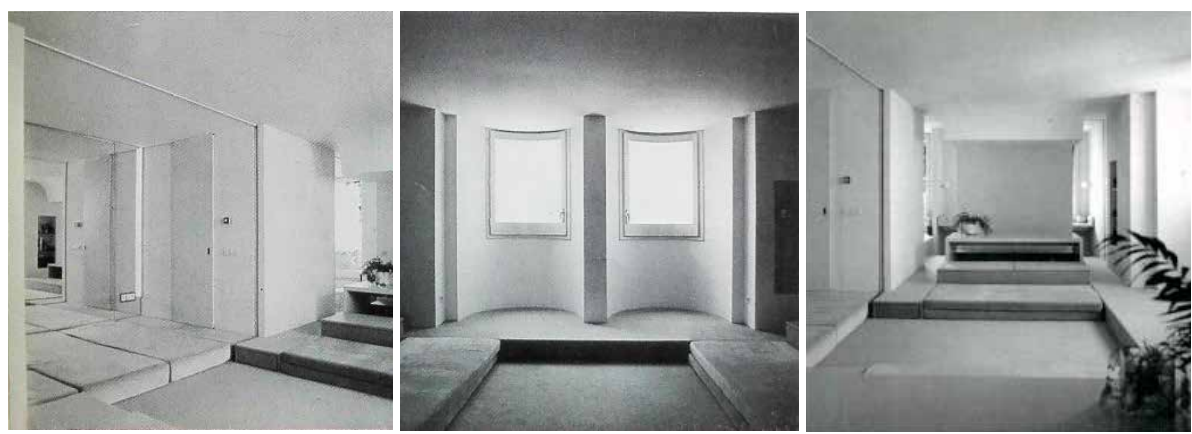

El concepto de estar invade en estas viviendas todos los espacios y cada estancia es un lugar donde 'estar', solo o en compañía, tumbado o sentado, escuchando música o trabajando.

\section{Ricardo Bofill ${ }^{43}$}

El nucleo social urbano Walden 7 fue proyectado para ser construido dentro del área metropolitana de Barcelona, en Sant Just Desvern, concretamente en un terreno que estaba ocupado en su parte central por una antigua fábrica de cemento, ya fuera de uso, que los vendedores del terreno pensaban destruir para dejarlo totalmente libre.

Las nuevas construcciones, destinadas a viviendas y servicios, se situaron alrededor de los restos, remodelados, de la antigua fábrica.

Walden 7 era fruto de sucesivas investigaciones sobre la vida en comunidad, 

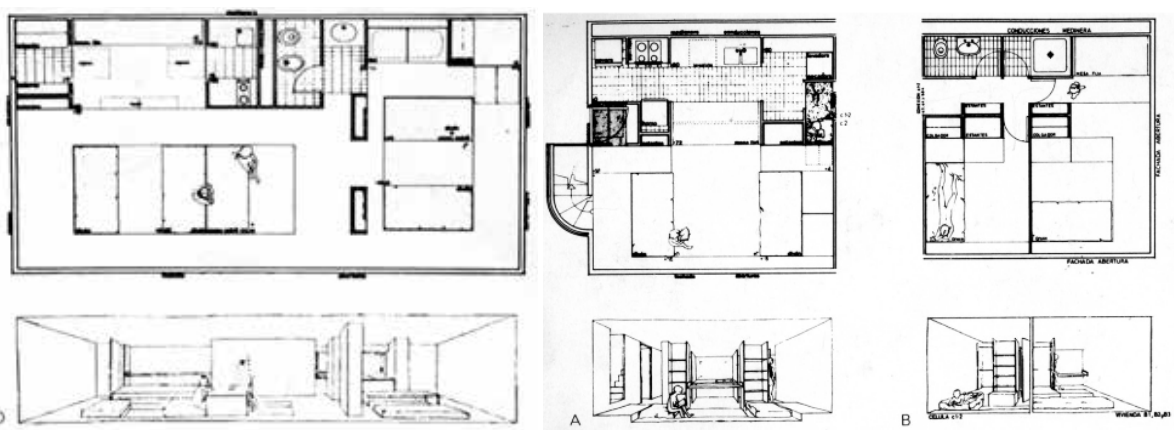

por eso, aparte de las viviendas, se incluían actividades colectivas y servicios públicos a nivel de planta baja del complejo. Había comedores colectivos, almacenes de venta de ropa, lavandería, gimnasio, guarderías, etc.

Todo el programa del edificio se desarrollaba en módulos que correspondían a la unidad mínima de vivienda, el estudio, que era de $30 \mathrm{~m}^{2}$ y donde podían vivir una o dos personas. El resto de los tipos se componían de dos, tres 0 cuatro módulos 0 células. En todas las viviendas el espacio total se dividía en sub-espacios o unidades elementales: cocina, baño, y sala de estar que por la noche se convertía en dormitorio. En los 'living-dormitorios', a su vez, se creaban zonas a base de desniveles diferenciados por distintos materiales que les proporcionaban diferentes cualidades hápticas pasando del ladrillo a la goma-espuma tapizada en moqueta. La idea era sustituir los sistemas de distribución y decoración tradicionales mediante mueble-objeto-artefacto, por espacios indiferenciados divididos en sub-espacios abiertos, con opción a la unión total 0 independencia completa y con mobiliario integrado recubierto de moqueta que adquiere la consistencia adecuada para sentarse, echarse a dormir o caminar.

Aun partiendo de la idea de tener todo el espacio disponible de una vez, y aun operando desde la fluidez, a veces era necesario generar sistemas que a la vez pudieran crear zonas cerradas, u ocultas para conseguir una cierta intimidad. El habitante contemporáneo, de finales de los ochenta, del proyecto de viviendas en

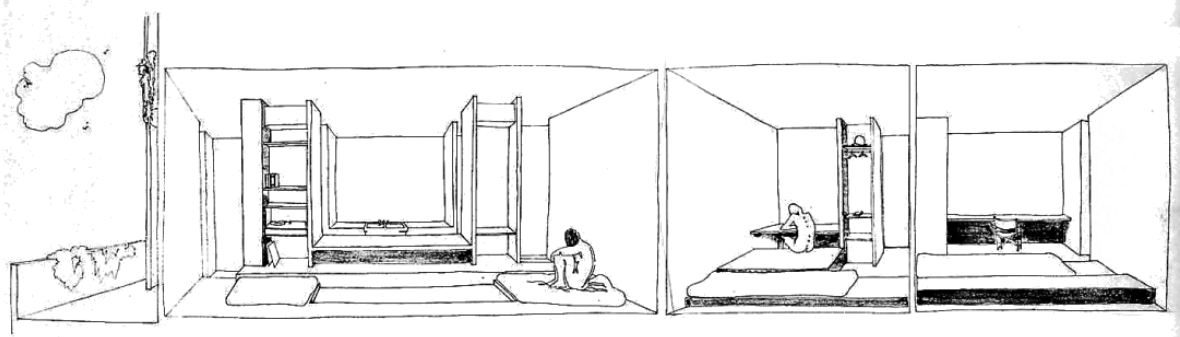

Fukuoka de Steven $\mathrm{Hol}^{44}$, requería un terreno que fuera mutable pero con poco esfuerzo y con transformaciones sencillas. La movilidad y articulación de elementos arquitectónicos, como son los tabiques, en un proceso de objetualización, a través de su definición según la ley gestáltica de reconocimiento de la figura frente al fondo por contraste gracias a los juegos de color, y por su ligereza, al ser de madera para pivotar más facilmente, conseguían que la flexibilidad, 'física' según Venturi, 'permanente' según Monique Eleb ${ }^{45}$, y que estuviera asociada a la condición del espacio en el que la tabiquería móvil estaba directamente implicada.

Los veintiocho interiores de los apartamentos se pensaron como 'espacios

44 Apartamentos en Fukuoka, Japón. Por Steven Holl en1989.

45 Monique Eleb, Anne Marie Châtelet y Thierry Mandoul. Penser L'Habité. Le Logement En Questions. (Paris: Mardaga, 1988) p. 10.
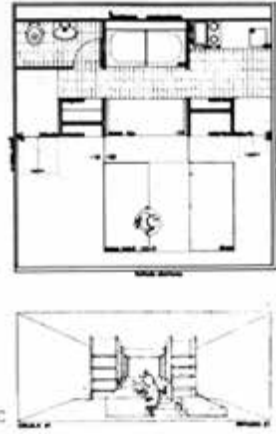

Imagen: Walden 7, Planta de vivienda de una célula y de dos células, con las posibles disposiciones en planta del mobiliario a nivel de pavimento, delimitando las zonas de estar dentro de la casa.

Imagen: Walden 7. Ricardo Bofill. Barcelona, 1975. Distintas posibilidades de posición de los tatamis. Croquis de Ricardo Bofill taller de arquitectura. 

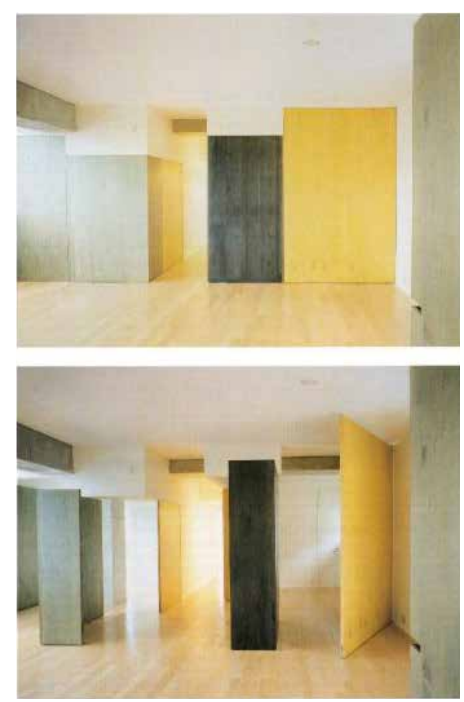

Imagen: Arriba y a la derecha, diferentes vistas interiores que reflejan la capacidad de mutar que adquiere el espacio interior gracias a los juegos de tabiquería móvil en los apartamentos en Fukuoka, Japon. Diseñados por Steven Holl, en 1989.
Imagen: Turner Residence. Aspen, Colorado. Arquitecto: John Lautner 1979. Detalle del solarium pivotante desplegado hacia el paisaje. Vista desde interior y exterior.

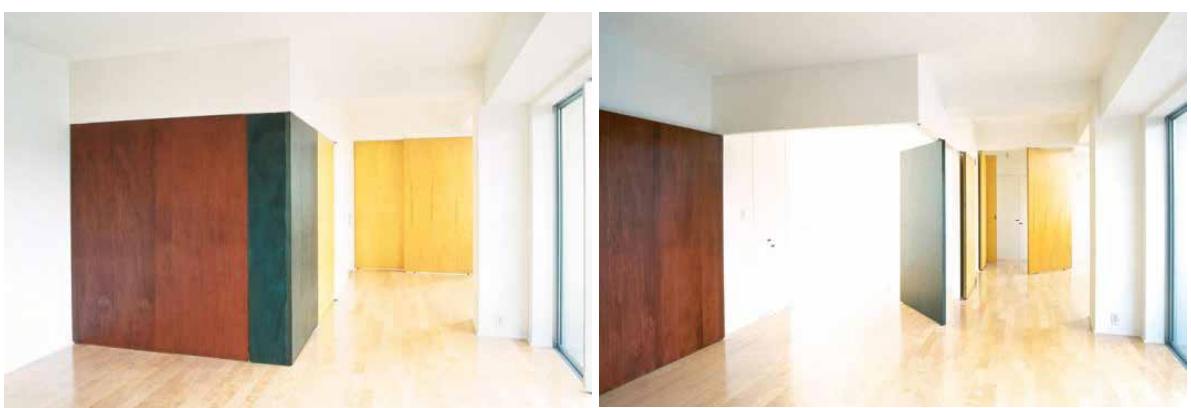

bisagra'46, una interpretación moderna del concepto de usos múltiples de la tradicional Fusuma ${ }^{47}$. En los apartamentos, la disposición diurna de los tabiques pivotantes permitía extender la zona de estar durante el día y ocuparla por habitaciones, por la noche. Las distintas posibilidades de configuración, podían hacer asumir al espacio los cambios en la familia a través del tiempo: las habitaciones podían sumarse o restarse, albergar hijos adultos que volvían o padres ancianos que se incorporaban a la familia. Fluidez e intimidad a un tiempo. Esta versatilidad fenomenológica implícita en los veintiocho apartamentos iguales podía conseguir que estos pudieran ser diferentes sin añadir ni quitar nada. El espacio discurría en aquel juego entre paneles abiertos y/o cerrados.

En casos extremos, la condición de movilidad en el espacio doméstico se asociaba a la capacidad de movimiento de la propia casa, es decir que un fragmento del edificio pudiera trasladarse convirtiendo el espacio interior en exterior. Esto ocurría en una casa de vacaciones, para ir a esquiar y habitarla ocasionalmente en verano, situada en un espectacular valle en Aspen, Colorado, diseñada por John Lautner en 1979.

Bajo una cubierta esférica de hormigón se situaba la casa en dos plantas, donde un mismo espacio combinaba zona de estar, comedor y cocina. Además contaba con dos dormitorios y un baño. La cubierta curva generaba una especie de montaña de nieve en invierno y de hierba en verano. La planta superior, contaba con un cerramiento de vidrio al sur, con vistas al paisaje. Una parte del extremo de la zona de estar pivotaba sobre un eje vertical pudiendo girar hasta $180^{\circ}$. Cuando el sistema motorizado se activaba, esta parte de la casa se abría totalmente al paisaje, quedando totalmente al exterior a modo de balcón volado.
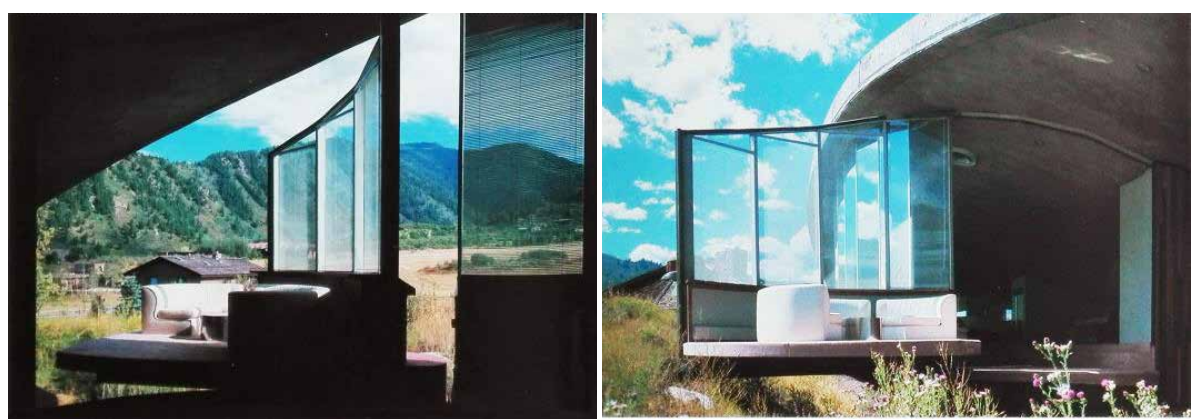

Este mecanismo permitía congelar la escena que se producía en el interior -con mobiliario, objetos, personas- y en un breve periodo de tiempo, minutos, trasladarla a un nuevo escenario con un nuevo fondo. El summum de la mutabilidad.

46 En http://www.stevenholl.com/

47 Tabiques móviles, utilizados en las viviendas tradicionales japonesas, compuestos por un bastidor de madera forrado exteriormente por varias capas de papel grueso y rematado en los bordes por listones de madera lacada. 


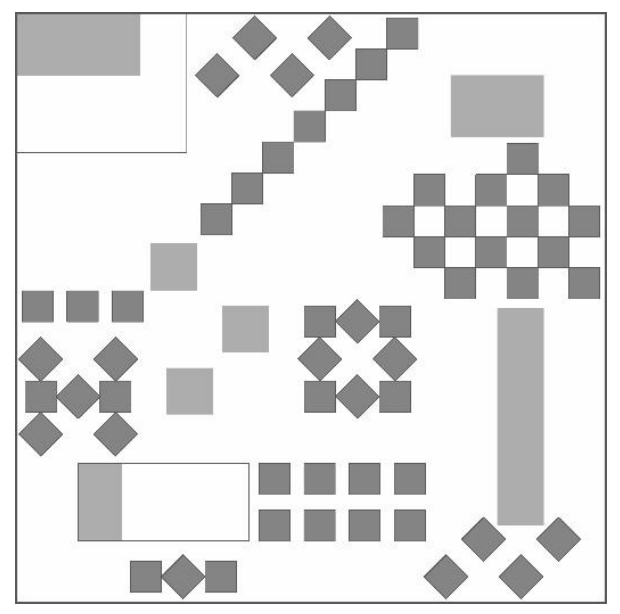

\subsection{LAAPROPIACIÓN COMO ACTO CREATIVO}

La difusión del tipo de vida en comuna hizo que ésta fuera interpretada por ciertos grupos que estaban relacionados con las corrientes contra-culturales de los cincuenta y los sesenta en Estados Unidos y con la generación beat americana. Algunos de ellos -especialmente un grupo reducido de jóvenes, que se mudaron del centro de Manhattan a una antigua zona industrial al sur de la Calle Houston en Nueva York, afincándose en el $\mathrm{SoH}^{48}$ - crearon la versión 'artística' del estilo de vida en comuna y la convirtieron en una técnica de habitar: la apropiación de un espacio industrial y neutro, el loft. La ocupación de un espacio no calificado como vivienda, a través de un proceso de invasión de objetos -muchos de ellos con vocación de objet trouvé- se convertía en una nueva base de reflexión sobre el espacio doméstico contemporáneo.

Pasar de 'alojarse en' a habitar, unía la noción de hábitat al concepto de apropiación del espacio, surgiendo así como idea de libertad y creatividad ligada al usuario. El loft, como arquetipo, representaba una forma de pensar y de habitar de determinados grupos cada vez más deseosos de desarrollar su creatividad en el ámbito doméstico mediante la apropiación lúdica de grandes volúmenes de aire sin cualidades.

Estos lugares aparecían 'preparados' para asimilar una ocupación imprevisible capaz de satisfacer la idea de domesticidad de sus particulares habitantes. De esta manera el SoHo de Nueva York se fue haciendo famoso como 'el vecindario de los artistas' durante los años 60 y 70 . En aquellas áreas desérticas de antiguos almacenes, tiendas o pequeñas fábricas abandonadas, cuando todavía los espacios eran baratos, los edificios se fueron reutilizando como estudios, viviendas, lugares donde exhibir obras de arte y donde organizar eventos -al principio era ilegal, pero luego se promulgó una ley especial-. Después de ser ocupado por los artistas, en el SoHo se instalaron también los galeristas. La galería perdía la connotación doméstica que la había caracterizado en el pasado y se presentaba como un lugar de grandes superficies donde exponer. Con la llegada del Arte Minimalista a los Estados Unidos y del Arte Povera en Europa, las exposiciones se transformaron en eventos de gran escala, y comenzaron a precisar espacios mucho más amplios. El traspaso de las galerías de arte principales a estos espacios consolidaba la total correspondencia entre los lugares de mercado y los lugares de creación de los artistas, los primeros habitantes de esta nueva e inédita representación de casa-estudio. Así surgió una nueva manera de habitar, no codificada por un

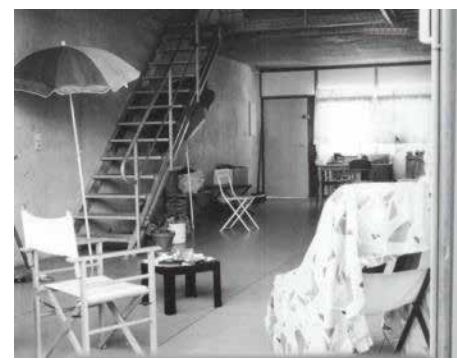

Imagen: Walden 7. Ricardo Bofill. Barcelona, 1975. Distintas posibilidades de posición de los tatamis. Croquis de Ricardo Bofill taller de arquitectura. 
proyecto a priori, demostrando que se podía tener un envidiable modo de vida instalándose en un espacio casi desnudo, desafiando las convicciones de los arquitectos, urbanistas y burgueses.

Si en los años 60 la casa-estudio, en un almacén reconvertido, representaba el ambiente vital, de creación y difusión del arte por excelencia, en los años 80 el loft perdió su esencia de espacio creado para la circulación de ideas y de escenario de acciones creativas y se convirtió en la sede habitacional de profesionaleshedonistas: emprendedores, personas de éxito, etc. Enun proceso de 'gentrificación'49, los barrios que habían sufrido esta transformación durante los 60 y 70, se pusieron de moda y subieron en la escala socioeconómica. Esto llevó finalmente a un éxodo de la mayoría de artistas, quedando únicamente las galerías, las boutiques, los restaurantes exclusivos y los nuevos inquilinos: los yuppies.

Los arquitectos, que al principio habían estado al margen del proceso, ahora surgían como el mejor intérprete del estatus de una clase que había decidido adoptar ese tipo particular de espacio como suyo. El loft se convirtió en un nuevo tipo doméstico, tanto en Estados Unidos como en Europa, sin embargo, a pesar de que el habitante era otro, como tipología adquirió algunas de las características propias de lo que fue en origen: la transformación de un espacio de producción en uno residencial. Algunas de las constantes que ha mantenido han sido su considerable tamaño, tanto en planta como en alzado, su diafanidad e indefinición dadas por una estructura de pilares y grandes luces, las grandes aberturas al exterior, la pobreza de los materiales de construcción a menudo prefabricados, detalles particulares como pilares de hierro fundido o de hormigón con capitel más o menos elaborado, los techos de chapa ondulada, los pavimentos acabados en hormigón, etc.

Un nuevo modo de vida, surgido en los años sesenta, convirtió al espacio industrial, con unas características propias, y lo calificó como vivienda aportándole unas cualidades acordes con sus propias ideas sobre lo que significaba 'habitar'. Y este proceso se produjo gracias a un modo de ocupación objetual como era la 'apropiación'.

Al igual que el antiguo almacén reconvertido en vivienda se consolidó como tipo años después, la apropiación se convirtió en uno de los enlaces esenciales entre el usuario y su hábitat, y de una manera espontánea, en una forma de configuración del espacio doméstico a través de sistemas de objetos, aparentemente 'no organizados' cuyo discurso -basado en sus caóticas relaciones- era el reflejo de una identidad social y cultural que implicaba libertad y creatividad.

The Factory, fue un espacio-comuna de convivencia y producción artística ideado por Andy Warhol en un antiguo almacén ubicado en la Calle 47 con la tercera Avenida de Nueva York, en 1965. Representa el modo de vida de aquel grupo de artistas que decidió trasladarse a vivir y trabajar en el sureste de Manhattan, adquiriendo grandes espacios en edificios industriales y comerciales abandonados y que dieron lugar a una de las formas más singulares de habitar que el siglo veinte inventó.

Apropiarse de ese volumen de aire era la esencia de aquella forma de habitar

49 Del inglés gentrification, anglicismo con el que se alude al proceso mediante el cual la población original de un sector o barrio, generalmente céntrico y popular, es progresivamente desplazada por otra de un nivel adquisitivo mayor. 
en comunidad mediante la técnica de la apropiación. Aunque esa tradición tomó su origen en los primeros socialistas utópicos derivó finalmente en una versión artística y más consumista de lo que parecía: el loft neoyorkino; y éste a su vez, devino en una forma de pensar, construir y habitar un arquetipo de casa contemporánea.

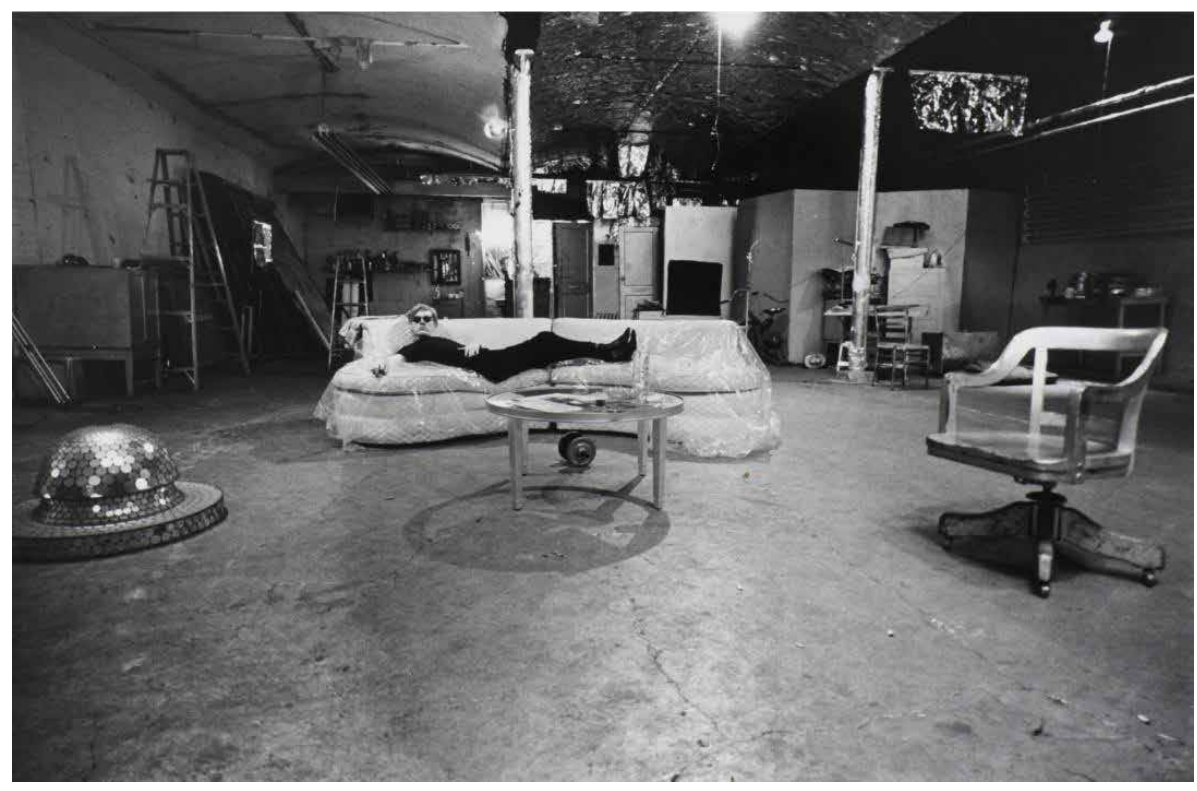

El lugar se había institucionalizado a sí mismo como en una casa abierta, intensamente frecuentada, en un lugar de trabajo, pero también de fiesta. El local medía unos quince por treinta metros y contaba con una hilera de ventanas en todo el frente sur. En el edificio había montacargas, que era poco más que una plataforma y una reja, y se abría directamente para acceder al local ${ }^{50}$.

Al igual que The Factory era en sí misma una nave en desuso y reciclada, los objetos a través de los cuales se producía la apropiación espacial también habían sido "apropiados", reciclados, convirtiéndose el objeto en el acto creativo, ya en sí mismo, reproduciendo el movimiento que significaba el objet trouvé duchampiano y descontextualizado. Esta idea de espacio basada en la descontextualización y la proliferación de objetos triviales, de desechos del consumo que reutilizados para otro contexto adquirían un significado estético e irónico, surgía como una reacción contra el sistema de vida cotidiano establecido, contra el lujo, el confort burgués, la intimidad, la tecnificación moderna. Así apareció una nueva categoría, la de lo 'retro', una estética asociada al reciclado que se concretaba en una domesticidad creada a base de objetos descontextualizados 0 , mejor dicho, re-contextualizados. Objetos ajenos a la tradición de la casa como piezas de coche, muebles de bares, elementos de decoración de discotecas, canastas de baloncesto, etc. eran los que configuraban el paisaje doméstico, un paisaje deliberadamente caótico y decadente. En aquel desorden estos espacios carecían de jerarquías, distribución, y especialización espacial. La simplicidad del contenedor neutro era el nuevo paradigma habitacional. La apropiación a través de objetos 'cogidos del contenedor' se convertía en un sistema de signos, no atendía a relaciones topológicas ni distributivas; ni siquiera organizativas, sino que respondía a generar una lógica de ambiente, una estructura con un fuerte imperativo cultural y contra-cultural cuyo discurso invadía de sentido a un espacio que, en su origen, se configuraba como una manera para representar un modo de vida muy determinado.

50 Iñaki Abalos. La buena vida: visita guiada a las casas de la modernidad. (Barcelona: Gustavo Gili, 2001) p.115.
Imagen: The Factory. Nueva York. Andy Warhol, 1965. Vista del espacio y Warhol tumbado en un sofá que había sido encontrado abandonado en la acera y fue arrastrado hasta the Factory. Aquel sofá se convirtió en una pieza importante del espacio y en el escenario donde se retrataron varios tipos de relaciones sociales y sexuales. 
Los lofts del SoHo, en gran medida, gracias a ese vendedor que fue Andy Warhol, pasaron a ser décadas después el gran objeto de deseo de la élite.

La apropiación, asociada en origen a un modo de vida en comunidad como el caso anterior, podía surgir también de planteamientos más existenciales, como en el proyecto de viviendas Diagoon Houses, construidas en Delft por Herman Hertzberger en 1970. En este proyecto, de nueva planta, la idea de Hertzberger era que las ocho casas, por principio, estuvieran inacabadas.

El programa era indefinido para que los ocupantes mismos pudieran decidir cómo dividir el espacio y cómo vivir en él: dónde dormir, dónde comer. Si la composición de la familia cambiaba, la casa se podría modificar e incluso ampliar. Interiormente existía una gran sala de estar en doble altura y el resto de la casa era como un gran balcón que volcaba sobre este espacio. No existía la tradicional división entre la sala de estar y los dormitorios. Cada miembro de la familia tenía su propia parte de la casa en la gran sala comunal. Las fachadas también podían ser diseñadas como un marco que podía ser compuesto libremente con vidrio o con paneles opacos, dentro de una estructura que sí era un invariante.

La casa inacabada se convertía en un marco que propiciaba el proceso creativo de la configuración del propio hábitat, definiéndolo y diferenciándolo en un marco mayor, que era la sala comunal. El espacio se convertía en una especie de collage compuesto por muchos espejos diferentes en los que se miraban cada uno de los individuos que lo habitaban, y que creaban su propio ámbito a través del discurso que generaban con el acoplamiento de sus propios objetos dentro de la porción de espacio que les correspondía.

Imagen: Diagoon Houses, Delft. Holanda. Herman Hertzberger, 1970. Vista del interior de una de las viviendas.

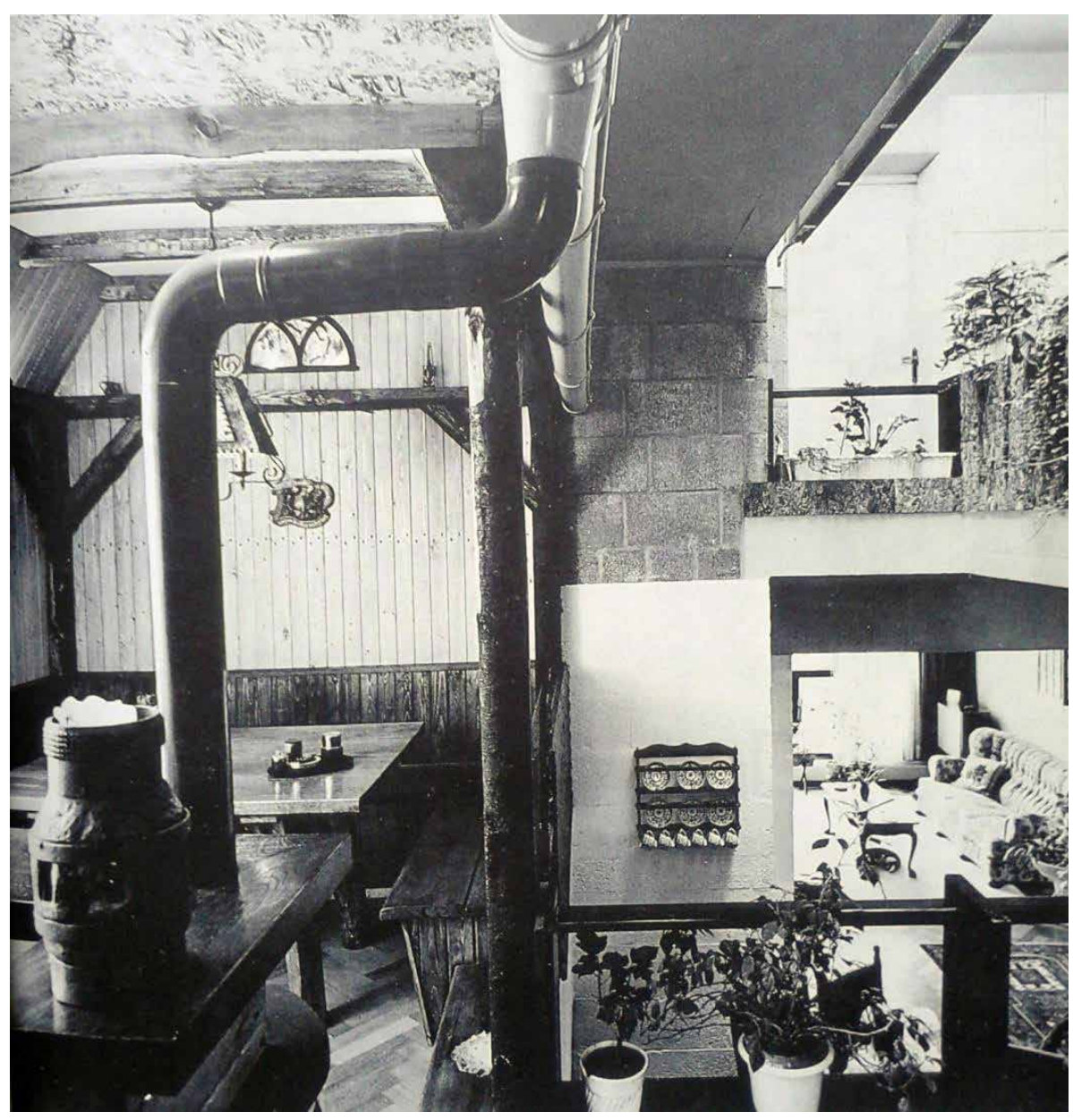


En Diagoon Houses la apropiación surgía como un proceso que iba implícito en el propio proyecto. Los modos de vida que se producían en el interior de las casas de Hertzberge estaban condicionados por el aspecto que más caracterizaba al propio espacio, el hecho de estar inacabado. La decisión sobre dónde comer, o dormir, o cual era la distribución más adecuada a las necesidades del momento, estaba íntimamente ligada a la de dónde colocar los muebles y los objetos libremente según estas premisas, convivir con los conductos y las bajantes, que eran parte del atrezzo.

Los objetos, tanto útiles como inútiles, las presencias del pasado como los souvenirs o las fotos, tejían en torno a cada uno el universo al cual pertenecía, configurando su propio espacio:

La apropiación constituye uno de los enlaces esenciales entre el usuario y su hábitat, es por ello que la vivienda se convierte en el reflejo de la identidad social, cultural y económica de sus habitantes. La apropiación es esencialmente de orden objetual, con objetos de todas las dimensiones: muebles, pequeños objetos, baratijas, marcos cosas colgadas, plantas, etc.

\section{Monique Eleb ${ }^{51}$}

Como en la casa que Charles Moore habitó en 1975 en Los Angeles, dentro del Moore, Roger, Hofflander Condominium ${ }^{52}$.

Moore, ansioso por adquirir una casa cerca del campus de la Universidad de UCLA, donde trabajaba, propuso a dos familias de profesores comprar un solar conjuntamente. A pesar de que el terreno no era demasiado grande, el programa comprendía tres viviendas, tres jardines de uso individual y plazas para seis coches que no querían soterrar. Al solar se accedía a través de un patio que distribuía a las tres viviendas. Por las dimensiones del solar y el amplio programa las viviendas se encajaban casi como si fuera puzzle en tres dimensiones. La casa de Moore se convirtió en una gran escalinata, con espacios intermedios donde colocar una multitud de objetos personales aprovechando los muy distintos niveles.
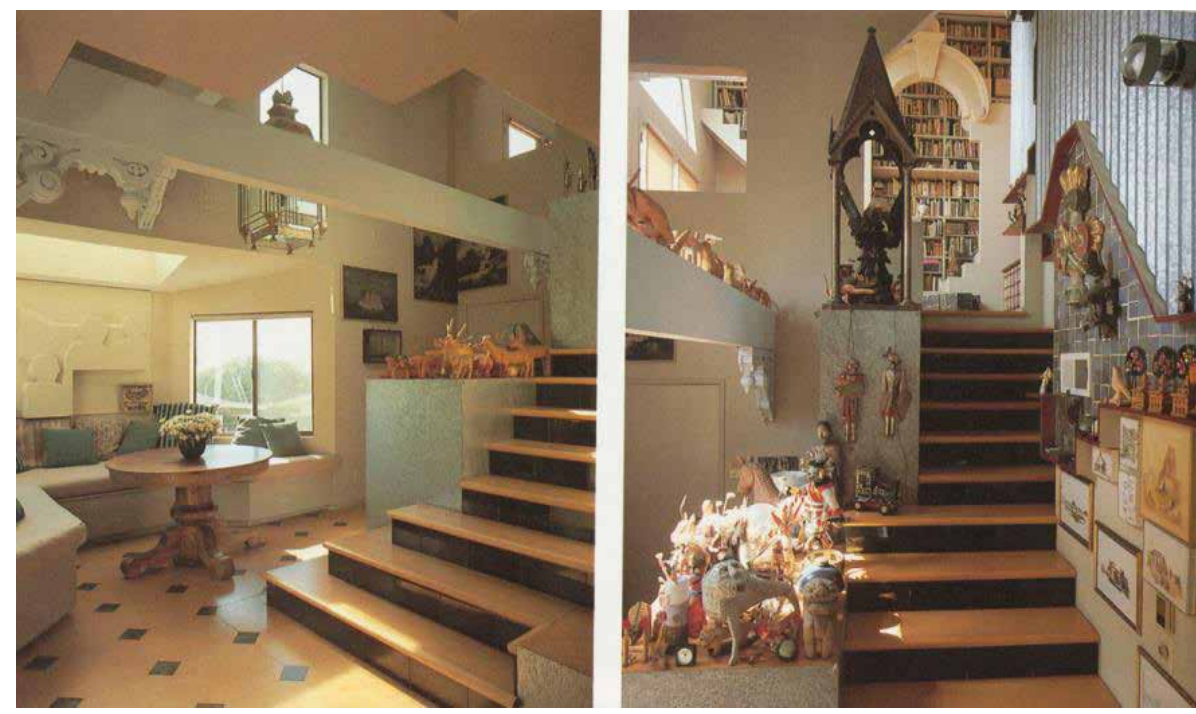

51 Monique Eleb, Anne Marie Châtelet y Thierry Mandoul. Penser L'Habité. Le Logement En Questions. (Paris: Mardaga, 1988) p.132.

52 Charles W. Moore, et.al. "The Work of Charles W. Moore". A+U Architecture and Urbanism, (ñ extra may-1978) 249. Al marchar Charles Moore a la Universidad de California, en Los Angeles, decidió construir su casa incluyéndola en un complejo de tres viviendas, compartiendo la compra del solar con otras dos familias, dado el elevado precio del suelo en Los Angeles.
Imagen: Casa Moore en Moore, Roger Hofflander Condominium. Los Angeles, California. Charles W. Moore, Richard Chilinsky. 1975 
Imagen: Mercer Street Loft. Nueva York. Arquitecto: Mark Cigolle. 1980. Vista de la zona de comedor, y del cuarto de baño, en el que conviven objetos, que son fragmentos de la casa tradicional, con mamparas de oficina y elementos industriales.

En este caso, apropiación, consistía en invasión de elementos arquitectónicos como vigas, escaleras, con objetos personales. Por un lado estaba afianzando los vínculos incluso con los elementos más tectónicos de la casa, por otro lado los estaba objetualizado dotándolos de otros significados.

Volviendo a los espacios recuperados para vivienda, otro factor que podía caracterizar el modo de apropiación en el interior es la construcción del discurso mediante fragmentos, dispuestos como grandes objetos, aparentemente sin orden lógico en el espacio indiferenciado y preexistente. La idea con que puede considerarse el interior del loft configurado por fragmentos es propiamente social y tiene que ver con la desintegración y la sucesiva recomposición de la imagen de la casa tradicional como signo, y consecuentemente de los modos de vida que se asociaban a aquellos espacios. El loft podía contener los vestigios de casi todos los elementos de la casa tradicional, pero colocados como fragmentos, como trazas deliberadamente dispuestas y capaces, en su nuevo papel, de generar nuevos significados. El espacio preexistente era tratado como una parcela de terreno desnudo donde los objetos adquirían protagonismo por sí mismos -en parte por los significados que se generaban por su descontextualización- y eran los que creaban la estructura, mientras los muros perimetrales se convertían en el horizonte de este paisaje artificial.

Esto ocurría en una reforma para una vivienda en un edificio del SoHo de seis plantas con fachada de ladrillo y pilares de hierro fundido, realizada por Mark Cigolle en 1980. El diseño, que contemplaba un área de vivienda y otra de estudio dentro de un loft de $300 \mathrm{~m}^{2}$, se basaba en una continua yuxtaposición entre la concepción moderna del espacio abierto y la clausura de las habitaciones, que surgen como una secuencia de volúmenes individuales dentro del propio espacio. La narrativa del proyecto se producía por medio de un contraste continuo de imágenes: las del ámbito industrial en la zona de trabajo con las de la vida doméstica, que aparecía representada por medio de fragmentos de la casa tradicional, y que se dispersaban por el espacio, como si de restos arqueológicos se tratase.

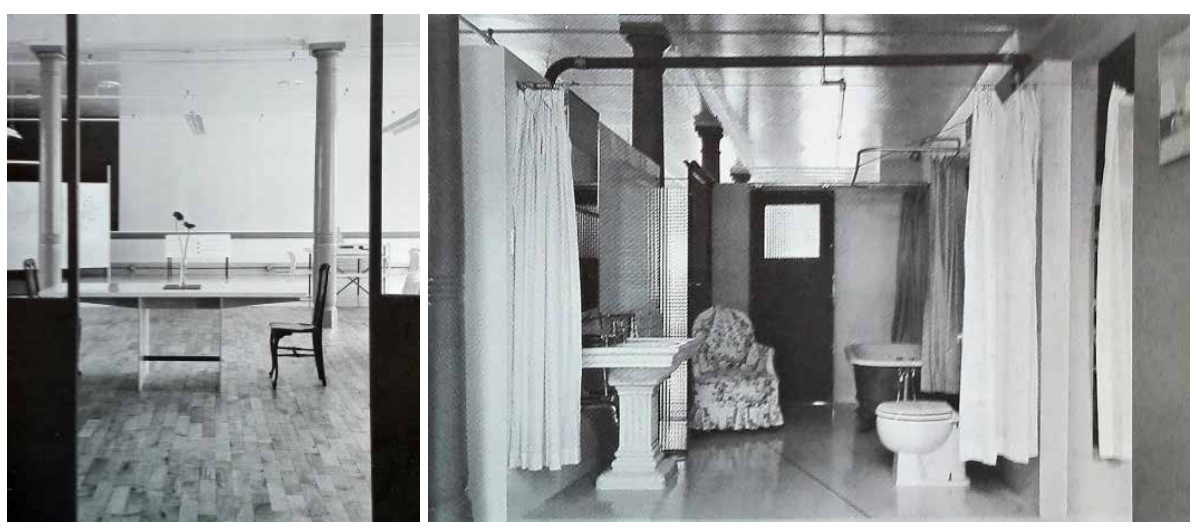

La intención era que esas conexiones se produjeran a través de los objetos y de los materiales en sí mismos. Por ejemplo, mamparas y estanterías de oficina en acero convivían con un lavabo con pedestal clásico o una bañera antigua de hierro fundido. El suelo estaba pintado por zonas, y esto reforzaba el diálogo doméstico-industrial y a su vez dibujaba el área de dominio de cada uno de los objetos, para evitar su absoluta dispersión: una isla de pavimento en madera natural marcaba el centro del hogar, posicionando en el espacio el lugar de lo que representaba el salón doméstico: el sofá y la mesa de comedor ${ }^{53}$. Lo que era evidente es que a través de esas experiencias se había creado

53 Mark Cigolle. "Mercer Street Loft, New York City, 1980", GA houses (n8 may. 1981) p.140-145. 
toda una técnica proyectual a desplegar. Esto se hacía más palpable cuando algunos proyectos, de nueva construcción, reproducían los valores espaciales, materiales y objetuales de lo que había sido el almacén recuperado y reconvertido para vivienda ${ }^{54}$.
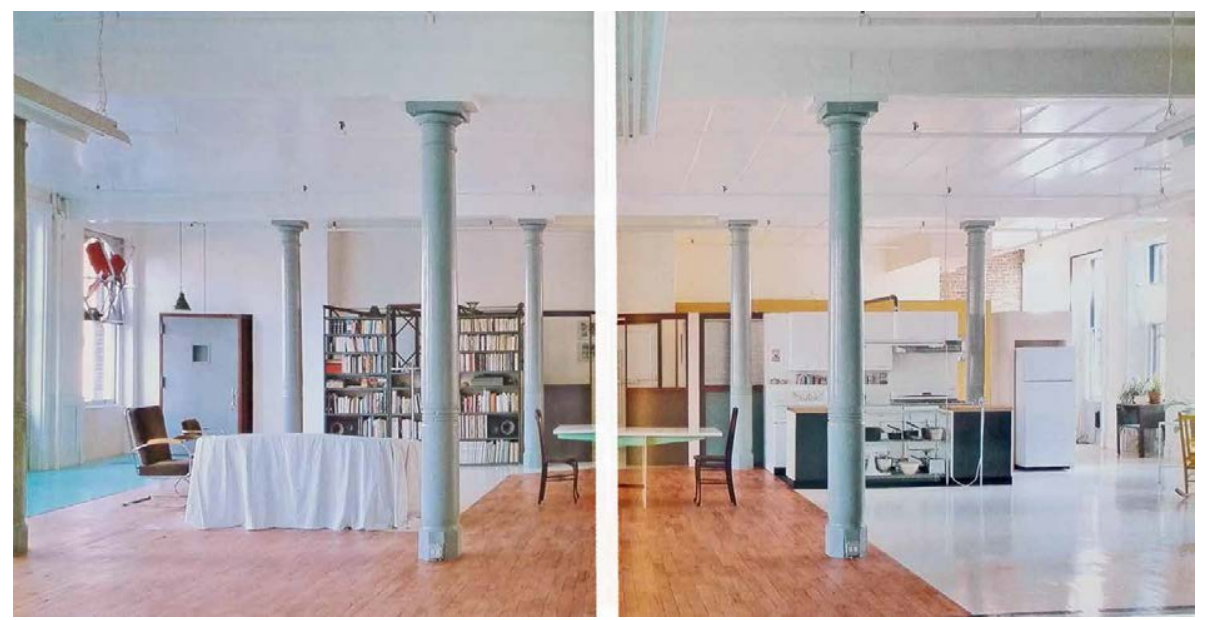

A este respecto, los sociólogos del hábitat hacían hincapié en que existían medios arquitectónicos para llevar a cabo la apropiación:

La célula base debe ofrecer un volumen habitable donde la transparencia y la percepción visual son los primeros factores de apropiación del espacio (...) Con una distribución apropiada, que permita variaciones, queda para los usuarios un amplio margen de maniobra para apropiarse del espacio: cerrarlo más o menos a través de elementos de mobiliario, vegetación o cualquier otro mecanismo -cortinas, por ejemplo-, según sus deseos o por la evolución de la familia.

\section{Monique Eleb y Anne M. Châtelet ${ }^{55}$}

La idea de habitar se consideraba íntimamente ligada al concepto de apropiación del espacio, y la noción de apropiación, a su vez, con la idea de que aquello implicaba dotar de libertad y de creatividad a los usuarios.

Chuck Arnoldi es un reconocido pintor y ha sido miembro influyente de la escena artística de Venice (California) durante décadas, y también es amigo de Frank Gehry. Su amistad inspiró un proyecto para estudios de artistas, que se materializó en tres casas en un estrecho solar en Indiana, un barrio de Venice. Los propietarios de la parcela, Chuck Arnoldi, Bill Norton y Laddie John Dill pensaron construir estudios 'tipo loft' para artistas y personas que quisieran convivir con éstos. No se sabe si para abaratar al máximo, o por razones más conceptuales, los interiores de los edificios se dejaron sin acabar. De esta manera los propietarios podrían hacer las divisiones y terminarlos según sus necesidades. Cada casa contaba con un baño, una cocina, tomas de corriente y chimenea. Para humanizar los edificios, contaba Gehry ${ }^{56}$, que obtuvo ideas inspirándose en las viviendas de Los Angeles de los años 30, sobre todo en las escaleras y chimeneas.

54 Iñaki Abalos. La buena vida: visita guiada a las casas de la modernidad. (Barcelona: Gustavo Gili, 2001) p.123.

55 Monique Eleb y Anne Marie Châtelet. Urbanité, Sociabilité et Intimité. Des Logements d'Aujourd'hui (Paris: l'Épure, 1997) p.219.

56 Mildred Friedman. Editado por. Frank Gehry, The Houses. (Nueva York: Rizzoli, 2009) p.163.
Imagen: Mercer Street Loft. Nueva York. Arquitecto: MarkCigolle. 1980. Vista general del espacio.

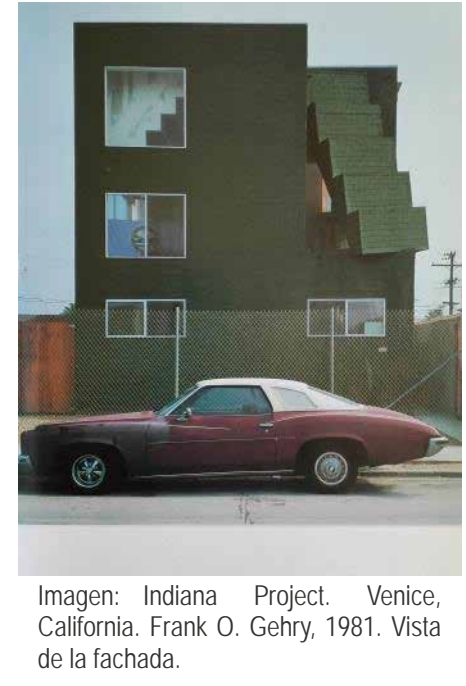
le la fachada. 
Imagen: Indiana Project. Venice, California. Frank O. Gehry, 1981. Vista del interior de las viviendas, cuya característica de espacio abierto e inacabado propiciaba la apropiación como sistema de configuración de espacio doméstico.
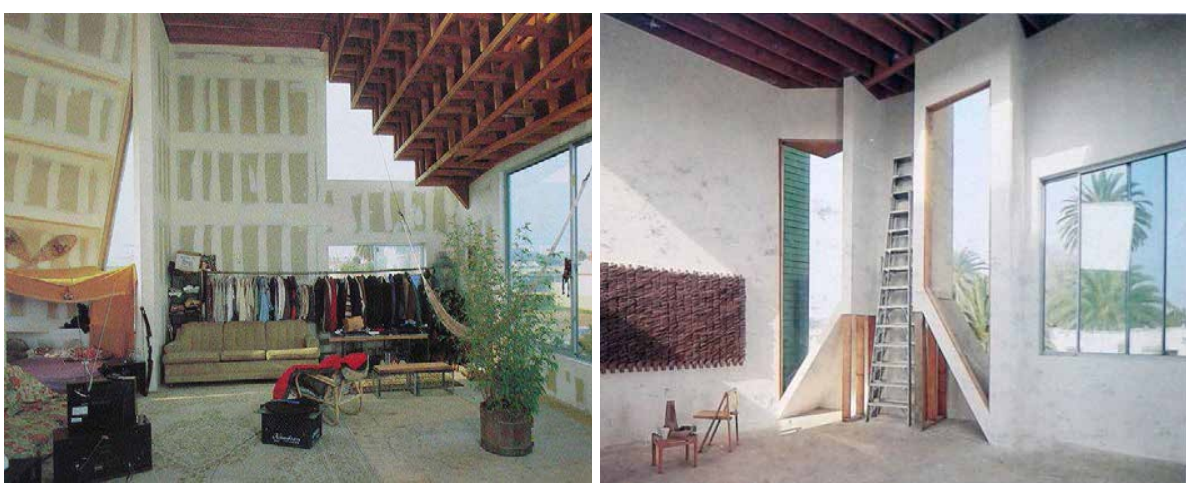

Por el tipo de cliente, que iba ligado a un modo de vida, el edificio se construyó basándose en las características de un espacio reconvertido a pesar de ser de nueva construcción. La apropiación, tal y como se aprecia en las imágenes, era inducida por la tipología de espacio y los acabados.

En los años 80 el loft perdió su esencia de espacio creado para la circulación de ideas y de escenario de acciones creativas, convirtiéndose más bien en la sede habitacional de profesionales hedonistas: emprendedores, personas de éxito.

Imma Forino ${ }^{57}$

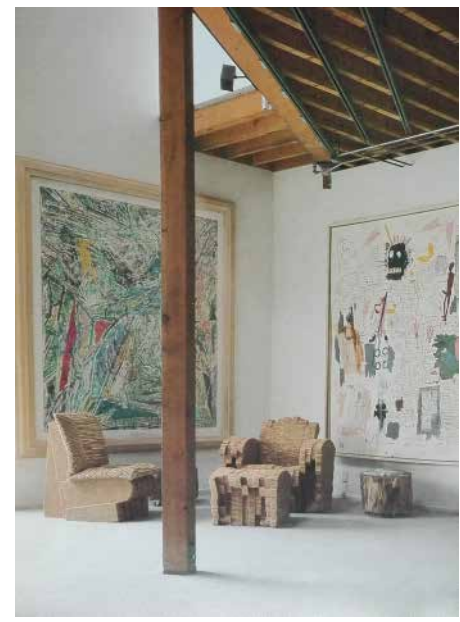

Imagen:Dennis Hopper House. Venice, California Reforma interior realizada por Bam Construction and Design en 1986, del proyecto realizado por Gehry en 1981.

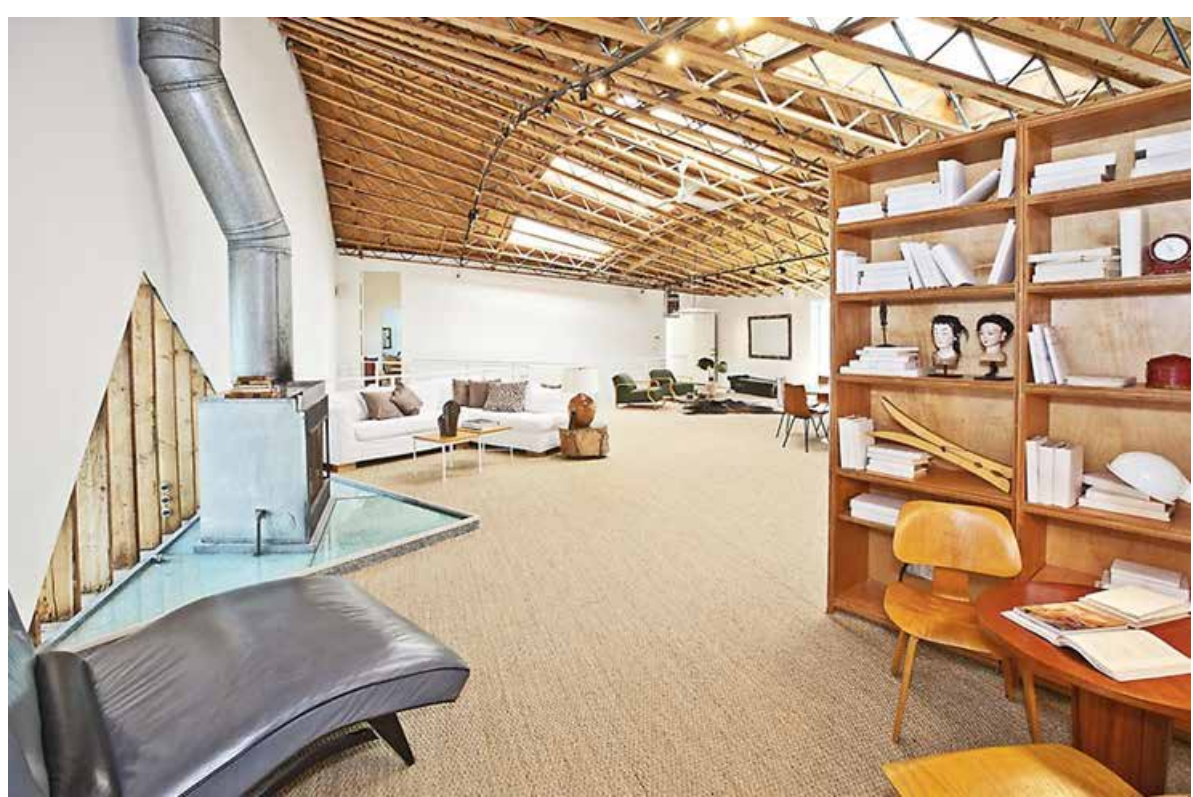

Para ilustrar esta afirmación: en 1986, el interior del conjunto de las tres casas construidas por Frank O. Gehry en Indiana Avenue en 1981, fue objeto de una obra de reforma para el actor Dennis Hopper, que necesitaba en planta baja un lugar protegido del vecindario y que fuese capaz de albergar y exhibir grandes obras de arte. El espacio se consolidaba con la iluminación, las dobles alturas para las obras de gran tamaño, la vegetación y los sistemas de seguridad. Desde la planta superior, la existencia de dobles alturas, conseguían que el apartamento contuviera las visuales necesarias para observar la colección de arte contemporáneo y étnico de sus propietarios, desde muy diversos puntos de vista. La chimenea, la bañera y la lámpara del comedor, hechas de encargo, funcionaban como focos visuales que marcaban los recorridos, pensados para

57 Imma Forino. L'interno nell'interno. Una fenomenologia dell'arredamento. (Florencia: Alinea Editrice. 2001) p.90. 
la contemplación de las obras exhibidas.

Este ejemplo muestra cómo el sistema de apropiación, como acto creativo asociado a un modo de vida, se vio frustrado por un proceso de tipificación del espacio y por su posterior aburguesamiento. Pero la apropiación, al entenderse como un modo espontáneo de acoplamiento, podía empañarse si el arquitecto estaba demasiado presente, si imponía los modos de ocupación o si prohibía determinadas prácticas decorativas. Por ejemplo Frank Lloyd Wright, según Eleb y Châtelet ${ }^{58}$, no soportaba que sus clientes cambiaran la posición de los muebles que él había diseñado o había aconsejado comprar, incluso llegaba a reamueblar los espacios aprovechando la ausencia de sus clientes. En proyectos más recientes, como las viviendas sociales realizadas en 1987 por Jean Nouvel en Nemausus, existía la prohibición explícita a sus habitantes de pintar los muros interiores de hormigón visto, defendiendo una posición particular del arquitecto que iba dirigida a proteger la arquitectura, llegando incluso a la coacción de sus habitantes: "la presencia fuerte de la arquitectura en el interior, es un incentivo para que el edificio resista a sus ocupantes". Algo que no acataron finalmente los habitantes del edificio, procediendo a pintar y colgando lo que quisieron en las paredes de sus apartamentos.
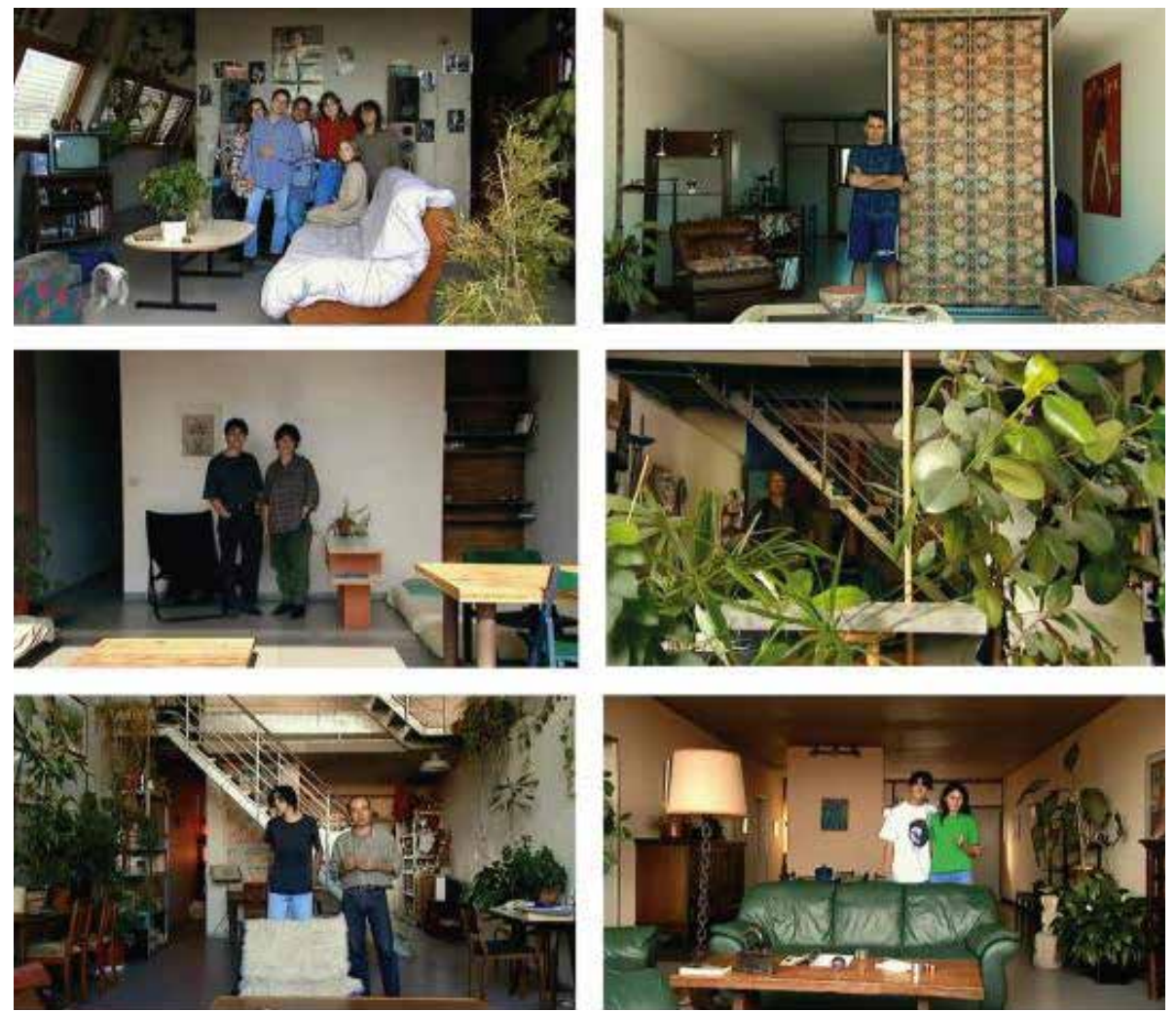

"Sin embargo los residentes parecen haber dicho no al Sr. Nouvel procediendo a pintar y colgando lo que quieran en las paredes de sus apartamentos, de una manera similar a los ocupantes de los Apartamentos Lafayette de Mies en Chicago"59.

"Si pudiéramos observar, uno junto a otro, diversos apartamentos iguales de un mismo edificio, nos daríamos cuenta de que nada o muy poco cambia en el soporte que presta la arquitectura a la vida doméstica en cada casa y, sin embargo, el trabajo de apropiación que

58 Monique Eleb y Anne Marie Châtelet. Urbanité, Sociabilité et Intimité. Des Logements d'Aujourd'hui (Paris: l'Épure, 1997) p.219.

59 Fuente: https://hotcharchipotch.wordpress.com/2012/05/09/houselife/
Imagen: Viviendas Nemausus. Nîmes. Jean Nouvel /Jean-Marc Ibos, 1987.

Vista interior de algunas de las viviendas, en las que se observan los distintos procesos de apropiación producidos dependiendo de sus habitantes. 
cada usuario realiza transforma sustancialmente la percepción de ese espacio"

Xavier Monteys, Pere Fuertes ${ }^{60}$

En 1985, el alcalde de Nîmes contrató a Nouvel para diseñar un proyecto de vivienda social en las afueras de la ciudad. Entre las cuestiones clave se encontraba que la definición fuera la de un 'buen' apartamento. Según Nouvel ${ }^{61}$, un buen piso era simplemente, el más grande posible, muy polivalente y modulable, y un buen apartamento no era caro. Luego estaba la cuestión de la ubicación. Nîmes al estar ubicada no muy lejos del Mediterráneo, tenía una temperatura más bien templada la mayor parte del año, y tradicionalmente se pasaba mucho tiempo al aire libre. La superficie máxima de los apartamentos se obtuvo a través de una reducción al mínimo de las zonas comunes, escaleras o pasillos -las escaleras eran exteriores, y cada apartamento tenía acceso desde galerías también exteriores-. El requisito para un bajo coste se cumplía mediante el uso de materiales industriales prefabricados tanto en el exterior como en el interior. Las terrazas permitían disfrutar mayormente del exterior ya que unas puertas de garaje de acordeón, al abrirse a lo ancho, hacían del balcón una parte integral de la sala principal. El grafismo en rayas rojas y blancas que marcan las escaleras, las líneas rojas en las puertas, o colores simples utilizados en diferentes puntos en el interior, en realidad iban en pos de la metáfora industrial y proporcionaban a los apartamentos unas cualidades que propiciaban, como se ha podido observar en las imágenes, la apropiación como modo de vida en un espacio industrial convertido en vivienda ${ }^{62}$.

Imagen: Viviendas Nemausus. Nîmes. Jean Nouvel /Jean-Marc Ibos 1987. Vista del interior de uno de los apartamentos y del sistema de apertura de las viviendas a la galería.
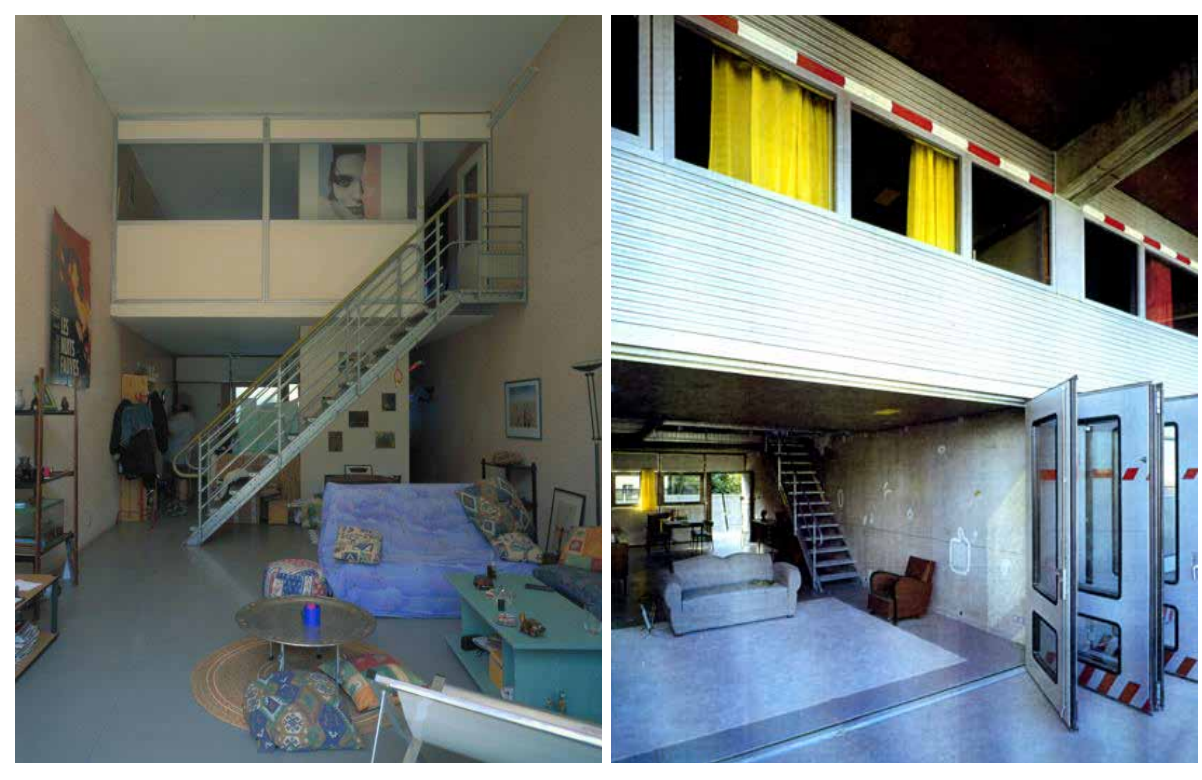

60 Xavier Monteys y Pere Fuertes. Casa collage. Un ensayo sobre la arquitectura de la casa (Barcelona: Gustavo Gili, 2001) p.26.

61 Fuente: http://www.jeannouvel.com/

62 Ibídem. 


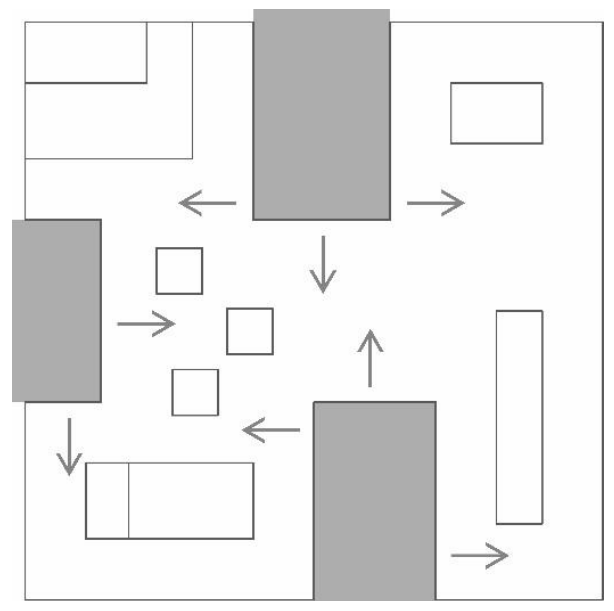

\subsection{MECANISMOS DE TRANSFORMACIÓN ESPACIAL}

Las dimensiones de la arquitectura son las dimensiones del espacio observable.

\section{Gerald Allen ${ }^{63}$}

Algunos arquitectos pensaban que poder modificar la percepción del espacio arquitectónico estaba en sus manos. Consideraban que el espacio interior era una categoría especial del espacio libre, fenoménicamente creada por el arquitecto, por lo que al igual que se podía crear el espacio, razonaban que también lo podían alterar, es decir, hacerlo expandirse o clausurarlo. En ese contexto hablaban de percepción, de la impresión del espacio que se podría tener, y en eso estaba implicada la experiencia.

Los ámbitos domésticos que, por sus características, podrían relacionarse con sistemas dirigidos a la transformación espacial, serían los que habían sido configurados sobre todo bajo una lógica de ambiente ${ }^{64} \mathrm{y}$ con el imperativo cultural como factor principal de tratamiento del espacio. A esto podían asociarse sistemas de objetos y elementos organizados con intenciones ilusionistas -en muchos de los casos influidos por la aplicación de las leyes de la Gestalt- y otros factores de 'ambiente' como las connotaciones asociadas al color, las sensaciones provocadas por las texturas de los materiales, 0 los efectos producidos por la iluminación y otras técnicas que regulaban la temperatura, el sonido o el olor dentro del espacio.

Eran casas implicadas culturalmente con movimientos artísticos de la época, como el arte Pop o el arte Op y con múltiples referencia a lo kitsch y vínculos con la contracultura de los sesenta y la psicodelia de los setenta. El tratamiento del espacio en estos entornos sobrepasaba los límites de los cánones establecidos en el marco doméstico tradicional -normas de confort, ambientación zonal 0 por actividades, vínculos personales- y se dirigía hacia la configuración de un hogar en el que parte de la vivencia radicara en obtener nuevas y múltiples experiencias. La intención era crear lugares especiales donde vivir.

En ese sentido, entre los arquitectos, tuvo especial influencia la aplicación de la fenomenología a la arquitectura, sobre todo entre los norteamericanos en

63 Charles W. Moore y Gerald Allen. Dimensiones de la arquitectura. Espacio, forma y escala. (Barcelona: Gustavo Gili, 1978) p.13.

64 Jean Baudrillard. "Las estructuras de ambiente", en El Sistema de los Objetos (Mexico: Siglo XXI, 1969) p.31.

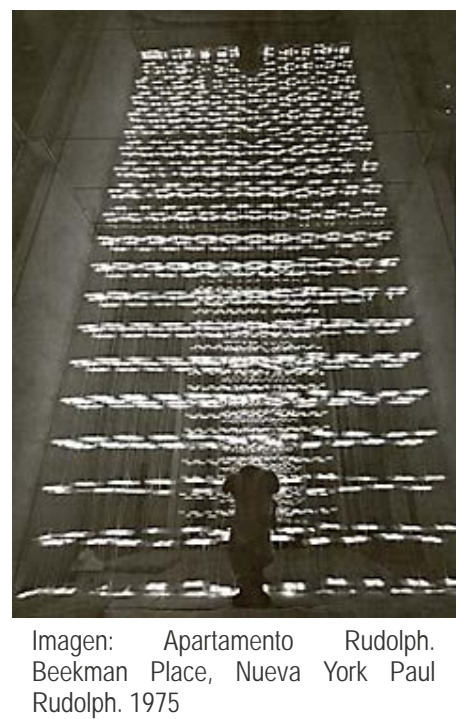

Rudolph. 1975 


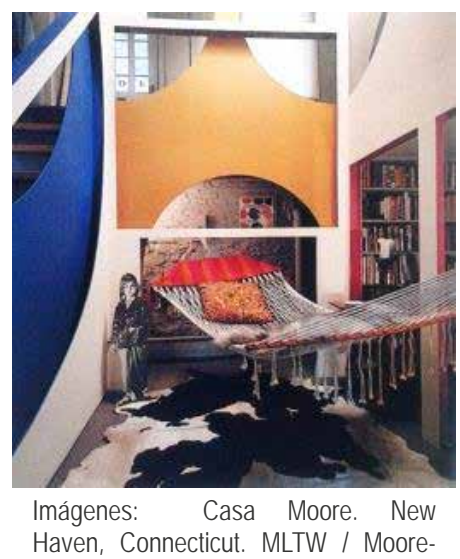

Turnbull,1967. Superposición de capas. los años sesenta. Hay que tener en cuenta, como ya se ha visto en apartados anteriores, que era una corriente filosófica cuya metodología se basaba en el estudio de aspectos subjetivos como la experiencia y la percepción, y para que 'brotaran' nuevos fenómenos o lo que algunos llamaron 'experiencias inmediatas' recurrieron a mecanismos como la superposición de capas layering, los supergráficos, la posición de objetos dispares entre los distintos estratos, iluminación con efectos ilusionistas, que podían asimilarse incluso a técnicas pictóricas como el trompe l'oeil o el anamorfismo que intentaba engañar la vista jugando con el entorno, la perspectiva, el sombreado, los juegos de escala y otros efectos ópticos para conseguir modificar el espacio percibido creando una realidad simulada.

Transformar la percepción de un espacio preestablecido o significar diferentes lugares introduciendo elementos, que subvertían las reglas, era hablar de posibilidades. Los mecanismos de transformación permitían transfigurar el espacio y, en un periodo de gran efervescencia como fueron los 60 y 70 , fue un recurso utilizado por los arquitectos contemporáneos tanto en espacios públicos como en el marco doméstico.

Cuando Charles Moore hablaba de que se podía capturar el espacio o soltarlo, "definirlo" o "hacerlo explotar" en gran medida se refería a la intervención que el arquitecto realizó en una antigua casa en New Haven ${ }^{65}$ para construir su propio espacio de vivienda. La casa, de dimensiones reducidas y poca luz natural, como ya se ha podido observar en otros apartados, adquirió nuevas dimensiones espaciales gracias al empotramiento de tres elementos verticales que definió "como muebles gigantes, insertados entre los distintos niveles". Estos elementos penetraron en el edificio y realmente consiguieron hacerlo explotar. A ello se sumaron otros múltiples mecanismos que enfatizaron la idea desde el punto de vista de la transformación de la percepción del espacio en el interior del edificio.

Uno de los principales recursos utilizados en este proyecto, fue la superposición de capas o layering. Los tres fustes comunicaban visualmente todas las plantas de la casa e introducían luz cenital por medio de lucernarios y claraboyas. Las paredes que los conformaban eran simples placas de contrachapado pintado, lo cual permitía que los muros pudieran estratificarse en varias capas, que se iban superponiendo y que, a modo de 'trampantojo', creaban sensaciones de vistas en perspectiva y efectos ilusorios de profundidad.

La estratificación también permitía que entre los huecos u hornacinas que se generaban, pudieran introducirse objetos que daban una nueva dimensión al espacio. Como ejemplo, Moore colocaba oleos de retratos del XIX entre los huecos abstractos generados por las capas en el interior de los fustes. El juego de 'marco dentro del marco' en varios niveles, generaba ambigüedad y multiplicaba la sensación de profundidad en su entorno más inmediato.

El sistema constructivo de las paredes, también permitió que se realizaran múltiples cortes y huecos a lo largo de los espacios que se introdujeron en el interior de la casa. Teniendo en cuenta las leyes de la Gestalt, los múltiples cortes de figuras geométricas, como partes de círculos o números, por la ley de cierre, conseguían que, al cerrar la forma de la imagen completa, como una configuración que percibe el cerebro, la sensación de espacio automáticamente aumentara.

65 Casa Moore en New Haven, Connecticut. Por MLTW / Moore-Turnbull, en 1967. 
Los múltiples cortes, combinados con los diferentes y variados pasos y escaleras en torno a Howard, Berengaria y Ethel ${ }^{66}$ aumentaban las visuales y perspectivas, consiguiendo que el interior de la casa adquiriera una casi total 'transparencia', fenomenológicamente habland $0^{67}$, respondiendo a condiciones como simultaneidad, interpenetración, superimposición o ambivalencia.

Para conseguir mayores ilusiones ópticas, en esta casa de MLTW, también recurrieron a técnicas pictóricas del momento, como el arte óptico o el anamorfismo, como el empleado en la escalera que conectaba el comedor con el jardín trasero de la casa.

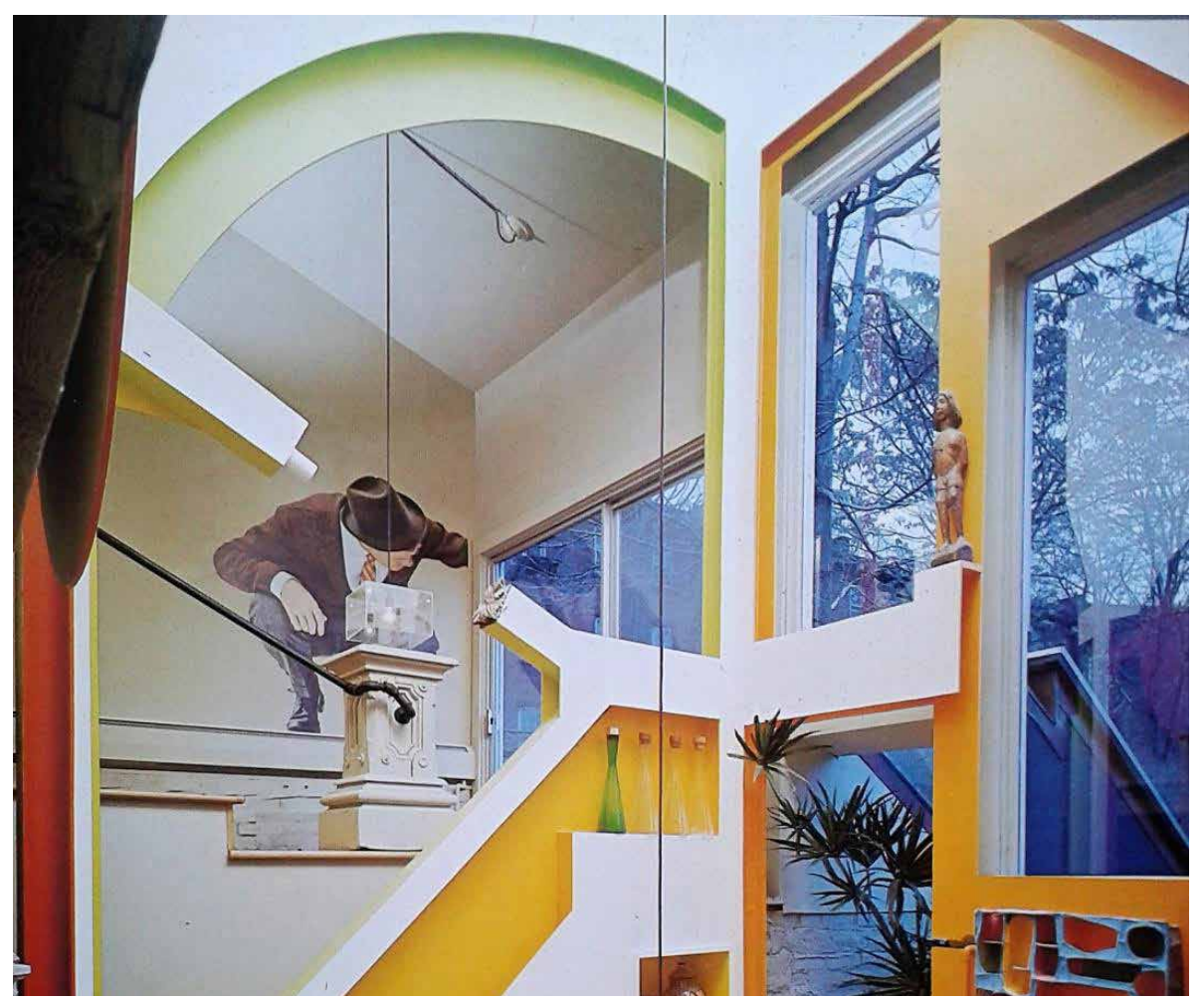

En esta casa, llena de intenciones para transformar su percepción, lo fundamental era su vivencia. Para ello era importante significar diferentes lugares a través de la inclusión de elementos que adquirian un mayor protagonismo subvirtiendo las reglas. Por ejemplo, Moore introdujo algunos elementos constructivos que, por medio de transformaciones formales y transgresoras adquirían un nuevo significado. Como las columnas dóricas del espacio de comedor, que al ser implementadas por puntales, perdían su referencia tectónica y tomaban otro rumbo semántico, más objetual.

Gerald Allen, en una monografía que publicó sobre Charles Moore en $1980^{68}$, definía este proyecto como una casa relajante y excéntrica, de una rica complejidad espacial y donde combinaba elementos tradicionales, pop, deportivos, kitsch, etc. En este sentido, los juegos de objetos interpuestos y de muy diferente naturaleza, eran utilizados también como recursos. Introduciendo la estética del centro comercial o del Strip de Las Vegas, con luces de neón, grandes números y colores brillantes, objetos folklóricos, bolas de discoteca, etc., combinada con mobiliario antiguo o pinturas decimonónicas, generaba un

66 Eran los nombres de los tres fustes introducidos en el edificio.

67 Colin Rowe/ Robert Slutzky, "Transparencia literal y fenomenal" en Clin Rowe. Manierismo y arquitectura moderna y otros ensayos. (Barcelona: Gustavo Gili, 1999).

68 Gerald Allen. Editado por. Charles Moore by Gerald Allen. (Nueva York: Whitney Library of Design, 1980) p.54.
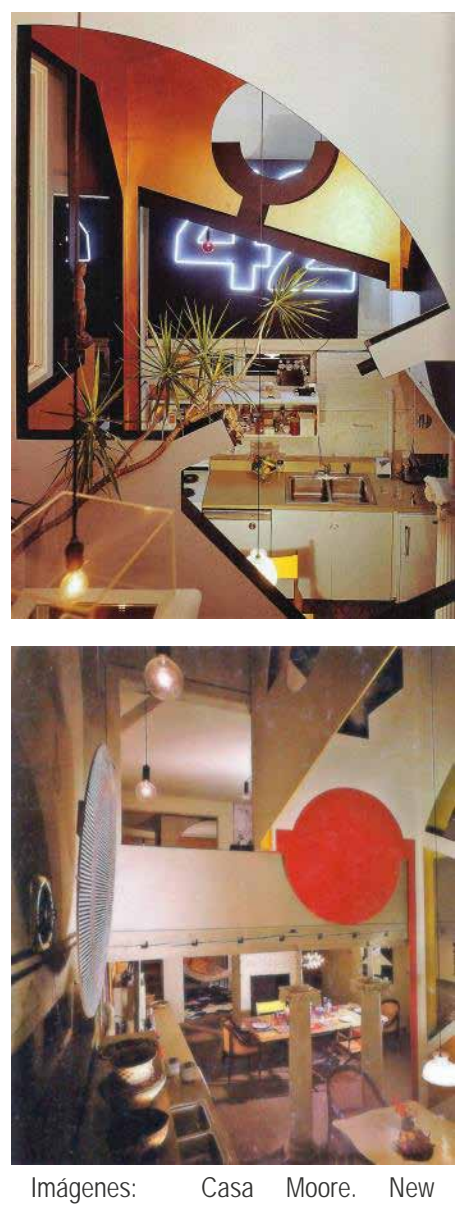

Haven, Connecticut. MLTW / Moore-

Turnbull,1967. Cortes y huecos.

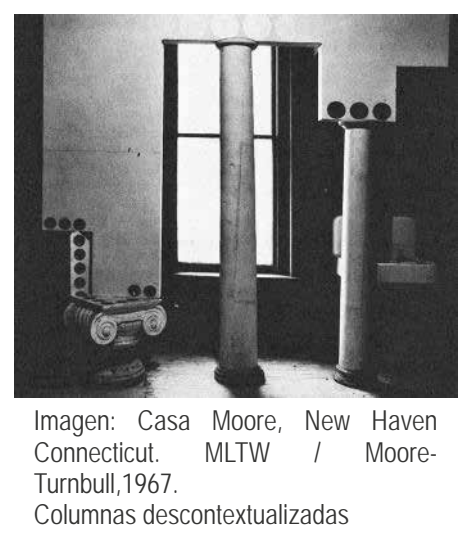

Turnbull,1967.
Columnas descontextualizadas 


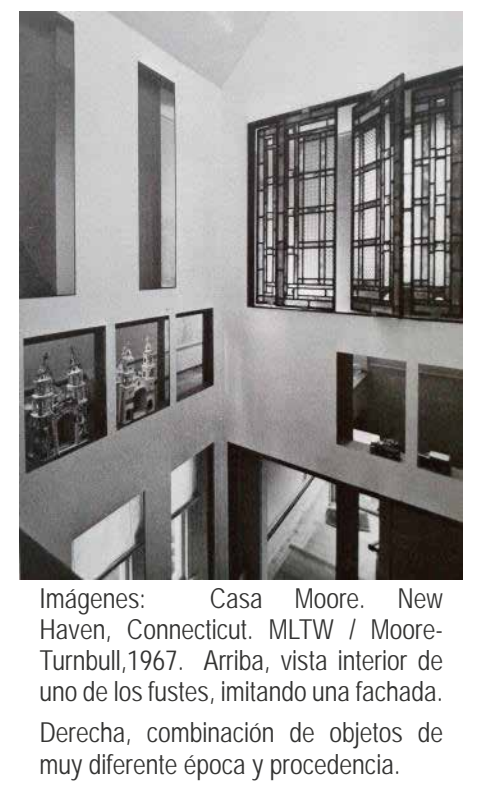

mundo de complejidades que dirigía hacia la ambigüedad espacial.

A los juegos ópticos también se unían los juegos de escala. El interior de uno de los fustes representaba la configuración de una fachada, lo cual aumentaba la idea de lugar o de espacio exterior, por lo que la sensación de amplitud del mismo modo era mayor.

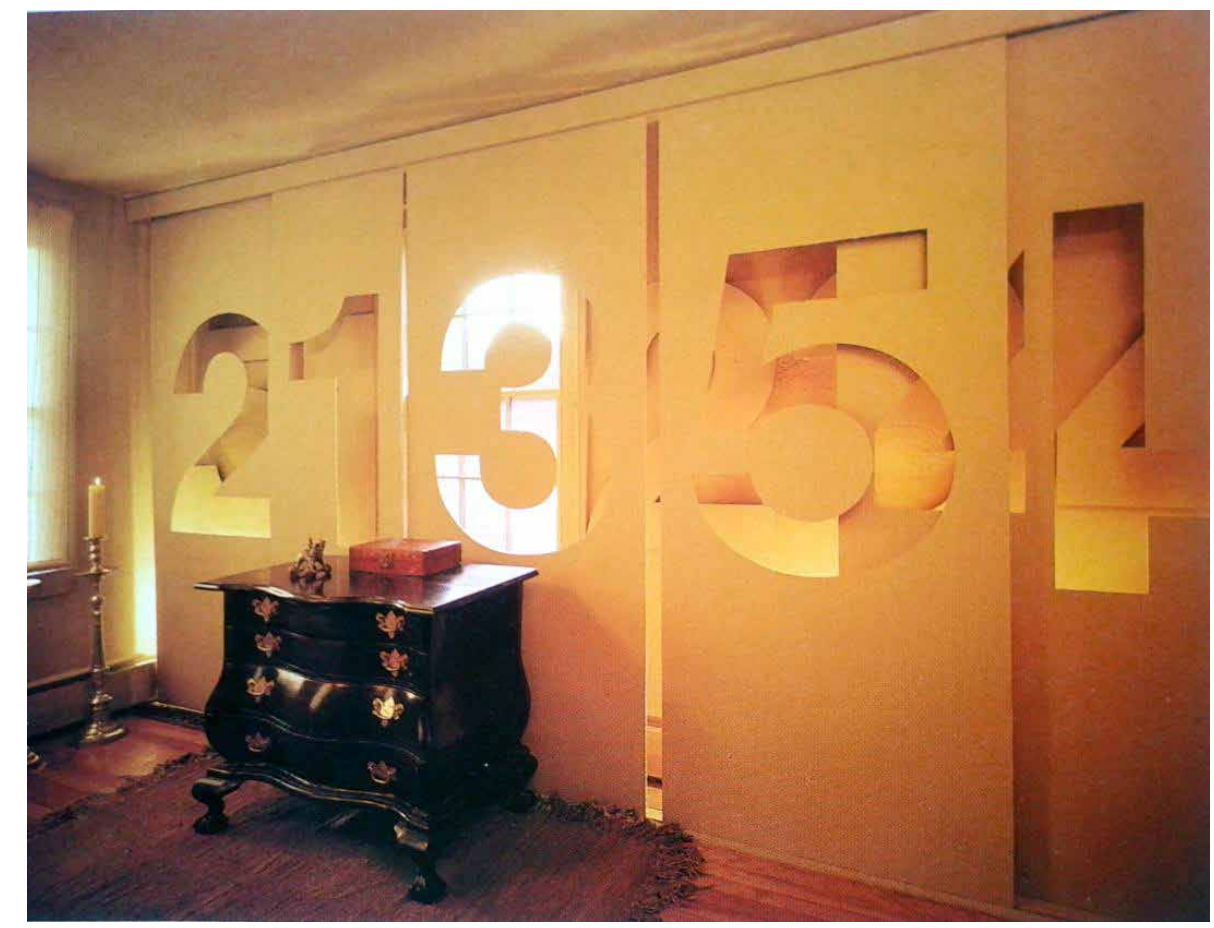

En el mismo año, en Milán, Nanda Vigo realizaba una reforma a la que llamó 'La Casa Blu' como referencia al 'azul Klein', color utilizado por Vigo para su primer interior monocromo no acromático.

La transformación del apartamento en Milán, fue un encargo de una pareja de coleccionistas de arte. Vigo aprovechó las obras, propiedad de sus clientes, para utilizarlas como objetos que transformaban la percepción espacial por sus características formales o por sus cualidades. Entre las obras de Accardi, Cascella, Dorazio, Fontana, Pomodoro, Schifano, destacaba en el techo una pieza de espejo de Enrico Baj, que reflejaba y multiplicaba el cromatismo en torno a la zona de estar, sobreelevada y tapizada de moqueta azul. Toda la sala estaba enmarcada con iluminación perimetral que incidía sobre las superficies acabadas en esmalte azul brillante y espejos. Las ventanas estaban cubiertas por paneles cronoscópicos. Para controlar estos efectos, la luz natural estaba prohibida...

Otro ejemplo es una reforma de un apartamento en Nueva York, realizada en 1977 por Paul Rudolph \& David Graham, en el que un sistema organizado gira en torno a la exhibición de una colección de obras, cuyo valor artístico es enfatizado por una serie de mecanismos que, finalmente, se convierten en el medio de configuración de toda la casa. El ámbito de actuación era un dúplex existente en New York para un cliente con bastante vida social y que contaba con una valiosa colección de arte antiguo. Manteniendo gran parte de la distribución existente, el proyecto transformaba la apariencia del espacio a través del uso de una serie de 'cortinas' hechas con piezas de espejo. Las nuevas superficies reflectantes y un importante trabajo de iluminación decorativa fueron los elementos clave para transformar completamente el espacio. En la entrada se situaba la colección de arte precolombino consistente 
en figuras y vasijas de terracota. Las piezas fueron colocadas sobre estantes de metacrilato que surgían de las paredes de un pórtico lacado en color rojo brillante. La colección se iluminaba por medio de focos ocultos en el techo, que bañaban de luz los muros rojos de arriba a abajo.

A lo largo del salón y del comedor se colocaron cortinas de piezas de espejo, que a veces también cubrían las paredes. El encuentro con el techo se resolvió con una cornisa continua de acero cromado que marcaba una línea de luz, reflejada, rodeando toda la zona de estar, quedando indefinidos los límites. Otra colección, esta vez de arte antiguo oriental, consistente en piezas de bronce, aparecía suspendida en un expositor etéreo que permitía que las piezas se vieran por todos sus lados. El comedor estaba delimitado por la cortina curva de espejos que colgaba del cilindro de acero cromado que recorría el techo. En el dormitorio principal, sobre la cama, se situaba un techo de bronce que con un preciso sistema de iluminación, surgía como un dosel de luz que continuaba hasta el cuarto de baño principal adyacente. El uso del cobre, del acero y del espejo hacía que el espacio se percibiera como ampliado.

Pero las obras de arte, en lugar de ser expuestas, podían ser también fuente de inspiración y convertirse en el eje conductor de una serie de decisiones que modelaban el espacio e iban configurando un universo, en este caso el de la propietaria. El proyecto comprendía la renovación total de la última planta de un edificio de apartamentos de cuatro pisos en Beverly Hills, que fue comprada por la artista Miriam Wosk al mudarse de New York al sur de California en 1978.
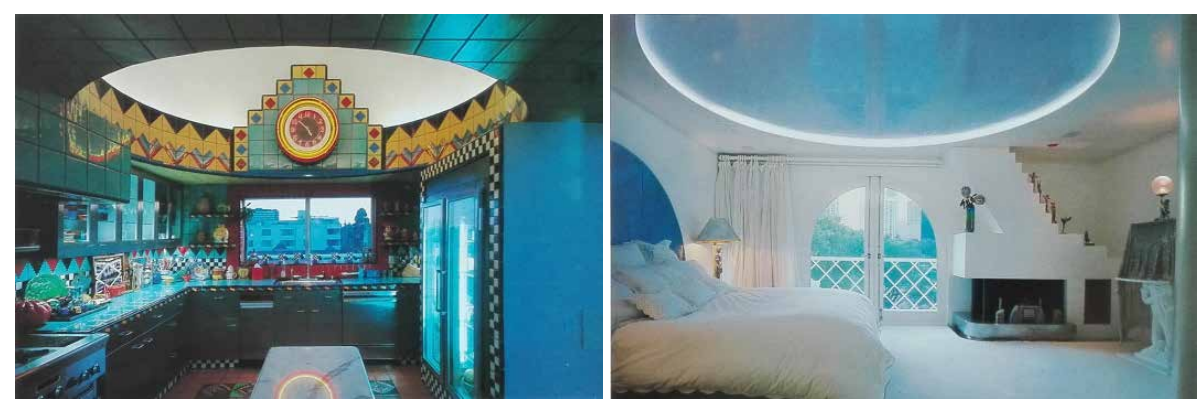

El proyecto fue realizado por Frank O. Gehry y su socio Greg Walsh:

Miriam Wosk: recopilé imágenes e ideas sobre lo que me gustaría en la casa y se las di a Frank -Gehry- todas ellas, el archivo completo de imágenes. Por ejemplo había fotografías de invernaderos como si fuera el comedor, también todo tipo de cosas coloridas, como azulejos exóticos hechos a mano para colocar por todas partes de la casa, que luego él utilizó para la parte superior de la chimenea, convirtiendo la cocina en una especie de Mezquita Azul. Me gustan las estructuras pintadas, es una manera de incorporar mi arte y mi color a la arquitectura. El estudio sería como un hangar de aviones. Quería un espacio abierto, amplio, como un almacén, con mucha luz la más posible, y él incorporó todas mis fantasías dentro de esas estructuras. No había un programa específico, sí una inspiración. Me invitó a participar lo máximo posible. La primera vez que fui a su estudio me presentó la maqueta de mi nuevo edificio con la cuarta planta totalmente cambiada, con nuevas estructuras que formaban un nuevo último piso. Los nuevos elementos eran un templo -ziguratdorado, un invernadero comedor, una cocina abovedada, un estudio que era una nave en chapa grecada de aluminio, una gran escalera cubierta por un baldaquino de granito negro, un rincón revestido de
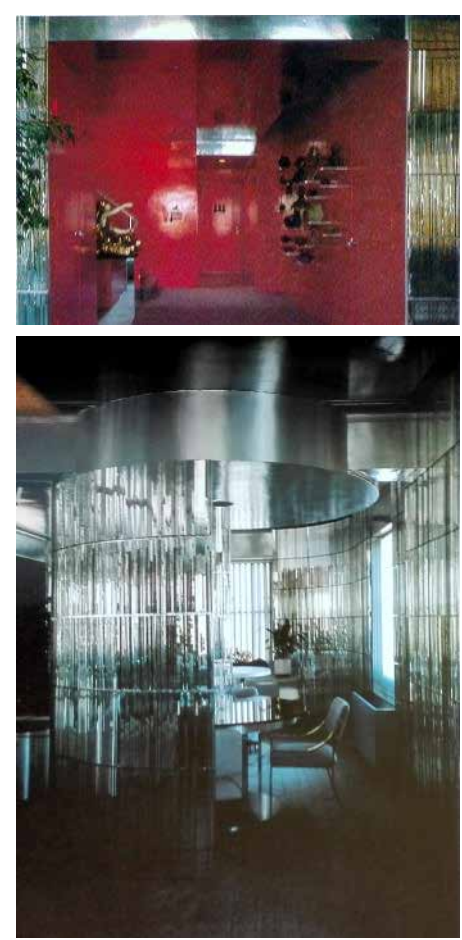

Imágenes: Apartamento en Nueva York. 1977. Paul Rudolph \& David Graham.

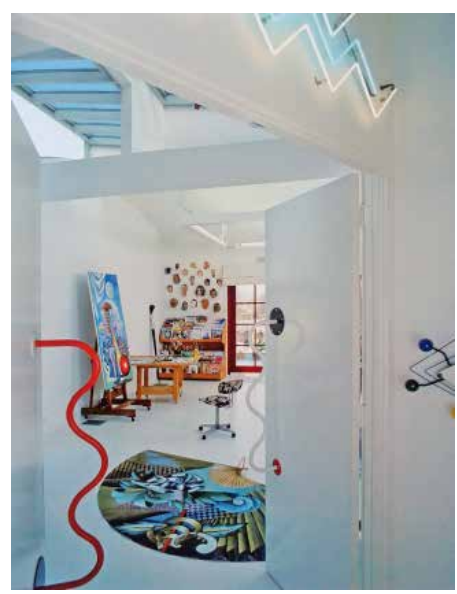

Imágenes: izquierda y arriba. Wosk Residence. Beverly Hills, California. Frank O. Gehry,1981. 
Imagen abajo: Supergráfico, diseño previo a 'carboncillo'. Barbara Stauffacher Salomon.

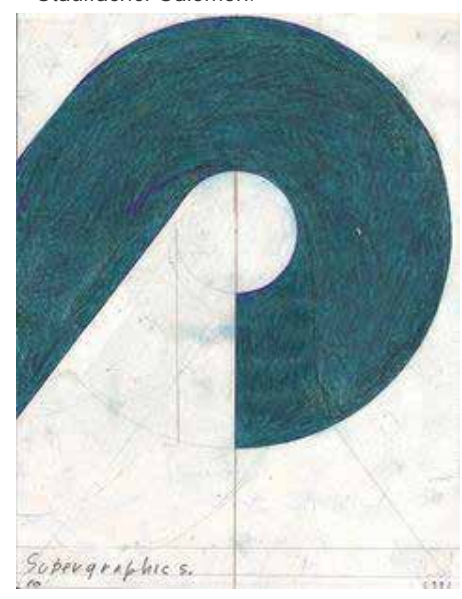

Imagen: Sea Ranch Athletic Club. Sea Ranch, California. 1965, MLTW Moore-Turnbull y Barbara Stauffacher Salomon. azulejo en forma de escamas de pescado de color azul, jera fabuloso!. Después de eso empecé a pintar y a darle los dibujos sobre ideas de los interiores. Sobre azulejos y color inspirados en Gaudí, artesanía mexicana y cosas de influencia española en California. Quería un edificio rosa, algo que no estaba en el lenguaje de Gehry. El proceso fue divertido superponiendo distintos elementos, materiales y colores como si de un puzle se tratara.

Greg Walsh: Todo tenía un patrón. Era una forma de trabajar que ni Frank -Gehry- ni yo habíamos practicado, pero fue interesante y definitivamente más decorativa. Frank decía que le recordaba al pueblo y a la azotea del Château de Chambord, castillo construido en el s. XVII en el Valle del Loira durante el reinado de Francisco $I^{69}$.

Elementos como la bóveda, el baldaquino, los azulejos, los materiales de colores brillantes, los objetos coloristas sobre fondo blanco neutro, transformaban la percepción convirtiendo el espacio en un lienzo donde se superponían los múltiples objetos de diversos colores y texturas como si de un cuadro se tratara.

Hacer uso de los paramentos que conforman el volumen interno, como si de un lienzo se tratara, llevó a un mecanismo muy utilizado en los años 60 y 70 , tanto en edificios públicos como en el espacio doméstico. El supergráfico o supergraphics, por su gran escala, dejaba de ser un gráfico convencional para convertirse en un implemento añadido que podía modificar visualmente el trazado y las dimensiones de un ámbito concreto.

La mayoría de las clases de objetos tienen, dentro de ciertos límites aproximados, un tamaño habitual. (...) Esta es una de las razones por la que a mucha gente le parecían interesantes los supergráficos en los años sesenta, porque eran mucho mayores que los gráficos habituales.

\section{Charles Moore ${ }^{70}$}

Para Moore la técnica del supergraphic operaba tanto en el sujeto, trastocando sus niveles racionales de percepción, como en el objeto, modificando el orden

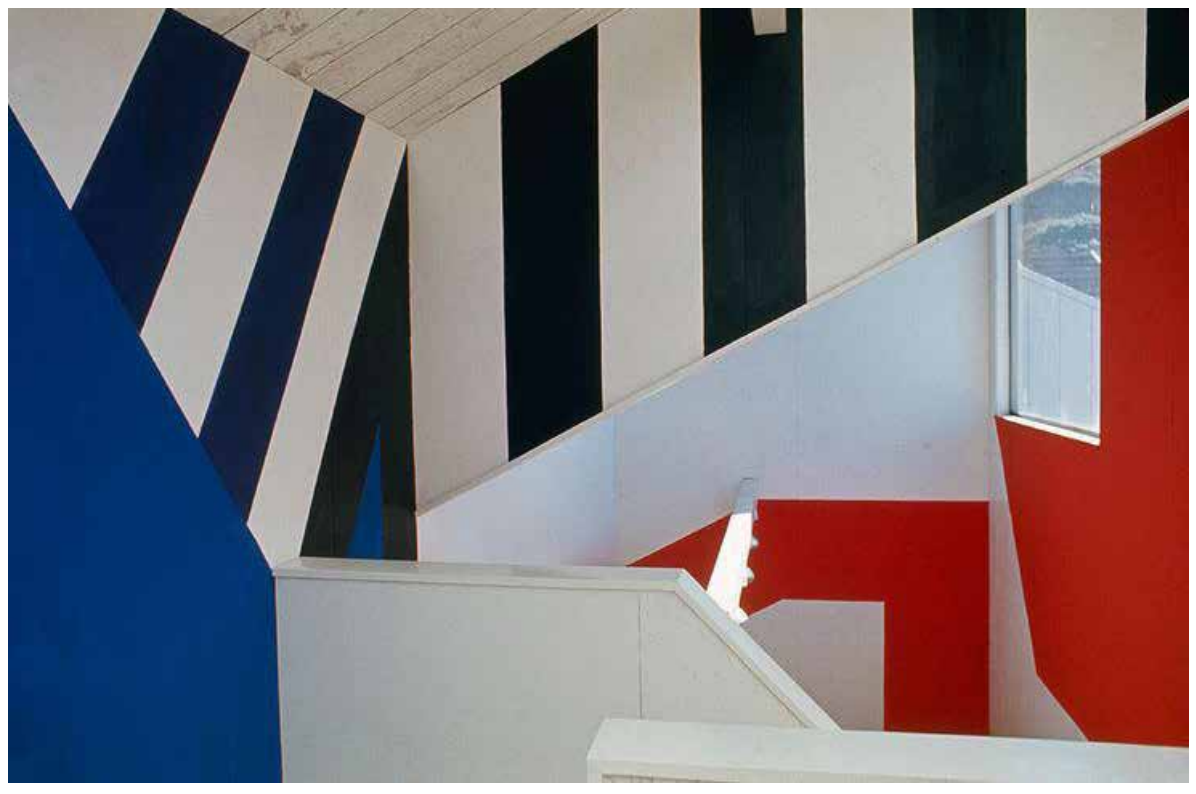

69 Entrevista publicada en Mildred Friedman. Editado por. Frank Gehry. The houses (Nueva York: Rizzoli, 2009) p.191-202.

70 Charles W. Moore y Gerald Allen. Dimensiones de la arquitectura. Espacio, forma y escala. (Barcelona: Gustavo Gili, 1978) p.13. 
espacial del interior del edificio.

Todo empezó cuando los arquitectos MLTW -Moore, Lyndon, Turnbull y Whitaker- estaban realizando el proyecto para los vestuarios del complejo turístico de Sea Ranch, al norte de San Francisco, donde ya habían trabajado ${ }^{71}$. Por problemas de presupuesto, hubo que reducir el tamaño de la casa de baños en Sea Ranch Athletic Club ${ }^{72}$, por lo que los arquitectos decidieron contar con Barbara Stauffacher, una diseñadora gráfica para aumentar la percepción espacial del diminuto interior de los vestuarios. En sólo tres días, Stauffacher transformó las paredes blancas con su trabajo basado en el uso de supergráficos, que además tuvo mucha aceptación tanto por parte de los promotores como de los usuarios. Stauffacher dejo hecha la mayor parte de sus diseños en las paredes con carbón vegetal, y posteriormente dos rotulistas los completaron con colores. Por ejemplo, en el lavabo de señoras, pintaron la mitad de un corazón que al reflejarse en el espejo se convertía en un todo, la señalización era sobredimensionada, como la flecha que señalaba el camino arriba para el vestuario de las mujeres o la palabra 'sauna' indicando su situación. En el vestuario de los hombres, un semicírculo al borde de una puerta invitaba a cerrar el círculo.
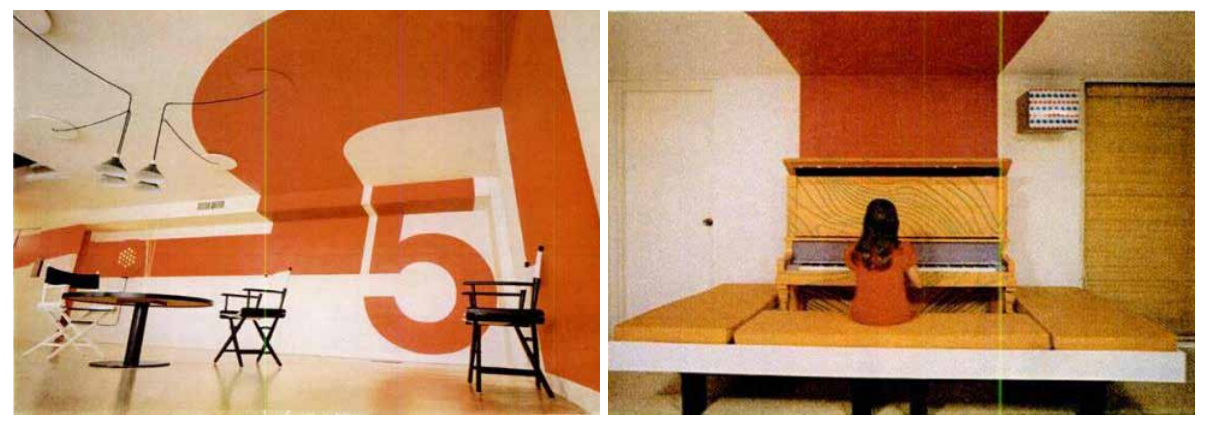

Dos años más tarde, el número de marzo de 1967 de la revista Progressive Architecture editaba un monográfico sobre este trabajo, en el que identificaba este método de diseño como el origen de un movimiento emergente al que denominaron Supergraphics.

Los gráficos a gran escala aumentaban la altura del techo y alargaban las paredes de la casa de Jay Vlock a las afueras de New Haven. El supergráfico consistía en una gran banda roja, que partía del piano y hacía de telón de fondo para el instrumento. La idea era derribar paredes con el supergráfico.
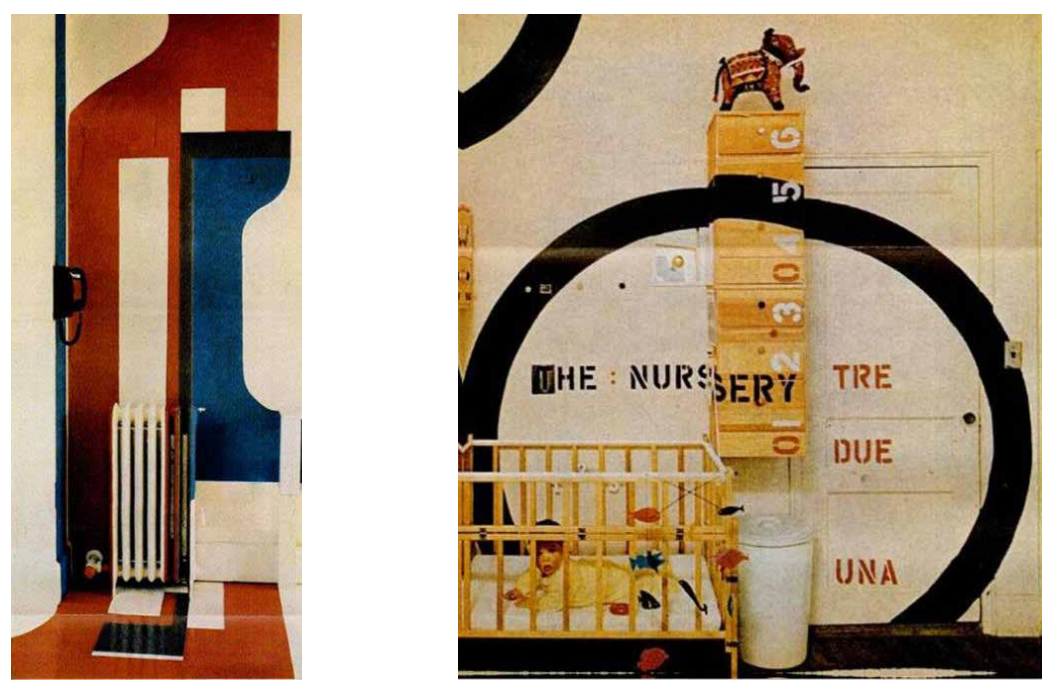

71 En 1964 los arquitectos MLTW habían realizado el complejo de apartamentos turísticos Sea Ranch Condominium en Sea Ranch, California.

72 "Supergraphics" Life Magazine (mayo 1968).

http://sighswhispers.blogspot.com.es/2012/04/at-home-its-supergraphics-1968.html
Imagen: Casa Jay Wlock, New Haven. William Groover, 1968

Imágenes: derecha, Casa Hardy Wlock, Nueva York. Hugh Hardy. Un círculo delimita la zona de cuna dentro de una misma habitación

Izquierda, Estudio Charles Moore en New Haven. Dough Michels. El uso del supergráfico camuflaba un radiador. 
Imágenes: Izquierda, Casa Frey en Bellvue, Washington. Wendell $\mathrm{H}$. Lovett. 1971

Derecha, casa Klotz, en Rhode Island. MLTW, 1969

Eso era lo que un grupo cada vez mayor de jóvenes arquitectos y diseñadores estaban tratando de hacer: cambiar la forma aparente de habitaciones, poner orden en el espacio laberíntico, romper los límites de la caja, y todo mediante la aplicación de diseños de talla XXL en suelos, paredes y techos. Para aumentar la altura de la habitación, un estudiante de arquitectura de Yale, William Groover, había diseñado una banda roja que se arremolinaba por el techo y continuaba por la pared hasta alinearse con el piano. El número cinco de gran tamaño añadido a la pared, también contribuía a aumentar visualmente la altura del techo.

El arquitecto de Nueva York, Hugh Hardy en su propio apartamento, de un dormitorio, delimitaba la zona de dormitorio infantil a través de un gran círculo dibujado en la pared. Y Doug Michels -alumno de Charles Moore y cofundador de Ant Farm- a través de un supergráfico de suelo a techo, camuflaba un radiador en la antigua oficina de New Haven de Charles Moore.

El supergráfico podía tomar partido de todo el ámbito de la casa, como en la casa Frey en Bellvue, Washington. Una pareja joven sin hijos y que recibían amigos con frecuencia, realizaron el encargo a Wendell H. Lovett en 1971. En el espacio estaban implicados en el grafismo hasta los textiles que cubrían las camas. En la casa Klotz, en Rhode Island, realizada por MLTW en 1969, los supergráficos estaban implicados en los muebles, ya que la idea consistía en crear una casa construida en torno a hitos identificables y directamente asociados a los usos cotidianos.
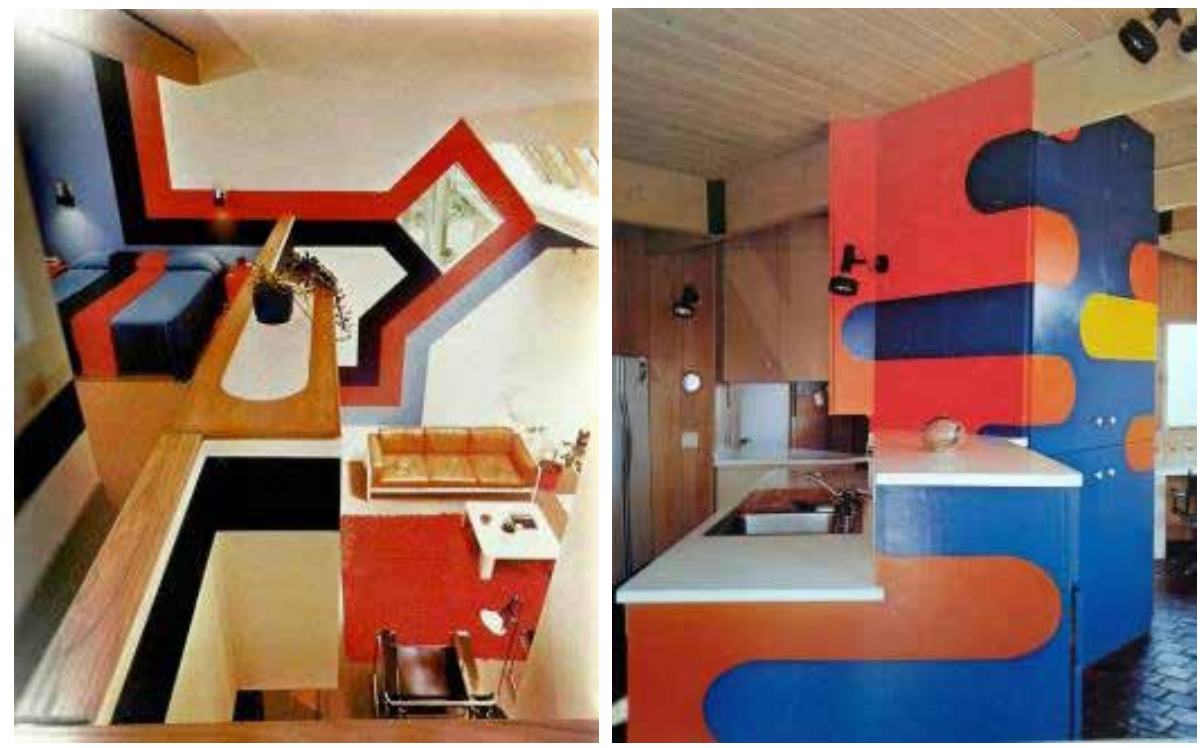

En una restauración de una casa de campo del S.XVIII, respetando la estructura original, distribución y aspecto exterior, los supergráficos se utilizaron como un sistema de códigos. Situada en Piamonte, cerca del lago Viverone, la casona se ubicaba a los pies de un viñedo. El edificio se adaptó para albergar a cuatro familias diferentes.

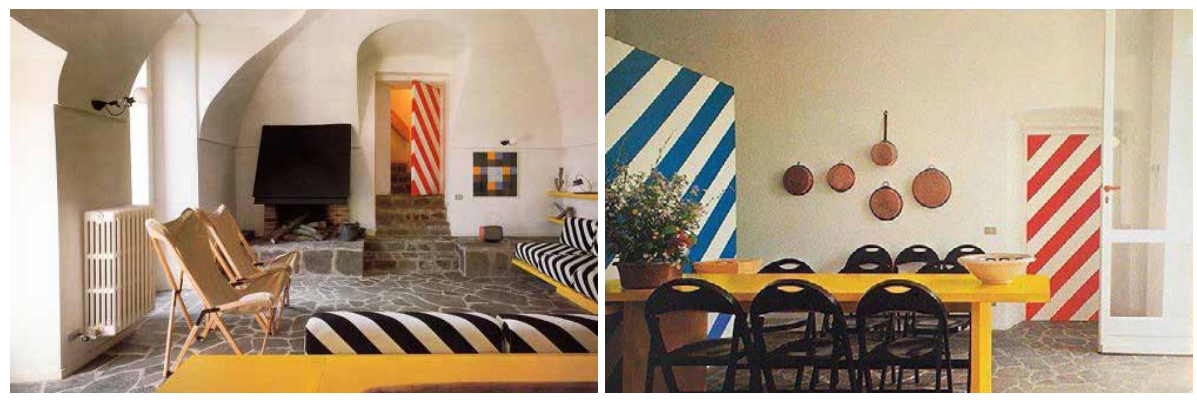


A pesar de mantener la estructura original, los interiores se codificaron con mobiliario amarillo y verde, y con puertas blancas con diagonales rojas 0 azules. Con este recurso se unifican los espacios a través de códigos de color. Los muebles eran diseño de los arquitectos, pintados en amarillo en la planta baja y en verde en la planta primera y con tapicería similar a las puertas pero con diagonales en negro. A pesar de que se trataba de un lenguaje muy diferente al de la arquitectura original, los gráficos unificaban los espacios. Las relaciones entre las piezas conseguían que en la actuación se apreciara idea de conjunto.

El baldaquino ${ }^{73}$ es un antiguo símbolo de la realeza. Significa lugares especiales y puntos de atención cuando no hay realeza. Su connotación de algo especial puede llevarse a determinados sitios de la casa, creando un espacio diferenciado, formando baldaquinos especiales en el techo o pintando una parte del forjado como si estuvieras protegido por una canopia, más alta en el centro, más baja en los bordes. Los baldaquinos generalmente suelen ser brillantes y con colorido.

Donlyn Lyndon ${ }^{74}$

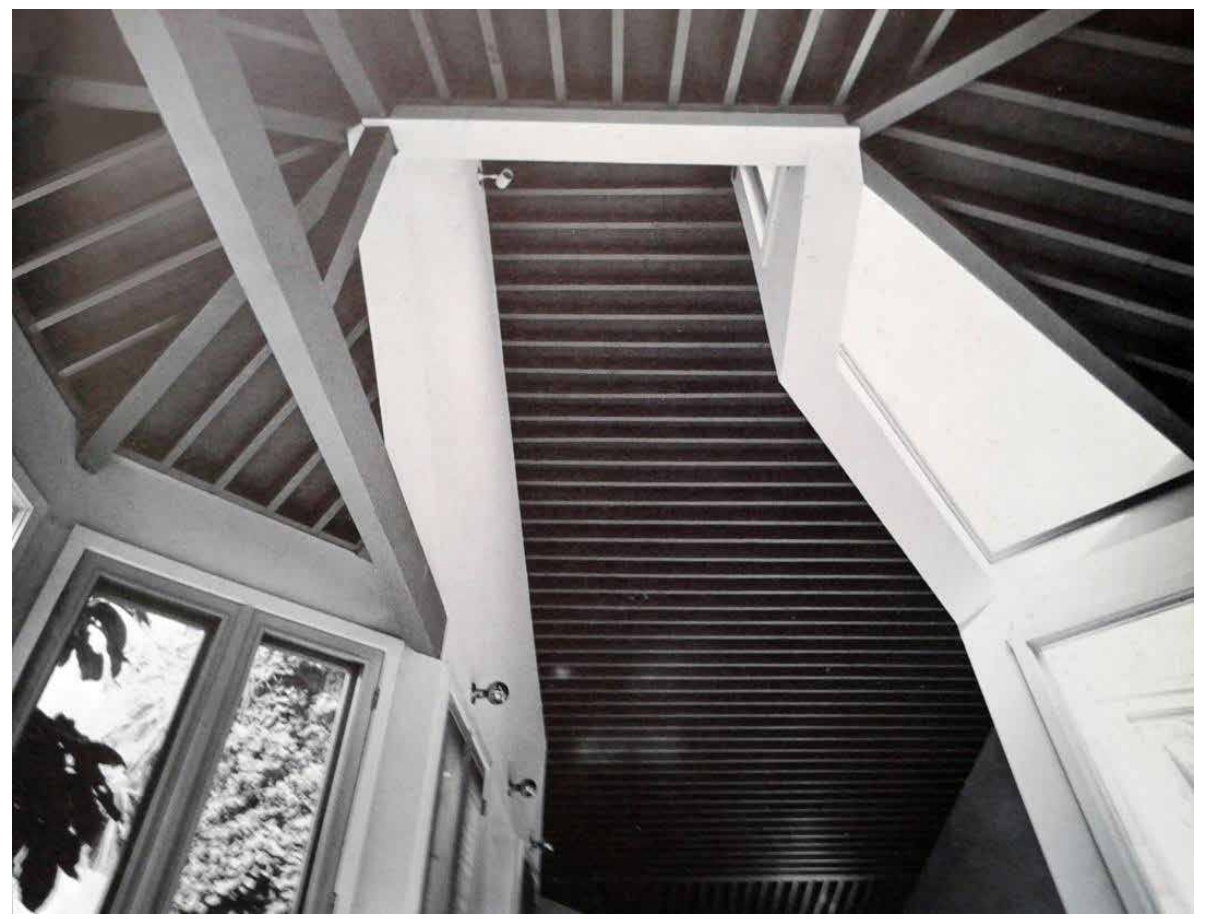

Lograr la notoriedad en un espacio concreto dentro de la casa, o alcanzar la significación de algo especial, lo explica Donlyn Lyndon ${ }^{75}$, se puede conseguir a través de una transposición contemporánea del baldaquino "una celebración de un espacio pequeño que adquiere dimensiones especiales y propicia nuevos recorridos y articulaciones". Como en la Casa Murray en Cambridge, Massachussets - Charles Moore Associates, 1973-, una reforma de una vivienda familiar en la que la intervención por medio de la inclusión de un techo superpuesto al existente, pintado de colores vivos y brillantes:

73 'canopy', en el texto original.

74 Donlyn Lyndon "The House of the mind: Houses by MLTW" en Houses by MLTW. Moore, Lyndon, Turnbull \& Whitaker 1959-1975 (vol-1). Editado por Yukio Futagawa (Tokio: A.D.A. Edita, 1975).

75 Donlyn Lyndon "The House of the mind: Houses by MLTW" en Houses by MLTW. Moore, Lyndon, Turnbull \& Whitaker 1959-1975 (vol-1). Editado por Yukio Futagawa (Tokio: A.D.A Edita, 1975). FALTA NOTA

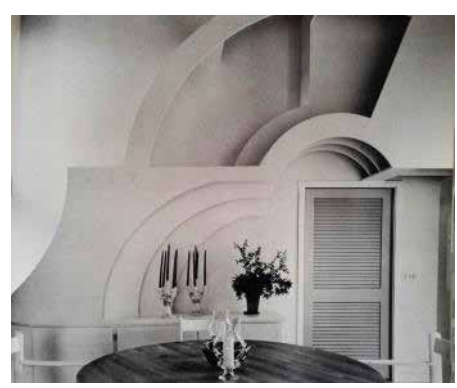

Imágenes: Casa Rudolph. Captiva Island, Florida. Charles Moore Ass. 1971. Arriba, intervención en el techo de la sala principal. El lugar se significaba a través de un caprichoso sistema a base de relaciones entre líneas maestras y entramados de fondo que generaban una sensación de cubierta del espacio a modo de baldaquino Izquierda, el layering enmarcaba otros espacios y aumentaban su profundidad espacial. 

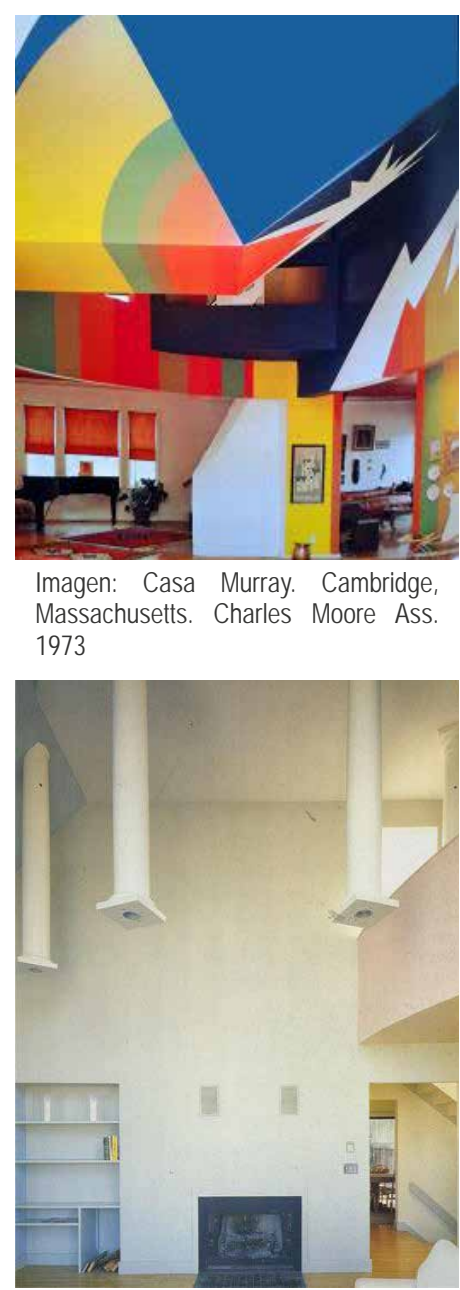

Imagen: Casa Mittelstadt. S. Francisco California.

Robert Mittelstadt, 1975

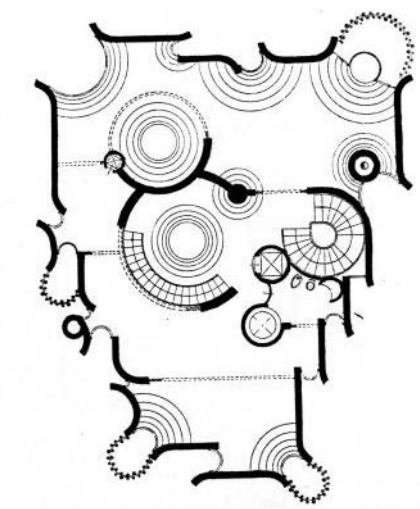

Imágenes: Casa Papanice, Roma Paolo Portoghes, 1970

Vistas interiores de la sala de estar y planta tipo. abrió nuevos caminos entre habitaciones que ya estaban allí y alteraron tanto su uso como su forma aparente (...) toda la estructura de circulación de la casa fue replanteada, perforando un núcleo abierto que había en el centro para que diesen a él las habitaciones restantes de ambas plantas. La dentada rotonda que cobijaba la frontal estaba pintada de brillantes colores e incidía en ella una iluminación pigmentada que la convertía en el hito central y extraordinario de la articulación preexistente de las habitaciones perimetrales ${ }^{76}$.

Salvo una crujía trasera, que se añadió con la intervención, la apariencia exterior de la casa continuó siendo la de una típica casa de madera de Cambridge de finales del S.XIX, sin existir signos fuera que insinuaran lo que se estaba produciendo dentro.

La celebración del lugar dentro de la casa a través de una intervención similar, puede dirigir a Roma, en la casa Papanice, una de las obras más significativas de Paolo Portoghesi, construida entre 1966 y 1970 en colaboración con el ingeniero Vittorio Gigliotti, pero en esta ocasión la actuación consistía en una intervención de múltiples baldaquinos a lo largo del espacio libre de la casa. A nivel tipológico el edificio respondía a los cánones de una villa señorial de tres plantas, con sala para piano y un pequeño ático. Cada una de las áreas de la sala de estar se encontraban definidas por un sistema de techos compuestos de cilindros concéntricos que descolgaban a modo de estalactitas y que se iban manifestando a lo largo de la sala. También incluyó elementos de mobiliario basado en el mismo lenguaje del edificio y que iban marcando topológicamente los puntos de importancia que señalizaban los techos. La curvatura de las paredes perimetrales, que se alternaban entre cóncavo y convexo, caracterizaba formalmente la composición y acompañaba a las formas que iban provocando visualmente los descuelgues de los techos. Las paredes estaban pintadas con bandas horizontales de colores, un recurso que, a modo de representación del horizonte, aumentaba la sensación de profundidad y evidenciaba aún más la incidencia de los baldaquinos en la composición del lugar.

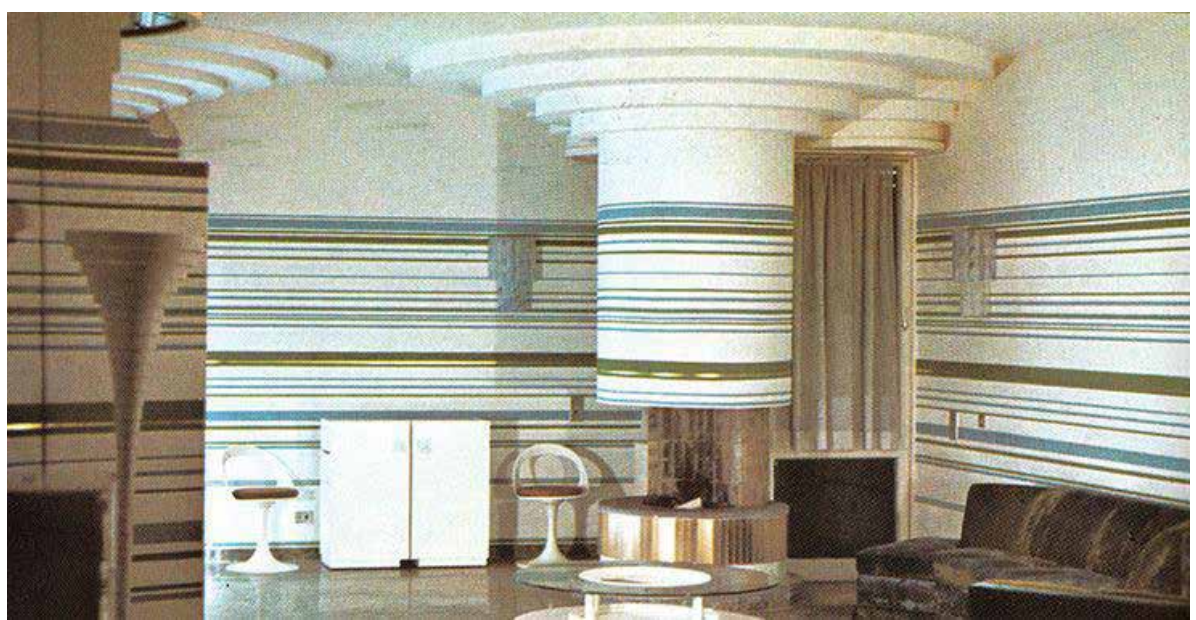

76 Charles Moore, Gerald Allen, Donlyn Lyndon. La casa: forma y diseño. (Barcelona: Gustavo Gili, 1999) p.221. 
En San Francisco, en la casa de Robert Mittelstadt, aquellas "columnas voladoras"77 que aparecían suspendidas del techo de la segunda planta y que no llegaban al suelo definían un lugar importante en torno a la chimenea a modo de baldaquino, dándole mayor notoriedad al transgredir y colocar luminarias en la cara inferior de las basas de las columnas.

A veces el uso de mecanismos de transformación espacial, como la interrelación de múltiples pasos y escaleras entrelazados en el espacio, provocaban deliberadamente en el observador una especie de 'alienación' que alteraba la percepción del mismo. Como en los grabados de Piranesi del S.XVIII, o en el Club de la Facultad de la Universidad de Santa Bárbara, de MLTW/ MooreTurnbull, el uso de escaleras, pasos, rampas y múltiples objetos intermedios, en un complejo sistema de relaciones y conexiones entre ellos, generaban desconcierto y a su vez múltiples planos y enrevesadas perspectivas.

En 1970 en Malibú, California, Frank O. Gehry realizó la vivienda-estudio del pintor Ronald Davis. En esta vivienda-estudio Gehry planteó varias cuestiones; por un lado la idea de la percepción de la profundidad creando un sistema de ilusiones ópticas, entrando en el mundo del artificio espacial, y por otro lado, el efecto que podría tener la relación de la arquitectura y el arte. Utilizó como referencia el trabajo de Davis, consistente en obras ligeras y bidimensionales que generaban visiones tridimensionales, por eso buscó la perspectiva en el proceso de realización del edificio. Recorridos, diferentes niveles y escaleras objetualizadas, intercalándose con obras de arte, planos intermedios, todo bajo un mismo techo, componían un espacio inestable y dinámico a la vez, respondiendo a las cuestiones sobre el estilo de vida de los artistas en los estudios y sobre la creación de los propios espacios dentro de los mismos. Por ello pensó en una cáscara única y vigorosa pero sin merma de la flexibilidad interior.
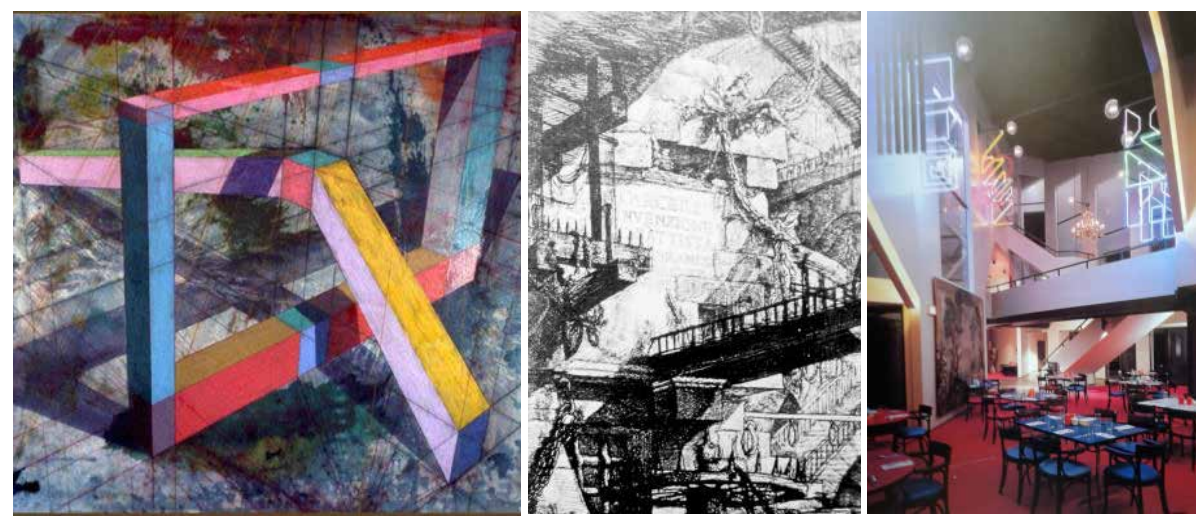

Jean Baudrillard, en El sistema de los objetos, incluía al color como uno de los factores que intervenían en el tratamiento del espacio, por un lado desde el punto de vista de las connotaciones añadidas que, psicológicamente, podían influir en la vivencia del espacio y por tanto en su percepción, y por otro lado desde el punto de vista físico, involucrándose en la definición, por contraste, de determinados elementos siguiendo la ley gestáltica de figura fondo, o por lo contrario, a través de la ley de similaridad, consiguiendo la abstracción de un lugar mimetizando los objetos que en él se encuentran, aplicando a todo, el mismo color.

Grandemente culpabilizado, el color llevará a cabo su liberación muy tarde (...) será la pintura la que libere al color pero se necesitará

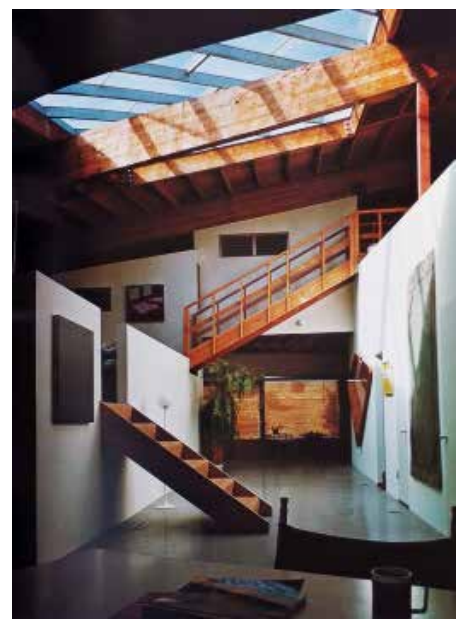

Imagen: Casa-estudio Ronald Davis. Malibu, California. Frank O. Gehry, 1970.

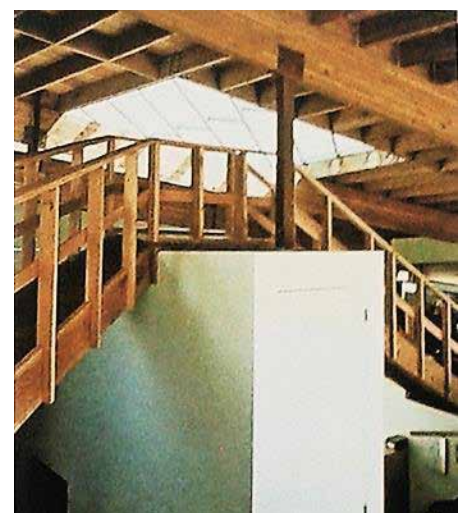

Imagenes de izquierda a derecha:

-Ronald Davis. Bridge Thru Frame, Serie Snapline-I. Acrílico sobre lienzo. 1974 -Piranesi. Cárceles Imaginarias. Grabado, 1749

-MLTW/Moore-Turnbull. Faculty Club, Universidad de Santa Bárbara. 1961

-Frank Gehry. Casa-estudio Ron Davis 1970. Vista interior de la pasarela que conectaba la zona de vivienda con la de trabajo.

77 Así lo describían en "New Waves in American Architecture", GA Houses (n¹1 may-1982). 


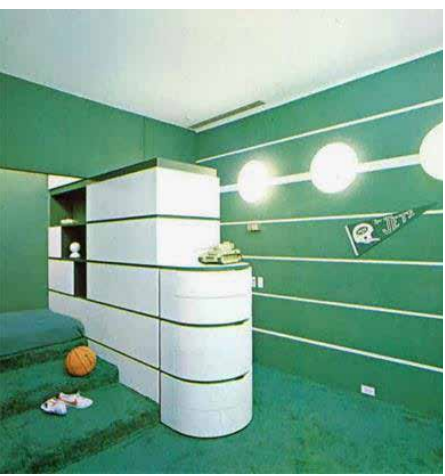

Imágenes: Vivienda entre Medianeras. New York. Robert A. Stern, 1974. Vista de los tres dormitorios infantiles.
Imágenes: Apartamento Zancopè Milán. Joe Colombo, 1964. Vista interior del apartamento de pequeñas dimensiones, en la que el color unifica todos los elementos y objetos en un proceso de abstracción que amplifica la percepción del espacio. mucho tiempo para que este efecto se advierta sensiblemente en lo cotidiano: sillones de color rojo vivo, divanes azul cielo, mesas negras, cocinas policromas, salas de estar en dos 0 tres tonos, paredes de colores contrastados, fachadas azules o rosas (...) esta liberación está ligada a la ruptura de un orden global. Además es contemporánea de la liberación del objeto funcional.

\section{Jean Baudrillard ${ }^{78}$}

A través del proyecto de una reforma completa de una vivienda entre medianeras situada entre bloques de apartamentos realizada por Robert A. Stern en 1974 en una de las avenidas más modernas de la ciudad de Nueva York, se buscó la privacidad y la luz natural en un contexto urbano difícil para ello, ya que el solar aparte de estrecho era bastante largo. Los interiores reflejaban un estilo de vida informal de una familia con tres hijos. Los espacios principales y de entretenimiento estaban unidos a través de un juego de escaleras y espacios de paso describiendo una promenade arquitectónica, que iba desde el vestíbulo hasta la suite principal en la parte superior trasera del edificio. En la planta baja había un local para un consultorio médico. Los espacios intermedios, dobles alturas y juegos de colores y formas van dirigidos a evitar la monotonía, por las características del solar. Incluso dentro de los dormitorios infantiles, los cuales adquirieron su propia definición y características gracias al uso sistemático del color.
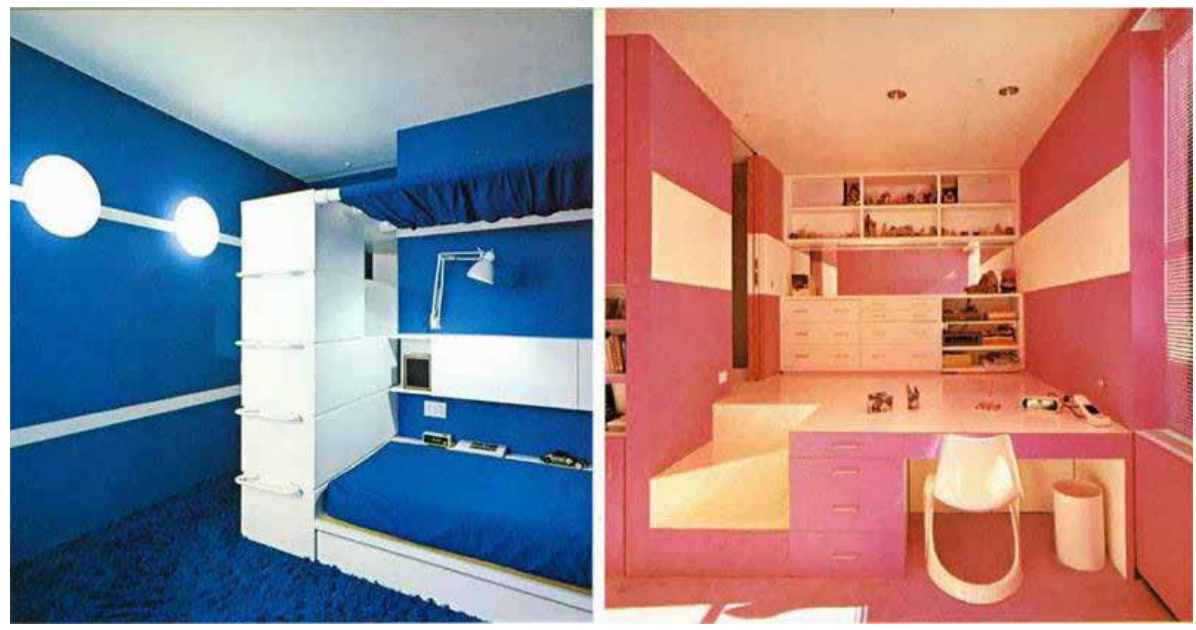

Los tres espacios, monocromáticos -no acromáticos- utilizaban la base de color para involucrar a elementos como paramentos, suelos, escaleras con los muebles y objetos, creando un todo casi abstracto, en el que un sistema de signos, esta vez en blanco, creaba su propio discurso en el espacio, en una especie de éter verde, azul o rosa.
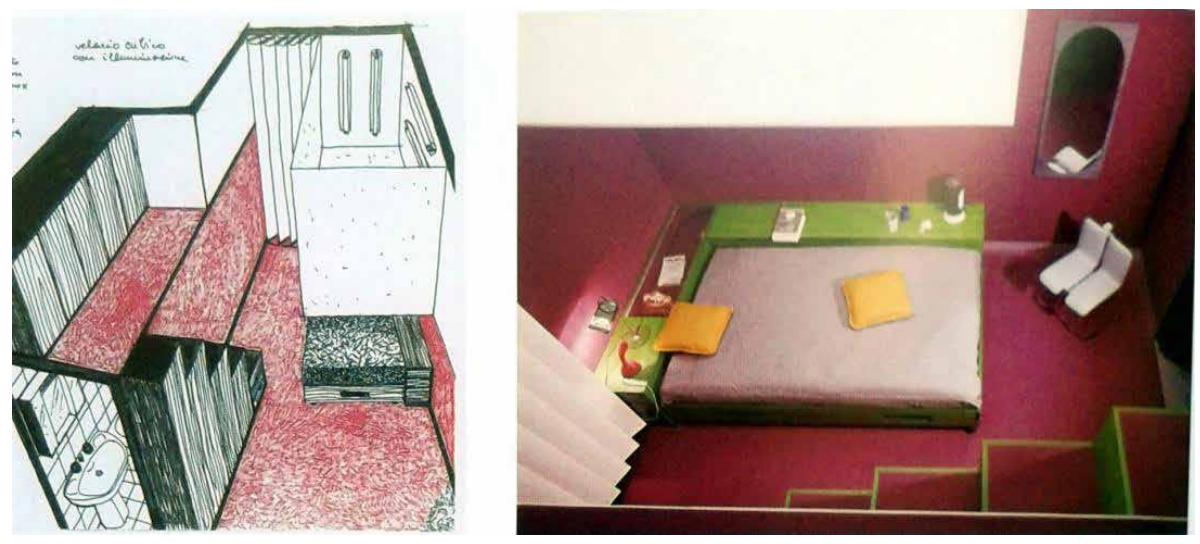
Joe Colombo, en la reforma del apartamento Zancopè en Via Sismondi, Milan, en 1964 también había utilizado el mismo recurso años antes.

Como en otros ejemplos, la reforma de un apartamento llevada a cabo por los arquitectos Salvati \& Tresoldi en 1976 en Milán, no precisó de una modificación significativa de la distribución en planta -sólo el pequeño vestíbulo se había eliminado para que se entrara directamente al salón- para cambiar notoriamente las características del espacio. El diseño, aun siendo bastante convencional, sin embargo hacía que la casa se transformara gracias a un fuerte código de color. Desde el suelo hasta el techo las paredes aparecían revestidas con paneles de colores brillantes, amarillos, rojos, y verdes según las diferentes habitaciones. Las puertas y los armarios eran hasta el techo y se trataron de la misma manera, de forma que se integraban en los muros. Esto generaba efectos que hacían percibir el espacio más continuo y fluido.
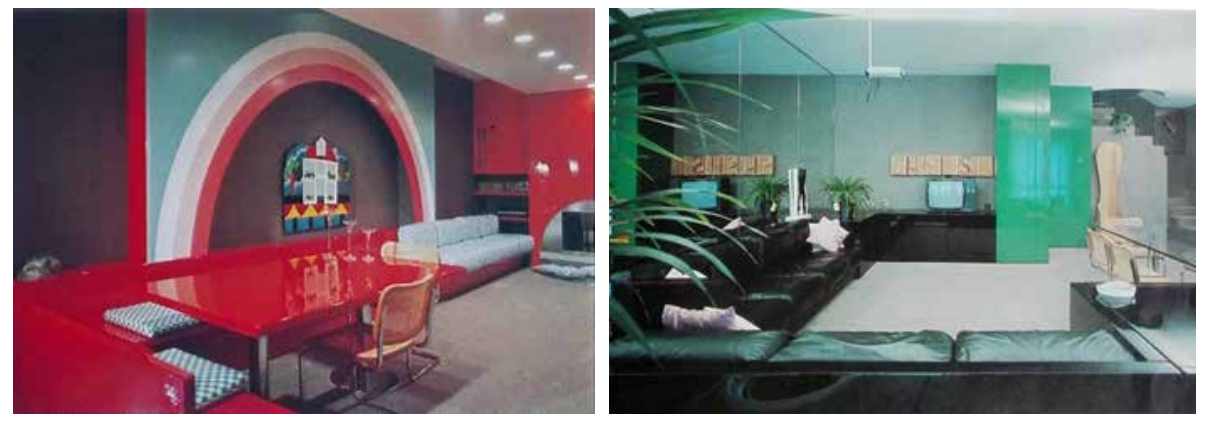

"Un hábitat flotante que busca la inmaterialidad, esta casa está en un nivel evaporativo de ensueño por encima de la metrópolis" ${ }^{\prime \prime}$.

Steven Holl intentó ahondar en las sensaciones creadas a través de los objetos y los elementos que se ubicaban a nivel del suelo. En una reforma que realizó en una torre de apartamentos en Nueva York en 1987, su idea era crear el efecto de como si se estuviera flotando en las nubes.

Aprovechó por un lado las características propias del espacio, su cota a nivel de calle - se situaba en una de las últimas plantas de una torre en Nueva York-y las superficies acristaladas que ofrecían una vista panorámica impresionante de la ciudad, y por otro lado, Holl aprovechó su propia habilidad de para introducir las características de la acuarela en la arquitectura. Los efectos cromáticos y los haces de luz se movían libremente sobre las superficies de las paredes, suelos y techos. Centrando la atención en el plano horizontal -el suelo- parecía obvio que las composiciones que allí se encontraban habían sido creadas para transmitir la sensación de ligereza que se pretendía. Holl exploró el diseño de las alfombras en algunos de los primeros proyectos residenciales con el fin de enfatizar el suelo, como una superficie coloreada. En este proyecto el pavimento era de terrazo blanco y negro con una densidad variable de grano con el fin de recrear la sensación de 'un paseo sobre las nubes'. Se diseñó de aquella manera para enfatizar la sensación de estar en un lugar tan alto sobre la ciudad pero sin gravedad. Las alfombras que había incluido en este apartamento habían sido diseñadas de manera que conmemoraban un hábitat sobre una nube flotante. La introducción de elementos de color en el suelo pretende envolver al espectador en un espacio psicológico competo.
Imagen: Apartamento. Via Garibaldi, Milán. Salvati \& Tresoldi, 1976.

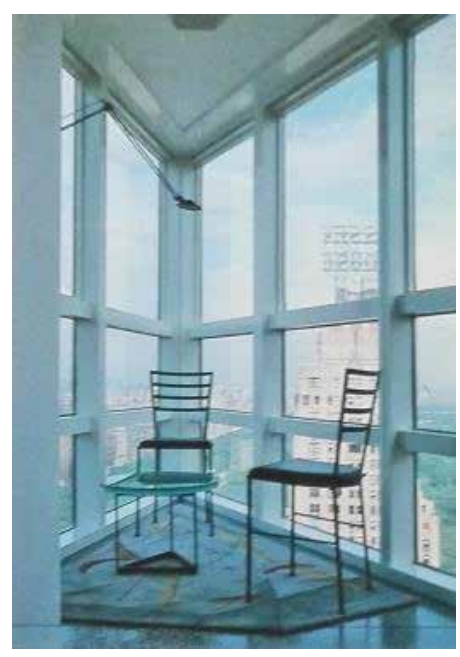

Imagen: Metropolitan Tower Apartment. Nueva York. Steven Holl, 1987. 
Imagen: Metropolitan Tower Apartment Nueva York. Steven Holl, 1987.

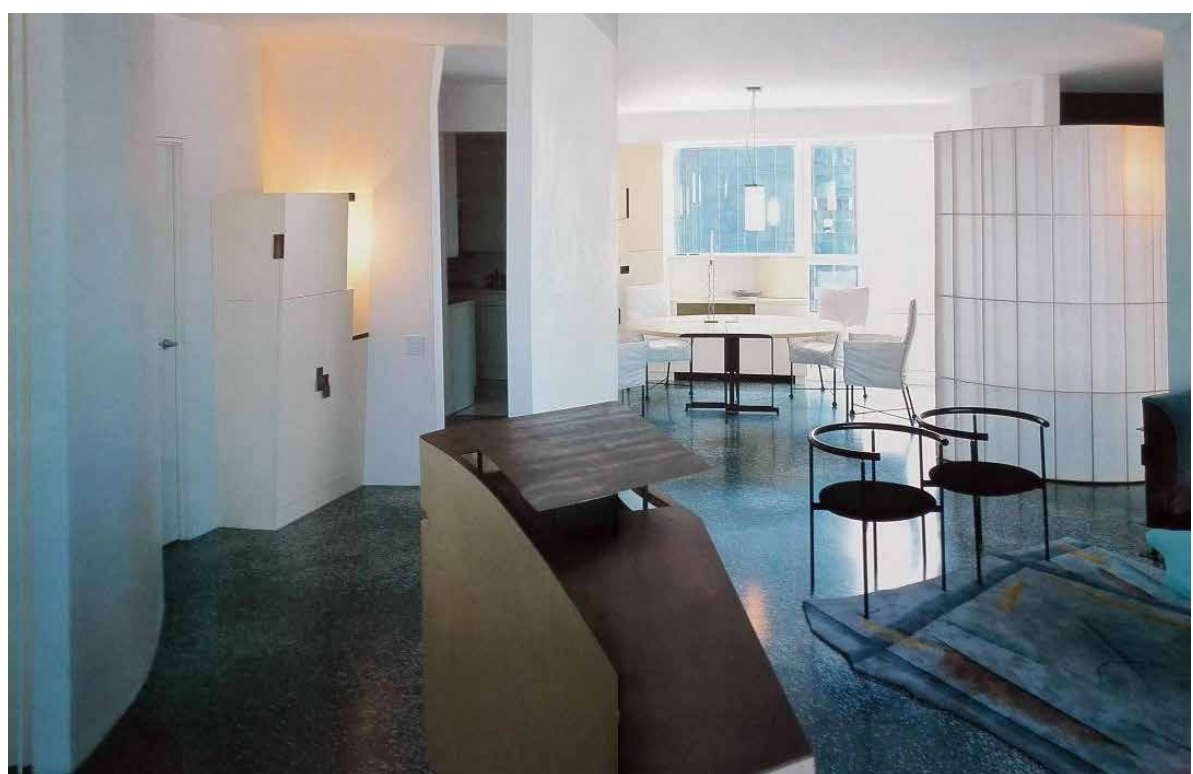

Los dibujos de Holl para este suelo se basaron en la pieza musical Landscapes of the Mind, inspirada a su vez, en un lienzo de Georgia O'Keeffe titulado Sky Above Clouds. Al igual que las manchas de color suprematistas, estas alfombras proclaman un plano horizontal sin gravedad.

\section{Jordi Safont-Tria i Oms ${ }^{80}$}

Otro de los mecanismos, al que ya se ha hecho referencia a través de la casa Moore en New Haven, es la superposición de capas. Esta fue la solución dada por Robert A. Stern en un pabellón especial para el uso de la piscina en Greenwich, Connecticut en 1973, junto a la casa existente. Aunque estaba unido por un paso cubierto, el pabellón tenía un cierto carácter escultórico e independiente, libre de los sistemas convencionales. Por eso, la iluminación natural, las formas libres interiores a base de un sistema de capas superpuestas relacionadas con piezas de espejo e iluminación, y el uso de colores deslumbrantes, multiplicaban los efectos espaciales y potenciaban la idea de partida, que era huir de los convencionalismos.

El layering, unido a un proceso de complejidades en el que los cortes, giros y desplazamientos de capas se unen a un sistema de recorridos, como en la School-House Condominium de Graham Gund \& Ass. en Boston, Massachusetts, recupera las ideas de Colin Rowe y Robert Sluzky sobre transparencia fenomenológica a partir de las cuales, un espacio se convierte en transparente, no por sus cualidades materiales contrarias a la opacidad, sino por la simultaneidad de planos y perspectivas entrelazados que permiten que el espacio se perciba con dimensiones mayores a las físicamente reales. LO mismo ocurre con los juegos de escala, que a través de tamaños relativos, en algunos casos, sobre todo en procesos de miniaturización, hacían percibir el espacio mayor, en proporción a los objetos que en él se situaban.

Mientras que la realización formal tiene que ver con el significado de las cosas individuales, la escala tiene que ver con su tamaño físico y por tanto con su importancia y su significado en relación con otras cosas, como decía Charles Moore $^{81}$.

80 Jordi Safont-Tria. "Water Colors. La dimensión horizontal del color en la arquitectura de Steven Holl". Diagonal (n037 primavera 2014). En: http://www.revistadiagonal.com/articles/analisicritica/water-colors-steven-holl/\#more-5215

81 Charles W. Moore y Gerald Allen. Dimensiones de la arquitectura. Espacio, forma y escala. (Barcelona: Gustavo Gili, 1978) p.27. 
La escala, que implica ordenar los distintos tamaños de alguna manera, y elegir los tamaños concretos cuando la opción es posible, es de gran interés para todos los arquitectos y también suscita muchas polémicas (...) Existe una superescala, una escala en miniatura, una escala monumental y -tal vez la más famosa- una escala humana.

Se supone que la gente usa todos estos términos porque significan algo. La escala no es lo mismo que el tamaño; la escala es el tamaño 'relativo', el tamaño de algo relativo a otra cosa. (...) Existen muchas posibilidades, lo que es precisamente la razón por lo que la manipulación de la escala sea una herramienta tan útil en arquitectura.

\section{Charles Moore ${ }^{82}$}

Como en las viviendas Taylor en Norwalk, de Charles Moore Ass., la metáfora de la ciudad en el interior, a través de un proceso de miniaturización ha sido un recurso muy utilizado por los arquitectos para convertir el interior doméstico en un ámbito de grandes dimensiones, muy ligado a la contemporánea idea de lugar dentro de la arquitectura.

En la mayoría de los casos, los juegos de escala se producían representando en el interior de la casa lo que sería una mini-ciudad, con fachadas o minicasas distribuidas por el espacio, como si al transitar, de una calle o una plaza se tratase.

En tres viviendas en San Diego, California, proyectadas por Ted Smith en 1978, elementos como la cocina -movible- se convertían en muebles que representaban fachadas. Los alzados interiores estaban inspirados en el entorno directo, muy heterogéneo, de un barrio lleno de mezclas y de ambigüedades que lo convertían en un interesante contexto. La metáfora de la ciudad configuraba el espacio como un 'paisaje' artificial.

Las tres casas, económicas, casi sin particiones como ventaja para la especulación comercial, gracias a aquella percepción inducida por los mueblesedificio de espacio amplio y preparado para admitir cualquier acontecimiento, como en la ciudad, pretendían transmitir un mensaje de 'flexibilidad' para ser más 'vendible'. El sistema de división a través del módulo de cocina movible, así como el de separación entre dormitorios, que por su propia morfología también representaban una escena urbana en miniatura, planteaban tres viviendas con dos opciones cada una.

En la reforma del edificio de la Escuela Callender en Rhode Island para convertirlo en viviendas realizada por George Ranalli en 1979, todas las viviendas contaban con una gran sala de estar con doble altura donde existía una especie de fachada tras la cual estaban los espacios más privados. Además, el conjunto de fachadas de todas las viviendas agrupadas en torno al espacio común creaban una ciudad en miniatura dentro del edificio.

La multiplicidad de visuales y la fragmentación de los planos de 'fachada' en distintas capas contribuía a generar, casi de modo pictórico, la ilusión óptica que se pretendía con el proyecto.

En la casa Kohagura en Okinawa, vivienda proyectada por Hiroshi Hara, la representación de fachadas en miniatura gracias a la morfología de los muebles y los elementos distribuidores, que las imitaban, bajo una cubierta común,

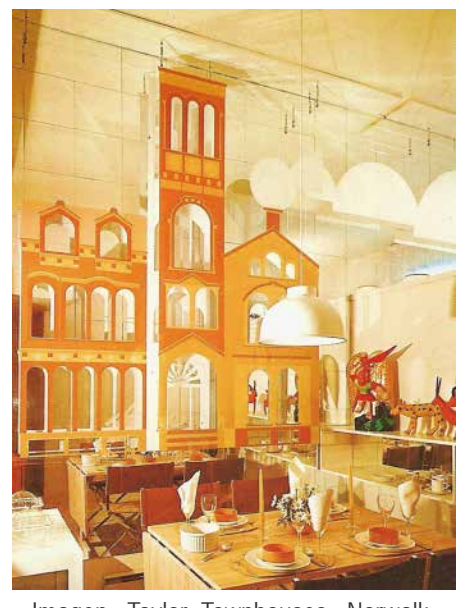

Imagen: Taylor Townhouses. Norwalk, Connecticut. Charles W. Moore Ass. Grover, Harper, Rumney 1973
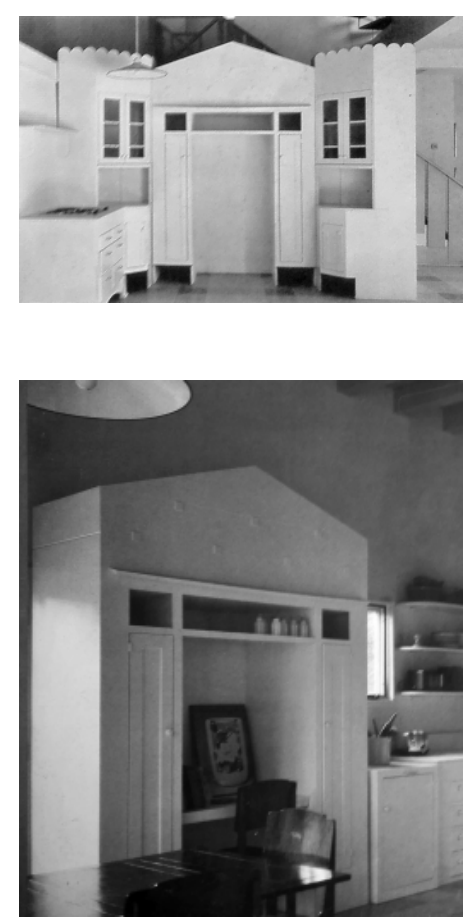

82 Ibíd. p.28. 
Imagen: Callender School. Newport Rhode Island. George Ranalli, 1979. Vista del interior de lagunas de las viviendas.

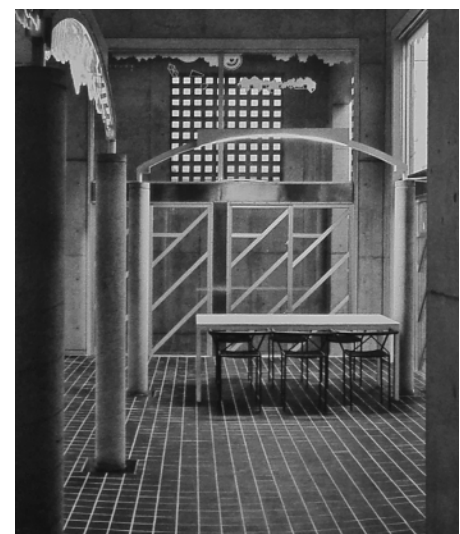

Imagen: Kohagura House Okinawa, Japón. Hiroshi Hara, 1984. Vistas del interior de la vivienda.

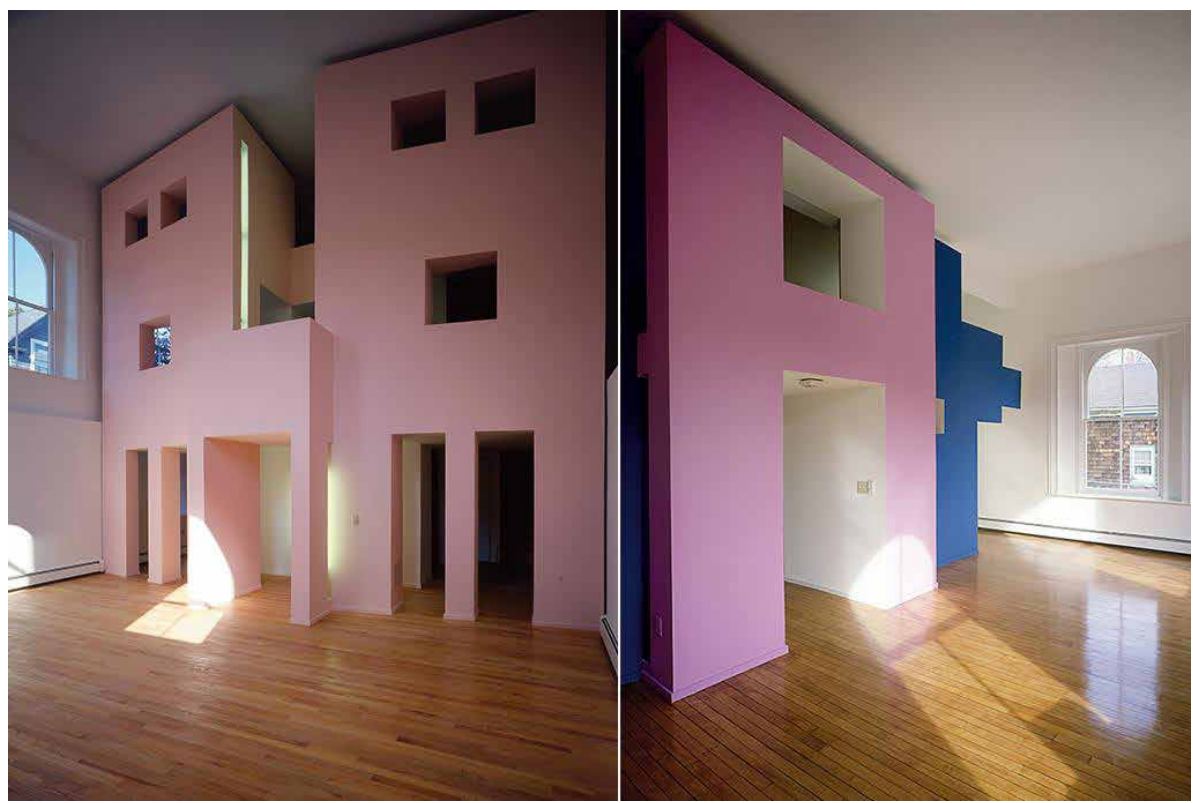

conseguía una atmósfera especial bajo los juegos de escala, la superposición de pérgolas y dinteles, y una calculada iluminación. Todo ello representaba otro ejemplo del recurso de la metáfora de la ciudad dentro del espacio doméstico para transformar la percepción del marco a través de su vivencia.

El objeto, como mecanismo transformador del espacio, en un sistema de relaciones y conexiones generado a través de los juegos de escala, también podía trasladar al usuario a lugares lejanos. Este es el caso de la Pool House, realizada por Robert A.M. Stern en 1979, en Llewellyn Park, New Jersey.
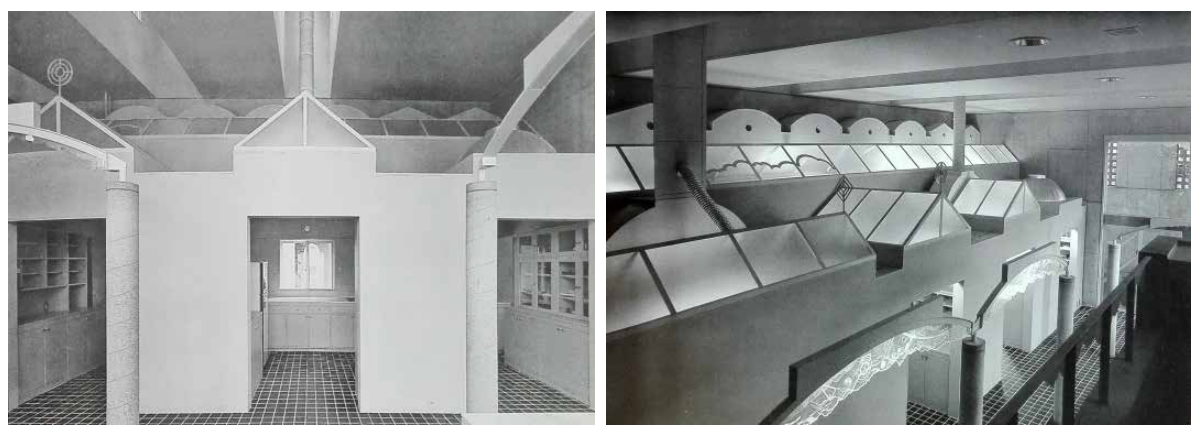

El proyecto comprendía dos actuaciones: la reforma de la casa georgiana de 1929 y la modificación de las terrazas y el jardín para crear un espacio que albergara una piscina cubierta. El pabellón de la piscina cubierta, fue deliberadamente complejo en sus referencias formales, creando en su interior una especie de representación de un paisaje. Las columnas, de palmera, recuerdan al pabellón de Brighton de John Nash, y son similares a las utilizadas por Hans Hollein en la agencia de viajes que había reformado en Viena en 1976. Para recrear un ambiente tropical Stern, además, utilizó otros recursos de tratamiento del espacio, como un revestimiento de azulejo de inspiración subacuática en las paredes. El uso de pilastras de falso mármol daban un aire casi arcaico que contrastaba con la alta tecnología empleada para abrir la piscina al jardín y para el aprovechamiento de la luz solar. 

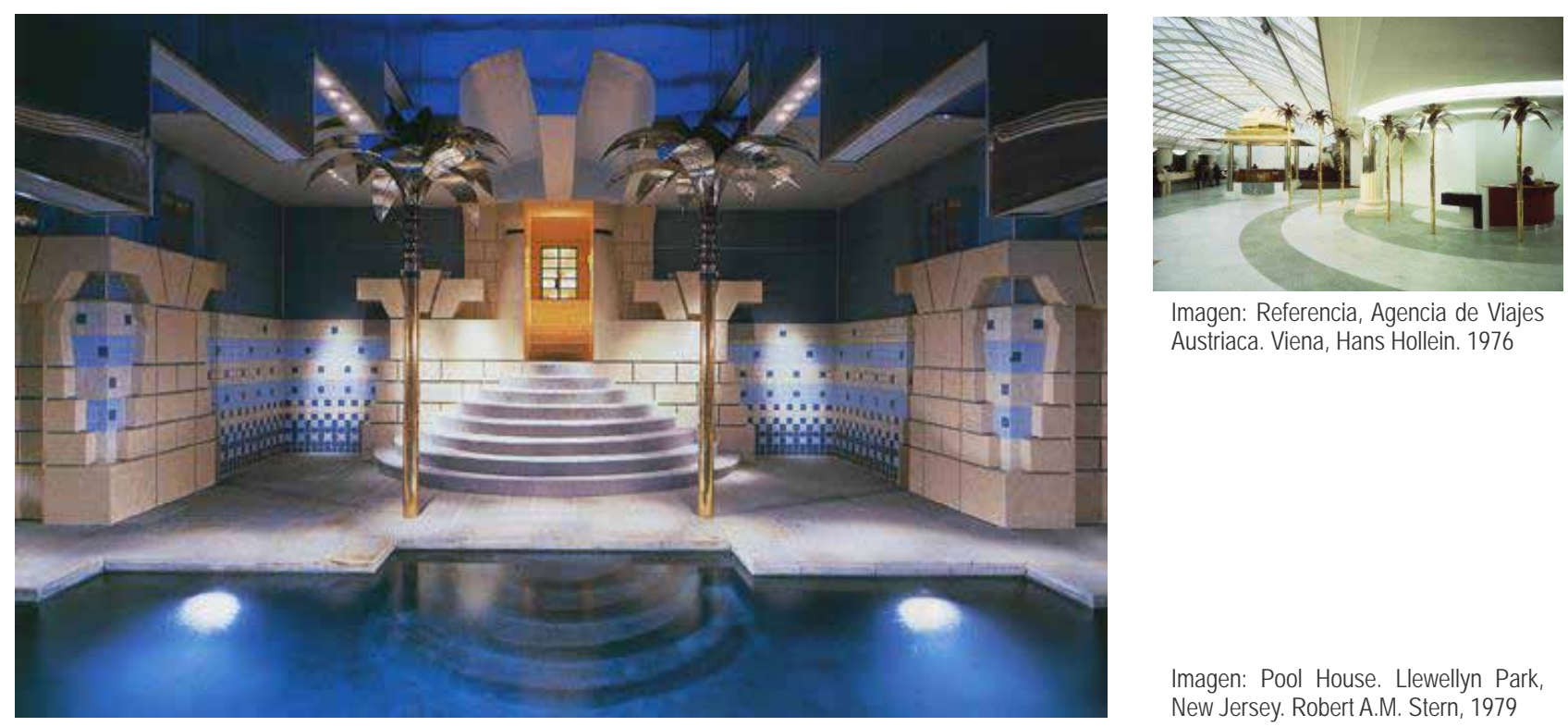

Imagen: Referencia, Agencia de Viajes Austriaca. Viena, Hans Hollein. 1976

Imagen: Pool House. Llewellyn Park, New Jersey. Robert A.M. Stern, 1979

El interior era tratado como un escenario, o mejor dicho, la composición completa era una escenografía donde se perseguía profundidad, espacio onírico y/o irónico a través de la relación entre elementos, las conexiones a través de los significados y connotaciones de determinados signos y los efectos creados a través de la técnica. 
Imagen: Interior-1, Inrerior-2,Interior-3. Serigrafías. George Sowden. Grupo Memphis, 1984. Ilustraciones de Sowden en los que los patrones de los materiales que revisten el espacio se funden con la arquitectura.

\subsection{FUSIÓN CASAY OBJETOS}

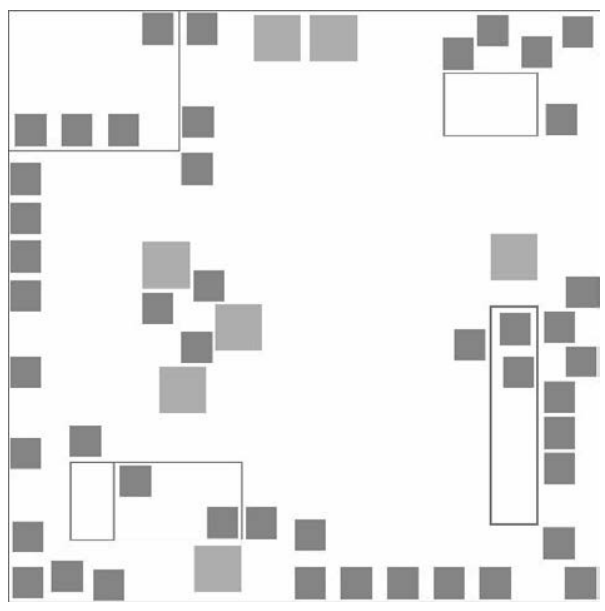

Un sistema rebosante de objetos, de almacenaje, acoplados en el espacio o en exposición, sometidos a proceso de interpenetración en lo que todo se solapa, podía hacer incluso que la arquitectura se disolviera en ellos y viceversa. El 'aditamento' era parte de una fase de definición y tratamiento de las cualidades del lugar, dentro de lo que Baudrillard llamaba la lógica del ambiente. Este proceso se producía no solamente por los objetos en sí mismos, sino también por el emplazamiento de éstos, sus relaciones, las texturas, los colores, los materiales, etc. que acompañaban. Pero además existía un discurso subjetivo que complementaba a aquella estructura de colocación y cuyas connotaciones asociadas a factores como qué transmitían o qué representaban -su significadolos objetos, también formaban parte del sistema. Su influencia era importante, ya que incidía en la manera en que era percibido finalmente el entorno. La incorporación de lo simbólico, de lo personal, de los objetos que conformaban un vínculo entre el habitante y su espacio, haciéndolo suyo, implicaba una superposición de objetos, de formas e imágenes, que hacía que el espacio adquiera nuevas dimensiones gracias a la consideración de lo emocional y lo subjetivo, algo a lo que Sert llamó la recuperación de la faceta lírica del espacio ${ }^{83}$.

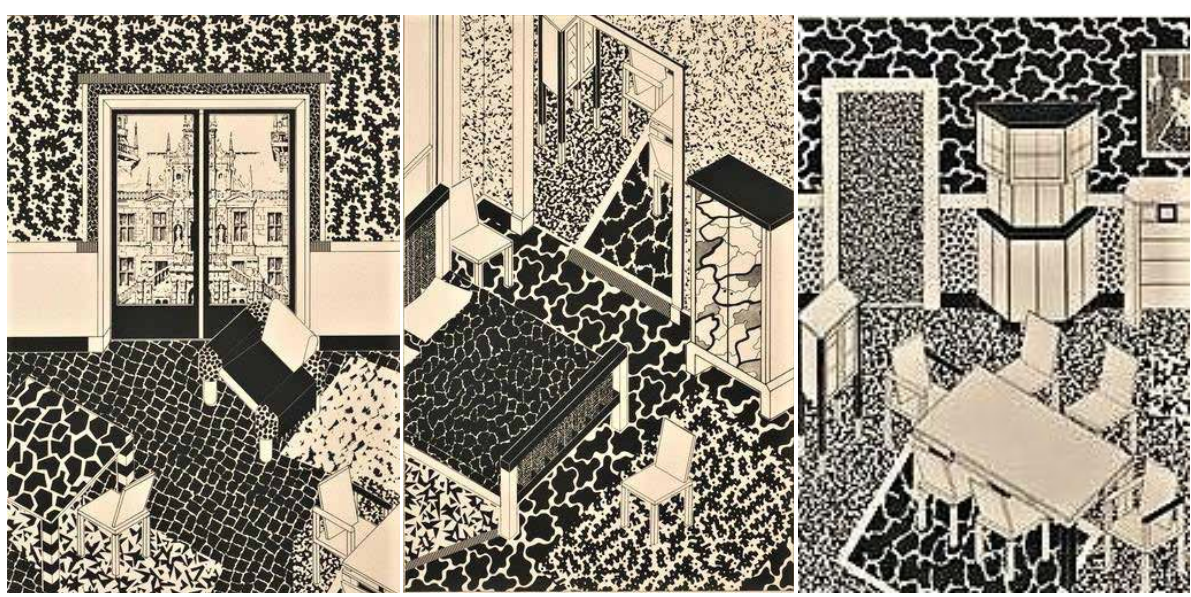

Moore, Lyndon y Allen ${ }^{84}$ ya hablaban de la posibilidad de "añadir algo" a la casa, haciendo referencia a un proceso de 'aditamento' en el que el ocupante

83 Sigfried Giedion, J. Lluis Sert, y Fernand Lèger. "Nueve puntos sobre monumentalidad", 1943. En En: Sert: Arquitecto en nueva York. Editado por Xavier Costa (Barcelona : Museu d'Art Contemporani de Barcelona, 1997).

84 Charles Moore, Gerald Allen, Donlyn Lyndon. "Recolección". En La casa: forma y diseño. (Barcelona: Gustavo Gili, 1999) p.214. 
jugaba con los objetos personales y los incorporaba al espacio doméstico con el fin de que las connotaciones que llevaban implícitas -sus recuerdos, sus vivencias, sus preferencias- pudieran establecer un vínculo que provocase que aquel marco pudiera reconocerse como suyo.

En la casa de los Eames, de la que tanto se ha tratado, las cualidades del espacio, existían en gran medida por los objetos que allí se alojaban. Objetos cotidianos que invadían un contenedor neutro y construido con materiales industriales y que sin embargo se había convertido en el ejemplo de la domesticidad más atrayente del momento. "Era la puesta en marcha de una forma completamente nueva de operar que fascinó a Europa del mismo modo que los modelos europeos habían fascinado a los Estados Unidos antes de la guerra. La Casa Eames tenía un atractivo especial"85. La casa y los objetos que allí se alojaban coexistían bajo un sistema de relaciones en el que casa y objetos eran partes de la misma cosa.

Norberg-Schulz, en Intenciones en arquitectura, decía que el término relación implicaba distribuir elementos. Pero existían relaciones topológicas basadas en el principio de proximidad en las que, aunque había conjuntos con un cierto grado de articulación, era difícil o imposible reconocer elementos distintos. En ese caso tendríamos que hablar de 'fusión'. Los elementos podían fundirse por medio de la interpenetración y la deformación, de tal modo que carecía de sentido su separación formal. Una 'interpenetración' se creaba cuando dos elementos se solapaban. Esto no significaba que pierdieran su independencia, sólo que se formaban zonas ambiguas, que pertenecían al mismo tiempo a los dos elementos. Aunque también era posible una separación genética. Podríamos empezar con un todo y subdividirlo posteriormente en un proceso de reconocimiento de los elementos que componen el sistema.

En 1969 Nanda Vigo transformó el proyecto original de Gio Ponti 'un escarabajo bajo la hoja' -lo scarabeo sotto la foglia. 1964- en una casa-museo permanente para Giobatta Meneguzzo. Vigo invadió con luz natural todo el interior -algo rarísimo en su trabajo-, por lo que el efecto, en todo el interior, de superficie neta y continua aumentaba gracias al uso de baldosa cerámica pulida que recubría toda la casa, paredes y suelos.

En un proceso de 'deformación' del piso, surgían los muebles principales: una especie de piscina-sofá para reuniones, y la cama de matrimonio. Parecía que los muebles -que no eran móviles- habían brotado del suelo, eran parte de la superficie continua de baldosa blanca y permanecían como un bajorrelieve. Sólo se diferenciaban por su acabado interior, que estaba forrado en una especie de 'peluche' gris de pelo largo y que contrastaba con la superficie dura cerámica.
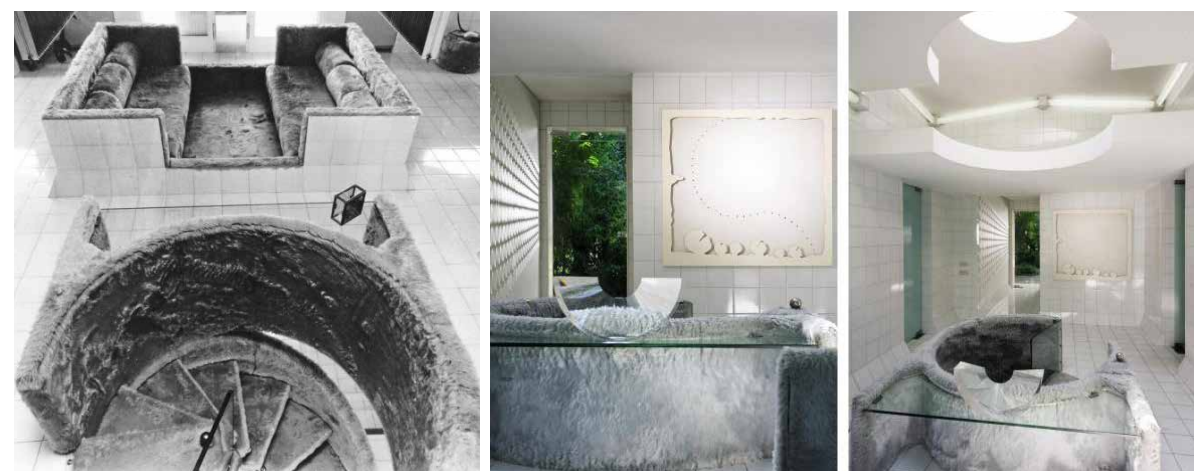

85 Beatriz Colomina, "Reflexiones sobre la casa Eames". Ra. Revista de Arquitectura (nº, 2007). 3.

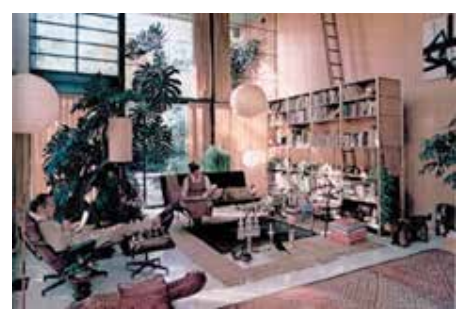

Imagen: Los Eames en su casa de Santa Mónica, California. 1949

Imágenes: Casa Sotto la Foglia. Malo, Italia. Nanda Vigo. 1969. Vistas del interior de la planta primera donde se ven obras de Bonalumi y Castellani, que se funden en el blanco continuo de la casa. En la imagen de la derecha, piscina-sofá diseñado por Nanda Vigo. 
Imagen: Casa French. Oakwood, Ohio. David L. Niland, 1965.

Imagen: Casa Savina Zentner. Zurich. Carlo Scarpa, 1968. Vista del espacio principal de la casa.
La casa contenía obras, que estaban expuestas en las paredes, de Lucio Fontana, Agostino Bonalumi o Enrico Castellani, cuya obra 'Superficie Bianca' -1967- , se fundía con las superficies de la casa, al igual que el resto, también con fondo blanco. En este caso, las relaciones topológicas entre el espacio y las obras expuestas, estaban caracterizadas por un proceso de fusión, en el que tanto las piezas, como los lucernarios y los signos en los techos se mezclaban en la superficie blanca y continua de la casa totalmente revestida de baldosa blanca.

Las relaciones de interpenetración y solapamiento entre el espacio y las obras de arte, podían surgir desde el origen del proyecto, como es el caso de la casa que realizó David L. Niland en 1965 en Ohio para una artista, cuya obra también invadía el espacio. La casa, se situaba perpendicularmente a la calle, y tenía una poco usual orientación Norte-Sur, según la dirección de un eje Este-Oeste. Esto era debido a que la dueña, Mrs. French, que era artista, necesitaba orientación norte para su estudio, así poder aumentar la luz natural con lucernarios en la cubierta. El aspecto quizás más característico de la casa es la simbiosis que se producía entre las obras de arte y el espacio en el que se ubicaban. La casa estaría incompleta sin la presencia de las obras de arte.
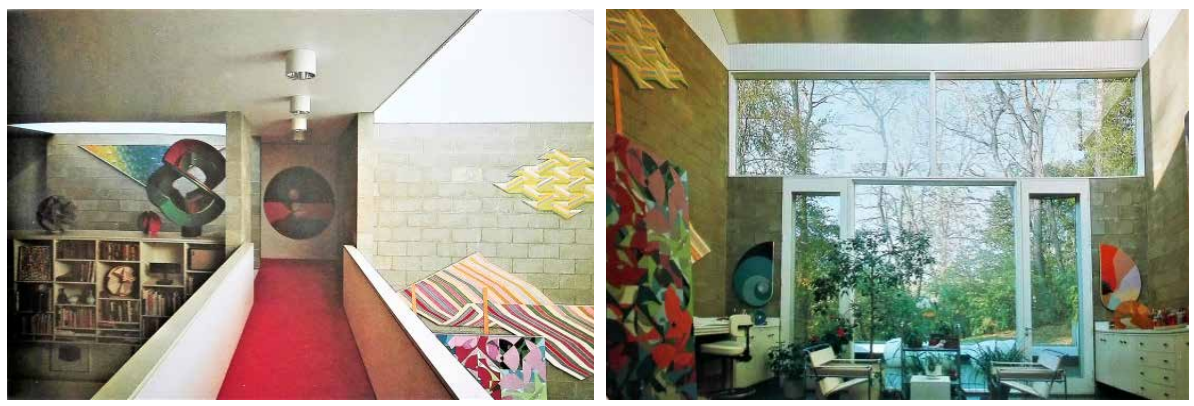

En el proyecto realizado por Scarpa, en Zurich en 1968 para Savina Zentner, la relación de fusión entre casa y objetos se produce gracias a las conexión que se produce en el espacio entre las piezas de arte, que participaban directamente de la configuración espacial, con los materiales y texturas de los acabados interiores y de mobiliario.
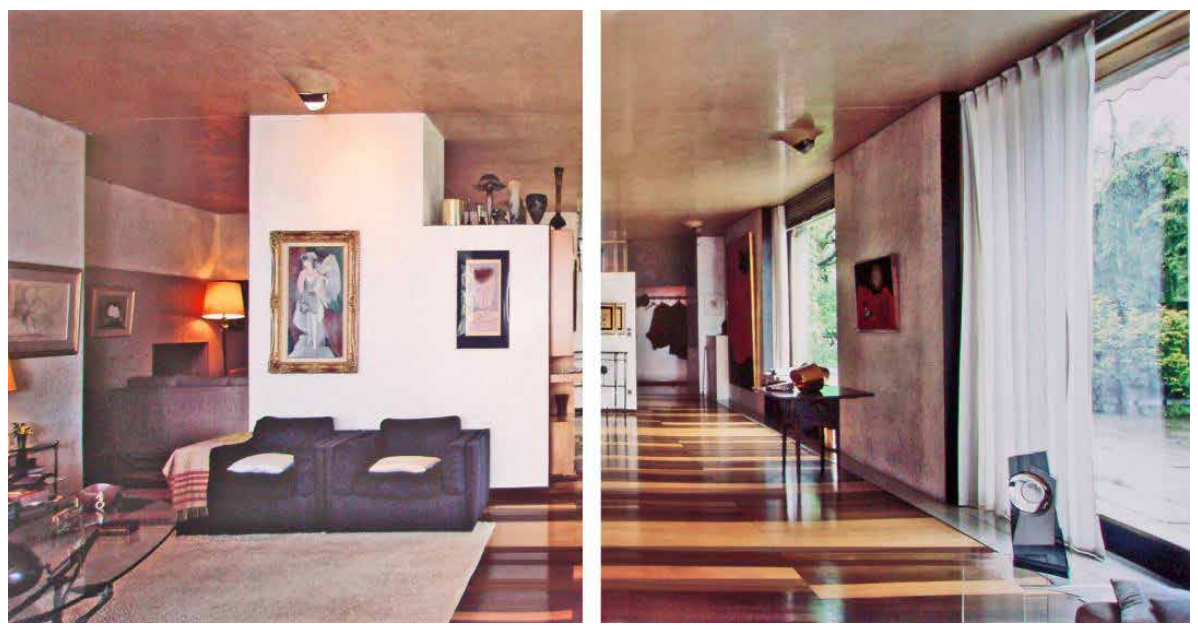

La reforma y ampliación de la casa para Savina Zentner, viuda de Masieri, fue la única obra de Scarpa fuera de Italia. La casa original era de 1910 y en la reforma Scarpa añadió una segunda planta y transformó las fachadas y los interiores. La actuación reflejaba la afinidad entre el diseñador y los propietarios, así como el ambiente cultural que se vivía en Zurich en los años 
60, particularmente por la presencia de artistas y músicos que frecuentaban la casa de los Zentner. Todas aquellas connotaciones se convirtieron en parte del discurso que componían aquellas piezas, que de manera natural, se fundían con la arquitectura.

La planta baja, desde donde se producía la entrada, se yuxtaponía con el nivel del jardín, es como una continuidad del mismo. Las piezas de la zona de estancia se abrían al sur, hacia el jardín, lo que hacía que la sensación de espacio fuese mayor. El tránsito entre la zona exterior y la interior, la entrada, se pavimentó con cuarcita de Vipiteno. El techo de la zona de estancia era de estuco satinado en color claro y el pavimento era de parquet que mezclaba dos tonos, el de la madera de wengué y la madera de Tanzania. Esta mezcla de materiales proporcionaba una riqueza de tonos y texturas que se solapaba con las obras de arte existentes en la casa. Scarpa también diseñó el mobiliario, incluso un mueble bar que se accionaba con un mecanismo pivotante, una mesa de comedor con estructura en bronce y tablero de ébano, palisandro y varios tipos de mármol -precursora de la famosa mesa Doge, que posteriormente fue producida por Simon-, algunas estanterías y una mesa con teselas de mosaico empotradas en hormigón.

Incluso diseñó los apliques y las lámparas de techo, las puertas exteriores y las ventanas en roble blanqueado y quemado con herrajes en acero y bronce y las puertas interiores, incluida la puerta de madera y vidrio que da paso a la escalera que sube a los dormitorios, escalera pavimentada en piedra de Clauzetto.

La riqueza de material de esta casa contribuía en gran medida en la perfecta fusión entre las obras de arte, los objetos diseñados por Scarpa y el espacio, como si de una obra total se tratase.

Uno de los ejemplos más claro de relación de fusión entre casa y objetos por interpenetración, en la que todo se solapa, es la casa que en 1970 Moore construyó en Essex, Connecticut.

Moore en esta casa dio rienda suelta a una de sus aficiones: coleccionar y sobre todo exhibir sus objetos libremente. Contrariamente a los casos anteriores, en esta casa, los objetos que invadían el espacio y que se fundían con los muros, no eran obras de galería, se trataban más bien de objetos personales, de recuerdos de viajes, de bibelots, de colecciones de objetos cuyo valor radicaba en la historia asociada a cada pieza, más que el valor económico. La relación de fusión entre la casa y el objeto no sólo era topológica, también era psicológica, connotativa. Las conexiones con lugares lejanos, los recuerdos, la memoria y la historia, también formaban parte de este proceso.

El despliegue de colecciones las convierte en parte de la casa. La colocación de nuestros objetos preferidos en un lugar concentrado y en un orden que provoca la la comparación y la discriminación permite a otros compartir nuestro entusiasmo. Los cuadros que cubren completamente una pared o las estanterías repletas de libros son colecciones que ensanchan nuestra involucración en la casa. Sir John Soane amasó en su casa de Londres una extraordinaria de artefactos y objetos artísticos que se convirtió en parte integrante del lugar. (...) La casa y su colección son inseparables.

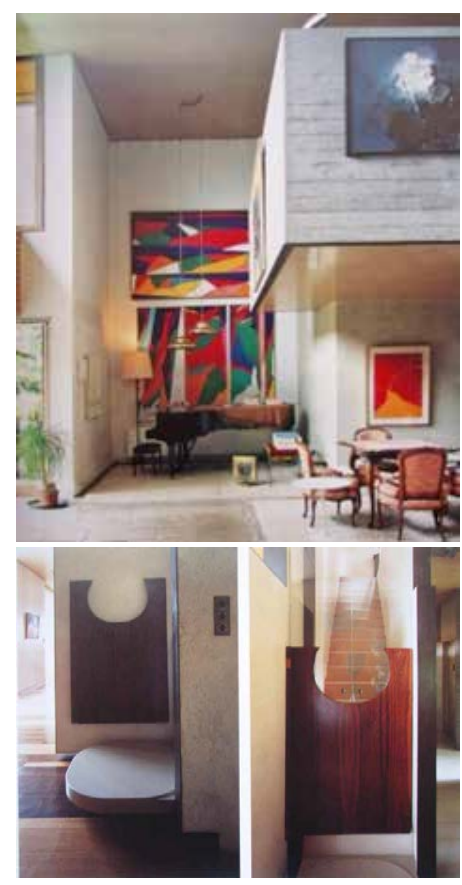

Imagen: Casa Savina Zentner. Zurich. Carlo Scarpa, 1968. Vista del espacio principal de la casa y de la puerta de vaivén diseñada por Scarpa. 
Imagen: Casa Moore en Essex, Connecticut. Charles Moore Ass. 1970.

Imagen: Apartamento Joanna Steichen Ciudad de Nueva York. Paul Rudolph, 1973

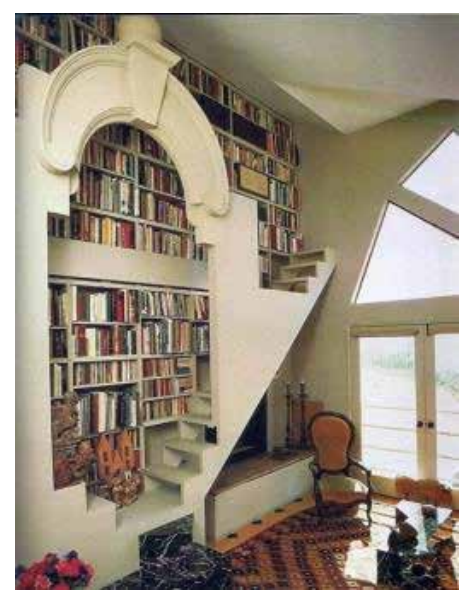

Imagen: Casa Moore. Moore, Roger, Hofflander Condominium. Los Angeles, Califormnia. Charles Moore, Richard Chylinski, 1975

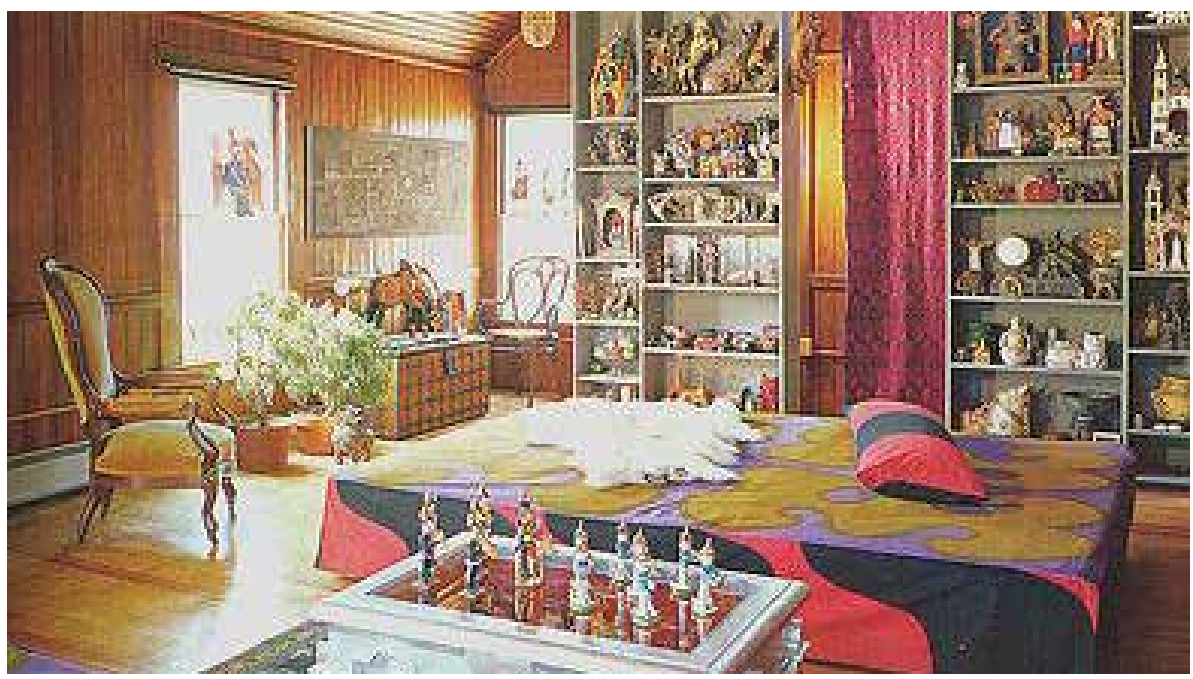

En otras ocasiones, la fusión se produce porque, como en el caso de la reforma que realizó Paul Rudolph en Nueva York, espacio se compone como un collage de planos y figuras, como si de un cuadro cubista se tratara.

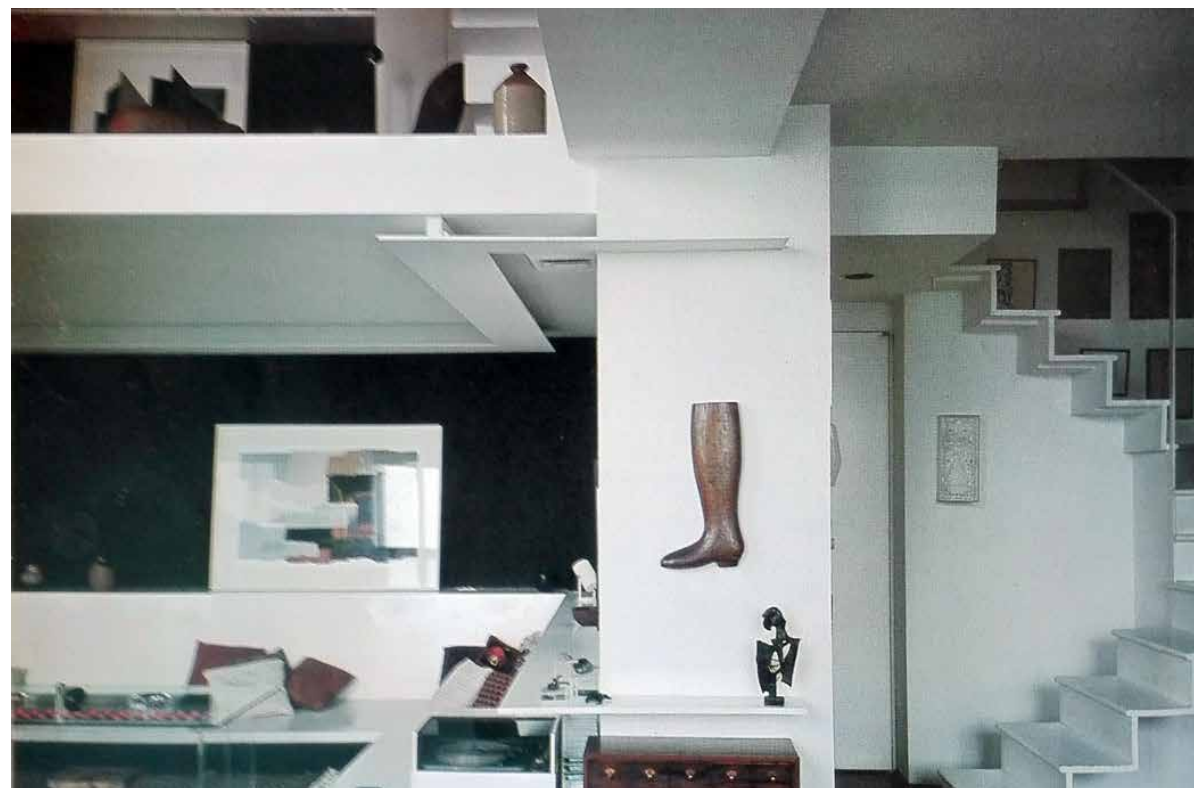

En la casa que Charles W. Moore se construyó en el condominio de los Angeles en $1975^{87}$.Aparte del proceso de objetualización de elementos portantes que realizó en la casa de forma sistemática, tal y como se ha analizado en otros apartados, y de la invasión de objetos personales que se produjo a modo de 'apropiación' del lugar, también realizó en proceso contrario, todo dentro del mismo espacio. En la planta superior de la casa, después de realizar un ascenso de dos tramos por una escalera que recorría longitudinalmente toda la vivienda, se situaba una librería que ocupaba toda la pared frontal de la sala. El mueble de biblioteca estaba enmarcado por una especie de arco o balconada, que lo convertía en la representación de un elemento arquitectónico: un arco que daba paso a un balcón que se abría al paisaje y que hacía que la perspectiva de la sala se prolongase y aumentase la sensación de amplitud de espacio. La librería se convertía pues en el paisaje, en el fondo en el que todo se fundía para proporcionar un telón al marco de la librería, que se había convertido en un elemento arquitectónico gracias a su posición, por contraste, respecto al fondo librería.

87 Moore, Roger, Hofflander Condominium. Los Angeles, California. Por Charles Moore y Richard Chylinski, en 1975. 
La fusión entre casa y objeto podía producirse desde el origen del proyecto, como se verá en algunos, y muy diferentes, ejemplos.
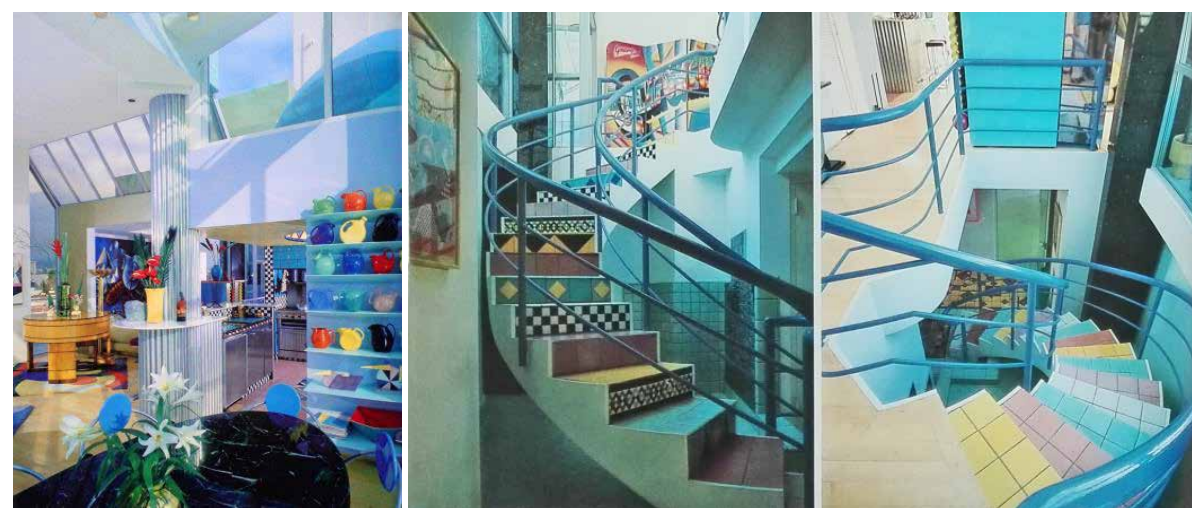

La casa de Miriam Wosk surgió como un collage. Proyectada por Frank O. Gehry en 1981, la idea partía de una recopilación de imágenes que la propietaria, una artista que se había mudado de Nueva York a California, había hecho llegar -el archivo completo de imágenes- al arquitecto para mostrar sus ideas sobre lo que le gustaría dentro de la casa.

El arquitecto reconoció que había sido una forma de trabajar que nunca había practicado ${ }^{88}$ pero que había resultado interesante. En el interior de la casa se incluían todas las imágenes que partían de los deseos y las fantasías de su propietaria, que en muchos casos partían de su propia obra pictórica. Objetos de muchos colores diferentes se mezclaban entre azulejos exóticos hechos a mano, con forma de escamas de pescado, en color azul, o con Gaudí como inspiración. También se incluían materiales industriales y se fundían entre la vegetación y mármoles. La cocina era concebida como una mezquita y el dormitorio como un zigurat, todo ello bajo la influencia de las obras de Wosk que iban marcando el recorrido hasta llegar al estudio.
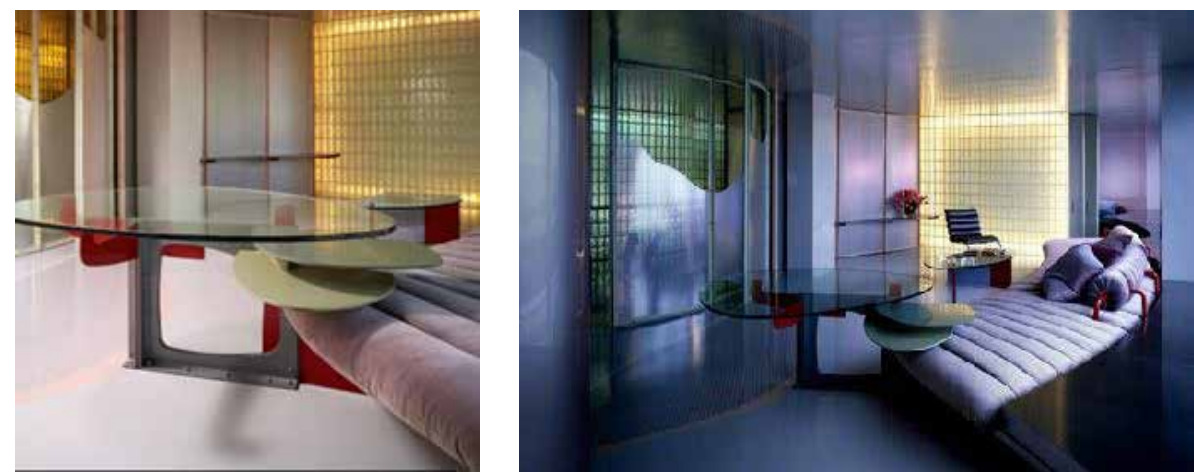

En este otro caso, la influencia del arte en la configuración de la casa, no se basaba en una composición por fragmentos como en el caso anterior, sino el el concepto en sí mismo, en el planteamiento de origen por el cual los propios objetos, texturas, colores, iluminación etc. eran los componentes de una obra pictórica. 'A Painted Apartment' fue la definición que los propios arquitectos ${ }^{89}$, Krueck \& Olsen dieron sobre este proyecto de reforma de un apartamento en Chicago. "La rigidez de un piso de 3 dormitorios en un rascacielos cuadriculado con vistas al Lincoln Park de Chicago y al Lake Front, se ha transformado en un 'apartamento pintado'".

88 Mildred Friedman. Frank Gehry. The houses (Nueva York: Rizzoli, 2009) p.202.

89 Krueck \& Olsen. "Marriott Residence - A Painted Apartment. Chicago, Illinois, 1982". GA houses (n017 febr-1985) 140-143.
Imagen: Casa Wosk Beverly Hills, California. Frank O. Gehry, 1981

Imagen: Casa Marriott, Chicago, Illinois Krueck \& Olsen Architects, 1982 
Imagen: Casa Marriott, Chicago, Illinois. Krueck \& Olsen Architects, 1982.
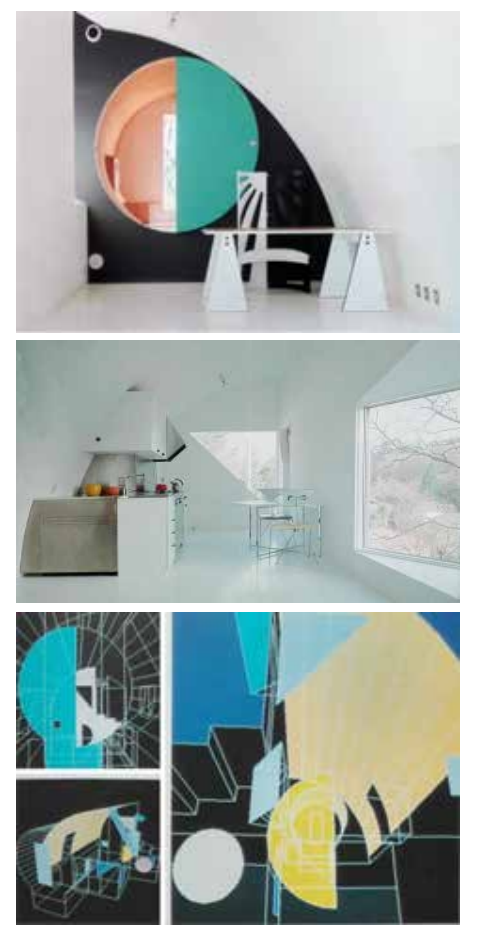

Imágenes: Casa en Yokohama. Nakagawa, Japón. Kazuo Shinohara, 1982.

Arriba,vistas del interior. Abajo, croquis del proyecto.
El resultado fue como respuesta a los deseos del cliente de 'vivir en un cuadro', algo que para el usuario era diferente a simplemente colocar en las paredes obras de arte. Los arquitectos plantearon el apartamento como una pintura en tres dimensiones a base de formas sinuosas inspiradas en elementos del parque, fabricadas en aluminio perforado, acero inoxidable, bloques de pavés, cojines tapizados y paneles metálicos pintados. Las formas dibujadas se convertían en pantallas que separan los espacios, en armarios, en elementos de almacenaje y mobiliario, que surgía en consonancia a lo que se reflejaba y siguiendo las líneas que habían sido dibujadas en suelos, muros y techos. El efecto generaba una percepción ilusoria de un espacio sin límites definido por capas de transparencias y veladuras de color y en el que todo se fundía, en un sistema de relaciones que surgía de la deformación de distintos planos y de los que se iban articulando distintas piezas, como los muebles, que conformaban el cuadro en 3D.
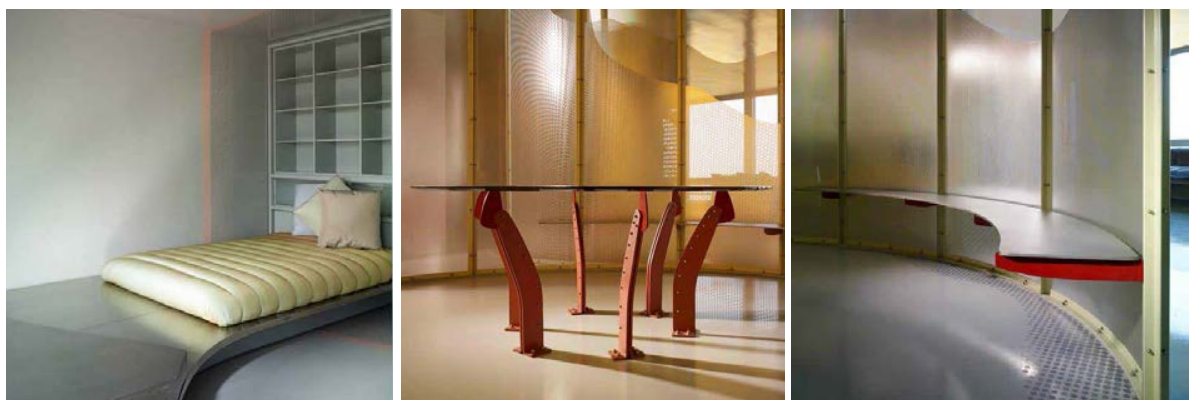

En esta casa en Japón, la fusión se producía en base a las relaciones que se producían en el espacio entre las distintas piezas, y en el que todo encajaba como si de una máquina se tratase. Según el autor, Kazuo Shinohara:

Lo defino como un "ruido aleatorio" que es una de las características de este estado de espacio, que surge de unir formas y volúmenes que han sido creados cada uno de ellos como partes distintas del engranaje de una máquina. Mi interés está en el estudio de estas características ${ }^{90}$.

El proyecto de Kazuo Shinohara consistía en la ampliación de una casa existente de madera en Yokohama, Nakagawa, en 1982, en un solar en alto donde una de las premisas era salvar los arboles existentes y no quitar luz natural a la casa antigua., lo cual no favorecía la configuración de formas regulares.

La entrada de luz natural se resolvió con grandes huecos que abrían al exterior, en una fachada principalmente de grandes paneles de chapa grecada de aluminio. Las ventanas y las puertas, cada una, eran diferentes. Las conexiones se iban produciendo según ciertos rituales, y como resultado a la complejidad formal, surgían escenas inesperadas sin conexión lógica que iban produciéndose con el movimiento del cuerpo y con los cambios de luz. El proyecto, según el arquitecto, estaba basado en la 'anarquía progresiva' aplicada a las ciudades y que estaba estrechamente relacionada con la idea de unir espacios pertenecientes a distintos conceptos compositivos.

En una especie de metáfora sobre la 'entropía urbana', los objetos se fundían en los recorridos, participando con sus propias características formales del concepto del cual partía el proyecto.

90 Kazuo Shinohara. "House in Yokohama. Nakagawa, 1982-84". GA houses (n²0 sep-1986) 20-29. 
El apartamento Cohen, un proyecto realizado por Steven Holl en 1983, consistía en la reforma de un piso con forma de "L" que surgía como una investigación de composición elemental arquitectónica planteada desde tres modos: la lineal, la planimétrica y la volumétrica. Los objetos se fundían con la arquitectura porque todo surgía de la misma composición geométrica.

- La zona de comedor surgía de modo lineal: una lámpara de techo hecha con tres tipos de líneas, una mesa lineal con cuatro sillas lineales sobre una alfombra estampada con todo tipo de líneas.

- El estar era de composición volumétrica, un sofá con cojines cilíndricos, una 'coffe table' volumétrica y una alfombra con volúmenes.

- El estudio y el dormitorio están compuestos con planos, el de la mesa de dibujo, los muros que se despliegaban y se conviertían en puertas y una alfombra tejida con elementos que eran planos.

A través de las alfombras, el plano del suelo adquiría una nueva dimensión por el juego alfombra+mesa+objetos. Un muro con forma de "L" que dividía el apartamento desde la entrada, ilustraba esta investigación en una progresión de dibujos grabados en vidrio al ácido: lo planimétrico, lo volumétrico y lo lineal.

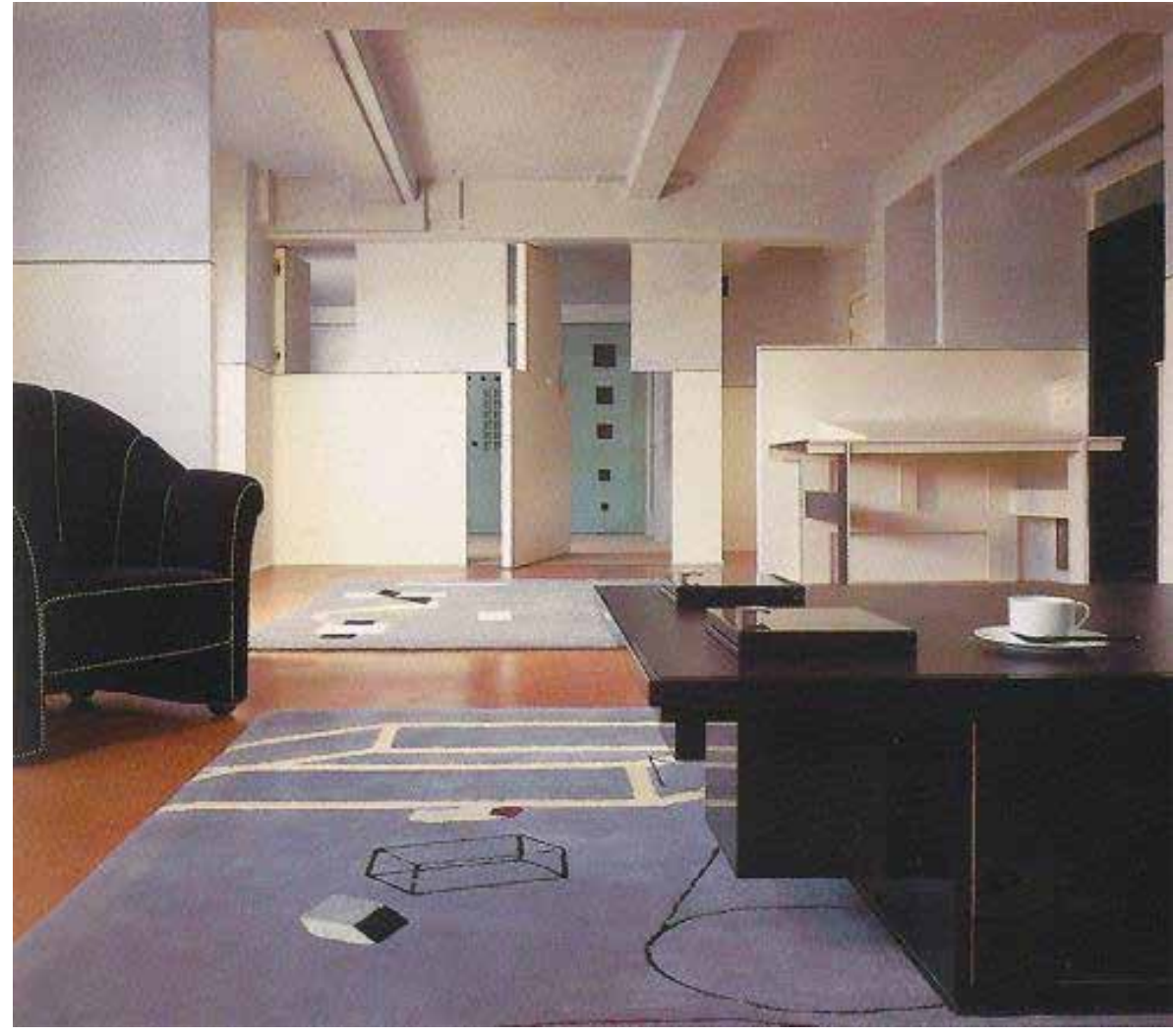

La casa de Moore - Moore/Andersson, 1984- en Austin, Texas, se convierte en el mejor ejemplo de cómo la fusión entre casa y objetos puede producirse a través de una invasión masiva de objetos. En un sistema de relación de superposición de capas sucesivas, se iba conformando una especie de segunda piel del edificio. Los intersticios entre capas eran una buena excusa para introducir más objetos.

El complejo en Austin comprendía dos casas y dos estudios. El reto fue compaginar las necesidades de grandes espacios de estudio y convivir con la escala de las casas del entorno. Para disminuir la escala del conjunto se dividieron los espacios de estudio y residencia en varios pequeños edificios

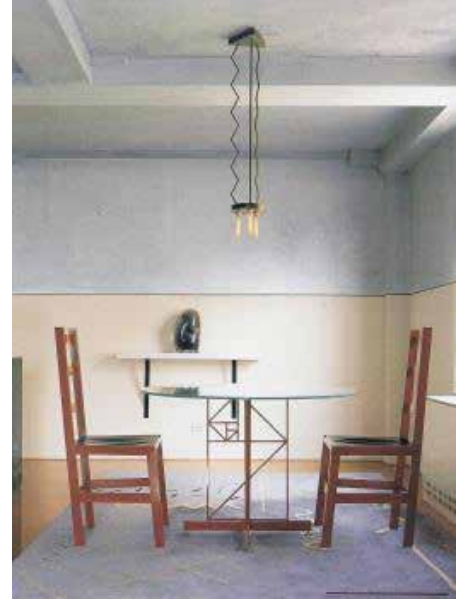

Imágenes: Apartamento Cohen, Nueva York. Steven Holl, 1983 


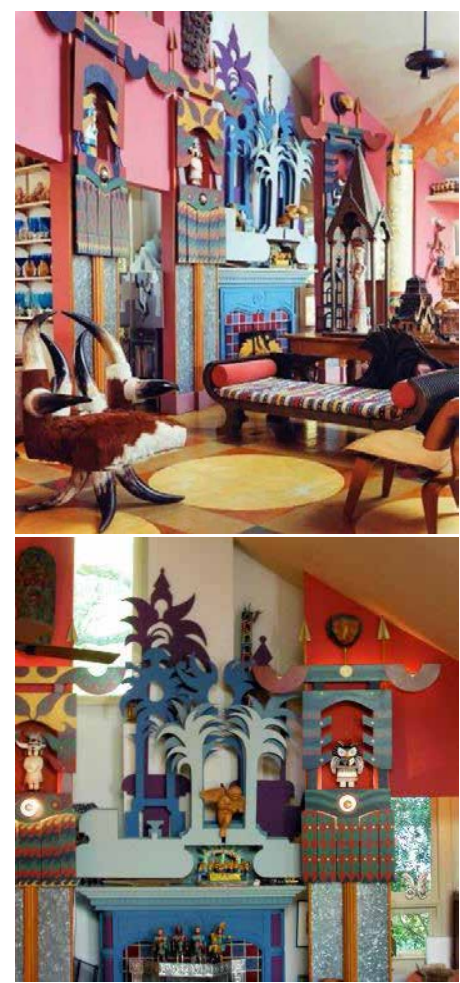

1985. Moore / Andersson Compound. Austin, Texas. Moore / Andersson ArchitectsVista de los talismanes diseñados por Schinkel para la escenografía de la escena de 'La reina de la noche'. A la derecha, esquema en planta de la modulación creada por la posición de los talismanes en la casa de Moore.

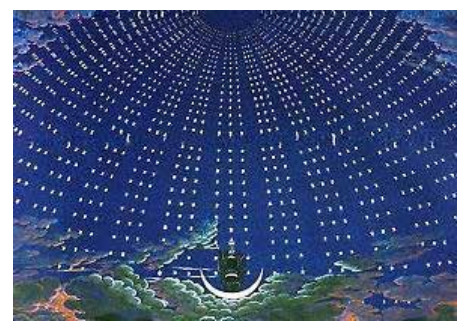

Imagen: K.F.Schinkel. Escenografia para ópera La Flauta Mágica, en la Royal Opera Berlin, 1816. Escena de 'La Reina de la noche'. organizados alrededor de un patio central y una pileta de $14 \mathrm{~m}$ de largo. "El patio y los interiores de los estudios y las casas fueron donde pudimos fomentar la magia", decía Moore. Una gran elipse iba desde la casa de Moore, cortaba a través de la casa de Andersson y luego viraba hacia afuera para formar la pared trasera del patio. La sección de elipse de Moore estaba compuesta por una amalgama de estanterías llenas de libros, juguetes folklóricos, objetos pertenecientes a diferentes colecciones personales, y una serie de talismanes de Friedrich Schinke ${ }^{91}$, adquiridos por Moore en una subasta, sobre unos escudos diseñados y pintados para ello. El estudio aparece poblado de columnas pintadas que imitan las de azulejos del Palau de la Música de Barcelona de Domenech i Montaner, pero con astas de alce. "En el recinto de Austin esperamos hacer un mundo donde drama y sorpresa se esconden en un movimiento de afuera hacia dentro a través de una cambiante serie de imágenes"92.
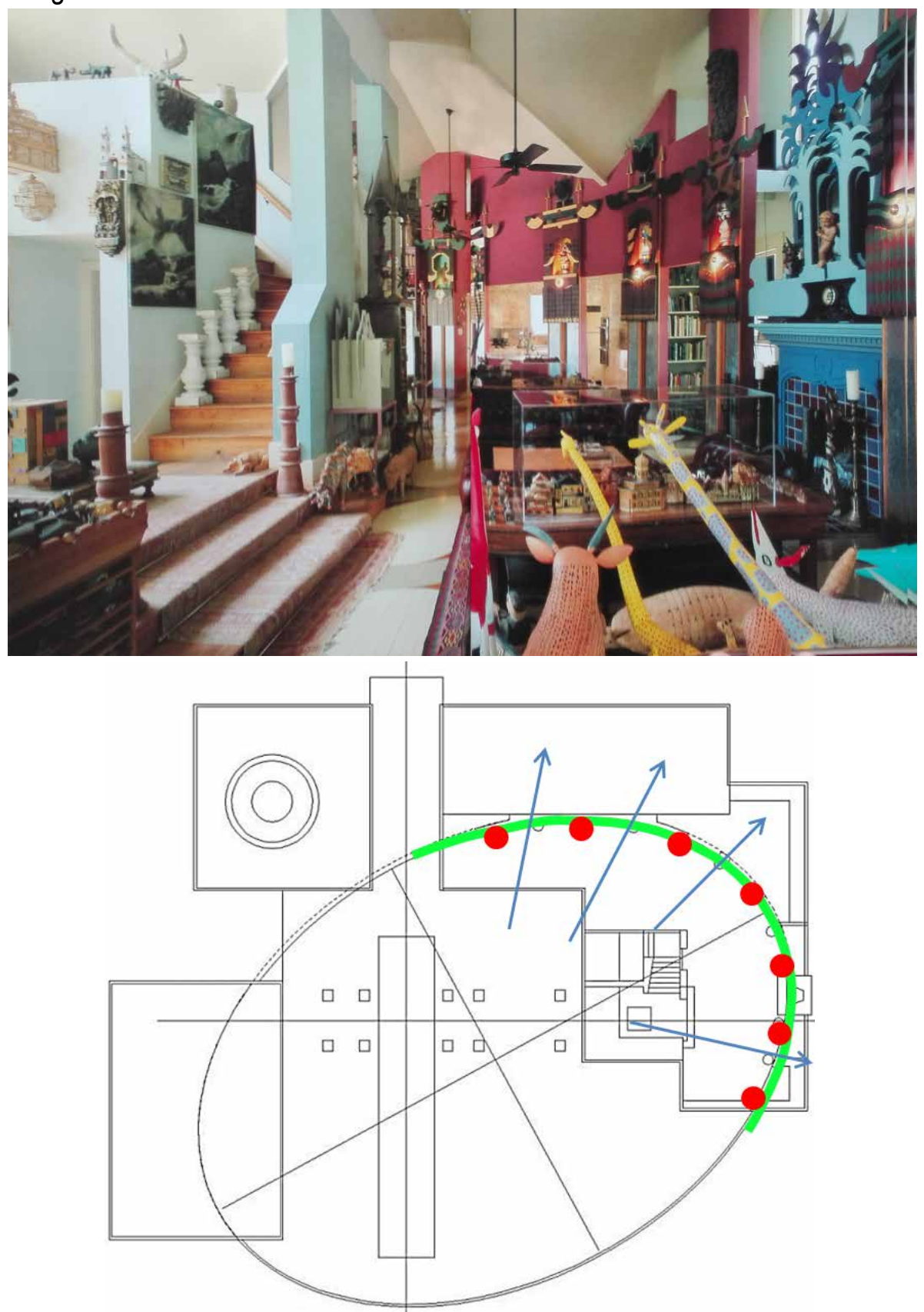

91 Escenografia diseñada por K. F. Schinkel para ópera La Flauta Mágica, en la Royal Opera Berlín en 1816.

92 Óscar Riera Ojeda, "Casa Camino Quarry" en Moore, Ruble, Yudell: Viviendas (Buenos Aires: Kliczkowski, 1994) p.52-63. 
El diseño de la casa podía estar condicionado por una colección, desde el primer esbozo del proyecto, como es el caso de la casa Rosenak, realizado por Hugh Newell Jacobsen en 1987 en Tesuque, Nuevo Mexico1987. Todo giraba en torno a la exposición de la colección de los propietarios de una mil piezas de arte folk norteamericano. Incluso el tratamiento de la fachada, conscientemente colorista, reflejaba el lugar de origen de las piezas y de la ingenuidad, independencia y, a veces excentricidad, del arte folk americano.

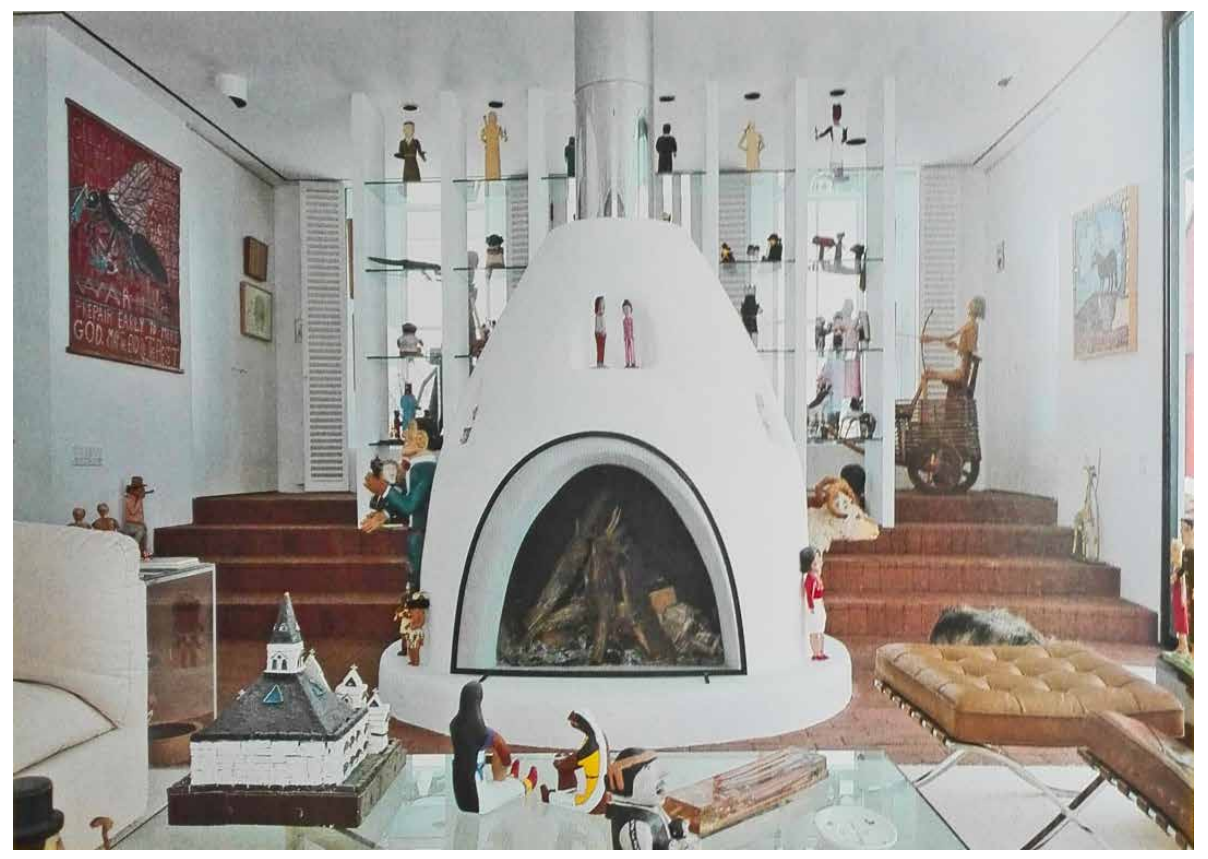

En otras ocasiones, la fusión se producía por el propio carácter del espacio, que conseguía que los propios objetos acabaran mimetizándose y colaborando en la representación del 'espíritu del lugar'.
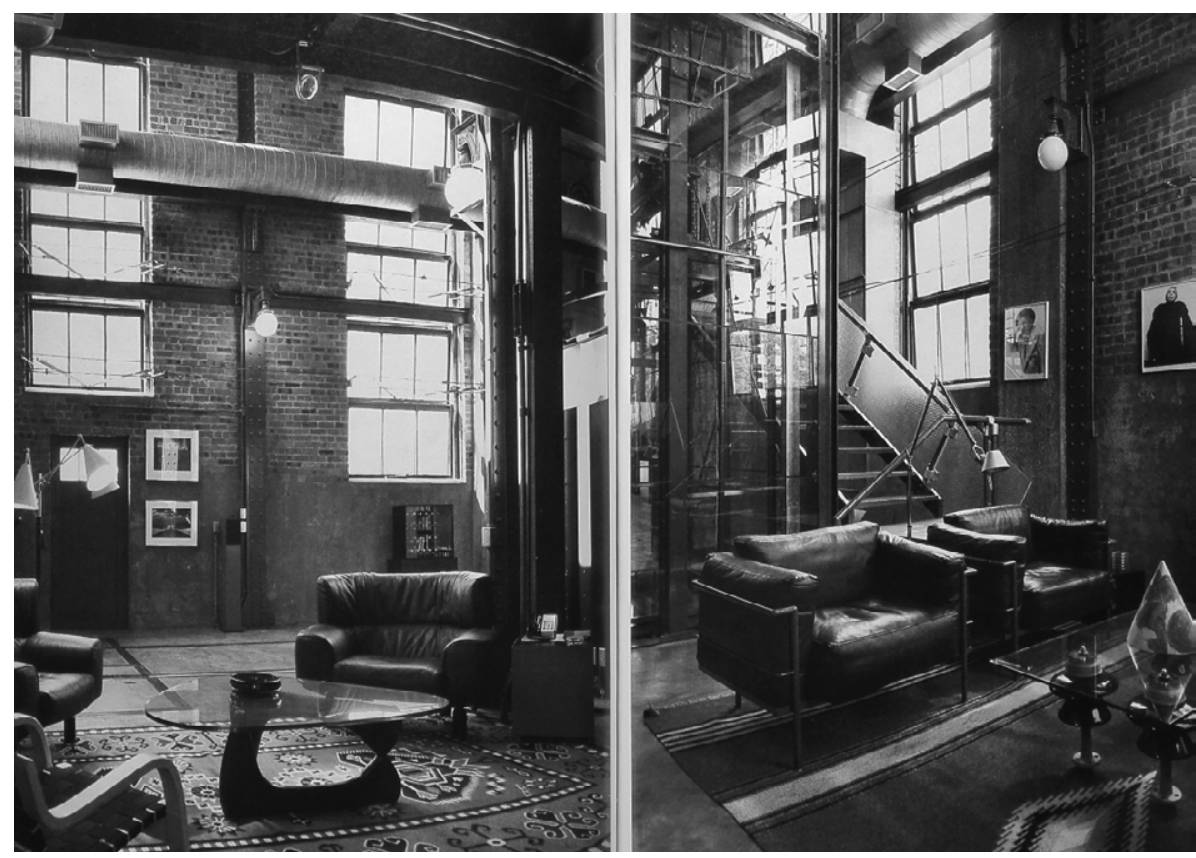

Imagen: Casa Rosenak Tesuque, Nuevo Mexico. Hugh Newell Jacobsen, 1987

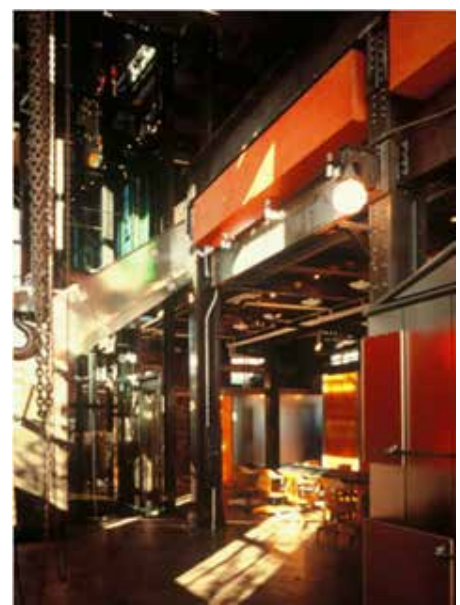

Imagen: Power House. Dallas, Texas. Cunningham Architects, 1988. 
El proyecto, denominado 'Power House' de Cunningham Architects-1988-, era una casa que surgía de la reconversión de un edificio industrial de Dallas de 1920, el 'Dallas Power Light Substation'. El programa incluía las necesidades domésticas típicas de una vivienda así como una sala de baile en la $3^{a}$ planta, una escultura en el jardín y un garaje para tres coches y varios cuartos trasteros. Sin embargo se quiso que actuación mantuviese el carácter industrial del edificio conservando el espíritu de lo que había sido. La fase de limpieza del edificio existente pronto se convirtió en una especie de 'excavación arqueológica'. Se salvaron y recuperaron materiales, accesorios y objetos con la intención de su posible reutilización.

En la fase de diseño, se decidió respetar la fachada, y se mantuvo la calidad espacial del edificio. Para respetar al máximo el contenedor de origen industrial, se colocaron en su interior una serie de nuevas estructuras autónomas que albergaban varias funciones dentro. Estas nuevas estructuras definían las distintas áreas de la casa, básicamente los espacios más privados, incluidos el dormitorio ppal. Los otros dos, más pequeños, ocupaban la entreplanta. Dispuestos de forma libre, ocho volúmenes de bloques de hormigón que contenían los baños y los armarios, separan la zona semipública, galeríabiblioteca, de las habitaciones. En la tercera planta, una sala de baile, diáfana, era un espacio multiusos con superficie suficiente para performances 0 conciertos de música de cámara. 


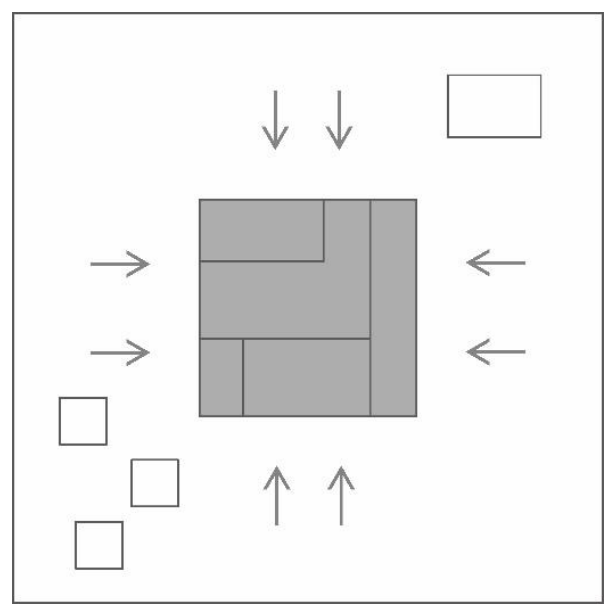

\subsection{LAAGRUPACIÓN Y EL ESPACIO FONDO}

Este sistema de configuración que consistía en agrupar y organizar la mayoría de los elementos de equipamiento, pasando de un conjunto de elementos a un gran objeto situado generalmente en el área central del ámbito, liberaba el resto del espacio de sus 'dominios' y lo mantenía como una habitación pura y simple, como un gran escenario, como decía Moore, preparado para la acción diaria. La agrupación, influida por la necesidad de concentrar y restringir los espacios de uso, estuvo influida por los avances en la producción industrial de los propios elementos y de las instalaciones de la casa -recordemos la Un-home de Reyner Banham, cuyo standard for living estaba basado en este principio- que ofrecían la posibilidad unirlos todos o parte consiguiendo células que fueran más fáciles de incorporar a un espacio existente, o que lo liberasen.

Imagen: 'Square Plastic System'. Joe Colombo, 1969. Producido por Elco Bellato en 1970, y fabricado en plástico ABS en módulos de $42 \times 42 \times 60 \mathrm{~cm}$.

Square Plastic System era un sistema de contenedores apilables formados por seis elementos: estructura, cubierta, cajón, panel de apoyo para suelo, cierre enrollable grande y cierre enrollable pequeño. Su combinación ofrecía múltiples variaciones: abierto 0 cerrado, con ruedas o con patas, como archivador, como estantería vertical, haciendo de elemento separador de espacios o agrupándose creando bloques aislados de almacenamiento ${ }^{93}$.

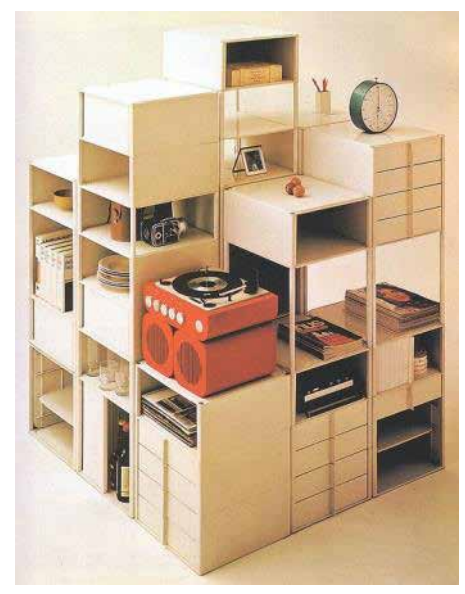

Volviendo a Moore, la agrupación sin embargo no era una necesidad absoluta, pero se consideraba que había buenas razones para agrupar fregaderos, baños, lavabos y otros elementos como armarios, electrodomésticos y sistemas multimedia aunque en muchos de los casos esas intenciones fueran más conceptuales que económicas.

Según Imma Forino ${ }^{94}$ respecto a sistemas constructivos tradicionales, los primeros ejemplos de concentración de servicios en el centro de una planta libre de habitaciones lo constituyeron la casa Farnsworth ${ }^{95}$ de Mies van der Rohe y la Glass House de Philip Johnson (1949, New Canaan, Connecticut). En la Glass House el baño se concentraba en un cilindro que era el único

93 Mateo Kries. Editado por. Joe Colombo. Inventing the future. (Weil am Rheim: Vitra Design Museum, 2005) p.239.

94 Imma Forino. L'interno nell'interno. Una fenomenologia dell'arredamento. (Florencia: Alinea Editrice. 2001) p.72.

95 1947, en Plano, Illinois. 
Imagen: Unidad de Amueblamiento Total, Total Furnishing Unit . MoMA, Nueva York. Exposición: Italy: The new domestic landscape. Joe Colombo 1972. elemento macizo en una casa concebida como un volumen transparente. La casa era comparable a una caja transparente colocada de manera estratégica en el paisaje. "La casa de vidrio abierta y la caja cerrada no eran más que habitaciones visibles en un reino doméstico mucho mayor, conceptual e invisible". La piel transparente de la casa se convertía en un fondo, que en realidad era el paisaje.

El boom del plástico de los sesenta y la revolución de la producción industrial por los nuevos materiales dieron un vuelco a la investigación sobre bloques tecnológicos de servicios que se transformaron en un auténtico macro-objeto autónomo respecto al espacio que le rodeaba. Con el poliéster reforzado con fibra de vidrio se consiguió que toda una célula de baño fuera prefabricada. Como el bloque de baño de Visiona de 1969, de Joe Colombo, que era una auténtica isla funcional en poliéster reforzado con fibra de vidrio, o para la exposición Italy: The New Domestic Landscape, celebrado en el MoMA de Nueva York en 1972, donde concentraron todos los equipos necesarios de la casa, incluido el baño, en un bloque compositivo llamado Total Furnishing Unit. Un solo bloque compuesto por una célula de cocina, de baño, armario y dormitorio, que podían separarse y desplazarse libremente y combinarse de múltiples maneras en muchos o pocos metros cuadrados.

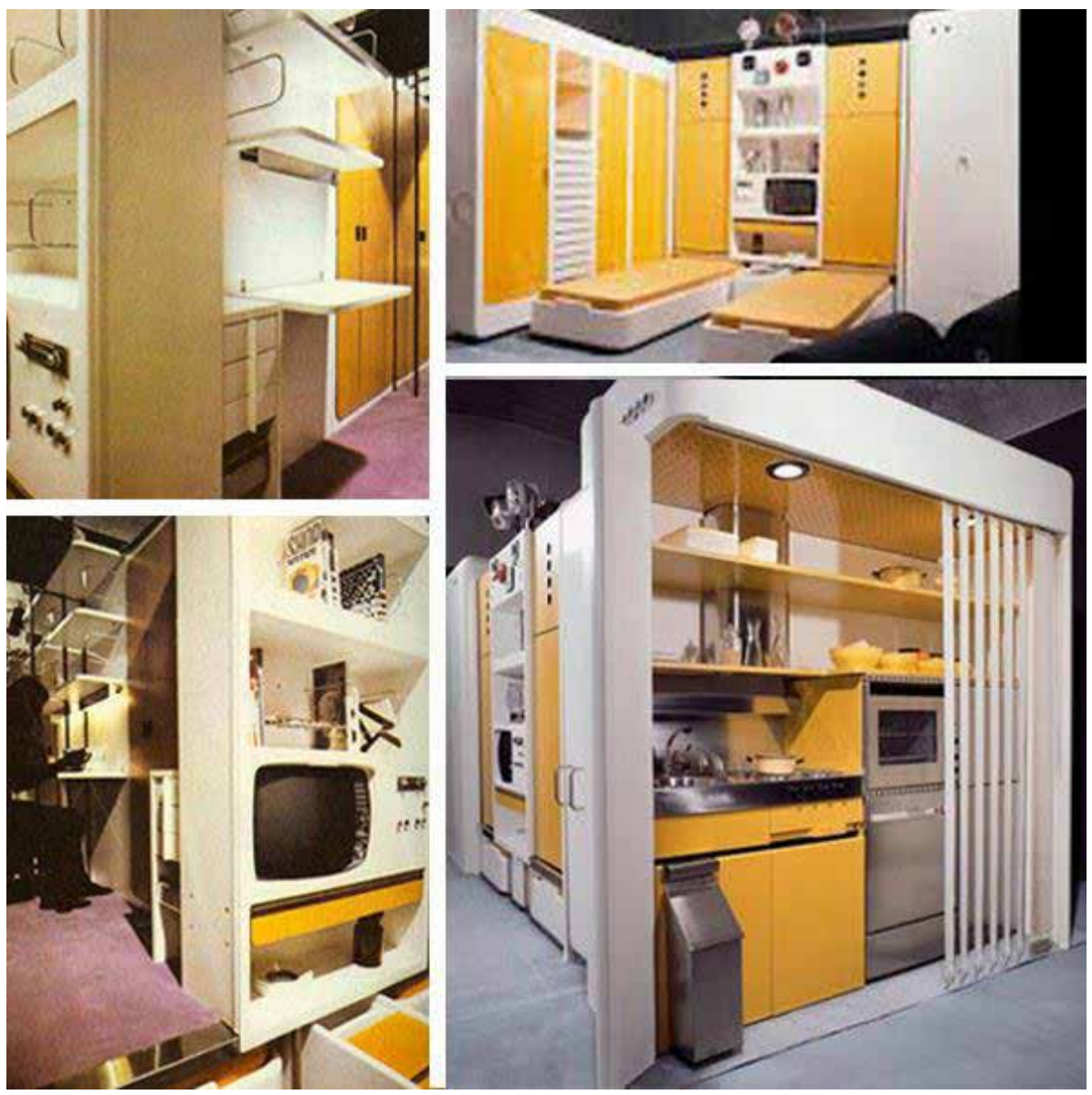

Todas las células funcionan de acuerdo al momento en que se usan. Mientras la cocina y el baño sirven solamente para la función a la que han sido creados, el armario también funciona como elemento de separación entre la entrada y la zona de noche cuando se utiliza. El dormitorio engloba distintas funciones desde dormir, comer, recibir amigos, entrar o retirarse privadamente a un espacio interior específicamente diseñado para ese fin. Todo ello en plástico y diseñado para ser producido en serie y cuya finalidad principal era poder 
colocarse en cualquier espacio, el resto del cual quedaría liberado.

En el complejo de diez apartamentos Sea Ranch Condominium -1964-, en Sea Ranch, California, de los arquitectos MLTW, todas las unidades contaban en su propio espacio interior 'dos pequeñas casas' construidas en madera, una de las cuales cubría el salón en la planta baja, y estaba conformada por cuatro pilares que sostenían una especie de entreplanta que era el dormitorio; y la

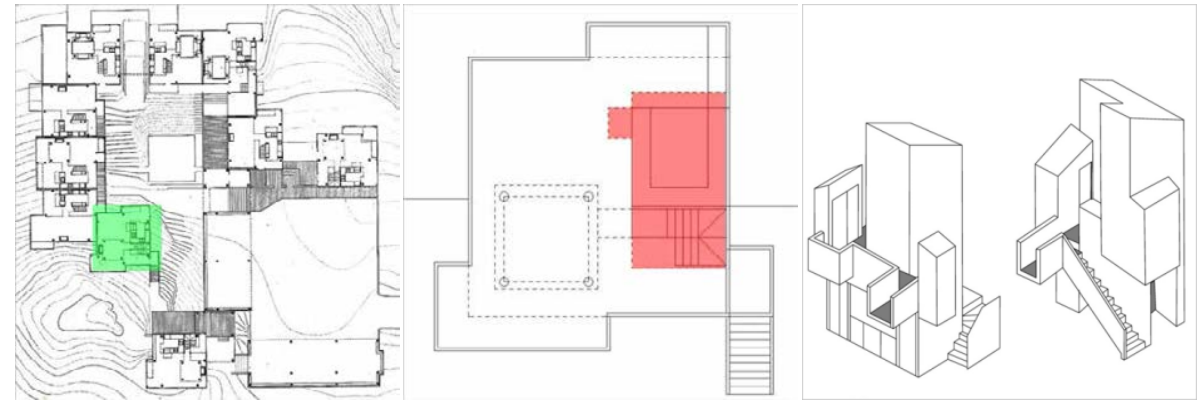

otra era un volumen de colores vivos con cocina, escalera v servicios en dos

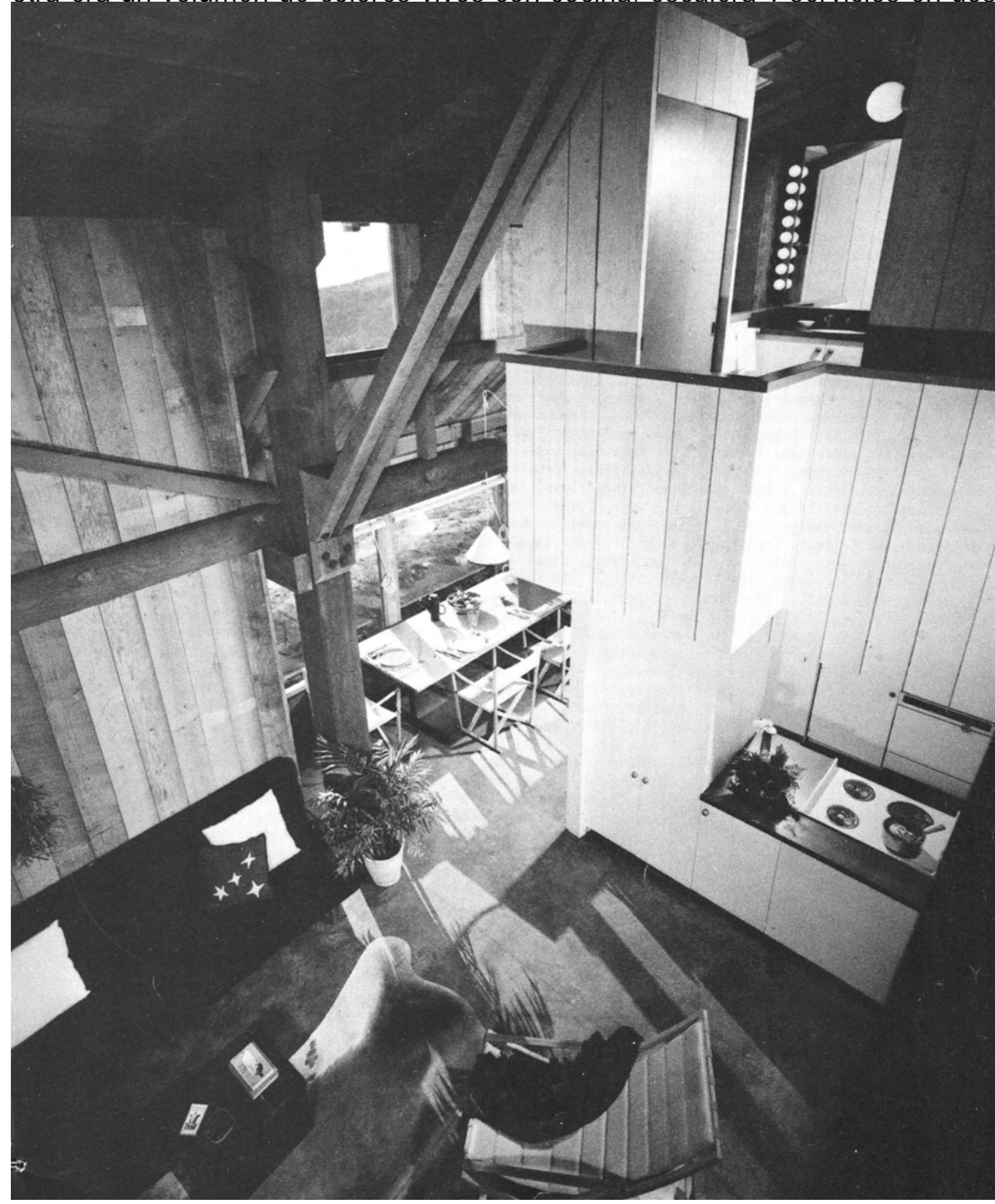

niveles, un cuerpo variadamente articulado con nichos y aberturas.

Sea Ranch Condominium consistía en diez apartamentos con torre, patios, miradores y solarios. Organizados en torno a dos patios comunes y de cara a un predominante y fresco viento del nordeste. Los patios aparecían rodeados de cubiertas que se inclinaban hacia el mar, siguiendo también la marcada
Imagen: Sea Ranch Condominium. Sea Ranch, California. MLTW,1964.

De izquierda a derecha: planta general del conjunto; planta tipo con la torre de equipamientos; axonometría de las torres de equipamientos, tipo1 y tipo 2.

Imagen: Sea Ranch Condominium. Sea Ranch, California. MLTW, 1964. Vista del interior de uno de los apartamentos, donde se aprecia la torre de equipamientos, en madera pintada que se diferencia del resto, de madera en acabado natural- 


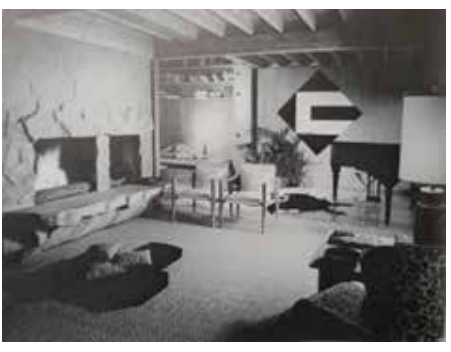

topografía en descenso hacia la costa. El principio fundamental según los arquitectos fue crear una imagen de lugar a través del territorio. El segundo principio fue que la modulación y los elementos constructivos y acabados exteriores, correspondieran con los de las construcciones de graneros y granjas locales, fachadas de madera vista e interiores de madera cepillada y pintada. El marcado carácter paisajístico del proyecto se apreciaba también en el interior de las viviendas. Cada vivienda se componía de un gran espacio que alberga dos pequeñas casas, un edículo formado por cuatro postes y un dormitorio encima, y una especie de torre que contenía los elementos de equipamiento, la cual estaba pintada en colores vivos, no como el resto. Aplicando el principio gestáltico de figura fondo, aquel elemento que emergía con voluntad de distinguirse de su entorno inmediato, cumplía dos requisitos compositivos muy importantes en este proyecto. Por un lado liberaba al resto del espacio, asimilándolo a la tipología del antiguo granero y por otro lado, conseguía que el espacio que lo enmarcaba, el espacio interior, adquiriera el significado de fondo, de 'paisaje interior', aumentando su perspectiva y prolongando psicológicamente la visión hasta el mar.

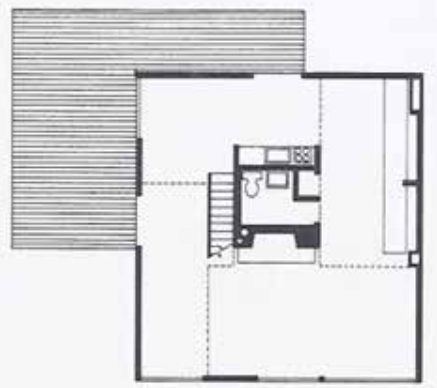

Imagen: Casa Karas. Monterey, California. MLTW, 1967

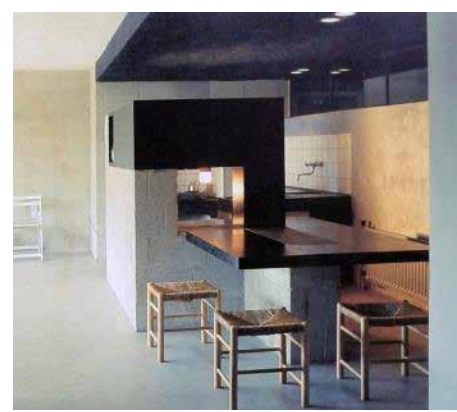

Imagenes: Residencia de estudiantes Amsterdam. Herman Hertzberger, 1967

Imagenes: Casa Fultz. Chesterton, Indiana. Hammond, Beeby \& Babka. 1970

En la casa Karas de Monterrey, otro proyecto de MLTW, de 1967, un volumen central, que liberaba el resto del espacio, incluía tanto los servicios como la cocina y la tradicional chimenea, con acabados en piedra que dotaban al conjunto interior de una mayor cualidad 'paisajística'.

La casa Karas en Monterrey tenía una máquina justo en el centro, decían los arquitectos. Los Karas les pidieron un diseño que les permitiese 'libertades espirituales' imposibles en su vieja casa. La casa tenía una planta compacta y casi cuadrada. En la planta baja un espacio cuadrado de habitaciones rodeaba un bloque de una planta de altura -la máquina- donde iba la chimenea, un aseo, una pequeña cocina, una escalera y un horno. La casa contaba con gran altura, por lo que el volumen central se evidenciaba mejor del resto. En el muro norte, una ventana encima de las altísimas librerías daba a una caja pintada de blanco que reflejaba la luz del sol hacia el interior. Un círculo pintado de amarillo intenso actuaba como sucedáneo del sol, sorprendiendo doblemente por estar en el lado norte y en un bosque tan nebuloso y frí ${ }^{96}$.

Herman Hertzberger, en la Residencia de Estudiantes de Amsterdam, de 1967, también agrupaba los equipamientos en la zona común del edificio, que alojaba a más de docientos estudiantes en la ciudad de Amsterdam. Existían amplias áreas de estar donde se podía cocinar, comer y otro tipo de actividades. Cuanto más agrupadas estuvieran las máquinas que daban servicio a estas actividades mayor sería el espacio liberado de las zonas comunes.

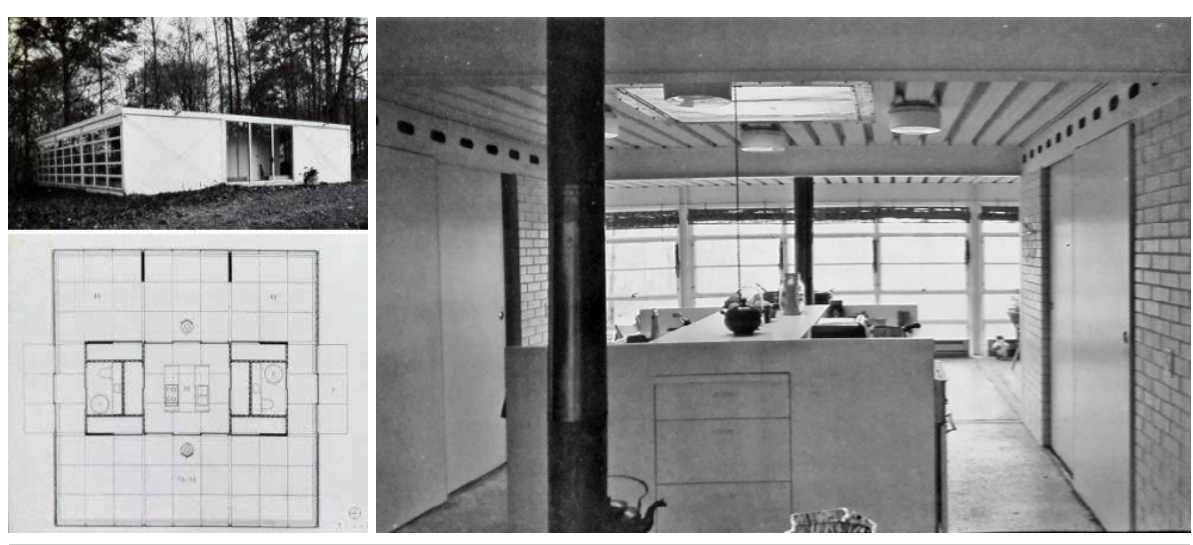

96 Charles Moore, Gerald Allen, Donlyn Lyndon. La casa: forma y diseño. (Barcelona: Gustavo Gili, 1999) p.171. 
Esto se producía también pro de manera más sistemática y modular, en la casa Fultz, en Chesterton, Indiana de Hammond, Beeby \& Babka, 1970. En medio de un bosque, como vivienda de fin de semana y posteriormente como residencia permanente. La casa es un cubo de estructura modular industrial con cubierta de chapa de acero grecado, fachada de panel industrial, pavimento de acero pintado y ventanas también de acero. Los bloques de baños y armarios, de ladrillo, se situaban exentos en el centro de la planta flanqueando la cocina, y se unían a los paramentos de fachada con puertas correderas para liberar el espacio y evitar particiones.

La agrupación de equipamiento y servicios, en la búsqueda del espacio como fondo, y como doble telón: el paisaje exterior, generándose varios niveles de fondo. 


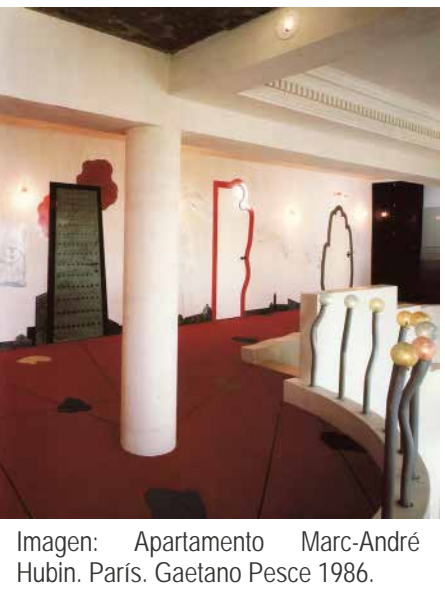

La creación de recorridos dentro del hábitat, la invitación a descubrir, a la exploración, se podía generar a través de la disposición de diferentes puntos de referencia o hitos, que a su vez estuvieran relacionados por medio de pasos, uniones y escaleras, y crearan recorridos. El placer del movimiento en el interior del espacio doméstico surgía como en una escenografía interna, pudiendo girar en torno a algo, o pudiendo mirar de una habitación a otra.

Esta forma de entender la casa fue un campo de exploración, característico, del espacio doméstico contemporáneo. Sistemas, incluso con cualidades yuxtapuestas, en su mutua contraposición o en su similitud, podían formar pequeños 'lugares' interiores gracias a su capacidad para producir secuencias a lo largo de toda la casa. A través de una relación de sucesión de objetos en el espacio, basada en la ubicación estratégica de artefactos, señales y puntos de referencia, la idea era que se generasen canales de conexión a lo largo de la topografía interior, que provocaran el movimiento del cuerpo de los habitantes, recreando sensaciones similares a las que se podría tener cuando se pasea uno por un bosque o se circula por la ciudad.

La idea para analizar el espacio doméstico desde las relaciones de sucesión de objetos, que provocan movimientos o visuales, y que permiten tener un conocimiento del lugar a través de dicha experiencia, parte de dos principios fundamentales: del concepto de 'lugar' en arquitectura y de la consideración del movimiento del cuerpo en un espacio topológico como base de proyecto.

Según Norgerg-Schulz ${ }^{97}$, a partir de la II Guerra Mundial, varios arquitectos pusieron en marcha nuevas interpretaciones de la planta libre, una de ellas fue el enfoque de 'lugar' en arquitectura. Este enfoque era fenomenológico, y su propósito era proporcionar lugares donde la vida pudiera "tener lugar"98. Para Norberg-Schulz un lugar era un entorno concreto que poseía orden y carácter, e iba implícito a la propia esencia de habitar. No tenía sentido hablar de la vida por un lado y del lugar por otro.

El equipo MLTW -Moore, Lyndon, Turnbull y Whitaker- era de particular interés en este contexto ${ }^{99}$, ya que su forma de pensar el espacio ya no estaba basada en términos geométricos, sino que se entendía como una interrelación

97 Christian Norberg-Schulz. Los principios de la arquitectura moderna. (Barcelona: Reverté, 2005) p.65.

98 Ibídem, p.12

99 Christian Norberg-Schulz. Los principios de la arquitectura moderna. (Barcelona: Reverté, 2005) p.68. 
de 'elementos de lugar' sometidos a un orden en dicho espacio y que proporcionaban oportunidades para que ocurrieran cosas.

De este modo, la planta libre se ha convertido en lo que originalmente se pretendía que fuese: una manifestación concreta de la simultaneidad de los lugares y, con ello, del modo de vida moderno

\section{Christian Norberg-Schulz ${ }^{100}$}

Charles Jenks ${ }^{101}$, para explicar esta idea, utilizaba como ejemplo un proyecto de Charles Moore: Kresge College, una residencia de estudiantes para la Universidad de California en Santa $\mathrm{Cruz}^{102}$, donde la idea de lugar, en un complejo de edificios que sugería la imagen de un pueblo mediterráneo, la desarrollaba a través de metáforas públicas.

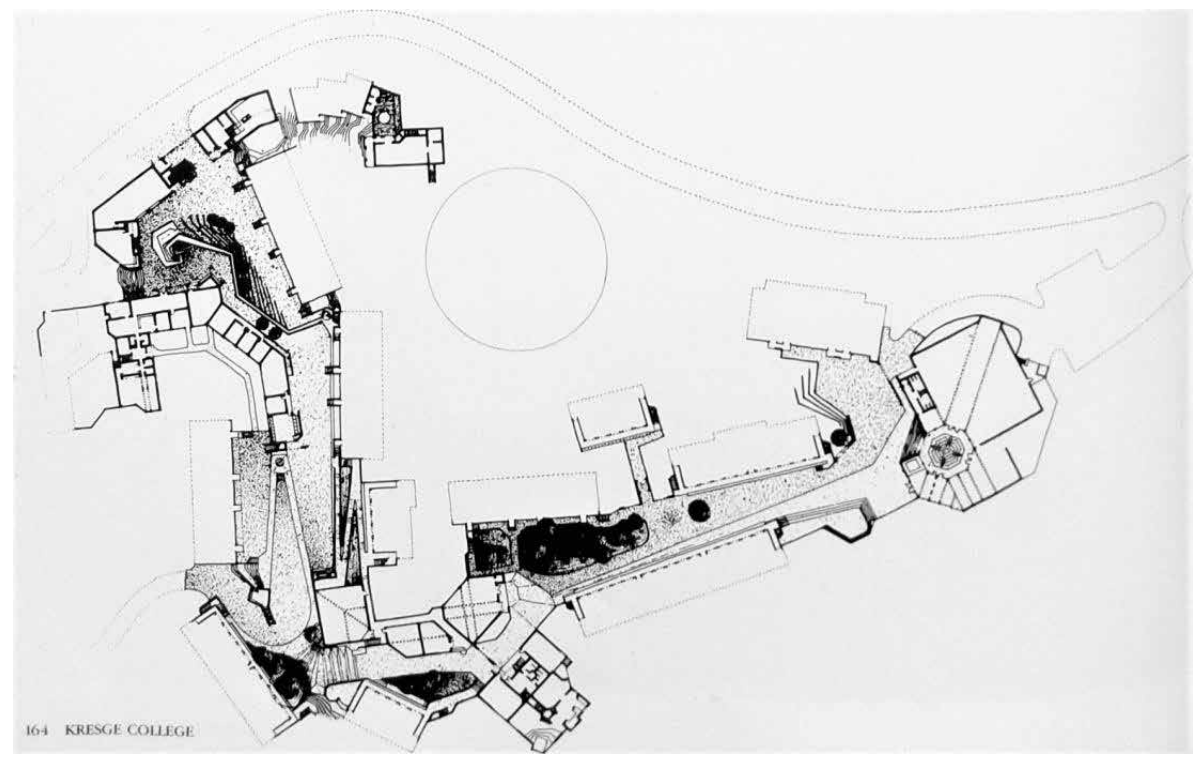

Una ruta serpenteante que discurría a través de un bosque, sorteando de pinos, creaba el recorrido a través de la relación secuencial de un sistema de 'antimonumentos': correos, lavandería, cabinas telefónicas, etc. Cada hito tenía una plaza y la sucesión de espacios públicos a lo largo del recorrido creaba una serie, en la cual cada monumento aislado definía un 'lugar'.

La idea de 'lugar' se enfatizaba creando actividades opuestas en los dos extremos del proyecto. En uno estaban correos y la entrada; en el otro de los extremos estaban los comedores y lugares de reunión. Así la calle se usa mucho y mantenía a los estudiantes yendo de un lado para otro.

Los 'antimonumentos' iban proporcionando señales a lo largo del recorrido, anticipando su presencia a través de supergráficos o formas llamativas. La presencia de esos focos de atención inducían al movimiento, aunque luego el contenido fuera banal.

En los interiores, como en la biblioteca, también era importante la presencia de puntos de atención.

\footnotetext{
100 Ibídem.

101 Charles Jencks. El lenguaje de la Arquitectura Posmoderna. (Barcelona: Gustavo Gili, 1980) p.125.

102 Kresge College. Universidad de California en Santa Cruz. Por Charles W. Moore Ass. y MLTW/ Turnbull Ass. en 1973
}

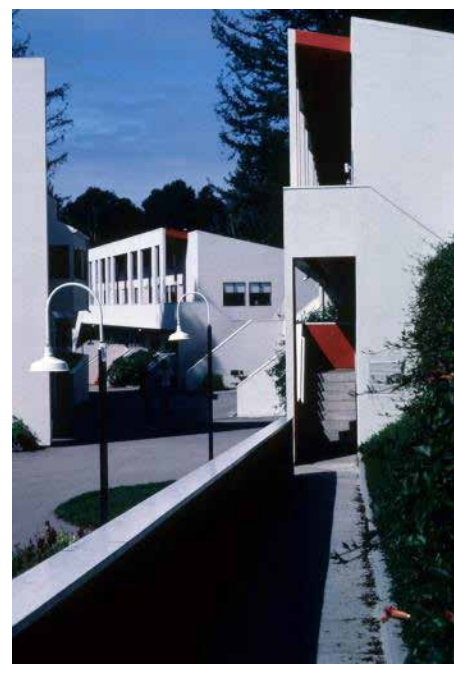

Imagen: Kresge College. Universidad de California. Santa Cruz, California. Charles W. Moore Ass. y MLTW / Turnbull Ass. 1973. Planta general del complejo. Arriba, vista de la calle que recorría el conjunto. 


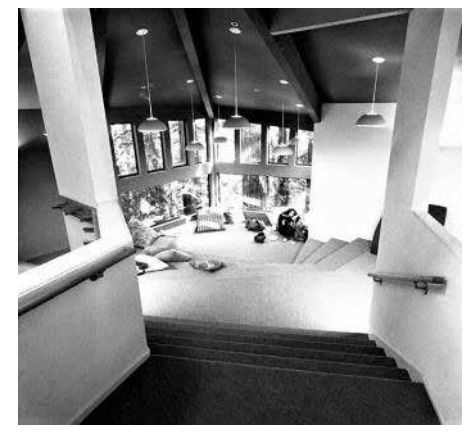

Todos los estudiantes estarán allí juntos cuatro o cinco años. Por tanto nos pareció importante establecer no un grupo de monumentos institucionales, sino más bien hacer un conjunto de monumentos triviales, de cosas que funcionaran como vías de relación.

Charles Moore ${ }^{103}$

Según Jenks, el 'lugar' era el resultado no sólo de las fuertes imágenes que surgían a lo largo del recorrido, sino de la cuidadosa distribución de las actividades.

Imagen: Kresge College. Vista interior de la sala de lectura de la biblioteca.

"El espacio se derrama desde la biblioteca en una cascada de escaleras que enfocan al rincón y a los pinos gigantes que hay más lejos -el típico espacio oblicuo posmoderno ${ }^{104}$

Charles Moore ${ }^{105}$, como en Kresge College, también utilizó la metáfora de la ciudad al interior de la casa. No tenía por qué haber una diferencia esencial entre cómo nos orientamos en el universo de una metrópolis y cómo lo hacemos en el interior de una casa. Para Moore las mismas cualidades de orientación y sensibilidad que se aplicaban a la casa podían tener su analogía en la ciudad. Un objeto doméstico de cierta importancia, como un reloj de pared, podía entenderse también como un hito urbano en forma de torre coronada por un reloj, decía.

Estos objetos funcionaban como elementos inductores, como puntos de atención -como los antimonumentos de Kresge College-: un solo foco congregaba en sí la atención, estructurando el espacio en torno a un solo centro de interés, como una chimenea o un sofá, incluso alrededor del mismo, y los focos múltiples inducían al movimiento tanto del cuerpo como de la mirada, generando recorridos y visuales. Para Moore en realidad, el sistema de orientación y el sistema háptico, eran los que en mayor medida servían para su entendimiento de la tridimensionalidad, es decir, eran "el sine qua non de la experiencia arquitectónica"106.

La casa Burns, de Charles W. Moore y Richard Chilinsky, realizada en Santa Mónica, California en 1974 para un profesor de la Universidad de California, representa perfectamente los dos principios a los que se hacía referencia, por un lado la consideración de la idea de lugar dentro del edificio y por otro lado, la presencia de múltiples focos de atención que generan recorridos e inducen al movimiento y a la percepción de diversos encuadres y perspectivas. Estos trayectos generaban la sorpresa, el giro, la vuelta en cada esquina y en cada rincón, algo que Charles Jencks ${ }^{107}$ incluso relacionaba con aspectos pintorescos. Aunque también relacionaba la metáfora del 'lugar' como resultado de la cuidadosa distribución de las imágenes que se producían en esta casa. Cada imagen que aparecía por el camino -un balcón mexicano, un órgano

103 Charles W. Moore et al. "Dossier: Charles Moore". L'Architecture d'Aujourd'hui (n¹84, mar/ abr-1976).

104 Charles Jencks. El lenguaje de la Arquitectura Posmoderna. (Barcelona: Gustavo Gili, 1980) p.126.

105 Charles W. Moore y Kent C. Bloomer. Cuerpo Memoria y Arquitectura. Introducción al Diseño Arquitectónico (Madrid: Blume, 1982) p.63.

106 Ibíd. p.46.

107 Charles Jencks. El lenguaje de la Arquitectura Posmoderna. (Barcelona: Gustavo Gili, 1980) p.126. 
con forma de altar, el rincón de la chimenea- era el principio, el foco de la atención visual y luego, a causa de la iluminación indirecta, se convertía en un mero pretexto para más descubrimientos. El paseo por la casa estaba lleno de sorpresas.

Las imágenes corporales sólo aparecen en el interior y tienen que ver con la colocación de ciertas señales de posición dentro de una especie de dominio en el que las personas se mueven y se encuentran a gusto.

\section{Kent C. Bloomer y Charles W. Moore ${ }^{108}$}

La presencia de la escalera de dos tramos, con nichos y libros recubriendo sus paredes como en los estudios victorianos, se sentía profundamente en todos los lugares de la casa, con su tramo recto -que subía al desván- y sus tramos quebrados que ascendían serpenteando por el espacio situado bajo la cubierta. Adaptándose a la forma de la escalera en su encuentro con el suelo, se colocó un banco de asiento irregular y blando delante de la chimenea -su cualidad de 'algo blando' era contradicha inmediatamente por su remate redondeado que evocaba los rígidos asientos propios de los vestíbulos de los hoteles de principios del S.XX.
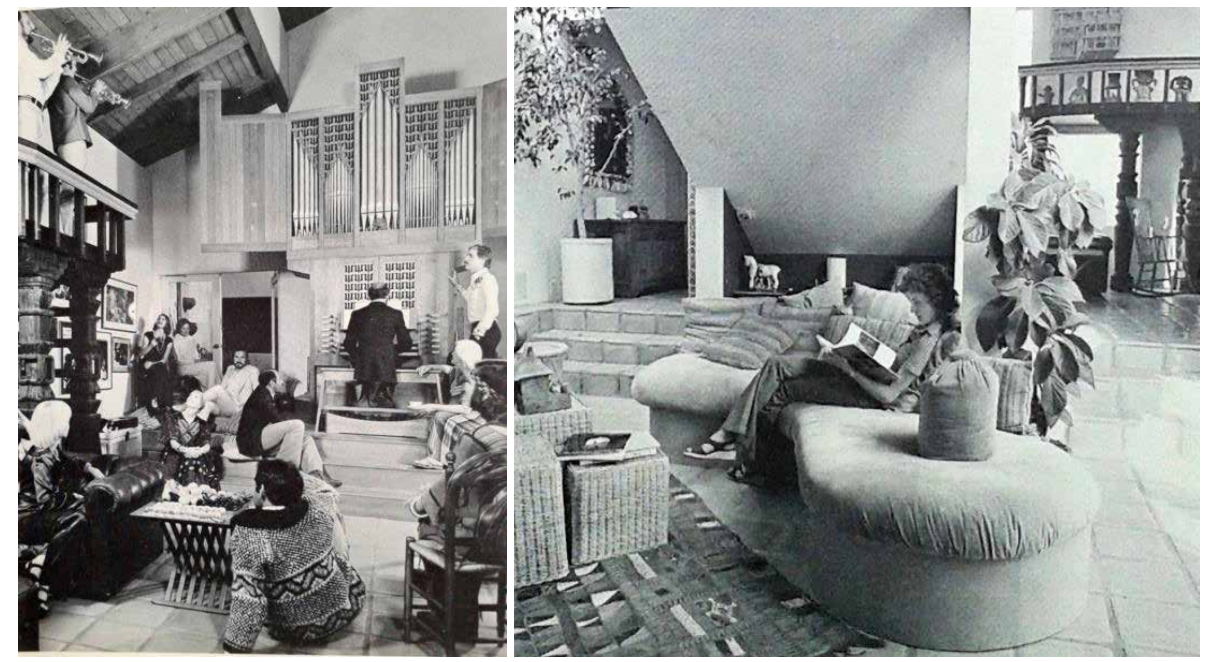

A pie de la escalera aparecía la sala del órgano, que era el alma de la casa. El órgano hacía el papel de símbolo de la mente ${ }^{109}$ y a la vez era el foco de mayor atención en todo el recorrido.

La estratificación de las paredes recortadas aumentaban las perspectivas. Muchas estaban colocadas en ángulos oblicuos con lo que se producía un sentido provocado de desorientación. A medida que el recorrido avanzaba por la escalera, la mirada hacia atrás revelaba una distorsión perspectiva de tal complejidad que se perdía la visión de la disposición de los objetos. Mientras que el camino seguía hacia delante, la ruta se dividía para luego ensancharse, creando una perspectiva inversa.

Al final de la escalera cabría esperar que se llegaría al lugar sagrado, al cubil del profesor, pero no, a su fin el trayecto devenía un vestidor Art Déco. "Desde México, pasando por la iglesia con su órgano y por una escalera de ático, hemos llegado a un tocador de teatro hollywoodiense (...) Las imágenes y la disposición eran totalmente inesperadas (...) Por todas partes hay detalles de color y forma dispuestos a ser descubiertos, trampas que podían de repente

108 Charles W. Moore y Kent C. Bloomer. Cuerpo Memoria y Arquitectura. Introducción al Diseño Arquitectónico (Madrid: Blume, 1982) p.139.

109 Ibíd. p.142.

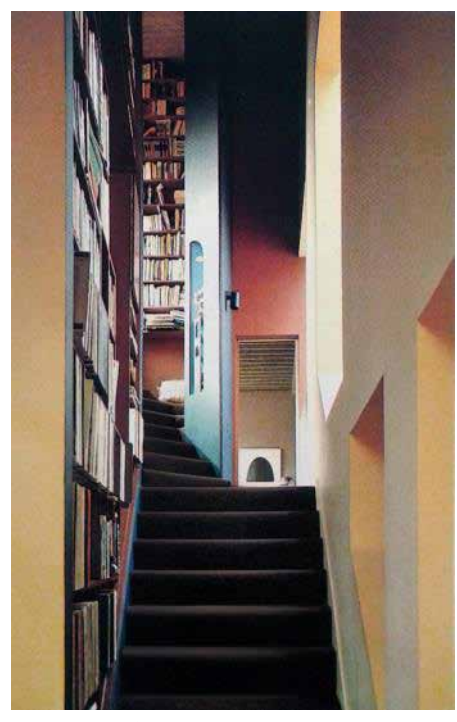

Imagen: Casa Burns. Santa Mónica, Ca. Ch. W. Moore, R. Chylinski, 1974. De arriba abajo, de izquierda a derecha. Vista de la librería instalada en la escalera. Vista de la sala principal, donde el órgano al fondo y el balcón mexicano son focos de atención. Vista del sofá bajo la escalera.

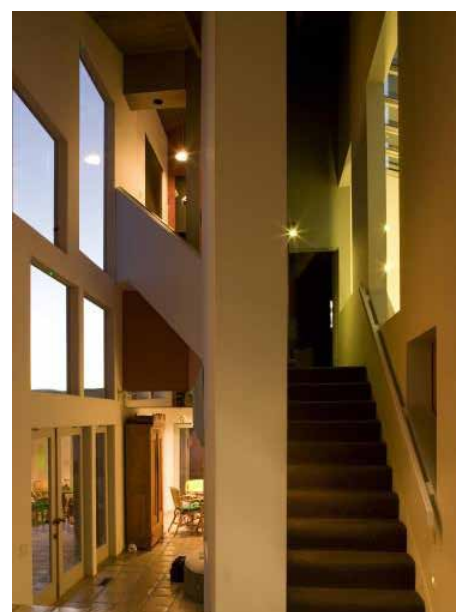

Imagen: Casa Burns. Vista de la escalera en su ascenso a la planta primera. 


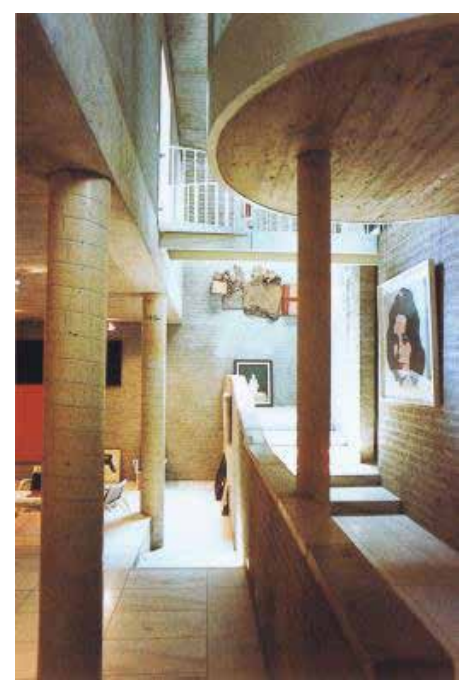

Imagen: Casa Schmela. Düsseldorf, Alemania. Aldo Van Eyck. 1967. cerrarse quedándose con su mirada"110.

El recorrido también podía producirse visualmente en dirección vertical, como en el caso de la casa de Alfred Schmela en Düsseldorf. Schmela, un galerista y coleccionista de arte contemporáneo, contactó con Le Corbusier para diseñar su galería y vivienda pero en el proceso fue que el arquitecto murió de forma repentina, por lo que finalmente Aldo van Eyck realizó el proyecto definitivo. Las pequeñas dimensiones del solar hicieron que la casa buscara la espacialidad en vertical, conectando todas las plantas de la galería, desde el sótano, a través de un cilindro de vidrio que discurría verticalmente por todo el espacio. Este recurso generaba un espacio dinámico, que se experimenta a través de las vistas diagonales que se producían de nivel a nivel de la galería. Como era de esperar, el arte generaba los recorridos y por tanto provocaba las visuales. El primer piso era como una constelación de cuadros entre paredes de ladrillo, que proporcionan la máxima superficie de exposición. En el segundo piso estaba la residencia del propietario que utiliza también para exhibir su colección de arte personal.

En la casa Tabarelli, diseñada por Carlo Scarpa en Bolzano, en 1968, la idea de lugar surgía inspirada directamente en las formas de las colinas de viñedos de los alrededores.

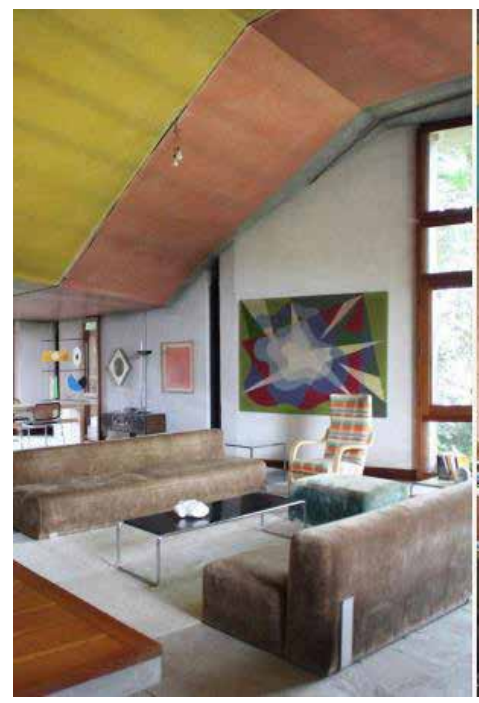

Imagen a la derecha: Casa Tabarelli. Bolzano. Carlo Scarpa. 1968. El espacio estaba pautado con elementos producidos por Dino Gavina, entre los que se encontraban sillas de Marcel Breuer, muebles funcionales de la línea Ultramobile de Simon Collezione diseñados por Meret Oppenheim Man Ray y Giacomo Balla. También se encontraban otros objetos como un sillón de Alvar Aalto, una alfombra de Sophie Teuber-Arp, un tapiz futurista de Giacomo Balla, esculturas rompecabezas del escultor Miguel Ortiz Berrocal, estantes del sistema uno sull'altro de Ugo la Pietra, un móvil de Bruno Munari, etc.

Imágenes: Casa Tabarelli. Bolzano. Carlo Scarpa. 1968. Vistas del espacio principal y del acceso al dormitorio tras el tapiz móvil de Giacomo Balla.
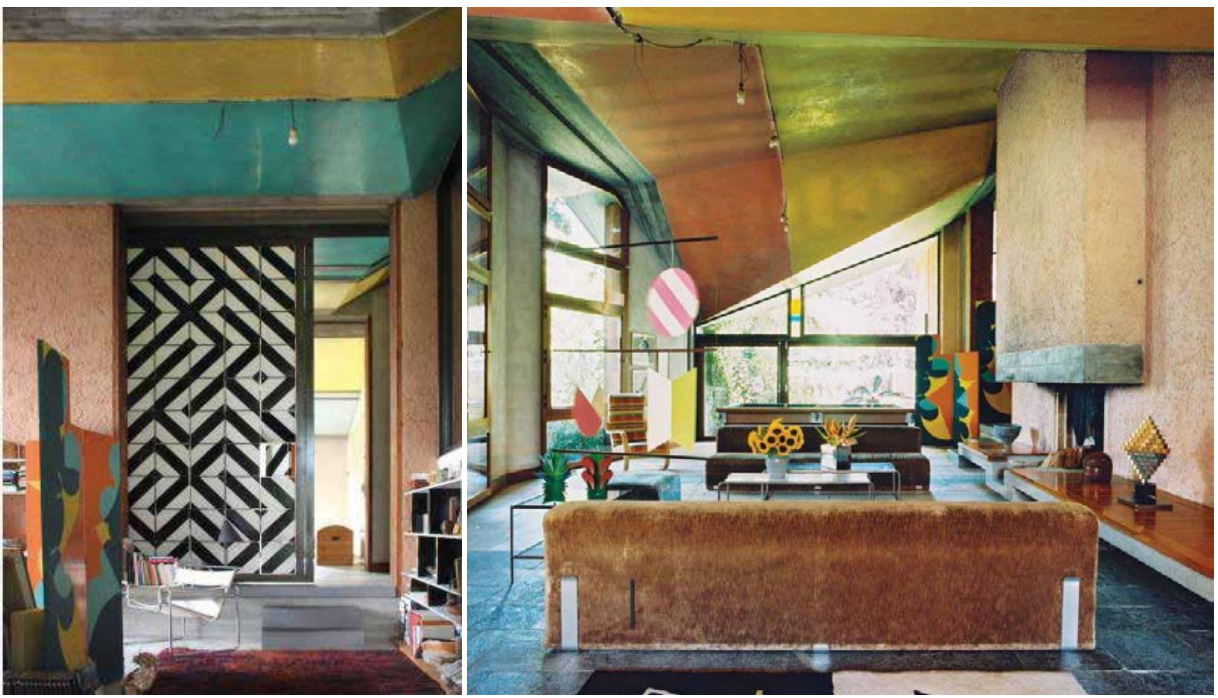
se conectaban entre ellas y que se reflejaban en el interior a través de techos inclinados, que se desvirtuaban como límite a través franjas de estuco de diferentes colores. Todas las habitaciones variaban de altura, siguiendo el principio de Raumplan de Loos. Estos recursos potenciaban la idea de topografía interior. El amplio salón está dominado por una chimenea y a través del juego de techos, resultaba un tanto abstracto. Existía un itinerario que por el que se podía recorrer la casa completa, en una trayectoria circular, cruzando por todas las estancias, de una habitación a otra. Desde el estudio a la cocina, pasando por los dormitorios. Los dueños, la familia Tabarelli, eran productores de muebles y estaban relacionados con la élite del diseño italiano de la época: Gavina, Scarpa, Boffi, Cassina, etc. La disposición de las obras maestras que había en la casa estaban dispuestas a lo largo de aquel recorrido, que en protagonismo en un espacio abierto y conectado.

110 Charles Jencks. El lenguaje de la Arquitectura Posmoderna. (Barcelona: Gustavo Gili, 1980) p.126.
La casa era de una sola planta con un sistema de cubiertas inclinadas que cierta modo estaba organizado de manera que todas las piezas tuvieran su 
En el caso de la casa Blackburn, diseñada por Peter Wilson en 1986 en Hampstead, Londres, la relación topológica de sucesión entre diferentes piezas, que por su propia significancia ya hablaban por sí mismas, generaba un nuevo discurso que fluía por el espacio, de abajo a arriba. Esta actuación era una oportunidad para reformar una hilera de casas de la deteriorada Mews Houses, incluyendo nuevas formas y funciones. La reforma había convertido un interior oscuro y deteriorado en una caja blanca y luminosa.

Cada elemento añadido a este blanco marco contaba su propia historia. Un gran hueco acristalado partía la fachada en dos, con un gran pilar interior que a modo de tótem, en acero pintado de azul, marcaba el punto de partida del recorrido. La planta baja era una oficina, las otras dos plantas superiores eran un apartamento que albergaba una colección de objetos y mobiliario contemporáneos.

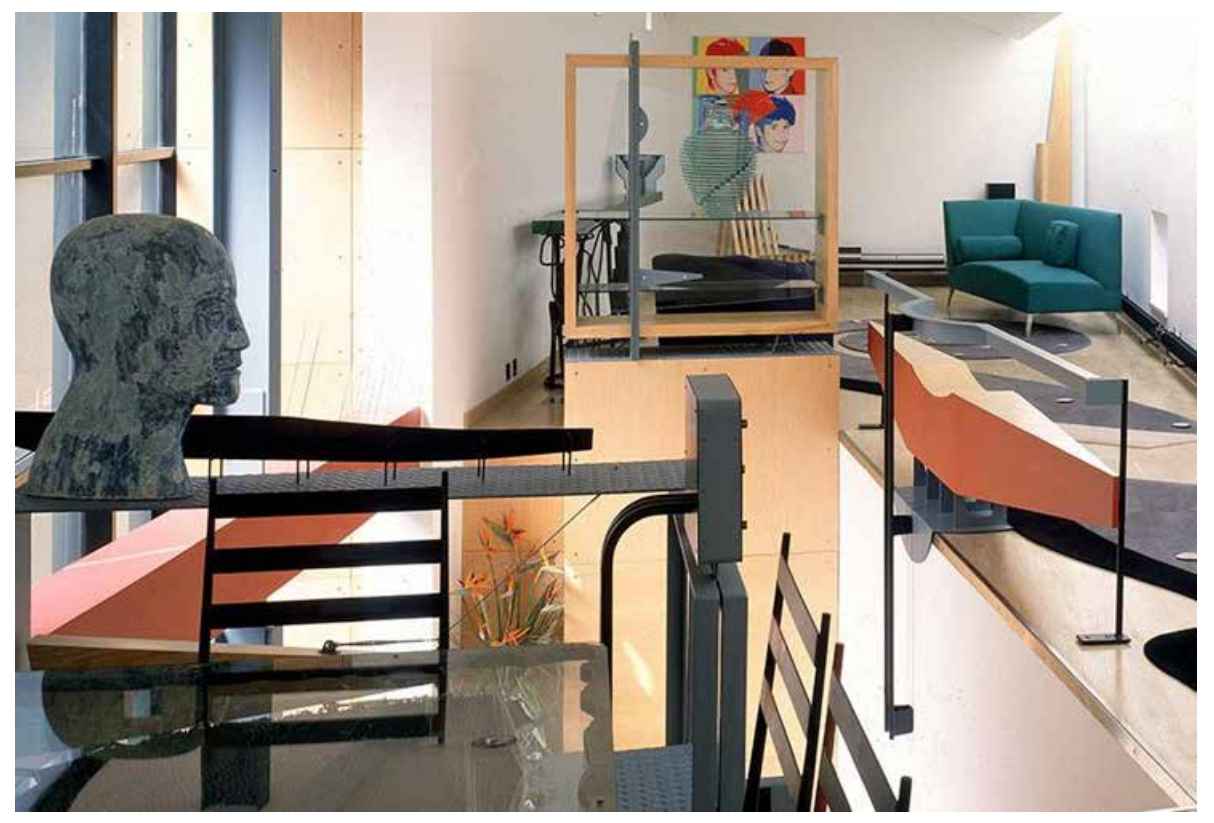

Todos los elementos se encargaron ex profeso a los artistas para la propia casa: Barry Flanagan -liebre-, Scott Burton-silla-, Andy Warhol -retrato-, Bruce Mclean -mesa- y a diseñadores de muebles entre los que se encontraban Ron Arad -mesa- y Jasper Morrison -sofá-. El discurso que se producía, en gran medida era por los detalles. Cada pieza poseía una narrativa autónoma pero todo funciona como un conjunto gracias a una lógica de ambiente que unificaba limitando el uso de los materiales: acero, madera de solo color y el blanco de la caja que los contenía.
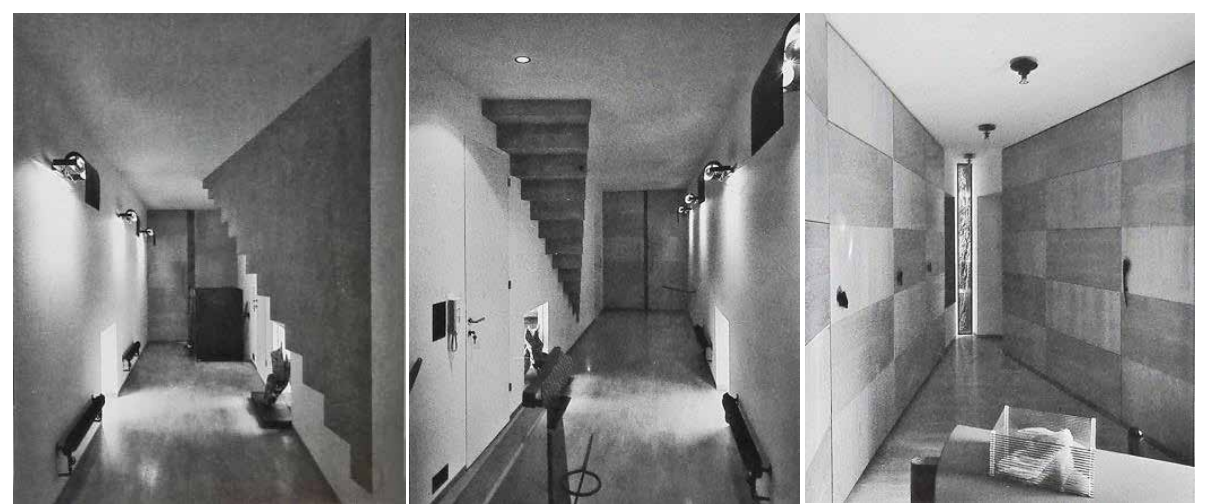

Imagen: Casa Blackburn, Hampstead, Londres. Peter Wilson. 1986. Vista de la última planta donde se sitúa el último foco del recorrido, un banco de madera que permite sentarse para contemplar desde arriba todo el recorrido efectuado.

Imagen: Casa Blackburn, Hampstead, Londres. Peter Wilson. 1986. Diferentes visuales a lo largo del recorrido. 


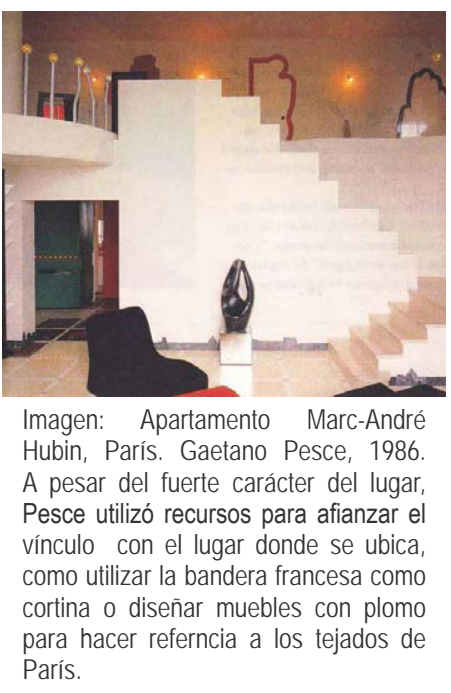

El visitante sólo terminaba de entender la casa cuando llegaba al último piso, donde en medio del salón-comedor flotaba un banco de madera sobre la doble altura dentro de la gran ventana. La luz entraba desde arriba y llegaba hasta el suelo. Sentado ahí el visitante finalmente comprendía cual es el centro de la casa.

En esta reforma realizada por Gaetano Pesce en 1986 en París, a pesar de que casa uno de los objetos, como en el caso anterior, tenía un fuerte carácter simbólico, o comunicativo, prevalecía la historia del conjunto, como si fuera una obra teatral. La fuerza del argumento que ligaba a unas piezas con otras, a pesar de ser todas ellas muy dispares, daba unidad al conjunto.

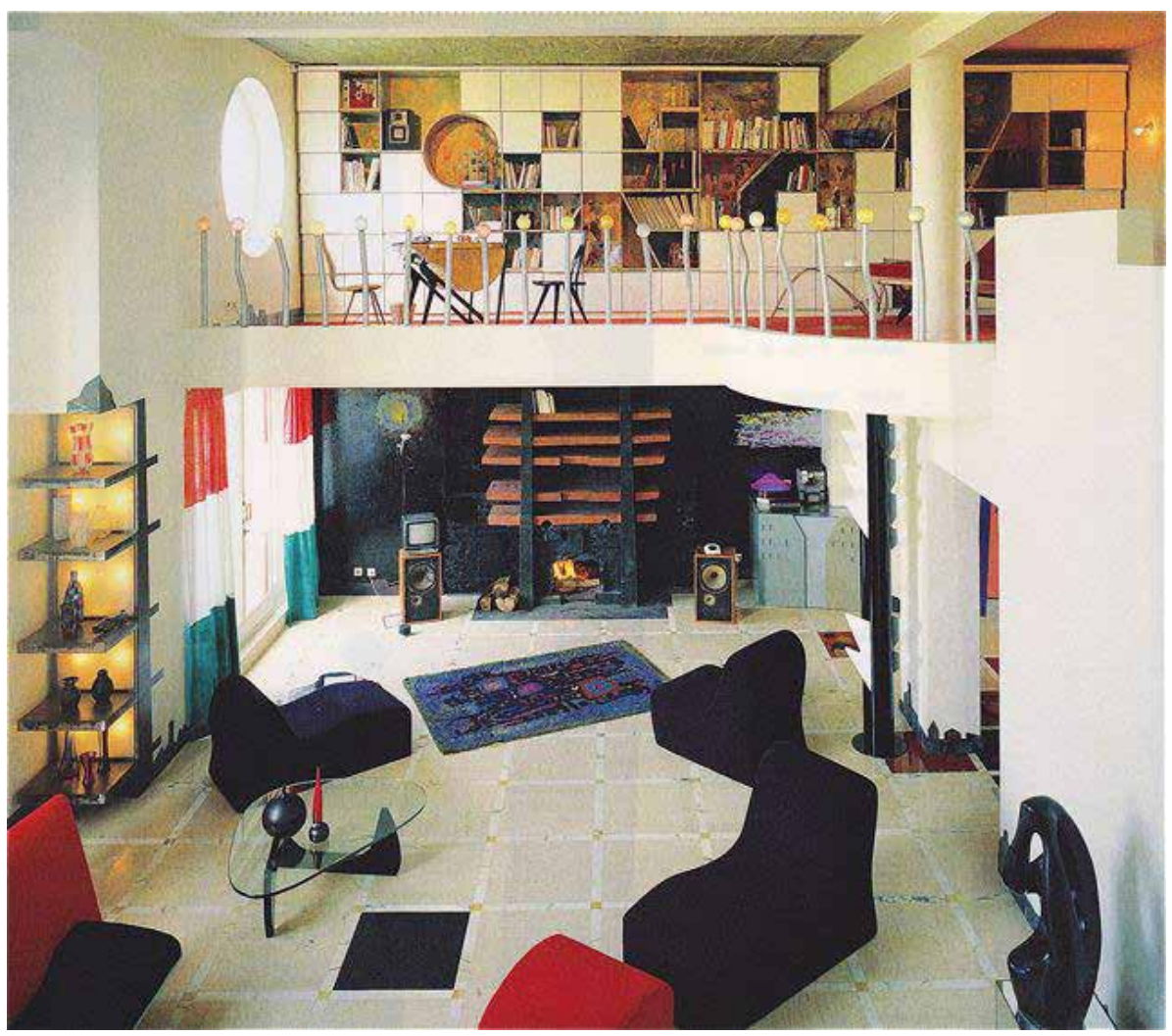

El apartamento pertenecía a un fotógrafo y coleccionista de arte moderno y objetos de diseño. Situado en un edificio Art Déco de los años 30 en París, este apartamento tradicional, fue transformado por Gaetano Pesce mediante la organización de una serie de cuentos mitológicos. La casa era como un retrato del propietario en un proyecto teatral, con puesta en escena, trama y personajes. Con colores fuertes, rojo, amarillo, azul, verde, con muebles inusuales como mesas con patas inclinadas, tiradores de puertas con formas extrañas, barandillas hechas con puntales inclinados rematados con bolas de vidrio iluminadas en distintos colores. Por imperativo de ambiente, las referencias culturales eran constantes: las cortinas tenían los colores de la bandera francesa, los muebles diseñados de plomo hacían referencia a los tejados de las cubiertas de París, la habitación se abría al espacio más público con una puerta de garaje. La idea de Pesce era crear sensaciones y generar un vínculo con el lugar. También utilizaba recursos surrealistas, cada puerta de un tamaño y aparecían dibujos simbólicos en las paredes inspirados en dibujos de Picasso, figuritas de Star Wars, un busto egipcio del año 500 a.c. Para el arquitecto lo importante era expresar algo diferente y original con cada diseño "una obra de arte no es más que un objeto útil de significado"11.

111 Brent Lewis, "The perfection of imperfection". Area (n¹19 sep-2014) https://www.area-arch.it/ 
En el MoMA Tower Apartment en Nueva Yok, de Steven Holl realizado 1986, el concepto de la reforma interior también surgió del sitio, durante la primera toma de contacto en Manhattan. La torre de apartamentos emergía directamente desde el nivel de la calle y crecía intensificando la experiencia de la cuadrícula de Manhattan. Según el arquitecto, de la ventana todas las perspectivas, tanto N-S como E-O, aparecían particularmente enfatizadas por la perspectiva vertical en el eje $Z$. Esta experiencia inspiró la organización de todos los elementos en el apartamento en las direcciones $X, Y$ y $Z$, reforzado por la iluminación. El acabado de los tabiques en la dirección $X$ era de color negro, el de los de la dirección $Y$ era amarillo. La dimensión $Z$ se enfatizaba con una lámpara alargada y estrecha en un rincón de la entrada, con una lámpara de pie en la esquina de la ventana principal, y con las líneas verticales del mobiliario. Las alfombras estaban diseñadas para este apartamento, una inspirada en la dirección $X$, otra en la $Y$ y otra en la $Z$. Los muebles también estaban especialmente diseñados e incluía una mesa de comedor en la que los ejes $X, Y, Z$ partían de su centro de acero del cual discurrían adquiriendo formas libres.

Todos estos elementos representaban la idea original de una u otra manera, a veces literal, otras más poética, sistemática, intuitiva. Vistos juntos no parecían una colección de piezas más o menos iguales, sus diferencias conseguían que esto no ocurriera. Sus relaciones de asociación eran sutiles pero esto hacía que la conexión fuera más misteriosa; cada elemento servía para formar un campo para el otro. La relación era espacial, un objeto colocado en una posición era una referencia para el otro ${ }^{112}$.

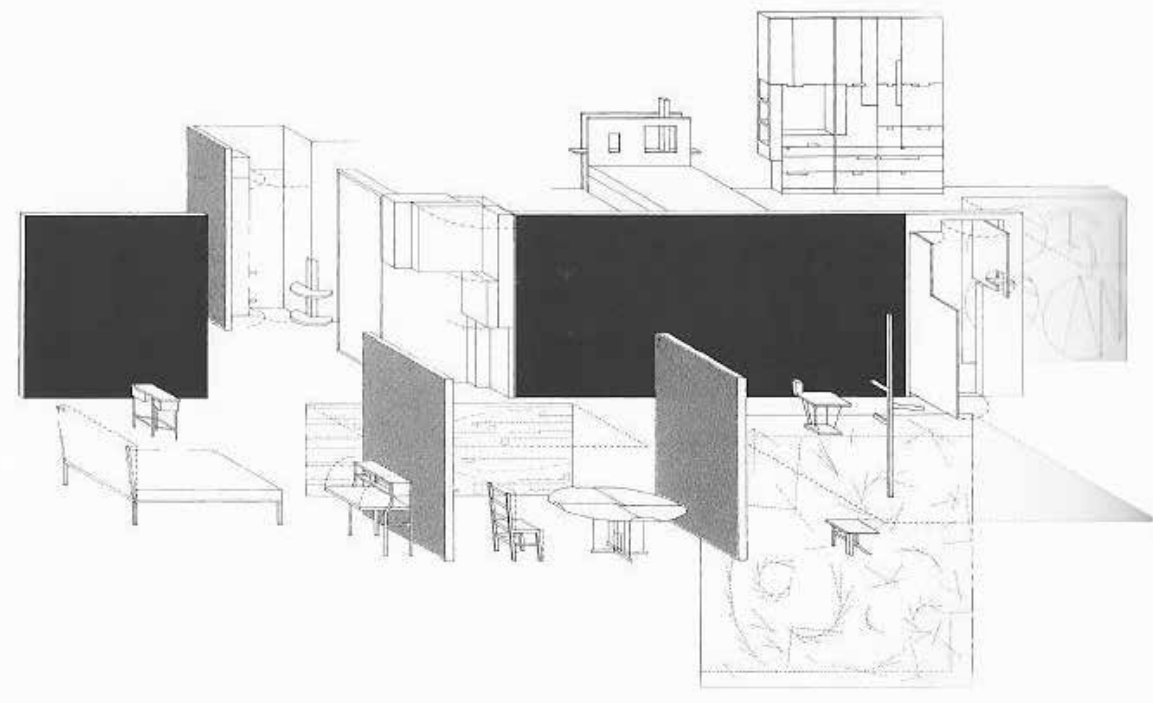

El sentido háptico, del que se trataba en la introducción de este apartado, es uno de los factores que han influido en la configuración de espacios domésticos contemporáneos, y también fue uno de los factores principales en la justificación de esta casa de Carlo Scarpa realizada en Venecia en 1974.

La principal característica de la reforma realizada por Scarpa era la búsqueda de la continuidad espacial en los dos niveles del apartamento a través de dos huecos de forma curva en el pasillo del segundo nivel, que volcaban sobre el pasillo del primer nivel, las formas redondeadas de las esquinas de los muros, las curvas de los petos de los espacios a doble altura, la ausencia de bordes

it/area-119-gaetano-pesce/

112 Steven Holl. Metropolitan Tower Apartment. New York City, U.S.A. 1987-88. En: Kenneth Frampton. "Meet the architect: Steven Holl", GA houses (n²5 mar-1989) p.214.
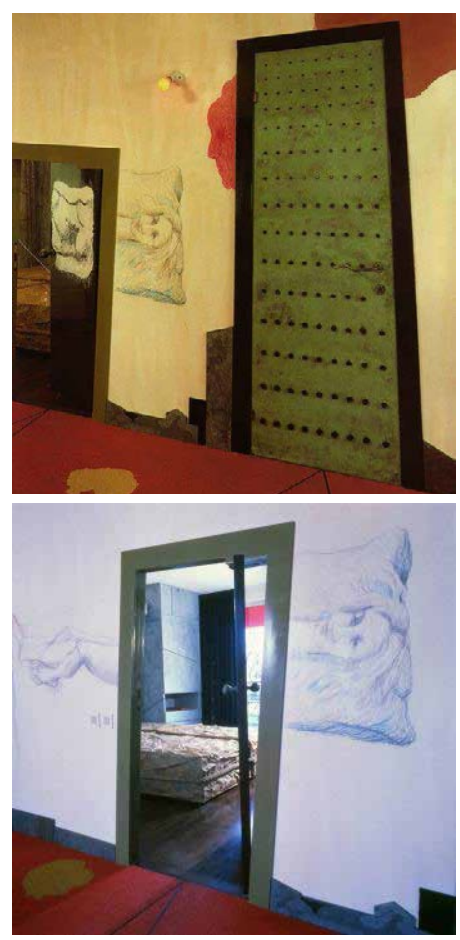

Imágenes: Apartamento Marc-André Hubin. Juegos de puertas, al ser cada una diferente se convierten en hitos que marcan el recorrido

Imagen: Croquis de MoMA Tower Apartment en Nueva Yok, Steven Holl. 1986.

La idea de lugar, inspirado en Manhattan se producía por relaciones geométricas entre elementos, llevadas al máximo y con referencias constantes a las tres coordenadas en las alfombras, los armarios, las lámparas, y el color de los tabiques. 
Imagen: Casa Balboni, Venecia. Carlo Scarpa. 1974. Diferentes visuales a lo largo del recorrido. En un espacio continuo revestido de stuco lucido color crema y mármol rosa de Verona, los muebles -de ébano y nogal-y las piezas de arte, marcan los ritmos y paradas.

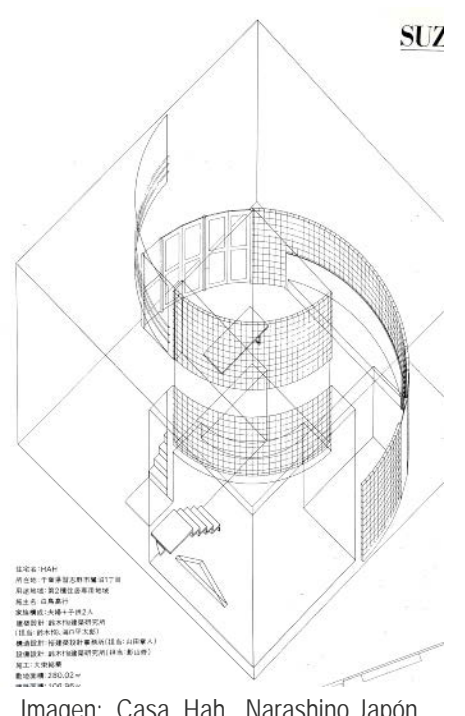

Imagen: Casa Hah Narashino,Japón. Makoto Suzuki. 1977 nítidos entre suelos, muros y techos y la uniformidad de los acabados en estuco satinado color crema. La fluidez de los recorridos daba oportunidades para la disposición de objetos y muebles -los de la entrada eran de madera de ébano-, los cuales marcaban, por la ley de contraste, los ritmos y paradas
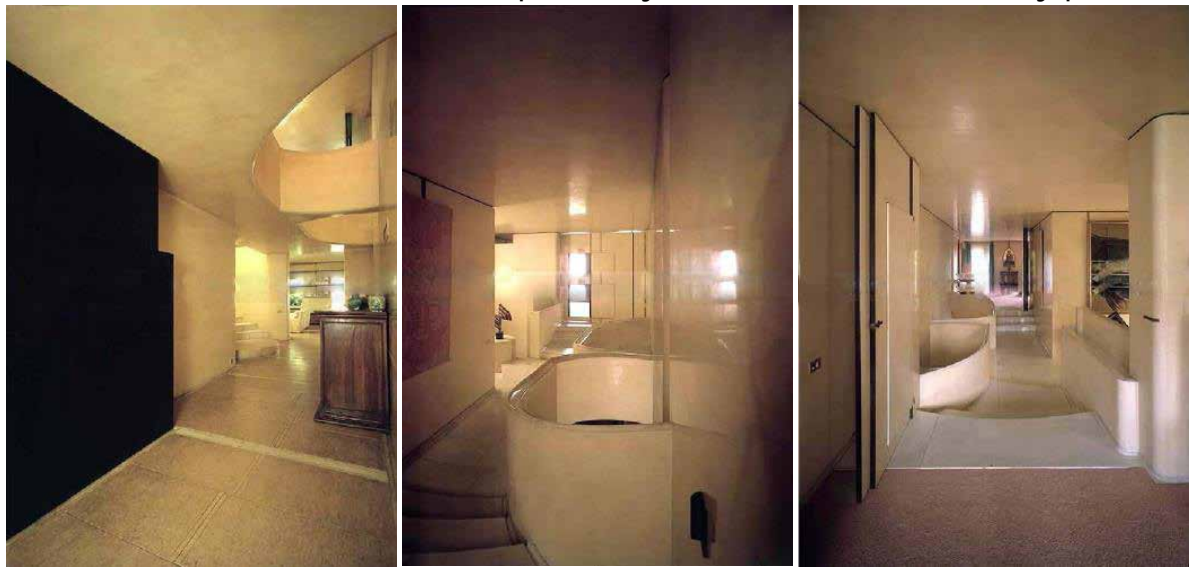

necesarias en un espacio prácticamente sin aristas.

La fluidez en el recorrido también fue una de las premisas en la casa $\mathrm{HAH}$, de Makoto Suzuki en Narashino -1977- . La casa HAH se situaba en una calle estrecha con bastante tráfico en una ciudad cercana a Tokio. Para huir del ruido de la calle y para mantener la privacidad, la casa se concibió como un sistema de capas superpuestas.

El sistema de relaciones por sucesión de muros curvos y rectilíneos, otorgaba a la casa el sentido de lugar. La planta era cuadrada, el edificio era un cubo de hormigón con huecos en fachada, desde los cuales desde la calle al interior sólo se veía una superposición de muros de hormigón y de pavés. El bloque de vidrio era una barrera translúcida que hacía que el espacio fuera abierto y cerrado a la vez. Por ejemplo, en el salón semicircular el pavés permitía la entrada de luz y a su vez hacía de barrera visual.

La organización interior se caracterizaba por el hecho de que las zonas de estar aparecían dispersas por diferentes puntos de la casa, generando un recorrido. El primero es el salón comedor, que recibe luz a través del pavés; el segundo es un espacio en penumbra en el rincón norte de la primera planta, junto a la escalera que hacía de articulación entre las distintas actividades dentro de la casa; el tercero era otro espacio común en la segunda planta delimitado por otro muro curvo de pavés.

Por medio de los dibujos realizados por Suzuki, a modo de storyboard, se entiende el proceso de proyecto.

Toyo Ito en 1983 asimilaba la idea de lugar en la casa Silver Hut, en Nakano, a través de un espacio doméstico concebido como un refugio. A pesar de ello, por el tipo de construcción de cubiertas abovedadas y pilares era considerada como una casa estilo high-tech. Sin embargo, según el arquitecto ${ }^{113}$, la estructura ligera significaba principalmente que lo que se pretendía erradicar, que era lo cerrado.

La idea de Ito a través de la propuesta era que persistiera la espacialidad de la arquitectura llevándola a niveles de refugio, al grado más primitivo de la

113 Toyo Ito. "Toyo Ito (Three Houses)". GA houses (n²0 sep-1986) 30-47. 


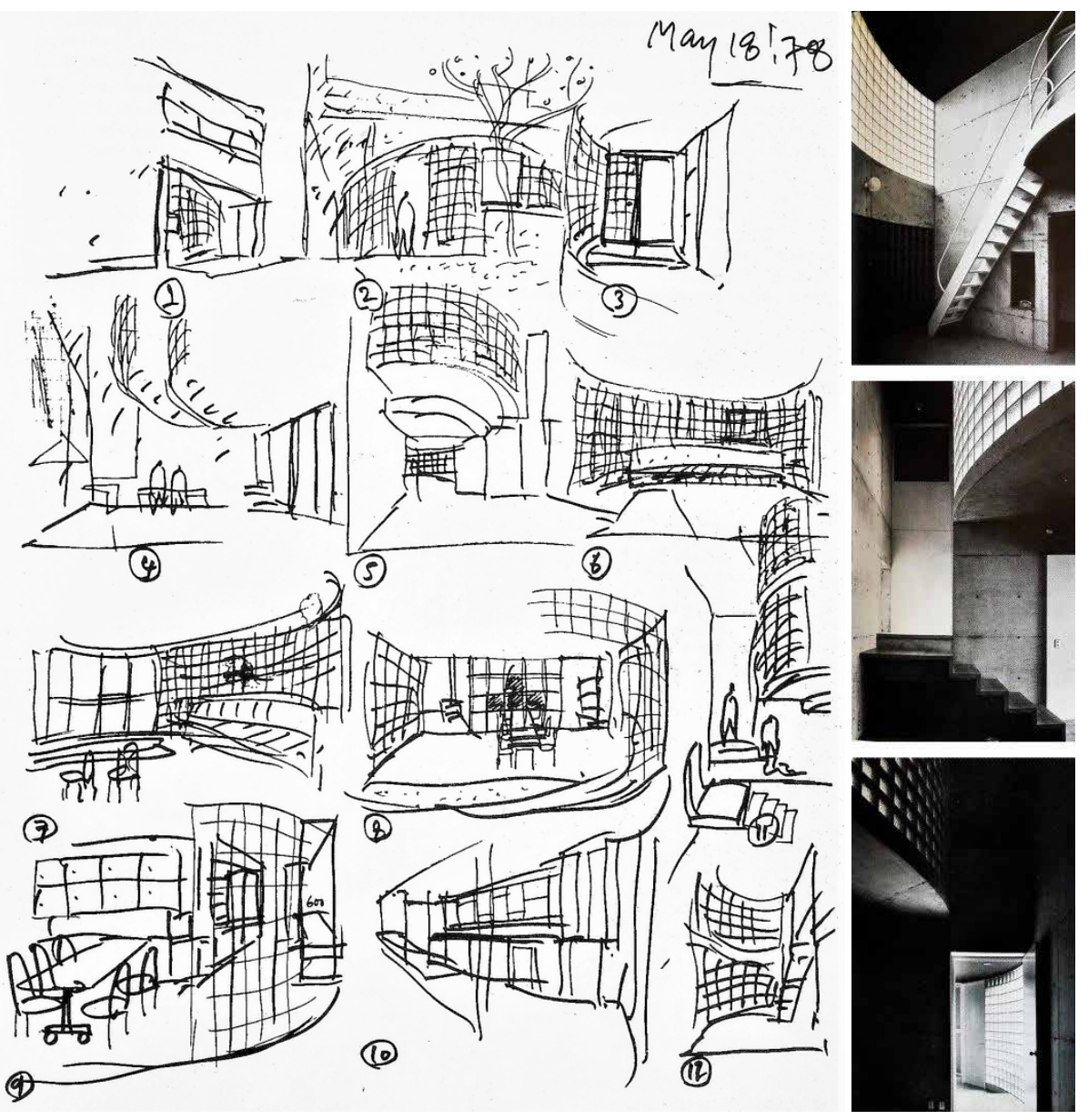

vivienda. El sistema estructural de pilares y cubiertas abovedadas liberaba de muros a la totalidad arquitectónica. Se colocaron paneles muy finos, casi como pantallas, entre las bóvedas, separándolas de manera que cada bóveda representaba una casa diferente. En lugar de ser parte de la arquitectura los muros se liberaban, a modo de mobiliario doméstico, lo cual les permitía tener su propia identidad, como objetos, no rompiendo la continuidad espacial de lugar. "El tema que estoy estudiando -el del refugio ligero para la protección y confortabilidad del cuerpo humano- sin duda seguirá siendo mi preocupación durante algún tiempo"114. En 1985 Ito presentó el Pao 1, con acercamientos
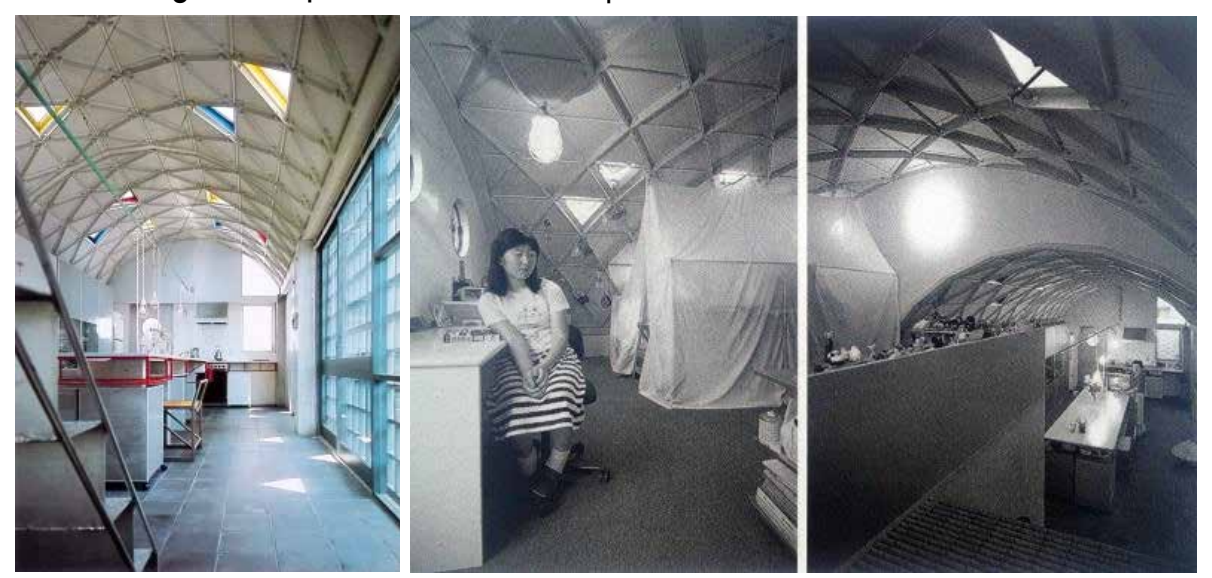

a la idea de refugio, aunque desde un punto de vista que difería del habitual.

Había casos en los que la idea de lugar en el interior de la casa era de manera casi literal, como una representación de un espacio exterior en el interior
Imágenes: Casa Hah, Narashino,Japón. Makoto Suzuki. 1977. Vistas del interior. A la derecha, Croquis de distintas escenas domésticas a lo largo del muro de pavés. Por medio de los dibujos se entiende cómo se han previsto, en el proceso de proyecto, cada una de las acciones que se sucederían a lo largo del recorrido que generaba el muro de vidrio. A modo de storyboard. Publicado en GA Houses n014, 1983 p.67.

Imagen: Silver Hut. Nakano, Tokyo. Toyo Ito. 1983. Diferentes vistas del interior, concebido como un 'refugio'. 
Imagen: William Kessler \& Ass., vivienda unifamiliar en Southeast, Michigan, 1977. Vista del espacio central de la casa.
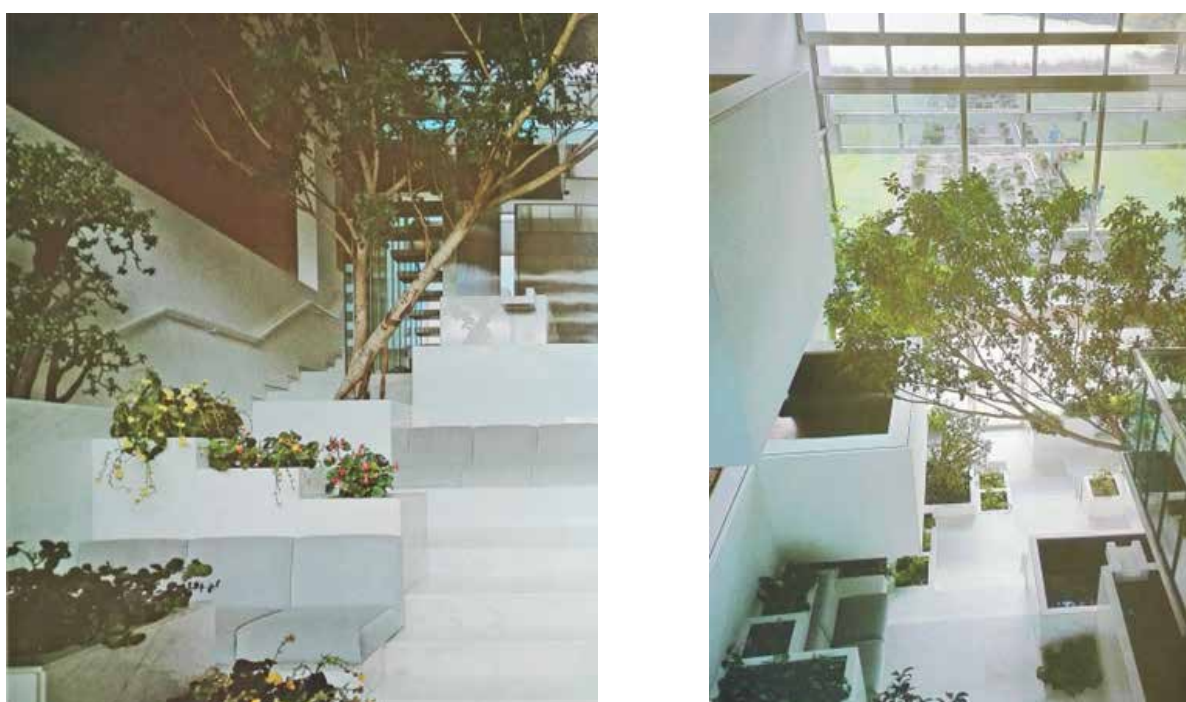

del ámbito doméstico. Una de las salas principales de la vivienda unifamiliar diseñada en 1977 por William Kessler \& Ass., en Southeast, Michigan, había sido concebida como un gran espacio-jardín central donde se ubicaban plantas, agua y diferentes zonas donde sentarse a distintos niveles. Esta especie de 'lugar' interior estuvo dentro del programa de necesidades desde el principio. La disposición en planta de este gran atrio central hacía que sirviera de separación entre la zona privada de los dueños y la zona de servicio y huéspedes.

El atrio, con el mármol y el acero como materiales básicos, hacía de lugar de descanso y de amortiguador entre las dos áreas de la casa. Se estructuraba en muy diferentes niveles, y entre las distintas plataformas se intercalaban asientos y otros muebles intercalándose con jardineras, lo cual ofrecía múltiples oportunidades para sentarse a contemplar las vistas de un lago, al fondo, desde el interior de la sala. El blanco predominante permitía que la vegetación adquiriera un mayor protagonismo y le hacía tomar las riendas de la composición de este espacio. Tanto la fachada como el interior eran de gran simplicidad formal y se optó por el color blanco para toda la casa con el fin de crear un fondo neutro que admitiera el eclecticismo general del mobiliario de los propietarios. Este recurso de relación figura fondo, también hacía más evidente la relación topológica entre muebles y plantas, que convivían entre los distintos niveles de la topografía interior y que estructuraban el recorrido
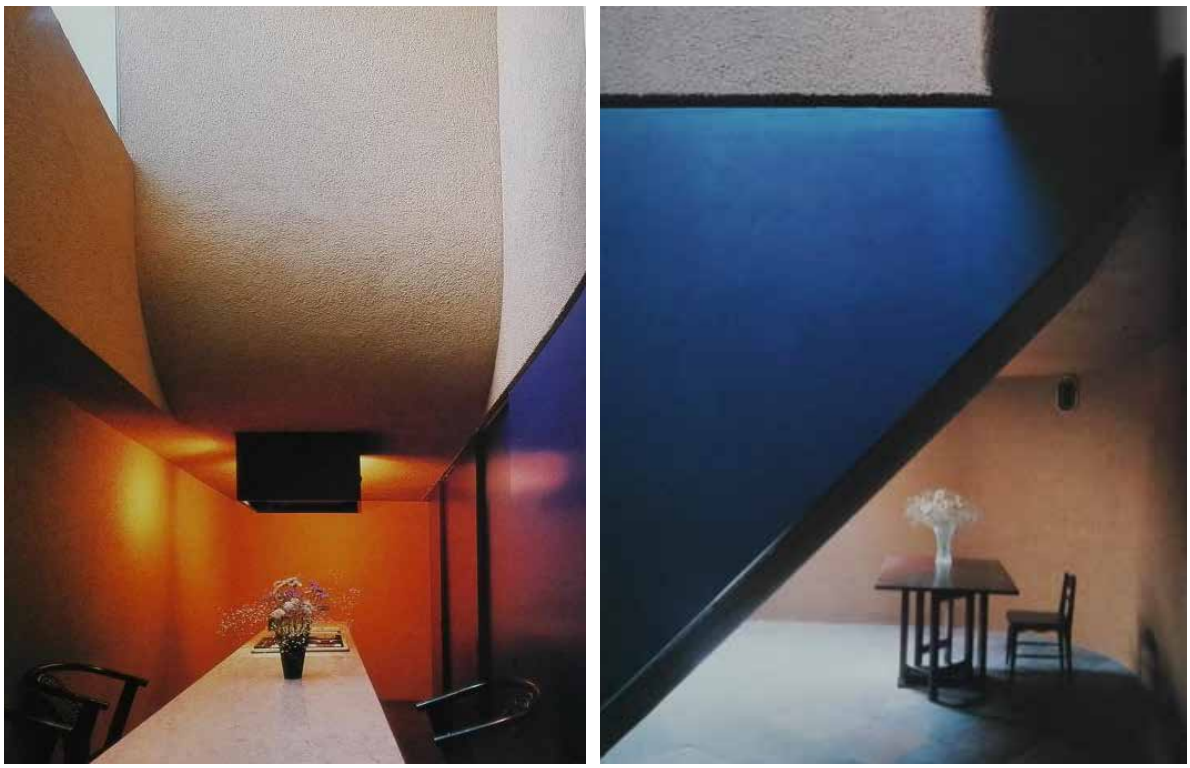
entre jardineras de mármol, promoviendo un ritual de descenso al lago, entre fuentes y asientos tapizados en tela.

El ritual podía convertirse en la idea principal para el Yutaka Saito, para diseñar la casa Chimenka-No-Ya en Nagano, Tokio en 1987. Los clientes eran la típica familia japonesa de tres miembros que vivía en una casa construida en un pequeño solar situado en una convencional zona residencial. Sin embargo, la casa en sí misma estaba lejos de ser la típica casa convencional. Primero porque siendo una casa tan pequeña, las circulaciones habían sido concebidas a propósito, para que fueran lo más largas posible, con muros que deban la vuelta a los espacios y sobre los que se proyectaba la luz. Segundo, y quizás más importante, porque al abrir la puerta de frente, era imposible tener una idea clara de la disposición de los espacios. A pesar de que los dormitorios estaban en la planta baja, cerca de la entrada, no se podía acceder directamente a ellos, había que hacer un recorrido que a modo de ritual preparaba al visitante hasta llegar al punto deseado ${ }^{115}$.

La amplia casuística y la consiguiente clasificación, permiten reconocer la relación entre los modos de actuación de los sistemas de objetos y las características de los ámbitos domésticos analizados, lo cual ofrece los argumentos suficientes para exponer las siguientes conclusiones. 


\section{CONCLUSIONES}



Imagen: 'Due in uno': "dos ambientes en un mismo espacio para un saxofonista imaginario". Por Gio Ponti. Salone delle Arti Domestiche, $8^{a}$ edición. Turín. Publicado en Domus, jul-1971.

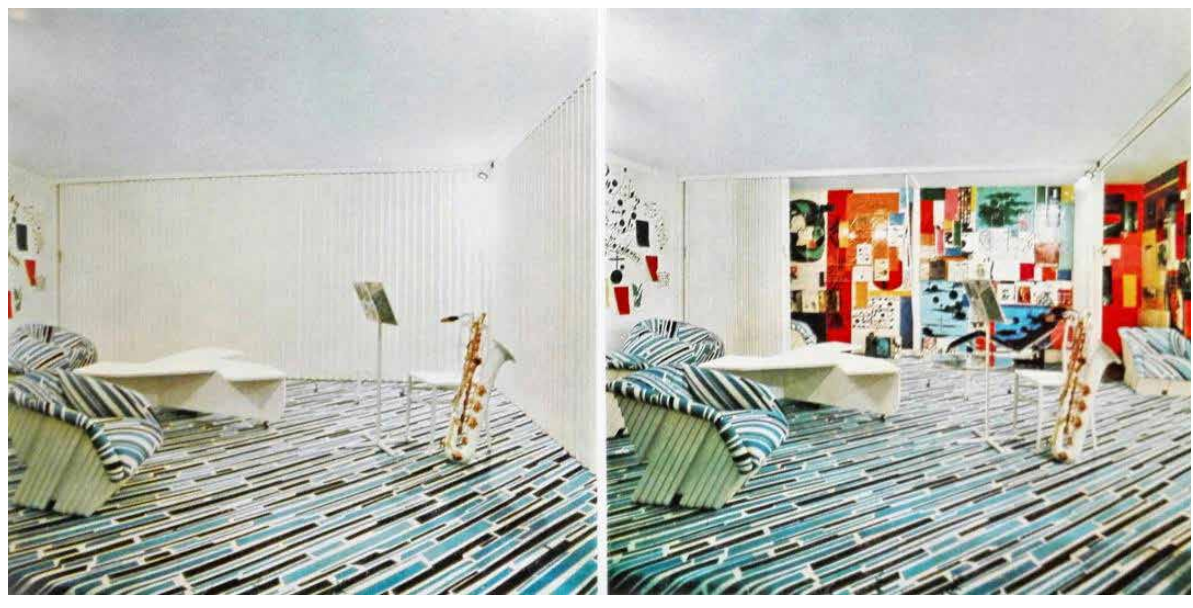

\section{CONCLUSIONES}

El resultado de este trabajo constata que el proceso de configuración del espacio doméstico contemporáneo está marcado en gran medida por el papel que ejerce el objeto como elemento compositivo, organizativo y experiencial, y es posible vincular sistemas de relaciones y conexiones de objetos en el espacio con características y cualidades que son propias de los ámbitos domésticos contemporáneos. A partir del sistema de clasificación realizado, se establece que determinados sistemas de relación y conexión de objetos cotidianos organizados en el espacio, participan en el proceso de configuración de dichos entornos. Los ámbitos se conforman respondiendo a ciertas características, las cuales adquiere consolidándose según unos determinados principios, que se avanzan a continuación, y que tendrán un posterior desarrollo dentro de este apartado de conclusiones :

En entornos donde prevalece la idea de espacio abierto, donde la planta se presenta libre de cualquier tipo de compartimentación, los objetos se ubican en su interior siguiendo reglas de colocación que responden a relaciones tridimensionales de masas y espacios. Como establece Norberg-Schulz ${ }^{1}$ estas relaciones topológicas suelen estar vinculadas principalmente a la proximidad, aunque existen otros vínculos, que veremos más adelante. La premisa es que los objetos distribuyan y ordenen, adaptando la organización de la casa según las necesidades y las acciones que en ella se producen. Los objetos, el mobiliario y otros elementos muebles son capaces de marcar las pautas siguiendo códigos de colocación -accesibilidad, densidad- tal y como los que determina Moles ${ }^{2}$, en las leyes sintácticas de acoplamiento.

Otro de los principales cambios que caracteriza al ámbito doméstico contemporáneo es la búsqueda de la cualidad de 'espacio flexible'. La polivalencia del lugar y la posibilidad de ofrecer distintas opciones a lo largo del día aparecen ligadas básicamente a la movilidad de los objetos que colonizan los hogares. La capacidad de mutabilidad del espacio está pues relacionada con los avances técnicos y los nuevos materiales que hacen posible que los objetos, los muebles, e incluso algunos elementos como tabiques móviles, se transformen cómodamente o puedan cambiar su ubicación dentro de la casa, sin grandes complicaciones. Hemos visto en el apartado 3.2. de este

1 Christian Norberg-Schulz Intenciones en arquitectura. (Barcelona: Gustavo Gili, 1998) p. 90.

2 A 'las leyes sintácticas de acoplamiento' se hace referencia en esta tesis en el apartado 3.1. 
trabajo, que el concepto de movilidad, asociado al espacio flexible, varía a lo largo de los años, pasando de lo mecánico y articulado de los años sesenta -recordemos los proyectos de Joe Colombo o de Archigram que vimos en el mismo apartado de esta tesis- a lo liviano y fácilmente transportable de los ochenta, como puede aprecierse en los muebles del Pao de Toyo Ito.

Los nuevos modos de vida, fruto de los cambios de los 60 , que ansían libertad y transgreden los principios básicos de la sociedad tradicional, se traducen en entornos alternativos para habitar y en nuevos modos de ocupación. Estas formas de vida pretenden representar a un sujeto 'liberado' y creativo, lo cual, en cierto modo, es consecuencia de la adopción por parte de la sociedad de las ideas que provienen de las corrientes contraculturales de los años 50 y 60 . De esta manera la 'apropiación' del espacio surge como la imagen ese nuevo modo de habitar que tanto se ansía por parte de grupos relacionados con estas ideas. En un contexto como el SoHo de Nueva York en los años 60 , entendemos por apropiación como la colonización del ámbito doméstico, de forma aparentemente caótica y despreocupada, con objetos reciclados y descontextualizados, y preferiblemente en espacios reconvertidos: antiguas fábricas, almacenes, etc. Estos locales, que se recuperan para uso de vivienda, sin embargo mantienen cuidadosamente la estructura distributiva y la estética original. La apropiación, como se constata de lo expuesto en el apartado 3.3. de esta tesis, es un sistema de organización del espacio a través de objetos, que se encuentra entre lo artístico y lo distributivo, y que a lo largo de los años se mantiene vigente - aunque en contextos muy diferentes a los que fueron en origen-. A este sistema de organización se unen, en origen, ciertas connotaciones culturales.

También en estos años, la consideración de la experiencia, que surge como un modo de entender el espacio, es en muchos casos fruto de la aplicación de la fenomenología a la arquitectura, así como del interés por el conocimiento de técnicas de percepción óptica como el camuflaje y de la consideración de la hapticidad, dentro de lo que se entiende como parte de la vivencia de un espacio. Estos factores, generan ámbitos cuyas premisas son la percepción y la sensorialidad. El habitante, cada vez más hedonista, reclama espacios que inciden cada vez más en su propia subjetividad y solicita lugares especiales donde vivir. La idea de crear ámbitos que producen sensaciones implica que existen en su interior sistemas de objetos concretos que consiguen actuar como mecanismos de transformación espacial. Esto dirige a lo que Baudrillard llama 'la lógica de ambiente's, un concepto que se mantiene en el tiempo y que implica de forma directa el objeto y a la tecnología para despertar sensaciones.

El desarrollo y la aplicación de la técnica en la construcción provocan una nueva fisonomía en los espacios domésticos. Hablamos de la aplicación de sistemas prefabricados de fachadas, de los nuevos materiales tanto en elementos arquitectónicos como en el mobiliario, de diferentes revestimientos, sistemas de iluminación más avanzados, etc. El nuevo aspecto de los contenedores, genera cierta necesidad de búsqueda hacia esa domesticidad perdida, algo que el hogar siempre reclama. Para provocar este enlace entre el habitante y su ámbito privado, se recurre a los llamados 'implementos añadidos': objetos personales y simbólicos que, a través de sistemas de conjunto o incluso de forma aislada, generan vínculos y conexiones psicológicas entre el usuario y el espacio. La implicación cada vez mayor de la propia subjetividad del habitante hace que en algunos casos se llegue incluso al recurso de lo onírico.

3 Jean Baudrillard, El Sistema de los Objetos. (México: Siglo XXI, 1969) p. 41. 
Recordemos que 'el orden de los sueños'4, surge como un mecanismo sistematizador de las fantasías del habitante y es utilizado como un elemento configurador. Este sistema está dentro del concepto de 'aditamento', introducido por arquitectos como Moore ${ }^{5}$ cuya novedad radica en la inclusión del objeto cotidiano en el discurso subjetivo.

El espacio doméstico contemporáneo también conlleva de manera casi inherente la necesidad de liberar espacio. Esta característica suele ir unida a configuraciones en sistemas de objetos y otros elementos que aparecen agrupados, inicialmente por razones prácticas. Las mejoras en las instalaciones otorgan mayor libertad para empaquetar servicios y equipamiento, sin embargo estas conformaciones en el entorno contemporáneo suelen tener, más bien, fines compositivos y conceptuales. A las relaciones topológicas de proximidad -incluso relaciones de fusión-, se une la sintaxis generada por la accesibilidad y el 'orden próximo' de los objetos 6 , así como la consideración gestáltica de relación figura-fondo. Todo ello confiere al espacio una la condición de escenario, que los ámbitos contemporáneos reclaman cada vez más, y que potencia las relaciones espaciales con el resto de los elementos.

La liberación de espacio va unida también a la idea de la simultaneidad de lugares, que es establecida por Norberg-Schulz ${ }^{7}$ como uno de los factores que caracteriza al espacio posmoderno. La idea de lugar surge ligada a los objetos desde el punto de vista de su utilización como elementos de reclamo. Consideraciones de percepción de figura por contraste, hasta relaciones topológicas de simultaneidad o geométricas de axialidad -por ejemplo-, unido a la condición de singularidad de determinados elementos, confieren a los objetos la condición de hitos. Esto hace que se ubiquen en el espacio con el fin de inducir al movimiento y generar recorridos. Los objetos, ubicados de forma estratégica y controlada, pueden convertir al espacio en un lugar de exploración, aumentando la intensidad de su vivencia y potenciando la idea de lugar en arquitectura.

\section{Una condición de campo.}

Esta sinergia entre objetos puede entenderse de manera clara a través de un símil, una instalación llamada 'Table' del arquitecto Junya Ishigami realizada en Tokio en 2005, donde un juego de relaciones gravitatorias de objetos colocados estratégicamente en un tablero de acero de $3 \mathrm{~mm}$ de espesor y de más de $9 \mathrm{~m}$ de largo, consigue que el plano de la mesa permanezca totalmente horizontal. El equilibrio de pesos, debido a la posición relativa de los objetos en el marco, evita que se produzca la flexión del plano sobre el que están situados. La principal premisa es que permanezca totalmente horizontal. Los objetos son cotidianos -platos, floreros, vasos, etc.- pero son utilizados por otras acepciones, en este caso por su peso y su capacidad para generar un equilibrio entre el soporte, las fuerzas y los objetos. Las relaciones y tensiones entre elementos conforman un sistema que consigue la no flexión de la mesa.

4 nota: Charles W. Moore, Gerald Allen, Donlyn Lyndon. La casa: forma y diseño. (Barcelona: Gustavo Gili, 1999) p. 119.

5 Ibíd. p. 214

6 Abraham A. Moles, "leyes sintácticas de acoplamiento", en Teoría de los objetos (Barcelona: Ed. Gustavo Gili, 1975) p. 113.

7 Christian Norberg-Schulz. Los Principios de la Arquitectura Moderna. Barcelona: Reverté S.A., 2005) p. 68. 

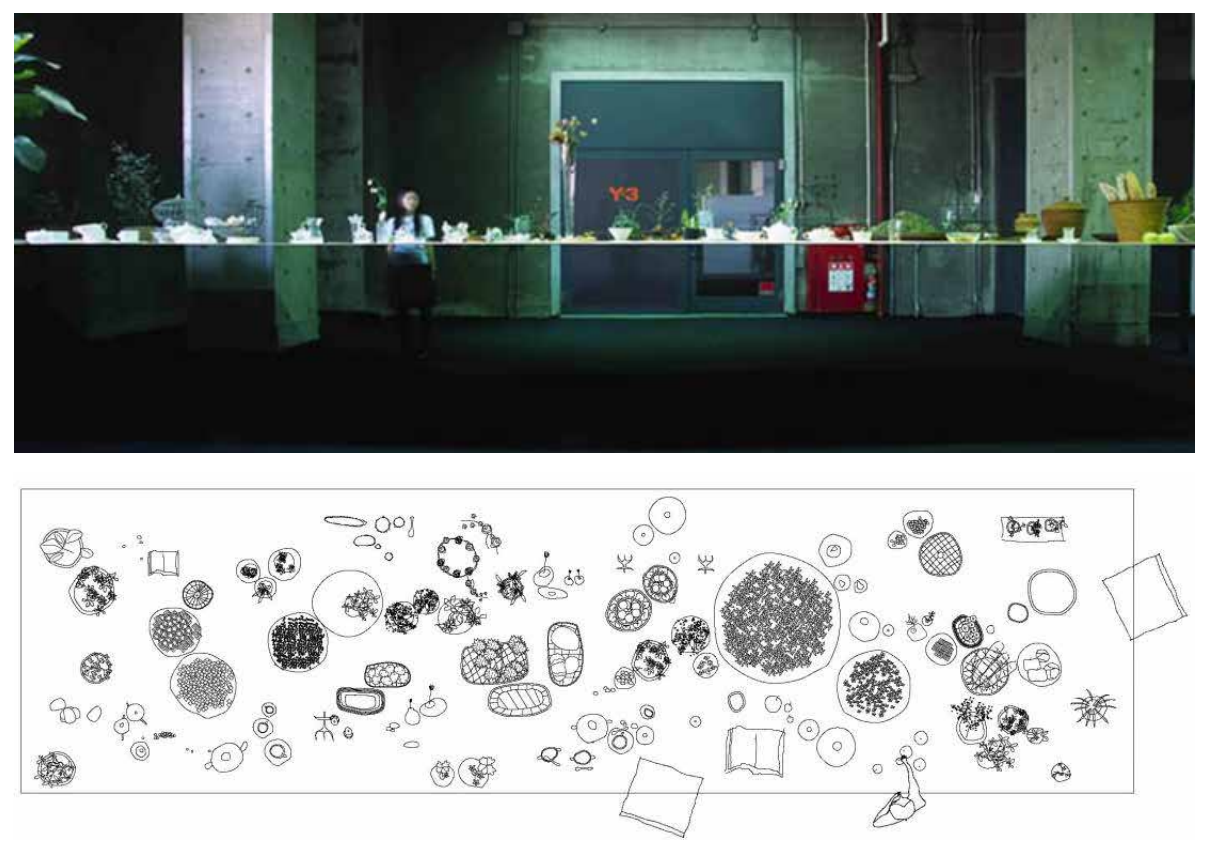

Si se observa el proceso como resultado de un conjunto de fuerzas y acciones, podemos entrar en la consideración de campo. "El campo es el lugar para las relaciones y las apropiaciones indefinidas y por otro lado es también parte del proceso que genera la forma de un conjunto". Sin pretender ahondar en este tema, ya que no está en los objetivos de esta tesis, sí es interesante hacer señalar esta consideración como parte del proceso. "Una condición de campo no se define por esquemas geométricos, sino por conexiones locales intrincadas". Por lo que, teniendo en cuenta los términos anteriores, el sistema de relaciones y conexiones que se produce en el interior de un ámbito -doméstico-, entre los distintos objetos que participan en un proceso de configuración espacial, puede dirigirnos hacia la idea de campo.

\section{Objetos y un nuevo lenguaje.}

Previo a las conclusiones que se establecen en cuanto a la relación entre sistemas de objetos y la configuración de ámbitos contemporáneos, y a las que se ha hecho mención de forma somera en el inicio de este apartado, cabe establecer los puntos ligados a la visión contemporánea del objeto y las ideas que giran en torno a su relación con el hábitat en estos años.

Son decisivos los distintos modos de entender el objeto cotidiano en la sociedad contemporánea, que parten de las definiciones, teorías y clasificaciones sobre el objeto que se estudian en esta tesis. Ello permite visualizar los conceptos asociados a la nueva manera de abordarlo en una sociedad de consumo, pasados los años de posguerra. De este modo se constata que la consideración de objeto sufre un cambio significativo. Los estudios sociológicos de Baudrillard, Moles o Barthes, entre otros, realizados sobre objetos -análisis sociológicos

8 Elena Farini, "Procesos configurativos: de la trama a la noción de campo en los mat buildings". (Tesis Doctoral: UPM, 2013) p. 322.

9 Stan Allen en Del objeto al campo, (ed. rev.) en Naturaleza y artificio: el ideal pintoresco en la arquitectura y el paisajismo contemporáneos, (ed. p.) Iñaki Abalos, (Barcelona: Gustavo Gili, 2009).
Imagen: Junya Ishigami. 'Table', Tokio 2005, Osaka 2005, Basilea 2008, Jerusalén 2010 
que se enmarcan entre los años 60 y 70 , a los que ya se ha hecho referencia en otros apartados- inciden en cuál es el cambio principal de la visión del mismo: la consideración tradicional, que se basa en la propia función, se desvía dirigiéndose hacia una nueva manera de entenderlo: el objeto doméstico en un mundo de consumo y de cambios en la sociedad adquiere nuevas acepciones, lo que significa que se libera de la exclusividad de la función. La idea del objeto cotidiano pasa a ser la de un elemento de consumo y se convierte así en un símbolo de bienestar y estatus. Lo más importante ya no es su utilidad, sino su capacidad para comunicar y lo perceptible que pueda llegar a ser. Esta visión del objeto ordinario, es novedosa e influye, como dice Moles, de forma directa a todos los territorios del objeto, desde la tienda hasta el hogar. Frente esta idea es importante aclarar que aunque el objeto adquiere nuevas acepciones, este dato no implica que abandone las anteriores. Se hace hincapié en el concepto contemporáneo del objeto entendido como signo, en la consciencia de su capacidad para comunicar y en su consideración como agente activo para la elaboración de un discurso dentro del marco doméstico. Las nuevas acepciones no invalidan a las anteriores, sino que las complementan. En su nueva visión, la función del objeto pasa a ser su significado: "funcional' no califica de ninguna manera lo que está adaptado a un fin, sino lo que está adaptado a un orden o sistema: la funcionalidad es la facultad de integrarse a un conjunto"10.

La Un-home de Banham, una idea novedosa en los 60, desvincula el hogar contemporáneo de la forma de la casa tradicional, y lo hace buscando la esencia de lo doméstico en un conglomerado de objetos que representan el significado del confort desde el punto de vista moderno y consumista: un ambiente bien acondicionado en un enclave idílico con música en alta fidelidad, provisto de pantallas, antenas, trituradores de basura, etc. Pero también es importante desde el punto de vista de que, gracias a la idea de Banham, los artefactos son capaces de contar una historia por sí mismos, ya no desde el punto de vista tecnológico, sino desde la perspectiva de una figura que busca un escenario, un fondo donde colocado pueda hacerse perceptible "en un claro en el bosque o en una roca en la ensenada" sugiere Banham.

Esta idea puede relacionarse con la culminación del desarrollo de la planta abierta como una de las principales características del hábitat contemporáneo. El al espacio, por un lado, se concibe como un lugar o escenario abierto previsto para la acción humana, y por otro lado, el avance de la tecnología se refleja en los objetos, simbolizando una nueva era. Quizás por esta razón se percibe una cierta tendencia a representar los nuevos modos de vida en contenedores repletos de objetos tecnológicos y transformables que dotan al espacio doméstico de una nueva fisonomía, como vimos en los proyectos de Joe Colombo o Mandred Schiedhelm de finales de los $60^{11}$. En estos casos, los objetos, dentro del espacio, elaboran un doble discurso, el que corresponde al mensaje objetivo, basado en sus múltiples y variables relaciones topológicas, y el mensaje de tipo cultural que conecta el entorno y sus habitantes con los imperativos técnicos y sociales del momento.

Desde la visión del objeto como elemento que representa la sociedad de consumo, que autores como Roman Gubern califican como 'sociedad objetual', pone de manifiesto un interés sobre cuál es su nuevo papel en un mundo, que

10 Jean Baudrillard, El Sistema de los Objetos. (México: Siglo XXI, 1969) p. 71.

11 ver proyecto en Via Argelati 30b de Colombo y propuesta "do it yourself" de Schiedhelm, en el apartado 3.2. de esta tesis. 
como dice Kenneth Frampton, está caracterizado por la abundancia en bienes de 'usar y tirar', de lo que se deduce que:

- Las definiciones contemporáneas sobre el objeto huyen de los enunciados etimológicos y básicamente lo encuadran en el entorno de la vida cotidiana, atribuyéndole la idea de elemento específicamente humano y accesible al usuario, y es tratado como producto de consumo: "en nuestra civilización el objeto es artificial"12. Fenomenológicamente es considerado como un elemento material, manipulable, accesible a la percepción y destacable de su entorno. Esto hace entender el objeto como una pieza que puede ser partícipe en el juego de la composición espacial.

- En los principales estudios sobre objetos, el ámbito doméstico es considerado el eslabón final en la cadena de consumo y el lugar más obvio donde encontrar gran cantidad de objetos. Así el hogar se convierte en el marco privilegiado para el estudio del objeto cotidiano. Considerado como el terreno natural del objeto, cada parte de la vivienda puede distinguirse de las otras simplemente por su organización. En este aspecto el hogar se convierte en un importante escenario donde poder estudiar la sintaxis de los objetos reunidos en un interior. Es el campo en el que Moles decide desarrollar sus leyes sintácticas de acoplamiento, en cuyo desarrollo intervienen varias leyes: gramaticales, de concordancia, de subordinación, de jerarquía, de sentido, etc.

Las 'leyes de acoplamiento' de Moles constatan que existe la consideración de una lógica y una estructura de colocación de los muebles en el espacio. De la aparición de normas basadas en relaciones de orden y topológicas, se deduce que se reconoce la existencia de códigos objetivos de acoplamiento. Lo cual apoya los objetivos de esta tesis. Surgen por ejemplo la consideración del dominio de los muebles, de su área de influencia, lo cual es una señal que la disposición de objetos responde a unas normas gramaticales. Sin embargo, la idea de que todo objeto irradia a su alrededor ${ }^{13}$, también tiene una componente psicológica.

Esta faceta psicológica de los objetos surge a través del discurso subjetivo. Los objetos personales, los objetos simbólicos, los que evocan la memoria, aparecen como elementos añadidos al nuevo ámbito con el fin de dotar a la casa de una nueva dimensión. Son los que dan sentido al espacio, funcionado como vínculo entre la casa y el que la ocupa. En este aspecto surge una nueva consideración del objeto desde la fase de proyecto de la casa, sobre todo teniendo en cuenta que en el proceso comienzan a incluirse factores como experiencia, percepción o simbología, lo cual en algunos casos lleva a introducir también los símbolos de la contracultura en el espacio doméstico. La pieza que introduce la cultura popular en la casa se convierte en el hilo que conecta el interior de la vivienda con las ideas de cambio en la sociedad. Con el objeto se inserta en la casa lo que está ocurriendo en la calle, en el centro comercial, pero también la imagen de lo que se está exponiendo en los museos.

El avance de la técnica y la contracultura confluyen en el artefacto cotidiano contemporáneo por excelencia: la televisión. A pesar de estar presente en la mayor parte de los hogares modernos, el televisor es entendido en casi todos

12 Abraham A. Moles, Teoría de los Objetos. (Barcelona: Gustavo Gili, 1975) p. 29

13 En el apartado 1.2. "el dominio de los muebles", 
los estudios como un objeto alienante, por su omnipresencia, por su capacidad de transmitir otra realidad. Este dato constata que la visión actual de este objeto se mantiene intacta. Al contrario que la mayoría de los aparatos domésticos, no ha sufrido un proceso de miniaturización, sino todo lo contrario, y todo ello a pesar de que han surgido gadgets como el teléfono móvil o la tablet que pueden llegar a funcionar como réplicas en miniatura de la televisión, aunque en definitiva son pantallas, que provocan una sobreexposición es cada vez mayor por el avance de las telecomunicaciones y el uso de las redes.

\section{Apertura / confinamiento.}

Existe una tendencia a la pérdida de la privacidad en el ámbito doméstico contemporáneo. Por un lado es porque los espacios, como ya se ha visto, son cada vez más abiertos y menos compartimentados, lo cual hace que sea más difícil conseguir lugares donde poder aislarse del resto de la casa. El otro motivo es consecuencia de los nuevos hábitos de relación. La línea que separa lo público de lo privado es cada vez más difusa, algo que con los años se va acrecentado con el desarrollo de las redes y la consecuente sobreexposición. Ante esto, surge el fenómeno de "la casa dentro de la casa" -o la caja dentro de la caja- , y se convierte en un mecanismo que prolifera en los proyectos de espacio domestico a partir de los $60^{14}$, como respuesta a la necesidad de crear lugares de confinamiento en un espacio abierto. De esta manera el habitáculo se 'objetualiza', y se convierte en una 'caja' diferenciada del resto, que ordena el espacio libre y a su vez potencia la sensación de amplitud. La consecución de distintos niveles de interior favorece la idea de lugar y a su vez aporta connotaciones psicológicas y simbólicas: la trasposición del edículo tradicional, por parte de Moore, conlleva la consideración del 'centro del universo' dentro de la casa. Por todas estas razones se convierte en un recurso muy utilizado en esos años. Posteriormente, aunque en menor medida, sigue aplicándose con intenciones similares. En proyectos actuales como la Casa- $\mathrm{N}$ de Sou Fujimoto, perdura la búsqueda de distintos grados de interior por medio del juego de pieles, o en la Casa en Chiharada de Studio Velocity, se potencia la sensación de amplitud interior gracias al juego de escala que se produce por la disposición de un surtido de cajas dentro de la 'caja'.

Izquierda: Casa-N. Oita, por Sou

Fujimoto en 2008. Vista interior.

Derecha: Casa en Chiharada, por

Studio Velocity en 2013

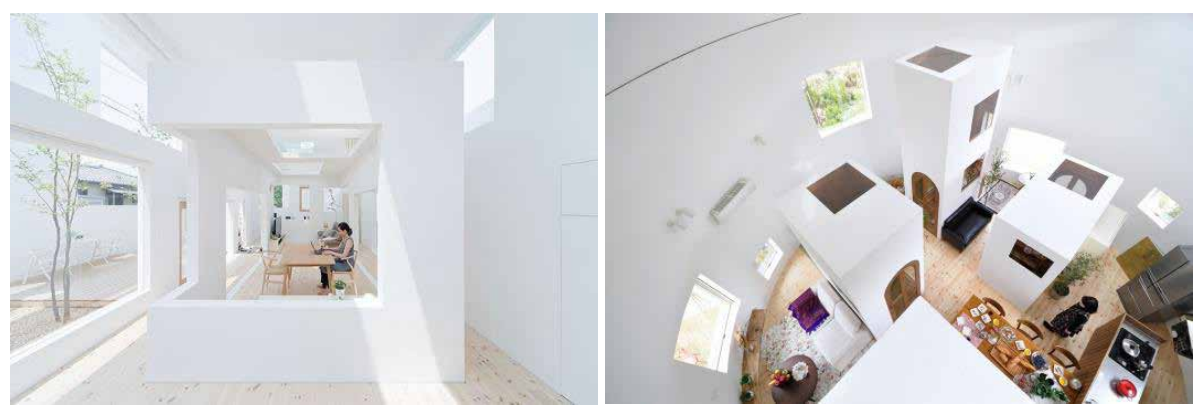

Existe un proceso inverso pero que, en la misma medida, se relaciona con la imagen de confinamiento y privacidad en un espacio doméstico abierto. Las mismas intenciones compositivas se aprecian en el uso de muebles, como las camas, que se transforman en habitáculos y adquieren la condición de espacios. La ambigüedad entre lo que es mueble y lo que no, vuelve sobre la consideración del objeto y sus nuevas acepciones. En la actualidad puede

14 Recordemos algunos proyectos de viviendas de MLTW en los 60 o de George Ranalli en los 70, en el apartado 1.3. "la casa dentro de la casa" de esta tesis. 

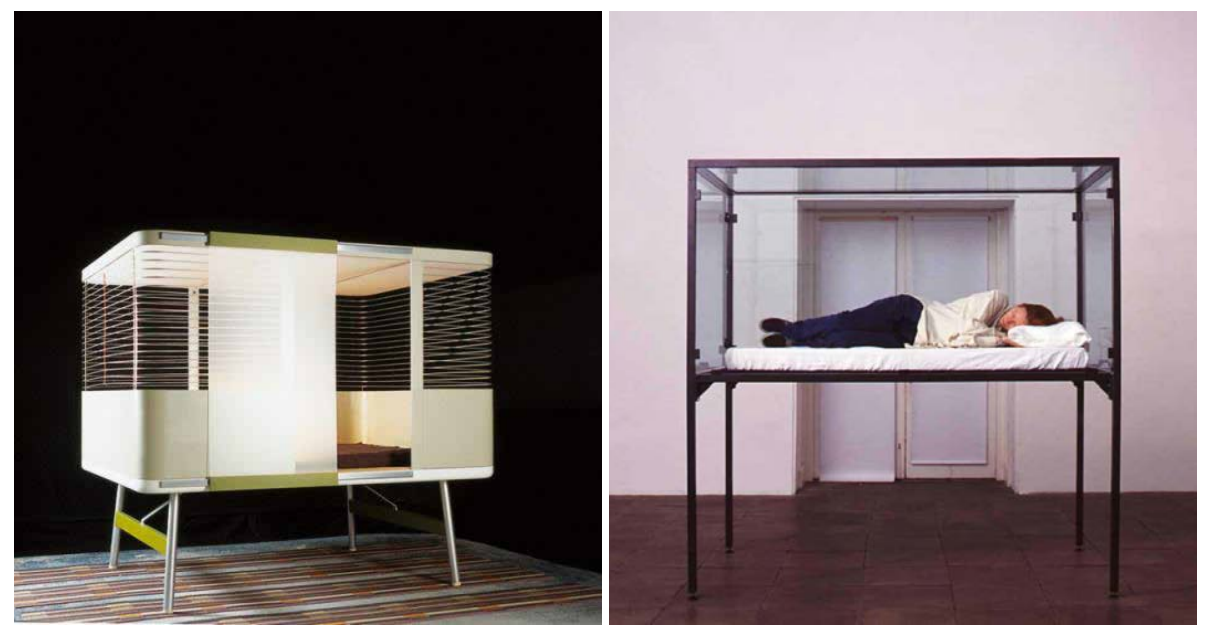

observarse esta idea en la línea de muebles como 'Lit clos' -2000- de Ronan y Erwan Bouroullec, o en instalaciones artísticas como The Maybe de Cornelia Parker de 1995.

Importante también, en este estudio, es el papel que adquiere el elemento arquitectónico cuando se desvincula del contexto, se distingue del fondo y asume la condición de objeto dentro del espacio. Este fenómeno como en el caso anterior, puede encuadrarse en estos años, y su razón de ser es la de que, una vez adquirida la condición de figura, pueda participar en el juego de signos que conforma el sistema de objetos. Por tanto, el elemento arquitectónico -escaleras, chimeneas, tuberías y conducciones, columnas, etc.-, debe 'objetualizarse' para convertirse en parte integrante del discurso generado por el sistema de objetos.

\section{Objeto y representación.}

De la representación del nuevo hábitat a través de las muestras y exposiciones de mobiliario y objetos para la vivienda en aquellos años, radica la comprensión de un proceso en el que la disposición de objetos se muestra en su forma más intencional y comunicativa. De cómo expresar a través de juegos y combinatorias de objetos en un marco no real ideas que son propias de los ámbitos contemporáneos, se deducen varios aspectos fundamentales:

- Que las exposiciones y muestras se convierten en el canal de difusión más importante, por su alcance al usuario, de las nuevas ideas relacionadas con el hogar y en las que participan los arquitectos y diseñadores más influyentes, acompañando a veces sus propuestas con manifiestos 0 simplemente memorias, que son textos de gran valor para comprender las ideas que se planteaban.

- En dichas muestras, las composiciones hechas con objetos -recreando espacios domésticos ficticios cuya base eran productos, en muchos de los casos, que comercializaban los patrocinadores- se convierten en el reflejo de las ideas que se están fraguando en ese momento y responden a los planteamientos del momento en torno a los nuevos modos de vida.

- Permite manejar el objeto de forma totalmente intencional, como en una escenografía, por lo que su grado de expresión, al ser mucho mayor, permite extraer las ideas de forma clara y concisa. La eventualidad 
convierte a las muestras en auténticos laboratorios de ideas.

También se aprecia un mayor afán por representar 'la escena doméstica'. Desde la más sencilla hasta la más futurista, los objetos configuran espacios ideales y la escena se produce en relación a su interacción con ellos. Todo consiste en recrear el marco de la vida cotidiana con habitantes ficticios en relación a un sistema de muebles y otros enseres domésticos, colocados en un espacio acotado y ubicados de una determinada manera, configurando un hogar simulado, lo que indica que:

- A medida que se avanza en el tiempo, el marco doméstico en el que se encuadra la escena aparece ligado a habitantes que responden a características propias del momento. Desde el habitante tradicional de las primeras exposiciones de los 50 que busca en el diseño un modo de vida más confortable, hasta el habitante cada vez más hedonista y consumista de los 80 . Sin embargo las exposiciones representan más bien lo que los diseñadores consideran que está reclamando la sociedad. Estas exposiciones pretenden ir a la vanguardia para marcar las pautas de los nuevos modos de vida.

- Los espacios representados en muchos casos aparecen 'modelados' por muebles y objetos de texturas suaves y agradables al tacto, simulando lugares que invitan a tumbarse y dirigiendo al espectador a una idea de hogar cuyo fin es albergar una vida de relax y deleite, donde las personas que habitan son felices en posición de descanso y en actitud de placer. La idealización del hogar es un síntoma consumista. En las exposiciones se recurre a la idea del espacio háptico y la multisensorialidad para satisfacer las necesidades de un habitante cada vez más hedonista y volcado en su propia subjetividad.

- Por ese motivo los avances técnicos, que inicialmente surgen por cuestiones prácticas, poco a poco, a medida que se avanza en el tiempo también se utilizan para crear 'sensaciones'. La técnica en los 80 va dirigida a la creación de placer y abandona la épica de los años 60. La incorporación de otros factores añadidos como olores, colores, sonido, iluminación, etc. tienen como objetivo generar 'atmósfera'. A través de las exposiciones se está presagiando la importancia del discurso de 'ambiente' y la aplicación de objetos y técnica para estos fines.

- La demanda de lugares especiales donde habitar lleva a representar espacios domésticos basados en nuevas ideas, como un lugar que represente el mundo interior del que lo habita, o un espacio onírico. Este aspecto conlleva a los arquitectos y diseñadores a trabajar con la realidad artístico-tecnológica y donde el objeto se convierte en parte de la búsqueda de atmósferas etéreas y metafísicas, como parte del sistema para la creación de 'ambiente'.

- No en vano existe el planteamiento sobre hasta qué punto reconocemos una casa, por sus características formales o por la presencia de una escena doméstica. La conclusión es que lo que transmite una escena doméstica es fundamental para entender lo que acontece en una época

- La obsesión por la creación de un decorado relacional donde todos los términos comuniquen continuamente entre sí y donde el visitante pueda observar 'en tiempo real' la vida de sus 'habitantes', se adelanta 
a esa especie de obscenidad donde los procesos más íntimos de la vida se convierten en el terreno del que hoy se alimentan los medios de comunicación.

\section{Exhibiciones y conceptos.}

En ese contexto arquitectos y diseñadores aprovechan las nuevas acepciones adquiridas por objeto para comunicar y expresar lo que está ocurriendo en el ámbito doméstico. Incluso, sobre todo en muestras de los 70 , lo utilizan para hacer crítica sobre la situación de la vivienda en sectores desfavorecidos de la sociedad de consumo. Por ejemplo, Sottsass utiliza muebles de plástico gris para desapegar al habitante contemporáneo de la cultura de consumo que asola el mundo. También Superstudio, con su instalación microenvironment ${ }^{15}$ hace una crítica similar planteando un modo de vida sin objetos. Este aspecto es fundamental para entender la importancia que tiene la presencia del objeto en el contexto en el que se enmarca esta tesis ya que, en un determinado momento, la ausencia de objetos se convierte en el verdadero sentido del proyecto.

De los ambientes y espacios recreados en las muestras también se deducen características de los hogares de la época y que pueden asimilarse como propias del proceso de desarrollo del espacio doméstico contemporáneo:

- La flexibilidad es quizás la característica más importante ligada a al tiempo en que se enmarca la tesis. En todo momento, este aspecto aparece asociado a la transformabilidad y movilidad de los muebles y del equipamiento, sobre todo en los años 60 y principios de los 70 . Es importante que, medida que avanza en el tiempo, la idea evoluciona y se apoya en otros conceptos. En las propuestas de Reyner Banham 0 Joe Colombo, en los 60, la condición de flexible del espacio contenedor es adquirida por la capacidad de transformación de los muebles articulados, que cambian de forma y lugar gracias a la técnica y a los nuevos materiales-. Posteriormente, llegando a los 80 , la versatilidad del espacio doméstico huye del artefacto mecánico y se dirige hacia lo efímero, la liviandad y la miniaturización, como los muebles que configuran el Pao de la muchacha nómada de Tokio: pequeños y ligeros, cuya fragilidad y tendencia a la obsolescencia representan el nuevo concepto de flexibilidad del espacio.

- En los ambientes analizados se alcanzan planteamientos de modos de vida contemporáneos, como el hecho de vivir en una casa compartida, donde la metáfora de la ciudad en torno a los espacios comunes, compartidos para la relación y el intercambio de información, incorporan la idea de lugar en el espacio doméstico.

- Se añaden al discurso arquitectónico-doméstico nuevos tipos de vivienda, ambiguas y polivalentes -en algunos casos establecidas en espacios reconvertidos-, como la casa para el artista, que representa la apropiación del espacio con objetos inacabados haciendo alusión a la creatividad del proceso, o como la casa que concilia hogar y trabajo

15 En apartado 2.4. "el nuevo paisaje doméstico" de esta tesis. 
en el mismo lugar. Todo ello surge como lectura de un fenómeno que se produce básicamente en la ciudad, pero que posteriormente se va incorporando a otros ámbitos de asentamiento.

- En sistemas donde proliferan múltiples objetos se evidencia la aparición del ordenador como herramienta única, lo que permite que muy diferentes trabajos se puedan realizar en un mismo lugar. Es el inicio de la consideración del teletrabajo, como un aspecto más a tener en cuenta en el diseño de la vivienda, que se aprecia en los proyectos de arquitectos implicados en esta vía de desarrollo de la vivienda contemporánea, como en los de Joe Colombo y la principal consideración de la relación espacio-tiempo, donde la tecnología adquiere especial protagonismo. Y como consecuencia, la miniaturización. La consecuencia de los avances técnicos, es la presencia de los gadgets en nuestras vidas. El hecho es que el habitante tiende a desvincularse cada vez más de sus objetos personales, llegando a casos como la representación 'promocional' de la casa de Steven Jobs, en la que la presencia de un ordenador aparece como más que suficiente para satisfacer todo lo necesario para la vida cotidiana; o la publicidad de hoy que utiliza slogans como "mi casa está donde está mi wi-fi", llegando al límite de la inmaterialidad absoluta, algo que ya anuncia Toyo Ito en el 'Pao de la muchacha nómada de Tokio' a finales de los ochenta. Incluso en estos casos, el objeto vuelve a ser protagonista, adquiriendo significancia de nuevo precisamente por su ausencia.

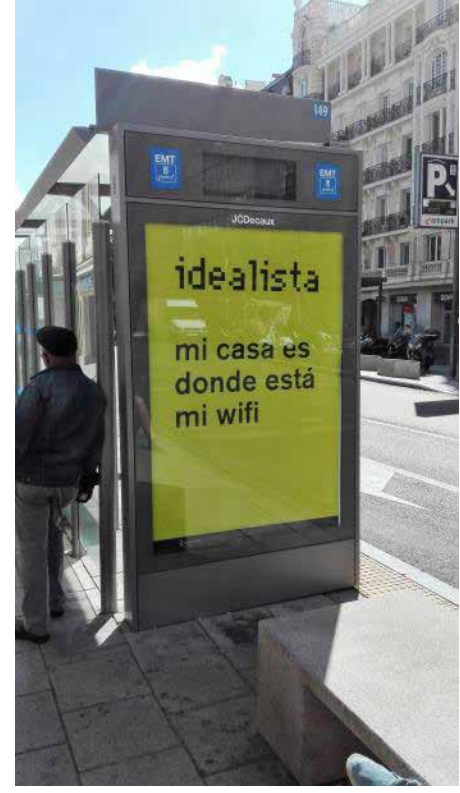

Imagen arriba: Publicidad tomada en una marquesina de la Calle Fuencarral de Madrid el 03/10/2016

Imagen: Steve Jobs, en su casa de Woodside, California, en 1984

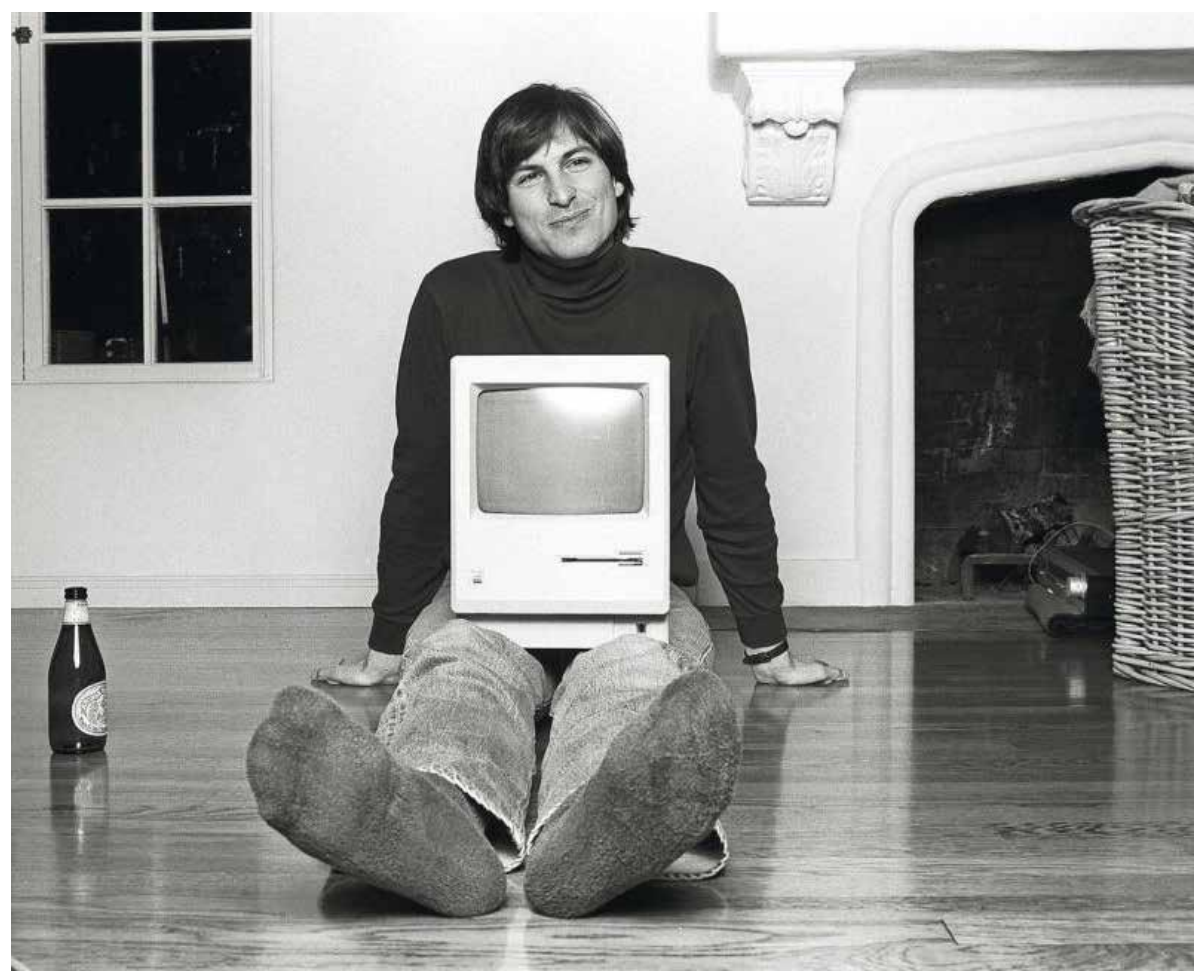




\section{Display'í: objetos y nuevos ámbitos.}

A la nueva visión del objeto como elemento de consumo se une su promoción y distribución. Abraham Moles ${ }^{17}$ utiliza el término display para referirse a la unidad de medida de cantidad de información aportada por el "discurso de los objetos" en unos grandes almacenes. Este término, aunque no está incluido en el diccionario, sin embargo aparece relacionado con términos como despliegue, y exhibición, para su promoción y venta. Igualmente puede utilizarse para la pantalla donde se ofrece información visual en un aparato electrónico. Esta polisemia, años después, del término utilizado por Moles, nos introduce en la evolución de la interpretación del marco doméstico a partir de las exposiciones: partiendo de un sistema de representación

- Existe una tendencia progresiva a la representación de una disolución del objeto en una escena ficticia que poco a poco se va instalando en la pantalla y que se divulga a través de la red. Propuestas como la 'casa telemática' de Ugo la Pietra ${ }^{18}$ dirigen a la idea de que los sistemas de información y comunicación tienen efectos reduccionistas sobre los objetos cotidianos -sólo sobreviven los que tienen valor tecnológico- y que la tendencia es la disgregación progresiva de la vivienda, que se dispersa por la ciudad.

- El proceso de dispersión por el efecto de los nuevos modos de relacionarse y de las redes presenta el ámbito doméstico en un 'limbo' entre lo privado y lo público. A través de propuestas de los 80 , como 'Whithdrawing Room' de Diller \& Scofidio'is, de nuevo existe una puesta en cuestión la idea de lo doméstico. La tendencia es a que todo se disgrega y se desdibuja. Los muebles levitan o desaparecen y los rituales cotidianos se subvierten en pos del narcisismo y el voyerismo: la vanidad, el hedonismo y la publicidad de lo privado marcan una nueva manera de representar el espacio doméstico.

Así pues, obtenidos los conceptos y modos de relación que se derivan de la nueva visión del objeto en el contexto de una sociedad de consumo y por tanto objetual, y adquiridas las nuevas ideas que giran en torno a la vivienda y a los nuevos modos de vida, a través del análisis de las propuestas presentadas en las principales muestras y exposiciones de la época, se concluye con un sistema de clasificación cuyo objetivo es vincular los sistemas de relaciones y conexiones de objetos en el espacio con las características y cualidades que son propias de los ámbitos domésticos contemporáneos. Del sistema de clasificación desarrollado en el capítulo 3 -objetos y espacio doméstico: relaciones y configuraciones- se deduce que:

16 Anotaciones de la RAE sobre el término display, aunque no está incluido en el diccionario."Voz inglesa cuyo uso es innecesario en español por existir alternativas propias para cada una de sus acepciones:

a) En su sentido más general, equivale a los términos españoles despliegue, exhibición o demostración, que son los que deben usarse.

b) En ciertos aparatos electrónicos, como teléfonos, calculadoras, equipos de música, etc., 'pequeña pantalla donde se ofrece información visual sobre su funcionamiento'. En español puede sustituirse por las expresiones pantalla de visualización o visualizador.

c) En el lenguaje publicitario, 'mueble o soporte en que se exhibe un producto para su promoción y venta'. El equivalente español es expositor.)"

17 Abraham A. Moles, "Display y surtido" en Teoría de los objetos (Barcelona: Gustavo Gili, 1975) p.173.

18 En apartado 2.5. "la desaparición de la escena y la disolución del objeto".

19 Ibídem. 


\section{Objetos y espacio y relaciones topológicas.}

Los entornos domésticos contemporáneos, requiere de elementos cuyas relaciones topológicas de proximidad, densidad y accesibilidad, distribuyan y ordenen según el programa de necesidades que se establece y las actividades que se producen. En estos casos el espacio se concibe como un escenario que el mobiliario configura según los actos de la vida cotidiana.

Vimos que las relaciones basadas en la irradiación de objetos procuran jerarquías y que efecto psicológico de un elemento centrado en el espacio genera orden a su alrededor en una especie de campo de acción que establece las condiciones para la disposición del resto de elementos. Un objeto con características formales o simbólicas fuertes puede desplazar al resto de los muebles a los límites del espacio generando recorridos a su alrededor, e incluso regularizando perceptivamente el espacio a través de las relaciones geométricas que se producen con los elementos que delimitan el ámbito. Hemos analizado casos en el apartado 3.1., pero incluso en proyectos recientes, como la Casa Okamura de Christian Kerez en Praga, el dominio y el efecto de irradiación del objeto acaban materializándose, convirtiéndose en las propias estancias, convirtiéndose en parte del proceso de diseño.

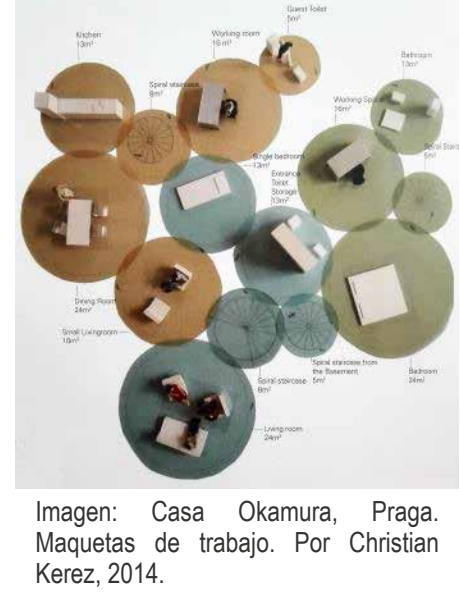

Kerez, 2014

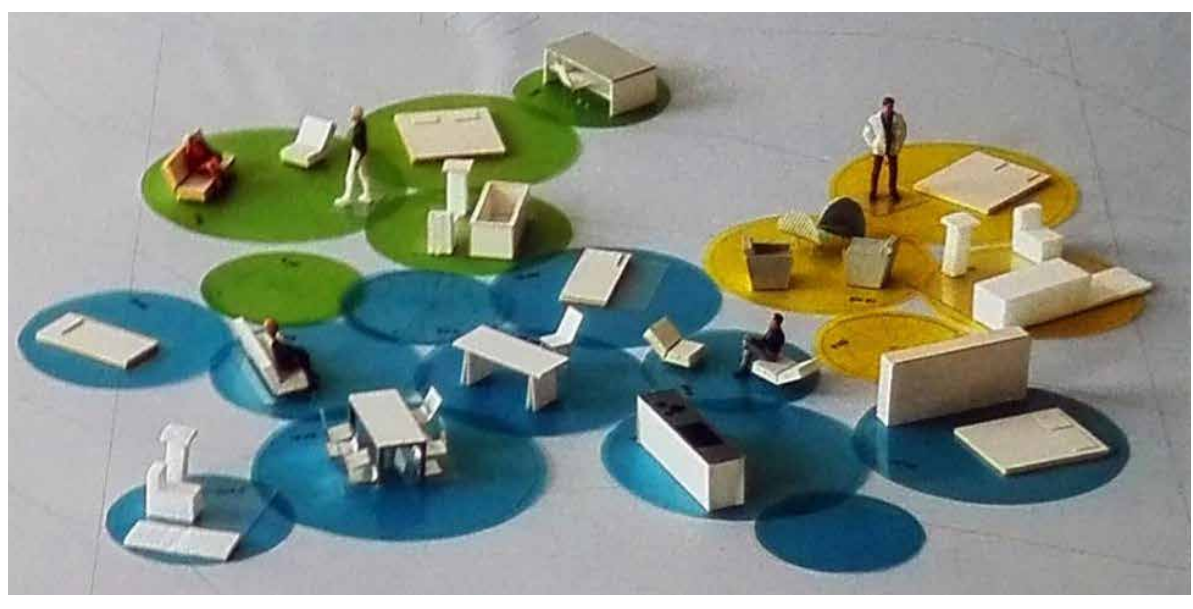

Varios objetos centradores, relacionados por contraste o también por cercanía, actúan como elementos articuladores. El diálogo que se produce entre dos o más objetos ordenadores multiplica las posibilidades espaciales, proporcionando espacios intermedios que relacionan las distintas zonas de la planta e implican a las áreas periféricas en la configuración global. Un ámbito abierto, sin compartimentaciones, también requiere de las relaciones topológicas entre objetos para zonificar, distribuir y organizar las distintas áreas dentro de un espacio único, según las necesidades. En la vivienda contemporánea es el método organizativo más habitual. Partiendo de una cierta ambigüedad espacial, los sistemas de objetos se basan principalmente en:

- Relaciones topológicas de accesibilidad, para estructurar y organizar la planta. Parte de los principios más básicos establecidos por Moles $^{20}$. Para que un objeto, un mueble o cualquier otra posesión sea utilizable es preciso que resulte accesible sin esfuerzo. Esto determina conscientemente la disposición topológica de una habitación y marca las condiciones de relación entre los distintos elementos, lo cual incluye que algunos objetos deban estar situados sobre, bajo o dentro de otros. 
- Relaciones de agrupación, proximidad o similitud, para calificar las áreas. Después de las relaciones de orden próximo, que dentro de los ámbitos, incitan a los elementos a aproximarse 0 agruparse manteniendo las correspondientes distancias semánticas, existe un segundo nivel de relación, más global y psicológico, que responde a la noción de densidad óptima ${ }^{21}$. Es el sistema 'hablado' de objetos más cotidiano, y a partir de ese discurso es posible diferenciar las áreas de la casa, por ejemplo: el comedor tiene el centro ocupado, el salón deja el centro vacío donde habitualmente se sitúa una alfombra, etc. Este tipo de relaciones suelen variar a lo largo del tiempo, como ocurre en la mayoría de los hogares actuales.

\section{Flexibilidad real y aparente.}

La necesidad de un espacio mutante establece el vínculo entre la flexibilidad, una característica íntimamente ligada al espacio doméstico contemporáneo, con la movilidad y transformabilidad de los objetos, algo que surge y se desarrolla gracias al avance de la técnica y a las nuevas necesidades del habitante en estos años.

Los espacios, cada vez más reducidos y las nuevas necesidades dirigidas a un lugar fácilmente adaptable a las circunstancias de cada momento, reclaman hogares polivalentes con capacidad para mutar, tanto en el espacio como en el tiempo. Paralelamente nuevos materiales y sistemas de montaje posibilitan la creación de muebles transformables. Ambas circunstancias influyen decisivamente en un cambio importante en el concepto de casa.

Se aprecian dos formas de abordar este tema. Por un lado existe la idea de flexibilidad generada por la movilidad de los muebles, los transformables, dentro de un espacio con los límites definidos e inamovibles. Y por otro lado la idea de que la flexibilidad está basada en la movilidad de los elementos, más o menos arquitectónicos, que hace que el contenedor sea más ambiguo en sus límites, dirigiendo la idea hacia una mutabilidad más física que aparente.

También existe una evolución a lo largo de los años en cuanto al concepto de movilidad de los objetos domésticos. La idea de flexibilidad y polivalencia del espacio de los 60 poco a poco deja de basarse en grandes artefactos articulados y en robots, y se dirige en los 80 hacia pequeños objetos efímeros cuya movilidad se basa en la fragilidad y su liviandad. Esta idea se observa claramente en los objetos que ocupan el Pao de la muchacha nómada de Tokio de Toyo Ito, pequeños enseres manejables, ligeros, asumen su obsolescencia y reciclaje como parte de su movilidad en la cultura consumista de 'usar y tirar'.

\section{Idea de apropriación: evolución..}

La apropiación representa otra manera nueva, que surge en los 60 , de colonizar los espacios contemporáneos. Se basa en la libertad de vida de sus habitantes, en muchos casos de las corrientes contra-culturales y artísticas que se desarrollan en el SoHo de Nueva York, y en un nuevo concepto de 


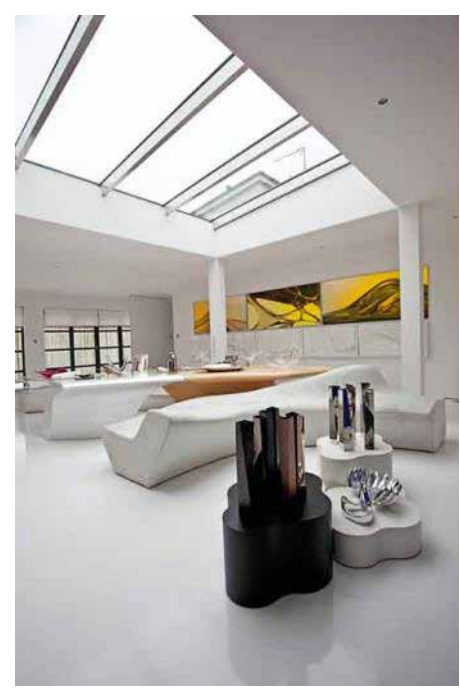

Imagen: Vivienda loft en Londres. Vista interior. Por Zaha Hadid en 2011. espacio doméstico que surge de aprovechar antiguos almacenes, lo que se conoce como loft.

Este fenómeno identifica al mismo tiempo la apropiación, entendida con un sistema de configuración del espacio en un proceso invasivo con objetos, con un modo de vida y con un contenedor con unas características muy determinadas: abierto, de aspecto industrial e inacabado. Recíprocamente se observa cómo un espacio con unas determinadas propiedades, puede inducir a un modo de vida que va ligado a un sistema de colonización del espacio muy similar en apariencia al que se producía en aquellos almacenes reconvertidos del SoHo neoyorkino. De un sistema de signos surgen espacios creados expresamente, simulando un espacio industrial reconvertido, para propiciar 0 conectar psicológicamente con modos de vida más libres y artísticos, desde las viviendas semejantes a los graneros de Sea Ranch de MLTW en los 60, hasta las viviendas sociales Nemausus de Jean Nouvel en Nîmes a finales de los 80. La apropiación, aparentemente caótica y basada en grandes cantidades de objetos reciclados, mezclados y descontextualizados, que surge como acto existencial y creativo a la vez, se convierte en un estilo que finalmente acaba desapareciendo tras el proceso de gentrificación de los 80 que convierte al loft en un tipo de vivienda para un sector emergente de las clases acomodadas, el yuppie. Ejemplos, como el de la vivienda/loft de Zaha Hadid en Londres -2011sirve para entender que aunque esta tipología perdura, no guarda ninguna relación con el concepto original, debido en gran medida a que el sistema de objetos implicados en el proceso de apropiación es completamente distinto. El objeto ha pasado de representar 'estatus contra-cultural' del habitante, a establecer el estatus económico y profesional del mismo.

\section{Objetos y casa: un lugar de 'sensaciones'.}

En el apartado de la clasificación 'Mecanismos de transformación espacial' muestra que factores que surgen de líneas de pensamiento contemporáneo, como vincular vivencia, experiencia y percepción al conocimiento de la arquitectura, también contribuyen en gran medida a determinar modos de relación de objetos en pos de crear lugares especiales donde vivir, ya que los nuevos hábitos lo reclaman. Para un habitante contemporáneo, inmerso una la sociedad de consumo, mayormente hedonista y con conexiones al mundo de la cultura y la contracultura que incorpora como algo cotidiano, se buscan lugares donde la experiencia de habitar sea algo nuevo y excitante. En este contexto, utilizar el objeto como mecanismo de transformación espacial se convierte en una herramienta más en el proceso de proyecto.

Cabe señalar dos aspectos importantes que se derivan de los modos de actuación y de las características de los ámbitos configurados según estos sistemas: el hedonismo y el concepto de ambiente.

Existe una búsqueda de nuevas sensaciones dentro de la vivienda, que se refleja en la aplicación de técnicas de diseño, de psicología de la percepción basada en la apreciación de configuraciones -gestalts- y en el uso de técnicas ilusionistas: métodos de camuflaje, trompe l'oeil, anamorfismos, incorporación de arte óptico, iluminación intencional, incorporación de objetos mezclados y descontextualizados, desde lo más clásico a lo más kistch, pasando por luces de neón y artefactos propios de un centro comercial, etc., su finalidad es provocar ambigüedad y desconcierto. En los 60 se aprecia un cierto 'manierismo', en 
las intenciones en ciertos arquitectos que pretenden modificar la percepción espacial. Ello es debido a la consideración de la experiencia como factor de conocimiento de la arquitectura, lo cual favorece que recursos ópticos como los supergráficos o la aplicación del diseño psicodélico invada todos los ámbitos de la arquitectura, incluida la vivienda. Las publicaciones monográficas de los 60 consolidan el supergráfico como método de tratamiento del espacio.

\section{Hedonismo y ambiente.}

Al perderse la imagen de la casa tradicional, recordando la frase de Banham: "Un hogar no es una casa", frente a lugares construidos con materiales prefabricados, con grandes superficies abiertas, o en espacios industriales reconvertidos, surge una necesidad de crear vínculos entre el habitante y los nuevos 'contenedores'. En esa búsqueda la domesticidad aflora añadiendo ingredientes subjetivos generando conexiones psicológicas a través de las connotaciones que van asociadas a objetos simbólicos o personales. Por esta razón en este contexto las colecciones adquieren mayor protagonismo en la configuración de los hogares, ya que se tratan de sistema de objetos, con tal carga emocional y compositiva, que son capaces por un lado de crear esos vínculos añorados y por otro de marcar las pautas decisivas en la organización espacial de la casa. Aunque existen antecedentes, a partir de la casa de los Eames en 1949, la colección particular y los objetos simbólicos son parte del discurso en torno a la vivienda contemporánea.

La casa hedonista, el habitante reclama espacios especiales donde vivir. Donde de rienda suelta a su propia vida, solicitando lugares especiales donde vivir. Hemos visto ejemplos que reflejan este fenómeno de finales de los 80 , con tintes irónicos como 'casa palestra, de Koolhaas, que incide en la cultura del culto al cuerpo de finales de los ochenta, the withdrawing romm de Diller $y$ Scofidio, que también hace hincapié en el componente narcisista del habitante contemporáneo.

Lo subjetivo también aparece unido al concepto de 'ambiente'. Entendido como el resultado del 'tratamiento del espacio', es un término que unifica muchos de los aspectos tratados en esta tesis. La consideración del 'ambiente', como sistema de signos, es un fenómeno contemporáneo, y es algo que en la actualidad resurge a través de la idea de 'atmósfera' en la arquitectura, presente en algunas obras de arquitectos como Peter Zumthor, Jean Nouvel -Hotel en Lucerna, 2000- o Studio Mumbai -Carrimjee House, 2015-. La colocación como tratamiento del espacio, se convierte también en elemento de ambiente.

\section{Agrupación y optimización.}

Del sistema de clasificación también se deduce que pesar de que existen antecedentes, la agrupación de los equipamientos es un fenómeno que surge a partir de los 60 ligado a dos aspectos fundamentales:

- Los avances técnicos provocan la proliferación de aparatos y electrodomésticos dentro del hogar. La necesidad de concentrarlos en un mismo punto de la casa surge por optimizar las instalaciones necesarias para su funcionamiento y para reducir el espacio necesario,

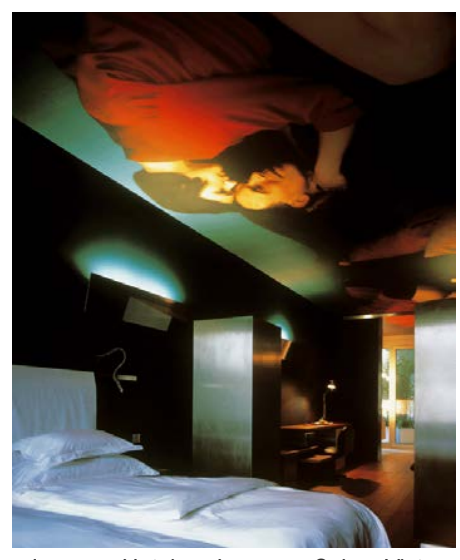

Imagen: Hotel en Lucerna, Suiza. Vista interior de una habitación. Por Jean Nouvel en 2000.

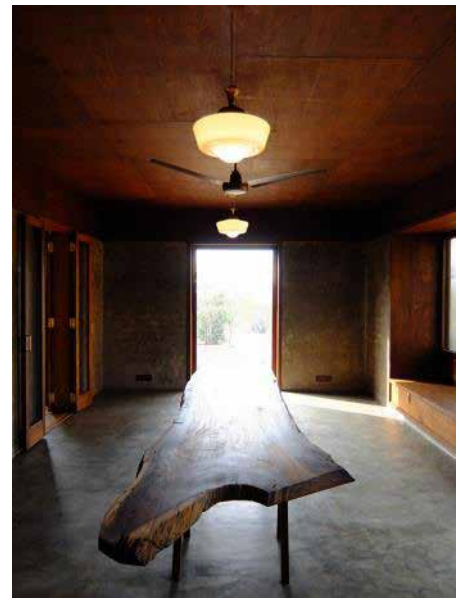

Imagen: Carrimjee House. Vista interior. Por Studio Mumbai en 2015. 
concentrando las zonas de uso.

- Por otro lado, en este tipo de relaciones por proximidad y fusión entre objetos y servicios, se aprecia la intención proyectual de liberar espacio y donde las razones son más compositivas que prácticas. Este aspecto, que es característico de los ámbitos contemporáneos, muestra un cambio importante en la distribución de elementos respecto de la casa tradicional -llena de aparatos distribuidos que son obstáculo para una distribución más libre- el problema de cómo abordar la organización espacial de un hogar lleno de electrodomésticos ya había sido planteado los Smithson en los 50.

\section{Agrupación y composición.}

Aunque son importantes los motivos técnicos para agrupar objetos de equipamiento y aparatos, tras el análisis de los casos se aprecia que en las relaciones de proximidad entre elementos concentrados, en uno o varios sistemas, existe una intención de clara de crear elementos netos y perceptibles en el espacio. Las configuraciones basadas en agrupación de elementos aprovechan las cualidades compositivas de las relaciones de figura fondo para aumentar la sensación de amplitud espacial en los hogares. Un aspecto además que en cierto modo va unido a otro factor que caracteriza en gran medida los modos de actuación con objetos en el espacio contemporáneo: la idea de lugar en arquitectura.

\section{Agrupación y optimización.}

La importancia de los recorridos en el espacio doméstico aparece ligado a la idea de lugar de Norberg-Schulz, al modo de vida moderno y a la manifestación concreta de la simultaneidad de los lugares. En este aspecto, se aprecia una implicación directa del uso del objeto con varias intenciones:

- Convertir la casa en un campo de exploración. Gracias a la disposición sucesiva de objetos, colocados de forma estratégica, se detecta, en los espacios analizados, que existe una clara intención de inducción al movimiento y al recorrido visual, generando secuencias a lo largo de la vivienda por relaciones de simultaneidad.

- El objeto, considerado como signo, actúa como hito y determina los lugares de parada o los de mayor interés visual. La naturaleza del objeto que funciona como hito va desde la obra de arte hasta el objeto cotidiano con grandes connotaciones psicológicas, pasando por lo kitsch o lo singular.

- La simultaneidad de lugares precisa de los puntos de referencia que establecen los objetos. Este aspecto influye de manera importante en el hogar contemporáneo en el sentido de que espacios que tradicionalmente eran de paso o de servicio gracias a los objetos se convierten en ámbitos de la casa que ofrecen nuevas posibilidades. Por ejemplo, un rellano de una escalera se convierte en zona de descanso o de lectura, un paso puede configurarse como biblioteca. 
- Un recorrido basado en una relación lineal entre hitos puede convertirse en el sentido del espacio.

\section{El paisaje artificial y los objetos.}

Otro aspecto que caracteriza el espacio a través de la relación entre objetos es la posibilidad de concebir la casa como un paisaje artificial. En este sentido, se determinan dos tipos de entornos:

- La consideración de la metáfora del paisaje urbano dentro de espacio. Este efecto se genera a través de juegos de escala, donde los objetos adquieren significados que los relacionan con hitos urbanos, con fachadas en miniatura, con edificios a una escala reducida. Este modo de actuación aúna dos aspectos, por un lado está la idea de lugar a través de la simultaneidad y la creación de hitos, y por otro la búsqueda del espacio como fondo o como 'paisaje' para potenciar el concepto del espacio abierto.

- La reproducción del paisaje natural dentro de la casa. La inclusión de la vegetación en el espacio doméstico con fines compositivos no deja de ser artificial. Tras un proceso de 'objetualización', los ámbitos contemporáneos utilizan la vegetación para conformar y organizar a través de relaciones topológicas de accesibilidad, densidad. La fusión con otros elementos proporciona cualifica determinados lugares dentro del paisaje artificial que en muchos casos puede englobar el mismo ámbito, encontrándose ejemplos en la actualidad como 'Casa con Plantas' de Ishigami, o como la 'Casa Jardín' de Ryue Nishizawa, en cuyo caso además reproduce un recurso paisajístico presente, como es el jardín vertical.
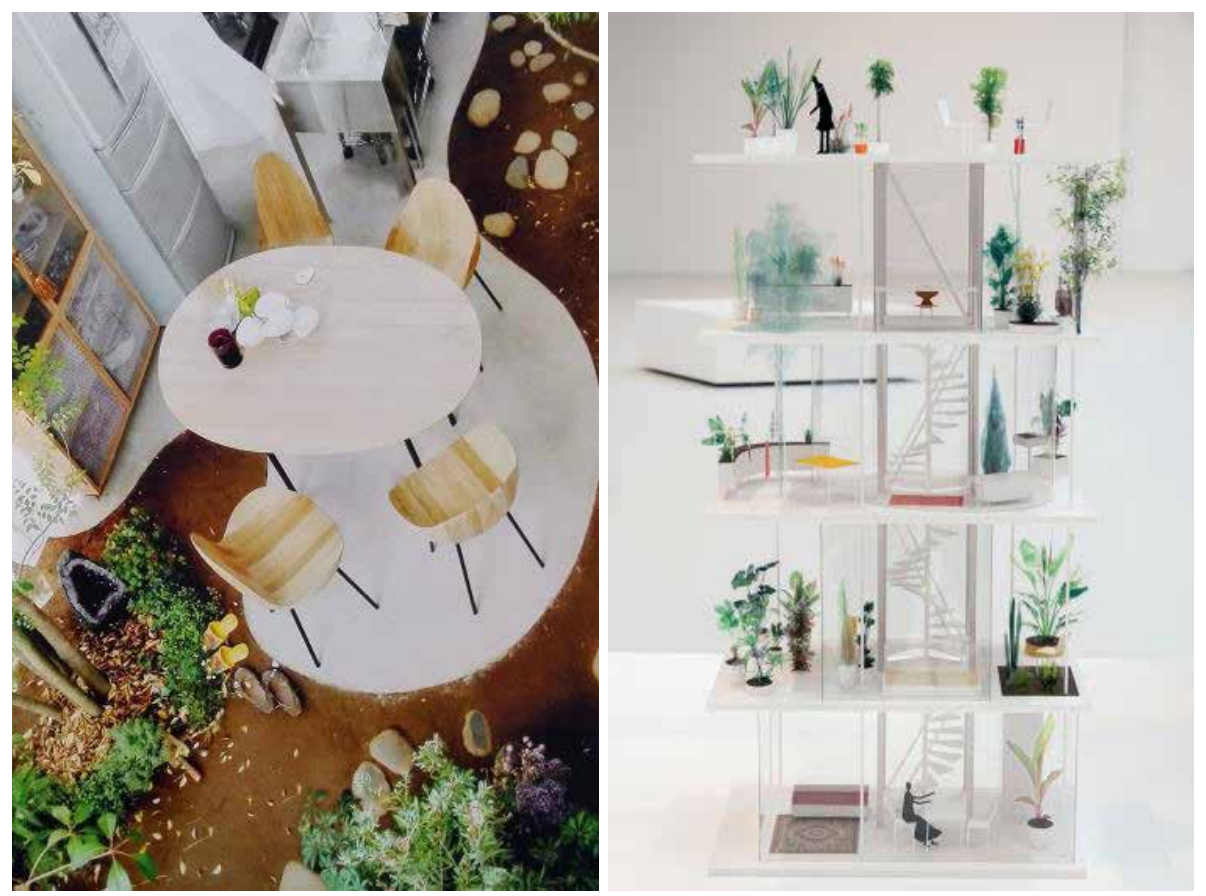

Este trabajo deja varios campos abiertos a futuras investigaciones. Desde la perspectiva de hacia donde se dirigen los distintos modos de relaciones 
y configuraciones, que se deducen de la clasificación realizada para esta tesis, hasta la evolución del espacio doméstico desde el punto de vista de la influencia de los nuevos sistemas de objetos y los hábitos sociales que surgen a partir de finales de los 80 , donde la influencia de las redes provoca una nueva escena doméstica y otros modos de relacionarse. 

BIBLIOGRAFÍA 

Imagen: Casa-estudio Andersson en Moore/Andersson Compound, Austin Texas. Por Moore/Andersson Architects. Detalle de la librería que recorre la casa.

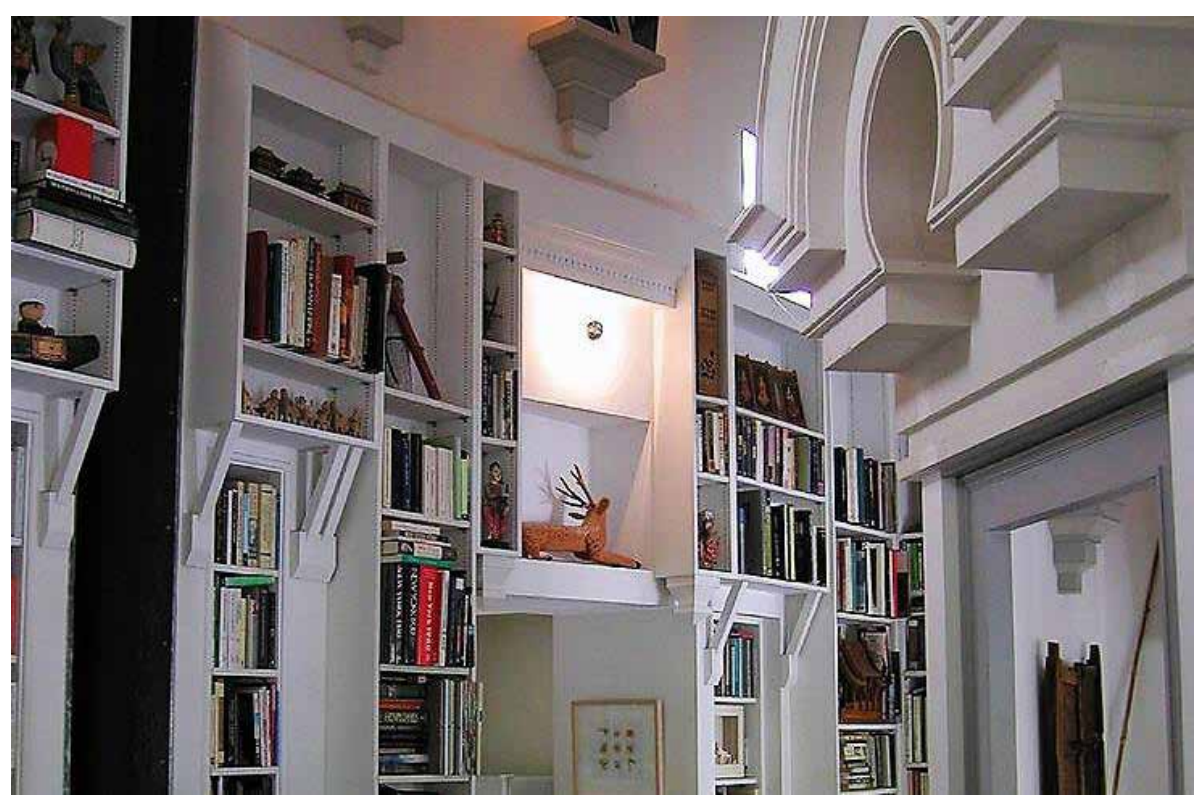

\section{BIBLIOGRAFÍA}

\section{BIBLIOGRAFI'A GENERAL}

Libros

Allen, Stan. Del Objeto al Campo. Edicion original 1997, revisada y reeditada en Naturaleza y artificio: el ideal pintoresco en la arquitectura y el paisajismo contemporáneos. Iñaki Abalos, Barcelona: Gustavo Gili, 2009.

Amann Alcocer, Atxu. El espacio doméstico: la mujer y la casa. Buenos Aires: Nobuko, 2011.

Bachelard, Gaston. La poética del espacio. México: Fondo de Cultura Económica, 2006. Edición original, 1957.

Baudrillard, Jean. Las Estrategias Fatales. Barcelona: Anagrama, 1984.

Baudrillard, Jean; Nouvel, Jean. Los objetos singulares: arquitectura y filosofía. México: Fondo de Cultura Económica, 2001.

Benevolo, Leonardo. Historia de la Arquitectura Moderna. Barcelona: Gustavo Gili, 1999 (8a ed. rev. y amp.)

Bourriaud, Nicolas. Estética Relacional. Buenos Aires: Adriana Hidalgo, 2008.

Bryson, Bill. En casa. Una breve historia de la vida privada. Barcelona: RBA, 2011.

Brooker, Graeme / Stone, Sally. Elementos y Objetos. San Sebastián: Nerea, 2010. 
Curtis, William J.R.. La Arquitectura Moderna desde 1900 (3a ed. amp. en castellano) Londres: Phaidon Press Limited, 2006.

Foster, Hal et al. (ed. p.). Arte desde 1900. Modernidad, antimodernidad, posmodernidad. Madrid: Akal S.A., 2006.

Frampton, Kenneth. Historia Crítica de la Arquitectura Moderna (4⿳亠丷厂 ed. amp.). Barcelona: Gustavo Gili, 2012.

Fusco, Renato de. Historia de la Arquitectura Contemporánea. Madrid: Hermann Blume, 1981. Edición original, 1974.

Gorostiza López, Jorge. La profundidad de la pantalla, Arquitectura + Cine. Santa Cruz de Tenerife: Colegio Oficial de Arquitectos de Canarias, 2007.

Gregotti, Vittorio. Desde el interior de la arquitectura: un ensayo de interpretación. Barcelona: Península, 1993.

Hall, Edward T. La dimensión oculta. Buenos Aires: Siglo XXI Editores, 2001. Edición original, 1966.

Holl, Steven. Cuestiones de percepción. Fenomenología de la arquitectura. Barcelona: Gustavo Gili, 2005. Edición original, 1994.

Jencks, Charles et al. El nuevo paradigma en la arquitectura contemporánea. Valencia: Ediciones Generales de la Construcción, 2004.

Le Corbusier. Hacia una Arquitectura. Madrid: Apóstrofe, 1998. Edición original, 1923.

Le Corbusier. El arte decorativo de hoy. Barañaín: EUNSA, 2013. Edición original, 1925.

Le Corbusier. Precisiones respecto a un estado actual de la arquitectura y del urbanismo. Barcelona: Poseidón, 1999. Edición original, 1930.

Lefebvre, Henri. La producción del espacio. Madrid: Capitán Swing Libros, 2013. Edición original, 1974.

Lleó Fernández, Blanca. Sueño de habitar. Barcelona: Gustavo Gili, 2005.

Maderuelo, Javier. La idea de espacio en arquitectura y arte contemporáneos. Madrid: Akal, 2008.

Méndez Baiges, María Teresa. Camuflaje: engaño y ocultación en el arte contemporáneo. Madrid: Siruela, 2007.

Merleau-Ponty, Maurice. Fenomenología de la percepción. Barcelona: Planetade Agostini, 1993. Edición original, 1945.

Norberg-Schulz, Christian. Genius Loci: towards a phenomenology of architecture. Londres: Academy, 1980.

Norman, Donald A. La psicología de los objetos cotidianos. San Sebastián: Nerea, 2010. 
Opel, Adolf; Quetglas, Josep (ed. p.). Escritos. Adolf Loos. Madrid: El Croquis, 1993.

Ozenfant, Amédée; Le Corbusier. Acerca del Purismo. Escritos 1918-1926. Madrid: El Croquis Editorial, 1994.

Pallasmaa, Juhani. Los Ojos de la Piel. Barcelona: Gustavo Gili, 2010. Edición original, 2005.

Praz, Mario. La casa de la vida. Madrid: DeBolsillo, 2004. Edición original, 1979.

Rasmussen, Steen Eiler. La experiencia de la arquitectura. Barcelona: Reverté, 2007. Edición original, 1957.

Rowe, Colin y Slutzky, Robert. Transparency. Basilea: Birkhauser, 1997.

Rybczynski, Witold. La casa. Historia de una idea. San Sebastián: Nerea, 2009 (9a ed.). Edición original, 1986.

Scott Brown, Denise. Aprendiendo del Pop. Barcelona: Gustavo Gili, 2007. Edición original, 1971.

Solaguren-Beascoa, Félix. "El mundo interior. El mundo de los objetos", en: Arne Jacobsen. Barcelona: Santa \& Cole, 1998.

Sudjic, Deyan. El lenguaje de las cosas. Madrid: Turner, 2009.

Tanizaki, Junichiro. El elogio de la sombra. Madrid: Siruela, 1997. Edición original, 1986.

Taylor, Victor E.; Winquist, Charles E (ed. p.). Enciclopedia del Posmodernismo. Madrid: Síntesis, 2002.

Venturi, Robert; Scott Brown, Denise; Izenour, Steve. Aprendiendo de Las Vegas. Barcelona: Gustavo Gili, 1978. Edición original, 1972.

Vilchis, Luz del Carmen. Metodología del diseño. Fundamentos teóricos. México D.F.: Claves Latinoamericanas S.A., 1998.

Weston, Richard. Evolución arquitectónica de la casa en el siglo XX. Barcelona: Blume, 2002.

Zumthor, Peter. Atmosferas: entornos arquitectónicos-las cosas que me rodean. Barcelona: Gustavo Gili, 2006.

Zumthor, Peter. Pensar la arquitectura. Barcelona: Gustavo Gili, 1999. 


\section{Artículos}

AAVV. "Record houses of 1969". Architectural Record, n6, tomo 145, may1969. 25-86.

AAVV. "Record houses of 1970". Architectural Record, n6, tomo 147, may1970. 25-85.

AAVV. "Record houses of 1972". Architectural Record, n6, tomo 151, may1972. 19-78.

Agrest, Diana. "Charles Moore: Portrait d'un artiste. Form Diggers". Architecture d'Aujourd'hui. n0184, mar/abr-1976.

Allende, Gabriel. "Del encanto de los geodos y huevos de pascua rusos a la correcta sorpresa en la arquitectura: Charles W. Moore". Arquitectura n²15, nov/dic-1978. 66-68.

Ambasz, Emilio. "Introducción a la última década del diseño en Italia". Temas de Diseño n³, jul/ago-1972. 3-5.

Cid Jurado, Alfredo. "El estudio de los objetos y la semiótica". Cuicuilco, no 9 may/ago-2002.http://www.redalyc.org/articulo.oa?id=35102511. ISSN 14057778.

Diaz Moreno, Cristina y García Grinda, Efrén. "A vueltas con la casa: 25 casos y un diagnóstico". AV Monografías, nº jul/ago-2001. 104-113.

Itoh, Teiji. "Tokonoma". GA houses. n³, 1977. 4-7.

Moore, Charles W. "Alcoves". GA houses. n02, 1977. 4-7.

Teyssot, Georges. "Architecture de prothèse pour un corps post-humain". L'Architecture d'aujourd'hui, nº 351, mar-2004. 46-55.

Wise, Pyra. "L'intérieur selon Proust". L'Architecture d'aujourd'hui, n³51, mar2004. 56-61. 


\section{BIBLIOGRAFIA ESPECIFICA}

Libros

Abalos, Iñaki. La Buena vida. Visita guiada a las casas de la modernidad. Barcelona: Gustavo Gili, 2001.

Allen, Gerald (ed. p.). Charles Moore, by Gerald Allen. Nueva York: Whitney Library of Design, 1980.

Ambasz, Emilio (ed. p.). Italy the New Domestic Landscape. Achievements and Problems of Italian Design. The Museum of Modern Art. New York. Greenwich, Connecticut: New York Graphic Society Ltd., 1972.

Barthes, Roland. "Semántica del Objeto" en Arte e Cultura nella civilita contemporánea. Editado por Piero Nardi. Florencia: Sansoni, 1966. Edición en PDF: http://mariosantiago.net/Textos\%20em\%20PDF/semanticadelobjeto.pdf

Baudrillard, Jean. El Sistema de los Objetos. México: Siglo XXI, 1969. Edición original, 1968.

Baudrillard, Jean. "El éxtasis de la comunicación", en La Posmodernidad, (ed. p.): Hal Foster. Barcelona: Kairós S.A., 1985. p.187-197.

Benjamin, Walter. Obra de los pasajes 1. Libro V, vol.1. (trad. p.): Juan Barja de Quiroga Losada. Madrid: Abada 2013. Edición original, 1940. http://www. circulobellasartes.com/benjamin/termino.php?id=1169

Branzi, Andrea. The work of Ettore Sottsass and Associates. New York: Universe, 1999.

Colomina, Beatriz. La Domesticidad en Guerra. Barcelona: Actar, 2006.

Colquhoun, Alan. Recueil d'Essais Critiques : Architecture moderne et changement historique. Bruselas: Mardaga Ed. 1981.

Cook, Peter (ed. p.). ARCHIGRAM. Nueva York: Princeton Architectural Press, 1999.

Crosbie, Michael J. Centerbrook: Reinventing American Architecture. Rockport: Rockport Publisher, 1993.

Eleb, Monique; Châtelet, Anne Marie y Mandoul, Thierry. Penser l'habité. Le logement en questions. Paris: Pierre Mardaga Editeur, 1988.

Eleb, Monique y Châtelet, Anne Marie . Urbanité, Sociabilité et Intimité. Des logements d'aujourd'hui. Paris: Les Editions de l'Épure, 1997.

Favata, Ignazia. Joe Colombo and italian design of the sixties. Milán: Idea Books, 1988.

Forino, Imma. L'interno nellinterno. Una fenomenología dell'arredamento. Florencia: Alinea Editrice, 2001. 
Foster, Hal. (ed. p.). La Posmodernidad. Barcelona: Kairós S.A., 1985.

Frampton, Kenneth (ed. p.). Steven Holl Architect. Milán: Electa, 2003.

Frampton, Kenneth (ed. p.). Hans Hollein. Tokio: A+U Publishing, 1985

Friedman, Mildred (ed. p.). Frank Gehry: The Houses. Nueva York: Rizzoli, 2009.

Futagawa, Yukio (ed. p.). Houses by MLTW Moore Lyndon Turnbull \& Whitaker 1959-1975. Tokio: A.D.A. Edita, 1975.

Futagawa, Yukio (ed. p.). Steven Holl 1975-1998. Volume-I. Tokio: A.D.A. Edita, 2012.

Gállego, Julián. El Cuadro dentro del Cuadro. Madrid: Cátedra, 1984.

Gehry, Frank O. La arquitectura de Frank Gehry. Barcelona: Gustavo Gili, 1988.

Giedion, Sigfried / Léger, Fernand / Sert, Josep Lluis. "Nueve puntos sobre monumentalidad". 1943. En: Sert: Arquitecto en nueva York. (ed. p.): Xavier Costa. Barcelona : Museu d'Art Contemporani de Barcelona, 1997.

Hereu, Pere; Montaner, Josep María; Oliveras, Jordi (ed. p.). Textos de Arquitectura de la Modernidad. Guipúzcoa: Nerea, 1994.

Hertzberger, Herman. Herman Hertzberger, 1959-1990. Tokio: A+U Publishing, 1991.

Holl, Steven. Entrelazamientos. Steven Holl 1989-1995. Barcelona: Gustavo Gili, 1997.

Ito, Toyo. "El pao de las muchachas nómadas de Tokio" en Toyo Ito. Escritos. Murcia: Colección de arquitectura. Colegio Oficial de Aparejadores y Arquitectos Técnicos de Murcia, 2000. Edición original, jun-1988.

Jacobson, Clare; Blieden, Molly (ed. p.). Entrelazamientos. Steven Holl 19891995. Barcelona: Gustavo Gili, 1997.

Jencks, Charles. El lenguaje de la Arquitectura Posmoderna. Barcelona: Gustavo Gili S.A., 1980. Edición original, 1977.

Johnson, Eugene J. (ed. p.). Charles Moore. Buildings and Projects 1949-1986. Nueva York: Rizzoli, 1986.

Kahn, Louis I. "Monumentalidad". 1944. Publicado en: Louis I. Kahn. Writings, Lectures, Interviews. Rizzoli, 1991.

Keim, Kevin. An Architectural Life: Memoirs \& Memories of Charles W. Moore. Boston: Little Brown and Co., 1996.

Koffka, Adrian; Kohn, Wendy (ed. p.). Moore Ruble Yudell: Building in Berlin. Victoria: Images Publishing Group, 1999.

Kries, Mateo; Vegesack, Alexander von (ed. p.). Joe Colombo. Inventing the 
future. Weil am Rheim: Vitra Design Museum, 2005.

Littlejohn, David. Architect. The life and work of Charles W. Moore. New York: Ed. Holt, Rinehart and Winston, 1984.

Los, Segio (ed. p.). Carlo Scarpa 1906-1978, un poeta de la arquitectura. Colonia: Taschen , 2009.

Lucan, Jacques (ed. p.). OMA, Rem Koolhaas: Architecture 1970-1990. Milán: Electa , 1991.

Lyndon, Donlyn / Alinder, Jim (ed. p.). The Sea Ranch. New York: Princeton Architectural Press, 2004.

Maniaque, Caroline. Le Corbusier et les maisons Jaoul. París: Picard, 2005.

Massobrio, Giavanna et al. Paolo Portoghesi Architetto. Milán: Skira, 2001.

McCarter, Robert (ed. p.). Aldo van Eyck. New Haven: Yale University Press, 2015.

Moleón, Pedro. John Soane (1753-1837) y la arquitectura de la razón poética. Madrid: Mairea, 2001.

Moles, Abraham A. Teoría de los objetos. Barcelona: Gustavo Gili, 1975. Edición original, 1972.

Monteys, Xavier / Fuertes, Pere. Casa collage: un ensayo sobre la arquitectura de la casa. Barcelona: Gustavo Gili, 2001.

Monteys, Xavier. Rehabitar: en nueve episodios. Madrid: Lampreave, 2012.

Monteys, Xavier. La habitación. Más allá de la sala de estar. Barcelona: Gustavo Gili, 2014.

Moore, Charles W. I Allen, Gerald / Lyndon, Donlyn. La casa: forma y diseño. Barcelona: Gustavo Gili S.A., 1999. Edición original, 1974.

Moore, Charles W. I Allen. Gerald. Dimensiones de la arquitectura. Espacio, forma y escala. Barcelona: Gustavo Gili S.A., 1978. Edición original, 1976.

Moore, Charles W. I Bloomer, Kent C. Cuerpo, Memoria y Arquitectura. Introducción al diseño arquitectónico. Madrid: H. Blume, 1982. Edición original, 1977.

Norberg-Schulz, Christian. Existencia, espacio y arquitectura. Barcelona: Blume, 1975. Edición original, 1971.

Norberg-Schulz, Christian. Intenciones en arquitectura. Barcelona: Gustavo Gili, 1998. Edición original, 1966.

Norberg-Schulz, Christian. Los Principios de la Arquitectura Moderna. Barcelona: Reverté S.A., 2005. Edición original, 2000.

Otero-Pailos, Jorge. Architecture's Historical Turn: Phenomenology and the 
Rise of the Postmodern. Minneapolis: University of Minnesota Press, 2010.

Perec, Georges. Especies de espacios. Barcelona: Montesinos, 2007. Edición original, 1974.

Quesada, Fernando. La caja mágica. Cuerpo y escena. Barcelona: Fundación Caja de Arquitectos, 2005.

Quesada, Fernando. Del cuerpo a la red. Madrid: Ediciones Asimétricas, 2013.

Raggi, Franco; Trabucco, Francesco (ed. p.). Le case della Triennale. Otto progetti di ambienti domestici contemporanei. Milán: I Quaderni della Triennale, Electa. 1983.

Riera Ojeda, Óscar (ed. p.). Moore Ruble Yudell: Viviendas. Buenos Aires: Kliczkowski, 1994.

Riera Ojeda, Óscar (ed. p.). George Ranalli. Buenos Aires: Kliczkowski, 1998.

Risselada, Max; van der Heuvel, Dirk. Alison y Peter Smithson. De la casa del futuro a la casa de hoy. Barcelona: Polígrafa, 2007.

Rowe, Colin y Slutzky, Robert. "Transparencia literal y fenomenal" en Colin Rowe, Manierismo y arquitectura moderna y otros ensayos. Barcelona: Gustavo Gili, 1999. Edición original, 1963.

Smith, C. Ray. Supermannerism: New Attitudes in Post-Modern Architecture. New York: E.P. Dutton, 1977.

Smithson, Alison / Smithson, Peter. Cambiando el arte de habitar: piezas de Mies, sueños de los Eames, los Smithson. Barcelona: Gustavo Gili, 2001.

Sottsass, Ettore. Sottsass Associati. Barcelona: Gustavo Gili, 1988.

Summerson, John. Heavenly Mansions and other essays on Architecture. Nueva York: W.W. Norton \& Co., 1998. Edición original, 1949.

Torres Nadal, José María (ed. p.). Toyo Ito. Escritos. Murcia: Colección de arquitectura. Colegio Oficial de Aparejadores y Arquitectos Técnicos de Murcia, 2000.

Underhill, Sarah Mollman (ed. p.). Stanley Tigerman: Buildings and Projects, 1966-1989. Nueva York: Rizzolli, 1989.

Venturi, Robert. Complejidad y Contradicción en la Arquitectura. Barcelona: Gustavo Gili, 1992. Edición original, 1966. 


\section{Artículos}

AAVV. "Alla XIII triennale. Alcune fra le prodizioni", Domus n418 sept-1964. $17-32$.

AAVV. "XVII Triennale di Milano. II progetto domestico". Domus n671 abr1986. 44-73.

Ábalos, Iñaki; Herreros, Juan. "Toyo Ito: el tiempo ligero", El Croquis n71, 1995. 32-48.

Ambasz, Emilio. "El diseño como postulación". Temas de Diseño n03, jul/ago1972. 15

Ando, Tadao. "Ishii Residence. Hamamatsu, Shizuoka, Japan, 1980-82. GA houses, n014, jul-198. 174-179.

Banham, Reyner. "A home is not a house". Art in America, n² 2, abr-1965.

Bofill, Ricardo. "Housing Walden 7". GA houses, n¹, nov-1976. 18-35.

Bofill, Ricardo. "Houses at Montras, near Costa Brava, Spain". GA houses, n9, jul-1981. 78-83.

Botta, Mario. "Family house, Origlio, Switzerland, 1981-83". 78-85.

Campens, Angelique. "Juliaan Lampens" Domus n0937, jun-2010. http://www. domusweb.it/en/architecture/2010/06/15/juliaan-lampens.html

Chalk, Warren. "La arquitectura como producto del consumidor". Perspecta, n'11, 1967.

Cigolle, Mark. "Mercer Street Loft. New York City, 1980". GA houses, n8, may1981. 140-145.

Coate, Roland. "Alexander House. Montecito, California, USA, 1971-74". 6067.

Collard, Pete. "Italy: The New domestic Landscape" Disegno Daily ,nov-2013. https://www.disegnodaily.com/article/italy-the-new-domestic-landscape

Colombo, Joe. "Visiona 69. Nouvelle conception de l'espace habitable". L'Architecture d'aujourd'hui, n0148, 1970. 60-62.

Colomina, Beatriz. "Reflexiones sobre la casa Eames". Ra. Revista de Arquitectura n09, 2007. 3-16.

Cook, Peter. "Algunas notas sobre el síndrome Archigram". Perspecta, n¹1, 1967.

Cunningham, Architects. "Power House. Dallas, Texas, 1988". GA houses, n²6, jul-1989. 96-105.

Defenbacher, Daniel S. "Editorial note" Everyday Art Quarterly n¹3, invierno 1949-50. 14. 
Diller Elizabeth / Scofidio Ricardo. "Body Buildings". A+U Architecture and Urbanisme, n²22, mar-1989. 57-64.

Erickson, Arthur. "Single Family Residence, Pacific Northwest, USA, 197881". GA houses, n¹9, feb-1986. 76-87.

Faerna, José María. "Joe Colombo, el profeta del interior moderno". Diseño Interior, n0164, mar-2006. 80-92.

Farini, Elena / Lasheras, Raquel / Samarán, Felipe. "El mueble que crea espacio". UPM, Arquitectura de Interiores, 2012. http://arquitecturainteriores. aq.upm.es/wp-content/uploads/2016/01/2_06.pdf

Fernández Galiano, Luis. "Koolhaas y los Elementos". Arquitectura Viva, no 164 jun-2014. http://www.arquitecturaviva.com/Info/News/Details/6010

Filler, Martin. "House near New York. Extra sensory perceptions". Progressive Architecture, nº abr-1978. 82-85.

Frampton, Kenneth. "El estatus del hombre y el estatus de sus objetos: una lectura de la condición humana". Ra Revista de Arquitectura, n¹0, jun-2008. 7-22.

Frampton, Kenneth. "Meet the architect: Steven Holl". GA houses, n²5, mar1989. 164-227.

Gandee, Charles K. "Homework: Cohen Apartment". Architectural Record, $\mathrm{n}^{0}$ sep-1984. 156-163.

Gehry, Frank O. "Davis Studio/Residence, Malibu, California, USA, 1970-72". GA houses, n², abr-1977. 54-59.

Gehry, Frank 0. "Stanley Tigerman vs. Frank O. Gehry: Frank O. Gehry on Stanley Tigerman". GA houses, n6, oct-1979. 20-55.

Gehry, Frank 0. "Indiana Project. Venice, California, 1981". GA houses, n¹1, may-1982. 26-32.

Gehry, Frank 0. "Wosk Residence. Beverly Hills, California, 1981-84". GA houses, n017, feb-1985. 8-17.

Girard, Alexander. "What is modern?" Pathfinder News Magazine n 5 oct1949. 42.

Grondona, Tom. "Talbot Street Train. San Diego, California, 1978". GA houses, n016, jul-1984. 13.

Gualdoni, Flaminio. "Meet the Architect: Alberto Salvati and Ambrogio Tresoldi. Apartamento". GA houses, n05, dic-1978. 25-51.

Gund, Graham. "School-House Condominiums. Boston, Massachusetts". GA houses, n011, may-1982. 86-91.

Hamilton, Richard. Richard Hamilton, "Una vista interior". Carta, n05 primavera/verano-2014. 60-63. http://www.museoreinasofia.es/publicaciones/ 
revista\#numero-5

Hammond, Beeby and Babka. "Fultz House. Chesterton, Indiana. USA, 1970". GA houses, n08, may-1981. 118-119.

Hara, Hiroshi. "Horoshi Hara (Houses). GA houses, n²0, sep-1986. 58-85.

Herreros, Juan. "Espacio Domestico. Sistemas de Objetos". AULA 261, Universidad San Pablo CEU, 2012. http://aula261.blogspot.com.es/

Holl, Steven. "Hybrid Building. Seaside, Florida,1985-88". GA houses, n²7, nov-1989. 98-111.

Hovey, David. "575 Elm Street Residence. Winnetka, Illinois, 1981-82". GA houses, n¹5, ene-1984. 132-139.

Isozaki, Arata. "Arata Isozaki". GA houses, n1, nov-1976. 150-155.

Isozaki, Arata. "Björson Studio. Venice, California, 1981-86". GA houses, n²4, oct-1988. 82-85.

Ito,Toyo. "Toyo Ito (Three Houses)". GA houses, n²0, sep-1986. 30-47.

Ito, Toyo. "The Pao for Tokyo's nomad woman". Japan Architect, n³51 jul1986, vol.61. 44-45.

Jacobsen, Hugh Newell. "Rosenak House. Tesuque, New Mexico. 1984-85. GA houses, n022, dic-1987. 106-111.

Kappe, Raymond. "Raymond Kappe". GA houses, n¹, nov-1976. 120-149.

Kessler, William. "Private residence, Southeast, Michigan, 1977-80". GA houses, n011, may-1982. 72-79.

Kitagawara, Atsushi. "Residence Amakura, Kanagawa, Japan, 1979-80". GA houses, n014, jul-1983. 292-295.

Koolhaas, Rem. "OMA: la casa palestra". AA files, n¹3, 1986. 8-15.

Koolhaas, Rem. "Rem Koolhaas; O.M.A., 1987-1992". El Croquis, n53, 1992.

Krueck \& Olsen. "Marriott Residence - A Painted Apartment. Chicago, Illinois, 1982". GA houses, n017, feb-1985. 140-143.

Krueck \& Olsen. "Untitled 1 and 2 (Apartments, Chicago, Illinois)". GA houses, n²4, oct-1988. 62-81.

Lautner, John. "Turner Residence. Aspen, Colorado, 1979-81". GA houses, n¹9, feb-1986. 20-25.

Legorreta, Ricardo. "Meet the architect: Ricardo Legorreta". GA houses, n²5, mar-1989. 32-115.

Lewis, Brent. "The perfection of imperfection". Area ,n¹19, sep-2014. https:// www.area-arch.it/it/area-119-gaetano-pesce/ 
Lovett, Wendell H. "Frey House. Bellvue, Washington, USA, 1971-72. GA houses, n², abr-1977. 38-43.

Lyndon, Turnbull y Whitaker. "A special place". Progressive Architecture, $\mathrm{n}^{0}$ may-1964, tomo 45. 154-159.

Maniaque, Caroline. "Charles Moore une Architecture des Sensations". L'Architecture d'Aujourd'hui. n²92, abr-1994. 42-47.

McLeod, Mary. "Arquitectura y política en la era de Reagan. Del posmoderno a la deconstrucción". Arquitectura Viva, n8, oct-1989. 7-19.

Millet, Mark. "Residence for Linda Farmis (gallery). Seattle, Washington, 198182. 116-121.

Mittelstadt, Robert. "Mittelstadt duplex. San Francisco, California, 1975-79". GA houses, n011, may-1982. 52-57.

Moore, Charles W., et. al. "Dossier: Charles Moore". L'Architecture d'Aujourd'hui. n0184, mar/abr-1976. 1-65.

Moore, Charles W., et.al. "The Work of Charles W. Moore". A+U Architecture and Urbanism, $n^{0}$ extra may-1978.

Moore, Charles W. "Un planteamiento personal". Arquitectura n²25, jul/ago1980. 55-68.

Moore, Charles W. "How to make a place: Kresge College, University of California at Santa Cruz". Progressive Architecture, nº may-1974, tomo 55. 7683.

Moore, Charles W. "Residence, Orinda, California". Progressive Architecture, no may-1963, tomo 144. 171-175.

Moore, Andersson, Dodge. "Moore/Andersson Residence Studio. Austin, Texas, 1984-87". GA houses, n027, nov-1989. 134-145.

Mourgue, Olivier. "In ottanta metri quadri". Domus n502, sep-1971. 34-37.

Murphy, Brian A. "Dixon Residence. Los Angeles, California, 1981-82". GA houses, n015, ene-1984. 126-131.

Murphy, Brian A. B.A.M in F.O.G house remodeling. Venice, California, 1984. GA houses, n018, ago-1985. 120-123.

Murphy, Brian A. "Hopper Residence. Venice, California, 1986-87". GA houses, n²4, oct-1988. 126-133.

Myers, Barton. "Wolf House. Roxborough Drive, Toronto, Canada. 1972-74". GA houses, n², abr-1977. 94-103.

Niland, David L. "French Residence. Oakwood, Ohio, 1965-69". GA houses, n¹3, mar-1983. 84-91.

Otero-Pailos, Jorge. "LSDesign: Charles Moore and the delirious interior". 
Volume n²4, 2010. http://c-lab.columbia.edu/0183.html

Pesce, Gaetano. "Gaetano Pesce: un apartamento a Parigi". Domus. no mar1987. 52-63.

Quigley, Rob. "Cohen Residence. Del Mar, California, 1975-76. GA houses, n016, jul-1984. 18-21.

Quigley, Rob. “Johnson Residence. Point Loma, San Diego, California, 197882". GA houses, n¹6, jul-1984. 32-35.

Ranalli, George. "Callender School Renovation. Newport, Rhode Island, 197981". GA houses, n¹2, oct-1982. 106-111.

Riley, Jefferson B. et al. "Riley House, Guilford, Connecticut" Architectural Record, no may-1978. 92-93.

Rudolph. Paul. "Paul Rudolph". GA houses, n¹, nov-1976. 78-91.

Rudolph Paul. "Paul Rudolph Apartment. New York City". GA houses, n5, dic1978. 106-109.

Rudolph, Paul. "N.Y. Apartment, 1977-78". GA houses, n6, oct-1979. 88-89.

Rudolph, Paul. "Joanna Steichen Apartment. New York City. 1973-74". GA houses, n'5, dic-1978. 100-105.

Safont-Tria, Jordi. "Water Colors. La dimensión horizontal del color en la arquitectura de Steven Holl". Diagonal, n037, primavera-2014. http:/l www.revistadiagonal.com/articles/analisi-critica/water-colors-stevenholl/\#more-5215

Saito, Yutaka. "Chimenka-no-ya. Nagano, Tokyo, Japan,1987-88". GA houses, n²6, jul-1989. 74-81.

Schiedhelm, Manfred. "Anachitecture. Idées pour une ville d'aujourd'hui". L'Architecture d'Aujourd'hui n0146, oct/nov-1969. 86.

Schmertz, Mildred F. "Two Houses by Charles Moore". Architectural Record, n07, tomo 161, jun-1977. 109-116.

Schroeder, Kenneth E. "Mergenthaler Condominiums. Chicago, Illinois, 1980". GA houses, n8, may-1981. 134-139.

Schulitz, Helmut. "Helmut Schulitz House. Beverly Hills, California, USA, 197576". GA houses, n², abr-1977. 68-73.

Shinohara, Kazuo. "House in Yokohama. Nakagawa, 1982-84". GA houses, n²0, sep-1986. 20-29.

Smith, C. Ray. "Bathhouse graphics". Progressive Architecture mar-1967. 156161.

Smith, Ted. "Upas Street. San Diego, California, 1978-83. GA houses, n¹6, jul-1984. 15. 
Smith, Miller, Hawkinson. "Model Apartment. Police Building. New York, 1989". GA houses, n²7, nov-1989. 127-129.

Stern, Robert A. M. "Five Houses". GA houses, n11, nov-1976. 36-77.

Stern, Robert A.M. "New York Brownstone (renovation) New York", GA houses, n'6, oct-1979. 100-105.

Stern, Robert A.M. "Residence Llewellyn Park, New Jersey, 1979-81". GA houses, n012, oct-1982. 16-29.

Stern, Robert A.M. "Not space but...room". GA houses. n05, 1978. 4-7.

Suzuki, Makoto. "HAH-House at Narashino, Chiba, 1977-79". GA houses, n014, jul-1983. 65-67.

Taki, Koji. "Conversaciones con Peter Wilson”. El Croquis nº 67, 1994.

Tuñón, Emilio. "Renacer". CIRCO nº 87, 2001. 1-10.

Veronda, George A. "Private Residence. New Buffalo, Michigan, 1979-81". GA houses, n015, ene-1984. 140-145.

Vigo, Nanda. "Apartment Monospazio. Merate, Milan, Italy, 1973-74". GA houses, n05, dic-1978. 90-93.

Wagner, Walter F. Jr. Editado por. "Record Houses of 1980". Architectural Record. nº may-1980.

Whitaker, Richard R., et.al. "Charles Moore and Company". GA houses $\mathrm{n}^{0}$ especial, 1980.

Wilson, Peter. "Blackburn Residence. Hampstead, London, 1986-88". GA houses, n²7, nov-1989. 22-35.

Yokoyama, Tadashi. "Savina Zentner House, Zurich, Switzerland". GA houses, n01, nov-1976. 186-191. 


\section{TESIS DOCTORALES}

Amann Alcocer, Atxu. "El espacio doméstico: la mujer y la casa". Tesis Doctoral. Universidad Politécnica de Madrid, Escuela Técnica Superior de Arquitectura, 2005.

Capomaggi, Julia. "DOMUS 1948-1978. La conformación del espacio doméstico a través del mobiliario". Universidad Politécnica de Cataluña. Escuela Técnica Superior de Arquitectura de Barcelona, 2015.

Farini, Elena. "Procesos configurativos: de la trama a la noción de campo en los mat buildings". Tesis Doctoral. Universidad Politécnica de Madrid, Escuela Técnica Superior de Arquitectura, 2013.

Fernández Lorenzo, Pablo. "La casa abierta. Hacia una vivienda variable y sostenible concebida como si el habitante importara". Tesis Doctoral. Universidad Politécnica de Madrid, Escuela Técnica Superior de Arquitectura, 2012.

Gorostiza López, Jorge. "La construcción de la ficción: espacio arquitectónicoespacio cinematográfico". Tesis Doctoral. Universidad Politécnica de Madrid, Escuela Técnica Superior de Arquitectura, 2015.

Herreros, Juan. "Mutaciones en la arquitectura contemporánea. El espacio doméstico". Tesis Doctoral. Universidad Politécnica de Madrid, Escuela Técnica Superior de Arquitectura, 1994.

Lleó Fernández, Blanca. "La casa, un sueño de habitar en el espacio moderno, un proyecto inacabado". Tesis Doctoral. Universidad Politécnica de Madrid, Escuela Técnica Superior de Arquitectura, 1996.

Pardo Díaz, Gonzalo. "Cuerpo y casa: hacia el espacio doméstico contemporáneo desde las transformaciones de la cocina y el cuarto de baño". Tesis Doctoral. Universidad Politécnica de Madrid, Escuela Técnica Superior de Arquitectura, 2016.

Pereira da Silva, Ana Sofía. "La intimidad de la casa: el espacio individual en la arquitectura doméstica en el siglo XX". Tesis Doctoral. Universidad Politécnica de Madrid, Escuela Técnica Superior de Arquitectura, 2013.

Roig Segovia, Eduardo. "El entorno aumentado: imperativo informacional para una ecología digital de lo arquitectónico". Tesis Doctoral. Universidad Politécnica de Madrid, Escuela Técnica Superior de Arquitectura, 2014. 


\section{PÅGINAS WEB}

http://archigram.westminster.ac.uk/

http:// arqueologiadelfuturo.blogspot.com/

http://bolles-wilson.com/

http://www.carloscarpa.es/

http://www.centrostudipoltronova.it/archizoom-associati/

http://www.centrostudipoltronova.it/superstudio/

http://www.charlesmoore.org/

http://www.design-museum.de/

http://www.domusweb.it/

http://www.dsrny.com/

http://www.eamesoffice.com/

https://www.foga.com/

http://www.fondationlecorbusier.fr/

http://www.gaetanopesce.com/

http://www.georgeranalli.com/

http://habitar.upc.edu/

http://www.hermanmiller.com/

http://www.imm-cologne.com/

http://independentgroup.org.uk/

http://www.jeannouvel.com/

http://www.joecolombo.it/

http://libraries.cca.edu/acquia-drupal6/capp/index.html

https://www.memphis-milano.com/

https://www.moma.org/

http://www.museoreinasofia.es/

http://www.nandavigo.com/

http://www.oldmagazinearticles.com/ 
http://www.oliviermourgue.com/

http://oma.eu/

http://www.plataformaarquitectura.cl/

http://www.ramsa.com/

http://www.ricardobofill.es/

http://www.sottsass.it/

http://www.stevenholl.com/

http://www.tate.org.uk/

http://tectonicablog.com/

http://www.toyo-ito.co.jp/

http://www.triennale.org/

http://www.tusquets.com/

http://www.ugolapietra.com/

https://www.unav.edu/publicaciones/revistas/index.php/revista-de-arquitectura

http://www.vernerpanton.com/

https://es.wikipedia.org/ 
